Department of the Interior

U.S. Geological Survey

\title{
Felt Reports and Intensity Assignments for Aftershocks and Triggered Events of the Great 1906 California Earthquake
}

Aron J. Meltzner ${ }^{1,2}$ and David J. Wald ${ }^{1}$

${ }^{1}$ U.S. Geological Survey 525 S. Wilson Ave. Pasadena, Calif. 91106

${ }^{2}$ Division of Geological and Planetary Sciences California Institute of Technology

Pasadena, Calif. 91125

USGS Open-File Report 02-37

This report is preliminary and has not been reviewed for conformity with

U.S. Geological Survey editorial standards or with the North American Stratigraphic Code. Any use of trade, firm, or product names is for descriptive purposes and does not imply endorsement by the U.S. Government. 


\section{TABLE OF CONTENTS}

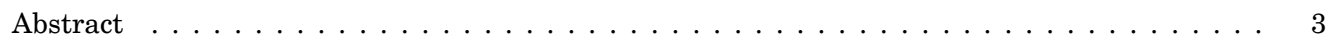

Introduction and Discussion $\ldots \ldots \ldots \ldots \ldots \ldots \ldots \ldots$

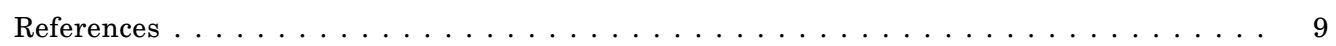

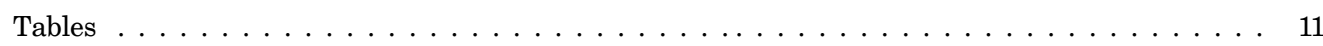

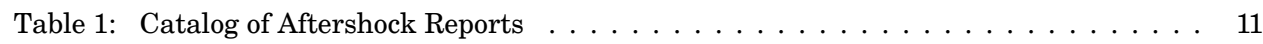

Table 2: Catalog of Triggered Event Reports (incl. events in So. Cal., AZ, NV, \& OR). . . . 135

Table 3: List of Newspapers and Manuscripts Checked . . . . . . . . . . . . . 168

Table 4: Latitude-Longitude Coordinates for Locations in Tables 1-2 and 5-15 . . . . . . . 189

Table 5: Primary Reports for the 18 Apr 1906, 14:28 aftershock . . . . . . . . . . . . . . . 198

Table 6: Primary Reports for the 18 Apr 1906 Imperial Valley triggered event . . . . . . . . 202

Table 7: Primary Reports for the 19 Apr 1906 Santa Monica Bay triggered event . . . . . . 214

Table 8: Primary Reports for the 19 Apr 1906 Western Nevada triggered event . . . . . . . 221

Table 9: Primary Reports for the 23 Apr 1906, 01:10 aftershock . . . . . . . . . . . . . . 224

Table 10: Primary Reports for the 25 Apr 1906, 15:17 aftershock . . . . . . . . . . . . . . 240

Table 11: Primary Reports for the 17 May 1906, 20:21 aftershock . . . . . . . . . . . . . 246

Table 12: Primary Reports for the 6 Jul 1906, 22:55 aftershock . . . . . . . . . . . . . . 256

Table 13: Primary Reports for the 5 Jun 1907, 00:27 aftershock . . . . . . . . . . . . . . 260

Table 14: Primary Reports for the 8 Aug 1907, 04:44 and 06:05 aftershocks . . . . . . . . . 268

Table 15: Primary Reports for the 11 Aug 1907, 04:19 aftershock . . . . . . . . . . . . . 271

Figure Captions . . . . . . . . . . . . . . . . . . . . . . . . . . . . . . 280

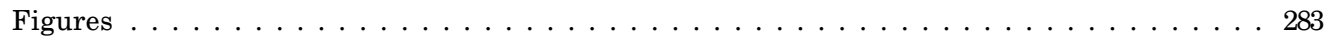

Figure 1: Map of the 1906 mainshock rupture . . . . . . . . . . . . . . . . 283

Figure 2: Intensity Map of the 18 Apr 1906, 14:28 aftershock . . . . . . . . . . . . . . 284

Figure 3: Intensity Map of the 18 Apr 1906 Imperial Valley triggered event . . . . . . . . 285

Figure 4: Intensity Map of the 19 Apr 1906 Santa Monica Bay triggered event . . . . . . . 286

Figure 5: Intensity Map of the 19 Apr 1906 Western Nevada triggered event . . . . . . . . 287

Figure 6: Intensity Map of the 23 Apr 1906, 01:10 aftershock . . . . . . . . . . . . 288

Figure 7: Intensity Map of the 25 Apr 1906, 15:17 aftershock . . . . . . . . . . . . . . 289

Figure 8: Intensity Map of the 17 May 1906, 20:21 aftershock . . . . . . . . . . . . . 290

Figure 9: Intensity Map of the 6 Jul 1906, 22:55 aftershock . . . . . . . . . . . . . 291

Figure 10: Intensity Map of the 5 Jun 1907, 00:27 aftershock _ . . . . . . . . . . . . . . 292

Figure 11: Intensity Map of the 8 Aug 1907, 04:44 and 06:05 aftershocks . . . . . . . . . . 293

Figure 12: Intensity Map of the 11 Aug 1907, 04:19 aftershock . . . . . . . . . . . . . 294

Appendix 1: Modified Mercalli Intensity Scale . . . . . . . . . . . . . . . . . . . . . 295

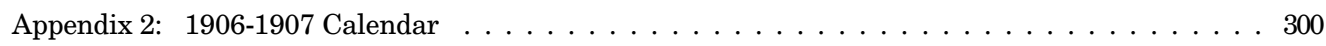




\title{
Felt Reports and Intensity Assignments for Aftershocks and Triggered Events of the Great 1906 California Earthquake
}

\begin{abstract}
The San Andreas fault is the longest fault in California and one of the longest strikeslip faults in the world, yet little is known about the aftershocks following the most recent great event on the San Andreas, the M 7.8 San Francisco earthquake, on 18 April 1906. This open-file report is a compilation of first-hand accounts (felt reports) describing aftershocks and triggered events of the 1906 earthquake, for the first twenty months of the aftershock sequence (through December 1907). The report includes a chronological catalog. For the larger events, Modified Mercalli intensities (MMIs) have been assigned based on the descriptions judged to be the most reliable.
\end{abstract}




\section{INTRODUCTION}

The 18 Apr 1906 (5:12 a.m. PST) M 7.8 San Francisco earthquake, which broke the northern San Andreas fault from San Juan Bautista to near Shelter Cove (see Figure 1), has been a centerpiece of seismological investigation in California, yet little attention has been paid to its aftershocks and triggered events. Questions as to the size, location, and timing of the largest aftershocks have not heretofore been addressed, even though an earthquake as large as the 1906 mainshock might be expected to have potentially damaging aftershocks. At least one sizable triggered event occurred in the Imperial Valley in southern California (11.3 hours after the mainshock), but the possibility of additional triggered events in other locations has not been explored. This study is an attempt to shed light on some of these unresolved issues, and to improve our understanding of the behavior of aftershocks following large earthquakes on the San Andreas fault. It is also an attempt to expand our knowledge of historical earthquake triggering. Until recently, the seismological community did not generally appreciate the fact that large earthquakes are capable of triggering events at distances far greater than those associated with classic aftershocks; since the 1992 Landers, California, earthquake, however, numerous studies have documented the reality of triggered earthquakes (e.g., Hill et al., 1993; Bodin and Gomberg, 1994; Gomberg and Davis, 1996; Brodsky et al., 2000; Gomberg et al., 2001; Hough, 2001; and Hough and Kanamori, 2002). This report provides additional data for triggering studies.

Although several efforts have been made to catalog the aftershocks and triggered events of the 1906 earthquake (e.g., Lawson, 1908, and Townley and Allen, 1939), those efforts were spotty in their completeness and often lacking in enough detail to permit reliable assessments or estimates of magnitude and location. Steeples and Steeples (1996) looked at triggered events that occurred within 24 hours of the 1906 San Francisco mainshock, but their data appear to be flawed by at least one substantial error. [Their erroneous data-a report taken from Lawson (1908) of an event supposed to have taken place at 12:31 p.m. on 18 Apr 1906 in Los Angeles-was not substantiated by a single newspaper or diary in southern California; rather, it appears to be a misdated report of the earthquake that was widely documented to have hit Los Angeles at 12:31 p.m. on 19 Apr 1906.] 
In spite of this, the historical record is full of useful and valuable information that can enhance the existing catalogs. For the present study, we have searched newspapers, diaries, and other historical documents for felt reports of potential aftershocks and triggered events of the 1906 earthquake. (A "felt report" is any written statement in which the author describes shaking and/or effects caused by an earthquake, or in which the author simply notes that an earthquake was felt.) These newspapers, diaries, and other records were located in libraries throughout California, Oregon, Nevada, and Arizona, and in the U. S. National Archives. Altogether, this work represents the most comprehensive compilation to date of earthquake data from the historical record during the period immediately following the 1906 San Francisco earthquake.

\section{DISCUSSION}

In general, the distinction between an aftershock and a triggered event is based on the distance of said event from its mainshock. An aftershock is generally defined as any earthquake that occurs within one fault rupture length of its mainshock [in this case, within 420 to $470 \mathrm{~km}$ of the mainshock rupture (Sieh, 1978)] and during the span of time that the seismicity rate in that region remains above its pre-mainshock background level (e.g., Hough and Jones, 1997). It is not clear that this general definition is applicable given the extraordinary length of the 1906 rupture. Likewise, no definition of a triggered event is universally accepted, but in this report, the term triggered event will apply to any earthquake that occurred more than $470 \mathrm{~km}$ from the mainshock rupture, and days to weeks after the mainshock. It will also apply to a number of earthquakes that occurred in or near the periphery of the aftershock zone in Oregon and Nevada-since these events occurred in the Basin and Range province, a tectonic region distinct from most of California, it was felt that they should not be classified as aftershocks-and also to several events that occurred in the periphery of the aftershock zone in southern California.

Hough and Jones (1997) suggest that the distinction between aftershocks and triggered events may reflect imprecise taxonomy rather than a clear distinction based on physical processes; the distinction is adopted in this paper as a means to emphasize the 
surprising number of significant "far-field aftershocks" that occurred in the hours and days following the San Francisco mainshock. It should be emphasized that no particular mechanism of earthquake triggering is being evaluated in this paper; rather, we are merely suggesting that these "far-field aftershocks" are triggered by the mainshock. Although these "far-field aftershocks" are not aftershocks by conventional definitions, their temporal proximity to the mainshock makes it difficult to imagine that they are entirely unrelated to the mainshock.

This report includes only those triggered events that occurred within the first week of the mainshock, and only those aftershocks that occurred within a 20-month period following the 1906 mainshock, i.e., between April 1906 and December 1907. The cutoff of one week for triggered events seems logical, as there was a marked clustering of earthquakes in the western U.S. during the first 48 hours following the mainshock, and this regional spurt of activity apparently died off rather soon thereafter. The cutoff of December 1907 for aftershocks is arbitrary, however; analysis of earthquakes in existing catalogs (e.g., Townley and Allen, 1939) makes it clear that the aftershock sequence continued long after the year 1907. Ellsworth et al. (1981) used the record of aftershocks felt at Berkeley to suggest that the aftershock sequence lasted until about 1915. Nevertheless, an investigation limited to the first twenty months has already been a formidable undertaking, and expanding the duration of the study period is left as a possible avenue for further research.

The data collected in this study are presented in this report in several formats. Tables 1 and 2 are catalogs of felt reports of aftershocks and triggered events, respectively. These are arranged chronologically and include all the reports found by the present authors in newspapers and other historical documents. These catalogs are intended to be used in conjunction with, but not to replace, Townley and Allen (1939) or Lawson (1908). Most earthquake reports listed in Townley and Allen (1939) and Lawson (1908) were not included in our catalogs; they were listed in our catalogs only for a few selected earthquakes and only when those reports contained information not found in the newspapers, diaries, and other historical documents. A list of all newspapers and historical documents searched is presented in Table 3, and a list of latitude-longitude coordinates for all locations in Tables 1 and 2 is given in Table 4 . 
Tables 5 through 15 are lists of felt reports for eight of the largest aftershocks and three of the largest triggered events. This is mostly the same information presented in Tables 1 and 2, but the reports are grouped geographically (in alphabetical order by county, for each event) rather than chronologically; this format facilitates the assignment of Modified Mercalli intensity (MMI) values for each location, as it allows the reader to readily determine which reports are the most reliable. Maps showing the distribution of intensities assigned in Tables 5 through 15 are presented in Figures 2 through 12, respectively.

As mentioned above, before assigning intensities, we attempted to assess the credibility of each report, and to identify reports that were unreliable. Sometimes, reports published far away from a point of observation (hereinafter, "distant reports") contradicted reports published in the same city as the observation (hereinafter, "local reports"). A prime example of this comes in the reports from Ashland and Grants Pass, Oregon, for the 23 Apr 1906 aftershock (see Table 9). We can never be sure why the contradictions exist, but we infer that in the process of communicating the information from the initial point of observation to the ultimate point of publication-whether that communication occurred by telegraph, telephone, or word of mouth-there were abundant opportunities for exaggeration. Additionally, some distant reports may have been based largely or entirely on unfounded rumors. In contrast, if a report was published in the same city as the observation, there is a lesser likelihood for exaggeration. For these reasons, when distant reports contradicted local reports, the local reports were normally considered to be more reliable. Also, there were cases in which distant newspapers reported that an event was felt in a given city, but no local newspapers indicated that it was felt there; in some of these cases, the distant reports were judged to be unreliable. For reports judged to be unreliable, an explanation of our concerns is ordinarily included with the entry in the table.

This report is intended to be the data archive for a companion paper (Meltzner and Wald, 2003) analyzing the aftershocks and triggered events of the 1906 earthquake. For analysis of these events and a discussion of the aftershock and triggered event sequence, please refer to that paper. 


\section{ACKNOWLEDGMENTS (A.J.M. \& D.J.W.)}

Many people have helped make this research possible or have helped significantly along the way. We would like to thank Tousson Toppozada of the California Division of Mines and Geology for sharing his thoughts, knowledge, and data, and we want to thank Bill Deverell (Caltech), Bill Bakun (USGS), Lucy Jones (USGS), and Lori Dengler (Humboldt State University) for their ongoing assistance, on our 1857 work, and now for 1906. We would also like to thank Nancy King (USGS) and Sue Hough (USGS) for their thoughtful reviews and very helpful suggestions. We are grateful and indebted to all of you.

\section{ADDITIONAL ACKNOWLEDGMENTS-(A.J.M.)}

I have had the opportunity to visit many libraries across the state, and I would like to thank all the librarians who have offered assistance. I would in particular like to thank the librarians of the Livermore Public Library for going out of their way to help locate uncatalogued newspapers, as well as the librarians of the King City Library and the librarians at CSU Stanislaus for being so kind and helpful. I am especially grateful to Mary Allely of the Local History Room of the National City Public Library, for being so helpful and resourceful. I am appreciative and impressed that she remembered the details of my visit when I called to ask a question more than six months later. I would also like to express my gratitude for all the assistance I have received over the years from the librarians in the California History Room of the California State Library in Sacramento-thanks for putting up with me, all the times I tried to work a few minutes past closing time!

Many of the locations I came across in my research were small towns or obscure places. For these locations, Durham's (1998) California Gazetteer has been an invaluable tool, giving locations and coordinates for anything from land grants to names of hills to obsolete names of small towns. Interestingly, I feel connected to Durham in a way: Durham holds a Bachelor of Science degree from Caltech and worked as a geologist with the USGS (see "About the Author" at the end of his gazetteer); for me, in the course of this research, I earned my Bachelor of Science degree from Caltech (an early form of this report and the accompanying paper served as my senior thesis) and I served as an intern with the USGS. I also wish to acknowledge the use of the Generic Mapping Tools software package by Wessel and Smith (1991) to generate all the figures in this report.

This work has been supported by funding from Caltech's Summer Undergraduate Research Fellowship (SURF) Program, from funds awarded in conjunction with the 1998-99 Fritz Burns Prize in Geology at Caltech, and by funding from the U. S. Geological Survey. I am grateful to the SURF Program, to the Division of Geological and Planetary Sciences at Caltech, and to the USGS for their support and insight. 


\section{REFERENCES}

Bodin, P. and J. Gomberg (1994). Triggered seismicity and deformation between the Landers, California, and Little Skull Mountain, Nevada, earthquakes, Bull. Seism. Soc. Am. 84, pp. 835-843.

Bolt, B.A. (1968). The focus of the 1906 California earthquake, Bull. Seism. Soc. Am. 58, pp. 457-471.

Brodsky, E.E., V. Karakostas, and H. Kanamori (2000). A new observation of dynamically triggered regional seismicity: earthquakes in Greece following the August, 1999 Izmit, Turkey earthquake, Geophys. Res. Let. 27, pp. 2741-2744.

California State Mining Bureau [CSMB] (1909). Mineral Productions, County Maps, and Mining Laws of California, Calif. State Mining Bureau Bulletin 56.

Carlson, H.S. (1974). Nevada Place Names: A Geographical Dictionary, University of Nevada Press, Reno.

Durham, D.L. (1998). California's Geographic Names: A Gazetteer of Historic and Modern Names of the State, Word Dancer Press, Clovis, CA.

Ellsworth, W.L., A.G. Lindh, W.H. Prescott, and D.G. Herd (1981). The 1906 San Francisco earthquake and the seismic cycle, in Earthquake Prediction; an International Review, D.W. Simpson and P.G. Richards (Editors), American Geophysical Union, Washington, DC, pp. 126-140.

Gomberg, J. and S. Davis (1996). Stress/strain changes and triggered seismicity at The Geysers, California, J. Geophys. Res. 101, pp. 733-749.

Gomberg, J., P.A. Reasenberg, P. Bodin, and R.A. Harris (2001). Earthquake triggering by seismic waves following the Landers and Hector Mine earthquakes, Nature 411, pp. $462-466$.

Hill, D.P., P.A. Reasenberg, A. Michael, W.J. Arabaz, G. Beroza, D. Brumbaugh, J.N. Brune, R. Castro, S. Davis, D. dePolo, W.L. Ellsworth, J. Gomberg, S. Harmsen, L. House, S.M. Jackson, M.J.S. Johnston, L. Jones, R. Keller, S. Malone, L. Munguia, S. Nava, J.C. Pechmann, A. Sanford, R.W. Simpson, R.B. Smith, M. Stark, M. Stickney, A. Vidal, S. Walter, V. Wong, and J. Zollweg (1993). Seismicity remotely triggered by the magnitude 7.3 Landers, California, earthquake, Science 260, pp. 1617-1623.

Hough, S.E. (2001). Triggered earthquakes and the 1811-1812 New Madrid, central United States, earthquake sequence, Bull. Seism. Soc. Am. 91, pp. 1574-1581.

Hough, S.E. and L.M. Jones (1997). Aftershocks: are they earthquakes or afterthoughts?, Eos 78, 505, 508.

Hough, S.E. and H. Kanamori (2002). Source properties of earthquakes near the Salton Sea triggered by the 16 October 1999 M 7.1 Hector Mine, California, earthquake, Bull. Seism. Soc. Am. 92, pp. 1281-1289.

Lawson, A.C., chairman (1908). The California Earthquake of April 18, 1906: Report of the State Earthquake Investigation Commission, Vols. I \& II and Atlas, Carnegie Inst., Washington, D.C.

Meltzner, A.J. and D.J. Wald (2003). Aftershocks and triggered events of the great 1906 California earthquake, Bull. Seism. Soc. Am., submitted.

“Official map of Trinity Co., California” (1915). (Publisher unknown.) Held in California State Library, Sacramento. 
Richter, C.F. (1958). Elementary Seismology, W. H. Freeman and Company, San Francisco.

Sieh, K.E. (1978). Slip along the San Andreas fault associated with the great 1857 earthquake, Bull. Seism. Soc. Am. 68, pp. 1421-1448.

Steeples, D.W. and D.D. Steeples (1996). Far-field aftershocks of the 1906 earthquake, Bull. Seism. Soc. Am. 86, pp. 921-924.

Toppozada, T.R. and D.L. Parke (1982). Areas damaged by California earthquakes, 1900-1949, Calif. Div. Mines Geol. Open-File Rept. 82-17 SAC.

Townley, S.D. and M.W. Allen (1939). Descriptive catalog of earthquakes of the Pacific coast of the United States: 1769 to 1928, Bull. Seism. Soc. Am. 29, pp. 1-297.

United States Geological Survey [USGS] (1908). "Reconnaissance map of the Salton Sink, California.” (1906, reprinted 1908).

Wessel, P. and W.H.F. Smith (1991). Free software helps map and display data, Eos 72, pp. 441, 445-446.

Wood, H.O. and F. Neumann (1931). Modified Mercalli Intensity Scale of 1931, Bull. Seism. Soc. Am. 21, pp. 277-283. 
TABLE 1: Catalog of Aftershock Reports following from the Great 18 April 1906 California Earthquake

\begin{tabular}{|c|c|c|c|c|c|c|}
\hline Date Felt & $\begin{array}{l}\text { Time Felt } \\
\text { (PST) }\end{array}$ & $\begin{array}{l}\text { Location Felt } \\
\text { (City) }\end{array}$ & $\begin{array}{l}\text { Location Felt } \\
\text { (County) }\end{array}$ & $\begin{array}{l}\text { Unreliable? } \\
\text { Not Felt? }^{+}\end{array}$ & Source & Relevant Citations and other Notes \\
\hline \multicolumn{7}{|l|}{1906} \\
\hline $\begin{array}{c}\text { week of } \\
\text { 15-Apr-06 (?) } \\
\text { (NOT AN } \\
\text { AFTERSHOCK?) }\end{array}$ & evening & Ashland & $\begin{array}{l}\text { Jackson Co. } \\
\text { (Oregon) }\end{array}$ & & $\begin{array}{l}\text { Medford Mail, } \\
20 \text { Apr 1906; p. 2, c. } 4\end{array}$ & $\begin{array}{l}\text { "Ashland experienced a slight earthquake shock one evening last } \\
\text { week." }\end{array}$ \\
\hline \begin{tabular}{c|} 
17-Apr-06 \\
(NOT AN \\
AFTERSHOCK)
\end{tabular} & 22:00 & Roseburg & $\begin{array}{l}\text { Douglas Co. } \\
\text { (Oregon) }\end{array}$ & & $\begin{array}{l}\text { Morning Oregonian (Portland) } \\
19 \text { Apr 1906; p. 2, c. 5-7 }\end{array}$ & $\begin{array}{l}\text { "ROSEBURG, Or., April 18.--(Special.)-Distinct vibrations of } \\
\text { an earthquake were first felt in this place last night about } 10 \\
\text { o'clock. The vibrations seemed to go from southwest to northeast. } \\
\text { The second earthquake was felt this morning a little after } 5 \\
\text { o'clock...." } \\
\text { The validity of this report is questionable, as it was not reported in } \\
\text { either the Roseburg Twice A Week Review or the Umpqua Valley } \\
\text { News, both of which were published semi-weekly in Roseburg, OR. }\end{array}$ \\
\hline \begin{tabular}{c|} 
18-Apr-06 \\
(NOT AN \\
AFTERSHOCK)
\end{tabular} & $\sim 03: 00$ & Grass Valley & Nevada & & \begin{tabular}{|c|} 
Daily Morning Union \\
(Grass Valley \& Nevada City) \\
19 Apr 1906; p. 8, c. 6
\end{tabular} & $\begin{array}{l}\text { "Some claim to have felt a distinct shock at about } 3 \text { o'clock in the } \\
\text { morning but there were comparatively few who felt such a shock } \\
\text { if it did occur." }\end{array}$ \\
\hline \multicolumn{7}{|c|}{ The mainshock time was 5:12 A.M. (PST), 18 April 1906. Felt reports of the mainshock are not included in this list. } \\
\hline 18-Apr-06 & $\begin{array}{c}\text { following the } \\
\text { mainshock } \\
\text { (two events) }\end{array}$ & Eureka & Humboldt & & $\begin{array}{l}\text { Humboldt Standard, } \\
18 \text { Apr 1906; p. 1, c. } 1\end{array}$ & $\begin{array}{l}\text { "[The mainshock] was followed, after a short interval by another } \\
\text { tremor which ... was not heavy enough to do any damage, while } \\
\text { the third shock, following at a longer interval, was scarcely } \\
\text { perceptible. The last two shocks, in fact, seemed like a gentle } \\
\text { readjustment of the earth, as though the first shock had seriously } \\
\text { displaced it and it was 'shaking itself back into place.'" }\end{array}$ \\
\hline 18-Apr-06 & morning & Eureka & Humboldt & & $\begin{array}{l}\text { Humboldt Times, } \\
19 \text { Apr 1906; p. 1, c. } 1\end{array}$ & $\begin{array}{l}\text { "[The mainshock] was followed by a less severe shock and } \\
\text { during the noon hour the last one." The two aftershocks were } \\
\text { described as "less violent motions" than the mainshock. }\end{array}$ \\
\hline 18-Apr-06 & $\begin{array}{l}\text { morning } \\
\text { (several } \\
\text { events) }\end{array}$ & Ukiah & Mendocino & & $\begin{array}{l}\text { Ukiah Republican Press, } \\
20 \text { Apr 1906; p. } 1 \text {, c. } 1\end{array}$ & $\begin{array}{l}\text { "One of the heaviest earthquakes in the history of the town was } \\
\text { felt here at 5:15... There were two distinct shocks and the } \\
\text { vibrations seemed to be from north to south. Three or four other } \\
\text { light shocks were felt during the morning but the latter ones did } \\
\text { no damage." }\end{array}$ \\
\hline 18-Apr-06 & $\begin{array}{c}\text { within } 15 \\
\text { min. after the } \\
\text { mainshock, } \\
\text { and later } \\
\text { during the } \\
\text { day } \\
\text { (many events) }\end{array}$ & Sausalito & Marin & & $\begin{array}{c}\text { Sausalito Newws, } \\
21 \text { Apr 1906; p. 1, c. 3-4 }\end{array}$ & $\begin{array}{l}\text { "... Within fifteen minutes after the first shock [the mainshock] } \\
\text { two slight shocks were felt, and had a tendency to increase the } \\
\text { alarm. During the day twelve or thirteen shocks followed...." }\end{array}$ \\
\hline
\end{tabular}


TABLE 1: Catalog of Aftershock Reports following from the Great 18 April 1906 California Earthquake

\begin{tabular}{|c|c|c|c|c|c|c|}
\hline Date Felt & $\begin{array}{l}\text { Time Felt } \\
\text { (PST) }\end{array}$ & $\begin{array}{l}\text { Location Felt } \\
\text { (City) }\end{array}$ & $\begin{array}{l}\text { Location Felt } \\
\text { (County) }\end{array}$ & $\begin{array}{c}\text { Unreliable? } \\
\text { Not Felt? }^{+}\end{array}$ & Source & Relevant Citations and other Notes \\
\hline 18-Apr-06 & $06: 15$ & San Francisco & San Francisco & & $\begin{array}{c}\text { Oakland Tribune, } \\
18 \text { Apr 1906; p. } 7, \text { c. } 1\end{array}$ & $\begin{array}{l}\text { "... At 6:15 a second sharp quake occurred, accentuating the } \\
\text { terror...." }\end{array}$ \\
\hline 18-Apr-06 & $06: 24$ & Boulder Creek & Santa Cruz & & $\begin{array}{l}\text { Santa Cruz Morning Sentinel, } \\
19 \text { Apr 1906; p. 1, c. } 4\end{array}$ & $\begin{array}{l}\text { "Another shock, not so severe as the first, was felt ... completing } \\
\text { the previous work of destruction." }\end{array}$ \\
\hline 18-Apr-06 & $06: 25$ & Boulder Creek & Santa Cruz & & $\begin{array}{l}\text { San Jose Mercury and Herald } \\
\text { (combined issue), } \\
19 \text { Apr 1906; p. 4, c. } 1\end{array}$ & $\begin{array}{l}\text { "Another shock, not so severe as the first, was felt ... completing } \\
\text { the previous work of destruction." }\end{array}$ \\
\hline 18-Apr-06 & $06: 27$ & Santa Clara & Santa Clara & & $\begin{array}{l}\text { San Jose Mercury and Herald } \\
\text { (combined issue), } \\
19 \text { Apr 1906; p. 4, c. } 7\end{array}$ & "minor shock" \\
\hline 18-Apr-06 & $06: 50$ & Santa Clara & Santa Clara & & $\begin{array}{l}\text { San Jose Mercury and Herald } \\
\text { (combined issue), } \\
19 \text { Apr 1906; p. 4, c. } 7\end{array}$ & "minor shock" \\
\hline 18-Apr-06 & $\begin{array}{c}\sim 05: 15 \text { to } \\
07: 15 \\
\text { (many events }\end{array}$ & Santa Cruz & Santa Cruz & & $\begin{array}{l}\text { Santa Cruz Morning Sentinel, } \\
19 \text { Apr 1906; p. 2, c. } 3\end{array}$ & $\begin{array}{l}\text { "... The worst shock lasted several minutes, ending at about 5:15 } \\
\text { A. M. Seven or eight minor shocks followed during the next } \\
\text { couple of hours...." }\end{array}$ \\
\hline 18-Apr-06 & \begin{tabular}{|c|}
$08: 00$, \\
other times \\
following the \\
mainshock \\
(many events
\end{tabular} & Oakland & Alameda & & $\begin{array}{c}\text { Oakland Herald, } \\
18 \text { Apr 1906; p. 3, c. 3-4 }\end{array}$ & $\begin{array}{l}\text { [quoting Professor Charles Burkhalter of the Chabot } \\
\text { Observatory:] "'... We have had several lighter shocks since the } \\
\text { big quake ... there have been a dozen or so, of which the shock at } 8 \\
\text { a. m. was of a magnitude which we would ordinarily consider a } \\
\text { hard earthquake, and yet in comparison to the great temblor of } \\
\text { three hours earlier was scarcely noticed....'” }\end{array}$ \\
\hline 18-Apr-06 & $08: 14$ & Oakland & Alameda & & $\begin{array}{c}\text { Oakland Herald, } \\
18 \text { Apr 1906; p. 3, c. 3-4 }\end{array}$ & $\begin{array}{l}\text { "After the terrible shocks at 5:13 o' clock this morning } \\
\text { Oaklanders hoped the earth would quit its terrible rockings, but } \\
\text { again, three hours later, or at 8:14 o'clock another tremblor came. } \\
\text { "It was mild in form, continuing for scarcely more than a second, } \\
\text { but was enough of a reminder of the horrors of three hours before } \\
\text { to cause great uneasiness." }\end{array}$ \\
\hline 18-Apr-06 & $08: 14$ & Sacramento & Sacramento & & $\begin{array}{c}\text { Sacramento Bee, } \\
18 \text { Apr 1906; p. 1, c. } 5\end{array}$ & $\begin{array}{l}\text { "A second shock occurred at 8:14 o'clock. It was but a slight } \\
\text { tremor, and lasted but a second. It was so slight, in fact, that it } \\
\text { was felt by but few people." }\end{array}$ \\
\hline 18-Apr-06 & $08: 15$ & San Francisco & San Francisco & & $\begin{array}{l}\text { Sacramento Bee, } \\
18 \text { Apr 1906; p. 1, c. 2-3 }\end{array}$ & $\begin{array}{l}\text { "SAN FRANCISCO, April 18, 8:15 a. m.- There has been another } \\
\text { shock which intensifies the panic. People have started to rush } \\
\text { into the streets, but the shock was of short duration and the alarm } \\
\text { subsided." }\end{array}$ \\
\hline 18-Apr-06 & $\begin{array}{c}08: 30 \\
\text { other times } \\
\text { during the } \\
\text { day } \\
\text { (several }\end{array}$ & Martinez & Contra Costa & & $\begin{array}{l}\text { Contra Costa Gazette, } \\
21 \text { Apr 1906; p. } 1, \text { c. } 3\end{array}$ & $\begin{array}{l}\text { "At 8:30 o' clock yesterday morning there was another shock and } \\
\text { during the day there were several others, but none serious enough } \\
\text { to do damage." } \\
\text { Although the newspaper was issued on } 21 \text { Apr, this article was }\end{array}$ \\
\hline
\end{tabular}


TABLE 1: Catalog of Aftershock Reports following from the Great 18 April 1906 California Earthquake

\begin{tabular}{|c|c|c|c|c|c|c|}
\hline Date Felt & $\begin{array}{l}\text { Time Felt } \\
\text { (PST) }\end{array}$ & $\begin{array}{l}\text { Location Felt } \\
\text { (City) }\end{array}$ & $\begin{array}{l}\text { Location Felt } \\
\text { (County) }\end{array}$ & \begin{tabular}{|c|} 
Unreliable? \\
Not Felt? $^{+}$
\end{tabular} & Source & Relevant Citations and other Notes \\
\hline & events) & & & & & $\begin{array}{l}\text { clearly written on } 19 \text { Apr, as it refers to the mainshock as having } \\
\text { occurred "yesterday." }\end{array}$ \\
\hline 18-Apr-06 & $\sim$ 10:00 & Santa Clara & Santa Clara & & $\begin{array}{l}\text { San Jose Mercury and Herald } \\
\text { (combined issue), } \\
19 \text { Apr 1906; p. 4, c. } 7\end{array}$ & "minor shock" \\
\hline 18-Apr-06 & 10:00 & Willits & Mendocino & & $\begin{array}{l}\text { Ukiah Republican Press, } \\
20 \text { Apr 1906; p. } 5 \text {, c. } 4\end{array}$ & $\begin{array}{l}\text { A hotel in Willits which was damaged during the mainshock "did } \\
\text { not fall until there was another shock at ten o'clock...." }\end{array}$ \\
\hline 18-Apr-06 & $\sim$ 10:12 & Mendocino & Mendocino & & $\begin{array}{l}\text { Mendocino Beacon, } \\
\text { 21 Apr 1906; p. 1, c. 1-2 }\end{array}$ & $\begin{array}{l}\text { "The next shock did not come until about five hours [after the } \\
\text { mainshock] and it was very light." }\end{array}$ \\
\hline 18-Apr-06 & $12: 29$ & Eureka & Humboldt & & $\begin{array}{l}\text { Humboldt Standard, } \\
18 \text { Apr 1906; p. 1, c. } 7\end{array}$ & $\begin{array}{l}\text { "... another quick but quite violent earthquake shock was felt in } \\
\text { the shape of what was described as two short tremors. It was } \\
\text { strong enough to cause people to run out of their houses and look } \\
\text { about. Of course, they could see nothing." }\end{array}$ \\
\hline 18-Apr-06 & $\begin{array}{l}\text { during the } \\
\text { noon hour }\end{array}$ & Eureka & Humboldt & & $\begin{array}{l}\text { Humboldt Times, } \\
19 \text { Apr 1906; p. 1, c. } 1\end{array}$ & $\begin{array}{l}\text { "[The mainshock] was followed by a less severe shock and } \\
\text { during the noon hour the last one." The two aftershocks were } \\
\text { described as "less violent motions" than the mainshock. }\end{array}$ \\
\hline 18-Apr-06 & $\sim$ 14:00 & Agnew & Santa Clara & & $\begin{array}{l}\text { San Jose Mercury and Herald } \\
\text { (combined issue), } \\
19 \text { Apr 1906; p. 4, c. 4-5 }\end{array}$ & $\begin{array}{l}\text { "The State Hospital for the Insane at Agnews lies in a mass of } \\
\text { ruins... The second shock that occurred about } 2 \text { o' clock terrified } \\
\text { the rescuing parties and part of the walls of the Administration } \\
\text { Building that remained standing fell to the ground with a crash." } \\
\text { See Table 5. }\end{array}$ \\
\hline 18-Apr-06 & 14:07 (?) & Santa Clara & Santa Clara & & $\begin{array}{l}\text { San Jose Mercury and Herald } \\
\text { (combined issue), } \\
19 \text { Apr 1906; p. } 4 \text {, c. } 7\end{array}$ & $\begin{array}{l}\text { "minor shock" } \\
\text { The minute of the time listed in the article is not completely legible. }\end{array}$ \\
\hline 18-Apr-06 & $14: 20$ & $\begin{array}{l}\text { Southampton } \\
\text { Shoal }\end{array}$ & San Francisco & & $\begin{array}{l}\text { Lawson (1908), } \\
\quad \text { vol. I, p. } 413\end{array}$ & $\begin{array}{l}\text { "Vertical throw north-south tremor 20s. before; no noise." } \\
\text { Duration } 5 \text { seconds. } \\
\text { See Table } 5 .\end{array}$ \\
\hline 18-Apr-06 & 14:20 & Stockton & San Joaquin & & $\begin{array}{l}\text { Lawson (1908), } \\
\text { vol. I, p. } 413\end{array}$ & $\begin{array}{l}\text { "Very light." } \\
\text { See Table } 5 .\end{array}$ \\
\hline 18-Apr-06 & 14:22 & Mare Island & Solano & & $\begin{array}{l}\text { Lawson (1908), } \\
\quad \text { vol. I, p. } 413\end{array}$ & $\begin{array}{l}\text { “Slight.” Duration 1-2 seconds. } \\
\text { See Table } 5 .\end{array}$ \\
\hline 18-Apr-06 & 14:22 (?) & Santa Clara & Santa Clara & & $\begin{array}{l}\text { San Jose Mercury and Herald } \\
\text { (combined issue), } \\
19 \text { Apr 1906; p. } 4, \text { c. } 7\end{array}$ & $\begin{array}{l}\text { "minor shock" } \\
\text { The minute of the time listed in the article is not completely legible. } \\
\text { See Table } 5 .\end{array}$ \\
\hline
\end{tabular}


TABLE 1: Catalog of Aftershock Reports following from the Great 18 April 1906 California Earthquake

\begin{tabular}{|c|c|c|c|c|c|c|}
\hline Date Felt & $\begin{array}{l}\text { Time Felt } \\
\text { (PST) }\end{array}$ & $\begin{array}{l}\text { Location Felt } \\
\text { (City) }\end{array}$ & $\begin{array}{l}\text { Location Felt } \\
\text { (County) }\end{array}$ & $\begin{array}{l}\text { Unreliable? } \\
\text { Not Felt? }^{+}\end{array}$ & Source & Relevant Citations and other Notes \\
\hline 18-Apr-06 & $14: 23: 10$ & Mount Hamilton & Santa Clara & & $\begin{array}{l}\text { Lawson (1908), } \\
\text { vol. I, p. } 413\end{array}$ & $\begin{array}{l}\text { Lawson (1908) estimates Rossi-Forel intensity II } \\
\text { See Table 5. }\end{array}$ \\
\hline 18-Apr-06 & $14: 24$ & San Francisco & San Francisco & & $\begin{array}{l}\text { Lawson (1908), } \\
\text { vol. I, p. } 413\end{array}$ & $\begin{array}{l}\text { "Very light." } \\
\text { See Table } 5 .\end{array}$ \\
\hline 18-Apr-06 & $14: 24: 37$ & Berkeley & Alameda & & $\begin{array}{l}\text { Lawson (1908), } \\
\text { vol. I, p. } 413\end{array}$ & $\begin{array}{l}\text { Ewing seismograph recording } \\
\text { See Table } 5 .\end{array}$ \\
\hline 18-Apr-06 & 14:25 & San Francisco & San Francisco & & $\begin{array}{l}\text { Lawson (1908), } \\
\text { vol. I, p. } 413\end{array}$ & $\begin{array}{l}\text { Duration } 4 \text { seconds. Lawson (1908) estimates Rossi-Forel } \\
\text { intensity III. } \\
\text { See Table } 5 .\end{array}$ \\
\hline 18-Apr-06 & 14:25 & $\begin{array}{c}\text { Alameda } \\
\text { (Alameda Pier) }\end{array}$ & Alameda & & $\begin{array}{l}\text { Lawson (1908), } \\
\text { vol. I, p. } 413\end{array}$ & $\begin{array}{l}\text { felt } \\
\text { See Table } 5 .\end{array}$ \\
\hline 18-Apr-06 & $14: 25$ & Modesto & Stanislaus & & $\begin{array}{l}\text { Modesto Daily Evening News, } \\
18 \text { Apr 1906; p. } 1, \text { c. } 4\end{array}$ & $\begin{array}{l}\text { “... another distinct shock of earthquake was felt in Modesto, } \\
\text { being especially noticeable in the downtown business blocks...." } \\
\text { See Table } 5 .\end{array}$ \\
\hline 18-Apr-06 & 14:25 & Los Gatos & Santa Clara & & $\begin{array}{l}\text { Lawson (1908), } \\
\text { vol. I, p. } 413\end{array}$ & $\begin{array}{l}\text { felt } \\
\text { See Table } 5 .\end{array}$ \\
\hline 18-Apr-06 & $14: 25$ & Salinas & Monterey & & $\begin{array}{l}\text { San Luis Obispo Tribune, } \\
20 \text { Apr 1906; p. } 1, \text { c. } 4\end{array}$ & $\begin{array}{l}\text { "Salinas April 18:-.... There were three distinct shocks here this } \\
\text { morning followed by } 3 \text { more at } 2: 25 \text { o' clock this afternoon...." } \\
\text { See Table } 5 \text {. }\end{array}$ \\
\hline 18-Apr-06 & 14:25 & Salinas & Monterey & & $\begin{array}{l}\text { Lawson (1908), } \\
\text { vol. I, p. } 413\end{array}$ & $\begin{array}{l}\text { felt } \\
\text { See Table } 5 .\end{array}$ \\
\hline 18-Apr-06 & $14: 27$ & Mare Island & Solano & & $\begin{array}{l}\text { Lawson (1908), } \\
\text { vol. I, p. } 413\end{array}$ & $\begin{array}{l}\text { "Slight." Duration 1-2 seconds. } \\
\text { See Table } 5 .\end{array}$ \\
\hline 18-Apr-06 & $14: 28$ & San Francisco & San Francisco & & $\begin{array}{l}\text { Lawson (1908), } \\
\text { vol. I, p. } 413\end{array}$ & $\begin{array}{l}\text { "Very light." } \\
\text { See Table } 5 .\end{array}$ \\
\hline 18-Apr-06 & $\begin{array}{c}14: 28, \\
\text { other times } \\
\text { (many events) }\end{array}$ & Salinas & Monterey & & $\begin{array}{l}\text { Salinas Weekly Journal, } \\
21 \text { Apr 1906; p. 3, c. 2-3 }\end{array}$ & $\begin{array}{l}\text { Under the heading "From Thursday's Daily Journal": } \\
\text { "... During the day and until midnight slight shocks, to the number } \\
\text { of twenty or more, kept our people in a state of nervous suspense. } \\
\text { A frisky one at 2:28 sent people running pell mell into the streets." } \\
\text { The daily version of the paper was printed in the morning, so the } \\
\text { events discussed above must have occurred on Wednesday. From }\end{array}$ \\
\hline
\end{tabular}


TABLE 1: Catalog of Aftershock Reports following from the Great 18 April 1906 California Earthquake

\begin{tabular}{|c|c|c|c|c|c|c|}
\hline Date Felt & $\begin{array}{l}\text { Time Felt } \\
\text { (PST) }\end{array}$ & $\begin{array}{l}\text { Location Felt } \\
\text { (City) }\end{array}$ & $\begin{array}{l}\text { Location Felt } \\
\text { (County) }\end{array}$ & $\begin{array}{l}\text { Unreliable? } \\
\text { Not Felt? }^{+}\end{array}$ & Source & Relevant Citations and other Notes \\
\hline & & & & & & $\begin{array}{l}\text { the context, } 2: 28 \text { is inferred to be in the afternoon. } \\
\text { See Table } 5 .\end{array}$ \\
\hline 18-Apr-06 & $14: 28: 36$ & Mount Hamilton & Santa Clara & & $\begin{array}{l}\text { Lawson (1908), } \\
\text { vol. I, p. } 413\end{array}$ & $\begin{array}{l}\text { Lawson (1908) estimates Rossi-Forel intensity III } \\
\text { See Table } 5 .\end{array}$ \\
\hline 18-Apr-06 & $14: 28: 50$ & Berkeley & Alameda & & $\begin{array}{l}\text { Lawson (1908), } \\
\text { vol. I, p. } 413\end{array}$ & See Table 5. \\
\hline 18-Apr-06 & $14: 29$ & Sacramento & Sacramento & & $\begin{array}{l}\text { Lawson (1908), } \\
\text { vol. I, p. } 413\end{array}$ & $\begin{array}{l}\text { "Very light." } \\
\text { See Table } 5 .\end{array}$ \\
\hline $\begin{array}{l}\text { 18-Apr-06 to } \\
21-A p r-06\end{array}$ & $\begin{array}{l}\text { just before } \\
\text { 14:30 on } \\
18 \mathrm{Apr}, \\
\text { other times } \\
\text { (many events }\end{array}$ & Boulder Creek & Santa Cruz & & $\begin{array}{c}\text { Mountain Echo (Boulder Creek) } \\
21 \text { Apr 1906; p. 3, c. } 1\end{array}$ & $\begin{array}{l}\text { "There have been numerous light shocks of earthquake every day } \\
\text { since Wednesday and on Wednesday afternoon there were two } \\
\text { quite heavy shocks just before half past two o'clock." } \\
\text { See Table } 5 .\end{array}$ \\
\hline 18-Apr-06 & $14: 30$ & Antioch & Contra Costa & & $\begin{array}{l}\text { Lawson (1908), } \\
\text { vol. I, p. } 413\end{array}$ & $\begin{array}{l}\text { felt } \\
\text { See Table } 5 .\end{array}$ \\
\hline 18-Apr-06 & $14: 30$ & $\begin{array}{l}4 \text { miles south of } \\
\text { Wright's Station } \\
\text { (now } \\
4 \text { miles south } \\
\text { of Wrights) }\end{array}$ & Santa Cruz & & $\begin{array}{l}\text { Lawson (1908), } \\
\text { vol. I, p. } 413\end{array}$ & $\begin{array}{l}\text { "Slight." } \\
\text { The locality given in Lawson (1908) is " } 4 \text { miles south of Wright's } \\
\text { Station." According to Durham (1998), Wright's Station is an old } \\
\text { name for Wrights, a village in Santa Clara County, near the Santa } \\
\text { Cruz County line. Four miles south of this point would be in Santa } \\
\text { Cruz County. } \\
\text { See Table } 5 .\end{array}$ \\
\hline 18-Apr-06 & $14: 30$ & Scotts Valley & Santa Cruz & & $\begin{array}{l}\text { Lawson (1908), } \\
\text { vol. I, p. } 413\end{array}$ & $\begin{array}{l}\text { "Extra hard, stopt clock hanging on wall facing south, 20" pend. } \\
\text { Stopt clock facing NW. by WNW., pend. about 5"." Lawson } \\
\text { (1908) estimates Rossi-Forel intensity IV. } \\
\text { See Table 5. }\end{array}$ \\
\hline 18-Apr-06 & afternoon & San Simeon & San Luis Obispo & & $\begin{array}{l}\text { Lawson (1908), } \\
\text { vol. I, p. } 299\end{array}$ & $\begin{array}{l}\text { "... at San Simeon ... the shock of the afternoon (of April 18) was } \\
\text { also noticed, which was not the case farther south...." } \\
\text { See Table } 5 .\end{array}$ \\
\hline 18-Apr-06 & $18: 00$ & Martinez & Contra Costa & & $\begin{array}{l}\text { Call-Chronicle-Examiner } \\
\text { (San Francisco, } \\
\text { special combined issue), } \\
19 \text { Apr 1906; p. 4, c. 2-3 }\end{array}$ & $\begin{array}{l}\text { "OAKLAND, April 18.-.... Another heavy shock was felt at } \\
\text { Martinez at } 6 \text { o' clock tonight, which still further wrecked the } \\
\text { already tottering buildings, and should there be any further } \\
\text { disturbance, many of them will collapse...." } \\
\text { A very similar article appeared in the Marin Journal of } 19 \text { Apr } \\
\text { 1906, p. 1, c. 3. }\end{array}$ \\
\hline
\end{tabular}


TABLE 1: Catalog of Aftershock Reports following from the Great 18 April 1906 California Earthquake

\begin{tabular}{|c|c|c|c|c|c|c|}
\hline Date Felt & $\begin{array}{l}\text { Time Felt } \\
\text { (PST) }\end{array}$ & $\begin{array}{l}\text { Location Felt } \\
\text { (City) }\end{array}$ & $\begin{array}{l}\text { Location Felt } \\
\text { (County) }\end{array}$ & $\begin{array}{l}\text { Unreliable? } \\
\text { Not Felt? }\end{array}$ & Source & Relevant Citations and other Notes \\
\hline 18-Apr-06 & $18: 50$ & Santa Clara & Santa Clara & & $\begin{array}{c}\text { San Jose Mercury and Herald } \\
\text { (combined issue), } \\
19 \text { Apr 1906; p. 4, c. } 7\end{array}$ & "minor shock" \\
\hline 18-Apr-06 & 19:00 & Sacramento & Sacramento & & $\begin{array}{l}\text { Sacramento Union, } \\
19 \text { Apr 1906; p. 9, c. } 7\end{array}$ & $\begin{array}{l}\text { "At } 7 \text { o'clock last evening another slight shock of earthquake } \\
\text { was felt in this city.... The shock was perceptibly felt, but was } \\
\text { nothing as compared with that of the early morning." }\end{array}$ \\
\hline 18-Apr-06 & 19:30 & San Francisco & San Francisco & & $\begin{array}{l}\text { Sacramento Bee, } \\
20 \text { Apr 1906; p. } 5, \text { c. } 3\end{array}$ & $\begin{array}{l}\text { "... [the] temblor was of such force as to drive men, women and } \\
\text { children in terror from the Ferry Building, and to make the street } \\
\text { shake under foot, as though it were about to open up. It did no } \\
\text { damage, however...." }\end{array}$ \\
\hline 18-Apr-06 & $22: 55$ & $\begin{array}{c}\text { Avila } \\
\text { (now Avila Beach) }\end{array}$ & San Luis Obispo & & $\begin{array}{l}\text { San Luis Obispo Tribune, } \\
20 \text { Apr 1906; p. 1, c. } 6\end{array}$ & $\begin{array}{l}\text { "Avila, April 18:-At 10:55 tonight another heavy and distinct } \\
\text { earthquake shock was felt. It was almost as heavy as the one this } \\
\text { morning." } \\
\text { This aftershock was apparently only reported from Avila Beach, } \\
\text { which suggests that its location was near Avila Beach. It is worth } \\
\text { noting that Avila Beach is } 200 \mathrm{~km} \text { SSE of San Juan Bautista, the } \\
\text { southern limit of the mainshock rupture. This distance is nearly } \\
\text { equal to half the rupture length away from the rupture itself. }\end{array}$ \\
\hline 18-Apr-06 & \begin{tabular}{c|} 
various \\
(many events)
\end{tabular} & Santa Cruz & Santa Cruz & & $\begin{array}{l}\text { Santa Cruz Morning Sentinel, } \\
19 \text { Apr 1906; p. 2, c. } 3\end{array}$ & $\begin{array}{l}\text { "... The earthquakes in Santa Cruz Wednesday were heavy and } \\
\text { numerous, but they killed no one and only slightly hurt a few...." }\end{array}$ \\
\hline 18-Apr-06 & $\begin{array}{c}\begin{array}{c}\text { during the } \\
\text { day } \\
\text { (four events) }\end{array} \\
\text { (1) }\end{array}$ & $\begin{array}{l}\text { Point Reyes } \\
\text { Lighthouse }\end{array}$ & Marin & & $\begin{array}{l}\text { Lighthouse Log for } \\
\text { Point Reyes Lighthouse, } \\
18 \text { Apr } 1906\end{array}$ & $\begin{array}{l}\text { Excerpts from the entry of } 18 \text { Apr 1906: } \\
\text { "A heavy shock of earthquak [sic] occurred at about } 5 \text { AM this } \\
\text { morning ... four more light shocks during the day...." }\end{array}$ \\
\hline 18-Apr-06 & $\begin{array}{c}\text { during the } \\
\text { day } \\
\text { (many events }\end{array}$ & Sausalito & Marin & & $\begin{array}{l}\text { Stockton Daily Evening Record, } \\
23 \text { Apr 1906; p. 5, c. } 2\end{array}$ & $\begin{array}{l}\text { "SAUSALITO, April 23.-After the great earthquake on } \\
\text { Wednesday morning ten or twelve minor shocks were felt during } \\
\text { the day...." }\end{array}$ \\
\hline 18-Apr-06 & $\begin{array}{l}\text { during the } \\
\text { day } \\
\text { (several } \\
\text { events) }\end{array}$ & $\begin{array}{c}\text { Napa Redwoods } \\
{[7 \mathrm{mi} \text { NE of }} \\
\text { Sonoma (?)] }\end{array}$ & Napa & & $\begin{array}{l}\text { Napa Daily Journal, } \\
28 \text { Apr 1906; p. 2, c. } 2\end{array}$ & $\begin{array}{l}\text { "During the day of April 18th there were several distinct shocks } \\
\text { felt...." } \\
\text { This was part of an article written by a regular correspondent, } \\
\text { dated "Napa Redwoods, April 27, 1906." }\end{array}$ \\
\hline 18-Apr-06 & \begin{tabular}{|c|} 
at intervals \\
during the \\
day and night \\
(many events
\end{tabular} & St. Helena & Napa & & $\begin{array}{l}\text { St. Helena Star, } \\
20 \text { Apr 1906; p. 3, c. } 4\end{array}$ & $\begin{array}{l}\text { "Slight shocks of earthquake were felt at intervals during } \\
\text { Wednesday and Wednesday night...." }\end{array}$ \\
\hline $\begin{array}{l}\text { 18-Apr-06 and } \\
\text { 19-Apr-06 }\end{array}$ & $\begin{array}{c}\text { at intervals } \\
\text { (many events) }\end{array}$ & San Francisco & San Francisco & & $\begin{array}{c}\text { Sacramento Bee, } \\
20 \text { Apr 1906; p. 5, c. 2-3 }\end{array}$ & $\begin{array}{l}\text { "... There were earthquakes at intervals during the day and night, } \\
\text { Wednesday and Thursday...." }\end{array}$ \\
\hline
\end{tabular}


TABLE 1: Catalog of Aftershock Reports following from the Great 18 April 1906 California Earthquake

\begin{tabular}{|c|c|c|c|c|c|c|}
\hline Date Felt & $\begin{array}{l}\text { Time Felt } \\
\text { (PST) }\end{array}$ & $\begin{array}{l}\text { Location Felt } \\
\text { (City) }\end{array}$ & $\begin{array}{l}\text { Location Felt } \\
\text { (County) }\end{array}$ & $\begin{array}{l}\text { Unreliable? } \\
\text { Not Felt? }\end{array}$ & Source & Relevant Citations and other Notes \\
\hline $\begin{array}{l}\text { 18-Apr-06 to } \\
\text { 19-Apr-06 }\end{array}$ & $\begin{array}{c}\text { night of } \\
18 \text { Apr to } \\
14: 0019 \text { Apr } \\
\text { (many events }\end{array}$ & Santa Cruz & Santa Cruz & & $\begin{array}{l}\text { Salinas Daily Index, } \\
19 \text { Apr 1906; p. 3, c. } 5\end{array}$ & $\begin{array}{l}\text { "... During last night and today up to } 2 \text { o'clock seventy minor } \\
\text { shocks have occurred and the people are very uneasy." }\end{array}$ \\
\hline $\begin{array}{l}\text { 18-Apr-06 to } \\
\text { 19-Apr-06 }\end{array}$ & $\mid \begin{array}{ccc}\text { 17:00 } 18 \text { Apr } \\
\text { to } \\
\text { 18:00 } 19 \text { Apr } \\
\text { (many events }\end{array}$ & $\begin{array}{c}\text { Salinas } \\
\text { Santa Cruz }\end{array}$ & $\begin{array}{l}\text { Monterey } \\
\text { Santa Cruz }\end{array}$ & & $\begin{array}{l}\text { San Luis Obispo Tribune, } \\
\text { 24 Apr 1906; p. 3, c. } 1-2\end{array}$ & $\begin{array}{l}\text { "Salinas, April 19:-Sixty-two distinct shocks have been counted } \\
\text { here between } 5 \text { o'clock yesterday afternoon and } 6 \text { o'clock this } \\
\text { evening. They are slight.... } \\
\text { "Reports from Santa Cruz are that } 71 \text { shocks were counted } \\
\text { there." }\end{array}$ \\
\hline 19-Apr-06 & $\begin{array}{l}\text { (early) } \\
\text { morning }\end{array}$ & Berkeley & Alameda & & $\begin{array}{l}\text { Visalia Daily Times, } \\
21 \text { Apr 1906; p. 5, c. } 3\end{array}$ & $\begin{array}{l}\text { "The following letter was received by Mrs. Ben M. Maddox } \\
\text { today from her son who is a student at the State University at } \\
\text { Berkeley: } \\
\text { "BERKELEY, Cal., April 19th.... } \\
\text { "Just as I was about to go to sleep this morning there was another } \\
\text { earthquake that shook down a few chimneys, and after that I } \\
\text { thought I never would go to sleep. There were twenty-five } \\
\text { different shocks yesterday up to midnight and you can imagine } \\
\text { how nervous every one is. Ihave not felt any today and hope } \\
\text { they are all over...." }\end{array}$ \\
\hline 19-Apr-06 & $11: 00$ & $\begin{array}{l}\text { Point Arena } \\
\text { Lighthouse }\end{array}$ & Mendocino & & $\begin{array}{l}\text { Lighthouse Log for } \\
\text { Point Arena Lighthouse, } \\
19 \text { Apr } 1906\end{array}$ & $\begin{array}{l}\text { Excerpt from the entry of } 19 \text { Apr 1906: } \\
\text { "Slight shock } 11 \text { a.m." }\end{array}$ \\
\hline 19-Apr-06 & $14: 25(?)$ & Salinas & Monterey & & $\begin{array}{l}\text { Salinas Weekly Journal, } \\
21 \text { Apr 1906; p. 2, c. } 4\end{array}$ & $\begin{array}{l}\text { Under the heading "From Friday's Daily Journal": } \\
\text { "There were several slight shocks of earthquake felt here } \\
\text { yesterday, several of which were sharp enough to send people } \\
\text { rushing pell-mell into the streets. The quakes at } 2: 25,2: 37 \text { and } \\
6: 02 \text { were quite strong, especially the last. Tremors of very slight } \\
\text { force were continually occurring and kept people's nerves on } \\
\text { edge." } \\
\text { From the context it is inferred that these quakes took place in the } \\
\text { afternoon, although they may have taken place in the early morning. }\end{array}$ \\
\hline 19-Apr-06 & 14:37 (?) & Salinas & Monterey & & $\begin{array}{l}\text { Salinas Weekly Journal, } \\
21 \text { Apr 1906; p. 2, c. } 4\end{array}$ & $\begin{array}{l}\text { Under the heading "From Friday's Daily Journal": } \\
\text { "There were several slight shocks of earthquake felt here } \\
\text { yesterday, several of which were sharp enough to send people } \\
\text { rushing pell-mell into the streets. The quakes at } 2: 25,2: 37 \text { and } \\
\text { 6:02 were quite strong, especially the last. Tremors of very slight } \\
\text { force were continually occurring and kept people's nerves on } \\
\text { edge." } \\
\text { From the context it is inferred that these quakes took place in the } \\
\text { afternoon, although they may have taken place in the early morning. }\end{array}$ \\
\hline
\end{tabular}


TABLE 1: Catalog of Aftershock Reports following from the Great 18 April 1906 California Earthquake

\begin{tabular}{|c|c|c|c|c|c|c|}
\hline Date Felt & $\begin{array}{l}\text { Time Felt } \\
\text { (PST) }\end{array}$ & $\begin{array}{l}\text { Location Felt } \\
\quad \text { (City) }\end{array}$ & $\begin{array}{l}\text { Location Felt } \\
\text { (County) }\end{array}$ & $\begin{array}{l}\text { Unreliable? } \\
\text { Not Felt? }^{+}\end{array}$ & Source & Relevant Citations and other Notes \\
\hline 19-Apr-06 & $\begin{array}{l}\text { shortly after } \\
15: 00 \\
\text { (several } \\
\text { events) }\end{array}$ & Salinas & Monterey & & $\begin{array}{l}\text { Fresno Morning Republican, } \\
20 \text { Apr 1906; p. 10, c. } 1\end{array}$ & $\begin{array}{l}\text { "SANTA BARBARA, April 19.-A special telephone message to } \\
\text { the Morning Press from Salinas states that that town suffered } \\
\text { from two distinct shocks shortly after } 3 \text { o' clock this afternoon. } \\
\text { As the message was coming over the wire, still another shock was } \\
\text { felt in the city. Although today's earthquakes have done very } \\
\text { little damage in Salinas, the inhabitants are greatly disturbed and } \\
\text { fear a repetition of Wednesday's disaster, which did damage to } \\
\text { property." }\end{array}$ \\
\hline 19-Apr-06 & 18:02 (?) & Salinas & Monterey & & $\begin{array}{l}\text { Salinas Weekly Journal, } \\
21 \text { Apr } 1906 ; \text { p. } 2 \text {, c. } 4\end{array}$ & $\begin{array}{l}\text { Under the heading "From Friday's Daily Journal": } \\
\text { "There were several slight shocks of earthquake felt here } \\
\text { yesterday, several of which were sharp enough to send people } \\
\text { rushing pell-mell into the streets. The quakes at } 2: 25,2: 37 \text { and } \\
\text { 6:02 were quite strong, especially the last. Tremors of very slight } \\
\text { force were continually occurring and kept people's nerves on } \\
\text { edge." } \\
\text { From the context it is inferred that these quakes took place in the } \\
\text { afternoon, although they may have taken place in the early morning. }\end{array}$ \\
\hline 19-Apr-06 & $\begin{array}{l}\text { during the } \\
\text { day } \\
\text { (several } \\
\text { events) }\end{array}$ & Hollister & San Benito & & $\begin{array}{l}\text { Salinas Daily Index, } \\
19 \text { Apr 1906; p. 3, c. } 6\end{array}$ & $\begin{array}{l}\text { "A dispatch from Hollister this afternoon was to the effect that ... } \\
\text { several slight shocks had been felt there during today." }\end{array}$ \\
\hline 19-Apr-06 & evening & Willits & Mendocino & & $\begin{array}{l}\text { Ukiah Republican Press, } \\
20 \text { Apr } 1906 \text { "Extra" edition; } \\
\text { p. } 1, \text { c. } 2\end{array}$ & $\begin{array}{l}\text { "Willits, } 4 \mathrm{p} \mathrm{m- \ldots ..} \mathrm{The} \mathrm{earthquakes} \mathrm{commenced} \mathrm{again} \mathrm{last} \\
\text { evening and two light shocks were felt...." } \\
\text { See the note following the report from this newspaper of the event } \\
\text { at "a few minutes before 16:00" on } 20 \text { Apr. }\end{array}$ \\
\hline 19-Apr-06 & $\begin{array}{c}\text { night } \\
\text { (or early } \\
\text { morning of } \\
\text { 20-Apr-06) }\end{array}$ & Willits & Mendocino & & $\begin{array}{l}\text { Humboldt Times, } \\
21 \text { Apr 1906; p. 1, } \\
\text { box under headline }\end{array}$ & $\begin{array}{l}\text { "WILLITS, April 20.-Two light shocks were felt at this place } \\
\text { last night...." }\end{array}$ \\
\hline 20-Apr-06 & $\sim 00: 30$ & Ferndale & Humboldt & & $\begin{array}{l}\text { Humboldt Standard, } \\
21 \text { Apr 1906; p. 4, c. } 4\end{array}$ & $\begin{array}{l}\text { "... slight.... No damage was done, but much nervousness was felt." } \\
\text { The last sentence was a general statement about all the earthquakes } \\
\text { felt early that morning in Ferndale. }\end{array}$ \\
\hline 20-Apr-06 & $00: 45$ & Burnt Ranch & Trinity & & $\begin{array}{l}\text { Humboldt Standard, } \\
27 \text { Apr 1906; p. 6, c. } 2\end{array}$ & $\begin{array}{l}\text { "... another quake shook us up and that event was harder than } \\
\text { that of Wednesday [April 18], but in other sections people say it } \\
\text { was not so hard." }\end{array}$ \\
\hline 20-Apr-06 & $01: 45$ & Willits & Mendocino & & $\begin{array}{l}\text { Ukiah Republican Press, } \\
20 \text { Apr } 1906 \text { "Extra" edition; } \\
\text { p. } 1, \text { c. } 2\end{array}$ & $\begin{array}{l}\text { "Willits, } 4 \mathrm{pm} \text { m-.... At quarter of two this morning a heavy shock } \\
\text { was felt...." } \\
\text { See the note following the report from this newspaper of the event } \\
\text { at "a few minutes before 16:00" on } 20 \text { Apr. }\end{array}$ \\
\hline
\end{tabular}


TABLE 1: Catalog of Aftershock Reports following from the Great 18 April 1906 California Earthquake

\begin{tabular}{|c|c|c|c|c|c|c|}
\hline Date Felt & $\begin{array}{l}\text { Time Felt } \\
\text { (PST) }\end{array}$ & $\begin{array}{l}\text { Location Felt } \\
\text { (City) }\end{array}$ & $\begin{array}{l}\text { Location Felt } \\
\text { (County) }\end{array}$ & \begin{tabular}{|c|} 
Unreliable? \\
Not Felt? $^{+}$
\end{tabular} & Source & Relevant Citations and other Notes \\
\hline 20-Apr-06 & 02:00 & Blocksburg & Humboldt & & $\begin{array}{l}\text { Humboldt Standard, } \\
26 \text { Apr 1906; p. 6, c. } 1\end{array}$ & "a shock at 2 a.m." \\
\hline 20-Apr-06 & $\sim 03: 00$ & Ferndale & Humboldt & & $\begin{array}{l}\text { Humboldt Standard, } \\
21 \text { Apr 1906; p. } 4, \text { c. } 4\end{array}$ & $\begin{array}{l}\text { "... slight ... two [shocks] at about } 3 \text { o'clock.... No damage was } \\
\text { done, but much nervousness was felt." } \\
\text { The last sentence was a general statement about all the earthquakes } \\
\text { felt early that morning in Ferndale. }\end{array}$ \\
\hline 20-Apr-06 & 03:00 & Eureka & Humboldt & & $\begin{array}{c}\text { Humboldt Times, } \\
20 \text { Apr 1906; p. 1, c. 6-7 }\end{array}$ & $\begin{array}{l}\text { "At exactly three o' clock this morning occurred another } \\
\text { earthquake, not so severe as the first one of Tuesday morning, but } \\
\text { sufficiently shocking to awaken a large number of people and } \\
\text { cause those who already had their eyes open to hike towards the } \\
\text { open. It is likely that some few panes of glass were broken and } \\
\text { other minor damage done, which will be discovered by the good } \\
\text { householders this morning. That people's nerves are on edge } \\
\text { regarding earthquakes in general is evidenced by the fact that } \\
\text { when this tremor was felt, people began to appear on the streets } \\
\text { in abbreviated attire and were soon discussing this late reminder } \\
\text { of the recent catastrophe." } \\
\text { The "first one" referred to is almost certainly the mainshock of } \\
\text { Wednesday morning, } 18 \text { Apr. }\end{array}$ \\
\hline 20-Apr-06 & 04:50 & Napa & Napa & & $\begin{array}{l}\text { Napa Daily Journal, } \\
3 \text { May 1906; p. } 3, \text { c. } 4\end{array}$ & "slight shock" \\
\hline 20-Apr-06 & 04:50 & St. Helena & Napa & & $\begin{array}{l}\text { St. Helena Star, } \\
20 \text { Apr 1906; p. 3, c. } 4\end{array}$ & $\begin{array}{l}\text { "... There were two distinct but slight shocks at } 4: 50 \text { o' clock this } \\
\text { morning." }\end{array}$ \\
\hline $\begin{array}{l}\text { 18-Apr-06 to } \\
20-A p r-06\end{array}$ & $\begin{array}{c}\text { 05:00 } 18 \text { Apr } \\
\text { to } \\
\text { 05:00 } 20 \text { Apr } \\
\text { (many events }\end{array}$ & Watsonville & Santa Cruz & & $\begin{array}{l}\text { Evening Pajaronian } \\
\text { (Watsonville), } \\
20 \text { Apr 1906; p. 1, c. } 3\end{array}$ & $\begin{array}{l}\text { "Up to } 5 \text { o'clock this morning, forty-eight hours after the big } \\
\text { earthquake, half a hundred smaller shakes and temblors have } \\
\text { been felt in Watsonville. No damage has been done by the little } \\
\text { fellows, except to the nerves of the frightened...." }\end{array}$ \\
\hline 20-Apr-06 & $\sim 05: 15$ & Ferndale & Humboldt & & $\begin{array}{l}\text { Humboldt Standard, } \\
21 \text { Apr 1906; p. 4, c. } 4\end{array}$ & $\begin{array}{l}\text { "... slight.... No damage was done, but much nervousness was felt." } \\
\text { The last sentence was a general statement about all the earthquakes } \\
\text { felt early that morning in Ferndale. }\end{array}$ \\
\hline 20-Apr-06 & morning & San Francisco & San Francisco & & $\begin{array}{l}\text { Diary of Charles Prinegar } \\
\text { (San Francisco, CA), } \\
20 \text { Apr 1906 (pp. 6-7) }\end{array}$ & $\begin{array}{l}\text { Excerpts from the entry of } 20 \text { Apr 1906: } \\
\text { "(This is Friday morning).... } \\
\text { "There was another earth-quake this morning that shook us up } \\
\text { some, but we were on the ground so no damage was done...." }\end{array}$ \\
\hline 20-Apr-06 & \begin{tabular}{|c|} 
afternoon \\
(two events)
\end{tabular} & San Francisco & San Francisco & & $\begin{array}{l}\text { Diary of Charles Prinegar } \\
\text { (San Francisco, CA), } \\
20 \text { Apr } 1906 \text { (pp. 8-13) }\end{array}$ & $\begin{array}{l}\text { Excerpts from the entry of } 20 \text { Apr 1906: } \\
\text { “(Friday P. M.) } \\
\text { “.... }\end{array}$ \\
\hline
\end{tabular}


TABLE 1: Catalog of Aftershock Reports following from the Great 18 April 1906 California Earthquake

\begin{tabular}{|c|c|c|c|c|c|c|}
\hline Date Felt & $\begin{array}{l}\text { Time Felt } \\
\text { (PST) }\end{array}$ & $\begin{array}{c}\text { Location Felt } \\
\text { (City) }\end{array}$ & $\begin{array}{l}\text { Location Felt } \\
\text { (County) }\end{array}$ & $\begin{array}{l}\text { Unreliable? } \\
\text { Not Felt? }^{+}\end{array}$ & Source & Relevant Citations and other Notes \\
\hline & & & & & & $\begin{array}{l}\text { "Just as I was writing the last sentence we had another light } \\
\text { shock that shook my false teeth loose.... } \\
\text { "A great many people think that after the fire is all over that all } \\
\text { of this land that San Francisco was built on will all go down in } \\
\text { the ocean again, for they say that it was an earth-quake that } \\
\text { raised this up out of the ocean and that it will all go back some } \\
\text { day. There goes another small one. They are getting smaller all } \\
\text { the time. I hope they will stop before some thing does happen. I } \\
\text { think that we have had enough experience for once...." }\end{array}$ \\
\hline 20-Apr-06 & $\begin{array}{l}\text { a few minutes } \\
\text { before } 16: 00\end{array}$ & Willits & Mendocino & unreliable & $\begin{array}{c}\text { Ukiah Republican Press, } \\
20 \text { Apr } 1906 \text { "Extra" edition; } \\
\text { p. 1, c. } 2\end{array}$ & $\begin{array}{l}\text { "Willits, } 4 \mathrm{p} \mathrm{m} \text {-Willits is still suffering from earthquakes and } \\
\text { the building owned by Mrs N M Vincent on Main street... has } \\
\text { just fallen as the result of a shock a few minutes ago. The } \\
\text { remainder The Irvine \& Muir Cos store which was partially } \\
\text { demolished Wednesday morning has gone down as has also the } \\
\text { rear walls of the McElroy building.... } \\
\text { "These buildings were all one story bricks and had been damaged } \\
\text { by former shocks. The earthquakes commenced again last evening } \\
\text { and two light shocks were felt. At quarter of two this morning a } \\
\text { heavy shock was felt and the one this afternoon completed the } \\
\text { damage. The one story wooden dwelling of C F Vincent was } \\
\text { thrown from its foundations and overturned." } \\
\text { A note under the heading "An Explanation" on p. } 4, \text { c. } 1-2 \text { of the } 27 \\
\text { Apr } 1906 \text { issue of the Ukiah Republican Press recants this report- } \\
\text { it is not clear what part of the report, if any, is true and accurate: } \\
\text { "In an extra issued from this office Friday evening ... there was a } \\
\text { misstatement in a communication from Willits which set forth that } \\
\text { another earthquake had occurred at Willits and destroyed some } \\
\text { of the buildings which had been injured in the first shocks.... } \\
\text { [After the paper went to press,] word reached us that the message } \\
\text { was untrue...." }\end{array}$ \\
\hline 20-Apr-06 & 16:00 & Willits & Mendocino & unreliable & $\begin{array}{l}\text { Humboldt Times, } \\
21 \text { Apr 1906; } \mathrm{p} .1, \\
\text { box under headline }\end{array}$ & $\begin{array}{l}\text { "WILLITS, April 20.-Two light shocks were felt at this place } \\
\text { last night and one at four this afternoon which was heavier and } \\
\text { demolished the Vincent building on Main Street.... Irving and } \\
\text { Muir Company's store, which was damaged Wednesday morning, } \\
\text { was also ruined, as was a part of the McElroy block. The mud } \\
\text { springs at Jackson Valley were turned into miniature geysers and } \\
\text { are spouting several feet in the air." } \\
\text { See the note in the preceding entry, following the report published } \\
\text { in the Ukiah Republican Press for this event. As the two articles } \\
\text { are similar, and as the article in the Ukiah Republican Press was } \\
\text { later recanted, the accuracy of all the statements in this report (in } \\
\text { the Humboldt Times) should be called into question. }\end{array}$ \\
\hline
\end{tabular}


TABLE 1: Catalog of Aftershock Reports following from the Great 18 April 1906 California Earthquake

\begin{tabular}{|c|c|c|c|c|c|c|}
\hline Date Felt & $\begin{array}{l}\text { Time Felt } \\
\text { (PST) }\end{array}$ & $\begin{array}{l}\text { Location Felt } \\
\text { (City) }\end{array}$ & $\begin{array}{l}\text { Location Felt } \\
\text { (County) }\end{array}$ & $\begin{array}{l}\text { Unreliable? } \\
\text { Not Felt? }^{+}\end{array}$ & Source & Relevant Citations and other Notes \\
\hline 20-Apr-06 & $\begin{array}{c}\text { during the } \\
\text { day, before } \\
\text { the paper } \\
\text { went to press }\end{array}$ & Salinas & Monterey & Not Felt & $\begin{array}{c}\text { Salinas Daily Index, } \\
20 \text { Apr 1906; p. 3, c. } 5\end{array}$ & "There were no earthquakes today...." \\
\hline 20-Apr-06 & evening & Santa Maria & Santa Barbara & & $\begin{array}{c}\text { Santa Maria Times, } \\
21 \text { Apr 1906; p. 1, c. 5-6 }\end{array}$ & $\begin{array}{l}\text { "Several reported that there was another earthquake shock in } \\
\text { this city last evening...." } \\
\text { This aftershock was apparently only reported from Santa Maria, } \\
\text { which suggests that its location was near Santa Maria. It is worth } \\
\text { noting that Santa Maria is } 230 \mathrm{~km} \text { SSE of San Juan Bautista, the } \\
\text { southern limit of the mainshock rupture. This distance is slightly } \\
\text { more than half the rupture length away from the rupture itself. }\end{array}$ \\
\hline 20-Apr-06 & $20: 30$ & $\begin{array}{l}\text { Watsonville } \\
\text { Salinas }\end{array}$ & $\begin{array}{l}\text { Santa Cruz } \\
\text { Monterey }\end{array}$ & & $\begin{array}{l}\text { Salinas Daily Index, } \\
21 \text { Apr 1906; p. 3, c. } 3\end{array}$ & $\begin{array}{l}\text { "F. A. Kilburn, general manager of the Ford \& Sanborn Company, } \\
\text { was over from Watsonville this morning. He says that at } 8: 30 \\
\text { o'clock last evening the most severe shock, excepting the one of } \\
\text { Wednesday morning, was felt. No great damage was done, but the } \\
\text { residents were greatly alarmed and ran out of their homes. The } \\
\text { shock was also felt here, but nothing like as severe as at } \\
\text { Watsonville." }\end{array}$ \\
\hline 21-Apr-06 & 03:00 & Napa & Napa & & $\begin{array}{c}\text { Napa Daily Journal, } \\
\text { 3 May 1906; p. 3, c. } 4\end{array}$ & "slight shock" \\
\hline 22-Apr-06 & \begin{tabular}{|c|} 
shortly after \\
$11: 00$
\end{tabular} & Santa Cruz & Santa Cruz & & $\begin{array}{c}\text { Santa Cruz Surf, } \\
23 \text { Apr 1906; p. 6, c. } 4\end{array}$ & $\begin{array}{l}\text { "The shock shortly after } 11 \text { yesterday sort of dismissed the } \\
\text { Congregational Church congregation. The large church creaked } \\
\text { and trembled, the congregation arose, and then the pastor thought } \\
\text { best to dismiss the people." }\end{array}$ \\
\hline 22-Apr-06 & $\begin{array}{c}11: 10, \\
\text { other times } \\
\text { (many events) }\end{array}$ & Santa Cruz & Santa Cruz & & $\begin{array}{c}\text { Santa Cruz Morning Sentinel, } \\
24 \text { Apr 1906; p. } 7, \text { c. } 2\end{array}$ & $\begin{array}{l}\text { "Light shocks of earthquake on Sunday, the one at 11:10 A. M. } \\
\text { nearly emptying the slightly attended churches. Some of the ladies } \\
\text { of the Congregational Church started to run out, but were } \\
\text { counseled by the pastor to remain where they were. The } \\
\text { congregation was dismissed at once." }\end{array}$ \\
\hline 22-Apr-06 & $\sim$ 12:00 (?) & San Francisco & San Francisco & & $\begin{array}{l}\text { Diary of Charles Prinegar } \\
\text { (San Francisco, CA), } \\
22 \text { Apr } 1906 \text { (pp. 41-60) }\end{array}$ & $\begin{array}{l}\text { Excerpts from the entry of } 22 \text { Apr } 1906: \\
\text { "... This is Sunday morning.... } \\
\text { “..... } \\
\text { "It is almost twelve oclock [noon].... } \\
\text { "..... } \\
\text { "Another quake came just now that was longer than any one that } \\
\text { has come since the first one...." }\end{array}$ \\
\hline 22-Apr-06 & 15:00 & Napa & Napa & & $\begin{array}{c}\text { Napa Daily Journal, } \\
3 \text { May 1906; p. 3, c. } 4\end{array}$ & "slight shock" \\
\hline
\end{tabular}


TABLE 1: Catalog of Aftershock Reports following from the Great 18 April 1906 California Earthquake

\begin{tabular}{|c|c|c|c|c|c|c|}
\hline Date Felt & $\begin{array}{l}\text { Time Felt } \\
\text { (PST) }\end{array}$ & $\begin{array}{l}\text { Location Felt } \\
\quad \text { (City) }\end{array}$ & $\begin{array}{l}\text { Location Felt } \\
\text { (County) }\end{array}$ & $\begin{array}{l}\text { Unreliable? } \\
\text { Not Felt? }^{+}\end{array}$ & Source & Relevant Citations and other Notes \\
\hline 22-Apr-06 & $15: 10$ & San Francisco & San Francisco & & $\begin{array}{c}\text { Sacramento Bee, } \\
23 \text { Apr 1906; p. 10, c. 3-4 }\end{array}$ & $\begin{array}{l}\text { "... there have been intermittent earthquakes. One of these } \\
\text { occurred at 3:10 yesterday (Sunday) afternoon and a dozen } \\
\text { people have told me of the terror in which it threw the people, } \\
\text { especially those people who had stayed by their houses. } \\
\text { "Frank Griffen was standing on Union Street, between Pierce and } \\
\text { Scott, yesterday afternoon when the shock occurred. He said it } \\
\text { was quite a severe one and caused people to run in panic from } \\
\text { their homes...." }\end{array}$ \\
\hline 22-Apr-06 & $\sim 16: 00$ & Berkeley & Alameda & & $\begin{array}{l}\text { Berkeley Daily Gazette, } \\
23 \text { Apr 1906; p. 1, c. } 4\end{array}$ & $\begin{array}{l}\text { "There was a slight earthquake shock Sunday afternoon at about } \\
\text { four o'clock and another at midnight. Neither of the tremblors did } \\
\text { any damage." }\end{array}$ \\
\hline 22-Apr-06 & $\sim 16: 00$ & Oakland & Alameda & & $\begin{array}{l}\text { Sacramento Bee, } \\
23 \text { Apr 1906; p. 3, c. } 3\end{array}$ & $\begin{array}{l}\text { "About } 4 \text { o'clock yesterday afternoon messages came to The Bee } \\
\text { from Oakland to the effect that a distinct earthquake had been felt } \\
\text { there about that hour and that considerable alarm had been } \\
\text { caused. The chief operator in the Sunset Telephone office said the } \\
\text { girls under her stuck to their posts though quite frightened. } \\
\text { "Investigation discloses, however, that no damage was done in } \\
\text { Oakland, and the alarm felt there yesterday in the Sunset office } \\
\text { and elsewhere was no doubt more due to the memory of the } \\
\text { Wednesday morning shock than anything else." }\end{array}$ \\
\hline 22-Apr-06 & $\sim 16: 00$ & $\begin{array}{l}\text { Oakland } \\
\text { Stockton }\end{array}$ & $\begin{array}{l}\text { Alameda } \\
\text { San Joaquin }\end{array}$ & & $\begin{array}{l}\text { The Searchlight (Redding), } \\
24 \text { Apr 1906; p. 1, c. 1-2 }\end{array}$ & $\begin{array}{l}\text { "STOCKTON, April } 23-8 \text { a. m.-.... Reports from Oakland say } \\
\text { that a slight earthquake was felt there yesterday afternoon about } \\
4 \text { o'clock. } \\
\text { "Several persons in Stockton declare that they felt the earthquake } \\
\text { here, too, yesterday afternoon at about } 4: 00 \text {, but it is to be noted } \\
\text { that they did not report their observations until after the news } \\
\text { came from Oakland that shocks had been felt in that city." }\end{array}$ \\
\hline 22-Apr-06 & afternoon & San Francisco & San Francisco & & $\begin{array}{l}\text { The Searchlight (Redding), } \\
24 \text { Apr 1906; p. 1, c. 1-2 }\end{array}$ & $\begin{array}{l}\text { "SAN FRANCISCO, April 23.-10 a. m.-There is absolutely no } \\
\text { truth in the report that a second earthquake had caused further } \\
\text { damage. A slight tremor was felt yesterday afternoon. It did no } \\
\text { harm." }\end{array}$ \\
\hline 22-Apr-06 & $23: 10$ & Hollister & San Benito & & $\begin{array}{l}\text { Salinas Daily Index, } \\
27 \text { Apr 1906; p. 4, c. } 2\end{array}$ & $\begin{array}{l}\text { "HOLLISTER, April } 26 .-\ldots . . \text { Miss Annie Berg ... died Sunday } \\
\text { night immediately after the earthquake at } 11: 10 \ldots . .\end{array}$ \\
\hline 22-Apr-06 & $23: 30$ & $\begin{array}{l}\text { Point Arena } \\
\text { Lighthouse }\end{array}$ & Mendocino & & $\begin{array}{l}\text { Lighthouse Log for } \\
\text { Point Arena Lighthouse, } \\
22 \text { Apr } 1906\end{array}$ & $\begin{array}{l}\text { Excerpt from the entry of } 22 \text { Apr 1906: } \\
\text { "At } 11^{\frac{30}{0}} \text { p.m. slight jar in tower." } \\
\text { Although the timing is a little off, this is inferred to be the event of } \\
\text { the early morning of } 23 \text { Apr. Even if it is not the same event as the } \\
\text { earthquake felt across much of northern California on } 23 \text { Apr, this } \\
\text { entry in the lighthouse log still provides some constraints: if the } \\
\text { lighthouse keeper would bother to note a "slight" earthquake in his }\end{array}$ \\
\hline
\end{tabular}


TABLE 1: Catalog of Aftershock Reports following from the Great 18 April 1906 California Earthquake

\begin{tabular}{|c|c|c|c|c|c|c|}
\hline Date Felt & $\begin{array}{l}\text { Time Felt } \\
\text { (PST) }\end{array}$ & $\begin{array}{l}\text { Location Felt } \\
\text { (City) }\end{array}$ & $\begin{array}{l}\text { Location Felt } \\
\text { (County) }\end{array}$ & $\begin{array}{l}\text { Unreliable? } \\
\text { Not Felt? }^{+}\end{array}$ & Source & Relevant Citations and other Notes \\
\hline & & & & & & $\begin{array}{l}\text { log, but he did not note a different earthquake about two hours later, } \\
\text { the later earthquake (i.e., the event felt across much of northern } \\
\text { California) must not have been strong enough to wake him. If that is } \\
\text { the case, the later event probably did not have an intensity (MMI) } \\
\text { greater than IV. } \\
\text { See Table 9. }\end{array}$ \\
\hline 22-Apr-06 & $\begin{array}{c}\text { during the } \\
\text { day and night } \\
\text { (many events }\end{array}$ & Santa Cruz & Santa Cruz & & $\begin{array}{l}\text { Santa Cruz Morning Sentinel, } \\
24 \text { Apr 1906; p. 1, c. 3-5 }\end{array}$ & $\begin{array}{l}\text { "There were six shakes felt in this section Sunday, up to } 6 \text { P. M., } \\
\text { and about as many more during the night, but none were hard } \\
\text { enough to cause much alarm." }\end{array}$ \\
\hline 22-Apr-06 & night & & Siskiyou & & $\begin{array}{c}\text { Yreka Journal, } \\
25 \text { Apr 1906; p. 3, c. } 4\end{array}$ & $\begin{array}{l}\text { "... All that occurred in any part of Siskiyou last week, was a } \\
\text { slight jar, which stopped a few clocks and made a slight vibration } \\
\text { of insignificant force. Clocks stopped at the first shock in San } \\
\text { Francisco on the 18th, and the other shock last Sunday night, the } \\
22 \mathrm{~d} \text {, was lighter and did not even stop a clock anywhere...." } \\
\text { The event of Sunday night, } 22 \text { Apr, is inferred to be the event of the } \\
\text { early morning of } 23 \text { Apr. } \\
\text { See Table } 9 .\end{array}$ \\
\hline 23-Apr-06 & 00:00 & Berkeley & Alameda & & $\begin{array}{l}\text { Berkeley Daily Gazette, } \\
23 \text { Apr 1906; p. 1, c. } 4\end{array}$ & $\begin{array}{l}\text { "There was a slight earthquake shock Sunday afternoon at about } \\
\text { four o'clock and another at midnight. Neither of the tremblors did } \\
\text { any damage." }\end{array}$ \\
\hline 23-Apr-06 & $00: 48$ & Trinidad Head & Humboldt & & $\begin{array}{l}\text { Lawson (1908), } \\
\text { vol. I, p. 416 }\end{array}$ & $\begin{array}{l}\text { “East-west tremor } 5 \mathrm{~s} \text {. before, short and heavy; clock stopt } \\
12^{\mathrm{h}} 48^{\mathrm{m}} \text { a. m., facing east; sound like thunder, preceded and } \\
\text { continued during shock; same throughout, no change." Duration } \\
8 \text { seconds. } \\
\text { See Table } 9 .\end{array}$ \\
\hline 23-Apr-06 & $\sim 00: 50$ & $\begin{array}{l}\text { Red Bluff } \\
\text { Medford } \\
\text { Seattle }\end{array}$ & $\begin{array}{l}\text { Tehama } \\
\text { Jackson Co. } \\
\text { (Oregon) } \\
\text { King Co. } \\
\text { (Washington) }\end{array}$ & $\begin{array}{l}\text { unreliable } \\
\text { unreliable }\end{array}$ & $\begin{array}{l}\text { Daily People's Cause } \\
\text { (Red Bluff), } \\
23 \text { Apr 1906; p. 1, c. } 2\end{array}$ & $\begin{array}{l}\text { "Another shock of earthquake was felt in Red Bluff at about ten } \\
\text { minutes to one this Monday morning, although the shock was not } \\
\text { so severe as the one of last Wednesday morning. Only a few } \\
\text { people felt it as most people were sleeping soundly at that hour. } \\
\text { Several clocks about town were stopped by the shock. } \\
\text { "A report was current here today that Medford, Oregon, and } \\
\text { Seattle had suffered by the shock, but this report was not } \\
\text { confirmed." } \\
\text { The statement about Medford suffering appears to be exaggerated } \\
\text { in comparison with reports from papers near Medford, and there } \\
\text { are no reliable reports which suggest that this earthquake was felt } \\
\text { in Seattle. } \\
\text { See Table 9. }\end{array}$ \\
\hline
\end{tabular}


TABLE 1: Catalog of Aftershock Reports following from the Great 18 April 1906 California Earthquake

\begin{tabular}{|c|c|c|c|c|c|c|}
\hline Date Felt & $\begin{array}{l}\text { Time Felt } \\
\text { (PST) }\end{array}$ & $\begin{array}{l}\text { Location Felt } \\
\text { (City) }\end{array}$ & $\begin{array}{l}\text { Location Felt } \\
\text { (County) }\end{array}$ & \begin{tabular}{|l|} 
Unreliable? \\
Not Felt? $^{+}$
\end{tabular} & Source & Relevant Citations and other Notes \\
\hline 23-Apr-06 & 00:55 & Cape Mendocino & Humboldt & & $\begin{array}{c}\text { Lighthouse Log for } \\
\text { Cape Mendocino Lighthouse, } \\
23 \text { Apr } 1906\end{array}$ & $\begin{array}{l}\text { Excerpt from the entry of } 23 \text { Apr 1906: } \\
\text { "shock of earthquake 0:55 a.m. and started stopped clock in } \\
\text { tower woke up everybode [sic] and rushing out of hous [sic] but } \\
\text { no damage was done the shock traveled from South to North." } \\
\text { See Table 9. }\end{array}$ \\
\hline 23-Apr-06 & 00:55 & Cape Mendocino & Humboldt & & $\begin{array}{l}\text { Lawson (1908), } \\
\text { vol. I, p. } 416\end{array}$ & $\begin{array}{l}\text { "Vertical. Southwest-northeast. Direction NE. increasing } \\
\text { intensity. Clock stopt. Pend. 22", facing SW. No sound." } \\
\text { Duration } 6 \text { seconds. } \\
\text { See Table } 9 .\end{array}$ \\
\hline 23-Apr-06 & 01:00 & Orick & Humboldt & & $\begin{array}{c}\text { Arcata Union, } \\
28 \text { Apr 1906; p. 8, c. } 3\end{array}$ & $\begin{array}{l}\text { "Orick. / April 23, 1906. / This vicinity was visited by an } \\
\text { earthquake Wednesday morning [18 Apr] at } 5: 20 \text { a. m. This } \\
\text { morning at } 1 \text { o'clock there was another fully as heavy as the first } \\
\text { and at half past five another, fully as heavy as any preceding. All } \\
\text { the damage done was to break a few panes of glass." } \\
\text { Lawson (1908) indicates Rossi-Forel Intensity V-VI at Orick for the } \\
\text { mainshock. It is not clear which of the earthquakes mentioned were } \\
\text { responsible for breaking the panes of glass. } \\
\text { See Table 9. }\end{array}$ \\
\hline 23-Apr-06 & 01:00 & Blocksburg & Humboldt & & $\begin{array}{l}\text { Humboldt Standard, } \\
26 \text { Apr 1906; p. 6, c. } 1\end{array}$ & $\begin{array}{l}\text { "a double sharp shake with distinct rumblings" } \\
\text { See Table } 9 .\end{array}$ \\
\hline 23-Apr-06 & $\sim \sim 01: 00$ & New River & Trinity & & $\begin{array}{l}\text { Humboldt Times, } \\
28 \text { Apr 1906; p. 6, c. } 2\end{array}$ & $\begin{array}{l}\text { "another heavy shock" } \\
\text { See Table } 9 .\end{array}$ \\
\hline 23-Apr-06 & $\begin{array}{l}\sim 01: 00 \\
\sim\end{array}$ & Burnt Ranch & Trinity & & $\begin{array}{l}\text { Blue Lake Advocate, } \\
5 \text { May 1906; p. 2, c. } 2\end{array}$ & $\begin{array}{l}\text { "... we were treated to three more temblors about } 1 \text { o'clock a.m. } \\
\text { No damage was done in this locality; in fact there has been no } \\
\text { danger done in Trinity county, that your correspondent has heard } \\
\text { of so far." } \\
\text { See Table 9. }\end{array}$ \\
\hline 23-Apr-06 & 01:00 & Kennett & Shasta & & $\begin{array}{l}\text { The Searchlight (Redding), } \\
25 \text { Apr 1906; p. 3, c. } 3\end{array}$ & $\begin{array}{l}\text { "The earthquake at } 1 \text { o'clock Monday morning was felt by } \\
\text { everybody working on night shift in the smelter." } \\
\text { See Table } 9 .\end{array}$ \\
\hline 23-Apr-06 & 01:00 & Fort Jones & Siskiyou & & $\begin{array}{c}\text { Farmer and Miner (Fort Jones), } \\
25 \text { Apr 1906; p. 3, c. } 2\end{array}$ & $\begin{array}{l}\text { "Another slight earthquake was felt in Fort Jones.... It was feared } \\
\text { that more damage might be done around the [San Francisco] bay } \\
\text { but the fears were groundless." } \\
\text { See Table 9. }\end{array}$ \\
\hline
\end{tabular}


TABLE 1: Catalog of Aftershock Reports following from the Great 18 April 1906 California Earthquake

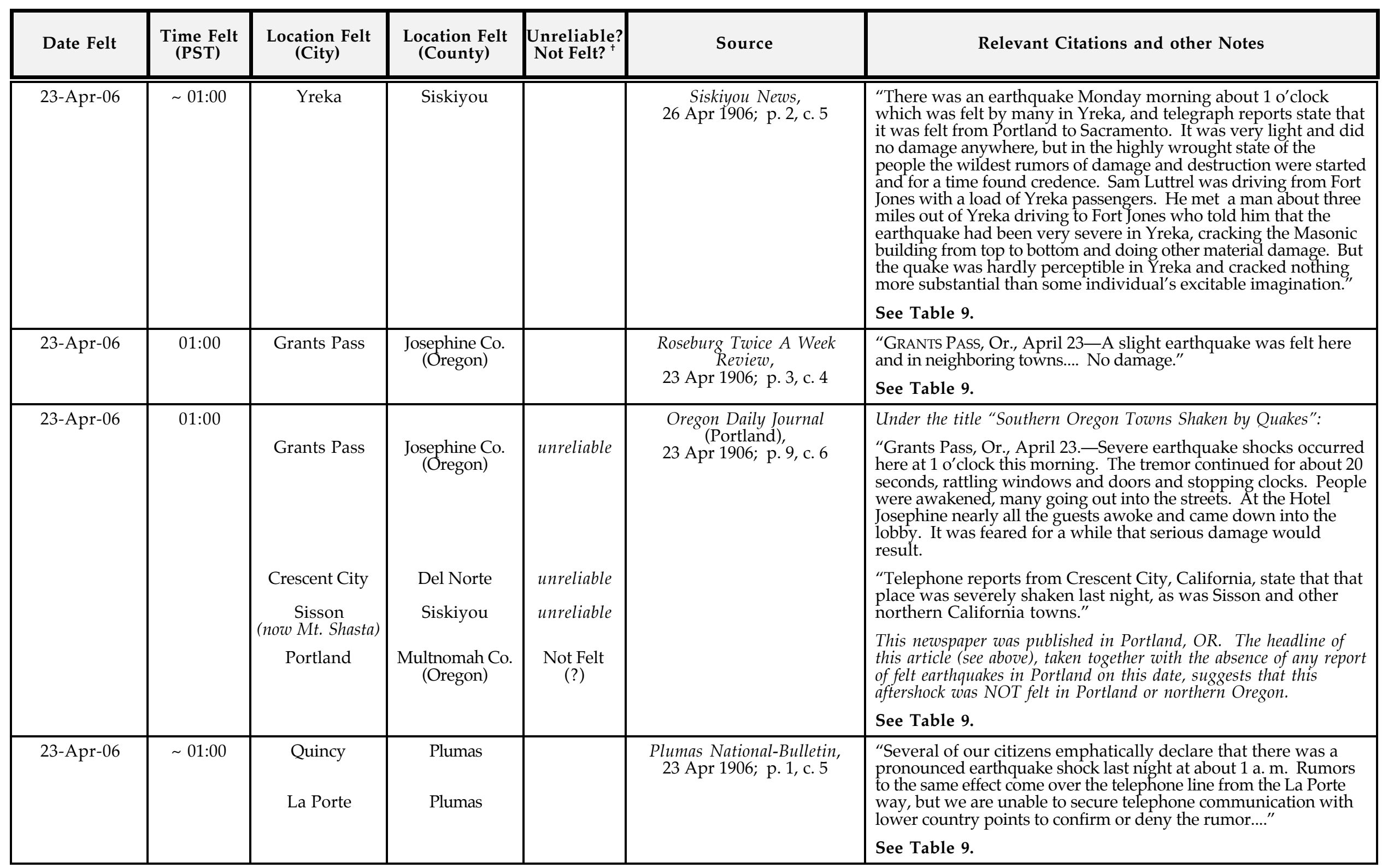


TABLE 1: Catalog of Aftershock Reports following from the Great 18 April 1906 California Earthquake

\begin{tabular}{|c|c|c|c|c|c|c|}
\hline Date Felt & $\begin{array}{l}\text { Time Felt } \\
\text { (PST) }\end{array}$ & $\begin{array}{l}\text { Location Felt } \\
\text { (City) }\end{array}$ & $\begin{array}{l}\text { Location Felt } \\
\text { (County) }\end{array}$ & $\begin{array}{l}\text { Unreliable? } \\
\text { Not Felt? }\end{array}$ & Source & Relevant Citations and other Notes \\
\hline 23-Apr-06 (?) & \begin{tabular}{|c|} 
shortly after \\
$01: 00$
\end{tabular} & Georgetown & El Dorado & & $\begin{array}{l}\text { Georgetown Gazette, } \\
4 \text { May 1906; p.3, c. } 1\end{array}$ & $\begin{array}{l}\text { "An earthquake shock was felt here shortly after one o'clock } \\
\text { Monday morning. No damage done." } \\
\text { Although the article implies that the "Monday morning" to which } \\
\text { it refers was the Monday of that week, i.e., } 30 \text { Apr, it is also possible } \\
\text { that it was the previous Monday, } 23 \text { Apr. The lack of corroborating } \\
\text { reports from nearby localities for } 30 \text { Apr, and the existence of a felt } \\
\text { report from Grass Valley (to the north) for an event at about 01:15 } \\
\text { on the morning of } 23 \text { Apr, suggest that this is the } 23 \text { Apr event. } \\
\text { See Table 9. }\end{array}$ \\
\hline 23-Apr-06 & 01:06 & Weaverville & Trinity & & $\begin{array}{l}\text { Weekly Trinity Journal, } \\
27 \text { Apr 1906; p. 2, c. } 1\end{array}$ & $\begin{array}{l}\text { "...there was another earthquake shock but not so severe as the } \\
\text { one of the 18th inst. It was strong enough, however to rouse } \\
\text { apprehensions as to damage elsewhere. Fortunately these fears } \\
\text { proved unfounded. While the shock was general no damage was } \\
\text { suffered in the State beyond the toppling of a few chimneys." } \\
\text { See Table 9. }\end{array}$ \\
\hline 23-Apr-06 & 01:08 & Weaverville & Trinity & & $\begin{array}{l}\text { The Searchlight (Redding), } \\
24 \text { Apr 1906; p. 2, c. 2-3 }\end{array}$ & $\begin{array}{l}\text { "Slight shocks of earthquake were felt.... The duration of the } \\
\text { temblor was only a few seconds-perhaps six or eight. But few } \\
\text { people were awakened by it. The earthquake was very much } \\
\text { lighter than that of last Wednesday morning, according to the } \\
\text { reports of those who observed both." } \\
\text { Lawson (1908) indicates Rossi-Forel Intensity V-VI at Weaverville } \\
\text { for the mainshock. } \\
\text { See Table 9. }\end{array}$ \\
\hline 23-Apr-06 & 01:08 & Stockton & San Joaquin & unreliable & $\begin{array}{l}\text { The Searchlight (Redding), } \\
24 \text { Apr 1906; p.1, c. 1-2 }\end{array}$ & $\begin{array}{l}\text { "For a period of perhaps six seconds the earth quivered slightly.... } \\
\text { Only people of nervous, restless temperament were awakened by } \\
\text { the tremor." } \\
\text { This report is not corroborated in any of the Stockton papers. } \\
\text { See Table } 9 .\end{array}$ \\
\hline 23-Apr-06 & 01:09 & Sacramento & Sacramento & unreliable & $\begin{array}{l}\text { The Searchlight (Redding), } \\
24 \text { Apr 1906; p. 1, c. 1-2 }\end{array}$ & $\begin{array}{l}\text { "a slight tremor of the earth" } \\
\text { This report is not corroborated in any of the Sacramento papers. } \\
\text { See Table 9. }\end{array}$ \\
\hline 23-Apr-06 & 01:10 & Eureka & Humboldt & & $\begin{array}{l}\text { Humboldt Standard, } \\
23 \text { Apr 1906; p. 5, c. 5-6 }\end{array}$ & $\begin{array}{l}\text { "Ever since the disastrous quake at } 5: 11 \text { a. m. Wednesday [April } \\
\text { 18], there have been innumerable shocks of more or less severity } \\
\text { at intervals but none approaching the severity of the first. One } \\
\text { o[f] the heaviest of these occurred at 1:10 o'clock this morning } \\
\text { and caused considerable consternation among the people owing } \\
\text { to the length of time that the vibrations continued. In fact the } \\
\text { period was fully as long as that of the first shake of Wednesday. } \\
\text { However, besides rattling things about considerably, spilling }\end{array}$ \\
\hline
\end{tabular}


TABLE 1: Catalog of Aftershock Reports following from the Great 18 April 1906 California Earthquake

\begin{tabular}{|c|c|c|c|c|c|c|}
\hline Date Felt & $\begin{array}{l}\text { Time Felt } \\
\text { (PST) }\end{array}$ & $\begin{array}{c}\text { Location Felt } \\
\text { (City) }\end{array}$ & $\begin{array}{l}\text { Location Felt } \\
\text { (County) }\end{array}$ & $\begin{array}{c}\text { Unreliable? } \\
\text { Not Felt? }^{+}\end{array}$ & Source & Relevant Citations and other Notes \\
\hline & & $\begin{array}{c}\text { between Alton } \\
\text { and Fortuna (?) } \\
\text { Hydesville } \\
\text { Ferndale }\end{array}$ & $\begin{array}{l}\text { Humboldt } \\
\text { Humboldt } \\
\text { Humboldt }\end{array}$ & & & $\begin{array}{l}\text { liquids from open dishes, and stopping clocks, as far as learned } \\
\text { there was no serious damage done about the city. The only } \\
\text { exciting incident appears to have been the breaking of a live } \\
\text { electric wire in front of the Daly Bros. store at Fourth and F } \\
\text { streets. This did no damage however. } \\
\text { "One effect of the earthquake shock of early this morning was to } \\
\text { cause a slide to come in on the Scotia road, which prevented the } \\
\text { train from coming in from there with the overland mail this } \\
\text { morning and delayed the arrival of the train from Alton about one } \\
\text { hour." } \\
\text { What was called the Scotia road probably ran from Fortuna to the } \\
\text { south, through Scotia. Because the slide blocked the trains from } \\
\text { both Scotia and Alton, the slide must have occurred north of Alton, } \\
\text { which is between Scotia and Fortuna. Hence the slide most likely } \\
\text { occurred between Alton and Fortuna. For several hundred meters } \\
\text { north of Alton, the road and railroad tracks run along the base of an } \\
\text { escarpment, and this seems to be the most likely location of the slide. } \\
\text { "The telephone wire was working spasmodically as far as } \\
\text { Hydesville, and from there it was learned that no damage was } \\
\text { done by this morning's earthquake. } \\
\text { "Telephonic communication with Ferndale was partially } \\
\text { restored late this forenoon, when it was learned that the shock } \\
\text { this morning did little or no damage there. A few more bricks } \\
\text { were knocked out of the walls of the Russ, Early \& Williams } \\
\text { wrecked brick store, a few movable articles about town were } \\
\text { disturbed, and that was about all." } \\
\text { See Table 9. }\end{array}$ \\
\hline 23-Apr-06 & $01: 10$ & $\begin{array}{c}\text { Eureka } \\
\text { Ferndale } \\
\text { Arcata } \\
\text { Crescent City }\end{array}$ & $\begin{array}{l}\text { Humboldt } \\
\text { Humboldt } \\
\text { Humboldt } \\
\text { Del Norte }\end{array}$ & ( & $\begin{array}{c}\text { Humboldt Times, } \\
24 \text { Apr 1906; p. 8, c. } 4\end{array}$ & $\begin{array}{l}\text { "As compared with the shock of last Wednesday morning, the } \\
\text { quakes felt here yesterday morning did little or no damage. A } \\
\text { window pane here and there which had been cracked from the big } \\
\text { temblor fell out, a few bricks which had become loosened on a } \\
\text { number of chimneys about town tumbled down, putting the fear of } \\
\text { the Almighty in the hearts of many, and the houses generally were } \\
\text { shaken up, sufficiently to awaken the populace. There were many } \\
\text { who remained awake the remainder of the night and few of the } \\
\text { more timid who sought the streets. } \\
\text { "The shock was felt at Ferndale, but comparatively no damage } \\
\text { was done. In fact it was felt by all the valley towns about the } \\
\text { same as in Eureka. } \\
\text { "As nearly as can be learned the recent shake extended farther } \\
\text { north than did the other, and it is reported that Arcata and the } \\
\text { towns in the northern part of the county felt the thrill, and that } \\
\text { Crescent City and Grants Pass got it stronger than ever before. }\end{array}$ \\
\hline
\end{tabular}


TABLE 1: Catalog of Aftershock Reports following from the Great 18 April 1906 California Earthquake

\begin{tabular}{|c|c|c|c|c|c|c|}
\hline Date Felt & $\begin{array}{c}\text { Time Felt } \\
\text { (PST) }\end{array}$ & $\begin{array}{c}\text { Location Felt } \\
\text { (City) }\end{array}$ & $\begin{array}{c}\text { Location Felt } \\
\text { (County) }\end{array}$ & $\begin{array}{l}\text { Unreliable? } \\
\text { Not Felt? }^{+}\end{array}$ & Source & Relevant Citations and other Notes \\
\hline & & $\begin{array}{c}\text { Grants Pass } \\
\text { Portland } \\
\text { Yreka } \\
\text { Redding }\end{array}$ & $\begin{array}{c}\begin{array}{c}\text { Josephine Co. } \\
\text { (Oregon) }\end{array} \\
\text { Multnomah Co. } \\
\text { (Oregon) } \\
\text { Siskiyou } \\
\text { Shasta }\end{array}$ & $\begin{array}{l}\text { unreliable } \\
\text { unreliable } \\
\text { unreliable } \\
\text { unreliable }\end{array}$ & & $\begin{array}{l}\text { Even Portland is reported as getting shaken up, in the same } \\
\text { manner as Eureka was Wednesday morning, perhaps not so } \\
\text { seriously. } \\
\text { "The shock was felt at Yreka more severely than the Wednesday } \\
\text { quake at that place. At Redding it lasted eight seconds, and a few } \\
\text { chimneys tumbled down, and there was a shirttail brigade. } \\
\text { "Locally [in Eureka] there were two shocks. The first was at } \\
\text { 1:10 a. m., with vibrations from south to north and lasting } 14 \\
\text { seconds. The second was exactly at } 6: 07 \text { a. m., with vibrations } \\
\text { from southwest to northeast, and lasting four seconds." } \\
\text { From this article alone, it is not clear which of the two events were } \\
\text { characterized by the effects described in the first two paragraphs, } \\
\text { and which of the two events were felt as described in the locations } \\
\text { mentioned in paragraphs three and four. From other reports, } \\
\text { however, it appears that the 01:10 shock was much the stronger, } \\
\text { and it is consequently inferred that the first four paragraphs of the } \\
\text { above article refer to the 01:10 shock and not the 06:07 shock. } \\
\text { The Portland report is not corroborated by Portland newspapers } \\
\text { and to some extent discredits the reports from Arcata, northern } \\
\text { Humboldt County, Crescent City, Grants Pass, Yreka, and Redding. } \\
\text { See Table 9. }\end{array}$ \\
\hline 23-Apr-06 & 01:10 & Redding & Shasta & & $\begin{array}{l}\text { The Searchlight (Redding), } \\
24 \text { Apr 1906; p. 1, c. 1-2 }\end{array}$ & $\begin{array}{l}\text { "Two distinct shocks of earthquake shook up Redding at } 1: 10 \\
\text { o'clock Monday morning. The second shock, which was much the } \\
\text { sharper, came about ten seconds after the first. The total duration } \\
\text { of the seismic disturbance is variously estimated at from ten to } \\
\text { twenty seconds. } \\
\text { "Guests in the Lorenz, Golden Eagle and Temple hotels were } \\
\text { alarmed and a few came down into the office or out into the street, } \\
\text { dressed only in their night clothing. The electric clock in the } \\
\text { Temple Hotel stopped at 1:10 a. m. No other electric clocks in } \\
\text { town were affected. } \\
\text { "The quake awakened people throughout Redding, but hundreds } \\
\text { and hundreds of sleepers were not disturbed at all and first } \\
\text { learned of the earthquake when they arose for the day. } \\
\text { "As compared with the shake-up of last Wednesday morning, the } \\
\text { earthquake of yesterday morning is described by some as being } \\
\text { sharper, while others insist that it was not so sharp. Perhaps the } \\
\text { happy mean is about the correct estimate and Monday's quiver } \\
\text { was only a duplicate of that of last Wednesday. } \\
\text { "H. Bemis, who sleeps in the Gem Lodging-house, says he was } \\
\text { awakened by a jerking motion of his bed. The jerking ceased } \\
\text { momentarily, but for a few seconds-perhaps eight or ten-the }\end{array}$ \\
\hline
\end{tabular}


TABLE 1: Catalog of Aftershock Reports following from the Great 18 April 1906 California Earthquake

\begin{tabular}{|c|c|c|c|c|c|c|}
\hline Date Felt & $\begin{array}{l}\text { Time Felt } \\
\text { (PST) }\end{array}$ & $\begin{array}{l}\text { Location Felt } \\
\text { (City) }\end{array}$ & $\begin{array}{l}\text { Location Felt } \\
\text { (County) }\end{array}$ & $\begin{array}{l}\text { Unreliable? } \\
\text { Not Felt? }^{+}\end{array}$ & Source & Relevant Citations and other Notes \\
\hline & & & & & & $\begin{array}{l}\text { bed continued to tremble a little, and then came the last and final } \\
\text { jerking, much sharper than the shake-up that had awakened him. } \\
\text { With that the event was over. During the earthquake he could } \\
\text { hear a tapping on the windows, perhaps caused by the rattling of } \\
\text { the panes. An open door somewhere in the house swung on its } \\
\text { hinges, grinding out a noise something like 'hee-haw, hee-haw!'" } \\
\text { See Table 9. }\end{array}$ \\
\hline 23-Apr-06 & 01:10 & $\begin{array}{l}\text { Redding } \\
\text { Chico }\end{array}$ & $\begin{array}{l}\text { Shasta } \\
\text { Butte }\end{array}$ & & $\begin{array}{l}\text { Chico Semi-Weekly Record, } \\
24 \text { Apr 1906; p. 1, c. } 6\end{array}$ & $\begin{array}{l}\text { "REDDING, April 23.-At 1:10 this morning a very distinct } \\
\text { shock of earthquake was felt here. It lasted about eight seconds } \\
\text { and there were two strong pulsations. } \\
\text { "The shock caused considerable alarm, particularly among the } \\
\text { guests in the various hotels. They were nervous, however, } \\
\text { because of the San Francisco horror, and to this fact was due } \\
\text { their fright, more than to the severity of the earthquake.... } \\
\text { "(The shock was felt by several in Chico, but was not of } \\
\text { sufficient severity to awaken more than a few in the town.)" } \\
\text { See Table 9. }\end{array}$ \\
\hline 23-Apr-06 & 01:10 & Yreka & Siskiyou & & $\begin{array}{l}\text { The Searchlight (Redding), } \\
24 \text { Apr 1906; p. 2, c. 3-4 }\end{array}$ & $\begin{array}{l}\text { "YREKA, April 23-8 a. m.-Two distinct shocks of earthquake } \\
\text { were experienced here... The second shock, coming five or six } \\
\text { seconds after the first, was the most severe. Opinions differ as to } \\
\text { whether the disturbance this morning was greater than that of } \\
\text { last Wednesday morning. People are nervous on the subject of } \\
\text { earthquakes and are disposed, naturally, to exaggerate } \\
\text { impressions formed. } \\
\text { "Mrs. Charles Cady insists that she was almost thrown out of } \\
\text { bed by the earthquake.... } \\
\text { "No damage whatever has been reported from any quarter of } \\
\text { Yreka." } \\
\text { See Table 9. }\end{array}$ \\
\hline 23-Apr-06 & 01:10 (?) & $\begin{array}{l}\text { Ashland } \\
\text { Grants Pass } \\
\text { Portland }\end{array}$ & $\begin{array}{l}\text { Jackson Co. } \\
\text { (Oregon) } \\
\text { Josephine Co. } \\
\text { (Oregon) } \\
\text { Multnomah Co. } \\
\text { (Oregon) }\end{array}$ & \begin{tabular}{l|} 
unreliable \\
unreliable \\
unreliable
\end{tabular} & $\begin{array}{l}\text { The Searchlight (Redding), } \\
24 \text { Apr 1906; p. 1, c. 1-2 }\end{array}$ & $\begin{array}{l}\text { "Reports reaching Redding early Monday morning said that the } \\
\text { earthquake was heavy in Ashland and Grants Pass, heavier in } \\
\text { the latter city, where chimneys were thrown down. } \\
\text { "An alarming report from Portland, coming no one knew how, } \\
\text { was that the city was in flames, the fire having followed the } \\
\text { earthquake. This report was soon denied, emphatically, in a } \\
\text { dispatch received about } 9 \text { o'clock from Ashland. } \\
\text { "No damage was done in Ashland and what was done in Grants } \\
\text { Pass is hardly worth mentioning." } \\
\text { This article was appended to another article which described the }\end{array}$ \\
\hline
\end{tabular}


TABLE 1: Catalog of Aftershock Reports following from the Great 18 April 1906 California Earthquake

\begin{tabular}{|c|c|c|c|c|c|c|}
\hline Date Felt & $\begin{array}{l}\text { Time Felt } \\
\text { (PST) }\end{array}$ & $\begin{array}{l}\text { Location Felt } \\
\text { (City) }\end{array}$ & $\begin{array}{l}\text { Location Felt } \\
\text { (County) }\end{array}$ & $\begin{array}{l}\text { Unreliable? } \\
\text { Not Felt? }^{+}\end{array}$ & Source & Relevant Citations and other Notes \\
\hline & & & & & & $\begin{array}{l}\text { earthquake effects elsewhere and which give the time as 01:10. } \\
\text { See Table } 9 .\end{array}$ \\
\hline 23-Apr-06 & $01: 10$ & $\begin{array}{l}\text { Ashland } \\
\text { Grants Pass } \\
\text { Glendale } \\
\text { Merlin } \\
\text { Redding }\end{array}$ & $\begin{array}{l}\text { Jackson Co. } \\
\text { (Oregon) } \\
\text { Josephine Co. } \\
\text { (Oregon) } \\
\text { Douglas Co. } \\
\text { (Oregon) } \\
\text { Josephine Co. } \\
\text { (Oregon) } \\
\text { Shasta }\end{array}$ & & $\begin{array}{l}\text { Ashland Tidings, } \\
23 \text { Apr 1906; p. 3, c. } 3\end{array}$ & $\begin{array}{l}\text { "Wild rumors flew along the wires this morning from the south of } \\
\text { a reported disastrous earthquake throughout Oregon last night. } \\
\text { The TIIINGS was called up by phone from Redding to confirm a } \\
\text { report that Ashland and Grants Pass had been damaged, but had } \\
\text { to deny knowledge of any disturbance here, although some people } \\
\text { reported a slight tremoro at 1:10 o'clock this morning. Others, } \\
\text { including the telegraph operators who were on duty all night } \\
\text { here, knew nothing of it. The Grants Pass telephone office } \\
\text { reported a slight tremor in that city and at Glendale and Merlin. } \\
\text { Redding, on the south, felt a slight tremor, and there was more or } \\
\text { less seismic disturbance through California which disarranged } \\
\text { the telegraph lines for an hour." } \\
\text { See Table 9. }\end{array}$ \\
\hline 23-Apr-06 (?) & 01:10 & $\begin{array}{l}\text { Ashland } \\
\text { Sisson } \\
\text { (now Mt. Shasta) } \\
\text { Hornbrook }\end{array}$ & $\begin{array}{l}\text { Jackson Co. } \\
\text { (Oregon) } \\
\text { Siskiyou } \\
\text { Siskiyou }\end{array}$ & & $\begin{array}{l}\text { Valley Record (Ashland), } \\
26 \text { Apr 1906; p. 7, c. } 6\end{array}$ & $\begin{array}{l}\text { "A slight shock of Earthquake was felt by some people in } \\
\text { Ashland at 1:10 Tuesday morning, also at Sisson, Hornbrook and } \\
\text { other points in Siskiyou...." } \\
\text { Tuesday would be } 24 \text { Apr; later in the same article, however, the } \\
\text { date is given as } 23 \text { Apr. [The remainder of this article is listed } \\
\text { chronologically in this catalog under } 23 \text { Apr, under (nearly) } \\
\text { identical entries published in the Morning Oregonian (Portland).] } \\
\text { Because this source is internally inconsistent, and because the } \\
01: 10 \text { time of the event matches the time of an event knowivn to have } \\
\text { occurred on } 23 \text { Apr (but not on } 24 \text { Apr), the obvious inference is } \\
\text { that the date stated above ("Tuesday") is in error. It should state } \\
\text { the date as being Monday morning, } 23 \text { Apr. } \\
\text { See Table 9. }\end{array}$ \\
\hline 23-Apr-06 & 01:10 & Eureka & Humboldt & & $\begin{array}{l}\text { Lawson (1908), } \\
\text { vol. I, p. 416 }\end{array}$ & $\begin{array}{l}\text { "South-north. Stopt clocks." Duration } 14 \text { seconds. Lawson } \\
\text { (1908) estimates Rossi-Forel intensity V-VI. } \\
\text { See Table } 9 .\end{array}$ \\
\hline 23-Apr-06 & 01:11 & Ferndale & Humboldt & & $\begin{array}{l}\text { Lawson (1908), } \\
\text { vol. I, p. } 416\end{array}$ & $\begin{array}{l}\text { "Severe shock." Duration } 10 \text { seconds. } \\
\text { See Table } 9 .\end{array}$ \\
\hline 23-Apr-06 & 01:11 & Grants Pass & $\begin{array}{l}\text { Josephine Co. } \\
\text { (Oregon) }\end{array}$ & unreliable & $\begin{array}{l}\text { Morning Oregonian (Portland), } \\
23 \text { Apr 1906; p. 3, c. } 1\end{array}$ & $\begin{array}{l}\text { "GRANTS PASS, Or., April 23.-(Special.)-An earthquake } \\
\text { shock which broke some windows and awoke sleeping citizens } \\
\text { was felt here at 1:11 this morning. The shock lasted between } 15 \\
\text { and } 20 \text { seconds and was accompanied by a distinct rumbling } \\
\text { noise. The motion of the undulation was from east to west and } \\
\text { the oscillation was sufficient to set hanging lamps and pictures to } \\
\text { swaying. }\end{array}$ \\
\hline
\end{tabular}


TABLE 1: Catalog of Aftershock Reports following from the Great 18 April 1906 California Earthquake

\begin{tabular}{|c|c|c|c|c|c|c|}
\hline Date Felt & $\begin{array}{l}\text { Time Felt } \\
\text { (PST) }\end{array}$ & $\begin{array}{l}\text { Location Felt } \\
\text { (City) }\end{array}$ & $\begin{array}{l}\text { Location Felt } \\
\text { (County) }\end{array}$ & $\begin{array}{l}\text { Unreliable? } \\
\text { Not Felt? }^{+}\end{array}$ & Source & Relevant Citations and other Notes \\
\hline & & & & & & $\begin{array}{l}\text { "Mayor George Good states that the shock was felt all over his } \\
\text { house, which is a structure } 75 \text { feet in length and two stories high. } \\
\text { His children, who were asleep, were awakened and cried out in } \\
\text { alarm, and a relative who was sleeping in an adjoining room, } \\
\text { despite the fact that he is quite deaf, was aroused by the sway of } \\
\text { electric light fixtures attached to the bed. } \\
\text { "Within a few minutes after the shock frightened citizens began } \\
\text { calling up the local telephone exchange to ascertain the cause of } \\
\text { the commotion. The telephone manager had been raised by the } \\
\text { shock and was able to allay the fears of all, as practically no } \\
\text { damage had been done beyond the breaking of window glass." } \\
\text { A very similar article appeared in the Valley Record (Ashland) of } \\
26 \text { Apr 1906, p. 7, c. } 6 \text {. } \\
\text { See Table 9. }\end{array}$ \\
\hline 23-Apr-06 & 01:11 & Glendale & $\begin{array}{l}\text { Douglas Co. } \\
\text { (Oregon) }\end{array}$ & unreliable & \begin{tabular}{|} 
Morning Oregonian (Portland) \\
23 Apr 1906; p. 3, c. 1
\end{tabular} & $\begin{array}{l}\text { "GLENDALE, Or., April 23.-(Special.)-A distinct shock of } \\
\text { earthquake was felt in this city at } 11 \text { minutes after } 1 \text { o'clock this } \\
\text { morning. The shock was apparently heavier than the one of April } \\
\text { 18, causing buildings to rock and rattle." } \\
\text { A very similar article appeared in the Valley Record (Ashland) of } \\
26 \text { Apr 1906, p. 7, c. } 6 \text {. } \\
\text { Lawson (1908) indicates Rossi-Forel Intensity II-III at Glendale, } \\
\text { Oregon for the mainshock. } \\
\text { See Table 9. }\end{array}$ \\
\hline 23-Apr-06 & 01:12 & Red Bluff & Tehama & & $\begin{array}{l}\text { Red Bluff Daily News, } \\
24 \text { Apr 1906; p. 1, c. } 2\end{array}$ & $\begin{array}{l}\text { "Light sleepers were awakened ... by a slight earth tremor which } \\
\text { stopped the clocks in the United States Weather Bureau, H. H. } \\
\text { Wiedenieck's and G. C. Wilkin's. The shock was felt as far north } \\
\text { as Grants' Pass and as far South of here but no damage was done } \\
\text { before Mother Earth stopped trembling...." } \\
\text { See Table 9. }\end{array}$ \\
\hline 23-Apr-06 & 01:13 & Grants Pass & $\begin{array}{l}\text { Josephine Co. } \\
\text { (Oregon) }\end{array}$ & unreliable & $\begin{array}{c}\text { Morning Oregonian (Portland) } \\
24 \text { Apr 1906; p. } 7, \text { c. } 2\end{array}$ & $\begin{array}{l}\text { "GRANTS PASS, Or., April 23.--(Special.)-The heaviest shock } \\
\text { of earthquake ever experienced in Southern Oregon was felt in } \\
\text { this city at 1:13 A. M. last night. It made doors and windows } \\
\text { rattle and awakened many people. A shock not quite so heavy as } \\
\text { this was felt here on the morning and to the very minute of the big } \\
\text { earthquake that wrecked San Francisco and other California } \\
\text { towns." } \\
\text { Lawson (1908) indicates Rossi-Forel Intensity II-III at Grants Pass, } \\
\text { Oregon for the mainshock. } \\
\text { See Table 9. }\end{array}$ \\
\hline
\end{tabular}


TABLE 1: Catalog of Aftershock Reports following from the Great 18 April 1906 California Earthquake

\begin{tabular}{|c|c|c|c|c|c|c|}
\hline Date Felt & $\begin{array}{l}\text { Time Felt } \\
\text { (PST) }\end{array}$ & $\begin{array}{l}\text { Location Felt } \\
\text { (City) }\end{array}$ & $\begin{array}{l}\text { Location Felt } \\
\text { (County) }\end{array}$ & $\begin{array}{l}\text { Unreliable? } \\
\text { Not Felt? }^{+}\end{array}$ & Source & Relevant Citations and other Notes \\
\hline 23-Apr-06 & $\sim 01: 14$ & Portland & \begin{tabular}{|l|} 
Southern Oregon \\
Multnomah Co. \\
(Oregon)
\end{tabular} & $\begin{array}{l}\text { Not Felt } \\
(?)\end{array}$ & $\begin{array}{c}\text { Morning Oregonian (Portland), } \\
24 \text { Apr 1906; p. } 7, \text { c. } 2\end{array}$ & $\begin{array}{l}\text { "WASHINGTON, [D.C.,] April 23.-(Special.)-The Southern } \\
\text { Oregon earthquake was recorded on the Government seismograph } \\
\text { in this city this morning, between } 4: 25 \text { and } 5 \text { o'clock, Washington } \\
\text { time, three hours later than Oregon time. The instrument showed } \\
\text { the heaviest shock occurred from } 4: 29 \text { to } 4: 33 \text {, just } 17 \text { minutes } \\
\text { after it was felt in Oregon. This is exactly the time required for } \\
\text { the San Francisco shock to traverse the continent." } \\
\text { This newspaper was published in Portland, OR. The reference to } \\
\text { "Southern Oregon," taken together with the absence of any report of } \\
\text { felt earthquakes in Portland on this date, suggests that this } \\
\text { aftershock was NOT felt in Portland or northern Oregon. } \\
\text { Very similar articles appeared in the Valley Record (Ashland) of } \\
26 \text { Apr } 1906, p .7, c .6 \text {, and in a number of other papers. } \\
\text { See Table 9. }\end{array}$ \\
\hline 23-Apr-06 & $01: 15$ & Hayfork & Trinity & & $\begin{array}{l}\text { The Searchlight (Redding), } \\
26 \text { Apr 1906; p. 3, c. } 1\end{array}$ & $\begin{array}{l}\text { "The earthquake shock ... was not very heavy. No damage was } \\
\text { done, but it was a reminder." } \\
\text { See Table } 9 .\end{array}$ \\
\hline 23-Apr-06 & $01: 15$ & Weaverville & Trinity & & $\begin{array}{l}\text { Courier-Free Press (Redding), } \\
23 \text { Apr 1906; p. 1, c. } 2\end{array}$ & $\begin{array}{l}\text { "WEAVERVILLE, April 23.-Many Weaverville people were } \\
\text { awakened from sound slumbers this morning at } 1: 15 \text { o'clock by a } \\
\text { slight earthquake shock and rumbling that lasted possibly two } \\
\text { seconds. } \\
\text { "The shock here was not so severe as that on Wednesday but the } \\
\text { people were of course frightened. All they have heard for five } \\
\text { days is earthquake and they are ready to go into a panic at the } \\
\text { slightest tremble of the earth. No damage resulted this morning." } \\
\text { See Table 9. }\end{array}$ \\
\hline 23-Apr-06 & $\sim 01: 15$ & $\begin{array}{c}\text { Sisson } \\
\text { (now } M t \text {. Shasta) }\end{array}$ & Siskiyou & & $\begin{array}{l}\text { The Searchlight (Redding), } \\
\text { 24 Apr } 1906 ; \\
\text { p. } 1, \text { c. } 1-2 \text {, and p. } 2, \text { c. } 2\end{array}$ & $\begin{array}{l}\text { "SISSON, April 23-5 a. m.-Two earthquake shocks occurred } \\
\text { here this morning at } 1: 15 \text {, though the exact time is in dispute. } \\
\text { There was an interval of about fifteen seconds between the } \\
\text { shocks, and the last one was much more severe than the first. } \\
\text { "The earthquake was almost an exact duplicate of that of last } \\
\text { Wednesday morning. Windows rattled, doors were slammed shut, } \\
\text { and restless sleepers were awakened. There was a continued } \\
\text { tremor between the two shocks, the last one closing the seismic } \\
\text { exhibition with a bang." } \\
\text { See Table 9. }\end{array}$ \\
\hline 23-Apr-06 & $01: 15$ & Yreka & Siskiyou & & $\begin{array}{c}\text { Courier-Free Press (Redding), } \\
23 \text { Apr 1906; p. } 1, \text { c. } 3\end{array}$ & $\begin{array}{l}\text { “YREKA, April 23.-Quite a severe shock of earthquake } \\
\text { occurred here at 1:15 o'clock this morning. The shock was felt } \\
\text { more distinctly than the one of Wednesday, but no damage was } \\
\text { done other than to put a keen edge to the fears of the people. }\end{array}$ \\
\hline
\end{tabular}


TABLE 1: Catalog of Aftershock Reports following from the Great 18 April 1906 California Earthquake

\begin{tabular}{|c|c|c|c|c|c|c|}
\hline Date Felt & $\begin{array}{l}\text { Time Felt } \\
\text { (PST) }\end{array}$ & $\begin{array}{l}\text { Location Felt } \\
\text { (City) }\end{array}$ & $\begin{array}{l}\text { Location Felt } \\
\text { (County) }\end{array}$ & $\begin{array}{l}\text { Unreliable? } \\
\text { Not Felt? }^{+}\end{array}$ & Source & Relevant Citations and other Notes \\
\hline & & & & & & $\begin{array}{l}\text { "Windows rattled and people were awakened from sound } \\
\text { slumbers." } \\
\text { See Table } 9 .\end{array}$ \\
\hline 23-Apr-06 & $\sim 01: 15$ & Ashland & $\begin{array}{l}\text { Jackson Co. } \\
\text { (Oregon) }\end{array}$ & unreliable & $\begin{array}{c}\text { Courier-Free Press (Redding) } \\
23 \text { Apr 1906; p. 1, c. } 1\end{array}$ & $\begin{array}{l}\text { "ASHLAND, Ore., April 23.-Southern Oregon had a lively } \\
\text { shakeup this morning about 1:15 o'clock, but so far no damage } \\
\text { has been reported from any point in this section. } \\
\text { "The temblor this morning was more severe than the one of } \\
\text { Wednesday. Houses shook and windows rattled, dishes were } \\
\text { knocked over and people were awakened in every part of the } \\
\text { town. } \\
\text { "Since the earthquake of Wednesday there have been predictions } \\
\text { that Portland and the north coast would be the next to receive a } \\
\text { visit from earthquakes, and the people were in a nervous state } \\
\text { that was not at all improved by this morning's shake. Many of } \\
\text { them ran from their homes in scant attire expecting to see the } \\
\text { business part of the town in ruins." } \\
\text { See Table 9. }\end{array}$ \\
\hline 23-Apr-06 & $\begin{array}{l}\text { 01:15 } \\
\sim\end{array}$ & $\begin{array}{l}\text { Crescent City } \\
\text { Grants Pass } \\
\text { San Francisco }\end{array}$ & $\begin{array}{l}\text { Del Norte } \\
\text { Josephine Co. } \\
\text { (Oregon) } \\
\text { San Francisco }\end{array}$ & $\begin{array}{c}\text { Not Felt } \\
\text { (unreliable) }\end{array}$ & $\begin{array}{c}\text { Del Norte Record, } \\
28 \text { Apr 1906; p. 3, c. } 2\end{array}$ & $\begin{array}{l}\text { "... another earthquake shock was felt here. Some who were } \\
\text { awakened reported that the shock was more severe than that on } \\
\text { the morning of the } 18 \text { th inst. The western and eastern portions of } \\
\text { town received the heaviest shock. No damage was done. The } \\
\text { shock was felt in Grants Pass, but not in San Francisco." } \\
\text { Lawson (1908) indicates Rossi-Forel Intensity IV-V at Crescent } \\
\text { City for the mainshock. } \\
\text { It is not clear where the report about the earthquake being unfelt in } \\
\text { San Francisco originated from, and considering that no sources in } \\
\text { San Francisco either confirmed or denied feeling this earthquake, } \\
\text { the statement in the Del Norte Record should not be fully trusted. } \\
\text { Note that it conflicts with a statement in the Courier-Free Press } \\
\text { (Redding) in an entry below (listed at the time 01:20, } 23 \text { Apr). } \\
\text { See Table 9. }\end{array}$ \\
\hline 23-Apr-06 & $\begin{array}{l}01: 15 \text { or } \\
01: 16\end{array}$ & Grass Valley & Nevada & & $\begin{array}{c}\text { Daily Morning Union } \\
\text { (Grass Valley \& Nevada City), } \\
24 \text { Apr 1906; p. 2, c. } 5\end{array}$ & $\begin{array}{l}\text { "Some watches caught it at 1:15 and some at 1:16 yesterday } \\
\text { morning. The shock was sufficient to set two-story dwellings } \\
\text { a-quiver, but did not possess strength enough to rattle doors and } \\
\text { windows and shake people up as did the shocks last Wednesday. } \\
\text { The course of the quake seemed to be about the same as that of last } \\
\text { week, from southeast to northwest. Only light sleepers were } \\
\text { awakened, but the few who chanced to be up at that hour give a } \\
\text { dependable account of the shock, which lasted fully fifteen } \\
\text { seconds." }\end{array}$ \\
\hline
\end{tabular}


TABLE 1: Catalog of Aftershock Reports following from the Great 18 April 1906 California Earthquake

\begin{tabular}{|c|c|c|c|c|c|c|}
\hline Date Felt & $\begin{array}{l}\text { Time Felt } \\
\text { (PST) }\end{array}$ & $\begin{array}{l}\text { Location Felt } \\
\text { (City) }\end{array}$ & $\begin{array}{l}\text { Location Felt } \\
\text { (County) }\end{array}$ & $\begin{array}{l}\text { Unreliable? } \\
\text { Not Felt? }^{+}\end{array}$ & Source & Relevant Citations and other Notes \\
\hline & & & & & & See Table 9. \\
\hline 23-Apr-06 & 01:16 & Crescent City & Del Norte & & $\begin{array}{l}\text { Lawson (1908), } \\
\text { vol. I, p. 416 }\end{array}$ & $\begin{array}{l}\text { “... Woke up everybody, no damage." } \\
\text { See Table } 9 .\end{array}$ \\
\hline 23-Apr-06 & 01:17 & Cape Mendocino & Humboldt & & $\begin{array}{c}\text { Lighthouse Log for } \\
\text { Cape Mendocino Lighthouse, } \\
23 \text { Apr } 1906\end{array}$ & $\begin{array}{l}\text { Excerpt from the entry of } 23 \text { Apr 1906: } \\
\text { "shock of earthquake } 0: 55 \text { a.m.* and started stopped clock in } \\
\text { tower woke up everybode [sic] and rushing out of hous [sic] but } \\
\text { no damage was done the shock traveled from South to North." } \\
\text { * "1.17" is written in above "0:55" and is inferred to denote a } \\
\text { second event. } \\
\text { See Table 9. }\end{array}$ \\
\hline 23-Apr-06 & 01:17 & Cape Mendocino & Humboldt & & $\begin{array}{l}\text { Lawson (1908), } \\
\text { vol. I, p. } 416\end{array}$ & $\begin{array}{l}\text { felt } \\
\text { See Table } 9 .\end{array}$ \\
\hline 23-Apr-06 & 01:20 & $\begin{array}{c}\text { Portland } \\
\text { Seattle } \\
\text { Oakland } \\
\text { San Francisco }\end{array}$ & $\begin{array}{c}\text { Multnomah Co. } \\
\text { (Oregon) } \\
\text { King Co. } \\
\text { (Washington) } \\
\text { Alameda } \\
\text { San Francisco }\end{array}$ & $\begin{array}{l}\text { unreliable } \\
\text { unreliable } \\
\text { unreliable } \\
\text { unreliable }\end{array}$ & $\begin{array}{c}\text { Courier-Free Press (Redding), } \\
23 \text { Apr 1906; p. 1, c. } 2\end{array}$ & $\begin{array}{l}\text { "The people of Redding experienced another earthquake shock at } \\
\text { 1:20 o'clock Monday morning. In some sections of town the } \\
\text { twister was felt more plainly than in others. Many people slept } \\
\text { through it all, not knowing of any disturbance until they } \\
\text { awakened and were told of the affair by their neighbors, whose } \\
\text { slumbers had been disturbed. } \\
\text { "The shock was accompanied by a rumbling noise similar to that } \\
\text { made by a locomotive. Many who felt the shock did not consider } \\
\text { it of sufficient import to get out of bed, while others made hasty } \\
\text { exits from their lodgings. } \\
\text { "Several guests at the Lorenz and Golden Eagle hotels were } \\
\text { awakened but none were badly frightened. } \\
\text { "A stone and concrete fence on the north Liberty street premises } \\
\text { of A. J. Martin ... was cracked in several places. } \\
\text { "The shake was felt as far north as Portland and Seattle and } \\
\text { south in Oakland and San Francisco, though no damage was } \\
\text { reported from any section in the state." } \\
\text { The last paragraph is almost certainly erroneous. It is not } \\
\text { corroborated in either the Oregon Daily Journal or the Morning } \\
\text { Oregonian, both of which were published daily in Portland. Also, } \\
\text { there are no reliable reports which suggest that this earthquake was } \\
\text { felt in Oakland, San Francisco, or Seattle. } \\
\text { Also note that "twister" is used in this article as a reference to the } \\
\text { earthquake. } \\
\text { See Table 9. }\end{array}$ \\
\hline
\end{tabular}


TABLE 1: Catalog of Aftershock Reports following from the Great 18 April 1906 California Earthquake

\begin{tabular}{|c|c|c|c|c|c|c|}
\hline Date Felt & $\begin{array}{l}\text { Time Felt } \\
\text { (PST) }\end{array}$ & $\begin{array}{l}\text { Location Felt } \\
\text { (City) }\end{array}$ & $\begin{array}{l}\text { Location Felt } \\
\text { (County) }\end{array}$ & \begin{tabular}{|l|} 
Unreliable? \\
Not Felt? $^{+}$
\end{tabular} & Source & Relevant Citations and other Notes \\
\hline 23-Apr-06 & 01:20 & Dunsmuir & Siskiyou & & $\begin{array}{c}\text { Courier-Free Press (Redding), } \\
23 \text { Apr 1906; p. 1, c. } 1\end{array}$ & $\begin{array}{l}\text { "DUNSMUIR, April 23.- This section was visited by a severe } \\
\text { twister at 1:20 o'clock this morning and many people were } \\
\text { frightened into the belief that the end of the world had arrived. } \\
\text { "The earthquake was most strongly felt on the hill and in the } \\
\text { higher sections of town. Down town and along the level of the } \\
\text { railroad track the shake resembled the rumbling of a locomotive, } \\
\text { an accustomed sound here, and the people did not notice it. } \\
\text { "But up on the hill back of the main street there was a lively } \\
\text { shaking up of windows, dishes and furniture. } \\
\text { "Frank Talmadge, who lives on the hill section, says his house } \\
\text { was severely wrenched and shaken. The windows rattled, } \\
\text { Talmadge's bed swayed perceptibly and he hastily telephoned } \\
\text { down town to see how much damage was done. Clocks were } \\
\text { stopped in various parts of town. } \\
\text { "The shock awakened all the residents of the hill section and was } \\
\text { twice as severe as the one of Wednesday morning." } \\
\text { "Twister" is used in this article as a reference to the earthquake. } \\
\text { See Table 9. }\end{array}$ \\
\hline 23-Apr-06 & 01:20 & $\begin{array}{c}\text { Sisson } \\
\text { (now Mt. Shasta) }\end{array}$ & Siskiyou & & $\begin{array}{c}\text { Courier-Free Press (Redding), } \\
23 \text { Apr 1906; p. 1, c. } 3\end{array}$ & $\begin{array}{l}\text { "SISSON, April 23.-Sisson folks experienced a very slight shock } \\
\text { of earthquake this morning at 1:20 o'clock. The shock was lighter } \\
\text { than that of Wednesday and not a particle of damage was done. } \\
\text { Windows rattled some. } \\
\text { "The stories sent out about Mount Shasta are silly. No smoke } \\
\text { has been issuing from the mountain or near it." } \\
\text { See Table } 9 .\end{array}$ \\
\hline 23-Apr-06 & 01:20 & $\begin{array}{l}\text { Medford } \\
\text { Ashland } \\
\text { Grants Pass } \\
\text { Glendale }\end{array}$ & $\begin{array}{c}\text { Jackson Co. } \\
\text { (Oregon) } \\
\text { Jackson Co. } \\
\text { (Oregon) } \\
\text { Josephine Co. } \\
\text { (Oregon) } \\
\begin{array}{c}\text { Douglas Co. } \\
\text { (Oregon) }\end{array}\end{array}$ & & $\begin{array}{c}\text { Medford Mail, } \\
27 \text { Apr 1906; p. 1, c. } 1\end{array}$ & $\begin{array}{l}\text { "Light sleepers-and some of those whose slumbers are usually } \\
\text { profound-were aroused about 1:20 Monday morning by a } \\
\text { distinct, though comparatively, slight seismic movement. J. S. } \\
\text { Howard was awakened by the shock and noted the time-1:20. } \\
\text { Dr. Pickel had the same experience and on making a professional } \\
\text { call at Central Point later in the morning was asked about the } \\
\text { first thing whether the temblor had been felt in Medford or not. } \\
\text { Distinct shocks were felt at Ashland, Grants Pass and Glendale." } \\
\text { See Table 9. }\end{array}$ \\
\hline
\end{tabular}


TABLE 1: Catalog of Aftershock Reports following from the Great 18 April 1906 California Earthquake

\begin{tabular}{|c|c|c|c|c|c|c|}
\hline Date Felt & $\begin{array}{l}\text { Time Felt } \\
\text { (PST) }\end{array}$ & $\begin{array}{l}\text { Location Felt } \\
\quad \text { (City) }\end{array}$ & $\begin{array}{l}\text { Location Felt } \\
\text { (County) }\end{array}$ & $\begin{array}{l}\text { Unreliable? } \\
\text { Not Felt? }^{+}\end{array}$ & Source & Relevant Citations and other Notes \\
\hline 23-Apr-06 & 01:30 & $\begin{array}{l}\text { Grants Pass } \\
\text { Ashland } \\
\text { Redding }\end{array}$ & $\begin{array}{l}\text { Josephine Co. } \\
\text { (Oregon) } \\
\text { Jackson Co. } \\
\text { (Oregon) } \\
\text { Shasta }\end{array}$ & \begin{tabular}{l|} 
unreliable \\
unreliable \\
unreliable
\end{tabular} & $\begin{array}{l}\text { Umpqua Valley News, } \\
23 \text { Apr 1906; p. } 7 \text {, c. } 6\end{array}$ & $\begin{array}{l}\text { "At half past one o' clock last night there was an earthquake felt } \\
\text { at various points throughout Southern Oregon. The tremor was } \\
\text { quite perceptible at Grants Pass, where for some twenty seconds } \\
\text { the earth trembled and buildings swayed to-and-fro, but no } \\
\text { damage resulted. Ashland also felt the same shock. } \\
\text { "Further down, in north California the tremor was much } \\
\text { stronger. At Redding the chimnneys tumbled down and caused } \\
\text { considerable confusion, but aside from that there was no damage } \\
\text { done." } \\
\text { See Table 9. }\end{array}$ \\
\hline 23-Apr-06 & 01:30 & Eureka & Humboldt & unreliable & $\begin{array}{l}\text { Courier-Free Press (Redding) } \\
23 \text { Apr 1906; p. } 1, \text { c. } 2\end{array}$ & $\begin{array}{l}\text { "slight ... no damage was done" } \\
\text { See Table } 9 .\end{array}$ \\
\hline 23-Apr-06 & $\sim 03: 00$ & Arcata & Humboldt & & $\begin{array}{l}\text { Humboldt Times, } \\
24 \text { Apr 1906; p. 7, c. 6-7 }\end{array}$ & $\begin{array}{l}\text { "ARCATA, April 23.-.... Another earthquake shock was felt } \\
\text { here this morning at about } 3 \text { o'clock. Although not as violent as } \\
\text { the first one, it caused a little damage and aroused people in some } \\
\text { instances from their houses." } \\
\text { Based on other accounts from Humboldt County, this was probably } \\
\text { the shock that occurred shortly after } 1 \text { am on } 23 \text { Apr. } \\
\text { See Table 9. }\end{array}$ \\
\hline 23-Apr-06 & $\begin{array}{l}\text { early } \\
\text { morning }\end{array}$ & Challenge & Yuba & & $\begin{array}{l}\text { Marysville Daily Appeal, } \\
26 \text { Apr 1906; p. 2, c. } 1\end{array}$ & $\begin{array}{l}\text { "... there was a light shock...." } \\
\text { See Table } 9 .\end{array}$ \\
\hline 23-Apr-06 & morning & Fieldbrook & Humboldt & & $\begin{array}{c}\text { Arcata Union, } \\
28 \text { Apr 1906; p. 8, c. } 3\end{array}$ & $\begin{array}{l}\text { "People were awakened from their sleep ... by another } \\
\text { earthquake." } \\
\text { See Table } 9 .\end{array}$ \\
\hline 23-Apr-06 & morning & Cape Mendocino & Humboldt & unreliable & $\begin{array}{l}\text { Humboldt Times, } \\
29 \text { Apr 1906; p. 5, c. } 2\end{array}$ & $\begin{array}{l}\text { "Information was received over the telephone at this office last } \\
\text { evening to the effect that the earthquake which occurred last } \\
\text { Monday morning, demolished the keeper's house at the Cape } \\
\text { Mendocino light-house. The stone tower which contains the light } \\
\text { was not damaged and neither was any of the other buildings." } \\
\text { This report appears to be incorrect. The lighthouse log, kept by the } \\
\text { lighthouse keeper at Cape Mendocino, states that no damage was } \\
\text { done at Cape Mendocino by this earthquake. The lighthouse log is } \\
\text { considered more reliable, since it is a first-hand account. } \\
\text { See Table 9. }\end{array}$ \\
\hline 23-Apr-06 & morning & Ashland & $\begin{array}{l}\text { Jackson Co. } \\
\text { (Oregon) }\end{array}$ & & $\begin{array}{l}\text { Eugene Daily Guard, } \\
23 \text { Apr 1906; p. 1, c. } 3\end{array}$ & $\begin{array}{l}\text { "a very slight earthquake shock" } \\
\text { See Table } 9 .\end{array}$ \\
\hline
\end{tabular}


TABLE 1: Catalog of Aftershock Reports following from the Great 18 April 1906 California Earthquake

\begin{tabular}{|c|c|c|c|c|c|c|}
\hline Date Felt & $\begin{array}{l}\text { Time Felt } \\
\text { (PST) }\end{array}$ & $\begin{array}{l}\text { Location Felt } \\
\text { (City) }\end{array}$ & $\begin{array}{l}\text { Location Felt } \\
\text { (County) }\end{array}$ & $\begin{array}{l}\text { Unreliable? } \\
\text { Not Felt? }^{+}\end{array}$ & Source & Relevant Citations and other Notes \\
\hline 23-Apr-06 & morning & $\begin{array}{c}\text { Grants Pass } \\
\text { Eugene }\end{array}$ & $\begin{array}{l}\text { Josephine Co. } \\
\text { (Oregon) } \\
\text { Lane Co. } \\
\text { (Oregon) }\end{array}$ & Not Felt & $\begin{array}{l}\text { Eugene Daily Guard, } \\
23 \text { Apr 1906; p. 2, c. } 1\end{array}$ & $\begin{array}{l}\text { "The earthquake seems to be moving northward-is getting a little } \\
\text { too close for comfort. Grant's Pass, where they felt a tremble } \\
\text { early this morning, is less than two hundred miles from Eugene." } \\
\text { This comment in the Eugene Daily Guard implies that the } \\
\text { earthquake of the morning of } 23 \text { Apr was NOT felt in Eugene. } \\
\text { See Table 9. }\end{array}$ \\
\hline 23-Apr-06 & morning & $\begin{array}{c}\text { Redding } \\
\text { Sacramento } \\
\text { Portland } \\
\text { Ashland } \\
\text { Grants Pass } \\
\text { Yreka }\end{array}$ & $\begin{array}{c}\text { Shasta } \\
\text { Sacramento } \\
\text { Multnomah Co. } \\
\text { (Oregon) } \\
\text { Jackson Co. } \\
\text { (Oregon) } \\
\text { Josephine Co. } \\
\text { (Oregon) } \\
\text { Siskiyou }\end{array}$ & $\begin{array}{l}\text { unreliable } \\
\text { unreliable } \\
\text { unreliable } \\
\text { unreliable } \\
\text { unreliable } \\
\text { unreliable }\end{array}$ & $\begin{array}{l}\text { Humboldt Standard, } \\
23 \text { Apr 1906; p. 1, c. 4-5 }\end{array}$ & $\begin{array}{l}\text { "... The earthquake this morning lasted eight seconds at Redding, } \\
\text { Cal. Chimneys were thrown down and the guests at the Hotel } \\
\text { Lorenz rushed into the streets clad only in their night robes. } \\
\text { "A very slight shock was felt in Sacramento. } \\
\text { "Portland, Oregon has received a heavy shock. The earthquake } \\
\text { seems heavier as it went further north. At Ashland, Oregon, and } \\
\text { Grant's Pass it was severe. At Yreka it was more severe than on } \\
\text { Wednesday." } \\
\text { Very similar articles appeared in the Humboldt Times of } 24 \text { Apr } \\
\text { 1906, p. 2, c. 2-3, and in the Arcata Union of } 25 \text { Apr 1906, p. } 4, c .1 . \\
\text { The Portland report is not corroborated in the Oregon Daily Journal } \\
\text { or in the Morning Oregonian, both of which were published daily } \\
\text { in Portland. Similarly, the Sacramento report is not corroborated in } \\
\text { any of the Sacramento newspapers. } \\
\text { See Table 9. }\end{array}$ \\
\hline 23-Apr-06 & morning & & $\begin{array}{l}\text { Northern } \\
\text { California } \\
\text { and Oregon }\end{array}$ & unreliable & $\begin{array}{c}\text { Arcata Union, } \\
25 \text { Apr 1906; p. 1, c. 3-4 }\end{array}$ & $\begin{array}{l}\text { "The earthquake which visited us again on Monday morning, } \\
\text { seemed to have worked as far north as Portland, but no great } \\
\text { amount of damage is reported from this tremblor." } \\
\text { This appears to be incorrect. The report of an earthquake felt in } \\
\text { Portland is not corroborated in either the Oregon Daily Journal or } \\
\text { the Morning Oregonian, both of which were published in Portland. } \\
\text { See Table 9. }\end{array}$ \\
\hline 23-Apr-06 (?) & & & $\begin{array}{l}\text { Northern } \\
\text { California } \\
\text { and Oregon }\end{array}$ & unreliable & $\begin{array}{c}\text { Daily Colusa Sun, } \\
25 \text { Apr 1906; p. 1, c. } 2\end{array}$ & $\begin{array}{l}\text { "The northern part of California and the southern portion of } \\
\text { Oregon escaped the great earthquake of Wednesday, the } 18 \text { th, but } \\
\text { that portion of our coast has been experiencing shocks of greater } \\
\text { or less degree during the past few days. Reports from Portland, } \\
\text { Grants Pass, Ashland, Jacksonville and Eugene in Oregon and } \\
\text { Redding, Sisson, Weaverville, Yreka, and several other Northern } \\
\text { California towns is to the effect that much uneasiness is felt, } \\
\text { though no damage has resulted from the shake." } \\
\text { Although the date of the event (or events) is not given specifically, } \\
\text { it is probably referring to the } 23 \text { Apr event. The information in this } \\
\text { article does not appear to be entirely accurate. The report of an }\end{array}$ \\
\hline
\end{tabular}


TABLE 1: Catalog of Aftershock Reports following from the Great 18 April 1906 California Earthquake

\begin{tabular}{|c|c|c|c|c|c|c|}
\hline Date Felt & $\begin{array}{l}\text { Time Felt } \\
\text { (PST) }\end{array}$ & $\begin{array}{l}\text { Location Felt } \\
\text { (City) }\end{array}$ & $\begin{array}{l}\text { Location Felt } \\
\text { (County) }\end{array}$ & $\begin{array}{l}\text { Unreliable? } \\
\text { Not Felt? }{ }^{+}\end{array}$ & Source & Relevant Citations and other Notes \\
\hline & & & & & & $\begin{array}{l}\text { earthquake felt in Portland is not corroborated in either the Oregon } \\
\text { Daily Journal or the Morning Oregonian, both of which were } \\
\text { published daily in Portland, nor is the report of an earthquake felt } \\
\text { in Eugene corroborated in either the Eugene Daily Guard or the } \\
\text { Morning Register, both of which were published daily in Eugene. } \\
\text { See Table 9. }\end{array}$ \\
\hline 23-Apr-06 & 04:00 & Oakland & Alameda & & $\begin{array}{l}\text { Humboldt Times, } \\
24 \text { Apr 1906; p. 2, c. 2-3 }\end{array}$ & “... Slight shock at Oakland...." \\
\hline 23-Apr-06 & $04: 30$ & Oakland & Alameda & & $\begin{array}{c}\text { Humboldt Standard, } \\
23 \text { Apr 1906; p. 1, c. } 4-5\end{array}$ & “... A slight shock occurred at Oakland...." \\
\hline 23-Apr-06 & $05: 30$ & Orick & Humboldt & & $\begin{array}{c}\text { Arcata Union, } \\
28 \text { Apr 1906; p. 8, c. } 3\end{array}$ & $\begin{array}{l}\text { "Orick. / April 23, 1906. / This vicinity was visited by an } \\
\text { earthquake Wednesday morning [18 Apr] at 5:20 a. m. This } \\
\text { morning at } 1 \text { o'clock there was another fully as heavy as the first } \\
\text { and at half past five another, fully as heavy as any preceding. All } \\
\text { the damage done was to break a few panes of glass." } \\
\text { Lawson (1908) indicates Rossi-Forel Intensity V-VI at Orick for the } \\
\text { mainshock. It is not clear which of the earthquakes mentioned were } \\
\text { responsible for breaking the panes of glass. }\end{array}$ \\
\hline 23-Apr-06 & 06:00 & Blocksburg & Humboldt & & $\begin{array}{l}\text { Humboldt Standard, } \\
26 \text { Apr 1906; p. 6, c. } 1\end{array}$ & "a slight shake" \\
\hline 23-Apr-06 & 06:00 & New River & Trinity & & $\begin{array}{l}\text { Humboldt Times, } \\
28 \text { Apr 1906; p. 6, c. } 2\end{array}$ & “a ... very light one" \\
\hline 23-Apr-06 & 06:07 & Eureka & Humboldt & & $\begin{array}{l}\text { Humboldt Times, } \\
24 \text { Apr 1906; p. } 8 \text {, c. } 4\end{array}$ & $\begin{array}{l}\text { "... vibrations from southwest to northeast, and lasting four } \\
\text { seconds." } \\
\text { See the note for the report from this newspaper of the 01:10 shock of } \\
23 \text { Apr. }\end{array}$ \\
\hline 23-Apr-06 & $11: 30$ & Santa Cruz & Santa Cruz & & $\begin{array}{l}\text { Santa Cruz Morning Sentinel, } \\
24 \text { Apr 1906; p. 1, c. 3-5 }\end{array}$ & $\begin{array}{l}\text { "The first shake felt on Monday was at 11:30 A. M., and was of } \\
\text { about fifteen seconds' duration." }\end{array}$ \\
\hline 23-Apr-06 & $22: 39$ & San Francisco & San Francisco & & $\begin{array}{l}\text { Fresno Morning Republican, } \\
24 \text { Apr 1906; p. } 1, \text { c. } 1\end{array}$ & $\begin{array}{l}\text { "SAN FRANCISCO, April 23.-A sharp earthquake shock was } \\
\text { felt here.... It lasted about three seconds, and was from east to } \\
\text { west. No damage has been reported." }\end{array}$ \\
\hline 23-Apr-06 & $22: 39$ & Oakland & Alameda & & $\begin{array}{l}\text { Fresno Morning Republican, } \\
24 \text { Apr } 1906 ; \text { p. } 4 \text {, c. } 6\end{array}$ & $\begin{array}{l}\text { "OAKLAND, April 23.-A quite perceptible earthquake shock } \\
\text { was felt here.... No damage resulted." }\end{array}$ \\
\hline 23-Apr-06 & $22: 40$ & San Francisco & San Francisco & & $\begin{array}{c}\text { The Bulletin (San Francisco), } \\
24 \text { Apr 1906; p. 9, c. } 2\end{array}$ & $\begin{array}{l}\text { "At 10:40 o'clock last night an earthquake shock was felt } \\
\text { throughout the city, and momentarily created considerable alarm } \\
\text { among the people, still unnerved and overwrought from their } \\
\text { recent experiences. No damage was done, but in some few } \\
\text { instances, persons living in houses ran out, badly frightened, and } \\
\text { called upon the sentries and guards to help carry out clothing and }\end{array}$ \\
\hline
\end{tabular}


TABLE 1: Catalog of Aftershock Reports following from the Great 18 April 1906 California Earthquake

\begin{tabular}{|c|c|c|c|c|c|c|}
\hline Date Felt & $\begin{array}{l}\text { Time Felt } \\
\text { (PST) }\end{array}$ & $\begin{array}{l}\text { Location Felt } \\
\text { (City) }\end{array}$ & $\begin{array}{l}\text { Location Felt } \\
\text { (County) }\end{array}$ & $\begin{array}{l}\text { Unreliable? } \\
\text { Not Felt? }^{+}\end{array}$ & Source & Relevant Citations and other Notes \\
\hline & & & & & & $\begin{array}{l}\text { other effects. The soldiers reassured them that there was no } \\
\text { danger and that any other time the shock would have caused little } \\
\text { comment. Shortly after the slight temblor an unconscious man } \\
\text { was found on the sidewalk in front of a house at Golden Gate } \\
\text { avenue and Buchanan streets. He had evidently fallen or jumped } \\
\text { from a window in his efforts to get out of the house when it was } \\
\text { shaken...." } \\
\text { Also in the Oakland Herald of } 24 \text { Apr } 1906, p .5, \text { c. } 4 \text {. }\end{array}$ \\
\hline 23-Apr-06 & 23:00 & San Francisco & San Francisco & & $\begin{array}{l}\text { Oakland Enquirer, } \\
24 \text { Apr 1906; p. } 1\end{array}$ & $\begin{array}{l}\text { "San Francisco, April 24.-The earthquake ... caused } \\
\text { considerable excitement here but no material damage. However, } \\
\text { Philip Duvol, of } 834 \text { Page Street, and W. H. Goucher, of } 1060 \text { Ellis } \\
\text { Street, died as a result of the shake." }\end{array}$ \\
\hline 23-Apr-06 & night & San Francisco & San Francisco & & $\begin{array}{c}\text { The Evening Mail (Stockton), } \\
24 \text { Apr 1906; p. } 1, \text { c. } 3\end{array}$ & $\begin{array}{l}\text { "A rumor started on the streets this afternoon, in some unknown } \\
\text { way, that there had been another earthquake in San Francisco } \\
\text { to-day. According to the report, all buildings which had } \\
\text { remained standing in the stricken city were leveled to the ground, } \\
\text { and the Ferry building had fallen over into the bay. The Mail } \\
\text { made inquiry through the Associated Press and ascertained that } \\
\text { the rumor was entirely without foundation. The Chamber of } \\
\text { Commerce telephoned to Oakland with similar result. The report } \\
\text { was probably caused by the fact that there was one last night, } \\
\text { which, however, did no damage." }\end{array}$ \\
\hline $\begin{array}{l}\text { 18-Apr-06 thru } \\
\text { 23-Apr-06 }\end{array}$ & $\begin{array}{l}\text { (several } \\
\text { events) }\end{array}$ & $\begin{array}{l}\text { Napa Redwoods } \\
\text { [7 mi NE of } \\
\text { Sonoma (?)] }\end{array}$ & Napa & & $\begin{array}{c}\text { Napa Register, } \\
27 \text { Apr 1906; p. 3, c. } 6\end{array}$ & $\begin{array}{l}\text { "Since the } 18 \text { th several slight shocks three being very distinct, } \\
\text { have been felt." } \\
\text { This was part of an article written by a regular correspondent, } \\
\text { dated "Napa Redwoods, April 23, 1906." }\end{array}$ \\
\hline $\begin{array}{l}\text { 18-Apr-06 thru } \\
\text { 23-Apr-06 }\end{array}$ & (many events) & San Francisco & San Francisco & & $\begin{array}{l}\text { San Francisco Chronicle, } \\
24 \text { Apr 1906; p. } 8 \text {, c. } 1-2\end{array}$ & $\begin{array}{l}\text { "Shocks by the score have been recorded by the United States } \\
\text { Weather Bureau under the direction of Forecaster M'Adie ever } \\
\text { since the first great temblor on Wednesday morning. On that } \\
\text { memorable day no less than seventeen distinct movements of the } \\
\text { earth's crust were recorded. } \\
\text { “The first one, occurring at 5:13 o' clock in the morning, lasted } \\
\text { forty-seven seconds. Another one came at 5:18 and lasted a few } \\
\text { seconds; another came at 5:20, another at 5:25, another at 5:42, } \\
\text { and then there came a lapse until } 8: 13 \text {. This shock lasted five } \\
\text { seconds and was the most severe since the big shake-up. The } \\
\text { occurrence of the following shocks came at 9:13, } 9: 25,10: 49 \text {, } \\
\text { 11:05, 12:03, 12:10, 2:23, 2:27, 4:50, 6:49, and } 7 \text { o' clock. } \\
\text { “The great movement of the earth in the bay region can hardly be } \\
\text { said to be over. McAdie says that he has records of numbers of } \\
\text { shocks for every day since the fateful Wednesday but he hastens } \\
\text { to assure the public that the danger from a heavy shock of a } \\
\text { destructive character is gone. The minor temblors, which are still }\end{array}$ \\
\hline
\end{tabular}


TABLE 1: Catalog of Aftershock Reports following from the Great 18 April 1906 California Earthquake

\begin{tabular}{|c|c|c|c|c|c|c|}
\hline Date Felt & $\begin{array}{l}\text { Time Felt } \\
\text { (PST) }\end{array}$ & $\begin{array}{l}\text { Location Felt } \\
\text { (City) }\end{array}$ & $\begin{array}{l}\text { Location Felt } \\
\text { (County) }\end{array}$ & $\begin{array}{l}\text { Unreliable? } \\
\text { Not Felt? }^{+}\end{array}$ & Source & Relevant Citations and other Notes \\
\hline & & & & & & $\begin{array}{l}\text { coming and one of which occurred at an early hour yesterday } \\
\text { morning, are merely the necessary movements of the earth in the } \\
\text { process of adjustment.... } \\
\text { "Although McAdie stayed by his post in the Mills building until } \\
\text { the structure caught fire and he was the last man to leave the } \\
\text { building, he has not stopped work. His instruments are } \\
\text { destroyed, but the records of the last sixty years are believed to } \\
\text { be intact in the safe.... } \\
\text { "McAdie has found ... at the Eckart home, } 3014 \text { Clay street, a } \\
\text { complete set of apparatus for just the work of his department. At } \\
\text { this address the Weather Bureau is now located, and will remain } \\
\text { until other arrangements are made for it...." } \\
\text { The "Forecaster McAdie" mentioned in this article is Professor } \\
\text { Alexander G. McAdie, who at the time of the } 1906 \text { earthquake was } \\
\text { Meteorologist in Charge of the San Francisco office of the United } \\
\text { States Weather Bureau. In } 1907 \text {, he published a catalog of } \\
\text { earthquakes on the Pacific coast, covering the years } 1897 \text { to } 1907 . \\
\text { It was published under the title Smithsonian Miscellaneous } \\
\text { Collections, part of Volume XLIX, No. } 1721 \text {. More information can } \\
\text { be found in the Preface and Introduction to the Townley and Allen } \\
\text { (1939) catalog, pp. 1-13. } \\
\text { The events listed in this article are not listed as individual entries } \\
\text { in this catalog because they are all listed in McAdie's catalog and } \\
\text { again in Townley and Allen (1939). It is not always clear which of } \\
\text { these aftershocks were actually felt or which were only recorded } \\
\text { instrumentally. } \\
\text { The times given in this article for all the aftershocks (except the } \\
\text { last aftershock, at 7pm) were adjusted by McAdie before he } \\
\text { published his catalog in } 1907 \text {. Each of the times listed in his } \\
\text { catalog for these aftershocks is one minute later than it is in this } \\
\text { article. }\end{array}$ \\
\hline 24-Apr-06 (?) & $\sim 01: 00$ & San Rafael & Marin & & $\begin{array}{c}\text { Marin Journal, } \\
26 \text { Apr 1906; p. 5, c. } 3\end{array}$ & $\begin{array}{l}\text { "A slight earthquake shock was felt here at about } 1 \text { o'clock } \\
\text { Monday night. It was of short duration and no damage." } \\
\text { It is not clear whether "about } 1 \text { o'clock Monday night" refers to the } \\
\text { early morning of } 23 \text { or } 24 \text { Apr. } \\
\text { See Table } 9 .\end{array}$ \\
\hline $\begin{array}{l}\text { 18-Apr-06 to } \\
\text { 24-Apr-06 }\end{array}$ & (many events) & Santa Cruz & Santa Cruz & & $\begin{array}{l}\text { Santa Cruz Morning Sentinel, } \\
24 \text { Apr 1906; p.9, c. } 3\end{array}$ & $\begin{array}{l}\text { "Though there have been many light shocks of earthquake in this } \\
\text { city since last Wednesday morning, some say over } 75 \text {, no further } \\
\text { damage has resulted, except to widen the cracks in the brick } \\
\text { buildings already damaged...." }\end{array}$ \\
\hline
\end{tabular}


TABLE 1: Catalog of Aftershock Reports following from the Great 18 April 1906 California Earthquake

\begin{tabular}{|c|c|c|c|c|c|c|}
\hline Date Felt & $\begin{array}{l}\text { Time Felt } \\
\text { (PST) }\end{array}$ & $\begin{array}{l}\text { Location Felt } \\
\text { (City) }\end{array}$ & $\begin{array}{l}\text { Location Felt } \\
\text { (County) }\end{array}$ & $\begin{array}{l}\text { Unreliable? } \\
\text { Not Felt? }^{+}\end{array}$ & Source & Relevant Citations and other Notes \\
\hline $\begin{array}{l}\text { 23-Apr-06 to } \\
\text { 24-Apr-06 }\end{array}$ & $\begin{array}{c}\text { night of } 23 \\
\text { Apr / early } \\
\text { morning of } \\
24 \mathrm{Apr}\end{array}$ & Salinas & Monterey & Not Felt & $\begin{array}{l}\text { Salinas Daily Index, } \\
24 \text { Apr 1906; p. 3, c. } 3\end{array}$ & $\begin{array}{l}\text { "For the first time since the earthquake of Wednesday morning a } \\
\text { night passes without a perceptible tremor and the city slept } \\
\text { soundly...." }\end{array}$ \\
\hline 24-Apr-06 & morning & Salinas & Monterey & & $\begin{array}{l}\text { Salinas Daily Index, } \\
24 \text { Apr 1906; p. 3, c. } 3\end{array}$ & $\begin{array}{l}\text { "For the first time since the earthquake of Wednesday morning a } \\
\text { night passes without a perceptible tremor and the city slept } \\
\text { soundly. This morning, however, there was a subterranean } \\
\text { upheaval which brought the residents to their feet with a start." }\end{array}$ \\
\hline $\begin{array}{l}\text { 24-Apr-06 to } \\
25-A p r-06\end{array}$ & $\begin{array}{l}\text { night of } \\
24 \mathrm{Apr} / \\
\text { morning of } \\
25 \mathrm{Apr} \\
\text { (several } \\
\text { events) }\end{array}$ & Salinas & Monterey & & $\begin{array}{l}\text { Salinas Daily Index, } \\
25 \text { Apr 1906; p. } 3, \text { c. } 3\end{array}$ & $\begin{array}{l}\text { "Three more earthquake shocks were felt last night and this } \\
\text { morning here, but they were so light that some did not feel them...." }\end{array}$ \\
\hline 25-Apr-06 & $\begin{array}{c}\sim 01: 00 \\
\sim\end{array}$ & $\begin{array}{c}\text { San Francisco } \\
\text { Oakland }\end{array}$ & $\begin{array}{c}\text { San Francisco } \\
\text { Alameda }\end{array}$ & & $\begin{array}{l}\text { The Bulletin (San Francisco), } \\
25 \text { Apr 1906; p. 7, c. } 1\end{array}$ & $\begin{array}{l}\text { "The slight shock of earthquake that was experienced about } 1 \\
\text { o'clock this morning was No. } 36 \text { in the series of seismic } \\
\text { disturbances that began with the one which was responsible for } \\
\text { the destruction wrought across the bay. Many Oakland people } \\
\text { were complaining today of smashed crockery and other slight } \\
\text { damage resultant from the shock, but as a whole it occasioned no } \\
\text { general alarm. } \\
\text { "At the Oakland Chabot Observatory today it was said that no } \\
\text { satisfactory record of the shock had been obtained on the } \\
\text { instruments there. The persons at the observatory were asleep } \\
\text { when the shock came and none of them were awakened by it." } \\
\text { Also in the Oakland Herald of } 25 \text { Apr 1906, p. 10, c. } 6 .\end{array}$ \\
\hline 25-Apr-06 & $15: 00$ & San Francisco & San Francisco & & $\begin{array}{l}\text { Diary of Charles Prinegar } \\
\text { (San Francisco, CA), } \\
25 \text { Apr } 1906 \text { (pp. 74-78) }\end{array}$ & $\begin{array}{l}\text { Excerpts from the entry of } 25 \text { Apr 1906: } \\
\text { "(Wednesday night) } \\
\text { "... At three o'clock another earth quake came that nearly tore the } \\
\text { Post Office down. I was on third floor and thought my time had } \\
\text { surely come when bricks and marble and such began to fall all } \\
\text { around me...." } \\
\text { See Table 10. }\end{array}$ \\
\hline 25-Apr-06 & & San Francisco & San Francisco & & $\begin{array}{l}\text { Diary of Charles Prinegar } \\
\text { (San Francisco, CA), } \\
26 \text { Apr } 1906 \text { (pp. 78-81) }\end{array}$ & $\begin{array}{l}\text { Excerpts from the entry of } 26 \text { Apr 1906: } \\
\text { “(Thursday morning.) } \\
\text { “..... } \\
\text { “There were a great many killed yesterday when the quake came } \\
\text { by falling walls and it does not look good to me. }\end{array}$ \\
\hline
\end{tabular}


TABLE 1: Catalog of Aftershock Reports following from the Great 18 April 1906 California Earthquake

\begin{tabular}{|c|c|c|c|c|c|c|}
\hline Date Felt & $\begin{array}{l}\text { Time Felt } \\
\text { (PST) }\end{array}$ & $\begin{array}{l}\text { Location Felt } \\
\text { (City) }\end{array}$ & $\begin{array}{l}\text { Location Felt } \\
\text { (County) }\end{array}$ & $\begin{array}{l}\text { Unreliable? } \\
\text { Not Felt? }^{+}\end{array}$ & Source & Relevant Citations and other Notes \\
\hline & & & & & & $\begin{array}{l}\text { "..... } \\
\text { "I would like to see one of the eastern papers for the papers out } \\
\text { here does [sic] not say a thing about the disaster or never } \\
\text { mentions a soul that was injured or killed. All they tell about is } \\
\text { the heroic work that people have done and where the homeless } \\
\text { can get relief, etc...." } \\
\text { See Table 10. }\end{array}$ \\
\hline 25-Apr-06 & & San Francisco & San Francisco & & $\begin{array}{l}\text { Diary of Charles Prinegar } \\
\text { (San Francisco, CA), } \\
30 \text { Apr } 1906 \text { (pp. 102-110) }\end{array}$ & $\begin{array}{l}\text { Excerpts from the entry of } 30 \text { Apr 1906: } \\
\text { "(Monday A. M.) } \\
\text { "..... } \\
\text { "If I had only known that there would not be any more earth- } \\
\text { quakes I could just as well kept on at the Post Office and be } \\
\text { making two dollars per day. I would have to walk four miles to } \\
\text { work and the same at night, but I would have done it, if that } \\
\text { quake had not come the first day I worked there. It scared me } \\
\text { about as bad as the first one did, and I did not want to take any } \\
\text { chances, every one that comes weakens the building that much } \\
\text { more, and it looks now as if it would fall at any time...." } \\
\text { Although this event scared the writer "about as bad as the first one } \\
\text { did," he also wrote in his diary, on } 29 \text { Apr 1906, that all the } \\
\text { aftershocks put together "would hardly make as great a one as the } \\
\text { first one was." } \\
\text { See Table 10. }\end{array}$ \\
\hline 25-Apr-06 & 15:00 & Mile Rocks & San Francisco & & $\begin{array}{l}\text { Lawson (1908), } \\
\text { vol. I, p. } 417\end{array}$ & $\begin{array}{l}\text { "Slight." } \\
\text { Durham (1998) identifies two locations named Mile Rocks, one in } \\
\text { Sonoma County and the other in San Francisco County. Looking at } \\
\text { the maps in the atlas portion of Lawson (1908), the San Francisco } \\
\text { County "Mile Rocks" location is on Maps } 4,17 \text {, and } 19 \text {, whereas } \\
\text { the Sonoma County location of that name is not on any of the maps. } \\
\text { The inference is made that "Mile Rocks" in the list of aftershocks in } \\
\text { Lawson (1908) refers to the San Francisco County location. } \\
\text { See Table 10. }\end{array}$ \\
\hline 25-Apr-06 & \begin{tabular}{|c|} 
shortly after \\
$15: 00$
\end{tabular} & Martinez & Contra Costa & & $\begin{array}{l}\text { Daily Gazette (Martinez), } \\
26 \text { Apr 1906; p. 1, c. } 4\end{array}$ & $\begin{array}{l}\text { "Martinez experienced a very heavy shock of earthquake shortly } \\
\text { after } 3 \text { o'clock Wednesday afternoon. The tremblor was the } \\
\text { heaviest since the one of April 18th and shook buildings } \\
\text { violently, rattled dishes and caused the entire population to make } \\
\text { a rush for the streets, in fear of a repetition of the earthquake that } \\
\text { wrecked half of California. As far as can be ascertained, no } \\
\text { serious damage was done beyond giving everyone a good scare. A } \\
\text { plate glass window in Bergamini's store was thrown down." }\end{array}$ \\
\hline
\end{tabular}


TABLE 1: Catalog of Aftershock Reports following from the Great 18 April 1906 California Earthquake

\begin{tabular}{|c|c|c|c|c|c|c|}
\hline Date Felt & $\begin{array}{c}\text { Time Felt } \\
\text { (PST) }\end{array}$ & $\begin{array}{l}\text { Location Felt } \\
\text { (City) }\end{array}$ & $\begin{array}{l}\text { Location Felt } \\
\text { (County) }\end{array}$ & $\begin{array}{l}\text { Unreliable? } \\
\text { Not Felt? }^{+}\end{array}$ & Source & Relevant Citations and other Notes \\
\hline & & & & & & See Table 10. \\
\hline 25-Apr-06 & \begin{tabular}{|c|} 
shortly after \\
$15: 00$
\end{tabular} & San Francisco & San Francisco & & $\begin{array}{l}\text { San Francisco Chronicle, } \\
26 \text { Apr 1906; p. 2, c. } 3\end{array}$ & $\begin{array}{l}\text { "... A slight earthquake shock which was felt in the city shortly } \\
\text { after } 3 \text { o' clock [yesterday afternoon] caused a leaning chimney at } \\
308 \text { Shotwell street to topple over and crash through the roof of } \\
\text { the house...." } \\
\text { See Table 10. }\end{array}$ \\
\hline 25-Apr-06 & $\sim 15: 10$ & $\begin{array}{l}\text { Oakland and the } \\
\text { cities of San } \\
\text { Francisco Bay }\end{array}$ & $\begin{array}{l}\text { Alameda, } \\
\text { others }\end{array}$ & & $\begin{array}{l}\text { Santa Cruz Morning Sentinel, } \\
26 \text { Apr 1906; p. 1, c. } 3\end{array}$ & $\begin{array}{l}\text { "OAKLAND, Cal., April 25.-Oakland and the cities of San } \\
\text { Francisco bay were visited by another earthquake shock.... The } \\
\text { shock was not severe, but it lasted fully ten seconds. No } \\
\text { buildings were reported damaged anew and no lives lost." } \\
\text { See Table 10. }\end{array}$ \\
\hline 25-Apr-06 & $15: 12$ & Point Bonita & Marin & & $\begin{array}{l}\text { Lawson (1908), } \\
\text { vol. I, p. 417 }\end{array}$ & $\begin{array}{l}\text { “Direction NW., no tremor, just a jar, } 1 \text { max. strongest at } \\
\text { beginning, no sound, may have been blasting." Duration } 2 \\
\text { seconds. Lawson (1908) estimates Rossi-Forel intensity V. } \\
\text { See Table 10. }\end{array}$ \\
\hline 25-Apr-06 & $15: 14$ & Oakland & Alameda & & $\begin{array}{c}\text { San Francisco Call, } \\
26 \text { Apr 1906; p. 2, c. } 4\end{array}$ & $\begin{array}{l}\text { "OAKLAND, April 25.-An earthquake jarred this city ... and } \\
\text { occasioned another scare. The shock was short and stiff. People } \\
\text { were frightened from buildings and many persons hurried for } \\
\text { safety into the middle of the streets. In several instances the } \\
\text { cracks in structures that were damaged by the great temblor of } \\
\text { one week ago were widened and loose plaster and bricks thrown } \\
\text { down." } \\
\text { See Table 10. }\end{array}$ \\
\hline 25-Apr-06 & $15: 15$ & Napa & Napa & & $\begin{array}{l}\text { Lawson (1908), } \\
\text { vol. I, p. 417 }\end{array}$ & $\begin{array}{l}\text { "Sharp." } \\
\text { Townley and Allen (1939) describe this as "slight," but as their } \\
\text { source is presumed to be Lawson (1908), it is assumed that Townley } \\
\text { and Allen incorrectly copied the information. } \\
\text { See Table 10. }\end{array}$ \\
\hline 25-Apr-06 & $15: 15$ & $\begin{array}{c}\text { San Francisco } \\
\text { Peninsula }\end{array}$ & $\begin{array}{l}\text { San Francisco, } \\
\text { San Mateo, } \\
\text { Santa Clara }\end{array}$ & & $\begin{array}{l}\text { Lawson (1908), } \\
\text { vol. I, p. 417 }\end{array}$ & $\begin{array}{l}\text { "Strongly felt on ground, causing landsliding along coast cliffs, } \\
\text { lasting } 10 \text { s. with a slight repetition after } 10 \text { s." Duration } 15 \\
\text { seconds. Lawson (1908) estimates Rossi-Forel intensity V. } \\
\text { The duration listed in the "Duration" column (15 seconds) is } \\
\text { inconsistent with the duration as described under "Remarks." } \\
\text { See Table 10. }\end{array}$ \\
\hline 25-Apr-06 & $15: 15$ & $\begin{array}{c}\text { San Francisco } \\
\text { Napa }\end{array}$ & $\begin{array}{c}\text { San Francisco } \\
\text { Napa }\end{array}$ & & $\begin{array}{l}\text { Napa Daily Journal, } \\
27 \text { Apr 1906; p. 2, c. } 1\end{array}$ & $\begin{array}{l}\text { "The shake at 3:15 Wednesday afternoon caused one death in San } \\
\text { Francisco, the victim being Mrs. Annie Whitaker..." } \\
\text { The article gives the impression that the writer expected people to }\end{array}$ \\
\hline
\end{tabular}


TABLE 1: Catalog of Aftershock Reports following from the Great 18 April 1906 California Earthquake

\begin{tabular}{|c|c|c|c|c|c|c|}
\hline Date Felt & $\begin{array}{l}\text { Time Felt } \\
\text { (PST) }\end{array}$ & $\begin{array}{l}\text { Location Felt } \\
\quad \text { (City) }\end{array}$ & $\begin{array}{l}\text { Location Felt } \\
\text { (County) }\end{array}$ & $\begin{array}{l}\text { Unreliable? } \\
\text { Not Felt? }^{+}\end{array}$ & Source & Relevant Citations and other Notes \\
\hline & & & & & & $\begin{array}{l}\text { already be aware of the earthquake; this would probably be the case } \\
\text { only if it was felt locally; hence, it is inferred that the earthquake } \\
\text { was felt in Napa; however, the inference is not without uncertainty. } \\
\text { See Table } \mathbf{1 0 .}\end{array}$ \\
\hline 25-Apr-06 & 15:15 & San Francisco & San Francisco & & $\begin{array}{l}\text { San Francisco Examiner, } \\
26 \text { Apr 1906; p. 1, c. } 3\end{array}$ & $\begin{array}{l}\text { "There was a distinct shock at } 3: 15 \text { yesterday afternoon. It was } \\
\text { felt all over the city, and caused general alarm. People in houses } \\
\text { ran into the street. Those in the parks and streets did not notice it } \\
\text { and were surprised when told there had been another seismic } \\
\text { disturbance.... } \\
\text { "Mrs. Whitaker was at work in the kitchen of her home on } \\
\text { Shotwell street in the Mission district when the shock came. The } \\
\text { chimney, which had been left in a tottering condition by the heavy } \\
\text { quake last Wednesday, crashed through the roof upon the young } \\
\text { woman.... } \\
\text { "The shock did no serious damage to property. Not a building } \\
\text { was harmed to any extent. Here and there bricks in unstable } \\
\text { chimneys fell. } \\
\text { "It was one of several small shocks which have followed the big } \\
\text { earthquake of April 18th...." } \\
\text { Very similar articles appeared in the Oakland Tribune of } 26 \text { Apr } \\
\text { 1906, p. } 20, \text { c. 3, in the Berkeley Daily Gazette of } 26 \text { Apr } 1906 \text {, } \\
\text { p. 3, c. 4, and in a number of other papers. } \\
\text { See Table } 10 .\end{array}$ \\
\hline 25-Apr-06 & $15: 15$ & $\begin{array}{c}\text { San Francisco (?) } \\
\text { Oakland }\end{array}$ & $\begin{array}{c}\text { San Francisco (?) } \\
\text { Alameda } \\
\end{array}$ & & $\begin{array}{c}\text { The Bulletin (San Francisco), } \\
26 \text { Apr 1906; p. 6, c. } 2-3\end{array}$ & $\begin{array}{l}\text { "The shock of earthquake felt at } 3: 15 \text { yesterday afternoon was } \\
\text { No. } 37 \text { of the series in which is included the one responsible for } \\
\text { starting the fire that caused the destruction of San Francisco. It } \\
\text { was a little less than three seconds in duration and would be } \\
\text { rated as a number three. Numbers one and two are not } \\
\text { perceptible shocks, and can be observed only through the agency } \\
\text { of seismic instruments. These registered the earthquake that did } \\
\text { all the damage in the city as a number nine. } \\
\text { "At the Chabot Observatory, Oakland, it was said today that the } \\
\text { shock felt yesterday was much lighter than the average layman } \\
\text { thought. } \\
\text { "'The people are now all tuned up for shocks,' said Professor } \\
\text { Burckhalter, 'and they unconsciously exaggerate the dimensions } \\
\text { of the slightest quake. That of yesterday afternoon was of a } \\
\text { significance hardly worth talking about. Instruments are } \\
\text { fortunately without nerves and have enabled us to be assured } \\
\text { that it was incapable of any material consequence."” } \\
\text { Also in the Oakland Herald of } 26 \mathrm{Apr} 1906, p .2, \text { c. 3-4. }\end{array}$ \\
\hline
\end{tabular}


TABLE 1: Catalog of Aftershock Reports following from the Great 18 April 1906 California Earthquake

\begin{tabular}{|c|c|c|c|c|c|c|}
\hline Date Felt & $\begin{array}{l}\text { Time Felt } \\
\text { (PST) }\end{array}$ & $\begin{array}{c}\text { Location Felt } \\
\text { (City) }\end{array}$ & $\begin{array}{l}\text { Location Felt } \\
\text { (County) }\end{array}$ & $\begin{array}{l}\text { Unreliable? } \\
\text { Not Felt? }^{+}\end{array}$ & Source & Relevant Citations and other Notes \\
\hline & & & & & & $\begin{array}{l}\text { It is not clear whether the statement in the first paragraph about it } \\
\text { lasting three seconds and being "rated as a number three" describes } \\
\text { the earthquake in San Francisco or Oakland. By comparison to } \\
\text { reports in the Oakland Enquirer (27 Apr) and The Bulletin (28 } \\
\text { Apr), it appears as though all of this information came from } \\
\text { Professor Burchalter at Chabot Observatory in Oakland; still, } \\
\text { there are minor inconsistencies between all three reports that are } \\
\text { puzzling. } \\
\text { See Table 10. }\end{array}$ \\
\hline 25-Apr-06 (?) & $15: 15$ & Oakland & Alameda & & $\begin{array}{l}\text { Oakland Enquirer, } \\
27 \text { Apr 1906; p. 2, c. } 5\end{array}$ & $\begin{array}{l}\text { "Professor Burckhalter of the Chabot Observatory states that the } \\
\text { earthquake which occurred yesterday afternoon at fifteen } \\
\text { minutes after } 3 \text { o'clock, was only a small one, in spite of the } \\
\text { miniature panic it caused. It lasted only two seconds, he says, } \\
\text { and ordinarily would hardly be noticed. } \\
\text { "It was rumored that yesterday's shake was due to an extra large } \\
\text { dynamite explosion in San Francisco. Professor Burckhalter says } \\
\text { that such was not the case, and that the dynamiting over there has } \\
\text { no effect on the earth's crust over here." } \\
\text { Although the earthquake is stated to have occurred "yesterday," the } \\
\text { report almost certainly refers to the earthquake at around } 15: 15 \text { on } \\
25 \text { Apr; compare this with the report in The Bulletin (San } \\
\text { Francisco), } 26 \text { Apr 1906, p. } 6, c .2-3 \text {. } \\
\text { See Table } 10 .\end{array}$ \\
\hline 25-Apr-06 & $15: 15$ & Oakland & Alameda & & $\begin{array}{l}\text { Lawson (1908), } \\
\text { vol. I, p. } 417\end{array}$ & $\begin{array}{l}\text { Duration } 3 \text { seconds. Lawson (1908) estimates Rossi-Forel } \\
\text { intensity III. } \\
\text { See Table } \mathbf{1 0 .}\end{array}$ \\
\hline 25-Apr-06 & $15: 15$ & Berkeley & Alameda & & $\begin{array}{l}\text { Berkeley Daily Gazette, } \\
25 \text { Apr 1906; p. 1, c. } 1\end{array}$ & $\begin{array}{l}\text { “... a severe earthquake was felt in this city which caused a } \\
\text { general exodus from the brick buildings in the business section. } \\
\text { The temblor was the most severe that has been felt since the one of } \\
\text { a week ago this morning, which caused the destruction of San } \\
\text { Francisco's business section. } \\
\text { "So far as has been learned the earthquake caused no damage in } \\
\text { this section, although it is feared a number of the partially } \\
\text { wrecked buildings in Oakland and San Francisco may have } \\
\text { suffered. } \\
\text { "Occupants of the First National Bank building were not } \\
\text { alarmed, a majority of them remaining in their offices. } \\
\text { "The earthquake was of several seconds duration. Its direction } \\
\text { appeared to be from south to north. The officials at the } \\
\text { University were unable to give a report of the earthquake this } \\
\text { afternoon, but will be prepared to give a seismographic record of }\end{array}$ \\
\hline
\end{tabular}


TABLE 1: Catalog of Aftershock Reports following from the Great 18 April 1906 California Earthquake

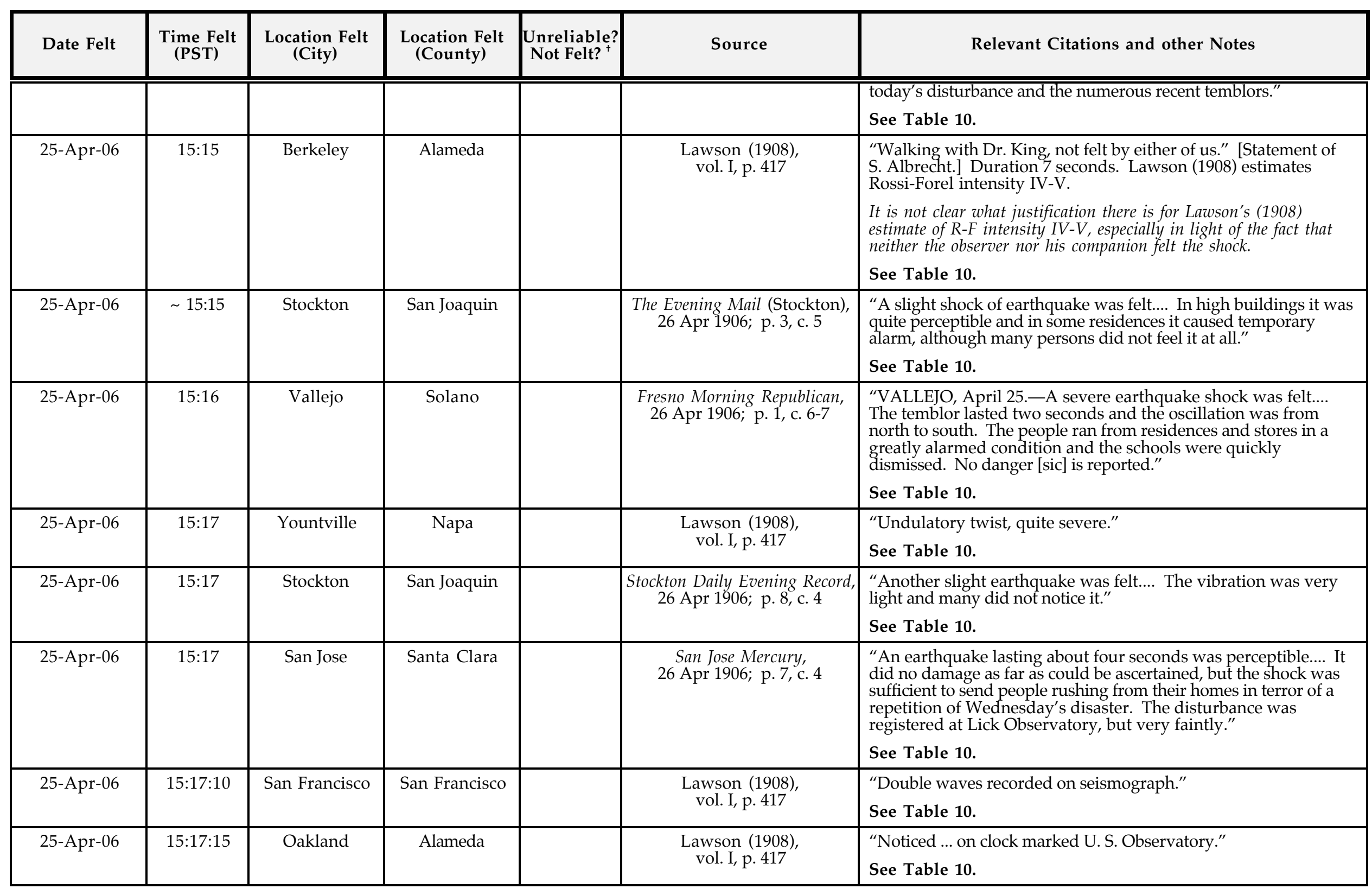


TABLE 1: Catalog of Aftershock Reports following from the Great 18 April 1906 California Earthquake

\begin{tabular}{|c|c|c|c|c|c|c|}
\hline Date Felt & $\begin{array}{l}\text { Time Felt } \\
\text { (PST) }\end{array}$ & $\begin{array}{l}\text { Location Felt } \\
\text { (City) }\end{array}$ & $\begin{array}{l}\text { Location Felt } \\
\text { (County) }\end{array}$ & $\begin{array}{l}\text { Unreliable? } \\
\text { Not Felt? }^{+}\end{array}$ & Source & Relevant Citations and other Notes \\
\hline 25-Apr-06 & $15: 17: 40$ & Mount Hamilton & Santa Clara & & $\begin{array}{l}\text { Lawson (1908), } \\
\text { vol. I, p. } 418\end{array}$ & $\begin{array}{l}\text { Lawson (1908) estimates Rossi-Forel intensity II-III } \\
\text { See Table } \mathbf{1 0 .}\end{array}$ \\
\hline 25-Apr-06 & $15: 18: 20$ & Berkeley & Alameda & & $\begin{array}{l}\text { Lawson (1908), } \\
\text { vol. I, p. } 418\end{array}$ & $\begin{array}{l}\text { "2 tremors about } 5 \mathrm{~s} \text {. apart. Time is of last one." } \\
\text { See Table } \mathbf{1 0 .}\end{array}$ \\
\hline 25-Apr-06 & $15: 20$ & $\begin{array}{c}\text { Oakland } \\
\text { San Francisco }\end{array}$ & $\begin{array}{l}\text { Alameda } \\
\text { San Francisco }\end{array}$ & & $\begin{array}{c}\text { Oakland Times, } \\
26 \text { Apr 1906; p. 1, c. } 4\end{array}$ & $\begin{array}{l}\text { "... there was an earthquake shock which, while not serious in its } \\
\text { consequences, nevertheless had the effect of badly frightening } \\
\text { people. Many rushed from their homes bareheaded and into the } \\
\text { streets, looking at each other with blanched faces, fearing a } \\
\text { repetition of the shock of last week. Practically no damage was } \\
\text { done, only a few loose bricks toppling from their shaky positions, } \\
\text { not having been securely replaced since the earth quake of April } \\
\text { 18. The shock yesterday consisted of one short, sharp 'jerk.' It is } \\
\text { said by the scientists that it was one of the to be expected } \\
\text { 'settling' shocks caused by the earth's crust in the affected region } \\
\text { adjusting its self to the conditions caused by the great quake. } \\
\text { "The building inspecting authorities say that no damage } \\
\text { whatever was caused by the shock. } \\
\text { "In San Francisco a number of tottering walls were thrown } \\
\text { down." } \\
\text { See Table } 10 .\end{array}$ \\
\hline 25-Apr-06 & $15: 20$ & $\begin{array}{l}\text { Oakland } \\
\text { San Francisco } \\
\text { Sacramento }\end{array}$ & $\begin{array}{l}\text { Alameda } \\
\text { San Francisco } \\
\text { Sacramento }\end{array}$ & & $\begin{array}{l}\text { Marysville Daily Appeal, } \\
26 \text { Apr 1906; p.1, c. 5-6 }\end{array}$ & $\begin{array}{l}\text { "OAKLAND, April 25.-At 3:20 o'clock this afternoon another } \\
\text { earthquake shock was felt in this city, which caused } \\
\text { consternation in many quarters and especially among the } \\
\text { sufferers who were made homeless by the shock of a week ago. } \\
\text { As far as can be learned the tremblor did no material damage, } \\
\text { although a number of rickety walls were shaken down. So far no } \\
\text { loss of life has been reported. } \\
\text { "At Oakland mole the trains which were standing on the tracks } \\
\text { ready to receive passengers, were moved several feet by the force } \\
\text { of the shock. } \\
\text { "The tremblor was sufficient to cause a small wave on the bay, } \\
\text { which, so far as learned, did no damage to shipping. } \\
\text { "Out at the different camps of refugees consternation reigned for a } \\
\text { short time, but the soldiers on guard quickly quelled the } \\
\text { disturbance and quieted the fears of the sufferers. } \\
\text { "SACRAMENTO, April } 25 \text {.- The earthquake which occurred at } \\
\text { San Francisco was hardly noticeable here." } \\
\text { Some of the statements from Oakland are difficult to believe and } \\
\text { may weaken the article's credibility. }\end{array}$ \\
\hline
\end{tabular}


TABLE 1: Catalog of Aftershock Reports following from the Great 18 April 1906 California Earthquake

\begin{tabular}{|c|c|c|c|c|c|c|}
\hline Date Felt & $\begin{array}{l}\text { Time Felt } \\
\text { (PST) }\end{array}$ & $\begin{array}{l}\text { Location Felt } \\
\text { (City) }\end{array}$ & $\begin{array}{l}\text { Location Felt } \\
\text { (County) }\end{array}$ & $\begin{array}{l}\text { Unreliable? } \\
\text { Not Felt? }^{+}\end{array}$ & Source & Relevant Citations and other Notes \\
\hline & & & & & & See Table 10. \\
\hline 25-Apr-06 & 15:20 (?) & Oakland & Alameda & & $\begin{array}{l}\text { Fresno Morning Republican, } \\
26 \text { Apr 1906; p. 1, c. 1-2 }\end{array}$ & $\begin{array}{l}\text { "OAKLAND, April 25.-A sharp shock of earthquake was felt } \\
\text { here at 3:20 o'clock. It lasted about seven or eight seconds." } \\
\text { From this article, it is not clear whether "3:20" refers to } 3: 20 \text { am or } \\
\text { 3:20 pm; however, by comparison to similar reports, the time is } \\
\text { inferred to be in the afternoon. } \\
\text { See Table 10. }\end{array}$ \\
\hline 25-Apr-06 & $15: 20$ & $\begin{array}{c}\text { Alameda } \\
\text { (Alameda Pier) }\end{array}$ & Alameda & & $\begin{array}{l}\text { Lawson (1908), } \\
\text { vol. I, p. } 418\end{array}$ & $\begin{array}{l}\text { felt } \\
\text { See Table } 10 .\end{array}$ \\
\hline 25-Apr-06 & $15: 20$ & Antioch & Contra Costa & & $\begin{array}{c}\text { Lawson (1908), } \\
\text { vol. I, p. } 418\end{array}$ & $\begin{array}{l}\text { felt } \\
\text { See Table } 10 .\end{array}$ \\
\hline 25-Apr-06 & $15: 22$ & $\begin{array}{c}\text { Niles } \\
\text { (now Niles } \\
\text { District) }\end{array}$ & Alameda & & $\begin{array}{c}\text { Lawson (1908), } \\
\text { vol. I, p. } 418\end{array}$ & $\begin{array}{l}\text { felt } \\
\text { See Table } 10 .\end{array}$ \\
\hline 25-Apr-06 & 15:30 & San Francisco & San Francisco & & $\begin{array}{c}\text { Oakland Enquirer, } \\
26 \text { Apr 1906; p. 8, c. } 3\end{array}$ & $\begin{array}{l}\text { "An earthquake shook San Francisco at half-past } 3 \text { o' clock } \\
\text { yesterday afternoon. It was a little more severe than any that } \\
\text { have occurred since the day of the big temblor. In the section of } \\
\text { the ruins a few bricks were thrown out of place, but no walls fell } \\
\text { and there was only one fatality. } \\
\text { "Mrs. Tillie L. Whittaker of } 308 \text { Shotwell street lost her life. A } \\
\text { chimney fell from a building adjoining her home, crashed through } \\
\text { the roof and falling bricks and debris fractured Mrs. Whittaker's } \\
\text { skull... The chimney that fell was about two stories above the } \\
\text { roof of her dwelling and timbers, plaster, and shingles went down } \\
\text { with a roar...." } \\
\text { See Table 10. }\end{array}$ \\
\hline 25-Apr-06 & $16: 30$ & Oakland & Alameda & & $\begin{array}{l}\text { The Bulletin (San Francisco), } \\
28 \text { Apr 1906; p. 7, c. } 1\end{array}$ & $\begin{array}{l}\text { [quoting Professor Burckhalter of the Chabot Observatory in } \\
\text { Oakland: “'... The intensity of earthquakes I have graded into ten } \\
\text { classes ... the disturbance that is barely perceptible to a human } \\
\text { being I call the No. } 1 \text {. The earthquake of Wednesday morning, } \\
\text { April 18, was a No. } 9 . . . \\
\text { "“There was a shock felt yesterday afternoon at } 1 \text { o' clock, but it } \\
\text { was of but a very short duration and was classed as a No. } 3 \text {. The } \\
\text { shock which was felt Wednesday at } 4: 30 \text { in the afternoon was of } \\
\text { no longer duration but was of No. } 4 \text { intensity. The others which } \\
\text { have been felt since Wednesday of last week have been of No. } 2 \\
\text { and No. } 3 \text { and No. } 1 \text { intensity and of less degree which I have not } \\
\text { recorded."” }\end{array}$ \\
\hline
\end{tabular}


TABLE 1: Catalog of Aftershock Reports following from the Great 18 April 1906 California Earthquake

\begin{tabular}{|c|c|c|c|c|c|c|}
\hline Date Felt & $\begin{array}{l}\text { Time Felt } \\
\text { (PST) }\end{array}$ & $\begin{array}{l}\text { Location Felt } \\
\text { (City) }\end{array}$ & $\begin{array}{l}\text { Location Felt } \\
\text { (County) }\end{array}$ & $\begin{array}{l}\text { Unreliable? } \\
\text { Not Felt? }^{+}\end{array}$ & Source & Relevant Citations and other Notes \\
\hline & & & & & & See Table 10. \\
\hline 26-Apr-06 & $10: 22$ & $\begin{array}{l}\text { Los Gatos } \\
\text { San Jose }\end{array}$ & $\begin{array}{l}\text { Santa Clara } \\
\text { Santa Clara }\end{array}$ & Not Felt & $\begin{array}{c}\text { San Jose Mercury, } \\
27 \text { Apr 1906; p. 7, c. } 3\end{array}$ & $\begin{array}{l}\text { "A telephone message from Los Gatos ... stated that quite a severe } \\
\text { earthquake was felt in that town at } 22 \text { minutes past } 10 \text { o'clock } \\
\text { yesterday morning. No damage was done. A number of messages } \\
\text { to this city were sent from Los Gatos residents inquiring if the } \\
\text { shock had been felt here. It was not felt in San Jose." }\end{array}$ \\
\hline 26-Apr-06 & 10:25 & Santa Cruz & Santa Cruz & & $\begin{array}{l}\text { Santa Cruz Morning Sentinel, } \\
27 \text { Apr 1906; p. 7, c. } 1\end{array}$ & "... another perceptible quake...." \\
\hline 26-Apr-06 & $10: 30$ & Santa Cruz & Santa Cruz & & $\begin{array}{c}\text { Santa Cruz Surf, } \\
26 \text { Apr 1906; p. } 4, \text { c. } 3\end{array}$ & $\begin{array}{l}\text { "During the earthquake shock ... some of the plaster in } \\
\text { Chestnutwood's Business College fell from the walls." }\end{array}$ \\
\hline 26-Apr-06 (?) & $15: 15$ & Napa & Napa & & $\begin{array}{l}\text { Napa Daily Journal, } \\
3 \text { May 1906; p. 3, c. } 4\end{array}$ & 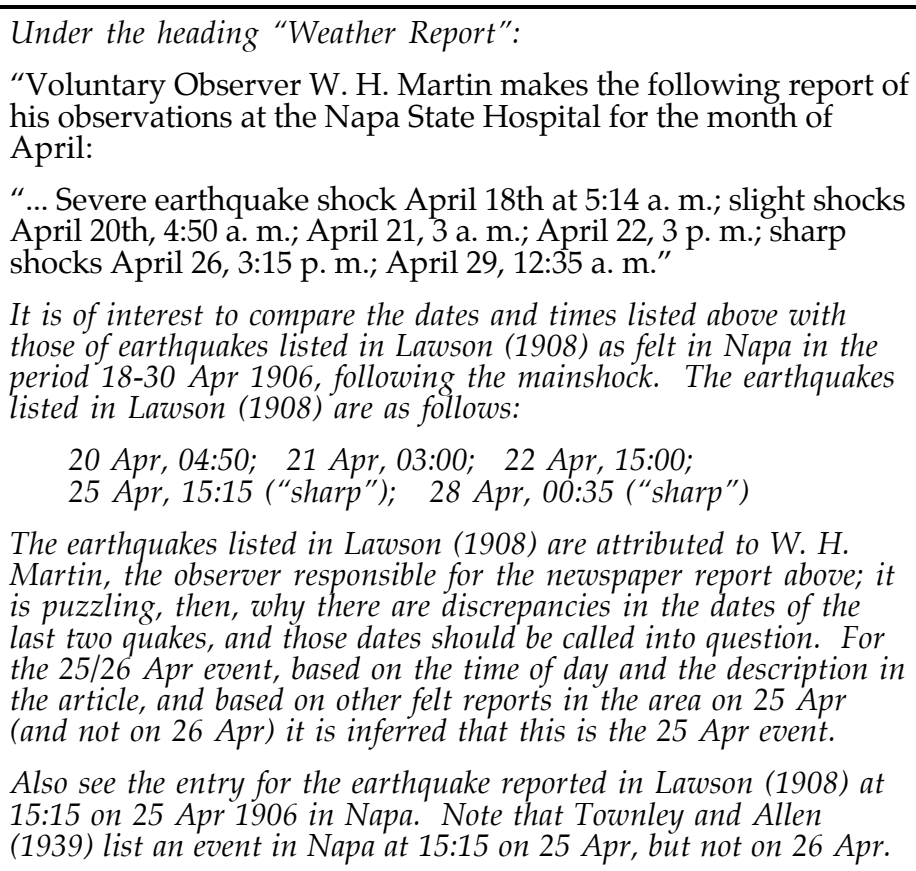 \\
\hline 26-Apr-06 (?) & $15: 25$ & $\begin{array}{l}\text { Napa Redwoods } \\
{[7 \text { mi NE of }} \\
\text { Sonoma (?)] }\end{array}$ & Napa & & $\begin{array}{l}\text { Napa Daily Journal, } \\
28 \text { Apr 1906; p. 2, c. } 2\end{array}$ & $\begin{array}{l}\text { "... yesterday at } 3: 25 \text { p. m. one of the hardest, though but short, } \\
\text { since [the mainshock]...." } \\
\text { This was part of a long article written by a regular correspondent, } \\
\text { dated "Napa Redwoods, April } 27,1906 . \text {." It is possible that the } \\
\text { first part of the article, containing the above passage, was written a } \\
\text { day before the article was signed and dated, in which case } \\
\text { "yesterday" may refer to the } 25 \text { Apr event instead. }\end{array}$ \\
\hline
\end{tabular}


TABLE 1: Catalog of Aftershock Reports following from the Great 18 April 1906 California Earthquake

\begin{tabular}{|c|c|c|c|c|c|c|}
\hline Date Felt & $\begin{array}{l}\text { Time Felt } \\
\text { (PST) }\end{array}$ & $\begin{array}{l}\text { Location Felt } \\
\text { (City) }\end{array}$ & $\begin{array}{l}\text { Location Felt } \\
\text { (County) }\end{array}$ & \begin{tabular}{|c|} 
Unreliable? \\
Not Felt? $^{+}$
\end{tabular} & Source & Relevant Citations and other Notes \\
\hline & & & & & & See Table 10. \\
\hline 26-Apr-06 & 20:00 & Salinas & Monterey & & $\begin{array}{l}\text { San Francisco Examiner, } \\
28 \text { Apr 1906; p. } 1, \text { c. } 4\end{array}$ & $\begin{array}{l}\text { "LOS ANGELES, April 27.-A long-distance telephone message } \\
\text { to this city from Salinas ... states that three more very heavy } \\
\text { earthquake shocks were felt there. One at } 8 \text { o'clock last night; } \\
\text { another at } 9: 50 \text {, and the last at } 2 \text { o'clock this morning. The shocks } \\
\text { lasted about four seconds each, but so far as known did no } \\
\text { damage...." } \\
\text { Very similar articles appeared in The Bulletin (San Francisco) of } \\
27 \text { Apr 1906, p. 2, c. 3, and in the Oakland Tribune of } 27 \text { Apr 1906, } \\
\text { p. 3, c. } 4 \text {. }\end{array}$ \\
\hline 26-Apr-06 & $\sim 20: 30$ & Salinas & Monterey & & $\begin{array}{l}\text { Salinas Weekly Journal, } \\
28 \text { Apr 1906; p.3, c. } 3\end{array}$ & $\begin{array}{l}\text { Under the heading "From Friday's Daily Journal": } \\
\text { "A slight earthquake tremor about half past } 8 \text { o'clock last night } \\
\text { and another a little stronger at 9:47 was not soothing to } \\
\text { overwrought nerves." }\end{array}$ \\
\hline 26-Apr-06 & $\begin{array}{c}\begin{array}{c}20: 50, \\
\text { and later } \\
\text { (many events) }\end{array} \\
\end{array}$ & Watsonville & Santa Cruz & & $\begin{array}{l}\text { Evening Pajaronian } \\
\text { (Watsonville), } \\
27 \text { Apr 1906; p. 1, c. } 5\end{array}$ & $\begin{array}{l}\text { "At 8:50 o'clock last night there was a very perceptible shock of } \\
\text { earthquake, and again at 9:50 the crust trembled with mighty } \\
\text { fervor. These two greater movements were followed during the } \\
\text { night by numerous slight tremors..." }\end{array}$ \\
\hline 26-Apr-06 & 21:00 & Salinas & Monterey & & $\begin{array}{l}\text { Salinas Daily Index, } \\
27 \text { Apr 1906; p. 2, c. } 2\end{array}$ & $\begin{array}{l}\text { "The overwrought nerves of the public were given three jars by } \\
\text { the unexpected quivers of the earth's crust last night. One tremor } \\
\text { occurred at } 9 \text { o'clock, another after } 10 \text { and yet another at } 3 \\
\text { o'clock this morning. The shocks were accompanied by a } \\
\text { rumbling noise and the one between } 10 \text { and } 11 \text { o'clock last night } \\
\text { was quite heavy." }\end{array}$ \\
\hline 26-Apr-06 & $21: 47$ & Salinas & Monterey & & $\begin{array}{l}\text { Salinas Weekly Journal, } \\
28 \text { Apr 1906; p.3, c. } 3\end{array}$ & $\begin{array}{l}\text { Under the heading "From Friday's Daily Journal": } \\
\text { "A slight earthquake tremor about half past } 8 \text { o'clock last night } \\
\text { and another a little stronger at 9:47 was not soothing to } \\
\text { overwrought nerves." }\end{array}$ \\
\hline 26-Apr-06 & $21: 50$ & Salinas & Monterey & & $\begin{array}{l}\text { San Francisco Examiner, } \\
28 \text { Apr 1906; p. } 1, \text { c. } 4\end{array}$ & $\begin{array}{l}\text { "LOS ANGELES, April 27.-A long-distance telephone message } \\
\text { to this city from Salinas ... states that three more very heavy } \\
\text { earthquake shocks were felt there. One at } 8 \text { o'clock last night; } \\
\text { another at } 9: 50, \text { and the last at } 2 \text { o'clock this morning. The shocks } \\
\text { lasted about four seconds each, but so far as known did no } \\
\text { damage...." } \\
\text { Very similar articles appeared in The Bulletin (San Francisco) of } \\
27 \text { Apr 1906, p. 2, c. 3, and in the Oakland Tribune of } 27 \text { Apr 1906, } \\
\text { p. 3, c. } 4 \text {. }\end{array}$ \\
\hline
\end{tabular}


TABLE 1: Catalog of Aftershock Reports following from the Great 18 April 1906 California Earthquake

\begin{tabular}{|c|c|c|c|c|c|c|}
\hline Date Felt & $\begin{array}{l}\text { Time Felt } \\
\text { (PST) }\end{array}$ & $\begin{array}{l}\text { Location Felt } \\
\text { (City) }\end{array}$ & $\begin{array}{l}\text { Location Felt } \\
\text { (County) }\end{array}$ & $\begin{array}{l}\text { Unreliable? } \\
\text { Not Felt? }^{+}\end{array}$ & Source & Relevant Citations and other Notes \\
\hline 26-Apr-06 & \begin{tabular}{|c|}
$21: 50$, and \\
later during \\
the night, \\
incl. the early \\
morning \\
hours of \\
27-Apr-06 \\
(many events)
\end{tabular} & Watsonville & Santa Cruz & & $\begin{array}{l}\text { Evening Pajaronian } \\
\text { (Watsonville), } \\
27 \text { Apr 1906; p. 1, c. } 5\end{array}$ & $\begin{array}{l}\text { "At 8:50 o'clock last night there was a very perceptible shock of } \\
\text { earthquake, and again at 9:50 the crust trembled with mighty } \\
\text { fervor. These two greater movements were followed during the } \\
\text { night by numerous slight tremors...." }\end{array}$ \\
\hline 26-Apr-06 & after 22:00 & Salinas & Monterey & & $\begin{array}{l}\text { Salinas Daily Index, } \\
27 \text { Apr 1906; p. 2, c. } 2\end{array}$ & $\begin{array}{l}\text { "The overwrought nerves of the public were given three jars by } \\
\text { the unexpected quivers of the earth's crust last night. One tremor } \\
\text { occurred at } 9 \text { o' clock, another after } 10 \text { and yet another at } 3 \\
\text { o'clock this morning. The shocks were accompanied by a } \\
\text { rumbling noise and the one between } 10 \text { and } 11 \text { o'clock last night } \\
\text { was quite heavy." }\end{array}$ \\
\hline 27-Apr-06 & 02:00 & Salinas & Monterey & & $\begin{array}{l}\text { San Francisco Examiner, } \\
28 \text { Apr 1906; p. 1, c. } 4\end{array}$ & $\begin{array}{l}\text { "LOS ANGELES, April 27.-A long-distance telephone message } \\
\text { to this city from Salinas ... states that three more very heavy } \\
\text { earthquake shocks were felt there. One at } 8 \text { o'clock last night; } \\
\text { another at } 9: 50 \text {, and the last at } 2 \text { o'clock this morning. The shocks } \\
\text { lasted about four seconds each, but so far as known did no } \\
\text { damage...." } \\
\text { Very similar articles appeared in The Bulletin (San Francisco) of } \\
27 \text { Apr } 1906, \text { p. } 2, \text { c. 3, and in the Oakland Tribune of } 27 \text { Apr 1906, } \\
\text { p. 3, c. } 4 .\end{array}$ \\
\hline 27-Apr-06 & 03:00 & Salinas & Monterey & & $\begin{array}{l}\text { Salinas Daily Index, } \\
27 \text { Apr 1906; p. 2, c. } 2\end{array}$ & $\begin{array}{l}\text { "The overwrought nerves of the public were given three jars by } \\
\text { the unexpected quivers of the earth's crust last night. One tremor } \\
\text { occurred at } 9 \text { o' clock, another after } 10 \text { and yet another at } 3 \\
\text { o'clock this morning. The shocks were accompanied by a } \\
\text { rumbling noise and the one between } 10 \text { and } 11 \text { o'clock last night } \\
\text { was quite heavy." }\end{array}$ \\
\hline 27-Apr-06 & $10: 30$ & Eureka & Humboldt & & $\begin{array}{l}\text { Humboldt Times, } \\
28 \text { Apr 1906; p. 5, c. } 2\end{array}$ & $\begin{array}{l}\text { "It was at just } 10: 30 \text { o'clock yesterday morning that a large } \\
\text { percentage of Eureka people felt an earthquake shock, one of } \\
\text { those swaying kind, and in all probability it rocked old } \\
\text { Humboldt a little. Several ladies are known to have left their } \\
\text { homes for the broad street. Many other people there are, } \\
\text { however, who knew not that they had been visited by a temblor. } \\
\text { Weather observer A. H. Bell stated yesterday afternoon that he } \\
\text { did not feel it in the least, and also that if there was a shock, it } \\
\text { was very slight, and that his instruments had failed to record it." }\end{array}$ \\
\hline
\end{tabular}


TABLE 1: Catalog of Aftershock Reports following from the Great 18 April 1906 California Earthquake

\begin{tabular}{|c|c|c|c|c|c|c|}
\hline Date Felt & $\begin{array}{l}\text { Time Felt } \\
\text { (PST) }\end{array}$ & $\begin{array}{l}\text { Location Felt } \\
\text { (City) }\end{array}$ & $\begin{array}{l}\text { Location Felt } \\
\text { (County) }\end{array}$ & $\begin{array}{l}\text { Unreliable? } \\
\text { Not Felt? }^{+}\end{array}$ & Source & Relevant Citations and other Notes \\
\hline 27-Apr-06 & $\sim 10: 30$ & $\begin{array}{l}\text { Ferndale } \\
\text { Eureka }\end{array}$ & $\begin{array}{l}\text { Humboldt } \\
\text { Humboldt }\end{array}$ & & $\begin{array}{c}\text { Humboldt Times, } \\
28 \text { Apr 1906; p. 6, c. } 4\end{array}$ & $\begin{array}{l}\text { "A message received here from Ferndale yesterday stated that } \\
\text { quite a severe shock was felt there about 10:30 o' clock that } \\
\text { morning. There was little if any damage done. The same shock } \\
\text { was scarcely perceptible here." }\end{array}$ \\
\hline 27-Apr-06 & $\sim 10: 30$ & Garberville & Humboldt & & $\begin{array}{l}\text { Humboldt Standard, } \\
2 \text { May 1906; p. } 2^{*}, \text { c. } 2 \\
{ }^{*} \text { mislabeled as p. } 6\end{array}$ & $\begin{array}{l}\text { "... about 10:30 o'clock a. m. two shocks of earthquake were felt, } \\
\text { the first being hard enough to rock the buildings and cause some } \\
\text { of the timid ones to run out of doors, but the last one was merely a } \\
\text { shudder of the ground as if a cold streak was running through it." }\end{array}$ \\
\hline 27-Apr-06 & $10: 30$ & Garberville & Humboldt & & $\begin{array}{c}\text { Humboldt Times, } \\
3 \text { May 1906; p. 2, c. } 3\end{array}$ & $\begin{array}{l}\text { "This little town is still being kept on the qui vive for an } \\
\text { earthquake shock, as we were treated to quite a temblor.... Many } \\
\text { ran out of doors but the excitement was over in a short time. Some } \\
\text { of the houses here would not stand many more quakes without } \\
\text { getting out of plumb." }\end{array}$ \\
\hline 27-Apr-06 & 13:00 & Redding & Shasta & & $\begin{array}{l}\text { The Searchlight (Redding), } \\
28 \text { Apr 1906; p. 1, c. } 4\end{array}$ & $\begin{array}{l}\text { “A slight earthquake was observed in Redding Friday afternoon } \\
\text { at } 1 \text { o'clock. But few persons noticed it, yet there were enough } \\
\text { independent observers to establish the fact beyond all question } \\
\text { and to fix the time at } 1 \text { o'clock exactly. } \\
\text { “W. D. Tillotson was lying down at his home in West Redding. } \\
\text { He noticed a decided quivering of the sofa on which he reclined. } \\
\text { He is sure that the motion was caused by an earthquake. He } \\
\text { called his wife's attention to the phenomenon, but she had } \\
\text { observed nothing unusual. Mr. Tillotson has had a wide } \\
\text { experience with earthquakes because of his long residence in } \\
\text { Japan. } \\
\text { “James E. Isaacs, the attorney, was in his office in the second } \\
\text { story of the Frisbie building playing penuchle with Dr. T. D. } \\
\text { Head. Mr. Isaacs felt his chair shake under him and heard a } \\
\text { rattling of the window panes. He called Dr. Head's attention to } \\
\text { the fact, saying,'That's an earthquake.' Dr. Head had noticed } \\
\text { nothing unusual. } \\
\text { "Mr. Isaacs and Mr. Tillotson agree that their observations were } \\
\text { made at exactly } 1 \text { o'clock, according to their watches, which they } \\
\text { looked at directly after the earthquake." }\end{array}$ \\
\hline 27-Apr-06 & 13:00 & Oakland & Alameda & & $\begin{array}{c}\text { The Bulletin (San Francisco), } \\
28 \text { Apr 1906; p. 7, c. } 1\end{array}$ & $\begin{array}{l}\text { [quoting Professor Burckhalter of the Chabot Observatory in } \\
\text { Oakland:] “.... The intensity of earthquakes I have graded into ten } \\
\text { classes ... the disturbance that is barely perceptible to a human } \\
\text { being I call the No. } 1 \text {. The earthquake of Wednesday morning, } \\
\text { April 18, was a No. } 9 . . . \\
\text { "“'There was a shock felt yesterday afternoon at } 1 \text { o'clock, but it } \\
\text { was of but a very short duration and was classed as a No. } 3 \text {. The } \\
\text { shock which was felt Wednesday at } 4: 30 \text { in the afternoon was of } \\
\text { no longer duration but was of No. } 4 \text { intensity. The others which } \\
\text { have been felt since Wednesday of last week have been of No. } 2\end{array}$ \\
\hline
\end{tabular}


TABLE 1: Catalog of Aftershock Reports following from the Great 18 April 1906 California Earthquake

\begin{tabular}{|c|c|c|c|c|c|c|}
\hline Date Felt & $\begin{array}{l}\text { Time Felt } \\
\text { (PST) }\end{array}$ & $\begin{array}{l}\text { Location Felt } \\
\text { (City) }\end{array}$ & $\begin{array}{l}\text { Location Felt } \\
\text { (County) }\end{array}$ & $\begin{array}{l}\text { Unreliable? } \\
\text { Not Felt? }^{+}\end{array}$ & Source & Relevant Citations and other Notes \\
\hline & & & & & & $\begin{array}{l}\text { and No. } 3 \text { and No. } 1 \text { intensity and of less degree which I have not } \\
\text { recorded."' }\end{array}$ \\
\hline 27-Apr-06 & \begin{tabular}{c|} 
night \\
(two events?)
\end{tabular} & Salinas & Monterey & & $\begin{array}{l}\text { Salinas Daily Index, } \\
28 \text { Apr 1906; p. 1, c. } 4\end{array}$ & $\begin{array}{l}\text { "There were two minor shocks of earthquake last night, but no } \\
\text { damage...." }\end{array}$ \\
\hline 27-Apr-06 & night & Santa Rosa & Sonoma & & $\begin{array}{l}\text { The Searchlight (Redding), } \\
30 \text { Apr 1906; p. 2, c. } 2\end{array}$ & $\begin{array}{l}\text { "Santa Rosa shaken up Friday night-one heavy shock followed } \\
\text { by two light ones. Locomotive thrown from rails. Considerable } \\
\text { alarm, but not much damage." }\end{array}$ \\
\hline 28-Apr-06 (?) & $\begin{array}{l}\text { after } \\
\text { midnight } \\
\text { (several } \\
\text { events) }\end{array}$ & Santa Rosa & Sonoma & & $\begin{array}{l}\text { San Francisco Chronicle, } \\
30 \text { Apr 1906; p. 14, c. } 1\end{array}$ & $\begin{array}{l}\text { "SANTA ROSA, April 29.-This city and vicinity experienced } \\
\text { another earthquake shock after midnight Friday, causing terror to } \\
\text { those who experienced the recent shake which brought such } \\
\text { disaster to the City of Roses. Many people left their beds and } \\
\text { hastened to the streets, expecting momentarily to see their } \\
\text { residences collapse. This heavy shake was followed by two of } \\
\text { less violence. Southern Pacific employees found a locomotive off } \\
\text { the rails in the yards this morning, apparently caused by the } \\
\text { earthquake through a faulty piece of rail on which it was } \\
\text { standing. Evidently when the upheaval of the earth occurred the } \\
\text { rail turned sideways and permitted the locomotive to slip from the } \\
\text { rails...." } \\
\text { It is not clear whether "after midnight Friday" means that the } \\
\text { earthquakes occurred early Friday or early Saturday morning. }\end{array}$ \\
\hline 28-Apr-06 & \begin{tabular}{c|} 
shortly \\
before 01:00, \\
and later \\
(three events)
\end{tabular} & Santa Rosa & Sonoma & & $\begin{array}{c}\text { Santa Rosa Press-Democrat, } \\
\text { published in conjunction with } \\
\text { Santa Rosa Republican, } \\
\text { under the title } \\
\text { Democrat-Republican } \\
28 \text { Apr 1906; p. 2, c. } 1\end{array}$ & $\begin{array}{l}\text { "A distinct shock of earthquake was felt here this morning } \\
\text { shortly before } 1 \text { o'clock followed by two other slight tremblers." }\end{array}$ \\
\hline 28-Apr-06 & 05:00 & Yreka & Siskiyou & & $\begin{array}{l}\text { The Searchlight (Redding), } \\
29 \text { Apr 1906; p. 1, c. } 6\end{array}$ & $\begin{array}{l}\text { "YREKA, April 28.-A light earthquake shock was felt here at } 5 \\
\text { o'clock this morning. The disturbance lasted but a second or two } \\
\text { and was observed by several persons, who agree upon the time." }\end{array}$ \\
\hline 28-Apr-06 & 05:12 & $\begin{array}{c}\text { Yreka } \\
\text { San Francisco }\end{array}$ & $\begin{array}{c}\text { Siskiyou } \\
\text { San Francisco }\end{array}$ & & $\begin{array}{l}\text { Siskiyou News, } \\
3 \text { May 1906; p. 3, c. } 5\end{array}$ & $\begin{array}{l}\text { "An earthquake shock was felt in Yreka last Saturday morning at } \\
\text { 5:12. It was felt more severely in San Francisco than any shock } \\
\text { since the initial one of April 18th according to Yrekaites who } \\
\text { were in the city at the time. Walls tottered and fell and great } \\
\text { alarm was felt by the people for a time." }\end{array}$ \\
\hline 28-Apr-06 & 10:30 & $\begin{array}{l}\text { Point Arena } \\
\text { Lighthouse }\end{array}$ & Mendocino & & $\begin{array}{l}\text { Lighthouse Log for } \\
\text { Point Arena Lighthouse, } \\
28 \text { Apr } 1906\end{array}$ & $\begin{array}{l}\text { Excerpt from the entry of } 28 \text { Apr 1906: } \\
\text { "Slight shock at } 10^{30} \text { a.m. from N. to S." }\end{array}$ \\
\hline
\end{tabular}


TABLE 1: Catalog of Aftershock Reports following from the Great 18 April 1906 California Earthquake

\begin{tabular}{|c|c|c|c|c|c|c|}
\hline Date Felt & $\begin{array}{l}\text { Time Felt } \\
\text { (PST) }\end{array}$ & $\begin{array}{l}\text { Location Felt } \\
\text { (City) }\end{array}$ & $\begin{array}{l}\text { Location Felt } \\
\text { (County) }\end{array}$ & $\begin{array}{l}\text { Unreliable? } \\
\text { Not Felt? }^{+}\end{array}$ & Source & Relevant Citations and other Notes \\
\hline $\begin{array}{l}\text { 21-Apr-06 thru } \\
\text { 28-Apr-06 (?) }\end{array}$ & (many events) & Livermore (?) & Alameda (?) & & $\begin{array}{l}\text { Livermore Herald, } \\
28 \text { Apr 1906; p. 2, c. } 1\end{array}$ & $\begin{array}{l}\text { "There have been numerous light shocks of earthquakes during } \\
\text { the past week to remind people of the big shock of last week, } \\
\text { provided they needed any reminder." } \\
\text { The location(s) where the events were felt is not stated. }\end{array}$ \\
\hline 29-Apr-06 (?) & 00:35 & Napa & Napa & & $\begin{array}{l}\text { Napa Daily Journal, } \\
3 \text { May 1906; p. } 3 \text {, c. } 4\end{array}$ & 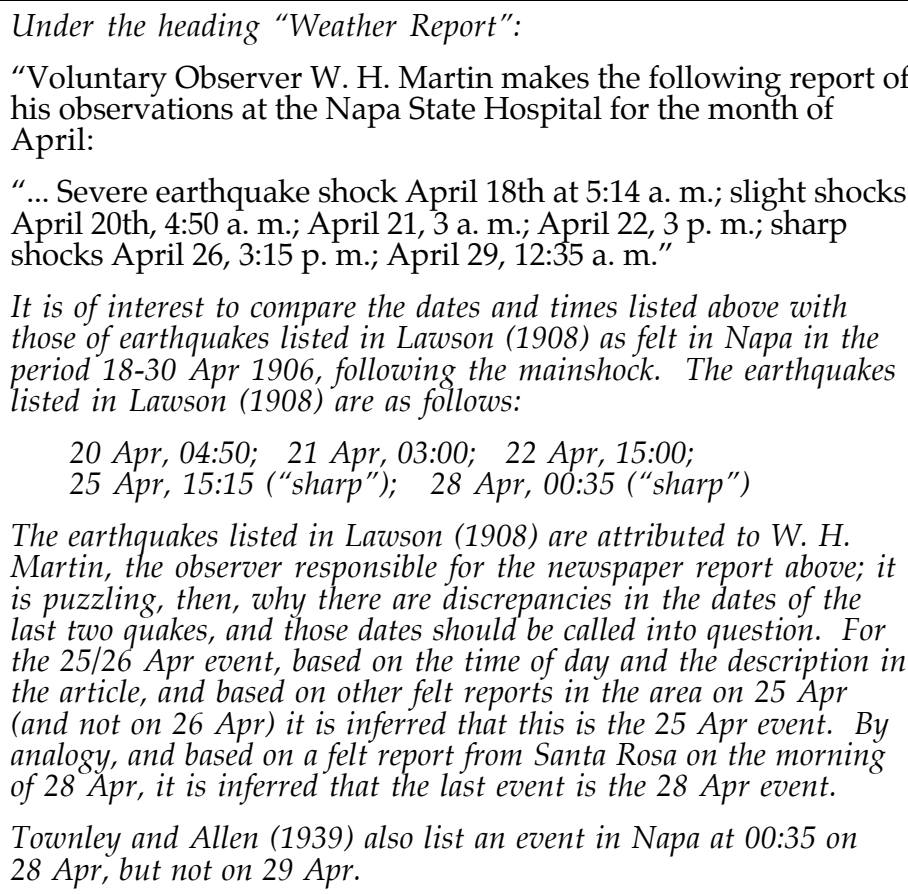 \\
\hline 29-Apr-06 & morning & Hollister & San Benito & & $\begin{array}{l}\text { The Free Lance (Hollister), } \\
4 \text { May 1906; p. 3, c. } 4\end{array}$ & $\begin{array}{l}\text { "A slight shock of earthquake, Sunday morning, while the } \\
\text { churches were holding services caused considerable excitement. } \\
\text { The desire for outdoor exercise was almost uncontrollable." }\end{array}$ \\
\hline $\begin{array}{l}\text { 18-Apr-06 thru } \\
\text { 29-Apr-06 }\end{array}$ & (many events) & San Francisco & San Francisco & & $\begin{array}{l}\text { Diary of Charles Prinegar } \\
\text { (San Francisco, CA), } \\
29 \text { Apr } 1906 \text { (pp. 100-102) }\end{array}$ & $\begin{array}{l}\text { Excerpts from the entry of } 29 \text { Apr 1906: } \\
\text { "(Sunday morning) } \\
\text { "..... } \\
\text { "There has been just twenty nine earthquakes up to the present } \\
\text { time including the first one, but by putting the whole twenty eight } \\
\text { together they would hardly make as great a one as the first one } \\
\text { was...." }\end{array}$ \\
\hline
\end{tabular}


TABLE 1: Catalog of Aftershock Reports following from the Great 18 April 1906 California Earthquake

\begin{tabular}{|c|c|c|c|c|c|c|}
\hline Date Felt & $\begin{array}{l}\text { Time Felt } \\
\text { (PST) }\end{array}$ & $\begin{array}{l}\text { Location Felt } \\
\text { (City) }\end{array}$ & $\begin{array}{l}\text { Location Felt } \\
\text { (County) }\end{array}$ & $\begin{array}{l}\text { Unreliable? } \\
\text { Not Felt? }\end{array}$ & Source & Relevant Citations and other Notes \\
\hline 30-Apr-06 & $\begin{array}{c}\text { early } \\
\text { morning } \\
\text { (two events) }\end{array}$ & San Francisco & San Francisco & & $\begin{array}{l}\text { San Francisco Examiner, } \\
1 \text { May } 1906 ; \text { p. } 4 \text {, c. } 4\end{array}$ & $\begin{array}{l}\text { "Two slight earthquake shocks at an interval of an hour were } \\
\text { felt here early yesterday morning. They were of the same nature } \\
\text { as a dozen other shocks that have been felt since the big quake of } \\
\text { April } 18 \text {. No damage was done this morning and there was no } \\
\text { alarm." } \\
\text { A very similar article appeared in the Berkeley Daily Gazette of } \\
1 \text { May 1906, p. } 1, \text { c. } 3 \text {. }\end{array}$ \\
\hline 30-Apr-06 & $\begin{array}{c}\text { some few } \\
\text { moments after } \\
23: 00\end{array}$ & Ferndale & Humboldt & & $\begin{array}{l}\text { Humboldt Standard, } \\
3 \text { May 1906; p. 6, c. 3-4 }\end{array}$ & $\begin{array}{l}\text { "Some few moments after } 11 \text { o'clock Monday evening, Ferndale } \\
\text { experienced quite a heavy shock of earthquake. No damage was } \\
\text { done however except to the nerves of some who have not yet fully } \\
\text { recovered from effects of the previous shocks." }\end{array}$ \\
\hline 30-Apr-06 & $23: 20$ & Fortuna & Humboldt & & $\begin{array}{l}\text { Humboldt Standard, } \\
3 \text { May 1906; p. 6, c. } 3\end{array}$ & $\begin{array}{l}\text { "... quite a shock of earthquake.... No damage was done at all, but } \\
\text { people are on the qui vive for quakes and are a bit nervous." }\end{array}$ \\
\hline 30-Apr-06 & $23: 20$ & Eureka & Humboldt & & $\begin{array}{l}\text { Humboldt Standard, } \\
1 \text { May 1906; p. } 8, \text { c. } 2\end{array}$ & $\begin{array}{l}\text { "At 11:20 o'clock last night two light earthquake shocks were } \\
\text { felt ... the tremors however were light and no damage was } \\
\text { reported." }\end{array}$ \\
\hline 01-May-06 & $\begin{array}{l}\text { between } \\
20: 00 \text { and } \\
21: 00\end{array}$ & Rumsey & Yolo & & \begin{tabular}{|c|} 
The Home Alliance (Woodland) \\
4 May 1906; p. 3, c. 1
\end{tabular} & $\begin{array}{l}\text { “... Between } 8 \text { and } 9 \text { o'clock Tuesday night another earthquake } \\
\text { was felt here and next morning the creek had fallen about three } \\
\text { and one-half feet. It was still falling at this writing...." }\end{array}$ \\
\hline 01-May-06 & $\begin{array}{l}\text { between } \\
\text { 20:00 and } \\
21: 00\end{array}$ & $\begin{array}{l}\text { Capay, } \\
\text { elsewhere }\end{array}$ & Yolo & & $\begin{array}{c}\text { The Home Alliance (Woodland) } \\
4 \text { May 1906; p. 9, c. } 1\end{array}$ & $\begin{array}{l}\text { "Our Rumsey correspondent mentions the fall of Cache Creek as a } \\
\text { result of an earthquake shock Tuesday night. The water has } \\
\text { continued to fall some since that date and in some places it is dry. } \\
\text { Upon investigation by the officials of the Water Company it was } \\
\text { found that a landslide had dammed the Creek near the Leonard } \\
\text { ranch in Lake county.... } \\
\text { "Mr. Schwab of Capay informed us by telephone at noon today } \\
\text { that the land slide took place at } 5 \text { o'clock Tuesday afternoon and } \\
\text { that the earthquake shock between } 8 \text { and } 9 \text { o'clock in the evening } \\
\text { of the same day was felt at Capay and throughout the Valley...." } \\
\text { "The Valley" most likely refers to the Capay Valley in Yolo } \\
\text { County, although it may instead refer to the Sacramento Valley. }\end{array}$ \\
\hline 01-Мay-06 & 21:00 & Rumsey & Yolo & & $\begin{array}{l}\text { Woodland Daily Democrat, } \\
14 \text { May } 1906 ; \text { p. 2, c. } 1-2\end{array}$ & $\begin{array}{l}\text { "... Cache creek, largely, makes Yolo county what it is, a garden } \\
\text { spot, and when on Wednesday morning, May [2]d, the water } \\
\text { therein began to rapidly disappear at Rumsey following a light } \\
\text { tremor Tuesday night at } 9 \text { o'clock, people began naturally to } \\
\text { wonder why, especially in view of the recent seismic disturbance. } \\
\text { It was, as we really expected, a big landslide which had stopped } \\
\text { the flow...." } \\
\text { This was part of letter, signed and dated "P. N. ASHLEY / } \\
\text { Woodland, May 10th." }\end{array}$ \\
\hline
\end{tabular}


TABLE 1: Catalog of Aftershock Reports following from the Great 18 April 1906 California Earthquake

\begin{tabular}{|c|c|c|c|c|c|c|}
\hline Date Felt & $\begin{array}{l}\text { Time Felt } \\
\text { (PST) }\end{array}$ & $\begin{array}{l}\text { Location Felt } \\
\text { (City) }\end{array}$ & $\begin{array}{l}\text { Location Felt } \\
\text { (County) }\end{array}$ & $\begin{array}{l}\text { Unreliable? } \\
\text { Not Felt? }^{+}\end{array}$ & Source & Relevant Citations and other Notes \\
\hline 01-May-06 & $\sim 21: 00$ & Capay Valley & Yolo & & $\begin{array}{c}\text { Winters Express, } \\
4 \text { May 1906; p. 3, c. } 4-5\end{array}$ & $\begin{array}{l}\text { "Cache creek has been almost shut off. A land slide so dammed it } \\
\text { up that since Wednesday morning the water has almost } \\
\text { disappeared. } \\
\text { "Tuesday evening about } 9 \text { o'clock the people of Capay valley } \\
\text { thought they felt a slight earthquake shock. The next morning it } \\
\text { was noticed that the water in Cache creek had fallen } \\
\text { considerably. By Monday [Thursday?] morning it had almost } \\
\text { ceased to flow where previously there had been a depth of three } \\
\text { feet. This morning it is still lower. } \\
\text { "A telephone message from Capay says that there has been a land } \\
\text { slide at the Wilson ranch at what is known as the shale rocks, } \\
\text { that dammed the water completely.... } \\
\text { Note that the reference to "Monday morning" must be incorrect, } \\
\text { as the article talks about a sequence of events which began on a } \\
\text { Tuesday night (1 May), and the article was printed on the } \\
\text { following Friday (4 May). }\end{array}$ \\
\hline 01-May-06 & 21:00 (?) & $\begin{array}{c}\text { Cache Creek, } \\
\text { about } 4 \text { miles east } \\
\text { of the junction of } \\
\text { North Fork with } \\
\text { Cache Creek }\end{array}$ & $\begin{array}{c}\text { Lake } \\
\text { (about } 4 \text { miles } \\
\text { WNW of } \\
\text { Yolo Co. line) }\end{array}$ & unreliable & $\begin{array}{l}\text { Woodland Daily Democrat, } \\
5 \text { May } 1906 ; \text { p. } 1 \text {, c. } 2\end{array}$ & $\begin{array}{l}\text { "Both Mr. Ashley and Mr. Gregory [who were among a party } \\
\text { surveying a landslide on Cache Creek, which they located at } \\
\text { 'about } 4 \text { miles east of the junction of North Fork with Cache } \\
\text { Creek'] are of the opinion that the landslide was due to a slight } \\
\text { temblor which occurred on Tuesday about } 9 \text { a. m." } \\
\text { The time given in this article is inconsistent with the time listed in } \\
\text { a letter from Mr. P.N. Ashley which was printed in the Woodland } \\
\text { Daily Democrat, } 14 \text { May 1906; the time in the latter account is } \\
\text { stated as } 9 \text { p.m., not } 9 \text { a.m. Because this source is internally } \\
\text { inconsistent, and because all other sources indicate that the event } \\
\text { occurred at around } 21: 00 \text { on the night of } 1 \text { May, the obvious } \\
\text { inference is that the time stated in this article ("9 a. m.") is in error. } \\
\text { Note that a report in The Home Alliance (Woodland), } 4 \text { May 1906, } \\
\text { p. 9, c. 1, indicates that the landslide occurred prior to and } \\
\text { independent of the earthquake. If that is the case, nothing should be } \\
\text { inferred from this report about the intensity at the site of the } \\
\text { landslide. }\end{array}$ \\
\hline 01-May-06 & 22:02 & $\begin{array}{l}\text { San Francisco } \\
\text { Palo Alto }\end{array}$ & $\begin{array}{l}\text { San Francisco } \\
\text { Santa Clara }\end{array}$ & & $\begin{array}{l}\text { The Bulletin (San Francisco), } \\
2 \text { May } 1906 ; \text { p. } 4 \text {, c. } 5\end{array}$ & $\begin{array}{l}\text { "... there was another earthquake shock. It was slightly felt in } \\
\text { San Francisco, but down the peninsula as far as Palo Alto the } \\
\text { shock was very severe. No damage has been reported." }\end{array}$ \\
\hline
\end{tabular}


TABLE 1: Catalog of Aftershock Reports following from the Great 18 April 1906 California Earthquake

\begin{tabular}{|c|c|c|c|c|c|c|}
\hline Date Felt & $\begin{array}{c}\text { Time Felt } \\
\text { (PST) }\end{array}$ & $\begin{array}{l}\text { Location Felt } \\
\text { (City) }\end{array}$ & $\begin{array}{l}\text { Location Felt } \\
\text { (County) }\end{array}$ & $\begin{array}{c}\text { Unreliable? } \\
\text { Not Felt? }^{+}\end{array}$ & Source & Relevant Citations and other Notes \\
\hline 01-May-06 & \begin{tabular}{c|} 
between \\
22:00 and \\
23:00, and \\
other times \\
at night \\
(several \\
events)
\end{tabular} & Berkeley & Alameda & & $\begin{array}{l}\text { Berkeley Daily Gazette, } \\
2 \text { May 1906; p. 1, c. } 7\end{array}$ & $\begin{array}{l}\text { "... Several light earthquakes occurred last night, but were not felt } \\
\text { in all parts of the city. The heaviest of these took place some time } \\
\text { between } 10 \text { and } 11 \text { o'clock last night...." } \\
\text { This article was reprinted in the Marin Journal, } 17 \text { May 1906, } \\
\text { p. 2, c. } 1 \text {. When it was reprinted, it was credited to the Berkeley } \\
\text { Gazette of } 8 \text { May 1906; however, the original appeared in the } \\
\text { Berkeley Daily Gazette on } 2 \text { May, not on } 8 \text { May. The date of the } \\
\text { described events, therefore, would be } 1 \text { May, not some later date. }\end{array}$ \\
\hline 01-May-06 (?) & $22: 58$ & Cape Mendocino & Humboldt & & $\begin{array}{c}\text { Lighthouse Log for } \\
\text { Cape Mendocino Lighthouse, } \\
1 \text { May } 1906\end{array}$ & $\begin{array}{l}\text { Excerpt from the entry of } 1 \text { May 1906: } \\
\text { "Another shock of earthquake was felt } 10.58 \text { p.m. no damage was } \\
\text { done and was very light...." } \\
\text { A one-line summary of the keeper's completed chores for the day } \\
\text { follows the description of the earthquake above. Because the } \\
\text { description of the earthquake precedes the summary of the day's } \\
\text { chores, either the entire entry was recorded late at night (after } \\
22: 58), \text { or the earthquake occurred the preceding night, on } 30 \text { Apr. } \\
\text { Townley and Allen (1939) list this event at } 22: 58 \text { on } 30 \text { Apr, but } \\
\text { the source of their information is not clear. This issue cannot be } \\
\text { resolved with any certainty. }\end{array}$ \\
\hline 02-May-06 & morning & San Francisco & San Francisco & & $\begin{array}{l}\text { Diary of Charles Prinegar } \\
\text { (San Francisco, CA), } \\
2 \text { May } 1906 \text { (p. 123) }\end{array}$ & $\begin{array}{l}\text { Excerpts from the entry of } 2 \text { May 1906: } \\
\text { "(Wednesday A. M. May } 2^{\text {nd }} \text { ) } \\
\text { "While I was standing in line for breakfast another shock came } \\
\text { that shook us up some but the worst shock was at the table when } \\
\text { the headman came around and said that was the last meal they } \\
\text { would serve...." } \\
\text { From its jovial nature and from the statement itself, it seems that } \\
\text { this earthquake was not very impressive. }\end{array}$ \\
\hline $\begin{array}{c}\text { week of } \\
\text { 02-May-06 }\end{array}$ & $\begin{array}{c}16: 50 \text { on } \\
02 \text { May, } \\
\text { other times } \\
\text { (many events) }\end{array}$ & Boulder Creek & Santa Cruz & & $\begin{array}{c}\text { Mountain Echo (Boulder Creek) } \\
5 \text { May 1906; p. 3, c. } 2\end{array}$ & $\begin{array}{l}\text { "There was quite a distinct shock of earthquake at } 4: 50 \\
\text { Wednesday afternoon and another equally marked at } 6 \text { o'clock } \\
\text { Thursday morning. In addition to these two there have been many } \\
\text { light quivers during the week." }\end{array}$ \\
\hline 02-May-06 & $16: 53$ & Santa Cruz & Santa Cruz & & $\begin{array}{c}\text { Santa Cruz Morning Sentinel, } \\
3 \text { May 1906; p. } 7, \text { c. } 1\end{array}$ & "... a lively shock of earthquake...." \\
\hline
\end{tabular}


TABLE 1: Catalog of Aftershock Reports following from the Great 18 April 1906 California Earthquake

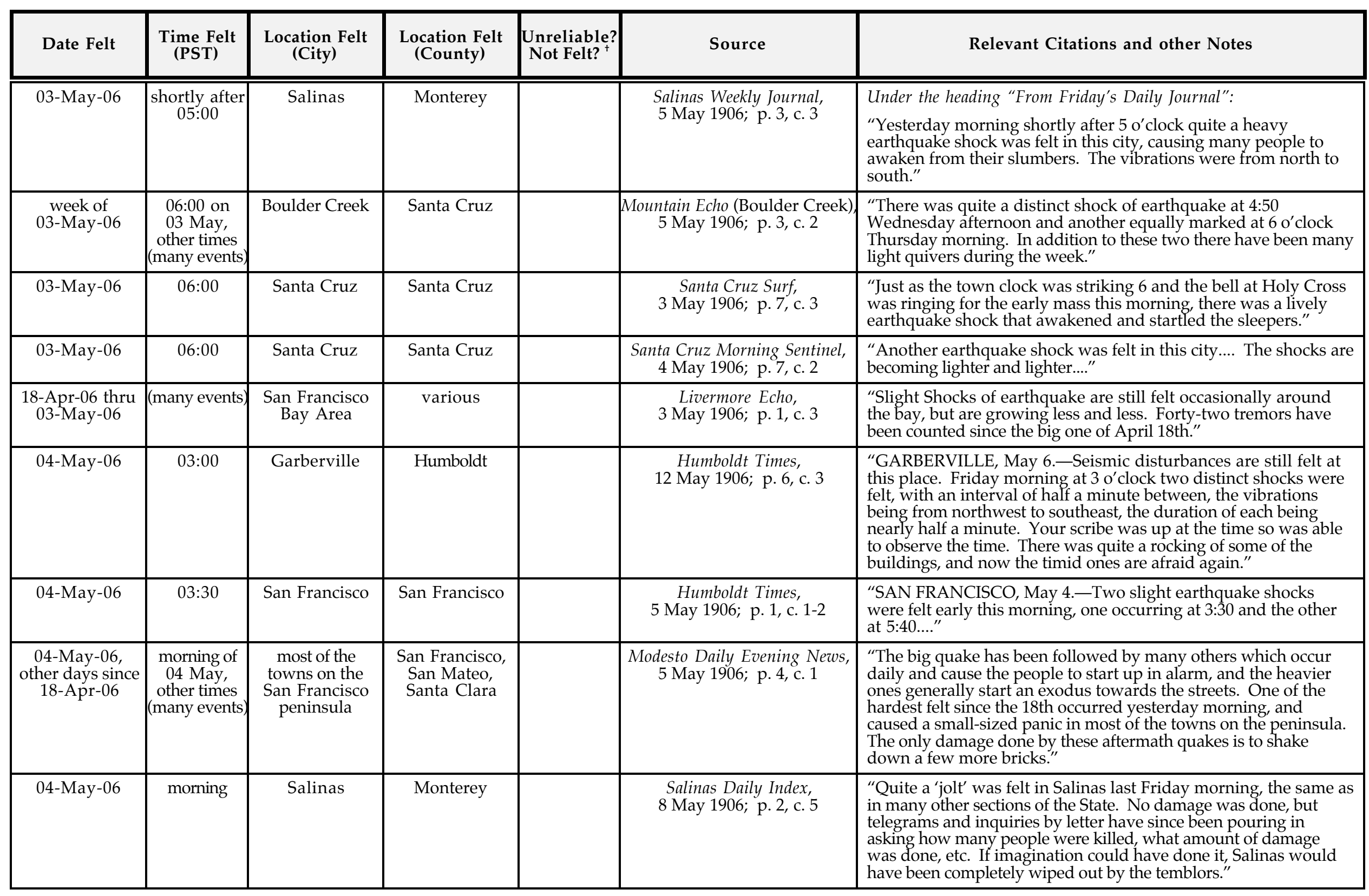


TABLE 1: Catalog of Aftershock Reports following from the Great 18 April 1906 California Earthquake

\begin{tabular}{|c|c|c|c|c|c|c|}
\hline Date Felt & $\begin{array}{l}\text { Time Felt } \\
\text { (PST) }\end{array}$ & $\begin{array}{l}\text { Location Felt } \\
\text { (City) }\end{array}$ & $\begin{array}{l}\text { Location Felt } \\
\text { (County) }\end{array}$ & $\begin{array}{l}\text { Unreliable? } \\
\text { Not Felt? }^{+}\end{array}$ & Source & Relevant Citations and other Notes \\
\hline 04-May-06 & morning & Monterey & Monterey & & $\begin{array}{l}\text { Salinas Weekly Journal, } \\
5 \text { May 1906; p. 3, c. } 5\end{array}$ & $\begin{array}{l}\text { Under the heading "From this morning's Daily Journal": } \\
\text { "... The earthquake shock at Monterey yesterday morning was } \\
\text { very light...." }\end{array}$ \\
\hline 04-May-06 & $\begin{array}{l}\text { between } \\
05: 00 \text { and } \\
06: 00\end{array}$ & Salinas & Monterey & & $\begin{array}{l}\text { Salinas Weekly Journal, } \\
5 \text { May 1906; p. 3, c. } 5\end{array}$ & $\begin{array}{l}\text { Under the heading "From this morning's Daily Journal": } \\
\text { "... A slight shock of earthquake between } 5 \text { and } 6 \text { o'clock } \\
\text { yesterday morning had a tendency to keep the nerves of highly } \\
\text { sensitive persons on edge...." }\end{array}$ \\
\hline 04-May-06 & 05:30 & Gilroy & Santa Clara & & $\begin{array}{c}\text { Gilroy Advocate, } \\
5 \text { May 1906; p. 1, c. } 4\end{array}$ & "An earthquake shock ... aroused many from their beds." \\
\hline 04-May-06 & 05:30 & Boulder Creek & Santa Cruz & & \begin{tabular}{|} 
Mountain Echo (Boulder Creek) \\
5 May 1906; p. 3, c. 1
\end{tabular} & "There was another light but distinct shock of earthquake...." \\
\hline 04-May-06 & 05:30 & Santa Cruz & Santa Cruz & & $\begin{array}{c}\text { Santa Cruz Morning Sentinel, } \\
5 \text { May 1906; p. } 7, \text { c. } 2\end{array}$ & $\begin{array}{l}\text { "A lively shock of earthquake awoke the people of Santa } \\
\text { Cruz...." }\end{array}$ \\
\hline 04-May-06 (?) & $\sim 05: 30$ & $\begin{array}{l}\text { Monterey } \\
\text { Salinas }\end{array}$ & $\begin{array}{l}\text { Monterey } \\
\text { Monterey }\end{array}$ & & $\begin{array}{l}\text { Salinas Weekly Journal, } \\
12 \text { May 1906; p. } 1, \text { c. } 5\end{array}$ & $\begin{array}{l}\text { "The following from the Monterey Cypress shows how } \\
\text { unreliable is the earthquake news in the present tension of the } \\
\text { nerves of our people. Here not a wall fell, nor a brick, but in } \\
\text { traveling the short distance of eighteen miles the news reads thus } \\
\text { in the Cypress: } \\
\text { "'There was a slight shock of earthquake in Monterey about 5:30 } \\
\text { yesterday morning. } \\
\text { "'At Salinas it is said the shock was much heavier, and that the } \\
\text { residents were so frightened they rushed out into the streets. A } \\
\text { number of walls of buildings wrecked in the big earthquake two } \\
\text { weeks ago were knocked down." } \\
\text { No issues of the Monterey Cypress could be located from 1906. The } \\
\text { date of the original report, and the date of the earthquake, are } \\
\text { unknown, although from the time stated it was probably either the } \\
3 \text { May or } 4 \text { May } 1906 \text { event. }\end{array}$ \\
\hline 04-May-06 & 05:40 & San Francisco & San Francisco & & $\begin{array}{l}\text { Humboldt Times, } \\
5 \text { May 1906; p. 1, c. } 1-2\end{array}$ & $\begin{array}{l}\text { "SAN FRANCISCO, May 4.-Two slight earthquake shocks } \\
\text { were felt early this morning, one occurring at } 3: 30 \text { and the other } \\
\text { at } 5: 40 \ldots . . \text { " }\end{array}$ \\
\hline 04-May-06 & $\sim 06: 00$ & Salinas & Monterey & & $\begin{array}{l}\text { Salinas Daily Index, } \\
\text { 4 May 1906; p. 1, c. } 5\end{array}$ & $\begin{array}{l}\text { "Quite a pronounced quake was felt here ... the motion, as usual, } \\
\text { being from north to south. The movement was of brief } \\
\text { duration...." }\end{array}$ \\
\hline 04-May-06 & $\sim 23: 00$ & Hanford & Kings & & $\begin{array}{l}\text { Hanford Weekly Sentinel, } \\
10 \text { May 1906; p. 2, c. } 2\end{array}$ & $\begin{array}{l}\text { "Harvey Read says that there was a shake here Friday night, that } \\
\text { he noticed. Others have said that they felt one. Jailor Morse } \\
\text { states that he felt a quake at about } 11 \text { o' clock at the jail. The } \\
\text { effect here must have been very slight." }\end{array}$ \\
\hline
\end{tabular}


TABLE 1: Catalog of Aftershock Reports following from the Great 18 April 1906 California Earthquake

\begin{tabular}{|c|c|c|c|c|c|c|}
\hline Date Felt & $\begin{array}{l}\text { Time Felt } \\
\text { (PST) }\end{array}$ & $\begin{array}{l}\text { Location Felt } \\
\text { (City) }\end{array}$ & $\begin{array}{l}\text { Location Felt } \\
\text { (County) }\end{array}$ & $\begin{array}{l}\text { Unreliable? } \\
\text { Not Felt? }^{+}\end{array}$ & Source & Relevant Citations and other Notes \\
\hline 05-May-06 & morning & $\begin{array}{c}\text { San Rafael } \\
\text { San Francisco }\end{array}$ & $\begin{array}{c}\text { Marin } \\
\text { San Francisco }\end{array}$ & & $\begin{array}{c}\text { Marin Journal, } \\
10 \text { May 1906; p. 8, c. } 5\end{array}$ & $\begin{array}{l}\text { "The earthquake shock on Saturday morning which was very } \\
\text { light in this city, was exceedingly heavy at San Francisco and } \\
\text { caused considerable alarm. People ran from buildings and there } \\
\text { was considerable excitement." }\end{array}$ \\
\hline 05-May-06 & $10: 00$ & San Francisco & San Francisco & & $\begin{array}{l}\text { Fresno Morning Republican, } \\
6 \text { May 1906; p. } 8, \text { c. } 1\end{array}$ & $\begin{array}{l}\text { "There was a persistent rumor in town last night that another } \\
\text { severe earthquake had occurred in San Francisco at } 5 \text { o' clock last } \\
\text { evening. As no dispatch to that effect was received, the } \\
\text { Republican queried the Associated Press, receiving the } \\
\text { information that at } 10 \text { o' clock in the forenoon a shock was felt } \\
\text { but it did no damage. French Strother, who came down from San } \\
\text { Francisco last night, said the shock was severe enough to give him } \\
\text { something of a scare." }\end{array}$ \\
\hline 05-May-06 & $\sim 10: 28$ & San Francisco & San Francisco & & $\begin{array}{l}\text { San Francisco Call, } \\
6 \text { May 1906; p. 1, c. } 1\end{array}$ & $\begin{array}{l}\text { "Another earth tremble that alarmed nervous people occurred.... } \\
\text { The quiver was short, but strong enough to create a general scare } \\
\text { and knock down a portion of one of the remaining walls of the } \\
\text { ruined Pacific Mutual Life building. In Franklin Hall, which has } \\
\text { been weak in the joists since the big jar on April 18, a meeting was } \\
\text { in progress, with Mayor Schmitz presiding. When the structure } \\
\text { began to wobble Garret McEnerney sprang to his feet and started } \\
\text { excitedly for the nearest door. Mayor Schmitz headed off a } \\
\text { stampede by remarking 'Mr. McEnerney has the floor.'” }\end{array}$ \\
\hline 05-May-06 & $10: 28$ & $\begin{array}{c}\text { San Francisco } \\
\text { Oakland }\end{array}$ & $\begin{array}{c}\text { San Francisco } \\
\text { Alameda }\end{array}$ & & $\begin{array}{c}\text { The Bulletin (San Francisco), } \\
5 \text { May 1906; p. 1, c. } 1\end{array}$ & $\begin{array}{l}\text { "An earthquake shock ... caused considerable damage in San } \\
\text { Francisco. The interior walls of the Hall of Justice trembled and } \\
\text { the wall of the Mutual Life building fell. Workmen in many } \\
\text { places were endangered by falling bricks, but no casualties were } \\
\text { reported. The shock was the most severe since that of April } 18 . \\
\text { "The shock was distinctly felt in Oakland, and while it did no } \\
\text { harm, it frightened some people. } \\
\text { "Professor C. H. Burkhalter, of the Chabot Observatory, said that } \\
\text { the shock had been a very slight one as recorded by the } \\
\text { seismograph. 'It was only one of many,' he declared, 'that are } \\
\text { being caused by the settling of the earth after the shock of April } \\
\text { 18...." } \\
\text { Also in the Oakland Herald of } 5 \text { May 1906, p. 1, c. } 3 \text {. }\end{array}$ \\
\hline 05-May-06 & $10: 29: 44$ & \begin{tabular}{|c|} 
Berkeley \\
San Francisco (?)
\end{tabular} & \begin{tabular}{c|} 
Alameda \\
San Francisco (?)
\end{tabular} & & $\begin{array}{l}\text { Berkeley Daily Gazette, } \\
5 \text { May 1906; p. 1, c. } 6\end{array}$ & $\begin{array}{l}\text { "Another severe earthquake shock occurred ... and was possibly } \\
\text { the heaviest since the great one of April } 18 \text {. The temblor was felt } \\
\text { in all parts of the city and at the University Observatory. Many } \\
\text { people ran from their homes and business houses, fearing a } \\
\text { repetition of the one of two weeks ago. } \\
\text { "Professor J. N. LeConte and Dr. Newkirk of the University, } \\
\text { recorded the temblor at the observatory, and its intensity was } \\
\text { taken on the Rossi-Forel scale which was II. The shock was }\end{array}$ \\
\hline
\end{tabular}


TABLE 1: Catalog of Aftershock Reports following from the Great 18 April 1906 California Earthquake

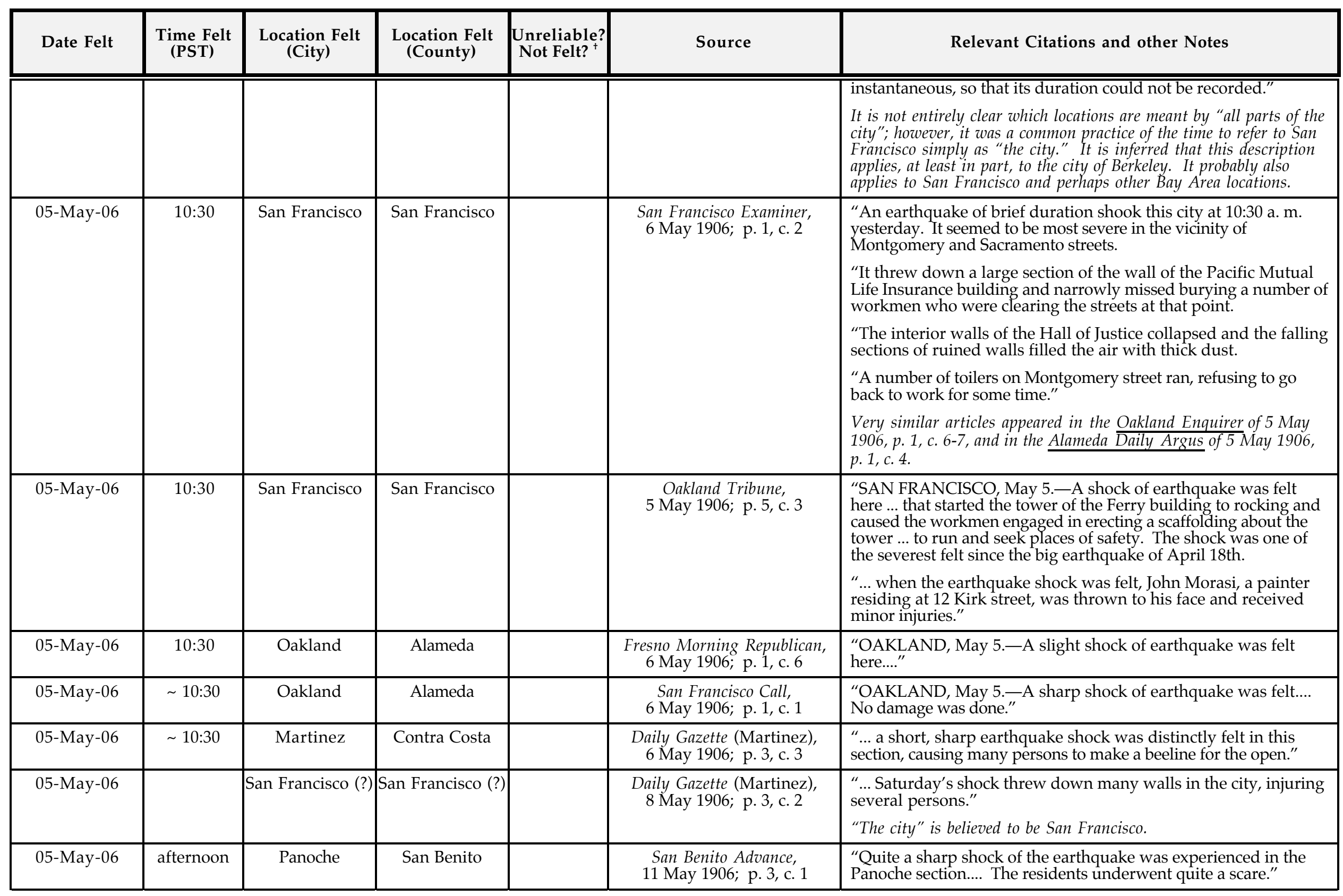


TABLE 1: Catalog of Aftershock Reports following from the Great 18 April 1906 California Earthquake

\begin{tabular}{|c|c|c|c|c|c|c|}
\hline Date Felt & $\begin{array}{l}\text { Time Felt } \\
\text { (PST) }\end{array}$ & $\begin{array}{l}\text { Location Felt } \\
\quad \text { (City) }\end{array}$ & $\begin{array}{l}\text { Location Felt } \\
\text { (County) }\end{array}$ & $\begin{array}{l}\text { Unreliable? } \\
\text { Not Felt? }^{+}\end{array}$ & Source & Relevant Citations and other Notes \\
\hline 06-May-06 & $\begin{array}{l}\text { early } \\
\text { morning }\end{array}$ & Martinez & Contra Costa & & $\begin{array}{l}\text { Daily Gazette (Martinez), } \\
8 \text { May 1906; p. 3, c. } 2\end{array}$ & "There was another slight shock early Sunday morning...." \\
\hline 06-May-06 & 03:00 & Blocksburg & Humboldt & & $\begin{array}{l}\text { Humboldt Standard, } \\
9 \text { May 1906; p. 2, c. } 1\end{array}$ & "a slight shock" \\
\hline 06-May-06 & $18: 30$ & Garberville & Humboldt & & $\begin{array}{l}\text { Humboldt Standard, } \\
9 \text { May 1906; p. 2, c. } 4\end{array}$ & "quite a vibration" \\
\hline 06-May-06 & $20: 15$ & $\begin{array}{c}\text { Lakeport } \\
\text { Bartlett Springs }\end{array}$ & $\begin{array}{l}\text { Lake } \\
\text { Lake }\end{array}$ & & $\begin{array}{l}\text { Lake County Bee, } \\
9 \text { May 1906; p. 3, c. } 4\end{array}$ & $\begin{array}{l}\text { "A mild-mannered and peaceable little earthquake shook } \\
\text { Lakeport a little last Sunday evening, just for fun, just to remind } \\
\text { us that the earthquake factory has not gone out of business since } \\
\text { the San Francisco fire. } \\
\text { "It reacht Lakeport at 8:15, coming from the west, and went on } \\
\text { over to Bartlett Springs, where its trail was lost. It did not pick } \\
\text { buildings up and let them down again, as its big brother did on the } \\
18 \text { th of April, nor did it cause the earth to roll in billows. It } \\
\text { simply took hold of the buildings and rattled them-gave them a } \\
\text { lively mischievous shaking, as if it wanted to frighten the people. } \\
\text { "And it frightened them, too, for their nerves were still on edge } \\
\text { from the 18th. They flockt into the streets in short order and most } \\
\text { of them made a bee line for Main street to see if the brick buildings } \\
\text { were still standing. They were, and no damage was done in the } \\
\text { town...." }\end{array}$ \\
\hline 06-May-06 & $\sim 21: 00$ & $\begin{array}{c}\text { Lakeport } \\
\text { Ukiah } \\
\text { Upper Lake } \\
\text { Kelseyville } \\
\text { Bartlett Springs } \\
\text { Santa Rosa } \\
\text { San Francisco }\end{array}$ & $\begin{array}{c}\text { Lake } \\
\text { Mendocino } \\
\text { Lake } \\
\text { Lake } \\
\text { Lake } \\
\text { Sonoma } \\
\text { San Francisco }\end{array}$ & $\begin{array}{l}\text { Not Felt } \\
\text { Not Felt }\end{array}$ & $\begin{array}{c}\text { Lake County Bee, } \\
9 \text { May 1906; p. 3, c. } 4\end{array}$ & $\begin{array}{l}\text { “... At about } 9 \text { o' clock [Sunday night, } 6 \text { May] there was another } \\
\text { little shock. At 2:30 Monday morning there was still another and } \\
\text { between } 7 \text { and } 8 \text { two others came along, shook us up and went } \\
\text { away chuckling in their sleeves. } \\
\text { "They were felt at Ukiah, Upperlake, Kelseyville and Bartlett } \\
\text { Springs, but did not visit Santa Rosa or San Francisco....” } \\
\text { From the general nature of the latter statement, it is not clear } \\
\text { whether each of these quakes was felt in all of the towns mentioned. }\end{array}$ \\
\hline 06-May-06 & $\begin{array}{c}\text { night } \\
\text { (two events, } \\
1 \text { hour apart) }\end{array}$ & Upper Lake & Lake & & $\begin{array}{l}\text { Lake County Bee, } \\
9 \text { May 1906; p. 2, c. } 3\end{array}$ & $\begin{array}{l}\text { "UPPER LAKE, MAY 8th.-Earthquakes still seem to be the rule. } \\
\text { Slight shocks have been quite frequent the past week and Sunday } \\
\text { night [ } 6 \text { May, during the Epworth League special services there } \\
\text { was quite a heavy shake which badly frightened the worshippers } \\
\text { and there was a stampede for the door. Mrs. Collins, who had } \\
\text { been through the San Francisco earthquake, was so frightened she } \\
\text { fainted. About an hour after the first one there was another } \\
\text { slight one, that caused a little excitement in the church but very } \\
\text { few went out.... }\end{array}$ \\
\hline
\end{tabular}


TABLE 1: Catalog of Aftershock Reports following from the Great 18 April 1906 California Earthquake

\begin{tabular}{|c|c|c|c|c|c|c|}
\hline Date Felt & $\begin{array}{l}\text { Time Felt } \\
\text { (PST) }\end{array}$ & $\begin{array}{l}\text { Location Felt } \\
\text { (City) }\end{array}$ & $\begin{array}{l}\text { Location Felt } \\
\text { (County) }\end{array}$ & $\begin{array}{l}\text { Unreliable? } \\
\text { Not Felt? }^{+}\end{array}$ & Source & Relevant Citations and other Notes \\
\hline & & & & & & $\begin{array}{l}\text { "As [these aftershocks] have never done any damage here we are } \\
\text { in hopes we are earthquake proof." }\end{array}$ \\
\hline $\begin{array}{l}\text { 06-May-06 to } \\
07-\text { May-06 }\end{array}$ & $\begin{array}{l}\text { night of } 06 \\
\text { May / early } \\
\text { morning of } \\
\text { 07 May } \\
\text { (several } \\
\text { events) }\end{array}$ & Garberville & Humboldt & & $\begin{array}{l}\text { Humboldt Standard, } \\
9 \text { May 1906; p. 2, c. } 4\end{array}$ & "... during the night a few shakes were felt." \\
\hline 07-May-06 & 02:30 & $\begin{array}{c}\text { Lakeport } \\
\text { Ukiah } \\
\text { Upper Lake } \\
\text { Kelseyville } \\
\text { Bartlett Springs } \\
\text { Santa Rosa } \\
\text { San Francisco }\end{array}$ & $\begin{array}{c}\text { Lake } \\
\text { Mendocino } \\
\text { Lake } \\
\text { Lake } \\
\text { Lake } \\
\text { Sonoma } \\
\text { San Francisco }\end{array}$ & $\begin{array}{l}\text { Not Felt } \\
\text { Not Felt }\end{array}$ & $\begin{array}{l}\text { Lake County Bee, } \\
9 \text { May 1906; p. 3, c. } 4\end{array}$ & $\begin{array}{l}\text { “.. At about } 9 \text { o' clock [Sunday night, } 6 \text { May] there was another } \\
\text { little shock. At 2:30 Monday morning there was still another and } \\
\text { between } 7 \text { and } 8 \text { two others came along, shook us up and went } \\
\text { away chuckling in their sleeves. } \\
\text { "They were felt at Ukiah, Upperlake, Kelseyville and Bartlett } \\
\text { Springs, but did not visit Santa Rosa or San Francisco....” } \\
\text { From the general nature of the latter statement, it is not clear } \\
\text { whether each of these quakes was felt in all of the towns mentioned. }\end{array}$ \\
\hline 07-May-06 & 07:00 & Upper Lake & Lake & & $\begin{array}{l}\text { Lake County Bee, } \\
9 \text { May 1906; p. 2, c. } 3\end{array}$ & $\begin{array}{l}\text { "UPPER LAKE, MAY 8th.-... We had another slight shock at } 7 \\
\text { Monday morning [7 May] and another, quite a hard one, about } 5 \\
\text { o'clock, so we are getting pretty well used to them now. As they } \\
\text { have never done any damage here we are in hopes we are } \\
\text { earthquake proof." }\end{array}$ \\
\hline 07-May-06 & \begin{tabular}{|c|} 
between \\
$07: 00$ and \\
$08: 00$ \\
(two events)
\end{tabular} & $\begin{array}{c}\text { Lakeport } \\
\text { Ukiah } \\
\text { Upper Lake } \\
\text { Kelseyville } \\
\text { Bartlett Springs } \\
\text { Santa Rosa } \\
\text { San Francisco }\end{array}$ & $\begin{array}{c}\text { Lake } \\
\text { Mendocino } \\
\text { Lake } \\
\text { Lake } \\
\text { Lake } \\
\text { Sonoma } \\
\text { San Francisco }\end{array}$ & $\begin{array}{l}\text { Not Felt } \\
\text { Not Felt }\end{array}$ & $\begin{array}{l}\text { Lake County Bee, } \\
9 \text { May 1906; p. 3, c. } 4\end{array}$ & $\begin{array}{l}\text { “... At about } 9 \text { o' clock [Sunday night, } 6 \text { May] there was another } \\
\text { little shock. At } 2: 30 \text { Monday morning there was still another and } \\
\text { between } 7 \text { and } 8 \text { two others came along, shook us up and went } \\
\text { away chuckling in their sleeves. } \\
\text { "They were felt at Ukiah, Upperlake, Kelseyville and Bartlett } \\
\text { Springs, but did not visit Santa Rosa or San Francisco...." } \\
\text { From the general nature of the latter statement, it is not clear } \\
\text { whether each of these quakes was felt in all of the towns mentioned. }\end{array}$ \\
\hline 07-May-06 & afternoon & Lakeport & Lake & & $\begin{array}{l}\text { Lake County Bee, } \\
9 \text { May 1906; p. 3, c. } 4\end{array}$ & $\begin{array}{l}\text { "... In the afternoon another playful quakelet dropt in to see if } \\
\text { Lakeport's brick buildings were still sound. It found them stout } \\
\text { of heart and did not tarry long." }\end{array}$ \\
\hline
\end{tabular}


TABLE 1: Catalog of Aftershock Reports following from the Great 18 April 1906 California Earthquake

\begin{tabular}{|c|c|c|c|c|c|c|}
\hline Date Felt & $\begin{array}{l}\text { Time Felt } \\
\text { (PST) }\end{array}$ & $\begin{array}{l}\text { Location Felt } \\
\text { (City) }\end{array}$ & $\begin{array}{l}\text { Location Felt } \\
\text { (County) }\end{array}$ & $\begin{array}{l}\text { Unreliable? } \\
\text { Not Felt? }\end{array}$ & Source & Relevant Citations and other Notes \\
\hline 07-May-06 (?) & $\begin{array}{l}\text { 17:00 (?) } \\
\end{array}$ & Upper Lake & Lake & & $\begin{array}{c}\text { Lake County Bee, } \\
9 \text { May 1906; p. 2, c. } 3\end{array}$ & $\begin{array}{l}\text { "UPPER LAKE, MAY 8th.-.... We had another slight shock at } 7 \\
\text { Monday morning [7 May] and another, quite a hard one, about } 5 \\
\text { o'clock, so we are getting pretty well used to them now. As they } \\
\text { have never done any damage here we are in hopes we are } \\
\text { earthquake proof." } \\
\text { The date and time of day (morning or afternoon) of the } 5 \text { o'clock }^{\prime} \\
\text { quake are ambiguous and our inference is not without uncertainty. }\end{array}$ \\
\hline $\begin{array}{l}\text { 05-May-06 to } \\
\text { 07-May-06 }\end{array}$ & $\begin{array}{l}\text { night of } \\
\text { 05 May } \\
\text { to 07 May } \\
\text { (several } \\
\text { events) }\end{array}$ & Salinas & Monterey & & $\begin{array}{l}\text { Salinas Daily Index, } \\
7 \text { May 1906; p. 2, c. } 4\end{array}$ & $\begin{array}{l}\text { "There have been two or three mild shakes since Saturday night, } \\
\text { although not of sufficient force to cause any alarm." }\end{array}$ \\
\hline $\begin{array}{l}\text { 07-May-06 to } \\
\text { 08-May-06 }\end{array}$ & $\begin{array}{l}\sim 01: 00 \text { on } \\
\text { 08 May; } \\
\text { other times } \\
\text { during the } \\
\text { night of } 07 \\
\text { May / early } \\
\text { morning of } \\
\text { 08 May } \\
\text { (several } \\
\text { events) }\end{array}$ & Salinas & Monterey & & $\begin{array}{l}\text { Salinas Daily Index, } \\
8 \text { May } 1906 ; \text { p. } 2, \text { c. } 3\end{array}$ & $\begin{array}{l}\text { "The minor shocks of earthquake that have followed in the wake } \\
\text { of the big one are becoming quite common and most of the residents } \\
\text { are getting so they sleep through them. Last night there were three } \\
\text { but they were so light that they did no damage. The hardest one } \\
\text { was about } 1 \text { o' clock when the chandeliers were well stirred up } \\
\text { and described circles, and semi-circles, and squares and all sorts } \\
\text { of designs." }\end{array}$ \\
\hline 08-May-06 & $17: 00$ & Edenvale & Santa Clara & unreliable & $\begin{array}{l}\text { Humboldt Times, } \\
10 \text { May 1906; p.3, c. } 6\end{array}$ & $\begin{array}{l}\text { "SAN FRANCISCO, May 9-The first section of the Coast } \\
\text { Limited Number Nine was wrecked at Edenvale, two miles south } \\
\text { of San Jose, at 7:25 this morning.... } \\
\text { "An earthquake shock at } 5 \text { o'clock last evening caused the track, } \\
\text { which was on made land, to sink, and the first train passing over } \\
\text { the spot met disaster..." } \\
\text { The assumption by the author of this report that the earthquake was } \\
\text { responsible for the derailment seems questionable. }\end{array}$ \\
\hline 08-May-06 & $\sim \sim 23: 00$ & Salinas & Monterey & & $\begin{array}{l}\text { Salinas Daily Index, } \\
9 \text { May } 1906 ; \text { p. } 1, \text { c. } 4\end{array}$ & $\begin{array}{l}\text { "A light shock of earthquake was felt here about eleven o'clock } \\
\text { last night...." }\end{array}$ \\
\hline 08-May-06 & $23: 30$ & Los Gatos & Santa Clara & & $\begin{array}{l}\text { San Jose Mercury, } \\
10 \text { May 1906; p. 9, c. } 3\end{array}$ & “... A light shock of earthquake occurred...." \\
\hline 08-May-06 & night & San Francisco & San Francisco & & $\begin{array}{l}\text { Humboldt Times, } \\
10 \text { May 1906; p. 1, c. } 1\end{array}$ & $\begin{array}{l}\text { "SAN FRANCISCO, May 9.-Two light earthquake shocks were } \\
\text { felt last night." }\end{array}$ \\
\hline 09-May-06 & $00: 15$ & Petaluma & Sonoma & & $\begin{array}{l}\text { Fresno Morning Republican, } \\
10 \text { May 1906; p. } 10, \text { c. } 4\end{array}$ & $\begin{array}{l}\text { "PETALUMA, May 9.-Several slight temblors were felt during } \\
\text { the early hours of the morning. The first shock occurred at 12:15, } \\
\text { the second and hardest at 5:13 and the third at } 6 \text { o'clock. No } \\
\text { damage was done." }\end{array}$ \\
\hline
\end{tabular}


TABLE 1: Catalog of Aftershock Reports following from the Great 18 April 1906 California Earthquake

\begin{tabular}{|c|c|c|c|c|c|c|}
\hline Date Felt & $\begin{array}{l}\text { Time Felt } \\
\text { (PST) }\end{array}$ & $\begin{array}{l}\text { Location Felt } \\
\text { (City) }\end{array}$ & $\begin{array}{l}\text { Location Felt } \\
\text { (County) }\end{array}$ & $\begin{array}{l}\text { Unreliable? } \\
\text { Not Felt? }\end{array}$ & Source & Relevant Citations and other Notes \\
\hline 09-May-06 & $05: 13$ & Petaluma & Sonoma & & $\begin{array}{l}\text { Fresno Morning Republican, } \\
10 \text { May } 1906 ; \text { p. } 10, \text { c. } 4\end{array}$ & $\begin{array}{l}\text { "PETALUMA, May 9.-Several slight temblors were felt during } \\
\text { the early hours of the morning. The first shock occurred at 12:15, } \\
\text { the second and hardest at 5:13 and the third at } 6 \text { o'clock. No } \\
\text { damage was done." }\end{array}$ \\
\hline 09-May-06 & 06:00 & Petaluma & Sonoma & & $\begin{array}{l}\text { Fresno Morning Republican, } \\
10 \text { May 1906; p. } 10, \text { c. } 4\end{array}$ & $\begin{array}{l}\text { "PETALUMA, May 9.-Several slight temblors were felt during } \\
\text { the early hours of the morning. The first shock occurred at 12:15, } \\
\text { the second and hardest at 5:13 and the third at } 6 \text { o'clock. No } \\
\text { damage was done." }\end{array}$ \\
\hline 09-May-06 & $\begin{array}{l}06: 50 \text { or } \\
18: 50\end{array}$ & Briceland & Humboldt & & $\begin{array}{l}\text { Humboldt Standard, } \\
21 \text { May 1906; p. 6, c. } 1\end{array}$ & $\begin{array}{l}\text { "Wednesday [9 May] at 6:50 o'clock we had quite a little } \\
\text { shake...." }\end{array}$ \\
\hline 09-May-06 & $07: 45$ & Garberville & Humboldt & & $\begin{array}{l}\text { Humboldt Standard, } \\
16 \text { May } 1906 ; \text { p. 6, c. } 3\end{array}$ & $\begin{array}{l}\text { "... the disturbance ... was severe enough to jar the dishes in the } \\
\text { pantry and shake up things more than any other shock since the } \\
\text { one of April 18th." }\end{array}$ \\
\hline 09-May-06 & forenoon & Salinas & Monterey & & $\begin{array}{l}\text { Salinas Daily Index, } \\
9 \text { May 1906; p. 1, c. } 4\end{array}$ & $\begin{array}{l}\text { "A light shock of earthquake was felt here about eleven o' clock } \\
\text { last night, and another this forenoon...." }\end{array}$ \\
\hline 09-May-06 & $\begin{array}{c}\text { shortly after } \\
21: 00\end{array}$ & Arcata & Humboldt & & $\begin{array}{l}\text { Arcata Union, } \\
12 \text { May } 1906 ; \text { p. } 1, \text { c. } 3\end{array}$ & $\begin{array}{l}\text { "Shortly after nine o'clock on Wednesday evening, Arcata people } \\
\text { were treated to a little shaker, which brought back unpleasant } \\
\text { reminders of the 18th. However they take them more } \\
\text { philosophically now than formerly, and not many people left } \\
\text { their houses...." }\end{array}$ \\
\hline 09-May-06 (?) & $\sim 21: 15$ & Hoopa & Humboldt & & $\begin{array}{l}\text { Humboldt Standard, } \\
22 \text { May 1906; p. 6, c. } 3\end{array}$ & $\begin{array}{l}\text { "Hoopa, May 18-The people of Hoopa felt two distinct } \\
\text { earthquake shocks last week; one in the evening at about 9:15 and } \\
\text { the other the following morning a few minutes after 7." } \\
\text { No date is given in the article, but by comparing dates and times of } \\
\text { other earthquakes reported in the area, it seems likely that this } \\
\text { writer is referring to the earthquakes of the evening of } 9 \text { May and } \\
\text { the morning of } 10 \text { May. }\end{array}$ \\
\hline 09-May-06 & 21:21 & Eureka & Humboldt & & $\begin{array}{l}\text { Humboldt Times, } \\
10 \text { May } 1906 ; \text { p. } 5 \text {, c. } 4\end{array}$ & $\begin{array}{l}\text { "A little earthquake was felt ... which made people sit up and } \\
\text { listen, and buildings creak and sway. It lasted only a few } \\
\text { seconds and seemed to be an offspring of the big temblor of the } \\
\text { 18th, as in a small way it acted like the one which created havoc } \\
\text { across the state. } \\
\text { "Naturally the population was a little nervous and many fled } \\
\text { into the streets, but the second one not putting in an appearance } \\
\text { as anticipated, returned within the family portals.... No reports } \\
\text { of damage have yet been received...." }\end{array}$ \\
\hline
\end{tabular}


TABLE 1: Catalog of Aftershock Reports following from the Great 18 April 1906 California Earthquake

\begin{tabular}{|c|c|c|c|c|c|c|}
\hline Date Felt & $\begin{array}{l}\text { Time Felt } \\
\text { (PST) }\end{array}$ & $\begin{array}{l}\text { Location Felt } \\
\text { (City) }\end{array}$ & $\begin{array}{l}\text { Location Felt } \\
\text { (County) }\end{array}$ & $\begin{array}{l}\text { Unreliable? } \\
\text { Not Felt? }^{+}\end{array}$ & Source & Relevant Citations and other Notes \\
\hline 09-May-06 & $\begin{array}{l}\text { between } \\
21: 25 \text { and } \\
21: 30\end{array}$ & Eureka & Humboldt & & $\begin{array}{l}\text { Humboldt Standard, } \\
10 \text { May 1906; p. 5, c. } 2\end{array}$ & $\begin{array}{l}\text { “The almost common salutation in Eureka this morning was: 'Did } \\
\text { you feel the shake last night?' to which the response would be } \\
\text { 'Did you feel it this morning?' Last night and this morning } \\
\text { Eureka experienced two rather heavy 'jars,' that of last night, } \\
\text { however, being much the heavier. It occurred between 9:25 and } \\
\text { 9:30, lasting several seconds, during which time it rattled things } \\
\text { about considerably. However, it was not severe enough to be felt } \\
\text { by those standing on terra firma, and the only thing which made it } \\
\text { apparent to those already on the street that there was something } \\
\text { doing in the seismic line was the sight of people rushing out of } \\
\text { doors, particularly from the Second street saloons. As far as can } \\
\text { be learned the only effect of last night's temblor was to rattle } \\
\text { things a little, principally dishes, glassware and sash weights, } \\
\text { and some people, many of whom appeared decidedly rattled as } \\
\text { they ran out from buildings. } \\
\text { "Although there was no panic, a large part of the audience at the } \\
\text { Girton theater hurriedly left the place with the first tremor. It } \\
\text { was a remarkable coincidence, and one that undoubtedly added } \\
\text { to the fear of the audience, that their nerves were keyed up by the } \\
\text { stereopticon views of earthquake scenes at San Francisco, which } \\
\text { were just then being projected on the screen at the theater. A } \\
\text { telephone message to San Francisco soon after the shake brought } \\
\text { the reply that the shock had not been felt there, and inquiry of } \\
\text { other places this morning and about the city brought no tales of } \\
\text { damage of any kind...." }\end{array}$ \\
\hline 09-May-06 & $\begin{array}{c}\text { shortly } \\
\text { before } 21: 30\end{array}$ & Arcata & Humboldt & & $\begin{array}{l}\text { Blue Lake Advocate, } \\
12 \text { May 1906; p. 4, c. 3-4 }\end{array}$ & $\begin{array}{l}\text { "... A severe earthquake was felt ... shortly before 9:30 } \\
\text { Wednesday evening. No damage was done." }\end{array}$ \\
\hline 09-May-06 & $21: 30$ & Stone Lagoon & Humboldt & & $\begin{array}{l}\text { Humboldt Standard, } \\
12 \text { May 1906; p. 6, c. } 1\end{array}$ & $\begin{array}{l}\text { "... quite a shake ... that rattled glassware and caused some of us } \\
\text { who had retired to roll out of bed." }\end{array}$ \\
\hline 09-May-06 & evening & Fortuna & Humboldt & & $\begin{array}{l}\text { Humboldt Standard, } \\
12 \text { May 1906; p. 6, c. } 2\end{array}$ & "The one [which occurred] Wednesday evening was hardly felt." \\
\hline 10-May-06 & $06: 55$ & Eureka & Humboldt & & $\begin{array}{c}\text { Humboldt Standard, } \\
10 \text { May 1906; p. 5, c. } 2\end{array}$ & $\begin{array}{l}\text { "... The shock this morning at } 6: 55 \text { o'clock was neither as long nor } \\
\text { as severe as that of last evening, and of course could not have } \\
\text { done any damage either." } \\
\text { Compare this with the text cited from this newspaper for Eureka for } \\
\text { the shock at } 21: 25 \text { to } 21: 30 \text { on } 9 \text { May. }\end{array}$ \\
\hline
\end{tabular}


TABLE 1: Catalog of Aftershock Reports following from the Great 18 April 1906 California Earthquake

\begin{tabular}{|c|c|c|c|c|c|c|}
\hline Date Felt & $\begin{array}{l}\text { Time Felt } \\
\text { (PST) }\end{array}$ & $\begin{array}{l}\text { Location Felt } \\
\quad \text { (City) }\end{array}$ & $\begin{array}{l}\text { Location Felt } \\
\text { (County) }\end{array}$ & \begin{tabular}{|l|} 
Unreliable? \\
Not Felt? $^{+}$
\end{tabular} & Source & Relevant Citations and other Notes \\
\hline 10-May-06 & 07:00 & Stone Lagoon & Humboldt & & $\begin{array}{l}\text { Humboldt Standard, } \\
12 \text { May 1906; p. 6, c. } 1\end{array}$ & $\begin{array}{l}\text { "We had another one this morning, the } 10 \text { th, at } 7 \text { o'clock, but not } \\
\text { quite so violent [as the one at } 21: 30 \text { on } 9 \text { May]." } \\
\text { Compare this with the text cited from this newspaper for Stone } \\
\text { Lagoon for the shock at } 21: 30 \text { on } 9 \text { May. }\end{array}$ \\
\hline 10-May-06 & $\sim 07: 00$ & Arcata & Humboldt & & $\begin{array}{l}\text { Humboldt Times, } \\
11 \text { May 1906; p. 7, c. 5-6 }\end{array}$ & $\begin{array}{l}\text { "... quite heavy and aroused considerable fear. No damage was } \\
\text { done as a result of the disturbance." }\end{array}$ \\
\hline 10-May-06 & $\sim 07: 00$ & Arcata & Humboldt & & $\begin{array}{c}\text { Arcata Union, } \\
12 \text { May 1906; p. 1, c. } 3\end{array}$ & "... Another very light shock was felt...." \\
\hline 10-May-06 & 07:00 & Weaverville & Trinity & & $\begin{array}{l}\text { Weekly Trinity Journal, } \\
12 \text { May 1906; p. } 3 \text {, c. } 1\end{array}$ & "...another quite severe earthquake shock...." \\
\hline 10-May-06 (?) & $\begin{array}{l}\text { a few minutes } \\
\text { after 07:00 }\end{array}$ & Hoopa & Humboldt & & $\begin{array}{l}\text { Humboldt Standard, } \\
22 \text { May 1906; p. 6, c. } 3\end{array}$ & $\begin{array}{l}\text { "Hoopa, May 18-The people of Hoopa felt two distinct } \\
\text { earthquake shocks last week; one in the evening at about 9:15 and } \\
\text { the other the following morning a few minutes after 7." } \\
\text { No date is given in the article, but by comparing dates and times of } \\
\text { other earthquakes reported in the area, it seems likely that this } \\
\text { writer is referring to the earthquakes of the evening of } 9 \text { May and } \\
\text { the morning of } 10 \text { May. }\end{array}$ \\
\hline 10-May-06 & morning & Fortuna & Humboldt & & $\begin{array}{l}\text { Humboldt Standard, } \\
12 \text { May 1906; p. 6, c. } 2\end{array}$ & $\begin{array}{l}\text { "The earthquake shock Thursday morning though quite severe } \\
\text { here did no damage." }\end{array}$ \\
\hline 11-May-06 & $\begin{array}{l}\text { before } \\
\text { daylight }\end{array}$ & Santa Cruz & Santa Cruz & & $\begin{array}{l}\text { Santa Cruz Morning Sentinel, } \\
\quad 12 \text { May 1906; p. 7, c. } 1\end{array}$ & $\begin{array}{l}\text { "A weak shock of earthquake ... almost too weak to be } \\
\text { mentioned." }\end{array}$ \\
\hline 11-May-06 & $13: 30$ & San Francisco & San Francisco & & $\begin{array}{l}\text { San Francisco Chronicle, } \\
12 \text { May 1906; p. 4, c. } 2\end{array}$ & $\begin{array}{l}\text { "Professor McAdie's seismograph at the temporary weather } \\
\text { bureau at } 3014 \text { Clay street recorded a slight earthquake shock } \\
\text { yesterday afternoon at } 1: 30 \text { o' clock. It was distinctly felt in } \\
\text { different parts of the city, but was not of sufficient force to cause } \\
\text { any damage. Professor McAdie says it was a number 'four and a } \\
\text { half.' He has a record of all the slight shocks which have been the } \\
\text { aftermath of the big shake. But the loss which he regrets the most } \\
\text { in his office in the Mills building, which was destroyed by fire, } \\
\text { was a manuscript of a book which he was preparing on } \\
\text { California earthquakes...." }\end{array}$ \\
\hline 11-May-06 & $13: 30$ & San Francisco & San Francisco & & $\begin{array}{l}\text { Oakland Herald, } \\
11 \text { May 1906; p. 1, c. } 5\end{array}$ & $\begin{array}{l}\text { "SAN FRANCISCO, May 11.--The earth gave a severe twist.... } \\
\text { The shock lasted about three seconds. Aside from tumbling down } \\
\text { a few weak walls, no damage was done. The motion was from } \\
\text { east to west." }\end{array}$ \\
\hline 11-May-06 & 13:30 & Alameda & Alameda & & $\begin{array}{l}\text { Alameda Daily Argus, } \\
11 \text { May } 1906 ; \text { p. } 5 \text {, c. } 6\end{array}$ & $\begin{array}{l}\text { "As a gentle reminder of April } 18 \text { there was a light shock of } \\
\text { earthquake.... It was very light and many persons, even those in } \\
\text { buildings, did not notice it." }\end{array}$ \\
\hline
\end{tabular}


TABLE 1: Catalog of Aftershock Reports following from the Great 18 April 1906 California Earthquake

\begin{tabular}{|c|c|c|c|c|c|c|}
\hline Date Felt & $\begin{array}{l}\text { Time Felt } \\
\text { (PST) }\end{array}$ & $\begin{array}{l}\text { Location Felt } \\
\text { (City) }\end{array}$ & $\begin{array}{l}\text { Location Felt } \\
\text { (County) }\end{array}$ & $\begin{array}{l}\text { Unreliable? } \\
\text { Not Felt? }^{+}\end{array}$ & Source & Relevant Citations and other Notes \\
\hline 11-May-06 & $13: 30$ & $\begin{array}{l}\text { Richmond } \\
\text { Oakland }\end{array}$ & $\begin{array}{l}\text { Contra Costa } \\
\text { Alameda }\end{array}$ & & $\begin{array}{l}\text { Richmond Terminal, } \\
12 \text { May 1906; p. 2, c. } 1\end{array}$ & $\begin{array}{l}\text { "Old Ma Earth is still alive. She quaked again at 1:30 p. m. } \\
\text { yesterday. It was scarcely felt at Richmond, but at Oakland } \\
\text { people ran out on the streets and bricks fell crashing from the } \\
\text { Baptist church tower." }\end{array}$ \\
\hline 11-May-06 & & Oakland (?) & Alameda (?) & & $\begin{array}{c}\text { Oakland Enquirer, } \\
12 \text { May 1906; p. 2, c. } 4\end{array}$ & $\begin{array}{l}\text { "The slight earthquake shock Friday was the cause of leaving a } \\
\text { man engaged in repairing the cornice of the new Grant school in a } \\
\text { perilous position for a short time. The cornice had been injured } \\
\text { by the quake of April } 18 \text { th. Friday a ladder was placed in } \\
\text { position and a workman was engaged in repairing the damage } \\
\text { when the shock threw the ladder to the ground, leaving the man } \\
\text { hanging to the cornice by his hands...." } \\
\text { The city in which this took place cannot be uniquely identified. }\end{array}$ \\
\hline 11-May-06 & $21: 30$ & Garberville & Humboldt & & $\begin{array}{l}\text { Humboldt Standard, } \\
16 \text { May 1906; p. 6, c. } 3\end{array}$ & "... quite a shake was felt...." \\
\hline 11-May-06 & night & Emeryville & Alameda & & $\begin{array}{l}\text { Oakland Herald, } \\
12 \text { May 1906; p. } 18, \text { c. } 4\end{array}$ & $\begin{array}{l}\text { "Last night there was another shock in Emeryville, but not quite } \\
\text { as severe as the temblor of a few weeks ago...." }\end{array}$ \\
\hline $\begin{array}{l}\text { 18-Apr-06 thru } \\
\text { 12-May-06 }\end{array}$ & (many events) & Crescent City & Del Norte & & $\begin{array}{l}\text { Del Norte Record, } \\
12 \text { May 1906; p. 1, c. } 5\end{array}$ & $\begin{array}{l}\text { "About every morning since April 18th someone reports having } \\
\text { felt an earthquake during the night previous. We believe there } \\
\text { has been a few light shocks-at least we thought so but was } \\
\text { afraid to mention the occurrences for fear of being accused of } \\
\text { having the rig-a-gigs." }\end{array}$ \\
\hline 13-May-06 & 11:00 (?) & Briceland & Humboldt & & $\begin{array}{l}\text { Humboldt Standard, } \\
21 \text { May 1906; p. 6, c. } 1\end{array}$ & $\begin{array}{l}\text { "Briceland, May 13.-Still we feel slight shocks of earthquake ... } \\
\text { today we had one about } 11 \text { o'clock." } \\
\text { Because the earthquake occurred "today" and not "tonight," and } \\
\text { because the article probably would have been written before bedtime } \\
\text { on the 13th, we assume the writer means } 11 \text { am, not } 11 \text { pm. }\end{array}$ \\
\hline 15-May-06 (?) & 11:56 (?) & San Jose & Santa Clara & & $\begin{array}{l}\text { San Luis Obispo Tribune, } \\
22 \text { May 1906; p. 2, c. } 2\end{array}$ & $\begin{array}{l}\text { "At 11:56 Tuesday San Jose experienced another earthquake } \\
\text { shock. No damage was done, but it was sufficient to scare the } \\
\text { people." } \\
\text { It is assumed that "Tuesday" refers to } 15 \mathrm{May} \text {, not } 22 \mathrm{May} \text {. It is } \\
\text { not clear whether "11:56" refers to } 11: 56 \text { am or } 11: 56 \mathrm{pm} \text {. }\end{array}$ \\
\hline 15-May-06 & night & Yountville & Napa & & $\begin{array}{c}\text { Napa Register, } \\
25 \text { May 1906; p. 5, c. } 4\end{array}$ & $\begin{array}{l}\text { "Old mother earth gave us two little shakes last night...." } \\
\text { This was part of an article written by a regular correspondent, } \\
\text { dated "Yountoille, May 16, 1906." }\end{array}$ \\
\hline 16-May-06 & $\sim 02: 00$ & Livermore & Alameda & & $\begin{array}{l}\text { Livermore Echo, } \\
17 \text { May 1906; p. 1, c. } 2\end{array}$ & $\begin{array}{l}\text { "Another light earthquake was felt by some people here Tuesday } \\
\text { night about } 2 \text { o'clock." }\end{array}$ \\
\hline
\end{tabular}


TABLE 1: Catalog of Aftershock Reports following from the Great 18 April 1906 California Earthquake

\begin{tabular}{|c|c|c|c|c|c|c|}
\hline Date Felt & $\begin{array}{l}\text { Time Felt } \\
\text { (PST) }\end{array}$ & $\begin{array}{l}\text { Location Felt } \\
\text { (City) }\end{array}$ & $\begin{array}{l}\text { Location Felt } \\
\text { (County) }\end{array}$ & $\begin{array}{l}\text { Unreliable? } \\
\text { Not Felt? }\end{array}$ & Source & Relevant Citations and other Notes \\
\hline 16-May-06 & $15: 40$ & Jamesburg & Monterey & & $\begin{array}{l}\text { Salinas Weekly Journal, } \\
19 \text { May 1906; p. 2, c. } 4\end{array}$ & $\begin{array}{l}\text { "JAMESBURG, May 17.-... We had two shocks of earthquake here } \\
\text { yesterday afternoon at 3:40 o'clock." }\end{array}$ \\
\hline 16-May-06 & $15: 55$ & Hollister & San Benito & & $\begin{array}{l}\text { San Benito Advance, } \\
18 \text { May 1906; p. 3, c. } 7\end{array}$ & $\begin{array}{l}\text { "Two heavy jolts of earthquake at } 3.55 \text { Wednesday afternoon, } \\
\text { brought down a shower of bricks from the upper story of the } \\
\text { Court House. Dick Nolte, McConnell's crack abstractor, never } \\
\text { touched the ground in his flight to the street. Mike Donovan went } \\
\text { into the Assessor's vault and closed the door. Deputy Clerk } \\
\text { Shaw and Treasurer Welch ran a tie foot race to the iron fence. } \\
\text { Sheriff Croxon and Under-Sheriff Kearney shot out of the old jail } \\
\text { like rockets. Mrs. John Garner, who was acting as School } \\
\text { Superintendent during John's absence, stood the shock well, but } \\
\text { concluded to call it a day and went home." } \\
\text { There is evidence to suggest a larger earthquake occurred in the } \\
\text { same area one day later, around } 20: 20 \text { on } 17 \text { May } 1906 \text {. This event, } \\
\text { on } 16 \text { May, may have been a preshock to the } 17 \text { May event. Note } \\
\text { that the } 17 \text { May event was not reported by this newspaper. This } \\
\text { may be because the newwspaper was published weekly on Fridays, } \\
\text { and it may have gone to press by the time the larger earthquake } \\
\text { occurred on Thursday night, } 17 \text { May. } \\
\text { This does not appear to be a misdated (and mistimed) report of the } \\
17 \text { May event, as all the people mentioned in the article were at } \\
\text { their place of business, which, most likely, would not have been the } \\
\text { case had the event occurred at night, after } 20: 00 \text {. }\end{array}$ \\
\hline 17-May-06 & evening & Potter Valley & Mendocino & & $\begin{array}{l}\text { Ukiah Republican Press, } \\
25 \text { May 1906; p. 4, c. } 5\end{array}$ & $\begin{array}{l}\text { "POTTER, May 22._.... Two shocks of earthquake were } \\
\text { experienced here Thursday evening last..." } \\
\text { See Table } 11 .\end{array}$ \\
\hline 17-May-06 & evening & Santa Cruz & Santa Cruz & & $\begin{array}{c}\text { Santa Cruz Surf, } \\
18 \text { May 1906; p. 8, c. } 1\end{array}$ & $\begin{array}{l}\text { "The hardest shock of earthquake since the one on the 18th of } \\
\text { April was felt last evening. There was practically no damage, but } \\
\text { the shock was heavy enough to drive people into the street." } \\
\text { See Table 11. }\end{array}$ \\
\hline 17-May-06 & $\begin{array}{l}\sim 20: 00 \\
\sim\end{array}$ & $\begin{array}{l}\text { San Francisco } \\
\text { Marysville }\end{array}$ & $\begin{array}{l}\text { San Francisco } \\
\text { Yuba }\end{array}$ & $\begin{array}{l}\text { Not Felt } \\
(?)\end{array}$ & $\begin{array}{l}\text { Marysville Daily Appeal, } \\
18 \text { May 1906; p.4, c. } 2\end{array}$ & $\begin{array}{l}\text { "Word was received in this city last night that another quite } \\
\text { severe earthquake was felt at San Francisco last evening about } 8 \\
\text { o'clock. No damage was done." } \\
\text { From the nature of this report, it appears as though the event was } \\
\text { not felt in Marysville. } \\
\text { See Table 11. }\end{array}$ \\
\hline 17-May-06 & $\begin{array}{c}\text { shortly after } \\
20: 00\end{array}$ & San Jose & Santa Clara & & $\begin{array}{c}\text { Sacramento Bee, } \\
18 \text { May 1906; p. } 11, \text { c. } 7\end{array}$ & $\begin{array}{l}\text { "SAN JOSE, May 18.- The sharpest earthquake since April 18th } \\
\text { occurred last evening shortly after } 8 \text { o' clock. No damage was } \\
\text { done and no one is camping in the streets or backyards, although } \\
\text { a few families who have been unable to have their chimneys or } \\
\text { houses repaired since the big quake are still sleeping in tents in }\end{array}$ \\
\hline
\end{tabular}


TABLE 1: Catalog of Aftershock Reports following from the Great 18 April 1906 California Earthquake

\begin{tabular}{|c|c|c|c|c|c|c|}
\hline Date Felt & $\begin{array}{l}\text { Time Felt } \\
\text { (PST) }\end{array}$ & $\begin{array}{l}\text { Location Felt } \\
\text { (City) }\end{array}$ & $\begin{array}{l}\text { Location Felt } \\
\text { (County) }\end{array}$ & $\begin{array}{l}\text { Unreliable? } \\
\text { Not Felt? }^{+}\end{array}$ & Source & Relevant Citations and other Notes \\
\hline & & & & & & $\begin{array}{l}\text { the rear of their residences." } \\
\text { See Table } 11 .\end{array}$ \\
\hline 17-May-06 (?) & $20: 15$ & $\begin{array}{c}\text { Napa } \\
\text { Salinas } \\
\text { San Jose }\end{array}$ & $\begin{array}{c}\text { Napa } \\
\text { Monterey } \\
\text { Santa Clara }\end{array}$ & & $\begin{array}{c}\text { Napa Register, } \\
25 \text { May 1906; p. 5, c. } 4\end{array}$ & $\begin{array}{l}\text { "An earthquake shock that was barely perceptible in Napa } \\
\text { occurred at 8:15 Thursday evening. It was quite severe in Salinas } \\
\text { and San Jose, although no damage was done." } \\
\text { It is not clear whether the date of this event was } 17 \text { or } 24 \text { May; } \\
\text { however, based on the timing of the event and on other felt reports } \\
\text { in the arrea on } 17 \text { May (and not on } 24 \text { May) it is presumed that this } \\
\text { is the } 17 \text { May event. } \\
\text { See Table 11. }\end{array}$ \\
\hline 17-May-06 & $20: 15$ & Mile Rocks & San Francisco & & $\begin{array}{l}\text { Lawson (1908), } \\
\text { vol. I, p. } 422\end{array}$ & $\begin{array}{l}\text { "Vertical. Strongest in middle." Duration } 35 \text { seconds. } \\
\text { Durham (1998) identifies two locations named Mile Rocks, one in } \\
\text { Sonoma County and the other in San Francisco County. Looking at } \\
\text { the maps in the atlas portion of Lawson (1908), the San Francisco } \\
\text { County "Mile Rocks" location is on Maps 4, 17, and 19, whereas } \\
\text { the Sonoma County location of that name is not on any of the maps. } \\
\text { The inference is made that "Mile Rocks" in the list of aftershocks in } \\
\text { Lawson (1908) refers to the San Francisco County location. } \\
\text { See Table 11. }\end{array}$ \\
\hline 17-May-06 & $20: 15$ & $\begin{array}{c}\text { San Francisco } \\
\text { Oakland } \\
\text { Salinas } \\
\text { San Jose }\end{array}$ & $\begin{array}{c}\text { San Francisco } \\
\text { Alameda } \\
\text { Monterey } \\
\text { Santa Clara }\end{array}$ & & $\begin{array}{c}\text { Sacramento Bee, } \\
18 \text { May 1906; p. 11, c. } 7\end{array}$ & $\begin{array}{l}\text { "SAN FRANCISCO, May 18._-At 8:15 last night shocks of } \\
\text { earthquake were felt in this city, Oakland, Salinas and San Jose. } \\
\text { No damage reported." } \\
\text { See Table 11. }\end{array}$ \\
\hline 17-May-06 & 20:15 & $\begin{array}{l}\text { San Francisco } \\
\text { Oakland } \\
\text { San Jose } \\
\text { Salinas }\end{array}$ & $\begin{array}{l}\text { San Francisco } \\
\text { Alameda } \\
\text { Santa Clara } \\
\text { Monterey }\end{array}$ & & $\begin{array}{l}\text { Amador Dispatch, } \\
18 \text { May 1906; p. 5, c. } 3\end{array}$ & $\begin{array}{l}\text { "STOCKTON, May 18.-Another earthquake shock occurred at } \\
\text { San Francisco... This was by far the most severe shock since the } \\
\text { one of April 18th. It has not been learned that any great damage } \\
\text { resulted, other than the overturning of a few already tottering } \\
\text { walls. } \\
\text { "The shock was also felt in Oakland and San Jose and to a more } \\
\text { considerable extent at Salinas, slight damage resulting at the } \\
\text { latter place." } \\
\text { See Table 11. }\end{array}$ \\
\hline 17-May-06 & $20: 15$ & Oakland & Alameda & & $\begin{array}{l}\text { San Francisco Chronicle, } \\
18 \text { May 1906; p. 1, c. } 6\end{array}$ & $\begin{array}{l}\text { "OAKLAND, May 17.-A slight shock of earthquake, lasting } \\
\text { several seconds, occurred on this side of the bay at 8:15 o' clock } \\
\text { to-night. While sharp enough to be perceptible all over the city, it } \\
\text { was not heavy enough to do any damage." }\end{array}$ \\
\hline
\end{tabular}


TABLE 1: Catalog of Aftershock Reports following from the Great 18 April 1906 California Earthquake

\begin{tabular}{|c|c|c|c|c|c|c|}
\hline Date Felt & $\begin{array}{l}\text { Time Felt } \\
\text { (PST) }\end{array}$ & $\begin{array}{l}\text { Location Felt } \\
\text { (City) }\end{array}$ & $\begin{array}{l}\text { Location Felt } \\
\text { (County) }\end{array}$ & $\begin{array}{l}\text { Unreliable? } \\
\text { Not Felt? }^{+}\end{array}$ & Source & Relevant Citations and other Notes \\
\hline & & & & & & See Table 11. \\
\hline 17-May-06 & $\sim 20: 15$ & Menlo Park & San Mateo & & $\begin{array}{c}\text { Times-Gazette (Redwood City), } \\
19 \text { May 1906; p. 3, c. } 7\end{array}$ & $\begin{array}{l}\text { Under the heading "Menlo Park Occurrences": } \\
\text { "An earthquake shock, the heaviest since April 18, was felt here } \\
\text { about 8:15 Thurs. evening. The shock, which was accompanied } \\
\text { by a heavy rumble, came from the northeast to southwest and } \\
\text { lasted } 21 \text { seconds. No damage was done." } \\
\text { See the notes in this catalog following the reports published in the } \\
\text { San Jose Mercury, the Sacramento Union, and the Weekly Galt } \\
\text { Gazette for the event at 20:15 on } 17 \text { May } 1906 \text { in Salinas. } \\
\text { See Table 11. }\end{array}$ \\
\hline 17-May-06 & $\sim 20: 15$ & Salinas & Monterey & unreliable & $\begin{array}{l}\text { San Jose Mercury, } \\
18 \text { May 1906; p. 1, c. } 2\end{array}$ & $\begin{array}{l}\text { Under the heading "By the Associated Press": } \\
\text { "SALINAS, May 17.-An earthquake shock, the heaviest since } \\
\text { April 18, was felt here about } 8: 15 \text { this evening. The shock, which } \\
\text { was accompanied by a heavy rumble, came from the northeast to } \\
\text { southwest and lasted } 21 \text { seconds. No damage was done." } \\
\text { The wording of this article is remarkably similar to the description } \\
\text { in the Times-Gazette of Redwood City (19 May 1906, } p .3, \text { c. } 7) \text {, } \\
\text { describing the effects in Menlo Park. As the Times-Gazette piece } \\
\text { appears as part of a regular column, and not as part of an Associated } \\
\text { Press report, the Times-Gazette article is deemed more reliable, and } \\
\text { the report in the San Jose Mercury is ignored. } \\
\text { See Table 11. }\end{array}$ \\
\hline 17-May-06 & $20: 15$ & Salinas & Monterey & unreliable & $\begin{array}{l}\text { Sacramento Union, } \\
18 \text { May 1906; p. } 1, \text { c. } 3\end{array}$ & $\begin{array}{l}\text { "SALINAS, May 17.-A temblor, the heaviest since April 18th, } \\
\text { visited Salinas about } 8: 15 \text { this evening. The shock, which was } \\
\text { accompanied by a heavy rumble, came from the northeast to } \\
\text { southwest, and lasted twenty-one seconds, causing people to } \\
\text { leave their houses in alarm. Fortunately no damage was caused, } \\
\text { all buildings heretofore damaged having been carefully braced." } \\
\text { The wording of this article is remarkably similar to the description } \\
\text { in the Times-Gazette of Redwood City (19 May } 1906, p .3, \text { c. } 7 \text { ), } \\
\text { describing the effects in Menlo Park. As the Times-Gazette piece } \\
\text { appears as part of a regular column, and is not (presumably) } \\
\text { transcribed from a (less reliable) telegraphic bulletin, the } \\
\text { Times-Gazette article is deemed more reliable, and the report in the } \\
\text { Sacramento Union is ignored. } \\
\text { See Table } 11 .\end{array}$ \\
\hline 17-May-06 & $\sim 20: 15$ & Salinas & Monterey & unreliable & $\begin{array}{l}\text { Weekly Galt Gazette, } \\
19 \text { May 1906; p. 3, c. } 1\end{array}$ & $\begin{array}{l}\text { "Thursday evening about } 8: 15 \text { o'clock an earthquake, the } \\
\text { heaviest since April } 18 \text { th, shook up Salinas. The shock, which } \\
\text { was accompanied by a heavy rumble, came from northeast to }\end{array}$ \\
\hline
\end{tabular}


TABLE 1: Catalog of Aftershock Reports following from the Great 18 April 1906 California Earthquake

\begin{tabular}{|c|c|c|c|c|c|c|}
\hline Date Felt & $\begin{array}{l}\text { Time Felt } \\
\text { (PST) }\end{array}$ & $\begin{array}{l}\text { Location Felt } \\
\text { (City) }\end{array}$ & $\begin{array}{l}\text { Location Felt } \\
\text { (County) }\end{array}$ & $\begin{array}{l}\text { Unreliable? } \\
\text { Not Felt? }^{+}\end{array}$ & Source & Relevant Citations and other Notes \\
\hline & & & & & & $\begin{array}{l}\text { Southwest, and lasted twenty-one seconds, causing people to } \\
\text { leave their houses in alarm. Fortunately no damage was caused, } \\
\text { all buildings heretofore damaged having been carefully braced...." } \\
\text { The wording of this article is remarkably similar to the description } \\
\text { in the Times-Gazette of Redwood City (19 May 1906, p. 3, c. 7), } \\
\text { describing the effects in Menlo Park. As the Times-Gazette piece } \\
\text { appears as part of a regular column, and is not (presumably) } \\
\text { transcribed from a (less reliable) telegraphic bulletin, the } \\
\text { Times-Gazette article is deemed more reliable, and the report in the } \\
\text { Galt Gazette is ignored. } \\
\text { See Table } 11 .\end{array}$ \\
\hline 17-May-06 & $\sim 20: 15$ & Stockton & San Joaquin & & $\begin{array}{c}\text { Stockton Daily Evening Record, } \\
18 \text { May 1906; p. 5, c. } 2\end{array}$ & $\begin{array}{l}\text { "A slight shock of earthquake was felt.... The shock was so slight } \\
\text { that not more than one in three persons felt it." } \\
\text { See Table 11. }\end{array}$ \\
\hline 17-May-06 & $20: 17$ & $\begin{array}{c}\text { Alameda } \\
\text { (Alameda Pier) }\end{array}$ & Alameda & & $\begin{array}{l}\text { Lawson (1908), } \\
\text { vol. I, p. } 422\end{array}$ & $\begin{array}{l}\text { felt } \\
\text { See Table } 11 .\end{array}$ \\
\hline 17-May-06 & $20: 20$ & $\begin{array}{c}\text { Oakland } \\
\text { (Chabot } \\
\text { Observatory) }\end{array}$ & Alameda & & $\begin{array}{l}\text { Lawson (1908), } \\
\text { vol. I, p. } 422\end{array}$ & See Table 11. \\
\hline 17-May-06 & $20: 20$ & Oakland & Alameda & & $\begin{array}{l}\text { Oakland Enquirer, } \\
18 \text { May 1906; p. } 10, \text { c. } 2\end{array}$ & $\begin{array}{l}\text { "... there was another earthquake shock of about two seconds' } \\
\text { duration, which sent hearts jumping, for while it lasted it was } \\
\text { rather energetic. So far as is known there was no damage." } \\
\text { Also in the Oakland Times of } 18 \text { May 1906, p. 1, c. } 1 \text {. } \\
\text { See Table 11. }\end{array}$ \\
\hline 17-May-06 & $20: 20$ & Oakland & Alameda & & $\begin{array}{c}\text { Oakland Times, } \\
18 \text { May 1906; p. 1, c. } 3\end{array}$ & $\begin{array}{l}\text { "... an earthquake of some force shook Oakland and had enough } \\
\text { energy back of it to throw many people into a considerable scare. } \\
\text { Some were so badly done out of their wits that they refused to go } \\
\text { to bed for the remainder of the night and camped on their } \\
\text { doorsteps. The City Council committees were in session at the } \\
\text { time. Although thick in the business of ordinances and } \\
\text { resolutions each separate city father dropped his work. Several } \\
\text { men in the lobby rose and left the room. City Attorney McElroy } \\
\text { confessed to being frightened, and the faces of others went white. } \\
\text { But it is confidently expected that there will be no other quake of } \\
\text { sufficient force to do any damage." }\end{array}$ \\
\hline
\end{tabular}


TABLE 1: Catalog of Aftershock Reports following from the Great 18 April 1906 California Earthquake

\begin{tabular}{|c|c|c|c|c|c|c|}
\hline Date Felt & $\begin{array}{c}\text { Time Felt } \\
\text { (PST) }\end{array}$ & $\begin{array}{l}\text { Location Felt } \\
\text { (City) }\end{array}$ & $\begin{array}{c}\text { Location Felt } \\
\text { (County) }\end{array}$ & $\begin{array}{l}\text { Unreliable? } \\
\text { Not Felt? }\end{array}$ & Source & Relevant Citations and other Notes \\
\hline & & & & & & See Table 11. \\
\hline 17-May-06 & $20: 20$ & Sunnyvale & Santa Clara & & $\begin{array}{c}\text { San Jose Mercury, } \\
19 \text { May 1906; p. 12, c. } 4\end{array}$ & $\begin{array}{l}\text { "SUNNYVALE, May 18.-At 8:20 p.m. we experienced another } \\
\text { jar, lasting about ten seconds. It occasioned some anxiety and } \\
\text { uneasiness, but no damage was done." } \\
\text { See Table 11. }\end{array}$ \\
\hline 17-May-06 & $\sim 20: 20$ & Los Gatos & Santa Clara & & $\begin{array}{c}\text { San Jose Mercury, } \\
19 \text { May 1906; p. 12, c. } 5\end{array}$ & $\begin{array}{l}\text { "LOS GATOS, May 18.--No serious damage was done by last } \\
\text { night's temblor, which was the most severe shake since April } \\
\text { 18th...." } \\
\text { See Table 11. }\end{array}$ \\
\hline 17-May-06 & $20: 20$ & Los Gatos & Santa Clara & & $\begin{array}{l}\text { Los Gatos Mail, } \\
24 \text { May 1906; p. 4, c. } 1\end{array}$ & $\begin{array}{l}\text { "The temblor ... was a pretty big chunk of the jar. Those who } \\
\text { know, however, say it only felt like thirty cents compared with } \\
\text { the dollar kind they had April 18th." } \\
\text { See Table 11. }\end{array}$ \\
\hline 17-May-06 & $20: 20$ & Salinas & Monterey & & $\begin{array}{l}\text { Lawson (1908), } \\
\text { vol. I, p. } 422\end{array}$ & $\begin{array}{l}\text { felt } \\
\text { See Table } 11 .\end{array}$ \\
\hline 17-May-06 & $20: 20$ & Point Piños & Monterey & & $\begin{array}{l}\text { Lawson (1908), } \\
\text { vol. I, p. } 422\end{array}$ & $\begin{array}{l}\text { "Horizontal. Two max. alike, sound like water in pipe with air } \\
\text { in it." Duration } 22 \text { seconds. } \\
\text { See Table } 11 .\end{array}$ \\
\hline 17-May-06 & $20: 20$ & Point Bonita & Marin & & $\begin{array}{l}\text { Lawson (1908), } \\
\text { vol. I, p. } 422\end{array}$ & $\begin{array}{l}\text { "Nearly vertical. Direction N., no tremor, just a jar, } 1 \text { max., } \\
\text { strongest at beginning. No sound, may have been blasting." } \\
\text { Duration } 2 \text { seconds. } \\
\text { See Table 11. }\end{array}$ \\
\hline 17-May-06 & $20: 21$ & Napa & Napa & & $\begin{array}{l}\text { Lawson (1908), } \\
\text { vol. I, p. } 422\end{array}$ & $\begin{array}{l}\text { felt } \\
\text { See Table } 11 .\end{array}$ \\
\hline 17-May-06 & $20: 21$ & $\begin{array}{c}\text { San Francisco } \\
\text { Peninsula }\end{array}$ & $\begin{array}{l}\text { San Francisco, } \\
\text { San Mateo, } \\
\text { Santa Clara }\end{array}$ & & $\begin{array}{l}\text { Lawson (1908), } \\
\text { vol. I, p. 422 }\end{array}$ & $\begin{array}{l}\text { "About the heaviest since first shock, causing people to rush out- } \\
\text { of-doors." Duration } 20 \text { seconds. Lawson (1908) estimates Rossi- } \\
\text { Forel intensity VI. } \\
\text { See Table 11. }\end{array}$ \\
\hline 17-May-06 & $20: 21$ & Campbell & Santa Clara & & $\begin{array}{l}\text { Lawson (1908), } \\
\text { vol. I, p. 422 }\end{array}$ & $\begin{array}{l}\text { "Violent." } \\
\text { See Table } 11 .\end{array}$ \\
\hline 17-May-06 & $20: 21$ & Gonzales & Monterey & & $\begin{array}{l}\text { Lawson (1908), } \\
\text { vol. I, p. } 422\end{array}$ & $\begin{array}{l}\text { felt } \\
\text { See Table } 11 .\end{array}$ \\
\hline
\end{tabular}


TABLE 1: Catalog of Aftershock Reports following from the Great 18 April 1906 California Earthquake

\begin{tabular}{|c|c|c|c|c|c|c|}
\hline Date Felt & $\begin{array}{l}\text { Time Felt } \\
\text { (PST) }\end{array}$ & $\begin{array}{l}\text { Location Felt } \\
\text { (City) }\end{array}$ & $\begin{array}{l}\text { Location Felt } \\
\text { (County) }\end{array}$ & $\begin{array}{l}\text { Unreliable? } \\
\text { Not Felt? }^{+}\end{array}$ & Source & Relevant Citations and other Notes \\
\hline 17-May-06 & $20: 21: 16$ & San Jose & Santa Clara & & $\begin{array}{c}\text { San Jose Mercury, } \\
18 \text { May 1906; p. 9, c. } 1\end{array}$ & $\begin{array}{l}\text { "The most severe shock since the earthquake of April } 18 \text { was } \\
\text { experienced yesterday evening at } 8.21 .16 \text {. The vibrations east } \\
\text { and west, lasted approximately fifteen seconds, beginning easily } \\
\text { and ending with considerable violence. No damage has been } \\
\text { reported. In the Jose Theater an incipient panic was quelled by } \\
\text { the presence of mind of those on the stage, who continued their } \\
\text { lines and declined to be interrupted." } \\
\text { See Table } 11 .\end{array}$ \\
\hline 17-May-06 & $20: 21: 17$ & Oakland & Alameda & & $\begin{array}{l}\text { Lawson (1908), } \\
\text { vol. I, p. 422 }\end{array}$ & $\begin{array}{l}\text { "Chandelier swung with period of } 1.25 \mathrm{~s} \text {. Shock NW.-SE. at } \\
\text { Vernon St." Duration } 12 \text { seconds. Lawson (1908) estimates } \\
\text { Rossi-Forel intensity IV-V. } \\
\text { See Table } 11 .\end{array}$ \\
\hline 17-May-06 & $20: 21: 22$ & Mount Hamilton & Santa Clara & & $\begin{array}{l}\text { Lawson (1908), } \\
\text { vol. I, p. } 422\end{array}$ & $\begin{array}{l}\text { "Vertical slightly, } 2 \text { max. } 5 \mathrm{~s} \text {. and } 10 \mathrm{~s} \text {. after beginning, mean of } \\
\text { two observers." Duration } 14 \text { seconds. Lawson (1908) estimates } \\
\text { Rossi-Forel intensity IV. } \\
\text { See Table 11. }\end{array}$ \\
\hline 17-May-06 & $20: 21: 34$ & Berkeley & Alameda & & $\begin{array}{l}\text { Lawson (1908), } \\
\text { vol. I, p. 422 }\end{array}$ & $\begin{array}{l}\text { "East-west." Duration } 8 \text { seconds. } \\
\text { See Table } 11 .\end{array}$ \\
\hline 17-May-06 & $20: 21: 40$ & Bolinas & Marin & & $\begin{array}{l}\text { Lawson (1908), } \\
\text { vol. I, p. 422 }\end{array}$ & $\begin{array}{l}\text { Duration } 8 \text { seconds. Lawson (1908) estimates Rossi-Forel } \\
\text { intensity III. } \\
\text { See Table 11. }\end{array}$ \\
\hline 17-May-06 & $20: 22$ & Yerba Buena* & San Francisco* & & $\begin{array}{l}\text { Lawson (1908), } \\
\text { vol. I, p. 422 }\end{array}$ & $\begin{array}{l}\text { "Light." } \\
\text { * Yerba Buena probably refers to the lighthouse station on Yerba } \\
\text { Buena Island in San Francisco Bay (Lawson collected a lot of } \\
\text { aftershock data from lighthouse stations), although it may instead } \\
\text { refer to the land grant of that name in Santa Clara County. } \\
\text { See Table 11. }\end{array}$ \\
\hline 17-May-06 & $20: 22: 25$ & Berkeley & Alameda & & $\begin{array}{l}\text { Lawson (1908), } \\
\text { vol. I, p. 422 }\end{array}$ & $\begin{array}{l}\text { felt in the Faculty Club at U.C. Berkeley } \\
\text { See Table } \mathbf{1 1 .}\end{array}$ \\
\hline 17-May-06 & $20: 23$ & Modesto & Stanislaus & & \begin{tabular}{|} 
Modesto Daily Evening News, \\
18 May 1906; p. 4, c. 3
\end{tabular} & $\begin{array}{l}\text { "A slight earthquake was felt here.... It jarred the chandeliers a } \\
\text { bit, but that was about all." } \\
\text { See Table 11. }\end{array}$ \\
\hline 17-May-06 & $\sim 20: 24$ & Livermore & Alameda & & $\begin{array}{l}\text { Livermore Echo, } \\
24 \text { May 1906; p. 1, c. } 3\end{array}$ & $\begin{array}{l}\text { "A sharp earthquake shock was felt here ... and caused lights, etc., } \\
\text { suspended from the ceiling to sway quite perceptibly." } \\
\text { See Table 11. }\end{array}$ \\
\hline
\end{tabular}


TABLE 1: Catalog of Aftershock Reports following from the Great 18 April 1906 California Earthquake

\begin{tabular}{|c|c|c|c|c|c|c|}
\hline Date Felt & $\begin{array}{l}\text { Time Felt } \\
\text { (PST) }\end{array}$ & $\begin{array}{l}\text { Location Felt } \\
\text { (City) }\end{array}$ & $\begin{array}{l}\text { Location Felt } \\
\text { (County) }\end{array}$ & $\begin{array}{l}\text { Unreliable? } \\
\text { Not Felt? }^{+}\end{array}$ & Source & Relevant Citations and other Notes \\
\hline 17-May-06 & $20: 24$ & Boulder Creek & Santa Cruz & & $\begin{array}{c}\text { Mountain Echo (Boulder Creek) } \\
19 \text { May 1906; p. 3, c. } 2\end{array}$ & $\begin{array}{l}\text { "There was another quite heavy shock of earthquake at } 8: 24 \\
\text { Thursday evening, causing many people to hurriedly vacate their } \\
\text { homes for the streets and sidewalks." } \\
\text { See Table 11. }\end{array}$ \\
\hline 17-May-06 & 20:24:30 & San Francisco & San Francisco & & $\begin{array}{l}\text { Lawson (1908), } \\
\text { vol. I, p. 422 }\end{array}$ & $\begin{array}{l}\text { "Moderate rolling motion." } \\
\text { See Table } 11 .\end{array}$ \\
\hline 17-May-06 & 20:24:33 (?) & Oakdale & Stanislaus & & $\begin{array}{l}\text { Lawson (1908), } \\
\text { vol. I, p. 422 }\end{array}$ & $\begin{array}{l}\text { "Very slight. No time given." } \\
\text { Although it states "No time given" in the Remarks column, the } \\
\text { precise time of 20:24:33 is given under the column for the time of } \\
\text { the earthquake. It is not clear how the given time was determined. } \\
\text { See Table 11. }\end{array}$ \\
\hline 17-May-06 & $\sim 20: 25$ & Livermore & Alameda & & $\begin{array}{c}\text { Livermore Herald, } \\
19 \text { May 1906; p. 2, c. } 1\end{array}$ & $\begin{array}{l}\text { "There was a lively earthquake shock..., which reminded nervous } \\
\text { people that the ground is not yet stable." } \\
\text { See Table } \mathbf{1 1 .}\end{array}$ \\
\hline 17-May-06 & $20: 25$ & San Jose & Santa Clara & & $\begin{array}{l}\text { Sacramento Union, } \\
18 \text { May 1906; p. } 1 \text {, c. } 3\end{array}$ & $\begin{array}{l}\text { "SAN JOSE, May 17.-A severe shock of earthquake was felt } \\
\text { here.... No damage is reported." } \\
\text { See Table 11. }\end{array}$ \\
\hline 17-May-06 & $\begin{array}{l}20: 25 \\
\sim\end{array}$ & $\begin{array}{l}\text { San Jose } \\
\text { Oakland }\end{array}$ & $\begin{array}{c}\text { Santa Clara } \\
\text { Alameda }\end{array}$ & & $\begin{array}{l}\text { Weekly Galt Gazette, } \\
19 \text { May 1906; p.3, c. } 1\end{array}$ & $\begin{array}{l}\text { "Thursday evening about } 8: 15 \text { o'clock an earthquake ... shook up } \\
\text { Salinas.... Ten minutes later a slight shock was felt at San Jose, } \\
\text { but did no damage. The temblor, about the same time, visited } \\
\text { Oakland." } \\
\text { See Table 11. }\end{array}$ \\
\hline 17-May-06 & $20: 25$ & $\begin{array}{c}\text { Salinas } \\
\text { San Jose } \\
\text { Corral de Tierra } \\
\text { Monterey } \\
\text { Watsonville } \\
\text { Oakland }\end{array}$ & $\begin{array}{c}\text { Monterey } \\
\text { Santa Clara } \\
\text { Monterey } \\
\text { Monterey } \\
\text { Santa Cruz } \\
\text { Alameda }\end{array}$ & & $\begin{array}{l}\text { Salinas Daily Index, } \\
18 \text { May 1906; p. 1, c. } 4\end{array}$ & $\begin{array}{l}\text { "There was another perceptible earthquake shake last night at } \\
\text { 8:25. Residents on Main Street are making records for themselves } \\
\text { in getting down stairs and out of public buildings. Reports from } \\
\text { San Jose, Corral de Tierra, Monterey, Watsonville, and Oakland } \\
\text { show that the shock was felt, but no damage was done." } \\
\text { See Table 11. }\end{array}$ \\
\hline 17-May-06 & $20: 25$ & Salinas & Monterey & & $\begin{array}{l}\text { Salinas Weekly Journal, } \\
19 \text { May 1906; p. } 3, \text { c. } 3\end{array}$ & $\begin{array}{l}\text { Under the heading "From Friday's Daily Journal": } \\
\text { "A sharp shock of earthquake here at 8:25 last evening caused } \\
\text { many persons to rush into the street." } \\
\text { See Table 11. }\end{array}$ \\
\hline
\end{tabular}


TABLE 1: Catalog of Aftershock Reports following from the Great 18 April 1906 California Earthquake

\begin{tabular}{|c|c|c|c|c|c|c|}
\hline Date Felt & $\begin{array}{l}\text { Time Felt } \\
\text { (PST) }\end{array}$ & $\begin{array}{l}\text { Location Felt } \\
\text { (City) }\end{array}$ & $\begin{array}{l}\text { Location Felt } \\
\text { (County) }\end{array}$ & $\begin{array}{l}\text { Unreliable? } \\
\text { Not Felt? }^{+}\end{array}$ & Source & Relevant Citations and other Notes \\
\hline 17-May-06 & $20: 26$ & $\begin{array}{l}\text { San Jose } \\
\text { Los Gatos }\end{array}$ & $\begin{array}{l}\text { Santa Clara } \\
\text { Santa Clara }\end{array}$ & & $\begin{array}{l}\text { San Francisco Chronicle, } \\
18 \text { May } 1906 ; \text { p. } 1, \text { c. } 6\end{array}$ & $\begin{array}{l}\text { "SAN JOSE, May 17.-A sharp earthquake was felt in this city } \\
\text { this evening. At the Lick Observatory the shock continued for ten } \\
\text { seconds, and was severest at 8:26 o' clock. } \\
\text { "No damage occurred in this city, nor, so far as could be } \\
\text { ascertained, in the neighborhood. } \\
\text { "A mild panic, however, prevailed for some time all over the city } \\
\text { and surroundings. People rushed from their homes and remained } \\
\text { outside for hours. Many are bringing their tents again into use. } \\
\text { Two automobiles felt the shock distinctly, although traveling at a } \\
\text { rapid pace. } \\
\text { "At the San Jose Theater, where the Frank Bacon company was } \\
\text { presenting 'The Hills of California,' the audience commenced to } \\
\text { stampede, but was quieted. No one was injured. } \\
\text { "At Los Gatos and along the foothills, where the shock of April } \\
18 \text { th was lightest and did the least damage, the shock was felt } \\
\text { more distinctly than in this city. Some plaster was knocked down } \\
\text { in various places." } \\
\text { A very similar article appeared in the Oakland Herald of } 18 \text { May } \\
1906, p .2, c .4 \text {. } \\
\text { See Table 11. }\end{array}$ \\
\hline 17-May-06 & $20: 30$ & $\begin{array}{l}\text { Southampton } \\
\text { Shoal }\end{array}$ & San Francisco & & $\begin{array}{l}\text { Lawson (1908), } \\
\text { vol. I, p. } 422\end{array}$ & $\begin{array}{l}\text { "Southeast-northwest. Rumbling before shake and continuing } 2 \mathrm{~s} . \\
\text { after." Duration } 2 \text { seconds. } \\
\text { See Table } \mathbf{1 1 .}\end{array}$ \\
\hline 17-May-06 & $20: 30$ & $\begin{array}{c}\text { Santa Cruz } \\
\text { San Francisco } \\
\text { Oakland } \\
\text { San Jose } \\
\text { Watsonville } \\
\text { Salinas } \\
\text { San Luis Obispo }\end{array}$ & \begin{tabular}{|} 
Santa Cruz \\
San Francisco \\
Alameda \\
Santa Clara \\
Santa Cruz \\
Monterey \\
San Luis Obispo
\end{tabular} & & $\begin{array}{c}\text { Santa Cruz Morning Sentinel, } \\
18 \text { May 1906; p. } 1, \text { c. } 5\end{array}$ & $\begin{array}{l}\text { "A little more severe earthquake shock than usual was felt in this } \\
\text { city at 8:30 on Thursday evening, lasting for about ten seconds. } \\
\text { "Although the vibrations in many buildings on Pacific Av. were } \\
\text { quite noticeable, and in fact all over the city, there was very little } \\
\text { alarm, no one was hurt and not a pane of glass nor a piece of } \\
\text { plaster was broken, so far as known. } \\
\text { "The shock was felt in San Francisco, Oakland, San Jose and } \\
\text { Watsonville and Salinas and slightly at San Luis Obispo. The } \\
\text { Associated Press reports that no damage was done in any of these } \\
\text { cities." } \\
\text { See Table 11. }\end{array}$ \\
\hline 17-May-06 & $20: 30$ & Stockton & San Joaquin & & $\begin{array}{c}\text { The Evening Mail (Stockton), } \\
18 \text { May 1906; p. } 3, \text { c. } 3\end{array}$ & $\begin{array}{l}\text { "There was a slight earthquake shock.... It was not generally felt, } \\
\text { and there was no damage." } \\
\text { See Table } \mathbf{1 1 .}\end{array}$ \\
\hline
\end{tabular}


TABLE 1: Catalog of Aftershock Reports following from the Great 18 April 1906 California Earthquake

\begin{tabular}{|c|c|c|c|c|c|c|}
\hline Date Felt & $\begin{array}{l}\text { Time Felt } \\
\text { (PST) }\end{array}$ & $\begin{array}{l}\text { Location Felt } \\
\text { (City) }\end{array}$ & $\begin{array}{l}\text { Location Felt } \\
\text { (County) }\end{array}$ & $\begin{array}{l}\text { Unreliable? } \\
\text { Not Felt? }^{+}\end{array}$ & Source & Relevant Citations and other Notes \\
\hline 17-May-06 & $20: 31: 29$ & \begin{tabular}{|c|} 
Berkeley \\
San Francisco (?) \\
Oakland \\
San Jose \\
Los Gatos
\end{tabular} & $\begin{array}{c}\text { Alameda } \\
\text { San Francisco (?) } \\
\text { Alameda } \\
\text { Santa Clara } \\
\text { Santa Clara }\end{array}$ & & $\begin{array}{l}\text { Berkeley Daily Gazette, } \\
18 \text { May 1906; p. 1, c. } 6\end{array}$ & $\begin{array}{l}\text { "An earthquake occurred last night ... which lasted eight seconds, } \\
\text { but did no damage whatever. } \\
\text { "The temblor was felt in all parts of the city and many nervous } \\
\text { people scampered from their homes fearing that a repetition of the } \\
\text { one of April } 18 \text { was at hand. The effect of the temblor on most } \\
\text { buildings was described as having a grinding sensation, but no } \\
\text { damage resulted. } \\
\text { "In Oakland persons ran from the buildings into the streets, and } \\
\text { while very perceptible in all parts of the city no damage was } \\
\text { done. } \\
\text { "In San Jose the quake was recorded at the Lick Observatory and } \\
\text { continued for ten seconds, and a mild panic prevailed all over the } \\
\text { city. In the theaters the people stampeded, but were finally } \\
\text { quieted before anyone was injured. At Los Gatos and along the } \\
\text { foothills the temblor was felt more distinctly than in the cities and } \\
\text { plastering was shaken from the walls in many homes." } \\
\text { It is not entirely clear which locations are meant by "all parts of the } \\
\text { city"; however, it was a common practice of the time to refer to San } \\
\text { Francisco simply as "the city." It is inferred that this description } \\
\text { applies, at least in part, to the city of Berkeley. It probably also } \\
\text { applies to San Francisco and perhaps other Bay Area locations. } \\
\text { A very similar article appeared in the Sun and Letter (West } \\
\text { Berkeley) of } 19 \text { May } 1906, p \text {. } 1, \text { c. } 5 \text {. } \\
\text { See Table } 11 .\end{array}$ \\
\hline 17-May-06 & $20: 40$ & San Francisco & San Francisco & & $\begin{array}{l}\text { San Luis Obispo Tribune, } \\
22 \text { May 1906; p. } 7, \text { c. } 2\end{array}$ & $\begin{array}{l}\text { "San Francisco, May 17:-At 8:40 tonight San Francisco received } \\
\text { another severe earthquake shock, which lasted about } 18 \text { seconds. } \\
\text { "No loss of life is reported and no very great damage resulted. } \\
\text { "Several of the walls standing in the burned district were shaken } \\
\text { down by the quake. } \\
\text { "All over the city the people were frightened almost into a panic } \\
\text { and hundreds in the residence section rushed out into the streets." } \\
\text { See Table 11. }\end{array}$ \\
\hline
\end{tabular}


TABLE 1: Catalog of Aftershock Reports following from the Great 18 April 1906 California Earthquake

\begin{tabular}{|c|c|c|c|c|c|c|}
\hline Date Felt & $\begin{array}{l}\text { Time Felt } \\
\text { (PST) }\end{array}$ & $\begin{array}{l}\text { Location Felt } \\
\text { (City) }\end{array}$ & $\begin{array}{l}\text { Location Felt } \\
\text { (County) }\end{array}$ & $\begin{array}{l}\text { Unreliable? } \\
\text { Not Felt? }^{+}\end{array}$ & Source & Relevant Citations and other Notes \\
\hline & & $\begin{array}{c}\text { Watsonville } \\
\text { Salinas }\end{array}$ & $\begin{array}{c}\text { Santa Cruz } \\
\text { Monterey }\end{array}$ & & & $\begin{array}{l}\text { young lady operators fainted through fright. } \\
\text { "Reports from Watsonville and Salinas state that the shock was } \\
\text { quite severe at both those places." } \\
\text { See Table 11. }\end{array}$ \\
\hline 17-May-06 (?) & $\sim 20: 40$ & San Luis Obispo & San Luis Obispo & & $\begin{array}{l}\text { San Luis Obispo Tribune, } \\
22 \text { May 1906; p. } 7, \text { c. } 3\end{array}$ & $\begin{array}{l}\text { "Many in this city felt a slight earthquake shock about } 8: 40 \\
\text { o'clock last evening. The telephone line between this city and San } \\
\text { Francisco was thrown almost out of working order by the } \\
\text { shock." } \\
\text { Although the reference to "last evening" would imply the event } \\
\text { took place on } 21 \text { May } 1906 \text {, this article was printed in a box } \\
\text { otherwise comprised of reports of the event on } 17 \text { May. The } 20: 40 \\
\text { event time matches the time given in all the other reports in the } \\
\text { "box" (which all describe the } 17 \text { May event). Most likely, this } \\
\text { "box" was first published in the daily version of this paper, on } \\
18 \text { May } 1906, \text { then reprinted verbatim in the San Luis Obispo } \\
\text { Tribune, a semi-weekly paper. When it was reprinted, "last } \\
\text { evening" was not corrected as it should have been to reflect the } \\
\text { passage of several days' time. The daily version of this paper could } \\
\text { not be located. } \\
\text { See Table } 11 .\end{array}$ \\
\hline 17-May-06 & $\sim 20: 45$ & King City & Monterey & & $\begin{array}{l}\text { King City Rustler, } \\
18 \text { May 1906; p. 1, c. } 5\end{array}$ & $\begin{array}{l}\text { "Last night at about } 8: 45 \text { windows began rattling, slightly at } \\
\text { first, but presently in an ominously violent manner, causing } \\
\text { people to look at each other in an inquiring sort of manner that } \\
\text { seemed to say: 'Isn't about time to hike outside?" } \\
\text { "The trembling lasted about } 18 \text { seconds, then came a succession of } \\
\text { thumps that only lasted a few seconds, but rocked some of the } \\
\text { people out of their houses pretty lively. It was nearly as severe } \\
\text { as No. } 1 \text { of the Big Series that came on the } 18 \text { th of last month, but } \\
\text { unlike that one, it was not followed up. No damage whatsoever } \\
\text { was done here." } \\
\text { See Table 11. }\end{array}$ \\
\hline 17-May-06 & night & San Jose & Santa Clara & & $\begin{array}{l}\text { San Francisco Examiner, } \\
18 \text { May } 1906 ; \text { p. } 3, \text { c. } 4\end{array}$ & $\begin{array}{l}\text { "SAN JOSE, May } 17 .- \text { Frightened by prophesies of the world's } \\
\text { end, hundreds of women became panic stricken to-night when } \\
\text { what seemed the heaviest shock since April 18th rocked the town. } \\
\text { Despite the apparent force of the temblor, however, not even the } \\
\text { shakiest walls were injured or disturbed. } \\
\text { "At the Jose Theatre a crowded house rose as the lights upon the } \\
\text { stage went out, and rushed towards the doors. The coolness of } \\
\text { the employees and several other men stopped the panic before any } \\
\text { one had been injured. Although many left the theatre, the } \\
\text { performance was continued. For days San Jose has been deeply } \\
\text { agitated over the mysterious appearance upon the fences and dead }\end{array}$ \\
\hline
\end{tabular}


TABLE 1: Catalog of Aftershock Reports following from the Great 18 April 1906 California Earthquake

\begin{tabular}{|c|c|c|c|c|c|c|}
\hline Date Felt & $\begin{array}{c}\text { Time Felt } \\
\text { (PST) }\end{array}$ & $\begin{array}{l}\text { Location Felt } \\
\text { (City) }\end{array}$ & $\begin{array}{l}\text { Location Felt } \\
\text { (County) }\end{array}$ & $\begin{array}{l}\text { Unreliable? } \\
\text { Not Felt? }^{+}\end{array}$ & Source & Relevant Citations and other Notes \\
\hline & & & & & & $\begin{array}{l}\text { walls of the city of placards and signs predicting the speedy end } \\
\text { of the earth.... } \\
\text { "When the shock came to-night the scenes throughout the } \\
\text { residence section of the city were those of a wildly disturbed } \\
\text { community. Women rushed from every house screaming and } \\
\text { terrorstricken. Crying to one another that the end of the world } \\
\text { had come, they dashed from their homes without a thought of } \\
\text { consequences. The efforts to calm them by the men that remained } \\
\text { collected were futile- their fear was not one that could be } \\
\text { reasoned with. Blind, unreasoning terror, superstitious fright, } \\
\text { was all powerful. There was scarcely a street upon which were } \\
\text { not huddled frightened groups of women seeking refuge from the } \\
\text { houses that rocked with the force of the quake. To persuade the } \\
\text { nervous to return to the houses was a difficult task, and in a few } \\
\text { instances impromptu tents formed the night's shelter." } \\
\text { See Table 11. }\end{array}$ \\
\hline 17-May-06 & night & Oakland & Alameda & & $\begin{array}{l}\text { Oakland Tribune, } \\
18 \text { May 1906; p. 4, c. } 2\end{array}$ & $\begin{array}{l}\text { "While the members of the City Council were deep in the } \\
\text { consideration of municipal business during the meeting of the } \\
\text { Council committees last night... an earthquake rocked the City } \\
\text { Hall, and in an instant the business of the meeting was forgotten. } \\
\text { Councilmen and lobby * seized their hats, and made ready to } \\
\text { fly to the safety of the open air, should the shock become more } \\
\text { violent. } \\
\text { "Several gentlemen ... took no chances but left the Council } \\
\text { chamber with more haste than dignity and sought safety in the } \\
\text { * until assured that the * was over. When satisfied that } \\
\text { there was no danger of the immediate destruction of the City Hall } \\
\text { by the convulsions of Mother Earth, those who had fled returned, } \\
\text { the City Fathers resumed the business which had been interrupted } \\
\text { and the earthquake was forgotten." } \\
\text { * This word is illegible. } \\
\text { See Table 11. }\end{array}$ \\
\hline 17-May-06 & night & Oakland & Alameda & & $\begin{array}{c}\text { San Jose Mercury, } \\
\text { 18 May 1906; p. 1, c. } 2\end{array}$ & $\begin{array}{l}\text { "OAKLAND, May 17.-A slight shock was felt here tonight. No } \\
\text { damage is reported." } \\
\text { A very similar article appeared in the Sacramento Union of } \\
18 \text { May 1906, } p .1, c .3 \text {. } \\
\text { See Table 11. }\end{array}$ \\
\hline 17-May-06 & night & $\begin{array}{l}\text { Oakland } \\
\text { Vallejo }\end{array}$ & $\begin{array}{l}\text { Alameda } \\
\text { Solano }\end{array}$ & & $\begin{array}{l}\text { Tuolumne Independent, } \\
19 \text { May 1906; p. 3, c. } 4\end{array}$ & $\begin{array}{l}\text { "A severe earthquake shock was felt in Oakland Thursday night. } \\
\text { As far as can be ascertained no lives were lost, but considerable } \\
\text { damage was done. A shock was also felt at Vallejo. Owing to } \\
\text { some of the lines being down, the news is very meager." }\end{array}$ \\
\hline
\end{tabular}


TABLE 1: Catalog of Aftershock Reports following from the Great 18 April 1906 California Earthquake

\begin{tabular}{|c|c|c|c|c|c|c|}
\hline Date Felt & $\begin{array}{l}\text { Time Felt } \\
\text { (PST) }\end{array}$ & $\begin{array}{l}\text { Location Felt } \\
\text { (City) }\end{array}$ & $\begin{array}{l}\text { Location Felt } \\
\text { (County) }\end{array}$ & $\begin{array}{l}\text { Unreliable? }^{\text {Not Felt? }}{ }^{+}\end{array}$ & Source & Relevant Citations and other Notes \\
\hline & & & & & & See Table 11. \\
\hline 17-May-06 (?) & night (?) & $\begin{array}{l}\text { San Francisco } \\
\text { Oakland } \\
\text { San Jose } \\
\text { Vallejo }\end{array}$ & $\begin{array}{l}\text { San Francisco } \\
\text { Alameda } \\
\text { Santa Clara } \\
\text { Solano }\end{array}$ & & $\begin{array}{l}\text { Union Democrat (Sonora), } \\
19 \text { May 1906; p. } 1, \text { c. } 4\end{array}$ & $\begin{array}{l}\text { "A telephone message received in Sonora Thursday night at nine } \\
\text { o'clock announced another severe earthquake shock in San } \\
\text { Francisco, Oakland, San Jose, and Vallejo. No damage was } \\
\text { reported." } \\
\text { The date and time of the event are not stated in the article, but it is } \\
\text { inferred to be the event of the night of } 17 \text { May. } \\
\text { See Table } 11 .\end{array}$ \\
\hline 17-May-06 & night & Crockett & Contra Costa & & $\begin{array}{l}\text { Daily Gazette (Martinez), } \\
19 \text { May 1906; p. 4, c. } 1\end{array}$ & $\begin{array}{l}\text { The following was quoted from the Crockett Signal. No copies of the } \\
\text { Crockett Signal could be located. } \\
\text { "CROCKETT ITEMS ... May 18, 1906... A baby temblor caused } \\
\text { hearts to come up in the mouths for a few seconds last night." } \\
\text { See Table } 11 .\end{array}$ \\
\hline 17-May-06 & night & Woodland & Yolo & & $\begin{array}{l}\text { Sacramento Bee, } \\
18 \text { May 1906; p. 7, c. } 1\end{array}$ & $\begin{array}{l}\text { "WOODLAND (Yolo Co.), May 18. A slight shock of earthquake } \\
\text { was felt by a number of people in Woodland last night." } \\
\text { See Table } 11 .\end{array}$ \\
\hline 17-May-06 & night & $\begin{array}{l}\text { Woodland } \\
\text { Sacramento }\end{array}$ & $\begin{array}{c}\text { Yolo } \\
\text { Sacramento }\end{array}$ & unreliable & \begin{tabular}{|} 
The Home Alliance (Woodland) \\
18 May 1906; p. 2, c. 1
\end{tabular} & $\begin{array}{l}\text { "A slight earthquake shock was felt here last night. It is reported } \\
\text { as being quite severe in Sacramento." } \\
\text { The statement about Sacramento is almost certainly erroneous. No } \\
\text { newspapers in or near Sacramento reported feeling the earthquake } \\
\text { locally. } \\
\text { See Table 11. }\end{array}$ \\
\hline 17-May-06 & night & Panoche & San Benito & & $\begin{array}{l}\text { The Free Lance (Hollister), } \\
25 \text { May 1906; p. 4, c. } 2\end{array}$ & $\begin{array}{l}\text { Under the heading "Panoche Items": } \\
\text { "There was quite a heavy shock here last Thursday night." } \\
\text { See Table 11. }\end{array}$ \\
\hline 18-May-06 & 02:40 & Boulder Creek & Santa Cruz & & $\begin{array}{c}\text { Mountain Echo (Boulder Creek) } \\
19 \text { May 1906; p. 3, c. } 3\end{array}$ & $\begin{array}{l}\text { "We are informed that, in addition to the heavy shock of } \\
\text { earthquake at 8:24 Thursday evening, there were two lighter } \\
\text { shocks the same night, the first at 2:40 A. M. and the second at } \\
\text { 4:37 A. M." }\end{array}$ \\
\hline 18-May-06 & $04: 37$ & Boulder Creek & Santa Cruz & & \begin{tabular}{|c|} 
Mountain Echo (Boulder Creek) \\
19 May 1906; p. 3, c. 3
\end{tabular} & $\begin{array}{l}\text { "We are informed that, in addition to the heavy shock of } \\
\text { earthquake at 8:24 Thursday evening, there were two lighter } \\
\text { shocks the same night, the first at 2:40 A. M. and the second at } \\
\text { 4:37 A. M." }\end{array}$ \\
\hline
\end{tabular}


TABLE 1: Catalog of Aftershock Reports following from the Great 18 April 1906 California Earthquake

\begin{tabular}{|c|c|c|c|c|c|c|}
\hline Date Felt & $\begin{array}{l}\text { Time Felt } \\
\text { (PST) }\end{array}$ & $\begin{array}{l}\text { Location Felt } \\
\text { (City) }\end{array}$ & $\begin{array}{l}\text { Location Felt } \\
\text { (County) }\end{array}$ & $\begin{array}{l}\text { Unreliable? } \\
\text { Not Felt? }{ }^{+}\end{array}$ & Source & Relevant Citations and other Notes \\
\hline 18-May-06 & $20: 55$ & $\begin{array}{l}\text { Mendocino } \\
\text { Fort Bragg }\end{array}$ & $\begin{array}{l}\text { Mendocino } \\
\text { Mendocino }\end{array}$ & & $\begin{array}{l}\text { Mendocino Beacon, } \\
26 \text { May } 1906 ; \text { p. } 5, \text { c. } 2\end{array}$ & $\begin{array}{l}\text { "A smart shaking of the earth ... stirred the people for awhile, } \\
\text { both here and at Fort Bragg." }\end{array}$ \\
\hline 18-May-06 & $\begin{array}{c}21: 00 \\
\text { and later (?) } \\
\text { (two events) }\end{array}$ & Garberville & Humboldt & & $\begin{array}{l}\text { Humboldt Times, } \\
24 \text { May 1906; p. } 7 \text {, c. } 6\end{array}$ & $\begin{array}{l}\text { "GARBERVILLE, May 23.-The seismic disturbances are still } \\
\text { felt here. Friday evening at } 9 \text { o' clock a tremblor was of a few } \\
\text { seconds duration; another one [occurred] the same night...." }\end{array}$ \\
\hline 18-May-06 & $21: 30$ & Blocksburg & Humboldt & & $\begin{array}{l}\text { Humboldt Standard, } \\
22 \text { May 1906; p. 6, c. } 1\end{array}$ & $\begin{array}{l}\text { "Blocksburg, May 19-At 9:30 p.m. the 18th and 2:15 a.m. today } \\
\text { we experienced two earthquake shocks." }\end{array}$ \\
\hline 19-May-06 & $02: 15$ & Blocksburg & Humboldt & & $\begin{array}{l}\text { Humboldt Standard, } \\
22 \text { May 1906; p. 6, c. } 1\end{array}$ & $\begin{array}{l}\text { "Blocksburg, May 19-At 9:30 p.m. the 18th and 2:15 a.m. today } \\
\text { we experienced two earthquake shocks." }\end{array}$ \\
\hline 19-May-06 & $\sim 12: 00$ & $\begin{array}{l}\text { near Pleasanton } \\
\text { Livermore }\end{array}$ & $\begin{array}{l}\text { Alameda } \\
\text { Alameda }\end{array}$ & $\begin{array}{l}\text { Not Felt } \\
\quad(?)\end{array}$ & $\begin{array}{l}\text { Livermore Echo, } \\
24 \text { May 1906; p. } 1, \text { c. } 3\end{array}$ & $\begin{array}{l}\text { "An earthquake severe enough to shake sauce-pans off of a stove } \\
\text { is reported to have occurred in the vicinity of the brickyard near } \\
\text { Pleasanton ... but must have been purely local." } \\
\text { From the nature of this report, it appears as though the event was } \\
\text { not felt in Livermore. }\end{array}$ \\
\hline 19-May-06 & evening & $\begin{array}{c}\text { southern } \\
\text { Humboldt Co. }\end{array}$ & Humboldt & & $\begin{array}{l}\text { Humboldt Standard, } \\
23 \text { May 1906; p. 6, c. } 3\end{array}$ & $\begin{array}{l}\text { "Mendocino Line, May 23-Southern Humboldt... Saturday } \\
\text { evening we experienced the third heavy shock of earthquake. It } \\
\text { was of a few minutes duration and acted for a time as though it } \\
\text { might prove disastrous." } \\
\text { The exact location is not known any more precisely than indicated. }\end{array}$ \\
\hline $\begin{array}{l}\text { 19-May-06 to } \\
\text { 21-May-06 }\end{array}$ & $\begin{array}{l}\text { nights of } \\
19,20, \& 21 \\
\text { May }\end{array}$ & Garberville & Humboldt & & $\begin{array}{c}\text { Humboldt Standard, } \\
25 \text { May 1906; p. 6, c. 3-4 }\end{array}$ & $\begin{array}{l}\text { "Garberville, May 22.-.... Three nights in succession temblors } \\
\text { protracted enough to cause some uneasiness have been felt } \\
\text { here...." }\end{array}$ \\
\hline 23-May-06 & 00:00 & Garberville & Humboldt & & $\begin{array}{l}\text { Humboldt Times, } \\
24 \text { May 1906; p. } 7, \text { c. } 6\end{array}$ & $\begin{array}{l}\text { "... The shock was severe enough to cause a disturbance in the } \\
\text { China cupboards, but we are getting accustomed to being rocked } \\
\text { in our beds." }\end{array}$ \\
\hline 30-May-06 (?) & $\sim 23: 00$ & Templeton & San Luis Obispo & & $\begin{array}{l}\text { Templeton Advance, } \\
6 \text { Jun 1906; p. 1, c. } 3\end{array}$ & $\begin{array}{l}\text { "A slight earthquake was felt in Templeton at or near the hour of } \\
11 \text { o'clock Wednesday night of this week. Wouldn't that jar } \\
\text { you?" } \\
\text { This paper was published weekly on Wednesdays. "Wednesday } \\
\text { night of this week" could not refer to } 6 \text { Jun, because the paper must } \\
\text { have been published by that time. Alternatively, it seems unusual } \\
\text { to refer to } 30 \text { May (one full week before publication) as "Wednesday } \\
\text {. of this week." The time of the event leads one to speculate that it } \\
\text { may be describing the event of } 4 \text { Jun 1906, in which case } \\
\text { "Wednesday" would have been erroneously substituted for } \\
\text { "Monday." At best, the date is speculative. }\end{array}$ \\
\hline $\begin{array}{c}\text { week of } \\
\text { 31-May-06 }\end{array}$ & $\begin{array}{l}\text { (several } \\
\text { events) }\end{array}$ & Tomales & Marin & & $\begin{array}{l}\text { Marin County Tocsin, } \\
\text { 2 Jun 1906; p. 1, c. } 6\end{array}$ & $\begin{array}{l}\text { "Last week we had several severe shocks of earthquake, but we } \\
\text { are used to them now and are getting braver every day." }\end{array}$ \\
\hline
\end{tabular}


TABLE 1: Catalog of Aftershock Reports following from the Great 18 April 1906 California Earthquake

\begin{tabular}{|c|c|c|c|c|c|c|}
\hline Date Felt & $\begin{array}{l}\text { Time Felt } \\
\text { (PST) }\end{array}$ & $\begin{array}{l}\text { Location Felt } \\
\text { (City) }\end{array}$ & $\begin{array}{l}\text { Location Felt } \\
\text { (County) }\end{array}$ & $\begin{array}{l}\text { Unreliable? } \\
\text { Not Felt? }^{+}\end{array}$ & Source & Relevant Citations and other Notes \\
\hline 31-May-06 & 05:45 & Vallejo & Solano & & $\begin{array}{l}\text { San Francisco Chronicle, } \\
1 \text { Jun 1906; p. 2, c. } 2\end{array}$ & $\begin{array}{l}\text { "VALLEJO, May 31.-An earthquake shock lasting slightly over } \\
\text { one second was felt here.... No damage was done." }\end{array}$ \\
\hline 31-May-06 & 05:55 & Santa Rosa & Sonoma & & $\begin{array}{l}\text { Humboldt Standard, } \\
31 \text { May 1906; p. 1, c. } 6\end{array}$ & $\begin{array}{l}\text { "Santa Rosa, May 31.-A sharp earthquake shock at 5:55 } \\
\text { o'clock this morning aroused all residents, many of whom rushed } \\
\text { from their houses. No damage was done." } \\
\text { Also in the Humboldt Times of } 1 \text { Jun 1906, p. 2, c. } 5 \text {. }\end{array}$ \\
\hline 01-Jun-06 (?) & 05:55 & Santa Rosa & Sonoma & & \begin{tabular}{|c|} 
Courier-Free Press (Redding) \\
1 Jun 1906; p. 7, c. 3
\end{tabular} & $\begin{array}{l}\text { "SANTA ROSA, June 1.-A sharp earthquake occurred here this } \\
\text { morning at 5:55, it being the most severe that has happened since } \\
\text { the big shake. } \\
\text { "The people were greatly alarmed and rushed from their home } \\
\text { into the streets. Many did not venture indoors for several hours. } \\
\text { It was feared that another shake was imminent. The entire } \\
\text { section felt the shake. It lasted for several seconds. No damage } \\
\text { has been reported." } \\
\text { Presumably, this is the } 31 \text { May event as reported in the Humboldt } \\
\text { Standard and Humboldt Times, but the date is incorrect here. } \\
\text { (If this is indeed the same event, the } 1 \text { Jun date must be incorrect, as } \\
\text { the story in the Humboldt Standard was published on the evening of } \\
31 \text { May 1906.) }\end{array}$ \\
\hline 03-Jun-06 (?) & 23:55 & Boulder Creek & Santa Cruz & & $\begin{array}{l}\text { Mountain Echo (Boulder Creek) } \\
9 \text { Jun 1906; p. 3, c. } 1\end{array}$ & $\begin{array}{l}\text { "There was another light earthquake at 11:55 last Sunday } \\
\text { evening." } \\
\text { This is almost certainly the } 4 \text { Jun } 1906 \text { event. }\end{array}$ \\
\hline 04-Jun-06 & night & $\begin{array}{c}\text { Petaluma } \\
\text { San Rafael } \\
\text { San Francisco } \\
\text { Stockton } \\
\text { Oakland }\end{array}$ & $\begin{array}{c}\text { Sonoma } \\
\text { Marin } \\
\text { San Francisco } \\
\text { San Joaquin } \\
\text { Alameda }\end{array}$ & & $\begin{array}{l}\text { Santa Rosa Press-Democrat, } \\
5 \text { Jun 1906; p. } 1, \text { c. } 2\end{array}$ & $\begin{array}{l}\text { "San Francisco, June 4-A severe earthquake tonight caused } \\
\text { many people in Petaluma, San Rafael, and this city to rush into the } \\
\text { streets, but no damage was done. Stockton and Oakland also felt } \\
\text { the shock." }\end{array}$ \\
\hline 04-Jun-06 & night & San Francisco & San Francisco & & $\begin{array}{l}\text { Santa Rosa Press-Democrat, } \\
\quad 6 \text { Jun 1906; p. } 1, \text { c. } 6\end{array}$ & $\begin{array}{l}\text { "M. Prince returned to San Francisco on Tuesday afternoon. He } \\
\text { reports that the earthquake on Monday night there was very } \\
\text { heavy." }\end{array}$ \\
\hline 04-Jun-06 & night & $\begin{array}{c}\text { San Francisco } \\
\text { Salinas }\end{array}$ & $\begin{array}{c}\text { San Francisco } \\
\text { Monterey }\end{array}$ & & $\begin{array}{l}\text { Salinas Daily Index, } \\
5 \text { Jun 1906; p. 3, c. } 5\end{array}$ & $\begin{array}{l}\text { "Since news arrived of the latest shake in San Francisco last } \\
\text { night, several people assert that they felt a tremblor here about } \\
\text { the same time. If so, it must have been only a tremblorette, as all } \\
\text { knowledge of it seems confined to a few...." }\end{array}$ \\
\hline
\end{tabular}


TABLE 1: Catalog of Aftershock Reports following from the Great 18 April 1906 California Earthquake

\begin{tabular}{|c|c|c|c|c|c|c|}
\hline Date Felt & $\underset{\text { (PST) }}{\text { Time Felt }}$ & $\begin{array}{l}\text { Location Felt } \\
\text { (City) }\end{array}$ & $\begin{array}{l}\text { Location Felt } \\
\text { (County) }\end{array}$ & $\begin{array}{l}\text { Unreliable? } \\
\text { Not Felt? }{ }^{+}\end{array}$ & Source & Relevant Citations and other Notes \\
\hline 04-Jun-06 & $\sim 23: 26$ & Martinez & Contra Costa & & $\begin{array}{l}\text { Contra Costa Gazette, } \\
9 \text { Jun } 1906 ; \text { p. } 5, \text { c. } 2\end{array}$ & $\begin{array}{l}\text { "Two earthquake shocks were reported on Monday night. One } \\
\text { was about 11:26; the other about 11:53 p. m. The former was } \\
\text { noticed by few people...." } \\
\text { Compare this with the text cited from this newspaper for Martinez } \\
\text { for the shock at } 23: 53 \text { on } 4 \text { Jun. }\end{array}$ \\
\hline 04-Jun-06 & $23: 50$ & San Francisco & San Francisco & & $\begin{array}{l}\text { San Francisco Call, } \\
5 \text { Jun 1906; p. } 14, \text { c. } 5\end{array}$ & $\begin{array}{l}\text { "... a sharp earthquake shock was felt throughout the city. No } \\
\text { damage was done. It was quite forcibly felt in the ferry building. } \\
\text { A bucket in one of the rooms was knocked off a table by the } \\
\text { temblor." }\end{array}$ \\
\hline 04-Jun-06 & $23: 50$ & $\begin{array}{l}\text { San Francisco } \\
\text { Oakland }\end{array}$ & $\begin{array}{c}\text { San Francisco } \\
\text { Alameda }\end{array}$ & & $\begin{array}{l}\text { Sacramento Union, } \\
5 \text { Jun 1906; p. 1, c. } 6\end{array}$ & $\begin{array}{l}\text { "SAN FRANCISCO, June 4.-A sharp earthquake shock was felt } \\
\text { here and in Oakland at 11:50 to-night. It was of the up and down } \\
\text { variety and lasted about ten seconds, and was hard enough to } \\
\text { rattle windows, but did no damage. It was over before people } \\
\text { had time to become alarmed." }\end{array}$ \\
\hline 04-Jun-06 & $23: 50$ & $\begin{array}{c}\text { San Francisco } \\
\text { Oakland }\end{array}$ & $\begin{array}{c}\text { San Francisco } \\
\text { Alameda }\end{array}$ & & $\begin{array}{l}\text { San Jose Mercury, } \\
5 \text { Jun 1906; p. 1, c. } 2\end{array}$ & $\begin{array}{l}\text { "SAN FRANCISCO, June 4.-A sharp earthquake shock was felt } \\
\text { here and in Oakland.... No damage has been reported." }\end{array}$ \\
\hline 04-Jun-06 & $23: 50$ & Vallejo & Solano & & $\begin{array}{l}\text { San Francisco Call, } \\
6 \text { Jun 1906; p. } 4 \text {, c. } 5\end{array}$ & $\begin{array}{l}\text { "VALLEJO, June 5.-An earthquake was felt here.... The temblor } \\
\text { lasted two seconds. No damage was done, but it frightened the } \\
\text { residents." }\end{array}$ \\
\hline 04-Jun-06 & $23: 50$ & Vallejo & Solano & & $\begin{array}{l}\text { San Francisco Chronicle, } \\
6 \text { Jun } 1906 ; \text { p. } 5, \text { c. } 4\end{array}$ & $\begin{array}{l}\text { "VALLEJO, June } 5 .- \text { There was a sharp shock of earthquake } \\
\text { here ... lasting several seconds. No damage was done, but it } \\
\text { greatly scared the residents." }\end{array}$ \\
\hline 04-Jun-06 & $23: 50$ & Vallejo & Solano & & $\begin{array}{l}\text { San Jose Herald, } \\
5 \text { Jun 1906; p. 2, c. } 2\end{array}$ & "VALLEJO, June 5.—A slight earthquake shock was felt here...." \\
\hline 04-Jun-06 & 23:51:07 & Berkeley & Alameda & & $\begin{array}{l}\text { Berkeley Daily Gazette, } \\
5 \text { Jun 1906; p. 1, c. } 2\end{array}$ & $\begin{array}{l}\text { "An earthquake shock of intensity five on the Rossi-Forel scale } \\
\text { was registered on the seismograph at the University Observatory } \\
\text { shortly before midnight Monday. The Ewing seismograph } \\
\text { commenced registering the vibrations at } 11 \text { o' clock, } 51 \text { minutes } \\
\text { and } 7 \text { seconds, Pacific Standard time. The vibrations lasted more } \\
\text { than a minute, but the greatest intensity occurred about the middle } \\
\text { of the shock. As in the case of most of the after shocks recorded } \\
\text { since April 18, the main direction of the temblor was from }\end{array}$ \\
\hline
\end{tabular}


TABLE 1: Catalog of Aftershock Reports following from the Great 18 April 1906 California Earthquake

\begin{tabular}{|c|c|c|c|c|c|c|}
\hline Date Felt & $\begin{array}{l}\text { Time Felt } \\
\text { (PST) }\end{array}$ & $\begin{array}{l}\text { Location Felt } \\
\text { (City) }\end{array}$ & $\begin{array}{l}\text { Location Felt } \\
\text { (County) }\end{array}$ & $\begin{array}{l}\text { Unreliable? } \\
\text { Not Felt? }^{+}\end{array}$ & Source & Relevant Citations and other Notes \\
\hline & & San Francisco & San Francisco & & & $\begin{array}{l}\text { southeast to northwest. } \\
\text { "The shock was very perceptible in all parts of this city, and } \\
\text { many of the residents who had retired were awakened by a dull, } \\
\text { rumbling sound, followed by a sudden shaking of buildings. } \\
\text { Others who were up at the hour of the seismic disturbance } \\
\text { noticed the shock. No damage resulted from the temblor. } \\
\text { "The shock was felt in the ferry building in San Francisco, and a } \\
\text { bucket on a table was thrown to the floor." }\end{array}$ \\
\hline 04-Jun-06 & $23: 53$ & $\begin{array}{l}\text { San Francisco } \\
\text { Oakland }\end{array}$ & $\begin{array}{l}\text { San Francisco } \\
\text { Alameda }\end{array}$ & & $\begin{array}{c}\text { Oakland Herald, } \\
5 \text { Jun 1906; p.9, c. } 7\end{array}$ & $\begin{array}{l}\text { "SAN FRANCISCO, June 5.-A brief though rather severe } \\
\text { earthquake shock was felt... While the shock would have been } \\
\text { classed as severe prior to that of April 18, it caused little } \\
\text { uneasiness except on the part of the very nervous. } \\
\text { "In the offices of the Western Union Telegraph Company in the } \\
\text { Ferry building a pail of water was thrown from a table by the } \\
\text { shock. No damage was done so far as has been reported." } \\
\text { Then, added below this article: } \\
\text { "The shock was also felt in Oakland. It disturbed the slumbers of } \\
\text { the nervous. No damage was done." }\end{array}$ \\
\hline 04-Jun-06 & $\sim 23: 53$ & Martinez & Contra Costa & & $\begin{array}{l}\text { Contra Costa Gazette, } \\
9 \text { Jun } 1906 ; \text { p. } 5, \text { c. } 2\end{array}$ & $\begin{array}{l}\text { "Two earthquake shocks were reported on Monday night. One } \\
\text { was about 11:26; the other about } 11: 53 \text { p. m... the latter shocked } \\
\text { itself into the notice of many." } \\
\text { Compare this with the text cited from this newspaper for Martinez } \\
\text { for the shock at } 23: 26 \text { on } 4 \text { Jun. }\end{array}$ \\
\hline 04-Jun-06 & $\begin{array}{c}\text { a few minutes } \\
\text { before } 00: 00 \\
05 \text { Jun }\end{array}$ & $\begin{array}{l}\text { Livermore } \\
\text { San Francisco } \\
\text { Santa Cruz }\end{array}$ & $\begin{array}{l}\text { Alameda } \\
\text { San Francisco } \\
\text { Santa Cruz }\end{array}$ & & $\begin{array}{c}\text { Livermore Echo, } \\
7 \text { Jun 1906; p.1, c. } 3\end{array}$ & $\begin{array}{l}\text { "A light shock of earthquake was felt here a few minutes before } \\
\text { midnight Monday night, by a few persons, and was also felt in } \\
\text { San Francisco, Santa Cruz, etc." }\end{array}$ \\
\hline 04-Jun-06 & $\begin{array}{c}\text { a few minutes } \\
\text { before 00:00, } \\
05 \text { Jun }\end{array}$ & Sonoma & Sonoma & & $\begin{array}{l}\text { Sonoma Index-Tribune, } \\
9 \text { Jun 1906; p. 3, c. } 3\end{array}$ & $\begin{array}{l}\text { "On Monday night a few minutes before } 12 \text { o'clock there was a } \\
\text { sharp but short shock of earthquake felt here. The vibrations } \\
\text { were from north to south and lasted but a few seconds." }\end{array}$ \\
\hline 05-Jun-06 & $\sim 00: 00$ & Alameda & Alameda & & $\begin{array}{l}\text { Alameda Daily Argus, } \\
5 \text { Jun 1906; p. 1, c. } 4\end{array}$ & $\begin{array}{l}\text { "The shock of earthquake about midnight last night was not } \\
\text { noticed by a large number of persons. Very few persons who } \\
\text { were asleep were awakened by it, and many of those up and } \\
\text { around were surprised to hear this morning that a slight jar had } \\
\text { occurred during the night. The difference between the vibration } \\
\text { caused by a train and the gentle lulling of a well-mannered } \\
\text { earthquake is quite similar and hard to distinguish." }\end{array}$ \\
\hline
\end{tabular}


TABLE 1: Catalog of Aftershock Reports following from the Great 18 April 1906 California Earthquake

\begin{tabular}{|c|c|c|c|c|c|c|}
\hline Date Felt & $\begin{array}{l}\text { Time Felt } \\
\text { (PST) }\end{array}$ & $\begin{array}{l}\text { Location Felt } \\
\text { (City) }\end{array}$ & $\begin{array}{l}\text { Location Felt } \\
\text { (County) }\end{array}$ & $\begin{array}{l}\text { Unreliable? } \\
\text { Not Felt? }^{+}\end{array}$ & Source & Relevant Citations and other Notes \\
\hline 07-Jun-06 & $\sim 16: 00$ & Burnt Ranch & Trinity & & $\begin{array}{l}\text { Blue Lake Advocate, } \\
\text { 16 Jun 1906; p. 6, c. } 2\end{array}$ & "A slight earthquake was noticed...." \\
\hline 07-Jun-06 & $16: 10$ & Upper Mattole & Humboldt & & $\begin{array}{l}\text { Humboldt Standard, } \\
\text { 11 Jun 1906; p. 6, c. } 1\end{array}$ & $\begin{array}{l}\text { "Upper Mattole, June 7.-A heavy shock of earthquake occurred } \\
\text { here this afternoon, commencing at } 4: 10 \text { o'clock and lasting about } \\
20 \text { seconds. Light shocks have been felt here at intervals since the } \\
\text { big one of April, but no damage has been done since then." }\end{array}$ \\
\hline 07-Jun-06 & $\sim 16: 14$ & Ferndale & Humboldt & & $\begin{array}{l}\text { Humboldt Standard, } \\
8 \text { Jun } 1906 ; \text { p. } 8, \text { c. } 2\end{array}$ & $\begin{array}{l}\text { "Ferndale reports having felt a light earthquake shock yesterday } \\
\text { afternoon. No damage is reported except the breaking of a vase at } \\
\text { the home of... In all, three clocks stopped-one registering the } \\
\text { shock at } 4: 13 \text {, and one at } 4: 15 . "\end{array}$ \\
\hline 07-Jun-06 & & Ferndale & Humboldt & & $\begin{array}{l}\text { Humboldt Standard, } \\
16 \text { Jun 1906; p. 6, c. 2-3 }\end{array}$ & $\begin{array}{l}\text { "Ferndale, June } 14 .-\ldots . \text { The shock Sunday evening [ } 10 \text { June] was } \\
\text { not as severe as the one last Thursday [7 June], and the one } \\
\text { Wednesday [13 June] was still lighter. It is hoped that they are } \\
\text { gradually diminishing." }\end{array}$ \\
\hline 07-Jun-06 & $16: 15$ & Garberville & Humboldt & & $\begin{array}{l}\text { Humboldt Standard, } \\
12 \text { Jun 1906; p. 6, c. } 1\end{array}$ & $\begin{array}{l}\text { "Garberville, June } 8 .-\ldots . \text { The hardest shake of Mother Earth } \\
\text { during the daytime was felt here yesterday afternoon at } 4: 15 \\
\text { o'clock, the buildings rocking from east to west. As usual the } \\
\text { temblor was over before the timid ones could run out in the } \\
\text { streets, and only the one disturbance being felt, the scare was } \\
\text { soon over." }\end{array}$ \\
\hline 07-Jun-06 & $16: 15$ & Fields Landing & Humboldt & & $\begin{array}{l}\text { Humboldt Standard, } \\
11 \text { Jun 1906; p. 6, c. } 1\end{array}$ & "Quite a shock of earthquake was felt...." \\
\hline 07-Jun-06 & $16: 15$ & $\begin{array}{l}\text { Eureka } \\
\text { Oakland }\end{array}$ & $\begin{array}{l}\text { Humboldt } \\
\text { Alameda }\end{array}$ & & $\begin{array}{l}\text { Humboldt Times, } \\
8 \text { Jun 1906; p. 5, c. } 1\end{array}$ & $\begin{array}{l}\text { "Eureka was visited yesterday afternoon at exactly } 4: 15 \text { o' clock } \\
\text { by the severest earthquake shock felt since the memorable April } \\
18 \text { th. The quake lasted for twenty-six seconds, according to } \\
\text { Aaron H. Bell, observer of the United States Weather Bureau. } \\
\text { "The shock was almost from west to east ... and was of somewhat } \\
\text { a different character from the big shake which created havoc with } \\
\text { the state. The greatest intensity was a few seconds after it was } \\
\text { first felt, and then it gradually died away. } \\
\text { "Although sharp, the quake was not at all violent, and did no } \\
\text { damage. Quite a number of people were frightened. At the Court } \\
\text { House the county officials hesitated in their work, and paid little } \\
\text { visits to each other in their respective offices, and the District } \\
\text { Attorney descended the stairs about four steps at a time.... } \\
\text { "The earthquake was general along the coast as far as heard } \\
\text { from, having about the same range as the big one. It was felt at } \\
\text { Oakland and intervening points. From the fact that the temblor } \\
\text { came from the west and was felt all along the coast with } \\
\text { practically the same intensity, it is considered that it was caused } \\
\text { by some disturbance in midocean." }\end{array}$ \\
\hline
\end{tabular}


TABLE 1: Catalog of Aftershock Reports following from the Great 18 April 1906 California Earthquake

\begin{tabular}{|c|c|c|c|c|c|c|}
\hline Date Felt & $\begin{array}{l}\text { Time Felt } \\
\text { (PST) }\end{array}$ & $\begin{array}{l}\text { Location Felt } \\
\text { (City) }\end{array}$ & $\begin{array}{l}\text { Location Felt } \\
\text { (County) }\end{array}$ & $\begin{array}{l}\text { Unreliable? } \\
\text { Not Felt? }\end{array}$ & Source & Relevant Citations and other Notes \\
\hline 07-Jun-06 & $16: 15$ & Arcata & Humboldt & & $\begin{array}{l}\text { Arcata Union, } \\
9 \text { Jun 1906; p. 1, c. } 3\end{array}$ & $\begin{array}{l}\text { "Arcata people were treated to a baby temblor ... which last [sic] } \\
\text { for } 20 \text { seconds. It was not hard enough to do any damage but was } \\
\text { hard on the nerves of the timid ones. The big clock in the A. \& M. } \\
\text { R. R. depot stopped at the time named [ } 4: 15 \text { pm]." }\end{array}$ \\
\hline 07-Jun-06 & afternoon & Waddington & Humboldt & & $\begin{array}{l}\text { Humboldt Standard, } \\
11 \text { Jun 1906; p. 6, c. } 1\end{array}$ & $\begin{array}{l}\text { "... This place was surprised ... by a rather heavy shock of } \\
\text { earthquake, but not heavy enough, we are glad to say, to do any } \\
\text { damage." }\end{array}$ \\
\hline 08-Jun-06 & $\sim 00: 00$ & Arcata & Humboldt & & $\begin{array}{l}\text { Arcata Union, } \\
9 \text { Jun 1906; p. 1, c. } 3\end{array}$ & $\begin{array}{l}\text { "Another light shock was felt about midnight Thursday night } \\
\text { [7 June]." }\end{array}$ \\
\hline 10-Jun-06 & morning & San Francisco & San Francisco & & $\begin{array}{l}\text { Mendocino Beacon, } \\
16 \text { Jun 1906; p. } 5, \text { c. } 2\end{array}$ & $\begin{array}{l}\text { "Former Mendocinoites write from San Francisco to the effect } \\
\text { that the hardest shock since the morning of April 18th was felt } \\
\text { there last Sunday morning." }\end{array}$ \\
\hline 10-Jun-06 & $17: 25$ & Petrolia & Humboldt & & $\begin{array}{l}\text { Humboldt Standard, } \\
18 \text { Jun 1906; p. 6, c. } 3\end{array}$ & $\begin{array}{l}\text { "Petrolia, June 15-.... Three very sharp earthquake shocks have } \\
\text { been felt in Petrolia this week, one Sunday evening [10 June] at } \\
\text { 5:25, one Wednesday noon [13 June] and one about } 3: 45 \text { this } \\
\text { morning. The shake of Wednesday noon was much the hardest, } \\
\text { giving many people a fright and setting all to thinking that the } \\
\text { shake of April } 18 \text { would be repeated." }\end{array}$ \\
\hline $\begin{array}{l}\text { 07-Jun-06 to } \\
\text { 10-Jun-06 }\end{array}$ & $\begin{array}{c}\text { 18:00 on } \\
10 \text { Jun; others } \\
\text { between } \\
07 \text { \& } 10 \text { Jun }\end{array}$ & Upper Mattole & Humboldt & & $\begin{array}{l}\text { Humboldt Standard, } \\
14 \text { Jun 1906; p. 6, c. } 1\end{array}$ & $\begin{array}{l}\text { "Upper Mattole, June 11._.... The earth still quakes. A lively } \\
\text { quake occurred at about } 6 \text { p. m. yesterday, another light one about } \\
9 \text { p. m., besides several light shocks since the one of the 7th." }\end{array}$ \\
\hline 10-Jun-06 & $\sim 18: 30$ & Ferndale & Humboldt & & $\begin{array}{l}\text { Humboldt Standard, } \\
12 \text { Jun 1906; p. 3, c. } 2\end{array}$ & $\begin{array}{l}\text { "... Ferndale was visited by quite a severe earthquake shock. The } \\
\text { tremble was of short duration but severe enough while it lasted to } \\
\text { make everyone sit up and take notice." }\end{array}$ \\
\hline 10-Jun-06 & & Ferndale & Humboldt & & $\begin{array}{l}\text { Humboldt Standard, } \\
16 \text { Jun 1906; p. 6, c. 2-3 }\end{array}$ & $\begin{array}{l}\text { "Ferndale, June 14.-.... The shock Sunday evening [10 June] was } \\
\text { not as severe as the one last Thursday [ } 7 \text { June], and the one } \\
\text { Wednnesday [13 June] was still lighter. It is hoped that they are } \\
\text { gradually diminishing." }\end{array}$ \\
\hline 10-Jun-06 & $\sim 21: 00$ & Upper Mattole & Humboldt & & $\begin{array}{l}\text { Humboldt Standard, } \\
\text { 14 Jun 1906; p. 6, c. } 1\end{array}$ & "light" \\
\hline 13-Jun-06 & $\begin{array}{l}\text { just before } \\
12: 00\end{array}$ & Eureka & Humboldt & & $\begin{array}{l}\text { Humboldt Times, } \\
\text { 14 Jun 1906; p. } 8, \text { c. } 4\end{array}$ & $\begin{array}{l}\text { "A slight earthquake shock was felt yesterday just before noon. } \\
\text { It was of short duration and of so little intensity that it attracted } \\
\text { but little attention." }\end{array}$ \\
\hline 13-Jun-06 & $\begin{array}{l}\text { a few minutes } \\
\text { before 12:00 }\end{array}$ & Ferndale & Humboldt & & $\begin{array}{l}\text { Humboldt Standard, } \\
16 \text { Jun 1906; p. 6, c. 2-3 }\end{array}$ & $\begin{array}{l}\text { "Ferndale, June } 14 .-\ldots . \text { Quite a severe shock was felt a few } \\
\text { minutes before twelve o' clock yesterday. No damage was done } \\
\text { however. The shock Sunday evening [10 June] was not as severe } \\
\text { as the one last Thursday [7 June], and the one Wednesday [13 } \\
\text { June] was still lighter. It is hoped that they are gradually } \\
\text { diminishing." }\end{array}$ \\
\hline
\end{tabular}


TABLE 1: Catalog of Aftershock Reports following from the Great 18 April 1906 California Earthquake

\begin{tabular}{|c|c|c|c|c|c|c|}
\hline Date Felt & $\begin{array}{l}\text { Time Felt } \\
\text { (PST) }\end{array}$ & $\begin{array}{l}\text { Location Felt } \\
\quad \text { (City) }\end{array}$ & $\begin{array}{l}\text { Location Felt } \\
\text { (County) }\end{array}$ & $\begin{array}{l}\text { Unreliable? } \\
\text { Not Felt? }^{+}\end{array}$ & Source & Relevant Citations and other Notes \\
\hline 13-Jun-06 & $12: 00$ & Petrolia & Humboldt & & $\begin{array}{l}\text { Humboldt Standard, } \\
18 \text { Jun 1906; p. 6, c. } 3\end{array}$ & $\begin{array}{l}\text { "Petrolia, June 15.-... Three very sharp earthquake shocks have } \\
\text { been felt in Petrolia this week, one Sunday evening [10 June] at } \\
\text { 5:25, one Wednesday noon [13 June] and one about 3:45 this } \\
\text { morning. The shake of Wednesday noon was much the hardest, } \\
\text { giving many people a fright and setting all to thinking that the } \\
\text { shake of April } 18 \text { would be repeated." }\end{array}$ \\
\hline 14-Jun-06 (?) & & San Francisco & San Francisco & & $\begin{array}{l}\text { Oakland Enquirer, } \\
\text { 16 Jun 1906; p. 10, c. } 6\end{array}$ & $\begin{array}{l}\text { "SAN FRANCISCO, June 16.-Dr. Omori of Japan ... in a } \\
\text { statement Friday declares that the light shock experienced last } \\
\text { Thursday is convincing indication that a repetition of a heavy } \\
\text { movement of the earth is unfeared...." } \\
\text { It is not absolutely clear which Thursday is being referred to. }\end{array}$ \\
\hline 15-Jun-06 & 03:30 & Mendocino & Mendocino & & $\begin{array}{l}\text { Mendocino Beacon, } \\
\text { 16 Jun 1906; p. } 5, \text { c. } 2\end{array}$ & $\begin{array}{l}\text { "A sharp earthquake shock was felt here ... shaking buildings } \\
\text { quite noticeably but no damage resulted." }\end{array}$ \\
\hline 15-Jun-06 & $\begin{array}{c}21: 35 \\
\text { and later } \\
\text { (two events) }\end{array}$ & San Francisco & San Francisco & & $\begin{array}{l}\text { Napa Daily Register, } \\
\text { 16 Jun 1906; p. } 1, \text { c. } 2\end{array}$ & $\begin{array}{l}\text { "SAN FRANCISCO, June 16.-A sharp earthquake shock was } \\
\text { felt at 9:35 o' clock last night, followed by another slighter one. } \\
\text { "Many frightened people rushed into the streets. There was no } \\
\text { damage done." }\end{array}$ \\
\hline 15-Jun-06 & $21: 35$ & San Francisco & San Francisco & & $\begin{array}{l}\text { Sacramento Star, } \\
16 \text { Jun 1906; p. 1, c. } 7\end{array}$ & $\begin{array}{l}\text { "SAN FRANCISCO, June 16.-A sharp earthquake was felt at } \\
\text { 9:35 last night and another slight shock half an hour later. } \\
\text { "No damage was done to buildings, but many people were } \\
\text { frightened and ran into the streets." }\end{array}$ \\
\hline 15-Jun-06 & 21:40 & $\begin{array}{l}\text { San Francisco } \\
\text { Oakland }\end{array}$ & $\begin{array}{l}\text { San Francisco } \\
\text { Alameda }\end{array}$ & & $\begin{array}{l}\text { San Jose Mercury, } \\
\text { 16 Jun 1906; p. 1, c. 6-7 }\end{array}$ & $\begin{array}{l}\text { "SAN FRANCISCO, June 15.-... Two distinct shocks in rapid } \\
\text { succession were felt in this city and in Oakland at 9:40 o'clock } \\
\text { tonight. The movement seemed to be from west to east and was } \\
\text { several seconds in duration. No damage was done...." } \\
\text { A very similar article appeared in the Sacramento Union of } \\
16 \text { Jun } 1906, p .1, c .7 \text {. }\end{array}$ \\
\hline 15-Jun-06 & $21: 40$ & Vallejo & Solano & & $\begin{array}{l}\text { San Jose Mercury, } \\
\text { 16 Jun 1906; p. 1, c. } 7\end{array}$ & $\begin{array}{l}\text { "VALLEJO, Cal., June 15.-Two distinct shocks of earthquake } \\
\text { were felt here at 9:40 o'clock tonight. No damage was done." } \\
\text { A very similar article appeared in the Sacramento Union of }\end{array}$ \\
\hline
\end{tabular}


TABLE 1: Catalog of Aftershock Reports following from the Great 18 April 1906 California Earthquake

\begin{tabular}{|c|c|c|c|c|c|c|}
\hline Date Felt & $\begin{array}{l}\text { Time Felt } \\
\text { (PST) }\end{array}$ & $\begin{array}{l}\text { Location Felt } \\
\quad \text { (City) }\end{array}$ & $\begin{array}{l}\text { Location Felt } \\
\text { (County) }\end{array}$ & $\begin{array}{l}\text { Unreliable? } \\
\text { Not Felt? }^{+}\end{array}$ & Source & Relevant Citations and other Notes \\
\hline & & & & & & 16 Jun 1906, p. 1, c. 7. \\
\hline 15-Jun-06 & $21: 41$ & San Francisco & San Francisco & & $\begin{array}{l}\text { Sacramento Union, } \\
16 \text { Jun 1906; p. 1, c. } 7\end{array}$ & $\begin{array}{l}\text { "SAN FRANCISCO, June 15.-A severe earthquake was felt here } \\
\text { at 9:41 p. m. It lasted about five seconds. It was probably not } \\
\text { heavy enough to do damage, though possibly it may have caused } \\
\text { some of the walls of ruined buildings to fall." }\end{array}$ \\
\hline 15-Jun-06 & 21:41:52 & Berkeley & Alameda & & $\begin{array}{l}\text { Berkeley Daily Gazette, } \\
16 \text { Jun 1906; p. 1, c. } 3\end{array}$ & $\begin{array}{l}\text { "... The intensity of the temblor was five and its movement was } \\
\text { from southeast to northwest... [It] was not heavy enough to cause } \\
\text { perceptible damage." }\end{array}$ \\
\hline 15-Jun-06 & $21: 45$ & Oakland & Alameda & & $\begin{array}{l}\text { Oakland Enquirer, } \\
\text { 16 Jun 1906; p. 16, c. } 5\end{array}$ & $\begin{array}{l}\text { "... The latest came last night at a quarter to ten o' clock and was } \\
\text { slight both in intensity and duration. No damage resulted." } \\
\text { Also in the Oakland Times of } 16 \text { Jun 1906, p. 1, c. } 4 .\end{array}$ \\
\hline 15-Jun-06 & $21: 45$ & Oakland & Alameda & & $\begin{array}{l}\text { Oakland Herald, } \\
16 \text { Jun 1906; p. } 14 \text {, c. } 3\end{array}$ & $\begin{array}{l}\text { "A slight temblor was felt ... which, although it was of short } \\
\text { duration, caused some excitement... No. } 3 \text { intensity...." }\end{array}$ \\
\hline 15-Jun-06 & $\sim 21: 45$ & Livermore & Alameda & & $\begin{array}{l}\text { Livermore Echo, } \\
\text { 21 Jun 1906; p. 1, c. } 2 \\
\end{array}$ & "A short earthquake was felt here by some residents...." \\
\hline 15-Jun-06 & $\sim 22: 00$ & Bennett Valley & Sonoma & & $\begin{array}{l}\text { Santa Rosa Press-Democrat, } \\
20 \text { Jun 1906; p. 4, c. } 2\end{array}$ & $\begin{array}{l}\text { "Bennett Valley, June } 18 \ldots . . \text { The earth in these parts seemed a little } \\
\text { "unsteady' last Friday evening at about ten o'clock." }\end{array}$ \\
\hline 15-Jun-06 & 22:05 & San Francisco & San Francisco & & $\begin{array}{l}\text { Sacramento Star, } \\
\text { 16 Jun 1906; p. 1, c. } 7\end{array}$ & $\begin{array}{l}\text { "SAN FRANCISCO, June 16-_A sharp earthquake was felt at } \\
\text { 9:35 last night and another slight shock half an hour later. } \\
\text { "No damage was done to buildings, but many people were } \\
\text { frightened and ran into the streets." }\end{array}$ \\
\hline 15-Jun-06 & 22:35 & San Francisco & San Francisco & & $\begin{array}{l}\text { San Jose Mercury, } \\
\text { 16 Jun 1906; p. 1, c. 6-7 }\end{array}$ & $\begin{array}{l}\text { "SAN FRANCISCO, June } 15 .- \text {.... Two more earthquake shocks } \\
\text { were experienced here at 10:35 tonight." } \\
\text { A very similar article appeared in the Sacramento Union of } \\
16 \text { Jun 1906, } p .1, c .7 \text {. }\end{array}$ \\
\hline 15-Jun-06 & & Santa Cruz & Santa Cruz & & $\begin{array}{l}\text { Santa Cruz Morning Sentinel, } \\
16 \text { Jun 1906; p. } 7, \text { c. } 1\end{array}$ & "A baby earthquake...." \\
\hline 25-Jun-06 & 09:15 & Ferndale & Humboldt & & $\begin{array}{l}\text { Humboldt Standard, } \\
\text { 26 Jun 1906; p. 3, c. } 4\end{array}$ & $\begin{array}{l}\text { "Quite a severe earthquake shock was felt.... No damage } \\
\text { resulted." }\end{array}$ \\
\hline 06-Jul-06 (?) & $\sim$ 13:00 & Shasta & Shasta & & \begin{tabular}{|c|} 
Courier-Free Press (Redding), \\
$12 \mathrm{Jul} 1906 ;$ p. 7, c. $1-2$
\end{tabular} & $\begin{array}{l}\text { "A little piece of belated news has floated down from the old } \\
\text { town of Shasta that is important inasmuch as it shows that on } \\
\text { last Friday afternoon there was some sort of a disturbance in the } \\
\text { Shasta region, probably an earthquake, that caused much } \\
\text { commotion and some damage. } \\
\text { "About } 1 \text { o'clock that afternoon, which in the quiet old town is } \\
\text { the quietest time of the day, when everything is still and not a soul } \\
\text { is to be seen except those who sit on their east porches to cool }\end{array}$ \\
\hline
\end{tabular}


TABLE 1: Catalog of Aftershock Reports following from the Great 18 April 1906 California Earthquake

\begin{tabular}{|c|c|c|c|c|c|c|}
\hline Date Felt & $\begin{array}{l}\text { Time Felt } \\
\text { (PST) }\end{array}$ & $\begin{array}{l}\text { Location Felt } \\
\text { (City) }\end{array}$ & $\begin{array}{l}\text { Location Felt } \\
\text { (County) }\end{array}$ & $\begin{array}{l}\text { Unreliable? } \\
\text { Not Felt? }^{+}\end{array}$ & Source & Relevant Citations and other Notes \\
\hline & & & & & & $\begin{array}{l}\text { themselves off, a terrific rumbling and crashing noise was heard, } \\
\text { coming apparently from the northern part of town. } \\
\text { "Those who heard it, and nearly everyone in Shasta experienced } \\
\text { the sensation, thought it was an earthquake and the street was } \\
\text { very soon filled with an anxious and inquiring populace. The } \\
\text { crashing noise emanated from the old Charles McDonald saloon } \\
\text { and there was a general rush for that building.... } \\
\text { "[Inside] on the floor lay tons of debris-bricks, laths and } \\
\text { plastering. The ceiling had fallen in with the exception of one } \\
\text { solitary joist and a portion of the interior walls collapsed. } \\
\text { "A peculiar feature about the affair is that a large and valuable } \\
\text { glass mirror that hung behind the bar escaped uninjured and } \\
\text { unscarred. } \\
\text { "About the same time that the McDonald saloon interior } \\
\text { collapsed an incident occurred on the Iron Mountain road that } \\
\text { gives strength to the earthquake theory. A driver was watering } \\
\text { his team at the trough between Shasta and Iron Mountain. He } \\
\text { asserts positively that about } 1 \text { o' clock, as he stood at the trough } \\
\text { watering his horses, he heard a terrible rumbling and rolling } \\
\text { noise and on looking up saw huge rocks and boulders rolling } \\
\text { down the hillside. He even saw the places from whence these } \\
\text { boulders came, and was confident nothing less than an } \\
\text { earthquake could have loosened them. } \\
\text { "There are many old buildings in Shasta that would not need } \\
\text { mudh of a shock to reduce them to a pile of debris and many } \\
\text { believe that Friday's affair was simply the natural cause of } \\
\text { decay, but the Iron Mountain incident, occurring at the same time, } \\
\text { is either evidence of a seismic disturbance or a very remarkable } \\
\text { coincidence." } \\
\text { An article on p. 2, c. } 1 \text { of the } 13 \text { Jul } 1906 \text { issue of the Courier-Free } \\
\text { Press adds more information to this story: } \\
\text { “... The building had not been used for years, but Will Hartman } \\
\text { was preparing to use the building for sleeping quarters, as it was } \\
\text { one of the coolest places in town. He noticed the walls spreading } \\
\text { and concluded not to occupy the place. Soon after the roof and } \\
\text { timbers crashed in." }\end{array}$ \\
\hline 06-Jul-06 & $\sim 22: 00$ & Coalinga & Fresno & & $\begin{array}{l}\text { Hanford Weekly Sentinel, } \\
12 \text { Jul 1906; p. 2, c. } 3\end{array}$ & $\begin{array}{l}\text { "A report came over the railroad wire Saturday saying that there } \\
\text { was an earthquake shock in Coalinga at about } 10 \text { o' clock Friday } \\
\text { night. The report stated that the Odd Fellows were holding a } \\
\text { meeting, and the severity of the jar caused the company to hurry } \\
\text { onto the streets. No damage is reported from the temblor, but the } \\
\text { people were badly frightened. }\end{array}$ \\
\hline
\end{tabular}


TABLE 1: Catalog of Aftershock Reports following from the Great 18 April 1906 California Earthquake

\begin{tabular}{|c|c|c|c|c|c|c|}
\hline Date Felt & $\begin{array}{l}\text { Time Felt } \\
\text { (PST) }\end{array}$ & $\begin{array}{l}\text { Location Felt } \\
\text { (City) }\end{array}$ & $\begin{array}{l}\text { Location Felt } \\
\text { (County) }\end{array}$ & $\begin{array}{c}\text { Unreliable? } \\
\text { Not Felt? }^{+}\end{array}$ & Source & Relevant Citations and other Notes \\
\hline & & $\begin{array}{l}\text { Lemoore } \\
\text { Hanford }\end{array}$ & $\begin{array}{l}\text { Kings } \\
\text { Kings }\end{array}$ & & & $\begin{array}{l}\text { "Railroad men coming from Lemoore Saturday morning, said that } \\
\text { the shock was felt there at about the same time that Coalinga was } \\
\text { shaken, but the jar was not so perceptible. The disturbance was } \\
\text { felt here by a few, and was apparently very slight, but Hanford } \\
\text { will not be envious of the two towns to the west on account of } \\
\text { their being favored by a greater shock." } \\
\text { See Table 12. }\end{array}$ \\
\hline 06-Jul-06 & \begin{tabular}{|c|} 
shortly after \\
$22: 00$
\end{tabular} & $\begin{array}{l}\text { Coalinga } \\
\text { Lemoore } \\
\text { Hanford }\end{array}$ & $\begin{array}{l}\text { Fresno } \\
\text { Kings } \\
\text { Kings }\end{array}$ & & $\begin{array}{l}\text { Hanford Daily Journal, } \\
7 \text { Jul 1906; p. 5, c. } 3\end{array}$ & $\begin{array}{l}\text { "An earthquake shock, lasting several seconds, visited Coalinga } \\
\text { shortly after } 10 \text { o' clock last night, causing no damage, but almost } \\
\text { creating a panic at a meeting of the local lodge of Odd Fellows, } \\
\text { which was in session at the time. } \\
\text { "Brakeman Roberts, of the Coalinga-Goshen S. P. passenger train, } \\
\text { reports that the shock was plainly felt by him in Lemoore, and } \\
\text { several Hanfordites state that the trembling was slightly } \\
\text { noticeable in this city." } \\
\text { See Table 12. }\end{array}$ \\
\hline 06-Jul-06 & $\begin{array}{c}\text { shortly after } \\
22: 00\end{array}$ & $\begin{array}{l}\text { Coalinga } \\
\text { Lemoore } \\
\text { Hanford } \\
\text { Fresno }\end{array}$ & $\begin{array}{l}\text { Fresno } \\
\text { Kings } \\
\text { Kings } \\
\text { Fresno }\end{array}$ & $\begin{array}{l}\text { Not Felt } \\
\quad(?)\end{array}$ & $\begin{array}{l}\text { Fresno Morning Republican, } \\
\text { 8 Jul 1906; p. 7, c. } 4\end{array}$ & $\begin{array}{l}\text { "HANFORD, July 7.-A slight earthquake shock was felt in } \\
\text { Coalinga, Lemoore and Hanford shortly after } 10 \text { o'clock last } \\
\text { night. It was most severe in Coalinga, where it was of sufficient } \\
\text { power to cause considerable fright. No damage has been } \\
\text { reported." } \\
\text { The lack of a report from Fresno in this or in other Fresno } \\
\text { newspapers suggests that this earthquake was not felt in Fresno. } \\
\text { See Table 12. }\end{array}$ \\
\hline 06-Jul-06 & $22: 50$ & King City & Monterey & & $\begin{array}{l}\text { Salinas Daily Index, } \\
\text { 11 Jul 1906; p. 1, c. } 4\end{array}$ & $\begin{array}{l}\text { "KING CITY, July 10.-This section was treated to quite a severe } \\
\text { shock of earthquake.... No damage." } \\
\text { See Table } \mathbf{1 2 .}\end{array}$ \\
\hline 06-Jul-06 & $22: 52$ & Salinas & Monterey & & $\begin{array}{l}\text { Lawson (1908), } \\
\text { vol. I, p. } 426\end{array}$ & $\begin{array}{l}\text { felt } \\
\text { See Table } 12 .\end{array}$ \\
\hline 06-Jul-06 & $22: 53$ & $\begin{array}{c}\text { San Luis Obispo } \\
\text { Santa Cruz } \\
\text { Watsonville }\end{array}$ & $\begin{array}{c}\text { San Luis Obispo } \\
\text { Santa Cruz } \\
\text { Santa Cruz }\end{array}$ & & $\begin{array}{l}\text { Semi-Weekly Breeze } \\
\text { (San Luis Obispo), } \\
10 \text { Jul 1906; p. 5, c. } 2\end{array}$ & $\begin{array}{l}\text { Under the heading "(From Saturday's Daily)": } \\
\text { "Some did and others did not feel a slight temblor at seven minutes } \\
\text { to } 11 \text { o'clock last night. Reports from Santa Cruz and } \\
\text { Watsonville state that several distinct shocks were felt, but no } \\
\text { damage was done. However there is no cause for alarm as a } \\
\text { slight shock is a daily occurrence in the northern cities." } \\
\text { See Table 12. }\end{array}$ \\
\hline
\end{tabular}


TABLE 1: Catalog of Aftershock Reports following from the Great 18 April 1906 California Earthquake

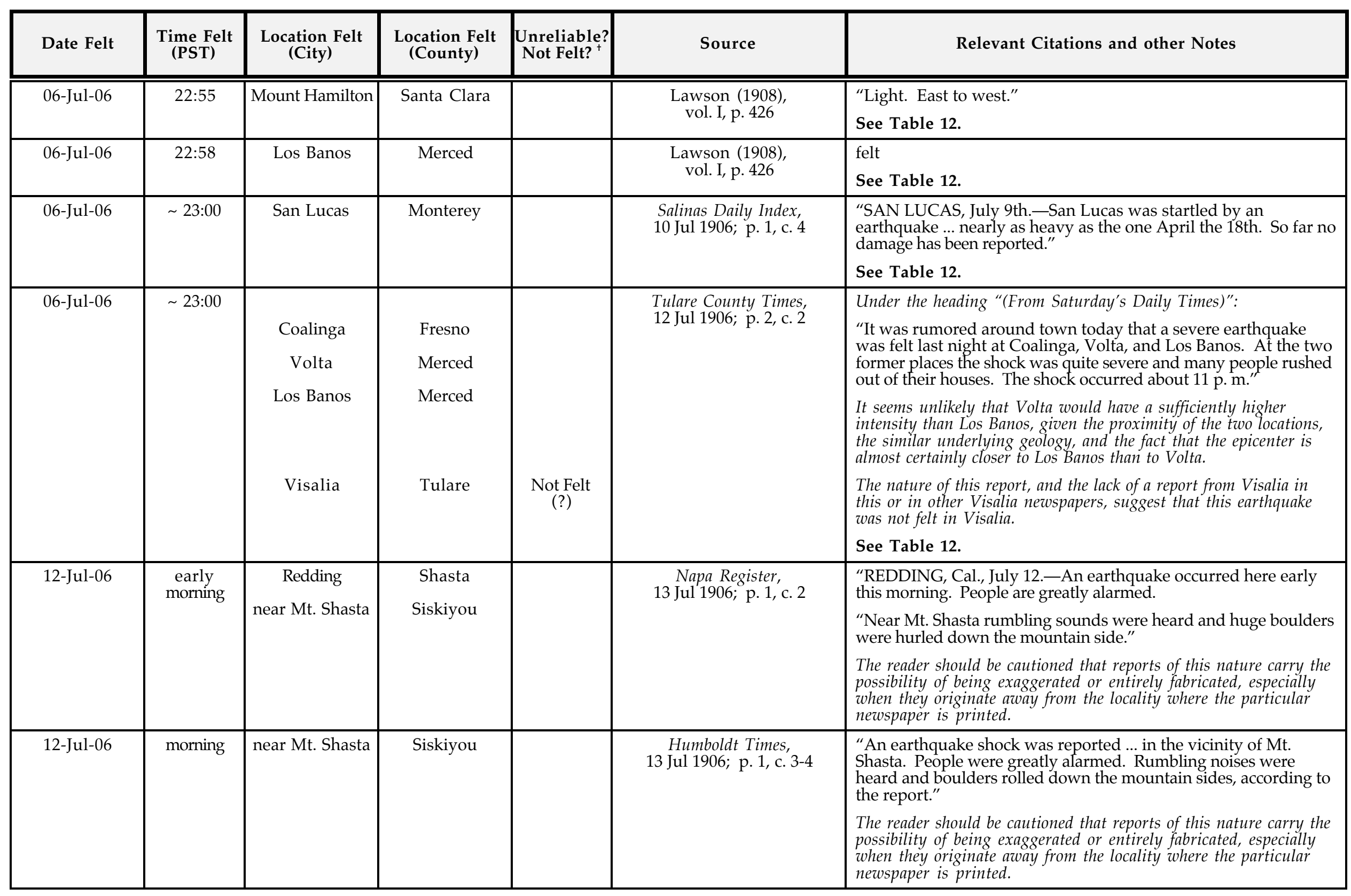


TABLE 1: Catalog of Aftershock Reports following from the Great 18 April 1906 California Earthquake

\begin{tabular}{|c|c|c|c|c|c|c|}
\hline Date Felt & $\begin{array}{l}\text { Time Felt } \\
\text { (PST) }\end{array}$ & $\begin{array}{l}\text { Location Felt } \\
\quad \text { (City) }\end{array}$ & $\begin{array}{l}\text { Location Felt } \\
\text { (County) }\end{array}$ & $\begin{array}{l}\text { Unreliable? } \\
\text { Not Felt? }^{+}\end{array}$ & Source & Relevant Citations and other Notes \\
\hline & & & & & & $\begin{array}{l}\text { Also in the Humboldt Standard of } 12 \mathrm{Jul} 1906, p .1, \text { c. } 6 . \\
\text { Also in the Santa Rosa Republican of } 12 \mathrm{Jul} \mathrm{1906,p.1,} \mathrm{c.} 7 .\end{array}$ \\
\hline 19-Jul-06 & $01: 25$ & San Francisco & San Francisco & & $\begin{array}{l}\text { Santa Rosa Press-Democrat, } \\
20 \text { Jul 1906; p. } 1 \text {, c. } 3\end{array}$ & $\begin{array}{l}\text { "San Francisco, July 19-... a sharp shock of earthquake was felt } \\
\text { here." }\end{array}$ \\
\hline 20-Jul-06 & $\begin{array}{l}\text { early } \\
\text { morning }\end{array}$ & Richmond & Contra Costa & & $\begin{array}{l}\text { Richmond Terminal, } \\
21 \text { Jul 1906; p. 2, c. } 1\end{array}$ & $\begin{array}{l}\text { "Early yesterday morning Old Grandma Earth trembled at the } \\
\text { great growth of the City of Richmond and Mt. Tamalpais is going } \\
\text { further away from Frisco." }\end{array}$ \\
\hline 20-Jul-06 (?) & $\sim 01: 00$ & Martinez & Contra Costa & & $\begin{array}{l}\text { Contra Costa Gazette, } \\
28 \text { Jul 1906; p. } 2, \text { c. } 3\end{array}$ & $\begin{array}{l}\text { "It is so long since the report of an earthquake in the State that it } \\
\text { kind of surprises one to learn that what the geographers call } \\
\text { terra firma, give a little shrug at about } 1 \text { o'clock Friday morning." } \\
\text { It is not clear whether the date of this event was } 20 \text { or } 27 \text { Jul. It } \\
\text { should be noted, however, that this paper was the weekly version of } \\
\text { the Daily Gazette (Martinez), and articles printed in the daily } \\
\text { version in a given week were often re-printed at the end of the week } \\
\text { in the weekly version, without any information as to the date on } \\
\text { which the article was originally published. (In other words, it is } \\
\text { possible that this article was originally printed as early as } 21 \text { Jul, } \\
\text { in which case "Friday" would refer to } 20 \text { Jul.) Based on the timing } \\
\text { of the event and on other felt reports in the area on } 20 \text { Jul (and not } \\
\text { on } 27 \text { Jul) it is presumed that this is the } 20 \text { Jul event. No copies of } \\
\text { the Daily Gazette could be located for Jul } 1906 \text {. }\end{array}$ \\
\hline 20-Jul-06 & 01:00 & Berkeley & Alameda & & $\begin{array}{l}\text { Oakland Enquirer, } \\
20 \text { Jul 1906; p. } 3 \text {, c. } 1\end{array}$ & $\begin{array}{l}\text { "BERKELEY, July 20.-An earthquake shock was felt in } \\
\text { Berkeley at an early hour this morning. According to the record } \\
\text { made on the university seismograph the exact time of the shock } \\
\text { was } 1 \text { o'clock and the direction from north to south. The shock } \\
\text { lasted for several seconds." }\end{array}$ \\
\hline 20-Jul-06 & $\begin{array}{c}\text { a little after } \\
01: 00\end{array}$ & Berkeley & Alameda & & $\begin{array}{l}\text { Oakland Tribune, } \\
20 \text { Jul 1906; p. } 8 \text {, c. } 5\end{array}$ & $\begin{array}{l}\text { "BERKELEY, July 20.-A slight earthquake is reported to have } \\
\text { occurred this morning a little after } 1 \text { o'clock by the university } \\
\text { authorities. The shock ... was from northwest to southeast. Its } \\
\text { duration was very slight [sic]." }\end{array}$ \\
\hline 20-Jul-06 & $\begin{array}{l}01: 20 \text {, and } \\
\text { other times } \\
\text { (several } \\
\text { events) }\end{array}$ & Alameda & Alameda & & $\begin{array}{l}\text { Daily Encinal (Alameda), } \\
20 \text { Jul 1906; p. 1, c. } 1\end{array}$ & $\begin{array}{l}\text { "Did you feel that earthquake this morning? Well, there was one, } \\
\text { and it occurred at 1:20 o'clock. It had a nice little twist to it, but } \\
\text { it was harmless. Other slight shakes were reported, but they } \\
\text { were so slight that they were hardly perceptible." }\end{array}$ \\
\hline
\end{tabular}


TABLE 1: Catalog of Aftershock Reports following from the Great 18 April 1906 California Earthquake

\begin{tabular}{|c|c|c|c|c|c|c|}
\hline Date Felt & $\begin{array}{l}\text { Time Felt } \\
\text { (PST) }\end{array}$ & $\begin{array}{l}\text { Location Felt } \\
\text { (City) }\end{array}$ & $\begin{array}{l}\text { Location Felt } \\
\text { (County) }\end{array}$ & \begin{tabular}{|l|} 
Unreliable? \\
Not Felt? $^{+}$
\end{tabular} & Source & Relevant Citations and other Notes \\
\hline 30-Jul-06 & $18: 45$ & Eureka & Humboldt & & $\begin{array}{l}\text { Humboldt Standard, } \\
1 \text { Aug 1906; p. 8, c. } 4\end{array}$ & $\begin{array}{l}\text { "... Already this week a number of quakes have been felt here.... } \\
\text { At } 6: 45 \mathrm{p} . \mathrm{m} \text {. Monday there was one that lasted several seconds } \\
\text { and rattled sash weights and sashes quite lively...." }\end{array}$ \\
\hline 30-Jul-06 & 18:48 & Ferndale & Humboldt & & $\begin{array}{l}\text { Humboldt Standard, } \\
2 \text { Aug 1906; p.6, c. } 2\end{array}$ & $\begin{array}{l}\text { "... a heavy shock of earthquake was felt in Ferndale, severe } \\
\text { enough to make the residents take notice, yet not severe enough to } \\
\text { cause any destruction." }\end{array}$ \\
\hline 30-Jul-06 & \begin{tabular}{|c|} 
shortly \\
before 00:00, \\
31 Jul
\end{tabular} & Eureka & Humboldt & & $\begin{array}{l}\text { Humboldt Standard, } \\
1 \text { Aug 1906; p. } 8, \text { c. } 4\end{array}$ & $\begin{array}{l}\text { "... Already this week a number of quakes have been felt here.... } \\
\text { At 6:45 p. m. Monday there was one that lasted several seconds } \\
\text { and rattled sash weights and sashes quite lively. Shortly before } \\
\text { midnight the same night there was another shake-up of about the } \\
\text { same intensity...." }\end{array}$ \\
\hline 01-Aug-06 & $11: 32$ & Eureka & Humboldt & & $\begin{array}{l}\text { Humboldt Standard, } \\
1 \text { Aug 1906; p. } 8, \text { c. } 4\end{array}$ & $\begin{array}{l}\text { "... Already this week a number of quakes have been felt here.... } \\
\text { between } 11: 32 \text { and } 11: 33 \text { a. m. today there was another distinct } \\
\text { shock. It lasted about two seconds, the vibrations being } \\
\text { southeast." }\end{array}$ \\
\hline 01-Aug-06 & $11: 50$ & Upper Mattole & Humboldt & & $\begin{array}{l}\text { Humboldt Standard, } \\
4 \text { Aug 1906; p. 6, c. } 2\end{array}$ & $\begin{array}{l}\text { "... The temblors still continue but are all comparatively light. } \\
\text { One occurred ... at } 11: 50 \text { a. m. and was quite a shock. There have } \\
\text { been none since April } 18 \text { and } 21 \text { heavy enough to do any damage." }\end{array}$ \\
\hline 02-Aug-06 & $\sim 06: 02$ & Martinez & Contra Costa & & $\begin{array}{l}\text { Contra Costa Gazette, } \\
4 \text { Aug 1906; p. } 5, \text { c. } 3\end{array}$ & "... a slight earthquake shock was felt...." \\
\hline 02-Aug-06 & $18: 45$ & $\begin{array}{l}\text { Point Arena } \\
\text { Lighthouse }\end{array}$ & Mendocino & & $\begin{array}{l}\text { Lighthouse Log for } \\
\text { Point Arena Lighthouse, } \\
2 \text { Aug } 1906\end{array}$ & $\begin{array}{l}\text { Excerpt from the entry of } 2 \text { Aug } 1906: \\
\text { "at } 6^{45} \text { p.m. shock of earthquake about } 3 \text { seconds, no visible } \\
\text { damage done, up \& down motion." }\end{array}$ \\
\hline 04-Aug-06 & 03:55 & Vallejo & Solano & & $\begin{array}{l}\text { San Francisco Chronicle, } \\
5 \text { Aug 1906; p. 21, c. } 6\end{array}$ & $\begin{array}{l}\text { "VALLEJO, August } 4 \text {.- There was a short shock of earthquake ... } \\
\text { lasting one second. The vibration was from east to west. No } \\
\text { damage was caused." }\end{array}$ \\
\hline 19-Aug-06 & $\sim 21: 00$ & Petrolia & Humboldt & & $\begin{array}{l}\text { Humboldt Standard, } \\
\text { 3 Sep 1906; p. 6, c. } 3\end{array}$ & $\begin{array}{l}\text { “... Quite a sharp earthquake shock was felt.... It did not damage } \\
\text { beyond giving people a good scare.” }\end{array}$ \\
\hline 17-Sep-06 & $16: 00$ & Ferndale & Humboldt & & $\begin{array}{l}\text { Humboldt Standard, } \\
20 \text { Sep 1906; p. 6, c. } 2\end{array}$ & "... short but severe.... No damage resulted." \\
\hline 17-Sep-06 & $20: 00$ & Ferndale & Humboldt & & $\begin{array}{l}\text { Humboldt Standard, } \\
20 \text { Sep 1906; p. 6, c. } 2\end{array}$ & "... short but severe.... No damage resulted." \\
\hline 17-Sep-06 & night & Fields Landing & Humboldt & & $\begin{array}{l}\text { Humboldt Standard, } \\
21 \text { Sep 1906; p. 6, c. } 3\end{array}$ & $\begin{array}{l}\text { "Fields Landing, Sept. 20._.... Quite sharp earthquake shock } \\
\text { was felt here...." }\end{array}$ \\
\hline 18-Sep-06 & night & Fields Landing & Humboldt & & $\begin{array}{l}\text { Humboldt Standard, } \\
21 \text { Sep 1906; p. 6, c. } 3\end{array}$ & $\begin{array}{l}\text { "Fields Landing, Sept. 20.-.... Quite sharp earthquake shock } \\
\text { was felt here last Monday night [17 Sep] and another Tuesday } \\
\text { night [18 Sep]." }\end{array}$ \\
\hline
\end{tabular}


TABLE 1: Catalog of Aftershock Reports following from the Great 18 April 1906 California Earthquake

\begin{tabular}{|c|c|c|c|c|c|c|}
\hline Date Felt & $\begin{array}{l}\text { Time Felt } \\
\text { (PST) }\end{array}$ & $\begin{array}{l}\text { Location Felt } \\
\text { (City) }\end{array}$ & $\begin{array}{l}\text { Location Felt } \\
\text { (County) }\end{array}$ & $\begin{array}{c}\text { Unreliable? } \\
\text { Not Felt? }^{+}\end{array}$ & Source & Relevant Citations and other Notes \\
\hline 21-Sep-06 & $\sim \sim 03: 00$ & Upper Mattole & Humboldt & & $\begin{array}{c}\text { Humboldt Times, } \\
25 \text { Sep 1906; p. 6, c. } 4\end{array}$ & $\begin{array}{l}\text { "An unusually long but not violent shock of earthquake was } \\
\text { felt...." }\end{array}$ \\
\hline 26-Sep-06 & $\sim \sim 21: 00$ & Ferndale & Humboldt & & $\begin{array}{l}\text { Humboldt Standard, } \\
1 \text { Oct 1906; p. 6, c. } 1\end{array}$ & “... Quite a severe earthquake shock was felt...." \\
\hline 11-Oct-06 & $\sim \sim 05: 30$ & Salinas & Monterey & & $\begin{array}{l}\text { Salinas Weekly Journal, } \\
13 \text { Oct 1906; p. } 3, \text { c. } 3\end{array}$ & $\begin{array}{l}\text { Under the heading "From Friday's Daily Journal": } \\
\text { "A slight shock of earthquake was felt here about 5:30 o'clock } \\
\text { Thursday morning, only hard enough to awaken light sleepers." }\end{array}$ \\
\hline 18-Oct-06 & \begin{tabular}{|c|} 
a few \\
moments after \\
$06: 00$
\end{tabular} & Ferndale & Humboldt & & $\begin{array}{l}\text { Humboldt Standard, } \\
19 \text { Oct 1906; p. 6, c. } 4\end{array}$ & $\begin{array}{l}\text { "Ferndale, Oct. 18._.... Quite a little earthquake shock was felt } \\
\text { here a few moments after } 6 \text { this morning." }\end{array}$ \\
\hline 07-Nov-06 & $02: 15$ & Eureka & Humboldt & & $\begin{array}{l}\text { Humboldt Times, } \\
8 \text { Nov 1906; p. } 8 \text {, c. } 4\end{array}$ & $\begin{array}{l}\text { "Several people felt a slight earthquake shock ... which was of } \\
\text { sufficient intensity to awaken a portion of the population." }\end{array}$ \\
\hline 29-Nov-06 & $\sim$ 17:00 & Potter Valley & Mendocino & & $\begin{array}{l}\text { Ukiah Republican Press, } \\
7 \text { Dec 1906; p. } 4 \text {, c. } 3\end{array}$ & "... a distinct temblor was felt...." \\
\hline 06-Dec-06 & night & $\begin{array}{c}\text { San Luis Obispo } \\
\text { Guadalupe } \\
\text { Cambria } \\
\text { Cayucos }\end{array}$ & $\begin{array}{l}\text { San Luis Obispo } \\
\text { Santa Barbara } \\
\text { San Luis Obispo } \\
\text { San Luis Obispo }\end{array}$ & & $\begin{array}{l}\text { Semi-Weekly Breeze } \\
\text { (San Luis Obispo), } \\
\text { 11 Dec 1906; p. 5, c. } 2\end{array}$ & $\begin{array}{l}\text { Under the heading "(From Friday's Daily)": } \\
\text { "An earthquake shock was felt in San Luis Obispo and Santa } \\
\text { Barbara counties last night. In this city the shock was slight, and } \\
\text { many did not feel it at all, while others were of the opinion that } \\
\text { the end of the world had come. It was felt in Guadalupe, Cambria, } \\
\text { Cayucos and other towns, but from reports received Cambria } \\
\text { seems to have had the most severe shock. } \\
\text { "It was purely local in the county, and was not felt in San } \\
\text { Francisco or Los Angeles. } \\
\text { "The city hall here was shaken and the plaster cracked." }\end{array}$ \\
\hline 06-Dec-06 & $22: 30$ & $\begin{array}{l}\text { Santa Maria } \\
\text { Cambria } \\
\text { Surf }\end{array}$ & \begin{tabular}{|c|} 
Santa Barbara \\
San Luis Obispo \\
Santa Barbara
\end{tabular} & & $\begin{array}{l}\text { Santa Maria Times, } \\
8 \text { Dec 1906; p. 3, c. } 2\end{array}$ & $\begin{array}{l}\text { "A severe earthquake shock was felt here.... The vibration was } \\
\text { from north to south. Judging from reports it was of a local } \\
\text { character, not extending beyond Cambria in the north and Surf in } \\
\text { the south. No damage has been reported." }\end{array}$ \\
\hline 06-Dec-06 & $22: 40$ & \begin{tabular}{|} 
San Luis Obispo \\
Santa Maria \\
Guadalupe \\
Cayucos \\
Cambria
\end{tabular} & \begin{tabular}{|l|} 
San Luis Obispo \\
Santa Barbara \\
Santa Barbara \\
San Luis Obispo \\
San Luis Obispo
\end{tabular} & & $\begin{array}{l}\text { The Morning Press } \\
\text { (Santa Barbara), } \\
8 \text { Dec 1906; p. } 1 \text {, c. } 3\end{array}$ & 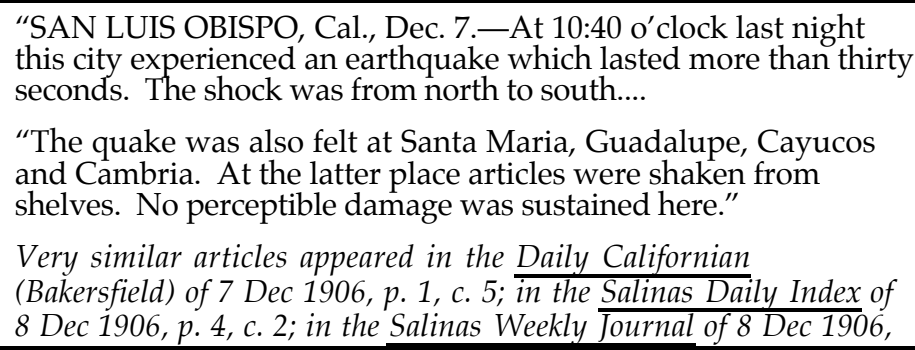 \\
\hline
\end{tabular}


TABLE 1: Catalog of Aftershock Reports following from the Great 18 April 1906 California Earthquake

\begin{tabular}{|c|c|c|c|c|c|c|}
\hline Date Felt & $\begin{array}{l}\text { Time Felt } \\
\text { (PST) }\end{array}$ & $\begin{array}{l}\text { Location Felt } \\
\text { (City) }\end{array}$ & $\begin{array}{l}\text { Location Felt } \\
\text { (County) }\end{array}$ & $\begin{array}{l}\text { Unreliable? } \\
\text { Not Felt? }^{+}\end{array}$ & Source & Relevant Citations and other Notes \\
\hline & & & & & & p. 2,c. 3; and in a number of other papers. \\
\hline 06-Dec-06 & 22:45 & San Luis Obispo & San Luis Obispo & & $\begin{array}{l}\text { Diary of A. F. Sinsheimer } \\
\text { (San Luis Obispo, CA), } \\
6 \text { Dec } 1906\end{array}$ & $\begin{array}{l}\text { Excerpt from the entry of } 6 \text { Dec 1906: } \\
\text { "Slight earthquake at 10:45 p.m. Gertrude [his wife] much } \\
\text { excited." }\end{array}$ \\
\hline 06-Dec-06 & 23:10 & San Luis Obispo & San Luis Obispo & & $\begin{array}{l}\text { The Morning Press } \\
\text { (Santa Barbara), } \\
8 \text { Dec 1906; p. 1, c. } 3\end{array}$ & $\begin{array}{l}\text { "SAN LUIS OBISPO, Cal., Dec. 7.-At 10:40 o'clock last night } \\
\text { this city experienced an earthquake which lasted more than thirty } \\
\text { seconds. The shock was from north to south. Half an hour later a } \\
\text { second shock was felt, but was not so pronounced as the first. } \\
\text { "The quake was also felt at Santa Maria, Guadalupe, Cayucos } \\
\text { and Cambria. At the latter place articles were shaken from } \\
\text { shelves. No perceptible damage was sustained here." } \\
\text { From the wording of the article, it is inferred that the statement } \\
\text { about a quake felt at Santa Maria, Guadalupe, Cayucos, and Cambria } \\
\text { refers only to the larger quake at } 22: 40 \text {. It is not clear whether the } \\
\text { second quake at } 23: 10 \text { was also felt in those locations. } \\
\text { Very similar articles appeared in the Daily Californian } \\
\text { (Bakersfield) of } 7 \text { Dec } 1906, p .1, c \text {. } 5 \text {; in the Salinas Daily Index of } \\
8 \text { Dec 1906, p. 4, c. 2; in the Salinas Weekly Journal of } 8 \text { Dec } 1906 \text {, } \\
\text { p. } 2, \text { c. 3; and in a number of other papers. }\end{array}$ \\
\hline 08-Dec-06 & \begin{tabular}{|c|} 
a little before \\
$03: 00$
\end{tabular} & Martinez & Contra Costa & & $\begin{array}{l}\text { Contra Costa Gazette, } \\
15 \text { Dec 1906; p. 5, c. } 1\end{array}$ & $\begin{array}{l}\text { "A little before } 3 \text { o'clock Saturday morning there was a pretty } \\
\text { sharp shock, followed a quarter of an hour or so later by a } \\
\text { second one, but much slighter." }\end{array}$ \\
\hline 08-Dec-06 & $\begin{array}{c}\text { "a quarter of } \\
\text { an hour or } \\
\text { so" after "a } \\
\text { little before } \\
03: 00^{\prime \prime}\end{array}$ & Martinez & Contra Costa & & $\begin{array}{l}\text { Contra Costa Gazette, } \\
15 \text { Dec 1906; p. 5, c. } 1\end{array}$ & $\begin{array}{l}\text { "A little before } 3 \text { o'clock Saturday morning there was a pretty } \\
\text { sharp shock, followed a quarter of an hour or so later by a } \\
\text { second one, but much slighter." }\end{array}$ \\
\hline 09-Dec-06 & \begin{tabular}{|c|} 
shortly after \\
$03: 00$
\end{tabular} & Martinez & Contra Costa & & $\begin{array}{l}\text { Contra Costa Gazette, } \\
15 \text { Dec 1906; p. 5, c. } 2\end{array}$ & $\begin{array}{l}\text { "Shortly after } 3 \text { a. m. on Sunday morning, old mother earth gave } \\
\text { herself another shake. It was not a very heavy one and did no } \\
\text { damage." }\end{array}$ \\
\hline 25-Dec-06 & $\sim$ 19:45 & Pepperwood & Humboldt & & $\begin{array}{l}\text { Humboldt Standard, } \\
29 \text { Dec 1906; p. 6, c. } 3\end{array}$ & "... A slight shock of an earthquake was felt...." \\
\hline 25-Dec-06 & $\sim 20: 15$ & Eureka & Humboldt & & $\begin{array}{l}\text { Humboldt Standard, } \\
\text { 26 Dec 1906; p. 2, c. } 4\end{array}$ & $\begin{array}{l}\text { "A little tremble was felt in Eureka... In some parts the } \\
\text { earthquake was unnoticed; in others people felt it and said that it } \\
\text { was of longer duration than the one of April 18th. It seems to } \\
\text { have been most noted in the southern portion of the city." }\end{array}$ \\
\hline 25-Dec-06 & $\sim 20: 15$ & Ferndale & Humboldt & & $\begin{array}{l}\text { Humboldt Standard, } \\
26 \text { Dec } 1906 ; \text { p. } 8, \text { c. } 3\end{array}$ & $\begin{array}{l}\text { "Inquiry from Ferndale this morning developed that very few } \\
\text { people there felt the shock of earthquake which was so } \\
\text { pronounced here about 8:15 last night." }\end{array}$ \\
\hline
\end{tabular}


TABLE 1: Catalog of Aftershock Reports following from the Great 18 April 1906 California Earthquake

\begin{tabular}{|c|c|c|c|c|c|c|}
\hline Date Felt & $\begin{array}{c}\text { Time Felt } \\
\text { (PST) }\end{array}$ & $\begin{array}{c}\text { Location Felt } \\
\text { (City) }\end{array}$ & $\begin{array}{c}\text { Location Felt } \\
\text { (County) }\end{array}$ & $\begin{array}{l}\text { Unreliable? } \\
\text { Not Felt? }\end{array}$ & Source & Relevant Citations and other Notes \\
\hline \hline 25-Dec-06 & $20: 18$ & Eureka & Humboldt & & $\begin{array}{c}\text { Humboldt Times, } \\
\text { 29 Dec 1906; p. 1, c. 3-4 }\end{array}$ & $\begin{array}{l}\text { "At 8:18 o'clock last Tuesday night a slight tremblor visited } \\
\text { Eureka and was felt by those indoors. It lasted about four } \\
\text { seconds and vibrated in a direction from north to south, as the } \\
\text { volt meter which records the transmission of electric voltage in } \\
\text { the Humboldt Transit Company's office shows. The pendulum on } \\
\text { this instrument swung about an eighth of an inch out of its usual } \\
\text { track and at exactly 8:18 o'clock Tuesday night...." }\end{array}$ \\
\hline
\end{tabular}

\begin{tabular}{|c|c|c|c|c|c|}
\hline 01-Jan-07 & $\sim 04: 00$ & Yreka & Siskiyou & $\begin{array}{c}\text { Courier-Free Press (Redding), } \\
2 \text { Jan 1907; p. 6, c. } 2\end{array}$ & $\begin{array}{l}\text { "YREKA, January 2.--One shock of earthquake was felt by many } \\
\text { people here yesterday morning at about } 4 \text { o'clock. } \\
\text { "No damage was done, but the visitation was sufficient to } \\
\text { convince those who felt it that it was an earthquake." }\end{array}$ \\
\hline 01-Jan-07 & 04:00 & Etna & Siskiyou & $\begin{array}{c}\text { Courier-Free Press (Redding), } \\
2 \text { Jan 1907; p. 6, c. } 2\end{array}$ & $\begin{array}{l}\text { "ETNA, January 2.-Two lively shocks of earthquake were felt } \\
\text { here yesterday morning. The first shock occurred at } 4 \text { o'clock and } \\
\text { it was the heaviest. } \\
\text { "Windows rattled and chandeliers swayed to and fro. } \\
\text { "People were considerably alarmed and a few rushed out of their } \\
\text { beds, fearing the quake would tear the houses down.... } \\
\text { "The visitation in both instances was northwest to southeast. } \\
\text { "Reports from several points in Western Siskiyou show that the } \\
\text { quake was felt in various places." }\end{array}$ \\
\hline 01-Jan-07 & $08: 00$ & Etna & Siskiyou & $\begin{array}{c}\text { Courier-Free Press (Redding), } \\
2 \text { Jan 1907; p. 6, c. } 2\end{array}$ & $\begin{array}{l}\text { "ETNA, January 2.-Two lively shocks of earthquake were felt } \\
\text { here yesterday morning. The first shock occurred at } 4 \text { o'clock and } \\
\text { it was the heaviest.... } \\
\text { "The second shock came at } 8 \text { o'clock but was much lighter than } \\
\text { the first and was scarcely felt. } \\
\text { "The visitation in both instances was northwest to southeast. } \\
\text { "Reports from several points in Western Siskiyou show that the } \\
\text { quake was felt in various places." } \\
\text { It is not clear whether the last statement refers to both events or to } \\
\text { only the } 4: 00 \text { event. }\end{array}$ \\
\hline 01-Jan-07 & & $\begin{array}{l}\text { Etna } \\
\text { Yreka }\end{array}$ & $\begin{array}{l}\text { Siskiyou } \\
\text { Siskiyou }\end{array}$ & $\begin{array}{c}\text { Farmer and Miner (Fort Jones), } \\
9 \text { Jan 1907; p. 2, c. } 2\end{array}$ & $\begin{array}{l}\text { “It is claimed that an earthquake occurred at Etna and Yreka on } \\
\text { New Year's day. No chimneys were damaged and so far no } \\
\text { fissures have been found in the earth. Fort Jones and Greenview } \\
\text { feel very much slighted that the New Year's day caller did not }\end{array}$ \\
\hline
\end{tabular}


TABLE 1: Catalog of Aftershock Reports following from the Great 18 April 1906 California Earthquake

\begin{tabular}{|c|c|c|c|c|c|c|}
\hline Date Felt & $\underset{\text { (PST) }}{\text { Time Felt }}$ & $\begin{array}{l}\text { Location Felt } \\
\quad \text { (City) }\end{array}$ & $\begin{array}{l}\text { Location Felt } \\
\text { (County) }\end{array}$ & $\begin{array}{l}\text { Unreliable? } \\
\text { Not Felt? }^{+}\end{array}$ & Source & Relevant Citations and other Notes \\
\hline & & $\begin{array}{l}\text { Fort Jones } \\
\text { Greenview } \\
\end{array}$ & $\begin{array}{l}\text { Siskiyou } \\
\text { Siskiyou }\end{array}$ & $\begin{array}{l}\text { Not Felt } \\
\text { Not Felt }\end{array}$ & & visit them...." \\
\hline 04-Jan-07 & $\sim 03: 15$ & Salinas & Monterey & & $\begin{array}{l}\text { Salinas Weekly Journal, } \\
12 \text { Jan 1907; p. 1, c. } 2\end{array}$ & $\begin{array}{l}\text { Under the heading "From last Saturday's Daily Journal": } \\
\text { "A light earthquake shock of about four seconds duration } \\
\text { occurred here about 3:15 o'clock yesterday morning." }\end{array}$ \\
\hline 07-Jan-07 & 23:00 & San Mateo & San Mateo & & $\begin{array}{l}\text { San Mateo Leader, } \\
\text { 9 Jan 1907; p. 3, c. } 2\end{array}$ & $\begin{array}{l}\text { "... a young earthquake reminded our residents that the big } \\
\text { furnace down below is in full blaze." }\end{array}$ \\
\hline 09-Jan-07 & & Point Arena & Mendocino & & $\begin{array}{l}\text { Mendocino Beacon, } \\
19 \text { Jan 1907; p. 5, c. } 3\end{array}$ & $\begin{array}{l}\text { "A slight earthquake shock was felt at Point Arena on } \\
\text { Wednesday of last week...." }\end{array}$ \\
\hline 13-Jan-07 & morning & Eureka & Humboldt & & $\begin{array}{l}\text { Humboldt Standard, } \\
14 \text { Jan } 1907 ; \text { p. } 5, \text { c. } 3\end{array}$ & "... Two slight shocks were ... felt...." \\
\hline 14-Jan-07 & $\sim 03: 00$ & Mendocino & Mendocino & & $\begin{array}{l}\text { Mendocino Beacon, } \\
19 \text { Jan 1907; p. } 5 \text {, c. } 3\end{array}$ & "... quite a pronounced shock was felt here...." \\
\hline 14-Jan-07 & $\sim 04: 00$ & Pepperwood & Humboldt & & $\begin{array}{l}\text { Humboldt Standard, } \\
23 \text { Jan 1907; p. } 5, \text { c. } 5\end{array}$ & $\begin{array}{l}\text { "... Quite an earthquake was felt.... No damage was done and } \\
\text { nobody was hurt." }\end{array}$ \\
\hline 14-Jan-07 & 04:40 & Blocksburg & Humboldt & & $\begin{array}{l}\text { Humboldt Standard, } \\
21 \text { Jan 1907; p. 6, c. } 1\end{array}$ & $\begin{array}{l}\text { “... at 4:40 o'clock we were treated to two earthquake shocks a } \\
\text { few moments apart- a shake and a jolt or apparent drop." }\end{array}$ \\
\hline 14-Jan-07 & $\sim 04: 44$ & Fortuna & Humboldt & & $\begin{array}{l}\text { Humboldt Standard, } \\
16 \text { Jan 1907; p. 5, c. } 4\end{array}$ & $\begin{array}{l}\text { "... our town was disturbed by an earthquake shock—not } \\
\text { disastrous, but enough to make us very wide awake with the } \\
\text { thought of what might happen." }\end{array}$ \\
\hline 14-Jan-07 & $\sim 04: 50$ & Eureka & Humboldt & & $\begin{array}{l}\text { Humboldt Standard, } \\
14 \text { Jan 1907; p. } 5, \text { c. } 3\end{array}$ & $\begin{array}{l}\text { "Another earthquake shook Eureka ... according to a number of } \\
\text { people who declare they felt the vibrations...." }\end{array}$ \\
\hline$\sim 14-J a n-07$ & $\begin{array}{l}\text { (several } \\
\text { events) }\end{array}$ & Burnt Ranch & Trinity & & $\begin{array}{l}\text { Humboldt Standard, } \\
23 \text { Jan 1907; p. 8, c. 6-7 }\end{array}$ & $\begin{array}{l}\text { "Burnt Ranch, January } 15 . \ldots \text {... There have been several } \\
\text { earthquakes in our vicinity lately. Shocks were slight." }\end{array}$ \\
\hline 17-Jan-07 & morning & Viola & Shasta & & $\begin{array}{l}\text { Courier-Free Press (Redding), } \\
24 \text { Jan 1907; p. 6, c. } 1\end{array}$ & $\begin{array}{l}\text { "VIOLA, January 20-- (Delayed in mail.)—An earthquake shock } \\
\text { was felt here ... but it did no damage that we have heard of." }\end{array}$ \\
\hline 18-Jan-07 & 02:00 & Anderson & Shasta & & $\begin{array}{l}\text { Courier-Free Press (Redding), } \\
18 \text { Jan 1907; p. 6, c. } 2\end{array}$ & $\begin{array}{l}\text { "ANDERSON, January 18.-.... Some of the citizens claim a } \\
\text { distinct shock of earthquake was felt here...." }\end{array}$ \\
\hline 21-Jan-07 & & Mendocino & Mendocino & & $\begin{array}{l}\text { Cloverdale Reveille, } \\
26 \text { Jan 1907; p. } 4, \text { c. } 3\end{array}$ & "hard shock" \\
\hline 23-Jan-07 & & Point Arena & Mendocino & & $\begin{array}{l}\text { Cloverdale Reveille, } \\
26 \text { Jan } 1907 ; \text { p. } 4, \text { c. } 3\end{array}$ & "hard shock" \\
\hline
\end{tabular}


TABLE 1: Catalog of Aftershock Reports following from the Great 18 April 1906 California Earthquake

\begin{tabular}{|c|c|c|c|c|c|c|}
\hline Date Felt & $\begin{array}{l}\text { Time Felt } \\
\text { (PST) }\end{array}$ & $\begin{array}{l}\text { Location Felt } \\
\text { (City) }\end{array}$ & $\begin{array}{l}\text { Location Felt } \\
\text { (County) }\end{array}$ & \begin{tabular}{|l|} 
Unreliable? \\
Not Felt? $^{+}$
\end{tabular} & Source & Relevant Citations and other Notes \\
\hline 30-Jan-07 & $\begin{array}{l}\text { night } \\
\text { (or early } \\
\text { morning of } \\
\text { 31-Jan-07) }\end{array}$ & Los Gatos & Santa Clara & & $\begin{array}{l}\text { Los Gatos Mail, } \\
\text { 31 Jan 1907; p. 4, c. } 1\end{array}$ & $\begin{array}{l}\text { "The earthquake last night said 'Shake!' and we shook." } \\
\text { Based on the time reported from nearby communities, this was } \\
\text { probably the earthquake of the early morning of } 31 \text { Jan. }\end{array}$ \\
\hline 31-Jan-07 (?) & & San Francisco & San Francisco & & $\begin{array}{l}\text { The Bulletin (San Francisco), } \\
31 \text { Jan 1907; p. 1, c. } 5\end{array}$ & $\begin{array}{l}\text { "A sharp jolt from the place where the moles live reminded the } \\
\text { city and the surrounding section that the earthquake habit had } \\
\text { not entirely deserted California. Though the little shake was not } \\
\text { serious enough to do any damage, it was sufficient to wake } \\
\text { nervous sleepers to a frightened alertness." } \\
\text { No date is given for this event. Based on the time reported from } \\
\text { nearby communities, this was probably the earthquake of the early } \\
\text { morning of } 31 \text { Jan. }\end{array}$ \\
\hline 31-Jan-07 & $00: 30$ & San Francisco & San Francisco & & $\begin{array}{l}\text { Humboldt Standard, } \\
1 \text { Feb 1907; p. } 5, \text { c. } 5\end{array}$ & $\begin{array}{l}\text { "Passengers who came up from San Francisco on today's Pomona } \\
\text { state that a severe earthquake was felt in the metropolis } \\
\text { Wednesday night at } 12: 30 \text { o' clock. It didn't last long but was a } \\
\text { good strong jerk that scared many people." }\end{array}$ \\
\hline 31-Jan-07 & $00: 32$ & San Francisco & San Francisco & & $\begin{array}{l}\text { San Francisco Call, } \\
\text { 31 Jan 1907; p. 10, c. } 3\end{array}$ & $\begin{array}{l}\text { "A slight earthquake shock was felt.... It was of very brief } \\
\text { duration and caused no damage." }\end{array}$ \\
\hline 31-Jan-07 & $00: 35$ & Palo Alto & Santa Clara & & $\begin{array}{l}\text { The Daily Palo Alto } \\
\text { (Stanford University), } \\
\text { 31 Jan 1907; p. 1, c. } 2\end{array}$ & $\begin{array}{l}\text { "A slight earthquake shock was felt here ... frightening the } \\
\text { residents of the campus and causing those who had not yet retired } \\
\text { to rush into the streets. Excitement reigned in Encina and Roble } \\
\text { throughout the duration of the tremor. No damage was caused by } \\
\text { the quake." }\end{array}$ \\
\hline 31-Jan-07 & $\sim 00: 45$ & Palo Alto & Santa Clara & & $\begin{array}{l}\text { Daily Palo Alto Times, } \\
\text { 31 Jan 1907; p. 1, c. } 6\end{array}$ & $\begin{array}{l}\text { "An earthquake of considerable force jarred the houses and set } \\
\text { the windows to rattling.... It was preceded by the usual rumbling } \\
\text { noise and caused many local residents to prepare for a hasty exit } \\
\text { from their houses should the disturbance show serious intentions. } \\
\text { However, the disturbance was over after a few seconds' } \\
\text { duration." }\end{array}$ \\
\hline 31-Jan-07 & $00: 45$ & San Francisco & San Francisco & & $\begin{array}{l}\text { The Press Democrat } \\
\text { (Santa Rosa), } \\
\text { 31 Jan 1907; p. 1, c. } 1\end{array}$ & $\begin{array}{l}\text { "San Francisco, Jan., 31.-A slight shock of earthquake was } \\
\text { experienced here...." }\end{array}$ \\
\hline 31-Jan-07 & 01:20 & $\begin{array}{c}\text { Livermore } \\
\text { Oakland } \\
\text { San Francisco }\end{array}$ & $\begin{array}{c}\text { Alameda } \\
\text { Alameda } \\
\text { San Francisco }\end{array}$ & & $\begin{array}{l}\text { Livermore Herald, } \\
2 \text { Feb 1907; p. 2, c. } 1\end{array}$ & $\begin{array}{l}\text { "A light shock of earthquake was experienced here.... The shock } \\
\text { was quite severe in Oakland and San Francisco although no } \\
\text { damage is reported." }\end{array}$ \\
\hline 11-Feb-07 & $\sim 19: 45$ & Crescent City & Del Norte & & $\begin{array}{l}\text { Crescent City News, } \\
14 \text { Feb 1907; p. 3, c. } 1\end{array}$ & $\begin{array}{l}\text { "A very perceptible earthquake was felt by many in town... Some } \\
\text { declare it as severe as any experienced here since the memorable } \\
\text { 18th April, while many others did not feel it at all." }\end{array}$ \\
\hline
\end{tabular}


TABLE 1: Catalog of Aftershock Reports following from the Great 18 April 1906 California Earthquake

\begin{tabular}{|c|c|c|c|c|c|c|}
\hline Date Felt & $\begin{array}{l}\text { Time Felt } \\
\text { (PST) }\end{array}$ & $\begin{array}{l}\text { Location Felt } \\
\text { (City) }\end{array}$ & $\begin{array}{l}\text { Location Felt } \\
\text { (County) }\end{array}$ & $\begin{array}{c}\text { Unreliable? } \\
\text { Not Felt? }^{+}\end{array}$ & Source & Relevant Citations and other Notes \\
\hline 11-Feb-07 & $\sim 20: 00$ & Crescent City & Del Norte & & $\begin{array}{l}\text { Del Norte Record, } \\
16 \text { Feb 1907; p.3, c. } 1\end{array}$ & "Some of our citizens reported an earthquake...." \\
\hline 18-Feb-07 & morning & Grizzly Bluff & Humboldt & & $\begin{array}{l}\text { Humboldt Standard, } \\
26 \text { Feb 1907; p. } 4 \text {, c. } 4\end{array}$ & $\begin{array}{l}\text { "Grizzly Bluff, Feb. 24-... An earthquake visited this section } \\
\text { Monday morning giving us a couple of shakes." }\end{array}$ \\
\hline 19-Feb-07 & $\sim \sim 06: 00$ & Petrolia & Humboldt & & $\begin{array}{l}\text { Humboldt Standard, } \\
23 \mathrm{Feb} 1907 ; \text { p. 3, c. } 2\end{array}$ & $\begin{array}{l}\text { "... Quite a sharp earthquake was felt.... No damage was done, } \\
\text { however." }\end{array}$ \\
\hline $25-\mathrm{Feb}-07$ & $\sim 04: 45$ & Fortuna & Humboldt & & $\begin{array}{l}\text { Humboldt Standard, } \\
27 \text { Feb 1907; p. 7, c.7 }\end{array}$ & $\begin{array}{l}\text { "Fortuna, February 26-This vicinity was treated to a slight } \\
\text { earthquake shock about 4:45 o'clock Monday morning." }\end{array}$ \\
\hline $25-\mathrm{Feb}-07$ & 05:10 & Cape Mendocino & Humboldt & & $\begin{array}{c}\text { Lighthouse Log for } \\
\text { Cape Mendocino Lighthouse, } \\
25 \text { Feb } 1907\end{array}$ & $\begin{array}{l}\text { Excerpt from the entry of } 25 \mathrm{Feb} 1907: \\
\text { "at } 5.10 \text { a.m. light earthquake shock was felt lasted } 4 \mathrm{sec}^{\prime}\end{array}$ \\
\hline $25-\mathrm{Feb}-07$ & $05: 15$ & Garberville & Humboldt & & $\begin{array}{l}\text { Humboldt Standard, } \\
1 \text { Mar 1907; p. 7, c. } 7\end{array}$ & "There was a distinct shock of earthquake...." \\
\hline 02-Mar-07 & $05: 45$ & Livermore & Alameda & & $\begin{array}{c}\text { Livermore Echo, } \\
7 \text { Mar 1907; p. 1, c. } 5\end{array}$ & $\begin{array}{l}\text { "An earthquake was felt here at 5:45 o'clock Saturday morning, } \\
\text { and another light shock at 12:25 P. M. the same day set hanging } \\
\text { lamps swinging slightly." }\end{array}$ \\
\hline 02-Mar-07 & $12: 25$ & Livermore & Alameda & & $\begin{array}{c}\text { Livermore Echo, } \\
7 \text { Mar 1907; p. 1, c. } 5\end{array}$ & $\begin{array}{l}\text { “... another light shock at 12:25 P. M. ... set hanging lamps swinging } \\
\text { slightly." }\end{array}$ \\
\hline 02-Mar-07 & afternoon (?) & $\begin{array}{l}\text { Cupertino } \\
\text { Santa Clara }\end{array}$ & $\begin{array}{l}\text { Santa Clara } \\
\text { Santa Clara }\end{array}$ & & $\begin{array}{l}\text { Mountain View Register, } \\
8 \text { Mar 1907; p. 2, c. } 4\end{array}$ & $\begin{array}{l}\text { Under the heading "Cupertino Correspondence": } \\
\text { "Saturday last there was a very heavy earthquake shock felt here } \\
\text { and the earth trembled all afternoon. A friend stated that in } \\
\text { Santa Clara their dishes rattled and the shock was very } \\
\text { noticeable." }\end{array}$ \\
\hline 24-Mar-07 & 05:00 & San Rafael & Marin & & $\begin{array}{l}\text { Marin Journal, } \\
28 \text { Mar 1907; p. 3, c. } 4\end{array}$ & $\begin{array}{l}\text { "A slight shock of earthquake was experienced.... It was light } \\
\text { and of very brief duration and many of the local citizens were not } \\
\text { awakened by the temblor. No damage was done." }\end{array}$ \\
\hline 24-Mar-07 & $\sim \sim 05: 30$ & $\begin{array}{c}\text { Napa } \\
\text { San Francisco }\end{array}$ & $\begin{array}{c}\text { Napa } \\
\text { San Francisco }\end{array}$ & & $\begin{array}{l}\text { Napa Daily Journal, } \\
26 \text { Mar 1907; p. 3, c. } 1\end{array}$ & $\begin{array}{l}\text { "A slight shock of earthquake was felt in this city at half-past } \\
\text { five Sunday morning. The 'shake' is said to have been quite } \\
\text { severe in San Francisco." }\end{array}$ \\
\hline 24-Mar-07 & $\sim 05: 45$ & Corte Madera & Marin & & $\begin{array}{l}\text { Marin County Tocsin, } \\
30 \text { Mar 1907; p. } 1, \text { c. } 3\end{array}$ & $\begin{array}{l}\text { "The residents of the community got quite a scare by the severe } \\
\text { earthquake...." }\end{array}$ \\
\hline 25-Mar-07 (?) & morning & Mill Valley & Marin & & $\begin{array}{l}\text { Sausalito News, } \\
30 \text { Mar 1907; p. 3, c. } 3\end{array}$ & $\begin{array}{l}\text { "Monday morning the Valley enjoyed an earthquake, but it did no } \\
\text { damage, although many of the residents arose as a result sooner } \\
\text { than they do usually." } \\
\text { Probably misdated; more likely, this is the event of } 24 \text { Mar } 1907 .\end{array}$ \\
\hline 30-Mar-07 & afternoon & Larkspur & Marin & & $\begin{array}{l}\text { Marin County Tocsin, } \\
6 \text { Apr 1907; p. 1, c. 6-7 }\end{array}$ & $\begin{array}{l}\text { "The shock ... seemed to renew the timidity left in the people after } \\
\text { the earthquake on the eighteenth." }\end{array}$ \\
\hline
\end{tabular}


TABLE 1: Catalog of Aftershock Reports following from the Great 18 April 1906 California Earthquake

\begin{tabular}{|c|c|c|c|c|c|c|}
\hline Date Felt & $\begin{array}{l}\text { Time Felt } \\
\text { (PST) }\end{array}$ & $\begin{array}{l}\text { Location Felt } \\
\text { (City) }\end{array}$ & $\begin{array}{l}\text { Location Felt } \\
\text { (County) }\end{array}$ & $\begin{array}{l}\text { Unreliable? } \\
\text { Not Felt? }^{+}\end{array}$ & Source & Relevant Citations and other Notes \\
\hline 30-Mar-07 & $14: 30$ & $\begin{array}{l}\text { San Francisco } \\
\text { San Rafael } \\
\text { Petaluma }\end{array}$ & $\begin{array}{l}\text { San Francisco } \\
\text { Marin } \\
\text { Sonoma }\end{array}$ & & $\begin{array}{c}\text { Marin Journal, } \\
4 \text { Apr 1907; p. 5, c. } 6\end{array}$ & $\begin{array}{l}\text { "There was a slight shock of earthquake on Saturday afternoon } \\
\text { at 2:30. It was felt at San Francisco, San Rafael and in Petaluma } \\
\text { and was quite sharp but of very brief duration. No damage } \\
\text { whatever was done by the temblor." }\end{array}$ \\
\hline 30-Mar-07 & $14: 30$ & $\begin{array}{l}\text { San Francisco } \\
\text { Livermore }\end{array}$ & $\begin{array}{l}\text { San Francisco } \\
\text { Alameda }\end{array}$ & $\begin{array}{l}\text { Not Felt } \\
\quad(?)\end{array}$ & $\begin{array}{l}\text { Livermore Echo, } \\
4 \text { Apr 1907; p. } 1, \text { c. } 3\end{array}$ & $\begin{array}{l}\text { "Several Livermore people who were in the city last Saturday } \\
\text { report having felt a sharp earthquake there at 2:30 P. M." } \\
\text { From the nature of this report, it appears as though the event was } \\
\text { not felt in Livermore. }\end{array}$ \\
\hline 30-Mar-07 & $14: 30$ & $\begin{array}{c}\text { San Rafael } \\
\text { San Francisco }\end{array}$ & $\begin{array}{c}\text { Marin } \\
\text { San Francisco }\end{array}$ & $\begin{array}{l}\text { Not Felt } \\
\quad(?)\end{array}$ & $\begin{array}{l}\text { Santa Rosa Republican, } \\
30 \text { Mar 1907; p. 5, c. } 4\end{array}$ & $\begin{array}{l}\text { "There was a slight temblor at San Rafael at 2:30 o'clock this } \\
\text { Saturday afternoon. It was not felt at San Francisco or } \\
\text { neighboring points." } \\
\text { The statement about San Francisco appears to be incorrect, as other } \\
\text { reports indicate that the earthquake was felt in San Francisco. }\end{array}$ \\
\hline 30-Mar-07 & $\sim 16: 30$ & Salinas & Monterey & & $\begin{array}{l}\text { San Francisco Call, } \\
31 \text { Mar 1907; p. 40, c. } 3\end{array}$ & $\begin{array}{l}\text { "SALINAS, March 30.-A slight shock of earthquake was felt } \\
\text { here.... The vibration was north and south. No damage was } \\
\text { done." }\end{array}$ \\
\hline 30-Mar-07 & $16: 32$ & Salinas & Monterey & & $\begin{array}{l}\text { Salinas Weekly Journal, } \\
6 \text { Apr 1907; p. 1, c. } 5\end{array}$ & $\begin{array}{l}\text { Under the heading "From Sunday's Daily Journal": } \\
\text { "At 4:32 yesterday afternoon there occurred two slight } \\
\text { earthquake shocks, following each other in quick succession. } \\
\text { They were the heaviest shocks felt here for some months. Several } \\
\text { persons ran out of the brick buildings into the street." }\end{array}$ \\
\hline early $\underset{(?)}{\text { Apr }} 1907$ & & Canby & Modoc & & $\begin{array}{c}\text { Courier-Free Press (Redding) } \\
9 \text { Apr 1907; p. } 2, \text { c. } 2\end{array}$ & $\begin{array}{l}\text { "ALTURAS, April 9.-During the recent record-breaking storm } \\
\text { an earthquake occurred at Canby which has left its mark upon } \\
\text { the landscape for all time. } \\
\text { "The temblor was felt by only a few persons, but the mountain } \\
\text { range that passes west of the little town was split open. } \\
\text { "A chasm about four feet wide and seemingly bottomless lies open } \\
\text { for over a mile through the snow. } \\
\text { "Whether the crack was caused by a readjustment of the earth's } \\
\text { crust in the vicinity, or by an explosion of gases, cannot yet be } \\
\text { determined. Some investigation has been made by people in the } \\
\text { vicinity and they have found a black mineralized substance } \\
\text { resembling asphalt in some of its properties.... } \\
\text { "The shock knocked down the chimney on Tilman Hess' [sic] } \\
\text { house, but did no other damage that has been reported...." }\end{array}$ \\
\hline early Apr 1907 & & near Canby & Modoc & & $\begin{array}{l}\text { Big Valley Gazette (Bieber), } \\
11 \text { Apr 1907; p. } 1, \text { c. } 3\end{array}$ & $\begin{array}{l}\text { "Supervisor Conklin brings up news this week of an interesting } \\
\text { occurrence of nature in the mountains near the Canby bridge, says } \\
\text { the Modoc Republican. }\end{array}$ \\
\hline
\end{tabular}


TABLE 1: Catalog of Aftershock Reports following from the Great 18 April 1906 California Earthquake

\begin{tabular}{|c|c|c|c|c|c|c|}
\hline Date Felt & $\begin{array}{l}\text { Time Felt } \\
\text { (PST) }\end{array}$ & $\begin{array}{l}\text { Location Felt } \\
\text { (City) }\end{array}$ & $\begin{array}{l}\text { Location Felt } \\
\text { (County) }\end{array}$ & $\begin{array}{l}\text { Unreliable? } \\
\text { Not Felt? }^{+}\end{array}$ & Source & Relevant Citations and other Notes \\
\hline & & & & & & $\begin{array}{l}\text { "From some cause the ground was split open. The fissure opened } \\
\text { up the side of the mountain, and was readily traceable with the } \\
\text { eye from the road, for a considerable distance of its course. } \\
\text { "The fissure makes a dark line where it opened up through the } \\
\text { snow on the mountain side. } \\
\text { "It would seem that the rending of the ground was accompanied } \\
\text { by an earthquake, as the chimney of a house belonging to Mr. } \\
\text { Hess, and standing about one hundred and fifty yards from the } \\
\text { fissure, was thrown down by the shock. The earthquake shock } \\
\text { did not extend very far however or at least it was not felt. } \\
\text { "The fissure must be a mile or more in length and seems to be very } \\
\text { deep. The occurrence is a strange one and is exciting considerable } \\
\text { curiosity." }\end{array}$ \\
\hline 08-Apr-07 & 11:30 & Jamesburg & Monterey & & $\begin{array}{l}\text { Salinas Weekly Journal, } \\
20 \text { Apr 1907; p. 1, c. } 1\end{array}$ & $\begin{array}{l}\text { "JAMESBURG, April 11.-We had a light shock of earthquake } \\
\text { Monday at 11:30 a. m." }\end{array}$ \\
\hline 17-Apr-07 & $\begin{array}{l}\text { 01:30 } \\
\end{array}$ & Ferndale & Humboldt & & $\begin{array}{l}\text { Humboldt Standard, } \\
19 \text { Apr 1907; p. 7, c. } 5\end{array}$ & “... light shock.... No damage." \\
\hline 17-Apr-07 & $\sim 04: 30$ & Ferndale & Humboldt & & $\begin{array}{l}\text { Humboldt Standard, } \\
19 \text { Apr 1907; p. 7, c. } 5\end{array}$ & “... light shock.... No damage." \\
\hline 17-Apr-07 & 15:50 & Salinas & Monterey & & $\begin{array}{l}\text { Monterey Daily Cypress, } \\
18 \text { Apr 1907; p. 1, c. } 5\end{array}$ & $\begin{array}{l}\text { "Two shocks of earthquake were felt at Salinas yesterday } \\
\text { afternoon. One occurred at 3:50.... } \\
\text { "No damage was done to any of the buildings." } \\
\text { Compare this with the text cited from this newspaper for Salinas } \\
\text { for the shock at 16:52 on } 17 \text { Apr. }\end{array}$ \\
\hline 17-Apr-07 & $16: 36$ & Salinas & Monterey & & $\begin{array}{l}\text { Salinas Daily Index, } \\
18 \text { Apr 1907; p. 3, c. } 5\end{array}$ & $\begin{array}{l}\text { "There was quite a jolt of earthquake yesterday afternoon at 4:36 } \\
\text { o'clock just to remind the people that the anniversary of the great } \\
\text { quake was about to occur. It rattled dishes but broke nothing." }\end{array}$ \\
\hline 17-Apr-07 & $16: 36$ & Salinas & Monterey & & $\begin{array}{l}\text { Salinas Weekly Journal, } \\
20 \text { Apr 1907; p. } 3 \text {, c. } 4\end{array}$ & $\begin{array}{l}\text { Under the heading "From Thursday's Daily Journal": } \\
\text { "... Yesterday afternoon at } 4: 36 \text { o'clock ... there was a pronounced } \\
\text { little shake that made chandeliers swing and glasses rattle. It } \\
\text { was a swaying motion of very short duration and the oscillations } \\
\text { seemed to be from south to north." }\end{array}$ \\
\hline 17-Apr-07 & $16: 52$ & Salinas & Monterey & & $\begin{array}{l}\text { Monterey Daily Cypress, } \\
18 \text { Apr 1907; p. 1, c. } 5\end{array}$ & $\begin{array}{l}\text { "Two shocks of earthquake were felt at Salinas yesterday } \\
\text { afternoon. One occurred at 3:50 and the other at 4:52. } \\
\text { "The second shock was a heavy one, and the people ran from } \\
\text { stores and houses into the streets. At the Court House the } \\
\text { officials were particularly active in getting out. } \\
\text { "County Surveyor Hare and a party of men were at work near }\end{array}$ \\
\hline
\end{tabular}


TABLE 1: Catalog of Aftershock Reports following from the Great 18 April 1906 California Earthquake

\begin{tabular}{|c|c|c|c|c|c|c|}
\hline Date Felt & $\begin{array}{l}\text { Time Felt } \\
\text { (PST) }\end{array}$ & $\begin{array}{l}\text { Location Felt } \\
\text { (City) }\end{array}$ & $\begin{array}{l}\text { Location Felt } \\
\text { (County) }\end{array}$ & $\begin{array}{c}\text { Unreliable? } \\
\text { Not Felt? }^{+}\end{array}$ & Source & Relevant Citations and other Notes \\
\hline & & & & & & $\begin{array}{l}\text { Salinas and the level on the instrument was in motion three } \\
\text { minutes from the shock. } \\
\text { "No damage was done to any of the buildings." }\end{array}$ \\
\hline 12-May-07 & $10: 21: 31$ & $\begin{array}{l}\text { Martinez } \\
\text { Berkeley }\end{array}$ & $\begin{array}{l}\text { Contra Costa } \\
\text { Alameda }\end{array}$ & & $\begin{array}{l}\text { Contra Costa Gazette, } \\
18 \text { May 1907; p. 1, c. } 3\end{array}$ & $\begin{array}{l}\text { "On Monday morning, there was a report that on Sunday there } \\
\text { had been an earthquake at Martinez. Not a very big one, but still } \\
\text { noticeable. Many who heard the story said it was not true, but } \\
\text { the following bit of news from Berkeley corroborates the } \\
\text { statement made. } \\
\text { "'A slight earthquake was recorded at the Student's Observatory } \\
\text { Sunday morning, May } 12 \text { th, at } 10 \text { hours, } 21 \text { minutes, } 31 \text { seconds } \\
\text { P.S. T. A very good record was received with the Omori } \\
\text { tromometer, from which Mr. Einarson had deduced the following: } \\
\text { "'Duration of preliminary tremor, } 5 \text { seconds; duration of heavy } \\
\text { motion."” } \\
\text { The last few words of the report appear to be missing in the } \\
\text { newspaper article. }\end{array}$ \\
\hline 12-May-07 & $\sim$ 11:00 & $\begin{array}{c}\text { Petaluma } \\
\text { San Rafael }\end{array}$ & $\begin{array}{l}\text { Sonoma } \\
\text { Marin }\end{array}$ & & $\begin{array}{c}\text { The Press Democrat } \\
\text { (Santa Rosa), } \\
14 \text { May 1907; p. } 8, \text { c. } 2\end{array}$ & $\begin{array}{l}\text { "The Petaluma Argus of Monday night states that a slight shock } \\
\text { of earthquake was felt there, and a severer one in San Rafael, } \\
\text { about eleven o'clock on Sunday morning." }\end{array}$ \\
\hline 15-May-07 & $21: 50$ & Pepperwood & Humboldt & & $\begin{array}{c}\text { Humboldt Standard, } \\
\text { 20 May } 1907^{*} ; \text { p. } 7, \text { c. } 5 \\
\text { * mislabeled as } 18 \text { May } 1907\end{array}$ & “... A very heavy earthquake was felt...." \\
\hline 04-Jun-07 (?) & $00: 27$ & $\begin{array}{l}\text { San Francisco } \\
\text { San Jose }\end{array}$ & $\begin{array}{l}\text { San Francisco } \\
\text { Santa Clara }\end{array}$ & & $\begin{array}{l}\text { San Jose Mercury, } \\
5 \text { Jun 1907; p. 1, c. } 4\end{array}$ & $\begin{array}{l}\text { "SAN FRANCISCO, June 4.-An earthquake shock lasting about } \\
\text { ten seconds was felt here at 12:27 this morning. The oscillation } \\
\text { was from north to south. No damage has been reported." } \\
\text { Then, added below this article: } \\
\text { "The same shock was experienced in San Jose, lasting about six } \\
\text { seconds and of sufficient violence to send many people in lodging } \\
\text { houses down town hustling from their beds into the street, there } \\
\text { to gather in groups and recall past unpleasantries. No damage } \\
\text { has been reported." } \\
\text { This is almost certainly the } 5 \text { Jun } 1907 \text { event. } \\
\text { See Table 13. }\end{array}$ \\
\hline
\end{tabular}


TABLE 1: Catalog of Aftershock Reports following from the Great 18 April 1906 California Earthquake

\begin{tabular}{|c|c|c|c|c|c|c|}
\hline Date Felt & $\begin{array}{l}\text { Time Felt } \\
\text { (PST) }\end{array}$ & $\begin{array}{l}\text { Location Felt } \\
\text { (City) }\end{array}$ & $\begin{array}{l}\text { Location Felt } \\
\text { (County) }\end{array}$ & $\begin{array}{l}\text { Unreliable? } \\
\text { Not Felt? }\end{array}$ & Source & Relevant Citations and other Notes \\
\hline & & & & & & $\begin{array}{l}\text { This is almost certainly the } 5 \text { Jun } 1907 \text { event. } \\
\text { See Table } \mathbf{1 3 .}\end{array}$ \\
\hline$\sim$ 04-Jun-07 & evening & Los Gatos & Santa Clara & & $\begin{array}{l}\text { Los Gatos News, } \\
7 \text { Jun 1907; p. 3, c. } 1\end{array}$ & $\begin{array}{l}\text { "There was a shock of earthquake the other evening that would } \\
\text { have been unnoticed if it had not been for the experience of last } \\
\text { year. Everybody is looking for trouble and excitement. Every } \\
\text { little counts." } \\
\text { Based on the time reported from nearby communities, this was } \\
\text { probably the earthquake of the early morning of } 5 \text { Jun. } \\
\text { See Table 13. }\end{array}$ \\
\hline 04-Jun-07 & night & Berkeley & Alameda & unreliable & $\begin{array}{l}\text { Oak Park Ledger, } \\
\text { 7 Jun 1907; p. 1, c. } 4\end{array}$ & $\begin{array}{l}\text { "... Berkeley was almost shaken to pieces last Tuesday night...." } \\
\text { This is almost certainly the } 5 \text { Jun } 1907 \text { event. The tone of this } \\
\text { article was that of an editorial, and the descriptions were without } \\
\text { doubt exaggerated. No measure of credibility should be given to the } \\
\text { description of shaking above. } \\
\text { See Table 13. }\end{array}$ \\
\hline 05-Jun-07 & $\begin{array}{c}\text { shortly after } \\
\text { midnight }\end{array}$ & $\begin{array}{l}\text { San Francisco } \\
\text { and neighboring } \\
\text { cities bordering } \\
\text { on the San } \\
\text { Francisco Bay } \\
\text { San Jose }\end{array}$ & $\begin{array}{l}\text { San Francisco, } \\
\text { others } \\
\text { Santa Clara }\end{array}$ & & $\begin{array}{l}\text { Evening Pajaronian } \\
\text { (Watsonville), } \\
5 \text { Jun 1907; p. 1, c. } 5\end{array}$ & $\begin{array}{l}\text { "San Francisco, June } 5 .- \text { This city and neighboring cities } \\
\text { bordering on the bay experienced a severe earthquake shock } \\
\text { shortly after midnight.... No serious damage is reported. San Jose } \\
\text { also felt the shock severely." } \\
\text { See Table 13. }\end{array}$ \\
\hline 05-Jun-07 & $\begin{array}{c}\text { shortly past } \\
\text { midnight }\end{array}$ & $\begin{array}{c}\text { Oakland; } \\
\text { about San } \\
\text { Francisco Bay } \\
\text { throughout } \\
\text { Tuolumne County }\end{array}$ & $\begin{array}{l}\text { Alameda, } \\
\text { San Francisco, } \\
\text { others } \\
\text { Tuolumne }\end{array}$ & & $\begin{array}{l}\text { Mother Lode Magnet } \\
\text { (Jamestown), } \\
5 \text { Jun 1907; p. 3, c. } 5\end{array}$ & $\begin{array}{l}\text { "There was a lively shake up by el temblor about San Francisco } \\
\text { bay at shortly past midnight last night. A phone message from } \\
\text { Oakland this a. m. states that no damage of note was done. The } \\
\text { shock was distinctly felt throughout Tuolumne county." } \\
\text { See Table 13. }\end{array}$ \\
\hline 05-Jun-07 & $00: 20$ & Sonoma & Sonoma & & $\begin{array}{l}\text { Sonoma Index-Tribune, } \\
8 \text { Jun 1907; p. 3, c. } 1\end{array}$ & $\begin{array}{l}\text { "There was quite a heavy shock on Wednesday morning at 12:20, } \\
\text { which was followed by a lesser temblor at about } 4 \text { A. M." } \\
\text { See Table } 13 \text {. }\end{array}$ \\
\hline 05-Jun-07 & $00: 25$ & $\begin{array}{l}\text { Napa } \\
\text { about the San } \\
\text { Francisco Bay } \\
\text { San Francisco }\end{array}$ & $\begin{array}{l}\text { Napa } \\
\text { San Francisco, } \\
\text { others } \\
\text { San Francisco }\end{array}$ & & $\begin{array}{l}\text { Napa Daily Journal, } \\
6 \text { Jun 1907; p. } 3 \text {, c. } 3\end{array}$ & $\begin{array}{l}\text { "A distinct shock of earthquake was felt in this city.... The } \\
\text { 'shake' was felt in a number of towns about the bay, and two } \\
\text { tremors were experienced in San Francisco." } \\
\text { See Table 13. }\end{array}$ \\
\hline
\end{tabular}


TABLE 1: Catalog of Aftershock Reports following from the Great 18 April 1906 California Earthquake

\begin{tabular}{|c|c|c|c|c|c|c|}
\hline Date Felt & $\begin{array}{l}\text { Time Felt } \\
\text { (PST) }\end{array}$ & $\begin{array}{l}\text { Location Felt } \\
\text { (City) }\end{array}$ & $\begin{array}{l}\text { Location Felt } \\
\text { (County) }\end{array}$ & $\begin{array}{l}\text { Unreliable? } \\
\text { Not Felt? }^{+}\end{array}$ & Source & Relevant Citations and other Notes \\
\hline 05-Jun-07 & $00: 25$ & San Francisco & San Francisco & & $\begin{array}{c}\text { The Bulletin (San Francisco), } \\
5 \text { Jun 1907; p. 1, c. } 5\end{array}$ & $\begin{array}{l}\text { "A heavy earthquake shock startled this city from its sleep this } \\
\text { morning when the day was just twenty-five minutes old. It lasted } \\
\text { for several seconds, and was felt distinctly in all parts of town. } \\
\text { No damage has been reported. } \\
\text { "According to Professor McAdie, of the Weather Bureau, the } \\
\text { temblor ranks as number four in the seismic scale. The } \\
\text { earthquake of April last year ranks as number nine...." } \\
\text { This article also appeared in the Oakland Tribune of } 5 \text { Jun 1907, } \\
\text { p. 10, c. 2, preceded by the dateline "SAN FRANCISCO, June 5." } \\
\text { See Table 13. }\end{array}$ \\
\hline 05-Jun-07 & $00: 25$ & Redwood City & San Mateo & & $\begin{array}{c}\text { Times-Gazette (Redwood City) } \\
\text { 8 Jun 1907; p. 3, c. } 6\end{array}$ & $\begin{array}{l}\text { "An earthquake visited this community ... which made up in } \\
\text { severity what it lacked in duration...." } \\
\text { See Table 13. }\end{array}$ \\
\hline 05-Jun-07 & $00: 25$ & Livermore & Alameda & & $\begin{array}{l}\text { Livermore Echo, } \\
6 \text { Jun 1907; p. 1, c. } 3\end{array}$ & $\begin{array}{l}\text { "Earthquake.-A short sharp shock of earthquake was felt here } \\
\text { at } 12: 25 \text { Wednesday morning, followed by a lighter shake, and } \\
\text { many light sleepers were awakened." } \\
\text { See Table 13. }\end{array}$ \\
\hline 05-Jun-07 & $00: 26$ & \begin{tabular}{|c|} 
San Francisco \\
and the Bay cities \\
Sacramento
\end{tabular} & $\begin{array}{l}\text { San Francisco, } \\
\text { others } \\
\text { Sacramento }\end{array}$ & unreliable & $\begin{array}{l}\text { San Francisco Call, } \\
5 \text { Jun 1907; p. 3, c. } 7\end{array}$ & $\begin{array}{l}\text { "Two small but distinct earthquake shocks were felt in San } \\
\text { Francisco and the bay cities at 12:26 this morning. The } \\
\text { dispatcher at Oakland pier stated that no reports of the temblor's } \\
\text { having been felt in the interior had been received except from } \\
\text { Sacramento. No damage was reported." } \\
\text { The nature of this report, and the lack of any corroborating reports, } \\
\text { makes the Sacramento report seem rather questionable. } \\
\text { See Table 13. }\end{array}$ \\
\hline 05-Jun-07 & $00: 26: 37$ & Berkeley & Alameda & & $\begin{array}{l}\text { Berkeley Daily Gazette, } \\
5 \text { Jun 1907; p. 1, c. } 3\end{array}$ & $\begin{array}{l}\text { "There was a baby earthquake in Berkeley about } 12: 30 \text { o'clock } \\
\text { this morning. It was not a very serious affair, but as it was slow } \\
\text { in action nervous people feared that it might be preliminary to a } \\
\text { more serious disturbance. Light sleepers in frail buildings were } \\
\text { awakened, but it was such a minor shake that they turned over } \\
\text { and went to sleep again... No damage whatever is reported. } \\
\text { "The seismograph at the students' observatory caught the records } \\
\text { distinctly and the belief is that the center of the vibrations was } \\
\text { about fifty miles away. Here is the official reading of the } \\
\text { seismograph: } \\
\text { "“The earthquake of this morning started at 12:26:37 P. S. T. The } \\
\text { preliminary tremor lasted for six seconds when the main shock } \\
\text { began. This was in two parts, the first and more severe lasting } \\
\text { for twenty-one seconds, the other lasting for twenty-eight }\end{array}$ \\
\hline
\end{tabular}


TABLE 1: Catalog of Aftershock Reports following from the Great 18 April 1906 California Earthquake

\begin{tabular}{|c|c|c|c|c|c|c|}
\hline Date Felt & $\begin{array}{l}\text { Time Felt } \\
\text { (PST) }\end{array}$ & $\begin{array}{l}\text { Location Felt } \\
\text { (City) }\end{array}$ & $\begin{array}{l}\text { Location Felt } \\
\text { (County) }\end{array}$ & $\begin{array}{l}\text { Unreliable? } \\
\text { Not Felt? }^{+}\end{array}$ & Source & Relevant Citations and other Notes \\
\hline & & & & & & $\begin{array}{l}\text { seconds, giving a total duration of } 49 \text { seconds for the main shock. } \\
\text { The Omori Seismograph from which these data have been taken } \\
\text { showed smaller tremors for nearly three minutes. The direction of } \\
\text { the vibrations was from southwest to northeast. A greater } \\
\text { disturbance is shown in the east and west component than in the } \\
\text { north and south. The center of the shock is about fifty miles } \\
\text { distant. The maximum amplitude of the shock is one-one- } \\
\text { hundredth of an inch.'"' } \\
\text { See Table 13. }\end{array}$ \\
\hline 05-Jun-07 & $00: 27$ & Oakland & Alameda & & $\begin{array}{c}\text { The Bulletin (San Francisco), } \\
5 \text { Jun 1907; p. 1, c. } 5\end{array}$ & $\begin{array}{l}\text { "... The seismograph at Chabot observatory in Oakland registered } \\
\text { an observation quite different from that of Professor McAdie [in } \\
\text { San Francisco]. According to the Chabot instrument the } \\
\text { earthquake occurred at } 12: 27, \text { two minutes later than in this city, } \\
\text { lasted three seconds and had a general direction of from } \\
\text { northwest to southeast. It was a number five shock, according to } \\
\text { the Oakland observation." } \\
\text { This article also appeared in the Oakland Tribune of } 5 \text { Jun 1907, } \\
\text { p. 10, c. 2, preceded by the dateline "SAN FRANCISCO, June 5." } \\
\text { See Table 13. }\end{array}$ \\
\hline 05-Jun-07 & $00: 27$ & $\begin{array}{c}\text { Palo Alto } \\
\text { all along the } \\
\text { San Francisco } \\
\text { peninsula }\end{array}$ & $\begin{array}{l}\text { Santa Clara } \\
\text { San Mateo, } \\
\text { San Francisco }\end{array}$ & & $\begin{array}{l}\text { Daily Palo Alto Times, } \\
5 \text { Jun 1907; p. } 4 \text {, c. } 2\end{array}$ & $\begin{array}{l}\text { "The earth trembled.... The shock was probably the most severe } \\
\text { that has been experienced since the day of the historic shakeup. } \\
\text { The shock this morning lasted six seconds and was felt all along } \\
\text { the peninsula and the shake was accompanied by a rumbling } \\
\text { noise. No damage was done." } \\
\text { See Table 13. }\end{array}$ \\
\hline 05-Jun-07 & $00: 27$ & \begin{tabular}{c|} 
Los Gatos \\
San Jose \\
San Francisco \\
all of the \\
San Francisco \\
peninsula towns
\end{tabular} & $\begin{array}{l}\text { Santa Clara } \\
\text { Santa Clara } \\
\text { San Francisco } \\
\text { San Mateo, } \\
\text { San Francisco }\end{array}$ & & $\begin{array}{l}\text { Los Gatos Mail, } \\
6 \text { Jun 1907; p. 1, c. } 4\end{array}$ & $\begin{array}{l}\text { "... a quite determined jolt occasioned by some internal } \\
\text { disturbance of Mother Earth. The shock lasted five or six } \\
\text { seconds, perhaps, and caused many a person to 'sit up and take } \\
\text { notice.' Some even got out of bed and out into the cold, cold world } \\
\text { evidently from fear that something might drop. But nothing did } \\
\text { drop or fall down, and so far as has been learned no damage was } \\
\text { done. The shock was also felt in San Jose, San Francisco and all } \\
\text { of the peninsula towns." } \\
\text { See Table 13. }\end{array}$ \\
\hline 05-Jun-07 (?) & $00: 27$ & San Francisco & San Francisco & & $\begin{array}{l}\text { The Evening Mail (Stockton), } \\
5 \text { Jun 1907; p. 1, c. } 7\end{array}$ & $\begin{array}{l}\text { "SAN FRANCISCO, June **-An earthquake shock lasting about } \\
\text { ten seconds was felt here at 12:27 this morning. The oscillation } \\
\text { was from north to south. No damage has been reported.... } \\
\text { "SAN JOSE, June 5.-A slight shock was experienced here. No } \\
\text { damage." } \\
\text { " The date is unreadable, although in comparison to other reports, } \\
\text { the date clearly should be June } 5 \text {. }\end{array}$ \\
\hline
\end{tabular}


TABLE 1: Catalog of Aftershock Reports following from the Great 18 April 1906 California Earthquake

\begin{tabular}{|c|c|c|c|c|c|c|}
\hline Date Felt & $\begin{array}{l}\text { Time Felt } \\
\text { (PST) }\end{array}$ & $\begin{array}{l}\text { Location Felt } \\
\text { (City) }\end{array}$ & $\begin{array}{l}\text { Location Felt } \\
\text { (County) }\end{array}$ & $\begin{array}{l}\text { Unreliable? } \\
\text { Not Felt? }^{+}\end{array}$ & Source & Relevant Citations and other Notes \\
\hline & & & & & & See Table 13. \\
\hline 05-Jun-07 & $00: 27$ & $\begin{array}{c}\text { San Francisco } \\
\text { San Jose }\end{array}$ & $\begin{array}{l}\text { San Francisco } \\
\text { Santa Clara }\end{array}$ & & $\begin{array}{l}\text { Stockton Daily Independent, } \\
5 \text { Jun 1907; p. 1, c. } 4\end{array}$ & $\begin{array}{l}\text { "SAN FRANCISCO, June 5.-An earthquake shock lasting about } \\
\text { ten seconds was felt here at 12:27 this morning. The oscillation } \\
\text { was from north to south. No damage has been reported. } \\
\text { "SAN JOSE, June 4.-A slight shock was experienced here. No } \\
\text { damage." } \\
\text { In comparison to other reports, the dateline for the San Jose report } \\
\text { clearly should be June 5, not June } 4 \text {. } \\
\text { See Table 13. }\end{array}$ \\
\hline 05-Jun-07 & $00: 27$ & \begin{tabular}{|c|} 
Berkeley \\
Mount Hamilton \\
Santa Clara \\
Campbell \\
Los Gatos \\
Oakland \\
Dimond \\
Kentfield \\
Napa \\
Mills College \\
Livermore \\
Menlo Park \\
Sonoma \\
Peachland \\
Boulder Creek \\
San Francisco \\
San Jose
\end{tabular} & $\begin{array}{c}\text { Alameda } \\
\text { Santa Clara } \\
\text { Santa Clara } \\
\text { Santa Clara } \\
\text { Santa Clara } \\
\text { Alameda } \\
\text { Alameda } \\
\text { Marin } \\
\text { Napa } \\
\text { Alameda } \\
\text { Alameda } \\
\text { San Mateo } \\
\text { Sonoma } \\
\text { Sonoma } \\
\text { Santa Cruz } \\
\text { San Francisco } \\
\text { Santa Clara }\end{array}$ & & $\begin{array}{l}\text { Townley and Allen (1939), } \\
\text { p. } 145\end{array}$ & $\begin{array}{l}\text { "San Francisco Bay Region. } \\
\text { Intensity IV to V at Berkeley; } \\
\text { II at Mount Hamilton; } \\
\text { severe at Santa Clara, duration six to seven seconds; } \\
\text { Campbell, Santa Clara Co., light; } \\
\text { Los Gatos, a few miles farther west, light; } \\
\text { Oakland, rather heavy, of five seconds duration; } \\
\text { Dimond, near Oakland, distinct; } \\
\text { Kentfield, Marin Co., sharp; } \\
\text { Napa State Hospital, light.; } \\
\text { Reports with no description came from Oakland, Mills College, } \\
\text { and Livermore, Alameda Co.; Menlo Park, San Mateo Co.; } \\
\text { Sonoma and Peachland, Sonoma Co.; Boulder Creek, Santa Cruz } \\
\text { Co.; San Francisco and San Jose. } \\
\text { "At Berkeley this shock wrote the largest seismogram obtained to } \\
\text { that date on the instrument installed at the University of } \\
\text { California in June of the previous year, with maximum amplitude } \\
\text { of } 251 \mu \text { and 1.9 seconds period in the east-west component, and } \\
\text { an interval L-P of six seconds, corresponding to a distance of } \\
\text { origin of about thirty miles." } \\
\text { This compilation of reports is attributed to the U.S. Weather Bureau } \\
\text { (Form } 1009 \text { ) and to H. F. Reid's Card Catalog. All intensities } \\
\text { estimated by Townley and Allen (1939) are in the Rossi-Forel scale. } \\
\text { See Table 13. }\end{array}$ \\
\hline
\end{tabular}


TABLE 1: Catalog of Aftershock Reports following from the Great 18 April 1906 California Earthquake

\begin{tabular}{|c|c|c|c|c|c|c|}
\hline Date Felt & $\begin{array}{l}\text { Time Felt } \\
\text { (PST) }\end{array}$ & $\begin{array}{l}\text { Location Felt } \\
\text { (City) }\end{array}$ & $\begin{array}{l}\text { Location Felt } \\
\text { (County) }\end{array}$ & $\begin{array}{l}\text { Unreliable? } \\
\text { Not Felt? }^{+}\end{array}$ & Source & Relevant Citations and other Notes \\
\hline 05-Jun-07 & $\begin{array}{l}00: 29 \text { or } \\
00: 30\end{array}$ & Alameda & Alameda & & $\begin{array}{l}\text { Alameda Daily Argus, } \\
5 \text { Jun 1907; p. 1, c. } 7\end{array}$ & $\begin{array}{l}\text { "There was a sharp earthquake shock at } 12: 30 \text { o' clock this } \\
\text { morning. The shock was one of the most severe since the big } \\
\text { quake of April of last year, and rocked houses and agitated timid } \\
\text { nerves. Some wall pieces and ornaments were hurled to the floor } \\
\text { in several homes, but no chimneys were cracked or other damage } \\
\text { sustained. } \\
\text { "Mr. Perrine of } 2138 \text { Alameda avenue, father of Professor } \\
\text { Charles Perrine, the well known astronomer, possesses the only } \\
\text { seismograph in Alameda... The record shows three-quarters of } \\
\text { an inch, almost directly east and west, with a slight variation to } \\
\text { the southeast and northwest. } \\
\text { "According to Mr. Perrine the shock occurred at exactly 12:29." } \\
\text { See Table 13. }\end{array}$ \\
\hline 05-Jun-07 & $\sim 00: 30$ & Martinez & Contra Costa & & $\begin{array}{l}\text { Contra Costa Gazette, } \\
8 \text { Jun } 1907 ; \text { p. } 5, \text { c. } 1\end{array}$ & $\begin{array}{l}\text { "... there was a short but pretty sharp earthquake shock. It was } \\
\text { noticed by a good many who were not asleep at the time and it } \\
\text { woke up quite a number." } \\
\text { See Table } \mathbf{1 3 .}\end{array}$ \\
\hline 05-Jun-07 & $\sim 00: 30$ & Livermore & Alameda & & $\begin{array}{l}\text { Livermore Herald, } \\
8 \text { Jun 1907; p. } 3 \text {, c. } 1\end{array}$ & $\begin{array}{l}\text { "A sharp shock of earthquake was felt here.... It was } \\
\text { accompanied by a subterranean roar which was much more } \\
\text { noticeable than that which preceded the big quake last year." } \\
\text { See Table 13. }\end{array}$ \\
\hline 05-Jun-07 & $00: 30$ & $\begin{array}{l}\text { San Francisco, } \\
\text { elsewhere }\end{array}$ & $\begin{array}{c}\text { San Francisco, } \\
\text { others }\end{array}$ & & $\begin{array}{l}\text { Napa Daily Register, } \\
5 \text { Jun 1907; p. 1, c. } 4\end{array}$ & $\begin{array}{l}\text { "SAN FRANCISCO, June 5.-An earthquake of easy undulating } \\
\text { movement lasting several seconds was felt at 12:30 this morning. } \\
\text { "It was felt in many other California cities. No damage is } \\
\text { reported anywhere." } \\
\text { See Table 13. }\end{array}$ \\
\hline 05-Jun-07 & $\sim 00: 30$ & $\begin{array}{c}\text { Mountain View } \\
\text { all along the } \\
\text { San Francisco } \\
\text { peninsula } \\
\text { San Francisco }\end{array}$ & $\begin{array}{l}\text { Santa Clara } \\
\text { San Mateo, } \\
\text { San Francisco } \\
\text { San Francisco }\end{array}$ & & $\begin{array}{l}\text { Mountain View Register, } \\
7 \text { Jun 1907; p. 3, c. } 3\end{array}$ & $\begin{array}{l}\text { "A little earthquake shock was felt by the citizens of Mountain } \\
\text { View last Tuesday night at about } 12: 30 \text {. It was also felt all along } \\
\text { the peninsula but no damage is reported. In San Francisco it } \\
\text { lasted about ten seconds while here it was only about six. It is } \\
\text { hard to explain the thoughts of a person when old mother earth } \\
\text { begins to rock even though she merely disturbs your midnight } \\
\text { slumbers." } \\
\text { See Table 13. }\end{array}$ \\
\hline 05-Jun-07 & $00: 30$ & $\begin{array}{c}\text { San Francisco } \\
\text { and the Bay cities }\end{array}$ & $\begin{array}{c}\text { San Francisco, } \\
\text { others }\end{array}$ & & $\begin{array}{l}\text { Semi-Weekly Breeze } \\
\text { (San Luis Obispo), } \\
7 \text { Jun 1907; p. 4, c. } 5\end{array}$ & $\begin{array}{l}\text { "San Francisco, June 5.-San Francisco and the bay cities } \\
\text { experienced a sharp earthquake at 12:30 this morning. There was } \\
\text { no damage done, but the shocks were severe and the people were } \\
\text { very much excited. }\end{array}$ \\
\hline
\end{tabular}


TABLE 1: Catalog of Aftershock Reports following from the Great 18 April 1906 California Earthquake

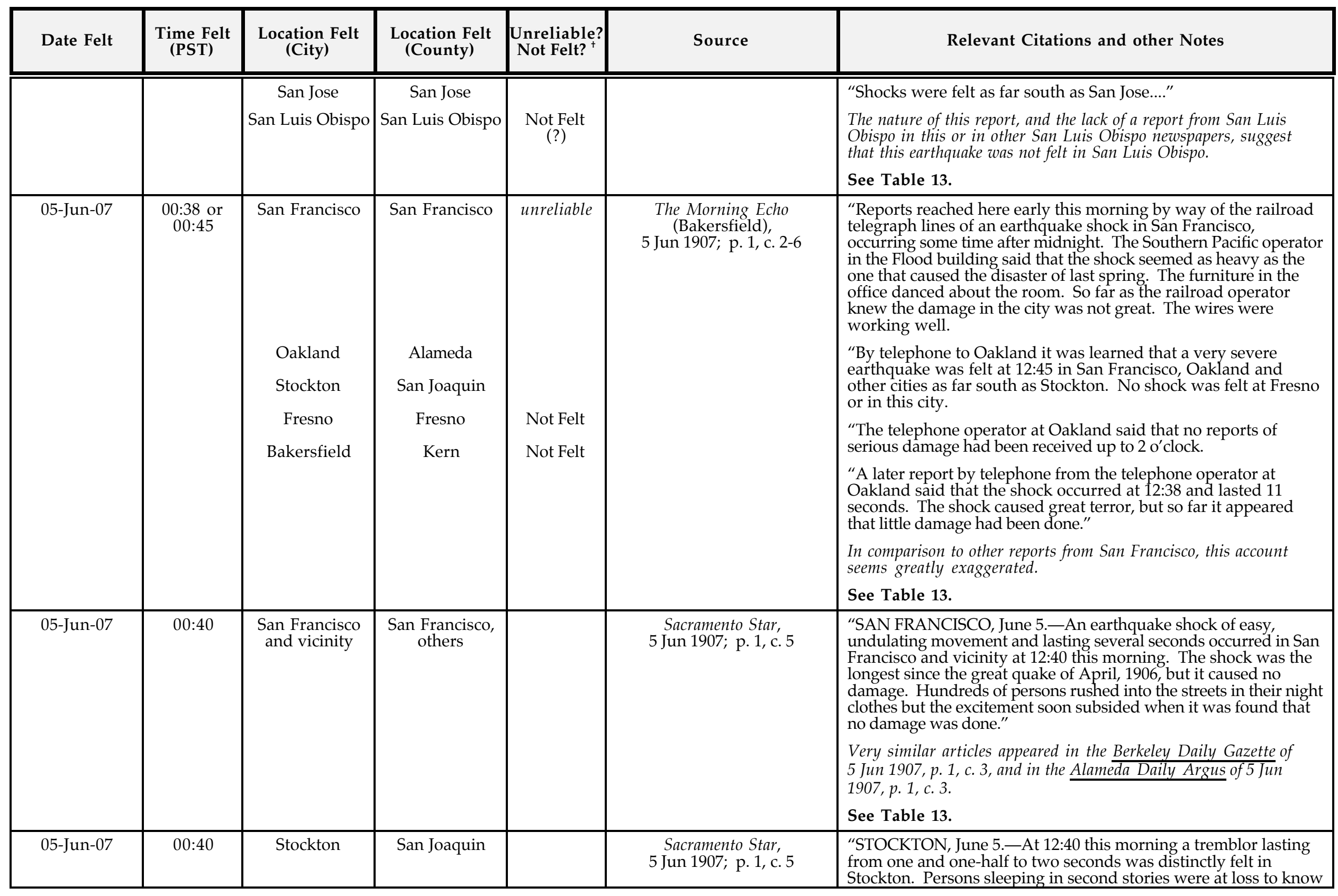


TABLE 1: Catalog of Aftershock Reports following from the Great 18 April 1906 California Earthquake

\begin{tabular}{|c|c|c|c|c|c|c|}
\hline Date Felt & $\begin{array}{l}\text { Time Felt } \\
\text { (PST) }\end{array}$ & $\begin{array}{l}\text { Location Felt } \\
\text { (City) }\end{array}$ & $\begin{array}{l}\text { Location Felt } \\
\text { (County) }\end{array}$ & $\begin{array}{l}\text { Unreliable? } \\
\text { Not Felt? }^{+}\end{array}$ & Source & Relevant Citations and other Notes \\
\hline & & & & & & $\begin{array}{l}\text { just what caused the disturbance and one after another sought the } \\
\text { telephone to verify their impressions. No damage was done." } \\
\text { Also in the Berkeley Daily Gazette of } 5 \text { Jun 1907, p. 1, c. } 3 . \\
\text { See Table 13. }\end{array}$ \\
\hline 05-Jun-07 & $00: 40$ & $\begin{array}{l}\text { Stockton } \\
\text { between } \\
\text { Stockton and } \\
\text { San Francisco }\end{array}$ & $\begin{array}{l}\text { San Joaquin } \\
\text { various }\end{array}$ & & $\begin{array}{l}\text { Stockton Daily Evening Record, } \\
5 \text { Jun 1907; p. } 5 \text {, c. } 4\end{array}$ & $\begin{array}{l}\text { "Stockton was visited by a slight temblor ... that lasted from one } \\
\text { and a half to two seconds. Residents sleeping in upper stories } \\
\text { were at a loss to know just what caused the disturbance and } \\
\text { sought the telephones to verify their impressions. Telegraph } \\
\text { operators along the wires between here and San Francisco } \\
\text { reported having felt the shock." } \\
\text { See Table 13. }\end{array}$ \\
\hline 05-Jun-07 & 00:40 & $\begin{array}{l}\text { Stockton } \\
\text { between } \\
\text { Stockton and } \\
\text { San Francisco }\end{array}$ & $\begin{array}{l}\text { San Joaquin } \\
\text { various }\end{array}$ & & $\begin{array}{l}\text { Stockton Daily Independent, } \\
5 \text { Jun 1907; p. } 5 \text {, c. } 4\end{array}$ & $\begin{array}{l}\text { "... a tremblor lasting from one and a half to two seconds was } \\
\text { distinctly felt in Stockton. Persons sleeping in second stories } \\
\text { were at a loss to know just what caused the disturbance and one } \\
\text { after another sought the telephone to verify their impressions. } \\
\text { Operators along the Associated Press wires from San Francisco } \\
\text { reported having felt the shock." } \\
\text { See Table 13. }\end{array}$ \\
\hline 05-Jun-07 & $\begin{array}{l}\text { during the } \\
\text { night }\end{array}$ & Alma & Santa Clara & & $\begin{array}{l}\text { Diary of Henry Lloyd Tevis } \\
\text { (Alma, CA), } \\
5 \text { Jun } 1907\end{array}$ & $\begin{array}{l}\text { Entry of } 5 \text { Jun 1907: } \\
\text { "Weather overcast all day. Quite a heavy earthquake shock } \\
\text { occurred during the night. Examiner said it was 'No. 4.' E.L.D. } \\
\text { returned on morning train and met H.L.T. at 4:20 San Jose in the } \\
\text { Large Loco [sic]." } \\
\text { According to T. Toppozada (CDMG; written comm., 2001), two sets } \\
\text { of diaries for each year exist-one for the ranch and one for the } \\
\text { office. Tevis did not write the diaries, his valet did. No mention is } \\
\text { given of the valet's name. Tevis lived in Alma, outside of Los Gatos } \\
\text { on the road to Santa Cruz. He was an early California millionaire } \\
\text { and had a ranch near Los Gatos and a house in San Francisco. } \\
\text { The location where the aforementioned earthquake was felt is not } \\
\text { stated but is inferred from the rest of the diary entry. } \\
\text { See Table 13. }\end{array}$ \\
\hline 05-Jun-07 & $\sim 04: 00$ & Sonoma & Sonoma & & $\begin{array}{l}\text { Sonoma Index-Tribune, } \\
8 \text { Jun } 1907 ; \text { p. } 3 \text {, c. } 1\end{array}$ & $\begin{array}{l}\text { "There was quite a heavy shock on Wednesday morning at 12:20, } \\
\text { which was followed by a lesser temblor at about } 4 \text { A. M...." }\end{array}$ \\
\hline
\end{tabular}


TABLE 1: Catalog of Aftershock Reports following from the Great 18 April 1906 California Earthquake

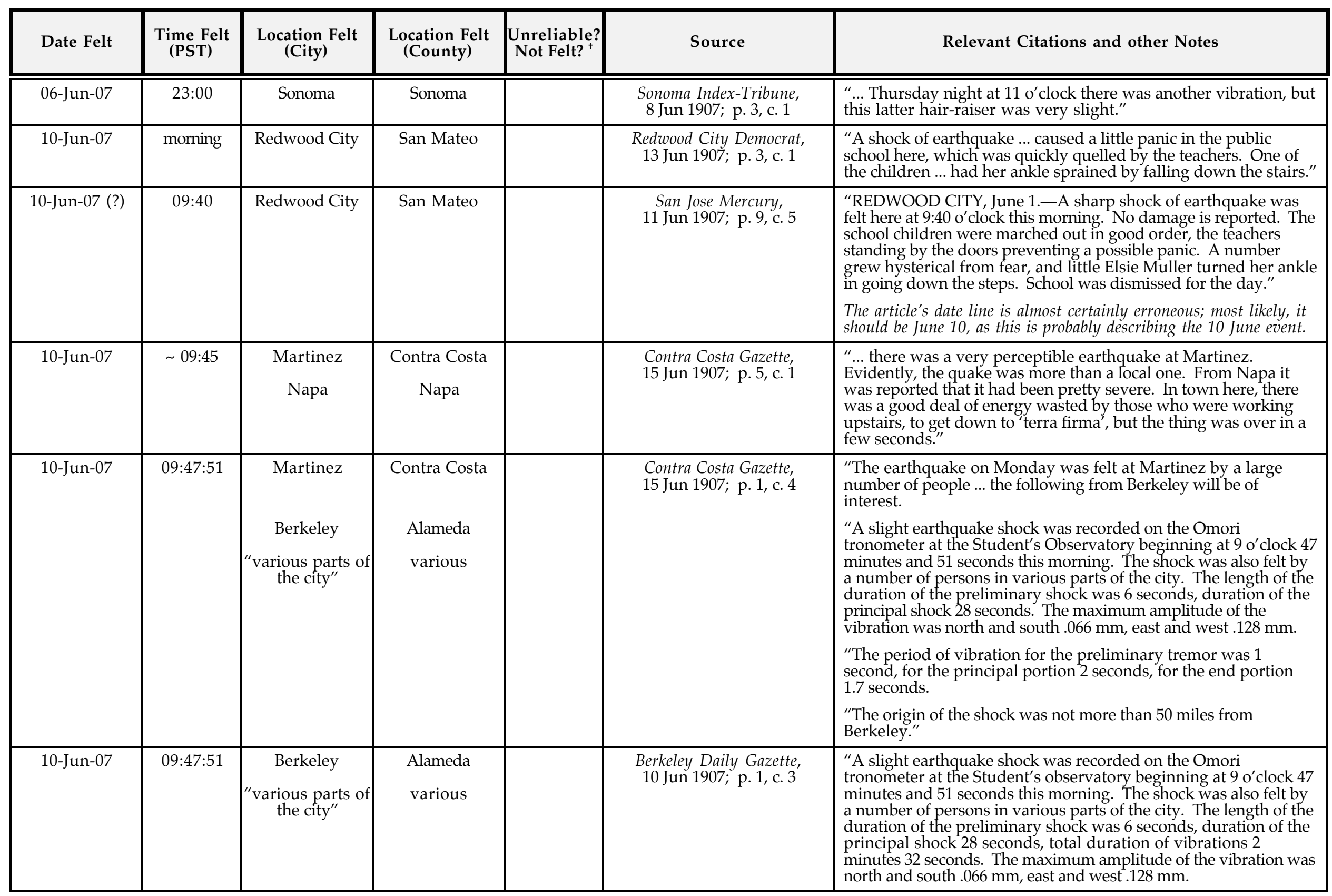


TABLE 1: Catalog of Aftershock Reports following from the Great 18 April 1906 California Earthquake

\begin{tabular}{|c|c|c|c|c|c|c|}
\hline Date Felt & $\begin{array}{l}\text { Time Felt } \\
\text { (PST) }\end{array}$ & $\begin{array}{l}\text { Location Felt } \\
\text { (City) }\end{array}$ & $\begin{array}{l}\text { Location Felt } \\
\text { (County) }\end{array}$ & $\begin{array}{l}\text { Unreliable? } \\
\text { Not Felt? }^{+}\end{array}$ & Source & Relevant Citations and other Notes \\
\hline & & & & & & $\begin{array}{l}\text { "The period of vibration for the preliminary tremor was } 1 \\
\text { second, for the principal portion } 2 \text { seconds, for the end portion } \\
1.7 \text { seconds. } \\
\text { "The origin of the shock was not more than } 50 \text { miles from } \\
\text { Berkeley." }\end{array}$ \\
\hline 10-June-07 & $09: 48: 30$ & Santa Rosa & Sonoma & & $\begin{array}{l}\text { The Press Democrat } \\
\text { (Santa Rosa), } \\
\text { 11 Jun 1907; p. 8, c. } 2\end{array}$ & $\begin{array}{l}\text { "A slight shock of earthquake was felt in this city yesterday } \\
\text { morning at 9:48:30 o'clock." }\end{array}$ \\
\hline 10-Jun-07 & \begin{tabular}{|c|} 
shortly \\
before $10: 00$
\end{tabular} & Napa & Napa & & $\begin{array}{l}\text { Napa Daily Register, } \\
10 \text { Jun 1907; p. } 5, \text { c. } 1\end{array}$ & $\begin{array}{l}\text { "A slight earthquake shock was felt in Napa shortly before ten } \\
\text { o'clock this forenoon." }\end{array}$ \\
\hline 10-Jun-07 & 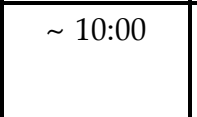 & $\begin{array}{l}\text { Oakland } \\
\text { Livermore }\end{array}$ & $\begin{array}{l}\text { Alameda } \\
\text { Alameda }\end{array}$ & Not Felt & $\begin{array}{l}\text { Livermore Echo, } \\
13 \text { Jun 1907; p. 1, c. } 2\end{array}$ & $\begin{array}{l}\text { "A sharp earthquake was felt in Oakland about } 10 \text { A. M. } \\
\text { Monday, but not noticed here." }\end{array}$ \\
\hline 10-Jun-07 & $\begin{array}{l}\text { 10:00 } \\
\sim\end{array}$ & Alma & Santa Clara & & $\begin{array}{l}\text { Diary of Henry Lloyd Tevis } \\
\text { (Alma, CA), } \\
10 \text { Jun } 1907\end{array}$ & $\begin{array}{l}\text { Entry of } 10 \text { Jun 1907: } \\
\text { "Beautiful Day. Small Earthquake Shock about } 10 \text { A. M. } \\
\text { H.L.T. and Guests caught 9:05 train out of San Jose. } \\
\text { J.S. went to the City." } \\
\text { The location where the aforementioned earthquake was felt is not } \\
\text { stated but is inferred from the rest of the diary entry. } \\
\text { See note about the Tevis diary following the citation for the event } \\
\text { "during the night" of } 5 \text { Jun 1907. }\end{array}$ \\
\hline 10-Jun-07 & 10:00 & Santa Clara & Santa Clara & & $\begin{array}{l}\text { Santa Clara News, } \\
11 \text { Jun 1907; p. 3, c. } 1\end{array}$ & "... a slight temblor...." \\
\hline $\begin{array}{l}\text { 05-Jun-07 thru } \\
\text { 12-Jun-07 (?) }\end{array}$ & (two events) & San Gregorio & San Mateo & & $\begin{array}{l}\text { Redwood City Democrat, } \\
13 \text { Jun 1907; p. } 3, \text { c. } 3\end{array}$ & $\begin{array}{l}\text { "SAN GREGORIO, June } 12-\ldots . \text { Two heavy shocks of } \\
\text { earthquake were felt during the week at San Gregorio." } \\
\text { See Table 13. }\end{array}$ \\
\hline $\begin{array}{c}\text { between } \\
\text { 05-Jun-07 and } \\
\text { 15-Jun-07 (?) }\end{array}$ & & Half Moon Bay & San Mateo & & $\begin{array}{c}\text { Los Gatos Mail, } \\
20 \text { Jun 1907; p. 5, c. } 3\end{array}$ & $\begin{array}{l}\text { "The earthquake last week injured a concrete building in course } \\
\text { of construction at Half Moon Bay, opening a gap an inch wide } \\
\text { from top to bottom, says the advocate." } \\
\text { The original article (which may have been printed in the } \\
\text { Coast Advocate, published in Half Moon Bay) could not be located, } \\
\text { and the date it was originally published is uncertain; it may have } \\
\text { been as much as a week old by the time it was re-printed in the } \\
\text { Los Gatos Mail. } \\
\text { See Table 13. }\end{array}$ \\
\hline
\end{tabular}


TABLE 1: Catalog of Aftershock Reports following from the Great 18 April 1906 California Earthquake

\begin{tabular}{|c|c|c|c|c|c|c|}
\hline Date Felt & $\begin{array}{l}\text { Time Felt } \\
\text { (PST) }\end{array}$ & $\begin{array}{l}\text { Location Felt } \\
\text { (City) }\end{array}$ & $\begin{array}{l}\text { Location Felt } \\
\text { (County) }\end{array}$ & $\begin{array}{l}\text { Unreliable? } \\
\text { Not Felt? }^{+}\end{array}$ & Source & Relevant Citations and other Notes \\
\hline 13-Jun-07 & $\sim 12: 55$ & Alma (?) & Santa Clara (?) & & $\begin{array}{l}\text { Diary of Henry Lloyd Tevis } \\
\text { (Alma, CA), } \\
\text { 13 Jun } 1907\end{array}$ & $\begin{array}{l}\text { Entry of } 13 \text { Jun 1907: } \\
\text { "Rained Heavily during latter part of the night and up to } 9 \text { A.M. } \\
\text { when it moderated. } \\
\text { Dusky put in jail to-day } \\
\text { Small earthquake about 12:55 P.M. } \\
\text { Rain at Noon } \\
\text { Cleared in Afternoon } \\
\text { H.L.T. returned from S.J. on } 3 \text { P.M. train } \\
\text { Red Loco from S.J. to Home [sic]." } \\
\text { The location where the aforementioned earthquake was felt is not } \\
\text { stated but is interpreted from the rest of the diary entry. Toppozada } \\
\text { (written comm., 2001) inferred the location to be San Francisco, but } \\
\text { we infer it to be Alma, outside of Los Gatos. The actual location } \\
\text { cannot be resolved with certainty. } \\
\text { See note about the Tevis diary following the citation for the event } \\
\text { "during the night" of } 5 \text { Jun 1907. }\end{array}$ \\
\hline 22-Jun-07 & $\sim 01: 30$ & Napa & Napa & & $\begin{array}{l}\text { Napa Daily Journal, } \\
\text { 23 Jun 1907; p. 3, c. } 2\end{array}$ & $\begin{array}{l}\text { "Quite a heavy shock of earthquake was experienced in this city } \\
\text { about half-past one Saturday morning. Although no damage } \\
\text { resulted from the temblor, it was severe enough to frighten the } \\
\text { timid." }\end{array}$ \\
\hline 23-Jun-07 & $\sim$ 23:00 & Hanford & Kings & & $\begin{array}{l}\text { Hanford Weekly Sentinel, } \\
27 \text { Jun 1907; p. } 7, \text { c. } 5\end{array}$ & $\begin{array}{l}\text { "Some people who had not gone to sleep at about } 11 \text { o'clock } \\
\text { Sunday night, report that there was a trembling of the earth here } \\
\text { that shook the houses perceptibly...." }\end{array}$ \\
\hline 03-Jul-07 & $01: 10$ & $\begin{array}{l}\text { Santa Barbara } \\
\text { Los Angeles }\end{array}$ & $\begin{array}{l}\text { Santa Barbara } \\
\text { Los Angeles }\end{array}$ & Not Felt & $\begin{array}{l}\text { The Morning Press } \\
\text { (Santa Barbara), } \\
3 \text { Jul 1907; p. 1, c. } 3\end{array}$ & $\begin{array}{l}\text { "Observations made generally yesterday that the oppressive heat } \\
\text { was 'earthquake weather' found verification at 1:10 o'clock this } \\
\text { morning, when a sharp though exceedingly brief shock was felt. It } \\
\text { was sufficient to rock buildings, rattle windows, etc., but so far } \\
\text { as known there was no damage occasioned. People were } \\
\text { wakened from their beds, and The Press office was besieged with } \\
\text { telephone messages of inquiry as to the quake. } \\
\text { "The shock was not felt in Los Angeles." }\end{array}$ \\
\hline
\end{tabular}


TABLE 1: Catalog of Aftershock Reports following from the Great 18 April 1906 California Earthquake

\begin{tabular}{|c|c|c|c|c|c|c|}
\hline Date Felt & $\begin{array}{l}\text { Time Felt } \\
\text { (PST) }\end{array}$ & $\begin{array}{l}\text { Location Felt } \\
\text { (City) }\end{array}$ & $\begin{array}{l}\text { Location Felt } \\
\text { (County) }\end{array}$ & $\begin{array}{c}\text { Unreliable? } \\
\text { Not Felt? }^{+}\end{array}$ & Source & Relevant Citations and other Notes \\
\hline 08-Aug-07 & 04:39 & Eureka & Humboldt & & $\begin{array}{l}\text { Humboldt Standard, } \\
8 \text { Aug 1907; p. } 1 \text {, c. } 3\end{array}$ & $\begin{array}{l}\text { "Two light earthquake shocks were felt this morning, the first at } \\
\text { 4:39 o'clock and the second about } 6 \text { o' clock. The vibrations were } \\
\text { from north to south and each lasted about six seconds. The } \\
\text { second was the heavier but neither did any damage." } \\
2 \text { events total were reported in this article for Eureka on } 8 \text { Aug. } \\
\text { See Table 14. }\end{array}$ \\
\hline 08-Aug-07 & $04: 44$ & $\begin{array}{l}\text { Upper Mattole } \\
\text { Eureka } \\
\text { Branscomb }\end{array}$ & $\begin{array}{l}\text { Humboldt } \\
\text { Humboldt } \\
\text { Mendocino }\end{array}$ & & $\begin{array}{l}\text { Townley and Allen (1939), } \\
\text { p. } 145\end{array}$ & $\begin{array}{l}\text { "1907 August } 8.4: 44 \text { a.m. and 6:05 a.m. Upper Mattole, } \\
\text { Humboldt Co. 'Quite severe, followed by several lighter shocks } \\
\text { during the month.' At Eureka: 'very light, duration about six } \\
\text { seconds, neither maximum nor minimum intensity, only steady } \\
\text { shaking of the earth.' Also felt at Branscomb, Mendocino Co." } \\
\text { This compilation of reports is attributed to the U.S. Weather Bureau } \\
\text { (Form 1009). It is not clear whether the descriptions refer to the } \\
\text { 04:44 event, the 06:05 event, or both. } \\
\text { See Table 14. }\end{array}$ \\
\hline 08-Aug-07 & $04: 44$ & Eureka & Humboldt & & $\begin{array}{l}\text { Humboldt Times, } \\
9 \text { Aug 1907; p. 3, c. } 1\end{array}$ & $\begin{array}{l}\text { "... very light.... The vibrations came from a southerly to } \\
\text { northerly direction and lasted ... six seconds...." } \\
2 \text { events total were reported in this article for Eureka on } 8 \text { Aug. } \\
\text { See Table } \mathbf{1 4 .}\end{array}$ \\
\hline 08-Aug-07 & $04: 45$ & Ferndale & Humboldt & & $\begin{array}{l}\text { Humboldt Times, } \\
9 \text { Aug 1907; p. 3, c. } 1\end{array}$ & $\begin{array}{l}\text { The shock was "of but short duration and did no damage to the } \\
\text { valley town [Ferndale]." } \\
3 \text { events total were reported in this article for Ferndale on } 8 \text { Aug. } \\
\text { See Table } 14 .\end{array}$ \\
\hline 08-Aug-07 & $\sim 04: 45$ & Upper Mattole & Humboldt & & $\begin{array}{l}\text { Humboldt Standard, } \\
12 \text { Aug 1907; p. 3, c. } 4\end{array}$ & $\begin{array}{l}\text { "Upper Mattole, August } 8 \text { - There were two heavy shocks of } \\
\text { earthquake at this place this morning. The first about } 4: 45 \text { and } \\
\text { the second about } 6 \text { a. m. They were both lively shakes and caused } \\
\text { some people to run for open ground. No damage was done." } \\
2 \text { events total were reported in this article for Upper Mattole on } \\
8 \text { Aug. } \\
\text { See Table } 14 .\end{array}$ \\
\hline
\end{tabular}


TABLE 1: Catalog of Aftershock Reports following from the Great 18 April 1906 California Earthquake

\begin{tabular}{|c|c|c|c|c|c|c|}
\hline Date Felt & $\begin{array}{l}\text { Time Felt } \\
\text { (PST) }\end{array}$ & $\begin{array}{l}\text { Location Felt } \\
\text { (City) }\end{array}$ & $\begin{array}{l}\text { Location Felt } \\
\text { (County) }\end{array}$ & $\begin{array}{l}\text { Unreliable? } \\
\text { Not Felt? }^{+}\end{array}$ & Source & Relevant Citations and other Notes \\
\hline 08-Aug-07 & 04:55 & Garberville & Humboldt & & $\begin{array}{l}\text { Humboldt Standard, } \\
13 \text { Aug 1907; p. 7, c. } 4\end{array}$ & $\begin{array}{l}\text { "Garberville, Aug. 9.-.... Did you feel the earthquake? was the } \\
\text { first question asked yesterday morning, when a couple met on the } \\
\text { street, and it was not only one but two good sized quakes we were } \\
\text { treated to, the first occurring at 4:55 o'clock in the morning, and the } \\
\text { second a few moments after } 6 \text { o'clock." } \\
2 \text { events total were reported in this article for Garberville on } 8 \text { Aug. } \\
\text { See Table 14. }\end{array}$ \\
\hline 08-Aug-07 & \begin{tabular}{|c|} 
05:00, \\
other times in \\
the morning \\
(several \\
events)
\end{tabular} & Upper Mattole & Humboldt & & $\begin{array}{c}\text { Humboldt Times, } \\
13 \text { Aug 1907; p. 2, c. } 4\end{array}$ & $\begin{array}{l}\text { "UPPER MATTOLE, Aug. 9.-Several sharp shocks of } \\
\text { earthquake were felt here yesterday morning, the hardest being } \\
\text { about } 5 \text { o'clock." } \\
\text { (Several events were reported for Upper Mattole on } 8 \text { Aug.) } \\
\text { See Table 14. }\end{array}$ \\
\hline 08-Aug-07 & 05:15 & Pepperwood & Humboldt & & $\begin{array}{l}\text { Humboldt Standard, } \\
10 \text { Aug 1907; p.7, c. } 7\end{array}$ & $\begin{array}{l}\text { "... Two heavy earthquakes were felt this morning but no damage } \\
\text { was done, only a few things were knocked down in Young's store. } \\
\text { One was at 5:15 and the other at 6:05 a. m." } \\
2 \text { events total were reported in this article for Pepperwood on } 8 \text { Aug. } \\
\text { See Table 14. }\end{array}$ \\
\hline 08-Aug-07 & 05:15 & Ferndale & Humboldt & & $\begin{array}{l}\text { Humboldt Times, } \\
9 \text { Aug 1907; p. 3, c. } 1\end{array}$ & $\begin{array}{l}\text { The shock was "of but short duration and did no damage to the } \\
\text { valley town [Ferndale]." } \\
3 \text { events total were reported in this article for Ferndale on } 8 \text { Aug. } \\
\text { See Table } 14 .\end{array}$ \\
\hline 08-Aug-07 & \begin{tabular}{|l|} 
before 06:00 \\
(two events)
\end{tabular} & Garberville & Humboldt & & $\begin{array}{c}\text { Humboldt Times, } \\
14 \text { Aug 1907; p. 6, c. 2-3 }\end{array}$ & $\begin{array}{l}\text { "... we were shaken up twice before six o'clock [a.m.]...." } \\
2 \text { events total were reported in this article for Garberville on } 8 \text { Aug. } \\
\text { See Table } \mathbf{1 4 .}\end{array}$ \\
\hline 08-Aug-07 & $\sim 06: 00$ & Eureka & Humboldt & & $\begin{array}{l}\text { Humboldt Standard, } \\
8 \text { Aug 1907; p. 1, c. } 3\end{array}$ & $\begin{array}{l}\text { "Two light earthquake shocks were felt this morning, the first at } \\
\text { 4:39 o'clock and the second about } 6 \text { o'clock. The vibrations were } \\
\text { from north to south and each lasted about six seconds. The } \\
\text { second was the heavier but neither did any damage." } \\
2 \text { events total were reported in this article for Eureka on } 8 \text { Aug. } \\
\text { See Table 14. }\end{array}$ \\
\hline 08-Aug-07 & 06:00 & Falk & Humboldt & & $\begin{array}{l}\text { Humboldt Standard, } \\
12 \text { Aug 1907; p. 3, c. } 1\end{array}$ & $\begin{array}{l}\text { “... light.... No damage was done." } \\
2 \text { events total were reported in this article for Falk on } 8 \text { Aug. } \\
\text { See Table } \mathbf{1 4 .}\end{array}$ \\
\hline
\end{tabular}


TABLE 1: Catalog of Aftershock Reports following from the Great 18 April 1906 California Earthquake

\begin{tabular}{|c|c|c|c|c|c|c|}
\hline Date Felt & $\begin{array}{c}\text { Time Felt } \\
\text { (PST) }\end{array}$ & $\begin{array}{l}\text { Location Felt } \\
\text { (City) }\end{array}$ & $\begin{array}{l}\text { Location Felt } \\
\text { (County) }\end{array}$ & $\begin{array}{c}\text { Unreliable? } \\
\text { Not Felt? }^{+}\end{array}$ & Source & Relevant Citations and other Notes \\
\hline 08-Aug-07 & $\begin{array}{c}\sim 06: 00 \\
\sim\end{array}$ & Upper Mattole & Humboldt & & $\begin{array}{l}\text { Humboldt Standard, } \\
12 \text { Aug 1907; p. 3, c. } 4\end{array}$ & $\begin{array}{l}\text { "Upper Mattole, August } 8 \text { - There were two heavy shocks of } \\
\text { earthquake at this place this morning. The first about } 4: 45 \text { and } \\
\text { the second about } 6 \text { a. } m \text {. They were both lively shakes and caused } \\
\text { some people to run for open ground. No damage was done." } \\
2 \text { events total were reported in this article for Upper Mattole on } \\
8 \text { Aug. } \\
\text { See Table 14. }\end{array}$ \\
\hline 08-Aug-07 & \begin{tabular}{|c|} 
a few \\
moments after \\
$06: 00$
\end{tabular} & Garberville & Humboldt & & $\begin{array}{l}\text { Humboldt Standard, } \\
13 \text { Aug 1907; p. 7, c. } 4\end{array}$ & $\begin{array}{l}\text { "Garberville, Aug. 9.-.... Did you feel the earthquake? was the } \\
\text { first question asked yesterday morning, when a couple met on the } \\
\text { street, and it was not only one but two good sized quakes we were } \\
\text { treated to, the first occurring at } 4: 55 \text { o'clock in the morning, and the } \\
\text { second a few moments after } 6 \text { o'clock." } \\
2 \text { events total were reported in this article for Garberville on } 8 \text { Aug. } \\
\text { See Table 14. }\end{array}$ \\
\hline 08-Aug-07 & 06:05 & $\begin{array}{l}\text { Upper Mattole } \\
\text { Eureka } \\
\text { Branscomb }\end{array}$ & $\begin{array}{l}\text { Humboldt } \\
\text { Humboldt } \\
\text { Mendocino }\end{array}$ & & $\begin{array}{c}\text { Townley and Allen (1939), } \\
\text { p. } 145\end{array}$ & $\begin{array}{l}\text { "1907 August 8. 4:44 a.m. and 6:05 a.m. Upper Mattole, } \\
\text { Humboldt Co. 'Quite severe, followed by several lighter shocks } \\
\text { during the month.' At Eureka: 'very light, duration about six } \\
\text { seconds, neither maximum nor minimum intensity, only steady } \\
\text { shaking of the earth.' Also felt at Branscomb, Mendocino Co." } \\
\text { This compilation of reports is attributed to the U.S. Weather Bureau } \\
\text { (Form 1009. It is not clear whether the descriptions refer to the } \\
\text { 04:44 event, the 06:05 event, or both. } \\
\text { See Table 14. }\end{array}$ \\
\hline 08-Aug-07 & 06:05 & Pepperwood & Humboldt & & $\begin{array}{l}\text { Humboldt Standard, } \\
10 \text { Aug 1907; p. 7, c. } 7\end{array}$ & $\begin{array}{l}\text { "... Two heavy earthquakes were felt this morning but no damage } \\
\text { was done, only a few things were knocked down in Young's store. } \\
\text { One was at } 5: 15 \text { and the other at } 6: 05 \text { a. m." } \\
2 \text { events total were reported in this article for Pepperwood on } 8 \text { Aug. } \\
\text { See Table } \mathbf{1 4 .}\end{array}$ \\
\hline 08-Aug-07 & 06:05 & Eureka & Humboldt & & $\begin{array}{l}\text { Humboldt Times, } \\
9 \text { Aug 1907; p.3, c. } 1\end{array}$ & $\begin{array}{l}\text { "... very light.... The vibrations came from a southerly to } \\
\text { northerly direction and ... lasted about three seconds..." } \\
2 \text { events total were reported in this article for Eureka on } 8 \text { Aug. } \\
\text { See Table } 14 .\end{array}$ \\
\hline 08-Aug-07 & $06: 10$ & Ferndale & Humboldt & & $\begin{array}{l}\text { Humboldt Times, } \\
9 \text { Aug 1907; p.3, c. } 1\end{array}$ & $\begin{array}{l}\text { The shock was "of but short duration and did no damage to the } \\
\text { valley town [Ferndale]." } \\
3 \text { events total were reported in this article for Ferndale on } 8 \text { Aug. } \\
\text { See Table } 14 .\end{array}$ \\
\hline
\end{tabular}


TABLE 1: Catalog of Aftershock Reports following from the Great 18 April 1906 California Earthquake

\begin{tabular}{|c|c|c|c|c|c|c|}
\hline Date Felt & $\begin{array}{l}\text { Time Felt } \\
\text { (PST) }\end{array}$ & $\begin{array}{l}\text { Location Felt } \\
\text { (City) }\end{array}$ & $\begin{array}{l}\text { Location Felt } \\
\text { (County) }\end{array}$ & \begin{tabular}{|c|} 
Unreliable? \\
Not Felt? $^{+}$
\end{tabular} & Source & Relevant Citations and other Notes \\
\hline 08-Aug-07 & 06:15 & Blocksburg & Humboldt & & $\begin{array}{c}\text { Humboldt Standard, } \\
10 \text { Aug 1907; p. 7, c.7 }\end{array}$ & $\begin{array}{l}\text { "a sharp movement north and south" } \\
2 \text { events total were reported in this article for Blocksburg on } 8 \text { Aug. } \\
\text { See Table } \mathbf{1 4 .}\end{array}$ \\
\hline 08-Aug-07 & $\begin{array}{c}\text { in the early } \\
\text { hours of the } \\
\text { morning } \\
\text { (two events? }\end{array}$ & Ferndale & Humboldt & & $\begin{array}{l}\text { Humboldt Standard, } \\
9 \text { Aug 1907; p. 7, c. 1-2 }\end{array}$ & $\begin{array}{l}\text { "Ferndale, August 8-... Our people were awakened in the early } \\
\text { hours this morning by a couple of slight shocks of earthquake...." } \\
\text { It is not clear if this refers to one or two separate events. No other } \\
\text { earthquakes were reported in this article for Ferndale on } 8 \text { Aug. } \\
\text { See Table } \mathbf{1 4 .}\end{array}$ \\
\hline 08-Aug-07 & $\begin{array}{l}\text { early } \\
\text { morning }\end{array}$ & Blue Lake & Humboldt & & $\begin{array}{c}\text { Humboldt Times, } \\
11 \text { Aug 1907; p. 8,c. } 1\end{array}$ & $\begin{array}{l}\text { "Quite a heavy earthquake was felt...." } \\
1 \text { event total was reported in this article for Blue Lake on } 8 \text { Aug. } \\
\text { See Table } \mathbf{1 4 .}\end{array}$ \\
\hline 08-Aug-07 & \begin{tabular}{|c|} 
morning \\
(two events \\
within about \\
an hour of \\
each other) \\
\end{tabular} & Grizzly Bluff & Humboldt & & $\begin{array}{c}\text { Humboldt Times, } \\
10 \text { Aug 1907; p. 2, c. } 3\end{array}$ & $\begin{array}{l}\text { "... two decided shocks within about an hour of each other." } \\
2 \text { events total were reported in this article for Grizzly Bluff on } \\
8 \text { Aug. } \\
\text { See Table 14. }\end{array}$ \\
\hline 08-Aug-07 & \begin{tabular}{|c|} 
morning \\
(two events?)
\end{tabular} & Arcata & Humboldt & & $\begin{array}{l}\text { Humboldt Times, } \\
13 \text { Aug 1907; p. 2, c. 1-2 }\end{array}$ & $\begin{array}{l}\text { "... two light [earthquake shocks] were felt...." } \\
\text { It is not clear if this refers to one or two separate events. No other } \\
\text { earthquakes were reported in this article for Arcata on } 8 \text { Aug. } \\
\text { See Table 14. }\end{array}$ \\
\hline 09-Aug-07 (?) & & Ruth & Trinity & & $\begin{array}{l}\text { Humboldt Standard, } \\
27 \text { Aug 1907; p. 7, c. } 7\end{array}$ & $\begin{array}{l}\text { "Ruth, Trinity Co., August } 23-\ldots . \text { We know that Mother Earth is } \\
\text { very uneasy for the temblors of the } 9 \text { th, } 11 \text { th, and } 12 \text { th insts. were } \\
\text { quite hard, but the one on the } 18 \text { th at } 3: 20 \mathrm{p} . \mathrm{m} \text {. was the most } \\
\text { severe...." } \\
\text { The reported date of this event is probably incorrect, as it is } \\
\text { described here as quite hard, but no other locality reported an event } \\
\text { on this date; it is probably the } 8 \text { Aug event. } \\
\text { See Table 14. }\end{array}$ \\
\hline 10-Aug-07 (?) & 04:00 & Island Mountain & Trinity & & $\begin{array}{l}\text { Humboldt Standard, } \\
17 \text { Aug 1907; p. 5, c. } 5\end{array}$ & $\begin{array}{l}\text { "Island Mountain, Aug. } 12-\ldots . \text { Saturday morning at } 4 \text { o'clock } \\
\text { the people of the island were awakened by a heavy earthquake." } \\
\text { The reported date of this event is almost certainly incorrect, as it is } \\
\text { described here as heavy, but no other locality reported an event on } \\
\text { this date; it is probably the } 11 \text { Aug event. } \\
\text { See Table } 15 .\end{array}$ \\
\hline
\end{tabular}


TABLE 1: Catalog of Aftershock Reports following from the Great 18 April 1906 California Earthquake

\begin{tabular}{|c|c|c|c|c|c|c|}
\hline Date Felt & $\begin{array}{l}\text { Time Felt } \\
\text { (PST) }\end{array}$ & $\begin{array}{l}\text { Location Felt } \\
\text { (City) }\end{array}$ & $\begin{array}{l}\text { Location Felt } \\
\text { (County) }\end{array}$ & $\begin{array}{l}\text { Unreliable? } \\
\text { Not Felt? }^{+}\end{array}$ & Source & Relevant Citations and other Notes \\
\hline 11-Aug-07 & $\sim 03: 40$ & Mendocino & Mendocino & & $\begin{array}{c}\text { Mendocino Beacon, } \\
17 \text { Aug 1907; p. 1, c. 1-2 }\end{array}$ & $\begin{array}{l}\text { "A sharp shock of earthquake startled some of our people from } \\
\text { their slumbers last Sunday morning about } 3: 40 \text { o'clock. No } \\
\text { damage was done, unless it was to some of the more sensitive } \\
\text { nerves. In fact the majority of the people did not feel the temblor." } \\
\text { Elsewhere in the same paper the time for the event was reported as } \\
04: 15 \text {-- this should provide an idea of minimum uncertainties and } \\
\text { errors involved in the reporting of times, especially for events } \\
\text { occurring while people are asleep. } \\
\text { See Table } 15 .\end{array}$ \\
\hline 11-Aug-07 & $\sim 03: 50$ & Grass Valley & Nevada & & $\begin{array}{l}\text { Sacramento Union, } \\
12 \text { Aug 1907; p. } 6, \text { c. } 3\end{array}$ & $\begin{array}{l}\text { "GRASS VALLEY, Aug. 11.- Three distinct shocks of } \\
\text { earthquake were felt here this morning at about } 3: 50 \text { o'clock. } \\
\text { Each shock was of about two seconds duration, and the } \\
\text { vibration was from west to east. The disturbance was heavy } \\
\text { enough to awaken and frighten a number of people, but no damage } \\
\text { has been reported. Some persons report hearing a peculiar } \\
\text { rumbling noise preceding and during the continuance of the } \\
\text { quakes. } \\
\text { "The seismic disturbance does not appear to have extended over } \\
\text { any considerable area." } \\
\text { See Table 15. }\end{array}$ \\
\hline 11-Aug-07 & $\sim 04: 00$ & $\begin{array}{c}\text { Nevada City } \\
\text { French Corral } \\
\text { North San Juan } \\
\begin{array}{c}\text { Shady Creek } \\
\text { gravel mine }\end{array}\end{array}$ & $\begin{array}{l}\text { Nevada } \\
\text { Nevada } \\
\text { Nevada } \\
\text { Nevada }\end{array}$ & & $\begin{array}{c}\text { Daily Morning Union } \\
\text { (Grass Valley \& Nevada City), } \\
13 \text { Aug 1907; p. 6, c. } 3\end{array}$ & $\begin{array}{l}\text { "A seismic tremor passed through this part of the country Sunday } \\
\text { morning about } 4 \text { o clock, sufficiently strong to arouse many } \\
\text { persons from their slumbers... } \\
\text { "Persons coming in from French Corral and North San Juan } \\
\text { yesterday report that the Sunday morning early tremor was felt at } \\
\text { those camps. } \\
\text { "Superintendent Graham of the Shady Creek gravel mine was in } \\
\text { Nevada City yesterday and said the trembling was experienced in } \\
\text { his camp...." } \\
\text { See Table 15. }\end{array}$ \\
\hline 11-Aug-07 & $\sim 04: 00$ & Red Bluff & Tehama & & $\begin{array}{l}\text { Weekly People's Cause } \\
\text { (Red Bluff), } \\
17 \text { Aug 1907; p. 8, c. } 3\end{array}$ & $\begin{array}{l}\text { "A portion of Red Bluff's population was furnished with some } \\
\text { excitement early Sunday morning that all did* share. The reason } \\
\text { that all did not share in the excitement was that some of the } \\
\text { people were sleeping too soundly. } \\
\text { "At about } 4 \text { o'clock Sunday morning Red Bluff was visited by an } \\
\text { earthquake that made the doors and windows of many of the } \\
\text { houses rattle.... } \\
\text { "No harm resulted from the earthquake, the vibrations only being } \\
\text { of a few seconds duration." }\end{array}$ \\
\hline
\end{tabular}


TABLE 1: Catalog of Aftershock Reports following from the Great 18 April 1906 California Earthquake

\begin{tabular}{|c|c|c|c|c|c|c|}
\hline Date Felt & $\begin{array}{l}\text { Time Felt } \\
\text { (PST) }\end{array}$ & $\begin{array}{l}\text { Location Felt } \\
\text { (City) }\end{array}$ & $\begin{array}{l}\text { Location Felt } \\
\text { (County) }\end{array}$ & $\begin{array}{l}\text { Unreliable? } \\
\text { Not Felt? }^{+}\end{array}$ & Source & Relevant Citations and other Notes \\
\hline & & & & & & $\begin{array}{l}\text { "Compare this article with similar articles that appeared in the } \\
\text { Courier-Free Press and the Searchlight, both of Redding. } \\
\text { The latter two articles were presumably copied from the Daily } \\
\text { People's Cause (the daily version of this paper, which could not } \\
\text { be located for 1907). In the two Redding papers, the word "not" } \\
\text { appears at the place marked by an asterisk above; in this article, } \\
\text { however, the word "not" does not appear at that location. Based } \\
\text { on the inconsistency, and from the context, it appears that this } \\
\text { was an accidental typographical omission. It is inferred that the } \\
\text { line was intended to read "... excitement early Sunday morning } \\
\text { that all did not share." } \\
\text { See Table } 15 .\end{array}$ \\
\hline 11-Aug-07 & $\sim 04: 00$ & Red Bluff & Tehama & & $\begin{array}{c}\text { Courier-Free Press (Redding), } \\
13 \text { Aug 1907; p. } 7, \text { c. } 1\end{array}$ & $\begin{array}{l}\text { "RED BLUFF, Aug. 18-A portion of Red Bluff's population was } \\
\text { furnished with some excitement early Sunday morning that all did } \\
\text { not share. The reason that all did not share in the excitement was } \\
\text { that some of the people were sleeping too soundly. } \\
\text { "At about } 4 \text { o'clock Sunday morning Red Bluff was visited by an } \\
\text { earthquake that made the doors and windows of many of the } \\
\text { houses rattle.... } \\
\text { "No harm resulted from the earthquake, the vibrations only being } \\
\text { of a few seconds duration." } \\
\text { The dateline is clearly incorrect; it should be either Aug. } 12 \text { or } 13 \text {. } \\
\text { See Table } 15 .\end{array}$ \\
\hline 11-Aug-07 & $\sim 04: 00$ & Red Bluff & Tehama & & $\begin{array}{l}\text { The Searchlight (Redding), } \\
14 \text { Aug 1907; p. 6, c. } 2\end{array}$ & $\begin{array}{l}\text { "Red Bluff was furnished with some excitement early Sunday } \\
\text { morning in which all did not share. The reason that all did not } \\
\text { share in the excitement was that some of the people were sleeping } \\
\text { too soundly, says the Cause. } \\
\text { "At about } 4 \text { o' clock Sunday morning Red Bluff was visited by an } \\
\text { earthquake that made the doors and windows of many of the } \\
\text { houses rattle.... } \\
\text { "No harm resulted from the earthquake, the vibrations only being } \\
\text { of a few seconds duration." } \\
\text { See Table } 15 .\end{array}$ \\
\hline 11-Aug-07 & $\sim$ 04:00 & Corning & Tehama & & $\begin{array}{c}\text { Corning Observer, } \\
15 \text { Aug 1907; p. 1, c. } 2\end{array}$ & $\begin{array}{l}\text { "About four o'clock Sunday morning those of us who were } \\
\text { awake were startled by a short series of earthquake shocks. The } \\
\text { vibrations seemed to be from east to west and the doors and } \\
\text { windows rattled for about thirty seconds. Aside from curiosity } \\
\text { and a slight alarm among a few the shock did not create much } \\
\text { comment...." }\end{array}$ \\
\hline
\end{tabular}


TABLE 1: Catalog of Aftershock Reports following from the Great 18 April 1906 California Earthquake

\begin{tabular}{|c|c|c|c|c|c|c|}
\hline Date Felt & $\begin{array}{l}\text { Time Felt } \\
\text { (PST) }\end{array}$ & $\begin{array}{l}\text { Location Felt } \\
\quad \text { (City) }\end{array}$ & $\begin{array}{l}\text { Location Felt } \\
\text { (County) }\end{array}$ & $\begin{array}{l}\text { Unreliable? } \\
\text { Not Felt? }^{+}\end{array}$ & Source & Relevant Citations and other Notes \\
\hline & & & & & & See Table 15. \\
\hline 11-Aug-07 & $\sim 04: 00$ & Chico & Butte & & $\begin{array}{c}\text { Chico Record, } \\
13 \text { Aug 1907; p. 5, c. } 1\end{array}$ & $\begin{array}{l}\text { "A slight earthquake shock was felt in this city.... The tremor } \\
\text { seemed to extend between Redding and Sacramento. No damage } \\
\text { was done." } \\
\text { See Table } 15 .\end{array}$ \\
\hline 11-Aug-07 & $\sim$ 04:00 & Willows & Glenn & & $\begin{array}{c}\text { Glenn Transcript, } \\
14 \text { Aug 1907; p. 3, c. } 2\end{array}$ & $\begin{array}{l}\text { "We had an earthquake here ... but it was so light that but few } \\
\text { people knew that we had such a visitor." } \\
\text { See Table } \mathbf{1 5 .}\end{array}$ \\
\hline 11-Aug-07 & $\sim 04: 00$ & Colusa & Colusa & Not Felt & $\begin{array}{l}\text { Daily Colusa Sun, } \\
13 \text { Aug 1907; p. } 4 \text {, c. } 5\end{array}$ & $\begin{array}{l}\text { "It is sleepy time at } 4 \text { a. } m \text {. That is the reason the light shake last } \\
\text { Sunday morning was not heard from in all quarters. No one } \\
\text { waked up, no damage done." } \\
\text { See Table } \mathbf{1 5 .}\end{array}$ \\
\hline 11-Aug-07 & 04:15 & Cape Mendocino & Humboldt & & $\begin{array}{l}\text { Lighthouse Log for } \\
\text { Cape Mendocino Lighthouse, } \\
11 \text { Aug } 1907\end{array}$ & $\begin{array}{l}\text { Excerpt from the entry of } 11 \text { Aug 1907: } \\
\text { "a light earthquake shock } 4.15 \text { a.m." } \\
\text { See Table 15. }\end{array}$ \\
\hline 11-Aug-07 & 04:15 & Mendocino & Mendocino & & $\begin{array}{c}\text { Mendocino Beacon, } \\
17 \text { Aug 1907; p. 5, c. } 2\end{array}$ & $\begin{array}{l}\text { "A slight seismic disturbance awakened the people of Mendocino } \\
\text { from sound slumber last Sunday morning at 4:15. It was of short } \\
\text { duration and was not repeated." } \\
\text { Elsewhere in the same paper the time for the event was reported as } \\
\sim 03: 40-\text { - this should provide an idea of minimum uncertainties } \\
\text { and errors involved in the reporting of times, especially for events } \\
\text { occurring while people are asleep. } \\
\text { See Table } 15 .\end{array}$ \\
\hline 11-Aug-07 & 04:19 & $\begin{array}{c}\text { Eureka } \\
\text { Laytonville } \\
\text { Fort Bragg } \\
\text { Willits } \\
\text { Covelo }\end{array}$ & $\begin{array}{l}\text { Humboldt } \\
\text { Mendocino } \\
\text { Mendocino } \\
\text { Mendocino } \\
\text { Mendocino }\end{array}$ & & $\begin{array}{c}\text { Humboldt Times, } \\
14 \text { Aug 1907; p. 8, c. } 4\end{array}$ & $\begin{array}{l}\text { "A light earthquake shock was felt Sunday morning at } 4: 19 \\
\text { o'clock in this city and for some distance down the coast. The } \\
\text { report of Observer Bell of the local Weather Bureau shows that } \\
\text { the shock lasted } 15 \text { seconds with the vibrations running from } \\
\text { southeast to northwest. The shock was felt at Laytonville, Fort } \\
\text { Bragg, Willits and Covelo. At Covelo the shock was great enough } \\
\text { to stop several of the clocks." } \\
\text { See Table 15. }\end{array}$ \\
\hline 11-Aug-07 & 04:19 & $\begin{array}{c}\text { Eureka } \\
\text { Fortuna } \\
\text { Blocksburg }\end{array}$ & $\begin{array}{l}\text { Humboldt } \\
\text { Humboldt } \\
\text { Humboldt }\end{array}$ & & $\begin{array}{l}\text { Townley and Allen (1939), } \\
\text { p. } 146\end{array}$ & $\begin{array}{l}\text { "VI or higher [Rossi-Forel scale]. Humboldt Co. At Eureka: } \\
\text { 'Quite heavy; southeast to northwest; duration about fifteen } \\
\text { seconds; steady shaking. This shock was felt at Fortuna, where } \\
\text { plaster in bank building became loosened somewhat near safe. At } \\
\text { Blocksburg and Covelo clocks stopped. Laytonville, Mendocino } \\
\text { Co., operator reported vibrations from east to west; also felt at }\end{array}$ \\
\hline
\end{tabular}


TABLE 1: Catalog of Aftershock Reports following from the Great 18 April 1906 California Earthquake

\begin{tabular}{|c|c|c|c|c|c|c|}
\hline Date Felt & $\begin{array}{l}\text { Time Felt } \\
\text { (PST) }\end{array}$ & $\begin{array}{l}\text { Location Felt } \\
\text { (City) }\end{array}$ & $\begin{array}{l}\text { Location Felt } \\
\text { (County) }\end{array}$ & $\begin{array}{l}\text { Unreliable? } \\
\text { Not Felt? }^{+}\end{array}$ & Source & Relevant Citations and other Notes \\
\hline & & $\begin{array}{l}\text { Covelo } \\
\text { Laytonville } \\
\text { Fort Bragg } \\
\text { Willits } \\
\text { Branscomb } \\
\text { La Porte } \\
\text { Nevada City } \\
\text { Willows }\end{array}$ & $\begin{array}{c}\text { Mendocino } \\
\text { Mendocino } \\
\text { Mendocino } \\
\text { Mendocino } \\
\text { Mendocino } \\
\text { Plumas } \\
\text { Nevada } \\
\text { Glenn }\end{array}$ & & & $\begin{array}{l}\text { Fort Bragg and Willits, Mendocino Co.' -AHB [A. H. Bell, } \\
\text { manuscript list of earthquakes at Eureka, Calif., } 1887 \text { to 1913] } \\
\text { “This shock was also reported from Branscomb, Mendocino Co., } \\
\text { La Porte, Plumas Co., Nevada City, Nevada Co., and Willows, } \\
\text { Glenn Co. It made a decided record on the seismograph at } \\
\text { Berkeley, and seems to have registered on a number of distant } \\
\text { seismographs, the most distant being that at Tiflis [now Tbilisi, } \\
\text { the capital of the Republic of Georgial. The data appear to } \\
\text { indicate a strongish shock at sea off Cape Mendocino. } \\
\text {-WB Form 1009 [U.S. Weather Bureau Form 1009], and the } \\
\text { Strassburg [Strasbourg?] catalog of teleseisms recorded during } \\
\text { 1907." } \\
\text { See Table 15. }\end{array}$ \\
\hline 11-Aug-07 & $04: 24$ & Willows & Glenn & & $\begin{array}{l}\text { Willows Review, } \\
16 \text { Aug 1907; p. } 3, \text { c. } 2\end{array}$ & $\begin{array}{l}\text { "A slight earthquake shock was felt here.... It lasted for about } \\
\text { two seconds but no damage was done." } \\
\text { See Table } 15 .\end{array}$ \\
\hline 11-Aug-07 & $04: 25$ & Blocksburg & Humboldt & & $\begin{array}{c}\text { Humboldt Standard, } \\
13 \text { Aug 1907; p. 7, c. } 7\end{array}$ & $\begin{array}{l}\text { "Blocksburg, Aug. 11.-At 4:25 a. m. we had quite a shake up, at } \\
\text { first gentle and then severe, stopping clocks, etc., etc., and } \\
\text { accompanied by a roaring noise. Except for that of the 19th [sic] } \\
\text { of April, 1906, it was the most pronounced in } 32 \text { years." } \\
\text { See Table } 15 .\end{array}$ \\
\hline 11-Aug-07 & $\begin{array}{c}\sim 04: 25 \\
\end{array}$ & Blocksburg & Humboldt & & $\begin{array}{c}\text { Humboldt Times, } \\
13 \text { Aug 1907; p.7, c. } 6\end{array}$ & $\begin{array}{l}\text { "BLOCKSBURG, Aug. 11.-The people of our little burg were } \\
\text { awakened from their slumbers by quite a severe shock of } \\
\text { earthquake.... The shock was heavy enough to stop clocks, but } \\
\text { otherwise no damage was done." } \\
\text { See Table 15. }\end{array}$ \\
\hline 11-Aug-07 & 04:30 & Weaverville & Trinity & & $\begin{array}{c}\text { Courier-Free Press (Redding), } \\
14 \text { Aug 1907; p. 7, c. } 3\end{array}$ & $\begin{array}{l}\text { "WEAVERVILLE, Aug. 14.-.... The earthquake Sunday morning } \\
\text { at 4:30 was plainly felt by several of our citizens." } \\
\text { See Table } 15 \text {. }\end{array}$ \\
\hline 11-Aug-07 & $\sim \sim 04: 30$ & Weaverville & \begin{tabular}{|c|} 
Trinity \\
Sacramento \\
Valley, and north \\
to the Oregon line
\end{tabular} & & $\begin{array}{l}\text { Weekly Trinity Journal, } \\
17 \text { Aug 1907; p. 3, c. } 6\end{array}$ & $\begin{array}{l}\text { "An earthquake shock was felt by a number of our citizens on } \\
\text { Sunday morning about } 4: 30 \text {. No damage done. The shock was felt } \\
\text { in various parts of the Sacramento valley and north to the Oregon } \\
\text { line. It was not noticed in San Francisco, or if it was none of the } \\
\text { papers of that city made mention of it." } \\
\text { See Table } 15 .\end{array}$ \\
\hline 11-Aug-07 & 04:30 & $\begin{array}{c}\text { Sisson } \\
\text { (now Mt. Shasta) }\end{array}$ & Siskiyou & & $\begin{array}{l}\text { The Searchlight (Redding), } \\
13 \text { Aug 1907; p. 1, c. 3-4 }\end{array}$ & $\begin{array}{l}\text { "SISSON, August 12.- - This place was disturbed yesterday } \\
\text { morning by a temblor which startled those who felt it and } \\
\text { frightened a few, though the earthquake was slight and lasted but }\end{array}$ \\
\hline
\end{tabular}


TABLE 1: Catalog of Aftershock Reports following from the Great 18 April 1906 California Earthquake

\begin{tabular}{|c|c|c|c|c|c|c|}
\hline Date Felt & $\begin{array}{l}\text { Time Felt } \\
\text { (PST) }\end{array}$ & $\begin{array}{l}\text { Location Felt } \\
\text { (City) }\end{array}$ & $\begin{array}{l}\text { Location Felt } \\
\text { (County) }\end{array}$ & $\begin{array}{l}\text { Unreliable? } \\
\text { Not Felt? }^{+}\end{array}$ & Source & Relevant Citations and other Notes \\
\hline & & & & & & $\begin{array}{l}\text { a few seconds. It came at } 4: 30 \text { a. m." } \\
\text { See Table } 15 .\end{array}$ \\
\hline 11-Aug-07 & 04:30 & \begin{tabular}{|c|} 
Baird \\
McCloud fishery \\
[on \\
McCloud River, \\
near Baird (?)]
\end{tabular} & $\begin{array}{l}\text { Shasta } \\
\text { Shasta }\end{array}$ & & $\begin{array}{l}\text { The Searchlight (Redding), } \\
13 \text { Aug 1907; p. 1, c. 3-4 }\end{array}$ & $\begin{array}{l}\text { "BAIRD, August 12.-A sharp earthquake shock was felt here at } \\
\text { 4:30 yesterday morning. All persons in camp along the [McCloud] } \\
\text { river felt it, but the severest shock was undoubtedly at the } \\
\text { McCloud fishery. Captain Lambson, superintendent of the } \\
\text { fishery, awakened by the earthquake, looked at his watch } \\
\text { immediately. It was 4:30 according to his time. It was a distant } \\
\text { and sharp shock at first, dying away in gentle quivers whose } \\
\text { duration was from eight to ten seconds." } \\
\text { See Table 15. }\end{array}$ \\
\hline 11-Aug-07 & 04:30 & $\begin{array}{l}\text { McCloud fishery } \\
\text { [on } \\
\text { McCloud River, } \\
\text { near Baird (?)] }\end{array}$ & $\begin{array}{c}\text { Sacramento Vly. } \\
\text { Shasta }\end{array}$ & & $\begin{array}{l}\text { The Searchlight (Redding), } \\
13 \text { Aug 1907; p. 1, c. 3-4 }\end{array}$ & $\begin{array}{l}\text { "Sunday's earthquake was felt generally all over the Sacramento } \\
\text { Valley, but seems to have been most pronounced at the McCloud } \\
\text { fishery. Adolph Dobrowsky, who was camping out near the } \\
\text { fishery, was awake when the shock occurred and noted the time } \\
\text { and duration. It was 4:30 and lasted about ten seconds." } \\
\text { See Table 15. }\end{array}$ \\
\hline 11-Aug-07 & $\sim 04: 30$ & Redding & Shasta & & $\begin{array}{l}\text { The Searchlight (Redding), } \\
13 \text { Aug 1907; p. 1, c. 3-4 }\end{array}$ & $\begin{array}{l}\text { "In Redding many were awakened from their early morning's } \\
\text { sleep. In private houses and in all-night restaurants the rattling } \\
\text { of dishes and cooking utensils proclaimed the sharpness of the } \\
\text { seismic disturbance. It was noticeable on the road by the drivers } \\
\text { of a few vehicles. } \\
\text { "The shock was well defined, starting at about 4:30 and lasting } \\
\text { not more than ten seconds. No reports have been received of the } \\
\text { breaking of even the lightest articles on bureaus and mantels, } \\
\text { however, and most healthy sleepers slept right through the } \\
\text { shock." } \\
\text { See Table 15. }\end{array}$ \\
\hline 11-Aug-07 & $\begin{array}{l}\text { 04:30 or a } \\
\text { little later }\end{array}$ & Chico & Butte & & $\begin{array}{l}\text { The Searchlight (Redding), } \\
13 \text { Aug 1907; p. 1, c. 3-4 }\end{array}$ & $\begin{array}{l}\text { "CHICO, August 12.--An earthquake was distinctly felt in Chico } \\
\text { at 4:30 or a little later yesterday morning. Many people were } \\
\text { awakened by the shock and their tales agree with those few late } \\
\text { retirers who were still up as to the time and duration of the } \\
\text { quake. It lasted something less than a quarter of a minute. No } \\
\text { damage." } \\
\text { See Table 15. }\end{array}$ \\
\hline 11-Aug-07 & before $05: 00$ & Garberville & Humboldt & & $\begin{array}{c}\text { Humboldt Times, } \\
14 \text { Aug 1907; p. 6, c. 2-3 }\end{array}$ & $\begin{array}{l}\text { "GARBERVILLE, Aug. 11-... a seismic disturbance nearly equal } \\
\text { to the long-to-be-remembered one of April 18th last year } \\
\text { disturbed the town, the shock lasting some seconds, the rocking } \\
\text { motion being perceptible for some time after the first shock...." } \\
\text { See Table 15. }\end{array}$ \\
\hline
\end{tabular}


TABLE 1: Catalog of Aftershock Reports following from the Great 18 April 1906 California Earthquake

\begin{tabular}{|c|c|c|c|c|c|c|}
\hline Date Felt & $\begin{array}{l}\text { Time Felt } \\
\text { (PST) }\end{array}$ & $\begin{array}{l}\text { Location Felt } \\
\text { (City) }\end{array}$ & $\begin{array}{l}\text { Location Felt } \\
\text { (County) }\end{array}$ & $\begin{array}{l}\text { Unreliable? } \\
\text { Not Felt? }^{+}\end{array}$ & Source & Relevant Citations and other Notes \\
\hline 11-Aug-07 & $\begin{array}{c}\text { early } \\
\text { morning } \\
(\text { two events?) }\end{array}$ & Arcata & Humboldt & & $\begin{array}{c}\text { Humboldt Times, } \\
13 \text { Aug 1907; p. 2, c. 1-2 }\end{array}$ & $\begin{array}{l}\text { "... two [earthquake shocks], a quite hard one and one light one, } \\
\text { were felt early in the morning." } \\
\text { It is not clear if this refers to one or two separate events. } \\
\text { See Table } 15 .\end{array}$ \\
\hline 11-Aug-07 & $\begin{array}{l}\text { early } \\
\text { morning }\end{array}$ & Ryan Slough & Humboldt & & $\begin{array}{l}\text { Humboldt Standard, } \\
14 \text { Aug 1907; p. 3, c. } 5\end{array}$ & $\begin{array}{l}\text { "One result of the earthquake shock of early Sunday morning, not } \\
\text { hitherto reported, was the throwing down of the smokestack at } \\
\text { the McKay \& Co.'s shingle mill on Ryan Slough...." } \\
\text { See Table } 15 .\end{array}$ \\
\hline 11-Aug-07 & $\begin{array}{l}\text { early } \\
\text { morning }\end{array}$ & $\begin{array}{c}\text { Eureka } \\
\text { Ferndale } \\
\text { San Francisco }\end{array}$ & $\begin{array}{c}\text { Humboldt } \\
\text { Humboldt } \\
\text { San Francisco }\end{array}$ & & $\begin{array}{l}\text { Humboldt Standard, } \\
12 \text { Aug 1907; p. 4, c. } 7\end{array}$ & $\begin{array}{l}\text { "Early morning shakes are getting to be a feature of the terrestrial } \\
\text { phenomena in these parts of late. Yesterday morning [11 Aug] and } \\
\text { again this morning [12 Aug] the people were treated to a rattling } \\
\text { of windows and doors. The quake of yesterday morning was } \\
\text { quite prolonged but as far as can be learned did no damage in this } \\
\text { city. At Ferndale it was a little sharper and one of the results } \\
\text { was the cracking of the plaster in the Ferndale Bank where the } \\
\text { vault is built into a wall. } \\
\text { "Report from San Francisco this morning was to the effect that it } \\
\text { was scarcely noticeable there." } \\
\text { It is not clear whether the report from San Francisco refers to the } \\
\text { event on } 11 \text { Aug or on } 12 \text { Aug; however, a report in the Humboldt } \\
\text { Times (see below) indicates that the } 11 \text { Aug event was felt lightly } \\
\text { in San Francisco. } \\
\text { See Table } 15 .\end{array}$ \\
\hline 11-Aug-07 & $\begin{array}{l}\text { early } \\
\text { morning }\end{array}$ & Briceland & Humboldt & & $\begin{array}{c}\text { Humboldt Times, } \\
15 \text { Aug 1907; p. 8, c. 4-6 }\end{array}$ & $\begin{array}{l}\text { "BRICELAND, Aug. 11.... A very heavy earthquake shook things } \\
\text { up here at an early hour this morning. It lasted much longer than } \\
\text { the two which occurred earlier in the week." } \\
\text { See Table } \mathbf{1 5 .}\end{array}$ \\
\hline 11-Aug-07 & $\begin{array}{l}\text { early } \\
\text { morning }\end{array}$ & Oroville & Butte & & $\begin{array}{l}\text { Oroville Daily Register, } \\
12 \text { Aug 1907; p. 1, c. } 5\end{array}$ & $\begin{array}{l}\text { "A slight earthquake shock is reported to have been felt...." } \\
\text { See Table } \mathbf{1 5 .}\end{array}$ \\
\hline 11-Aug-07 & $\begin{array}{l}\text { morning, at } \\
\text { an early houn }\end{array}$ & Crescent City & $\begin{array}{l}\text { Humboldt } \\
\text { Del Norte }\end{array}$ & Not Felt & $\begin{array}{l}\text { Del Norte Record, } \\
17 \text { Aug 1907; p. 3, c. } 1\end{array}$ & $\begin{array}{l}\text { "Quite a heavy earthquake was felt in Humboldt county last } \\
\text { Sunday morning, at an early hour. Del Norter's [sic] felt no } \\
\text { quake so far as heard from." } \\
\text { See Table } \mathbf{1 5 .}\end{array}$ \\
\hline 11-Aug-07 & morning & San Francisco & San Francisco & & $\begin{array}{l}\text { Humboldt Times, } \\
13 \text { Aug 1907; p. 3, c. } 1\end{array}$ & $\begin{array}{l}\text { "No great earthquake shock was felt in San Francisco Sunday } \\
\text { morning as was reported on the streets here yesterday. People } \\
\text { incoming by the steamers from San Francisco yesterday stated } \\
\text { that the shock was very light and nothing more than usual, for }\end{array}$ \\
\hline
\end{tabular}


TABLE 1: Catalog of Aftershock Reports following from the Great 18 April 1906 California Earthquake

\begin{tabular}{|c|c|c|c|c|c|c|}
\hline Date Felt & $\begin{array}{l}\text { Time Felt } \\
\text { (PST) }\end{array}$ & $\begin{array}{l}\text { Location Felt } \\
\text { (City) }\end{array}$ & $\begin{array}{l}\text { Location Felt } \\
\text { (County) }\end{array}$ & $\begin{array}{l}\text { Unreliable? } \\
\text { Not Felt? }^{+}\end{array}$ & Source & Relevant Citations and other Notes \\
\hline & & & & & & $\begin{array}{l}\text { tremors are still a common occurrence in the metropolis." } \\
\text { See Table } \mathbf{1 5 .}\end{array}$ \\
\hline 11-Aug-07 & morning & Falk & Humboldt & & $\begin{array}{l}\text { Humboldt Standard, } \\
16 \text { Aug 1907; p. 7, c. } 5\end{array}$ & $\begin{array}{l}\text { "... Another earthquake shock was felt ... but no damage was } \\
\text { done." } \\
\text { See Table } 15 .\end{array}$ \\
\hline 11-Aug-07 & $\begin{array}{l}\text { morning } \\
\text { (three } \\
\text { events?) }\end{array}$ & Ferndale & Humboldt & & $\begin{array}{l}\text { Humboldt Standard, } \\
13 \text { Aug 1907; p.7, c. } 6\end{array}$ & $\begin{array}{l}\text { "Ferndale, August } 12-\ldots \text { Q.. Quite a heavy shock of earthquake } \\
\text { was felt yesterday morning and another this morning, followed } \\
\text { each morning by two lighter ones. No damage reported. There } \\
\text { was no sudden jerk such as is usually felt." } \\
\text { It is not clear if this refers to one or three separate events each } \\
\text { morning. } \\
\text { See Table } 15 .\end{array}$ \\
\hline 11-Aug-07 (?) & morning & $\begin{array}{c}\text { near Reed } \\
\text { Mountain (?) }\end{array}$ & Humboldt & Not Felt & $\begin{array}{l}\text { Humboldt Standard, } \\
16 \text { Aug 1907; p.7, c. } 5\end{array}$ & $\begin{array}{l}\text { "Garberville, August 13-... Mr. and Mrs. Joe Caton returned } \\
\text { yesterday from their hunting trip above the Reed ranges. The } \\
\text { morning of the earthquake they were camped on a high ridge and } \\
\text { knew nothing of the disturbance at the time...." } \\
\text { Too much significance should not be placed in the fact that this } \\
\text { event was not felt by two particular people who were outdoors and } \\
\text { possibly moving about at the time. } \\
\text { See Table } 15 .\end{array}$ \\
\hline 11-Aug-07 (?) & & Rocky Glen (?) & Humboldt & & $\begin{array}{l}\text { Humboldt Standard, } \\
16 \text { Aug 1907; p. } 7, \text { c. } 5\end{array}$ & $\begin{array}{l}\text { "Garberville, August 13-.... Mrs. J. E. Sinclair of Rocky Glenn } \\
\text { [sic] and daughter Emma were in town today shopping, and } \\
\text { inquiring how we fared during the earthquake. The shocks were } \\
\text { about the same degree at Rocky Glenn [sic] as here...." } \\
\text { The earthquake in question is inferred to be that of } 11 \text { Aug. } \\
\text { See Table } 15 .\end{array}$ \\
\hline 11-Aug-07 & & Ruth & Trinity & & $\begin{array}{l}\text { Humboldt Standard, } \\
27 \text { Aug 1907; p.7, c. } 7\end{array}$ & $\begin{array}{l}\text { "Ruth, Trinity Co., August } 23-\ldots . \text { We know that Mother Earth is } \\
\text { very uneasy for the temblors of the 9th, } 11 \text { th, and } 12 \text { th insts. were } \\
\text { quite hard, but the one on the } 18 \text { th at } 3: 20 \mathrm{p} \text {. m. was the most } \\
\text { severe...." } \\
\text { See Table 15. }\end{array}$ \\
\hline 12-Aug-07 & $\begin{array}{l}\text { early } \\
\text { morning }\end{array}$ & Eureka & Humboldt & & $\begin{array}{l}\text { Humboldt Standard, } \\
12 \text { Aug 1907; p. } 4 \text {, c. } 7\end{array}$ & $\begin{array}{l}\text { "Early morning shakes are getting to be a feature of the terrestrial } \\
\text { phenomena in these parts of late. Yesterday morning [11 Aug] and } \\
\text { again this morning [12 Aug] the people were treated to a rattling } \\
\text { of windows and doors...." }\end{array}$ \\
\hline
\end{tabular}


TABLE 1: Catalog of Aftershock Reports following from the Great 18 April 1906 California Earthquake

\begin{tabular}{|c|c|c|c|c|c|c|}
\hline Date Felt & $\begin{array}{l}\text { Time Felt } \\
\text { (PST) }\end{array}$ & $\begin{array}{l}\text { Location Felt } \\
\text { (City) }\end{array}$ & $\begin{array}{l}\text { Location Felt } \\
\text { (County) }\end{array}$ & $\begin{array}{l}\text { Unreliable? } \\
\text { Not Felt? }^{+}\end{array}$ & Source & Relevant Citations and other Notes \\
\hline 12-Aug-07 & $\begin{array}{l}\text { morning } \\
\text { (three } \\
\text { events?) }\end{array}$ & Ferndale & Humboldt & & $\begin{array}{l}\text { Humboldt Standard, } \\
13 \text { Aug 1907; p. 7, c. } 6\end{array}$ & $\begin{array}{l}\text { "Ferndale, August } 12-\ldots \text { Quite a heavy shock of earthquake } \\
\text { was felt yesterday morning and another this morning, followed } \\
\text { each morning by two lighter ones. No damage reported. There } \\
\text { was no sudden jerk such as is usually felt." } \\
\text { It is not clear if this refers to one or three separate events each } \\
\text { morning. }\end{array}$ \\
\hline 12-Aug-07 & $\sim 06: 00$ & Eureka & Humboldt & & $\begin{array}{c}\text { Humboldt Times, } \\
14 \text { Aug 1907; p. 8, c. } 4\end{array}$ & “... a very slight shock was felt...." \\
\hline 12-Aug-07 & & Ruth & Trinity & & $\begin{array}{l}\text { Humboldt Standard, } \\
27 \text { Aug 1907; p. 7, c. } 7\end{array}$ & $\begin{array}{l}\text { "Ruth, Trinity Co., August } 23-\ldots . \text { We know that Mother Earth is } \\
\text { very uneasy for the temblors of the 9th, } 11 \text { th, and } 12 \text { th insts. were } \\
\text { quite hard, but the one on the } 18 \text { th at } 3: 20 \text { p. m. was the most } \\
\text { severe...." }\end{array}$ \\
\hline 18-Aug-07 & $15: 20$ & Ruth & Trinity & & $\begin{array}{l}\text { Humboldt Standard, } \\
27 \text { Aug 1907; p. 7, c. } 7\end{array}$ & $\begin{array}{l}\text { "Ruth, Trinity Co., August } 23-\ldots . \text { We know that Mother Earth is } \\
\text { very uneasy for the temblors of the 9th, } 11 \text { th, and } 12 \text { th insts. were } \\
\text { quite hard, but the one on the } 18 \text { th at } 3: 20 \text { p. m. was the most } \\
\text { severe...." }\end{array}$ \\
\hline 22-Aug-07 & $20: 40$ & Ruth & Trinity & & $\begin{array}{l}\text { Humboldt Standard, } \\
27 \text { Aug 1907; p. 7, c. } 7\end{array}$ & $\begin{array}{l}\text { "Ruth, Trinity Co., August } 23-\ldots . \text { We know that Mother Earth is } \\
\text { very uneasy for the temblors of the 9th, } 11 \text { th, and } 12 \text { th insts. were } \\
\text { quite hard, but the one on the } 18 \text { th at } 3: 20 \text { p. m. was the most } \\
\text { severe. Two distinct shocks with another last night at } 8: 40 \text { p. m., } \\
\text { a good shake." }\end{array}$ \\
\hline 25-Aug-07 & $18: 15$ & Alma & Santa Clara & & $\begin{array}{l}\text { Diary of Henry Lloyd Tevis } \\
\text { (Alma, CA), } \\
25 \text { Aug } 1907\end{array}$ & $\begin{array}{l}\text { Entry of } 25 \text { Aug 1907: } \\
\text { "Morning Cool. } \\
\text { Mr. \& Mrs. Chas. Page and party drove in from Santa Cruz for } \\
\text { lunch. Took them around New Drive... } \\
\text { Expect Guests and all to leave to-morrow morning at seven for } \\
\text { the city in Green Loco. [sic] } \\
\text { Slight earthquake at 6:15 P.M." } \\
\text { The location where the aforementioned earthquake was felt is not } \\
\text { stated but is inferred from the rest of the diary entry. } \\
\text { See note about the Tevis diary following the citation for the event } \\
\text { "during the night" of } 5 \text { Jun 1907. }\end{array}$ \\
\hline 16-Sep-07 & $\sim 02: 00$ & Alma & Santa Clara & & $\begin{array}{l}\text { Diary of Henry Lloyd Tevis } \\
\text { (Alma, CA), } \\
\text { 16 Sep } 1907\end{array}$ & $\begin{array}{l}\text { Entry of } 16 \text { Sep 1907: } \\
\text { "Morning cloudy. } \\
\text { Temp went down to } 45^{\circ} \text { during night. } \\
\text { Sharp, short earthquake shock about } 2 \text { A.M.... } \\
\text { H.L.T. \& Mr. Russell leave on } 7 \text { A.M. train from Los Gatos for } \\
\text { city. } \\
\text { Mr. \& Mrs. Mendell, Mrs. Atherton, Mrs. Russell, and Mr. \& } \\
\text { Mrs. Stevens were driven to San Jose at 9. }\end{array}$ \\
\hline
\end{tabular}


TABLE 1: Catalog of Aftershock Reports following from the Great 18 April 1906 California Earthquake

\begin{tabular}{|c|c|c|c|c|c|c|}
\hline Date Felt & $\begin{array}{c}\text { Time Felt } \\
\text { (PST) }\end{array}$ & $\begin{array}{l}\text { Location Felt } \\
\text { (City) }\end{array}$ & $\begin{array}{l}\text { Location Felt } \\
\text { (County) }\end{array}$ & $\begin{array}{l}\text { Unreliable? } \\
\text { Not Felt? }{ }^{+}\end{array}$ & Source & Relevant Citations and other Notes \\
\hline & & & & & & $\begin{array}{l}\text { E.L.D. leaves for city on } 3 \text { P.M. train at Alma. } \\
\text { Ready for New York. [sic]" } \\
\text { The location where the aforementioned earthquake was felt is not } \\
\text { stated but is inferred from the rest of the diary entry. } \\
\text { See note about the Tevis diary following the citation for the event } \\
\text { "during the night" of } 5 \text { Jun 1907. }\end{array}$ \\
\hline 22-Sep-07 & $\sim 23: 50$ & Salinas & Monterey & & $\begin{array}{l}\text { Salinas Weekly Journal, } \\
28 \text { Sep 1907; p. 3, c. } 6\end{array}$ & $\begin{array}{l}\text { Under the heading "From Tuesday's Daily Journal": } \\
\text { "... Sunday night two very slight shocks were felt here, the first } \\
\text { about 11:50 and the other about five minutes later." }\end{array}$ \\
\hline 22-Sep-07 & $\sim 23: 50$ & $\begin{array}{c}\text { Watsonville } \\
\text { Salinas }\end{array}$ & $\begin{array}{l}\text { Santa Cruz } \\
\text { Monterey }\end{array}$ & Not Felt & $\begin{array}{l}\text { Evening Pajaronian } \\
\text { (Watsonville), } \\
24 \text { Sep 1907; p. 4, c. } 3\end{array}$ & $\begin{array}{l}\text { The following article appeared in the Evening Pajaronian under } \\
\text { the heading "Wasn't Felt Here." It is assumed that none of the } \\
\text { events mentioned in the article were felt in Watsonville. The } \\
\text { original article, minus the heading, appeared in the Salinas (Daily) } \\
\text { Journal on } 24 \text { Sep } 1907 . \\
\text { "Quite a lively earthquake shock was felt in Salinas at } 4: 42 \\
\text { o'clock yesterday afternoon, causing people to run into the street } \\
\text { for fear that a harder one might follow. In the court house, during } \\
\text { the Naredo trial, consternation reigned for a moment and several } \\
\text { persons made for the door, but Judge Sargent rapped for order and } \\
\text { spoke a few words of reassurance, and allayed their fears. After } \\
\text { a few moments the trial proceeded. Sunday night two very slight } \\
\text { shocks were felt here, the first about } 11: 50 \text { and the other about } \\
\text { five minutes later.-Salinas Journal." }\end{array}$ \\
\hline 22-Sep-07 & $\sim 23: 55$ & Salinas & Monterey & & $\begin{array}{l}\text { Salinas Weekly Journal, } \\
28 \text { Sep 1907; p. 3, c. } 6\end{array}$ & $\begin{array}{l}\text { Under the heading "From Tuesday's Daily Journal": } \\
\text { "... Sunday night two very slight shocks were felt here, the first } \\
\text { about 11:50 and the other about five minutes later." }\end{array}$ \\
\hline 22-Sep-07 & $\sim 23: 55$ & $\begin{array}{c}\text { Watsonville } \\
\text { Salinas }\end{array}$ & $\begin{array}{l}\text { Santa Cruz } \\
\text { Monterey }\end{array}$ & Not Felt & $\begin{array}{l}\text { Evening Pajaronian } \\
\text { (Watsonville), } \\
24 \text { Sep 1907; p. 4, c. } 3\end{array}$ & $\begin{array}{l}\text { The following article appeared in the Evening Pajaronian under } \\
\text { the heading "Wasn't Felt Here." It is assumed that none of the } \\
\text { events mentioned in the article were felt in Watsonville. The } \\
\text { original article, minus the heading, appeared in the Salinas (Daily) } \\
\text { Journal on } 24 \text { Sep } 1907 . \\
\text { "Quite a lively earthquake shock was felt in Salinas at } 4: 42 \\
\text { o'clock yesterday afternoon, causing people to run into the street } \\
\text { for fear that a harder one might follow. In the court house, during } \\
\text { the Naredo trial, consternation reigned for a moment and several } \\
\text { persons made for the door, but Judge Sargent rapped for order and } \\
\text { spoke a few words of reassurance, and allayed their fears. After } \\
\text { a few moments the trial proceeded. Sunday night two very slight } \\
\text { shocks were felt here, the first about 11:50 and the other about } \\
\text { five minutes later.-Salinas Journal." }\end{array}$ \\
\hline
\end{tabular}


TABLE 1: Catalog of Aftershock Reports following from the Great 18 April 1906 California Earthquake

\begin{tabular}{|c|c|c|c|c|c|c|}
\hline Date Felt & $\begin{array}{l}\text { Time Felt } \\
\text { (PST) }\end{array}$ & $\begin{array}{l}\text { Location Felt } \\
\text { (City) }\end{array}$ & $\begin{array}{l}\text { Location Felt } \\
\text { (County) }\end{array}$ & $\begin{array}{l}\text { Unreliable? } \\
\text { Not Felt? }^{+}\end{array}$ & Source & Relevant Citations and other Notes \\
\hline 23-Sept-07 & $16: 41$ & Hollister & San Benito & & $\begin{array}{l}\text { San Benito Advance, } \\
25 \text { Sep 1907; p. 3, c. } 3\end{array}$ & $\begin{array}{l}\text { "A heavy shock of earthquake ... sent the people of town into the } \\
\text { streets on the run. No damage was reported." }\end{array}$ \\
\hline 23-Sept-07 & $16: 42$ & Hollister & San Benito & & $\begin{array}{l}\text { The Free Lance (Hollister), } \\
27 \text { Sep 1907; p. } 5, \text { c. } 4\end{array}$ & $\begin{array}{l}\text { "A sharp earthquake shock ... sent the people scurrying into the } \\
\text { streets. No damage was done." }\end{array}$ \\
\hline 23-Sep-07 & $16: 42$ & Salinas & Monterey & & $\begin{array}{l}\text { Salinas Weekly Journal, } \\
28 \text { Sep 1907; p. 3, c. } 6\end{array}$ & $\begin{array}{l}\text { Under the heading "From Tuesday's Daily Journal": } \\
\text { "Quite a lively earthquake shock was felt here at } 4: 42 \text { o'clock } \\
\text { yesterday afternoon, causing people to run into the street for fear } \\
\text { that a harder one might follow. In the court house, during the } \\
\text { Naredo trial, consternation reigned for a moment and several } \\
\text { persons made for the door, but Judge Sargent rapped for order and } \\
\text { spoke a few words of reassurance, and allayed their fears. After } \\
\text { a few moments the trial proceeded...." }\end{array}$ \\
\hline 23-Sep-07 & $16: 42$ & $\begin{array}{c}\text { Watsonville } \\
\text { Salinas }\end{array}$ & $\begin{array}{l}\text { Santa Cruz } \\
\text { Monterey }\end{array}$ & Not Felt & $\begin{array}{c}\text { Evening Pajaronian } \\
\text { (Watsonville), } \\
24 \text { Sep 1907; p. 4, c. } 3\end{array}$ & $\begin{array}{l}\text { The following article appeared in the Evening Pajaronian under } \\
\text { the heading "Wasn't Felt Here." It is assumed that none of the } \\
\text { events mentioned in the article were felt in Watsonville. The } \\
\text { original article, minus the heading, appeared in the Salinas (Daily) } \\
\text { Journal on } 24 \text { Sep } 1907 \text {. } \\
\text { "Quite a lively earthquake shock was felt in Salinas at 4:42 } \\
\text { o'clock yesterday afternoon, causing people to run into the street } \\
\text { for fear that a harder one might follow. In the court house, during } \\
\text { the Naredo trial, consternation reigned for a moment and several } \\
\text { persons made for the door, but Judge Sargent rapped for order and } \\
\text { spoke a few words of reassurance, and allayed their fears. After } \\
\text { a few moments the trial proceeded. Sunday night two very slight } \\
\text { shocks were felt here, the first about 11:50 and the other about } \\
\text { five minutes later.-Salinas Journal." }\end{array}$ \\
\hline 23-Sep-07 & $16: 45$ & Jamesburg & Monterey & & $\begin{array}{l}\text { Salinas Weekly Journal, } \\
28 \text { Sep 1907; p. 3, c. } 7\end{array}$ & $\begin{array}{l}\text { "JAMESBURG, Sept. 24.-.... We had two quite hard shocks of } \\
\text { earthquake yesterday afternoon at } 15 \text { minutes to } 5 \text { o'clock." }\end{array}$ \\
\hline 23-Sep-07 & afternoon & $\begin{array}{l}\text { Salinas } \\
\text { Watsonville } \\
\text { San Miguel } \\
\text { Canyon }\end{array}$ & $\begin{array}{l}\text { Monterey } \\
\text { Santa Cruz } \\
\text { Monterey }\end{array}$ & Not Felt & $\begin{array}{l}\text { Salinas Weekly Journal, } \\
28 \text { Sep 1907; p. 3, c. } 3\end{array}$ & $\begin{array}{l}\text { Under the heading "From Thursday morning's Daily Journal": } \\
\text { "The Pajaronian states that the earthquake shock that was quite } \\
\text { heavy here last Monday afternoon, was not felt in Watsonville. } \\
\text { It was felt very perceptibly in the San Miguel canyon country." }\end{array}$ \\
\hline 26-Sep-07 & $\begin{array}{c}\text { between } \\
\text { 03:00 and } \\
04: 00\end{array}$ & Martinez & Contra Costa & & $\begin{array}{l}\text { Contra Costa Gazette, } \\
28 \text { Sep 1907; p. 1, c. } 3\end{array}$ & $\begin{array}{l}\text { "On Thursday morning between three and four o' clock, there was } \\
\text { an earthquake. It seems to have been a fairly long one but it was } \\
\text { of equable wave motion and one that was unaccompanied by } \\
\text { damages of any kind. However, according to some who felt it, it } \\
\text { was the worst that had taken place since the big 'quake of last } \\
\text { year." }\end{array}$ \\
\hline
\end{tabular}


TABLE 1: Catalog of Aftershock Reports following from the Great 18 April 1906 California Earthquake

\begin{tabular}{|c|c|c|c|c|c|c|}
\hline Date Felt & $\begin{array}{c}\text { Time Felt } \\
\text { (PST) }\end{array}$ & $\begin{array}{l}\text { Location Felt } \\
\text { (City) }\end{array}$ & $\begin{array}{l}\text { Location Felt } \\
\text { (County) }\end{array}$ & \begin{tabular}{|} 
Unreliable? \\
Not Felt? $^{+}$
\end{tabular} & Source & Relevant Citations and other Notes \\
\hline 26-Sep-07 & $\sim 04: 05$ & Los Gatos & Santa Clara & & $\begin{array}{l}\text { Los Gatos Mail, } \\
26 \text { Sep 1907; p. 8, c. } 3\end{array}$ & "... that little earthquake shock." \\
\hline 03-Oct-07 (?) & & $\begin{array}{l}\text { San Francisco } \\
\text { San Jose }\end{array}$ & $\begin{array}{l}\text { San Francisco } \\
\text { Santa Clara }\end{array}$ & & $\begin{array}{l}\text { Santa Rosa Republican, } \\
3 \text { Oct 1907; p. 4, c. } 2\end{array}$ & $\begin{array}{l}\text { "SAN FRANCISCO, Sept 3.- This city and points south of here to } \\
\text { San Jose were shaken by an earthquake. It was a decided jar and } \\
\text { frightened many people. No damage of consequence was done." } \\
\text { The dateline is almost certainly incorrect; more likely, it should } \\
\text { read Oct } 3 \text {. Even so, the article does not state the time or date of the } \\
\text { shock; still, most likely, it was the event of } 3 \text { Oct } 1907 \text {. }\end{array}$ \\
\hline 03-Oct-07 & 13:10 & $\begin{array}{c}\text { San Mateo } \\
\text { all the } \\
\text { San Francisco } \\
\text { peninsula towns }\end{array}$ & $\begin{array}{l}\text { San Mateo } \\
\text { San Mateo, } \\
\text { San Francisco }\end{array}$ & & $\begin{array}{l}\text { San Mateo Leader, } \\
9 \text { Oct 1907; p. 5, c. } 1\end{array}$ & $\begin{array}{l}\text { "A sharp shock of earthquake was felt ... by many people here. } \\
\text { The quake is reported to have been felt in all the peninsula } \\
\text { towns." }\end{array}$ \\
\hline 03-Oct-07 & $13: 10$ & Redwood City & San Mateo & & $\begin{array}{c}\text { Times-Gazette (Redwood City) } \\
5 \text { Oct 1907; p. 3, c. } 1\end{array}$ & $\begin{array}{l}\text { Under the heading "County Seat Happenings" (Redwood City is } \\
\text { the county seat): } \\
\text { "Quite a severe earthquake startled the good people of the town ... } \\
\text { serving as a gentle reminder of old times." }\end{array}$ \\
\hline 03-Oct-07 & $13: 14$ & $\begin{array}{c}\text { San Francisco } \\
\text { Oakland } \\
\text { Alameda } \\
\text { Berkeley }\end{array}$ & $\begin{array}{l}\text { San Francisco } \\
\text { Alameda } \\
\text { Alameda } \\
\text { Alameda }\end{array}$ & & $\begin{array}{l}\text { Oakland Tribune, } \\
3 \text { Oct 1907; p. 2, c. } 5\end{array}$ & $\begin{array}{l}\text { "SAN FRANCISCO, Oct. 3.-A violent earthquake shock was felt } \\
\text { in this city.... Many frightened women rushed from their houses } \\
\text { and in many of the larger office buildings the occupants fled into } \\
\text { the hallways. } \\
\text { "No damage has thus far been reported." } \\
\text { Then, added below this article: } \\
\text { "The shock was also slightly felt in Oakland, Alameda and } \\
\text { Berkeley." }\end{array}$ \\
\hline 03-Oct-07 & $13: 16$ & $\begin{array}{l}\text { along the coast } \\
\text { and in the San } \\
\text { Francisco Bay } \\
\text { section }\end{array}$ & $\begin{array}{l}\text { San Francisco, } \\
\text { San Mateo, } \\
\text { Alameda, } \\
\text { Santa Clara, } \\
\text { others (?) }\end{array}$ & & $\begin{array}{l}\text { San Jose Mercury, } \\
4 \text { Oct 1907; p. 3, c. } 2\end{array}$ & $\begin{array}{l}\text { "A slight temblor was felt along the coast and in the bay section.... } \\
\text { No damage was done and little alarm felt." }\end{array}$ \\
\hline 03-Oct-07 & 13:17 (?) & Mountain View & Santa Clara & & $\begin{array}{l}\text { Diary of Samuel Haines } \\
\text { (Mountain View, CA), } \\
\text { 3 Oct } 1907\end{array}$ & $\begin{array}{l}\text { Entry of } 3 \text { Oct } 1907: \\
\text { "Quake at 1:17 lighter shock at about 2:25" } \\
\text { It is not stated whether the times are a.m. or p.m. By comparison to } \\
\text { similar reports, the times may be inferred to be in the afternoon. }\end{array}$ \\
\hline 03-Oct-07 & $13: 18$ & Palo Alto & Santa Clara & & $\begin{array}{l}\text { Daily Palo Alto Times, } \\
3 \text { Oct 1907; p. } 4 \text {, c. } 1\end{array}$ & $\begin{array}{l}\text { "A sharp earthquake shock occurred... The vibration was } \\
\text { sufficient to create considerable excitement and cause people } \\
\text { hurriedly to get out of buildings, but no damage was done. The }\end{array}$ \\
\hline
\end{tabular}


TABLE 1: Catalog of Aftershock Reports following from the Great 18 April 1906 California Earthquake

\begin{tabular}{|c|c|c|c|c|c|c|}
\hline Date Felt & $\begin{array}{l}\text { Time Felt } \\
\text { (PST) }\end{array}$ & $\begin{array}{l}\text { Location Felt } \\
\text { (City) }\end{array}$ & $\begin{array}{l}\text { Location Felt } \\
\text { (County) }\end{array}$ & $\begin{array}{c}\text { Unreliable? } \\
\text { Not Felt? }^{+}\end{array}$ & Source & Relevant Citations and other Notes \\
\hline & & & & & & $\begin{array}{l}\text { shake made most people feel as though a bigger disturbance were } \\
\text { due." }\end{array}$ \\
\hline 03-Oct-07 & $13: 20$ & San Francisco & San Francisco & & $\begin{array}{l}\text { Oakland Enquirer, } \\
3 \text { Oct 1907; p. } 1, \text { c. } 5\end{array}$ & $\begin{array}{l}\text { "SAN FRANCISCO, Oct. } 3 .- \text { A slight earthquake shock was felt } \\
\text { here...." } \\
\text { A very similar article appeared in the Oakland Herald of } \\
3 \text { Oct } 1907, p .1, c .5 \text {. }\end{array}$ \\
\hline 03-Oct-07 & $13: 20$ & $\begin{array}{c}\text { San Francisco } \\
\text { Alameda }\end{array}$ & $\begin{array}{l}\text { San Francisco } \\
\text { Alameda }\end{array}$ & & $\begin{array}{l}\text { Alameda Daily Argus, } \\
3 \text { Oct 1907; p. 1, c. } 2\end{array}$ & $\begin{array}{l}\text { "SAN FRANCISCO, Oct. 3.-A slight earthquake shock was felt } \\
\text { here...." } \\
\text { Then, added below this article: } \\
\text { "The shock was also quite noticeable in Alameda." }\end{array}$ \\
\hline 03-Oct-07 & $13: 20$ & $\begin{array}{l}\text { San Francisco } \\
\text { Stockton }\end{array}$ & $\begin{array}{l}\text { San Francisco } \\
\text { San Joaquin }\end{array}$ & & $\begin{array}{l}\text { Stockton Daily Independent, } \\
\quad 4 \text { Oct } 1907 ; \text { p. } 5, \text { c. } 2\end{array}$ & $\begin{array}{l}\text { "The sharp earthquake shock that startled San Francisco at 1:20 } \\
\text { o' clock yesterday afternoon was plainly felt in Stockton, but it } \\
\text { was not heavy enough to cause any local excitement. The } \\
\text { movement was apparently north and south. People who were } \\
\text { moving about at the time did not notice the jar, but those who } \\
\text { were sitting quietly in offices or at their homes unmistakably felt } \\
\text { the shake." }\end{array}$ \\
\hline 03-Oct-07 & $13: 20$ & Sonoma & Sonoma & & $\begin{array}{l}\text { Sonoma Index-Tribune, } \\
5 \text { Oct } 1907 ; \text { p. } 3, \text { c. } 2\end{array}$ & "A slight earthquake shock was felt here...." \\
\hline 03-Oct-07 & $\sim 13: 20$ & Martinez & Contra Costa & & $\begin{array}{l}\text { Contra Costa Gazette, } \\
5 \text { Oct 1907; p. } 5 \text {, c. } 2\end{array}$ & $\begin{array}{l}\text { "At about 1:20 p. m. on Thursday, Martinez was treated to } \\
\text { another little quake. Both the preceding tremor and the shake } \\
\text { itself were felt by a great number of the inhabitants, many of } \\
\text { whom consider the earthquake to have been a fairly big one...." }\end{array}$ \\
\hline 03-Oct-07 & $\sim 14: 00$ & Martinez & Contra Costa & & $\begin{array}{l}\text { Contra Costa Gazette, } \\
5 \text { Oct } 1907 ; \text { p. } 5, \text { c. } 2\end{array}$ & "... Some people report a second temblor at about 2 p. m." \\
\hline 03-Oct-07 & $\sim 14: 00$ & $\begin{array}{l}\text { Livermore } \\
\text { San Francisco }\end{array}$ & $\begin{array}{c}\text { Alameda } \\
\text { San Francisco }\end{array}$ & & $\begin{array}{l}\text { Livermore Echo, } \\
10 \text { Oct 1907; p. } 1, \text { c. } 5\end{array}$ & $\begin{array}{l}\text { "An earthquake was felt by some residents [in Livermore].... [It] } \\
\text { was quite heavy in San Francisco, and caused considerable alarm } \\
\text { for the moment." }\end{array}$ \\
\hline 03-Oct-07 & $14: 16$ & Palo Alto & Santa Clara & & $\begin{array}{l}\text { Daily Palo Alto Times, } \\
3 \text { Oct 1907; p. } 4 \text {, c. } 1\end{array}$ & “... Shook us up once more....” \\
\hline 03-Oct-07 & $\sim 14: 25(?)$ & Mountain View & Santa Clara & & $\begin{array}{l}\text { Diary of Samuel Haines } \\
\text { (Mountain View, CA), } \\
\text { 3 Oct } 1907\end{array}$ & $\begin{array}{l}\text { Entry of } 3 \text { Oct 1907: } \\
\text { "Quake at 1:17 lighter shock at about 2:25" } \\
\text { It is not stated whether the times are a.m. or p.m. By comparison to } \\
\text { similar reports, the times may be inferred to be in the afternoon. }\end{array}$ \\
\hline 05-Oct-07 & $00: 45$ & Livermore & Alameda & & $\begin{array}{l}\text { Livermore Echo, } \\
10 \text { Oct } 1907 ; \text { p. } 1 \text {, c. } 5\end{array}$ & "... A light shock is ... reported...." \\
\hline
\end{tabular}


TABLE 1: Catalog of Aftershock Reports following from the Great 18 April 1906 California Earthquake

\begin{tabular}{|c|c|c|c|c|c|c|}
\hline Date Felt & $\begin{array}{l}\text { Time Felt } \\
\text { (PST) }\end{array}$ & $\begin{array}{l}\text { Location Felt } \\
\text { (City) }\end{array}$ & $\begin{array}{l}\text { Location Felt } \\
\text { (County) }\end{array}$ & $\begin{array}{l}\text { Unreliable? } \\
\text { Not Felt? }^{+}\end{array}$ & Source & Relevant Citations and other Notes \\
\hline 07-Oct-07 & $\sim 17: 00$ & Briceland & Humboldt & & $\begin{array}{l}\text { Humboldt Standard, } \\
14 \text { Oct 1907; p. 2, c. } 2\end{array}$ & $\begin{array}{l}\text { "... Quite a tremble of the earth was felt.... It was severe enough to } \\
\text { frighten some from their houses for a few minutes." }\end{array}$ \\
\hline 07-Oct-07 & $17: 23$ & Eureka & Humboldt & & $\begin{array}{l}\text { Humboldt Standard, } \\
8 \text { Oct } 1907 ; \text { p. } 5, \text { c. } 3\end{array}$ & $\begin{array}{l}\text { "Eureka was given quite a lively and lengthy shake late } \\
\text { yesterday afternoon. The tremors were not perceptible to those } \\
\text { on the streets, but to people in houses, especially those on the } \\
\text { upper floors, were very noticeable. According to Observer Bell } \\
\text { of the U. S. Weather Bureau station the tremors began at 5:23 and } \\
\text { continued four seconds, the vibrations being from west to east." }\end{array}$ \\
\hline 07-Oct-07 & $17: 30$ & Glendale & Humboldt & & $\begin{array}{l}\text { Blue Lake Advocate, } \\
12 \text { Oct 1907; p. } 1, \text { c. } 4\end{array}$ & "Quite a heavy earthquake shock was felt...." \\
\hline 07-Oct-07 & $17: 30$ & Falk & Humboldt & & $\begin{array}{l}\text { Humboldt Standard, } \\
11 \text { Oct 1907; p. } 4, \text { c. } 1\end{array}$ & “... A light earthquake shock was felt.... No damage was done." \\
\hline 07-Oct-07 (?) & $17: 30(?)$ & Pepperwood & Humboldt & & $\begin{array}{l}\text { Humboldt Standard, } \\
10 \text { Oct } 1907 ; \text { p. 3, c. 3-4 }\end{array}$ & $\begin{array}{l}\text { "Pepperwood, Oct. 8, 1907.-... Quite a heavy shock of } \\
\text { earthquake ... at 5:30 o'clock. No damage...." } \\
\text { Several lines of the article were missing; the date of the event is } \\
\text { conjectural. }\end{array}$ \\
\hline 07-Oct-07 & $\sim$ 18:00 & Petrolia & Humboldt & & $\begin{array}{l}\text { Humboldt Standard, } \\
11 \text { Oct 1907; p. } 4, \text { c. } 1\end{array}$ & “... Petrolia was visited by a rather lively earthquake...." \\
\hline 14-Oct-07 & $14: 40$ & Eureka & Humboldt & & $\begin{array}{l}\text { Humboldt Standard, } \\
15 \text { Oct 1907; p. } 8, \text { c. } 3\end{array}$ & $\begin{array}{l}\text { "Old Mother Earth had another fit of ague in the region of } \\
\text { Eureka, yesterday afternoon. In fact she had two, neither, } \\
\text { however, of any mament [?] as they were manifest only to those in } \\
\text { houses, people on the street knowing nothing about them. The } \\
\text { first tremor was at 2:40 o'clock and the next at 3:03 o'clock." }\end{array}$ \\
\hline 14-Oct-07 & $15: 03$ & Eureka & Humboldt & & $\begin{array}{l}\text { Humboldt Standard, } \\
15 \text { Oct 1907; p. 8, c. } 3\end{array}$ & $\begin{array}{l}\text { "Old Mother Earth had another fit of ague in the region of } \\
\text { Eureka, yesterday afternoon. In fact she had two, neither, } \\
\text { however, of any mament [?] as they were manifest only to those in } \\
\text { houses, people on the street knowing nothing about them. The } \\
\text { first tremor was at 2:40 o'clock and the next at 3:03 o'clock." }\end{array}$ \\
\hline 14-Oct-07 & & Briceland & Humboldt & & $\begin{array}{l}\text { Humboldt Standard, } \\
18 \text { Oct } 1907 ; \text { p. } 5 \text {, c. } 5\end{array}$ & $\begin{array}{l}\text { "Briceland. Oct. 14-Two quite heavy shocks of earthquake } \\
\text { were felt here today." }\end{array}$ \\
\hline 15-Oct-07 (?) & 14:45 (?) & Pepperwood & Humboldt & & $\begin{array}{l}\text { Humboldt Standard, } \\
18 \text { Oct 1907; p. } 3 \text {, c. } 2\end{array}$ & $\begin{array}{l}\text { "Pepperwood, Oct. 16-... Two earthquakes were felt here, one } \\
\text { at a quarter to three o'clock and one at a quarter after three } \\
\text { o'clock, on Tuesday. No damage was done. The shocks were } \\
\text { quite heavy." } \\
\text { The reported date of these events is probably incorrect, as the two } \\
\text { events are described here as quite heavy, but no other locality } \\
\text { reported any events on this date; also, comparing the reported times } \\
\text { for these events with reported times for events on } 14 \text { Oct., it is } \\
\text { likely that these are indeed the } 14 \text { Oct events. If that is the case, the } \\
\text { times are p.m.; otherwise the times may be p.m. or a.m. }\end{array}$ \\
\hline
\end{tabular}


TABLE 1: Catalog of Aftershock Reports following from the Great 18 April 1906 California Earthquake

\begin{tabular}{|c|c|c|c|c|c|c|}
\hline Date Felt & $\begin{array}{l}\text { Time Felt } \\
\text { (PST) }\end{array}$ & $\begin{array}{l}\text { Location Felt } \\
\text { (City) }\end{array}$ & $\begin{array}{l}\text { Location Felt } \\
\text { (County) }\end{array}$ & $\begin{array}{l}\text { Unreliable? } \\
\text { Not Felt? }^{+}\end{array}$ & Source & Relevant Citations and other Notes \\
\hline 15-Oct-07 (?) & $\sim 15: 15(?)$ & Pepperwood & Humboldt & & $\begin{array}{l}\text { Humboldt Standard, } \\
18 \text { Oct 1907; p. 3, c. } 2\end{array}$ & $\begin{array}{l}\text { "Pepperwood, Oct. } 16-\ldots \text {... Two earthquakes were felt here, one } \\
\text { at a quarter to three ooclock and one at a quarter after three } \\
\text { o'clock, on Tuesday. No damage was done. The shocks were } \\
\text { quite heavy." } \\
\text { The reported date of these events is probably incorrect, as the two } \\
\text { events are described here as quite heavy, but no other locality } \\
\text { reported any events on this date; also, comparing the reported times } \\
\text { for these events with reported times for events on } 14 \text { Oct., it is } \\
\text { likely that these are indeed the } 14 \text { Oct events. If that is the case, the } \\
\text { times are p.m.; otherwise the times may be p.m. or a.m. }\end{array}$ \\
\hline 17-Oct-07 & night & Garberville & Humboldt & & $\begin{array}{l}\text { Humboldt Standard, } \\
24 \text { Oct 1907; p. 7, c. } 6\end{array}$ & "... An earthquake shock was felt...." \\
\hline $23-$ Oct-07 & \begin{tabular}{|c|} 
shortly \\
before 07:00
\end{tabular} & Arcata & Humboldt & & $\begin{array}{l}\text { Humboldt Standard, } \\
25 \text { Oct 1907; p. 7, c. 5-6 }\end{array}$ & $\begin{array}{l}\text { "Arcata, Oct. } 23-\ldots . \text { A shock of earthquake was felt in Arcata } \\
\text { shortly before } 7 \text { o'clock this morning." }\end{array}$ \\
\hline 29-Oct-07 & $13: 25$ & Berkeley & Alameda & & $\begin{array}{l}\text { San Francisco Call, } \\
30 \text { Oct 1907; p. 6, c. } 3\end{array}$ & $\begin{array}{l}\text { "BERKELEY, Oct. 29.- Two distinct earthquake shocks were } \\
\text { recorded by the Omori seismograph at the students' observatory } \\
\text { this afternoon. The first shock was experienced at } 1: 25 \text { o'clock, } \\
\text { followed a few seconds later by another. The tremors were short } \\
\text { but sharp...." } \\
\text { It is not clear whether this event was felt in Berkeley or only } \\
\text { recorded instrumentally. }\end{array}$ \\
\hline 29-Oct-07 & $13: 25$ & Berkeley & Alameda & & $\begin{array}{l}\text { Oakland Herald, } \\
30 \text { Oct 1907; p. 8, c. } 7\end{array}$ & $\begin{array}{l}\text { "BERKELEY, Oct. } 30 .- \text { Two shocks were registered on the } \\
\text { Omori seismograph at the U.C. yesterday afternoon, the first at } \\
1: 25 \text { p.m.t the other a few seconds later. Each was of slight force } \\
\text { and short duration...." } \\
\text { It is not clear whether this event was felt in Berkeley or only } \\
\text { recorded instrumentally. }\end{array}$ \\
\hline 29-Oct-07 & $13: 25$ & San Francisco & San Francisco & & $\begin{array}{l}\text { Santa Cruz Morning Sentinel, } \\
30 \text { Oct 1907; p. 1, c. } 4\end{array}$ & $\begin{array}{l}\text { "SAN FRANCISCO, Oct. 29._-An Earthquake was felt here ... but } \\
\text { not hard." }\end{array}$ \\
\hline 29-Oct-07 & 13:25 & Stockton & San Joaquin & & $\begin{array}{l}\text { Santa Cruz Morning Sentinel, } \\
30 \text { Oct 1907; p. } 1, \text { c. } 4\end{array}$ & $\begin{array}{l}\text { "STOCKTON, Oct. 29.--There was a sharp earthquake shock ... } \\
\text { in this city. No damage was done." }\end{array}$ \\
\hline 29-Oct-07 & 13:25 & Stockton & San Joaquin & & $\begin{array}{l}\text { The Evening Mail (Stockton), } \\
29 \text { Oct 1907; p. 1, c. } 4\end{array}$ & $\begin{array}{l}\text { "At 1:25 o' clock this afternoon a sharp earthquake shock was } \\
\text { felt in this city. The duration was only about two seconds, and } \\
\text { the vibration seemed more like that caused by some explosion of } \\
\text { dynamite than like a temblor. Many people evidently had the } \\
\text { same idea about it, for inquiries came pouring into the Mail office } \\
\text { by telephone from persons who wanted to know whether it was } \\
\text { really a genuine, simon-pure earthquake or not. } \\
\text { "The shock was more pronounced in buildings, especially tall } \\
\text { structures, than on the streets. At the High school the full force }\end{array}$ \\
\hline
\end{tabular}


TABLE 1: Catalog of Aftershock Reports following from the Great 18 April 1906 California Earthquake

\begin{tabular}{|c|c|c|c|c|c|c|}
\hline Date Felt & $\begin{array}{c}\text { Time Felt } \\
\text { (PST) }\end{array}$ & $\begin{array}{c}\text { Location Felt } \\
\text { (City) }\end{array}$ & $\begin{array}{l}\text { Location Felt } \\
\text { (County) }\end{array}$ & $\begin{array}{l}\text { Unreliable? } \\
\text { Not Felt? }^{+}\end{array}$ & Source & Relevant Citations and other Notes \\
\hline & & San Francisco & San Francisco & Not Felt & & $\begin{array}{l}\text { was felt, but the pupils were not uneasy. } \\
\text { "Immediately after the temblor a message was sent to San } \\
\text { Francisco by the Mail to ascertain whether any damage had been } \\
\text { done there. Word came back that no quake had been felt in the } \\
\text { metropolis." } \\
\text { Note that, with respect to San Francisco, this report contradicts } \\
\text { information given in the Antioch Ledger of } 2 \text { Nov } 1907 \text { (p. } 4, c .1) \text {, } \\
\text { and in the Stockton Daily Evening Record of } 29 \text { Oct } 1907(p .5, c \text {. } \\
\text { 1), which state that the earthquake was felt lightly in San Francisco. }\end{array}$ \\
\hline 29-Oct-07 & $13: 25$ & Stockton & San Joaquin & & $\begin{array}{l}\text { Stockton Daily Evening Record, } \\
29 \text { Oct 1907; p. } 5, \text { c. } 1\end{array}$ & $\begin{array}{l}\text { "Did you feel it? } \\
\text { "Yes, it was an earthquake, a real temblor, but a little one. It } \\
\text { happened at exactly 1:25 o' clock this afternoon. The motion, } \\
\text { whether from east to west or north to south, the reporter could } \\
\text { not determine, but he was assured that it was disagreeable and a } \\
\text { bit alarming... } \\
\text { "The shock was quite severe for Stockton, but not heavy enough } \\
\text { to do any damage, not even to buildings in course of construction. } \\
\text { At the time it happened a Record reporter was taking a telephone } \\
\text { message from the County Hospital. The speaker ceased talking for } \\
\text { a few moments and then cut in with, 'Say, did you feel that? My, } \\
\text { but it was heavy here. A patient was shaken right out of his } \\
\text { chair. No, it did no damage....' } \\
\text { "A message from the Holden drug store stated that the shock was } \\
\text { believed there to have been as severe as the big quake on April } \\
\text { 18th of last year. } \\
\text { "The Southern Pacific depot in this city also reported that the } \\
\text { shock was quite violent, nearly as heavy as the big one of } \\
\text { nineteen months ago.... } \\
\text { "Immediately after the shock people began telephoning from all } \\
\text { over town to the Record, asking if damage had been done in San } \\
\text { Francisco. The Record operator at once ticked off the query over } \\
\text { the Record's leased wire to San Francisco, asking if the quake } \\
\text { had done damage there. The answer flashed back that the quake } \\
\text { had been very light there and had done no damage.... } \\
\text { “'Long Distance,' in the telephone office, stated that the shock } \\
\text { was felt quite heavily in Oakland, but not in San Francisco. She } \\
\text { said no damage had been reported from anywhere... } \\
\text { "It is probable that the quake was a San Joaquin special. It was } \\
\text { apparently more severe in this county than anywhere else, but if } \\
\text { they never come harder than that no harm will be done.... } \\
\text { "Out in Fair Oaks the shock was particularly heavy. In the big }\end{array}$ \\
\hline
\end{tabular}


TABLE 1: Catalog of Aftershock Reports following from the Great 18 April 1906 California Earthquake

\begin{tabular}{|c|c|c|c|c|c|c|}
\hline Date Felt & $\begin{array}{l}\text { Time Felt } \\
\text { (PST) }\end{array}$ & $\begin{array}{l}\text { Location Felt } \\
\text { (City) }\end{array}$ & $\begin{array}{l}\text { Location Felt } \\
\text { (County) }\end{array}$ & $\begin{array}{l}\text { Unreliable? } \\
\text { Not Felt? }^{+}\end{array}$ & Source & Relevant Citations and other Notes \\
\hline & & & & & & $\begin{array}{l}\text { school house there the pupils and teachers were badly frightened. } \\
\text { The teachers lined up the pupils and marched them out into the } \\
\text { yard. One of the teachers became hysterical and the result was } \\
\text { that the school was dismissed for the day. The shock knocked } \\
\text { books off the shelves in the school library." } \\
\text { Note that, with respect to San Francisco, this report contradicts } \\
\text { information given in the Byron Times of } 1 \text { Nov } 1907 \text { (p. 1, c. 3), } \\
\text { and in the Evening Mail (Stockton) of } 29 \text { Oct } 1907 \text { (p. 1, c. 4), } \\
\text { which state that the earthquake was not felt in San Francisco. }\end{array}$ \\
\hline 29-Oct-07 & $13: 25$ & Stockton & San Joaquin & & $\begin{array}{l}\text { Stockton Daily Independent, } \\
30 \text { Oct 1907; p. } 8, \text { c. } 4\end{array}$ & $\begin{array}{l}\text { "Stocktonians were treated to a mild form of scare yesterday } \\
\text { afternoon at 1:25 o' clock, when an earthquake made its presence } \\
\text { felt in this community. Many people who happened to be on the } \\
\text { second and third floors at the time report having had quite a } \\
\text { shock. The upper stories of the court house and the Yosemite } \\
\text { building probably received the heaviest jar and a number of those } \\
\text { present made a dash for the street. The shake lasted about } 20 \\
\text { seconds. As far as known no damage resulted anywhere as a } \\
\text { result of the shock." }\end{array}$ \\
\hline 29-Oct-07 & $\sim 13: 25$ & $\begin{array}{c}\text { Antioch } \\
\text { Oakland } \\
\text { San Francisco } \\
\text { Stockton }\end{array}$ & $\begin{array}{l}\text { Contra Costa } \\
\text { Alameda } \\
\text { San Francisco } \\
\text { San Joaquin }\end{array}$ & & $\begin{array}{c}\text { Antioch Ledger, } \\
2 \text { Nov 1907; p. 4, c. } 1\end{array}$ & $\begin{array}{l}\text { "On Tuesday about } 1: 25 \text { p. m., an earthquake, which was } \\
\text { probably the hardest experienced since the notable one of April } \\
\text { 18th, } 1906, \text { caused many people in Antioch to rush from their } \\
\text { homes in terror. Owing to the peculiar rumbling noise preceding } \\
\text { the tremors, a report was at once circulated that a gas or oil well } \\
\text { had been struck by the local company.... Messages from Oakland } \\
\text { and San Francisco stated the shock was light in those places. } \\
\text { However farther east and south it was quite heavy, especially in } \\
\text { the vicinity of Stockton...." } \\
\text { Note that, with respect to San Francisco, this report contradicts } \\
\text { information given in the Byron Times of } 1 \text { Nov } 1907(p .1, c .3) \text {, } \\
\text { and in the Evening Mail (Stockton) of } 29 \text { Oct } 1907 \text { (p. 1, c. 4), } \\
\text { which state that the earthquake was not felt in San Francisco. }\end{array}$ \\
\hline 29-Oct-07 & & Oakley & Contra Costa & & $\begin{array}{c}\text { Antioch Ledger, } \\
2 \text { Nov } 1907 ; \text { p. } 4 \text {, c. } 3\end{array}$ & $\begin{array}{l}\text { Under the heading "OAKLEY DOINGS": } \\
\text { "The earthquake on Tuesday caused much excitement among the } \\
\text { children of the Oakley and Live Oak schools." }\end{array}$ \\
\hline 29-Oct-07 & $13: 26$ & Martinez & Contra Costa & & $\begin{array}{l}\text { Daily Gazette (Martinez), } \\
30 \text { Oct 1907; p. } 2 \text {, c. } 2\end{array}$ & $\begin{array}{l}\text { "... there was quite a shock of earthquake felt in Martinez. The } \\
\text { vibration was from north to south. The shock was heavy enough } \\
\text { to cause people to run out of doors." }\end{array}$ \\
\hline
\end{tabular}


TABLE 1: Catalog of Aftershock Reports following from the Great 18 April 1906 California Earthquake

\begin{tabular}{|c|c|c|c|c|c|c|}
\hline Date Felt & $\underset{\text { (PST) }}{\text { Time Felt }}$ & $\begin{array}{c}\text { Location Felt } \\
\text { (City) }\end{array}$ & $\begin{array}{l}\text { Location Felt } \\
\text { (County) }\end{array}$ & $\begin{array}{l}\text { Unreliable? } \\
\text { Not Felt? }^{+}\end{array}$ & Source & Relevant Citations and other Notes \\
\hline 29-Oct-07 & 13:28 & Stockton & San Joaquin & & $\begin{array}{l}\text { Oakland Enquirer, } \\
29 \text { Oct 1907; p. 2, c. } 2\end{array}$ & $\begin{array}{l}\text { "STOCKTON, Oct. 29.-Slight earthquake shocks were felt } \\
\text { here... The movement of the quake was from east to west. No } \\
\text { damage was done." }\end{array}$ \\
\hline 29-Oct-07 & 13:30 & $\begin{array}{c}\text { Byron } \\
\text { Oakland } \\
\text { San Francisco } \\
\text { Stockton }\end{array}$ & $\begin{array}{c}\text { Contra Costa } \\
\text { Alameda } \\
\text { San Francisco } \\
\text { San Joaquin }\end{array}$ & Not Felt & $\begin{array}{c}\text { Byron Times, } \\
1 \text { Nov 1907; p. 1, c. } 3\end{array}$ & $\begin{array}{l}\text { "An earthquake lasting two seconds was felt .... The shock was } \\
\text { experienced all over the county and in San Joaquin. It was felt in } \\
\text { Oakland, but not in San Francisco. The 'Record' says it was } \\
\text { probably a 'San Joaquin special,' as it was more severe in } \\
\text { Stockton than anywhere else. It did no damage, but probably } \\
\text { shook up the oil in the Byron belt." } \\
\text { Note that, with respect to San Francisco, this report contradicts } \\
\text { information given in the Antioch Ledger of } 2 \text { Nov } 1907 \text { (p. } 4, c .1) \text {, } \\
\text { and in the Stockton Daily Evening Record of } 29 \text { Oct } 1907 \text { (p.5, c. } \\
\text { 1), which state that the earthquake was felt lightly in San Francisco. }\end{array}$ \\
\hline 22-Nov-07 & $\sim$ 19:00 & Grizzly Bluff & Humboldt & & $\begin{array}{l}\text { Humboldt Standard, } \\
26 \text { Nov 1907; p. } 7, \text { c. } 7\end{array}$ & $\begin{array}{l}\text { "... there was quite a severe shock of earthquake and preceding } \\
\text { the shock there was a roaring noise." }\end{array}$ \\
\hline 22-Nov-07 & $\begin{array}{l}\text { 21:30 } \\
\sim\end{array}$ & Eureka & Humboldt & & $\begin{array}{c}\text { Humboldt Standard, } \\
23 \text { Nov 1907; p. 1, c. } 2\end{array}$ & $\begin{array}{l}\text { "Old earth had a slight convulsion.... It was not a serious one } \\
\text { however, for it was nothing more than a long drawn out } \\
\text { quivering. Farther south it appears that it was heavier...." }\end{array}$ \\
\hline 22-Nov-07 & \begin{tabular}{|c|} 
21:30, \\
other times \\
in the evening \\
(several \\
events)
\end{tabular} & Ferndale & Humboldt & & $\begin{array}{l}\text { Humboldt Standard, } \\
25 \text { Nov 1907; p.7, c. } 7\end{array}$ & $\begin{array}{l}\text { "Ferndale, Nov. 23.-.... Two or three shocks of earthquake were } \\
\text { felt last evening, one at about 9:30 being quite hard. No damage } \\
\text { was done." }\end{array}$ \\
\hline 22-Nov-07 & $\begin{array}{c}\text { 21:30 } \\
\text { (several } \\
\text { events) }\end{array}$ & & Humboldt & & $\begin{array}{l}\text { Blue Lake Advocate, } \\
30 \text { Nov 1907; p. } 7, \text { c. } 5\end{array}$ & $\begin{array}{l}\text { "Several slight shocks of earthquakes were felt throughout the } \\
\text { county ... about 9:30 o'clock. No damage was done except to the } \\
\text { nervous system." }\end{array}$ \\
\hline
\end{tabular}




\section{TABLE 1: Catalog of Aftershock Reports following from the Great 18 April 1906 California Earthquake}

\section{General Comments:}

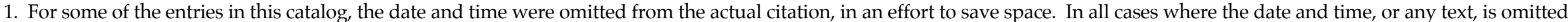
from the citation, it is replaced by editorial ellipses. The date and time are always given (when known) under the appropriate columns in the table.

2. Obvious typographical errors in newspaper sources were corrected without comment.

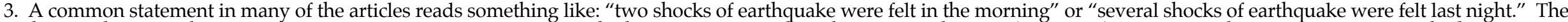

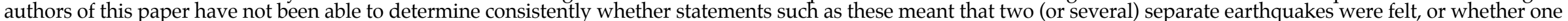

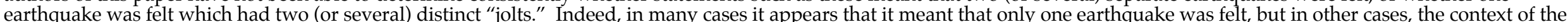

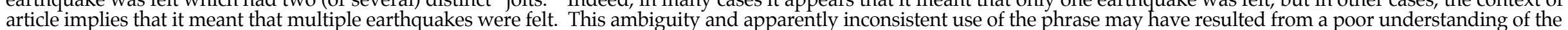
earthquake process, i.e., some people at the time may have thought that earthquakes which occurred minutes apart were all part of the same event.

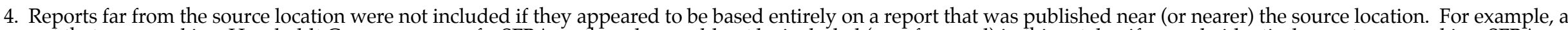

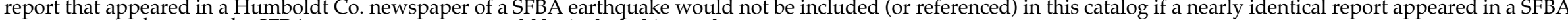
newspaper; in that case, the SFBA newspaper report would be included instead.

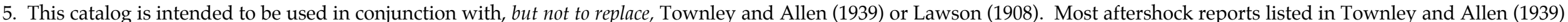

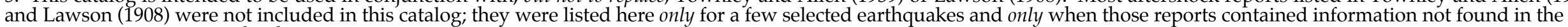
newspapers, diaries, and other historic documents.

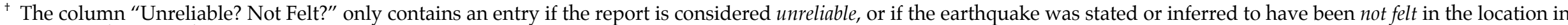
question; otherwise, this column is left blank. 
TABLE 2: Catalog of Triggered Event Reports following from the Great 18 April 1906 California Earthquake

\begin{tabular}{|c|c|c|c|c|c|c|}
\hline Date Felt & $\begin{array}{c}\text { Time Felt } \\
\text { (PST) }\end{array}$ & $\begin{array}{l}\text { Location Felt } \\
\text { (City) }\end{array}$ & $\begin{array}{l}\text { Location Felt } \\
\text { (County) }\end{array}$ & $\begin{array}{l}\text { Unreliable? } \\
\text { Not Felt? }^{+}\end{array}$ & Source & Relevant Citations and other Notes \\
\hline
\end{tabular}

\section{Triggered Events}

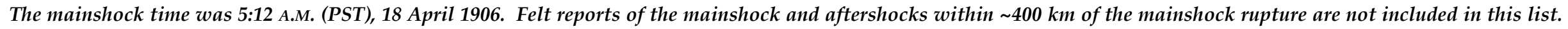

\begin{tabular}{|c|c|c|c|c|c|}
\hline 18-Apr-06 & $\begin{array}{c}05: 16 \text { PST } \\
(05: 48 \\
\text { local time } \\
\text { in Phoenix })\end{array}$ & Phoenix & $\begin{array}{l}\text { Maricopa Co. } \\
\text { (Arizona) }\end{array}$ & $\begin{array}{l}\text { Arizona Gazette (Phoenix), } \\
20 \text { Apr } 1906 \text { (early edition); } \\
\text { p. } 1 \text {, c. } 6\end{array}$ & $\begin{array}{l}\text { "Phoenix people were excited to such a high pitch by the dire } \\
\text { calamity that overtook San Francisco on Wednesday that a } \\
\text { majority of them did not observe a trembling of the earth in this } \\
\text { city on that day. Several people report, however, that they felt a } \\
\text { distinct shock. } \\
\text { "One of those who felt the shock was Attorney Frank H. Bennett, } \\
\text { who lives ... on North Center street. He was lying on a bed when } \\
\text { he experienced a distinct shaking of the earth. } \\
\text { "A few moments later his brother came in and asked him if he had } \\
\text { felt the shock. Both had observed it distinctly. } \\
\text { "Another party who noticed the disturbance was William H. } \\
\text { Hartranft, also residing on North Center street. He said he felt it } \\
\text { distinctly. He telephoned to the Bennett residence to inquire if } \\
\text { they had observed it and they informed him that they had. } \\
\text { "Mr. Jesunofsky, director of the local weather bureau, when seen } \\
\text { by the Gazette said that while he did not personally feel the } \\
\text { shocks, they undoubtedly did occur in this city at 5:48 } \\
\text { Wednesday morning. The director further says that he has been } \\
\text { approached by several Phoenicians who distinctly felt earth } \\
\text { tremors on Wednesday." } \\
\text { The reported time is assumed to be in Phoenix local time, } 32 \text { min. } \\
\text { ahead of PST; see Meltzner and Wald (2003) for discussion. }\end{array}$ \\
\hline 18-Apr-06 & $05: 48$ (?) & Phoenix & $\begin{array}{l}\text { Maricopa Co. } \\
\text { (Arizona) }\end{array}$ & $\begin{array}{l}\text { Lawson (1908), } \\
\text { vol. I, p. } 410\end{array}$ & $\begin{array}{l}\text { "Slight. West to east." } \\
\text { It is not clear whether the stated time is in local or standard time; } \\
\text { see Meltzner and Wald (2003) for discussion. }\end{array}$ \\
\hline 18-Apr-06 & $\sim 05: 48(?)$ & Phoenix & $\begin{array}{l}\text { Maricopa Co. } \\
\text { (Arizona) }\end{array}$ & $\begin{array}{l}\text { Townley and Allen (1939), } \\
\text { p. } 294\end{array}$ & $\begin{array}{l}\text { "Slight shock; motion west to east." } \\
\text { This report is attributed to the U.S. Weather Bureau. } \\
\text { It is not clear whether the stated time is in local or standard time; } \\
\text { see Meltzner and Wald (2003) for discussion. }\end{array}$ \\
\hline 18-Apr-06 & 05:59:13 (?) & Phoenix & $\begin{array}{l}\text { Maricopa Co. } \\
\text { (Arizona) }\end{array}$ & $\begin{array}{l}\text { Lawson (1908), } \\
\text { vol. I, p. } 410\end{array}$ & $\begin{array}{l}\text { Lawson (1908) estimates Rossi-Forel intensity II } \\
\text { It is not clear whether the stated time is in local or standard time; } \\
\text { see Meltzner and Wald (2003) for discussion. }\end{array}$ \\
\hline 18-Apr-06 & morning & Salome & $\begin{array}{l}\text { La Paz Co. } \\
\text { (Arizona) }\end{array}$ & $\begin{array}{c}\text { Arizona Republican (Phoenix), } \\
26 \text { Apr 1906; p. 5, c. } 3\end{array}$ & $\begin{array}{l}\text { "C. H. Pratt of Salome arrived in Phoenix yesterday on a hasty } \\
\text { business trip. He says that all western Arizona undoubtedly felt } \\
\text { the thrill of the seismic agitation that caused such havoc last }\end{array}$ \\
\hline
\end{tabular}


TABLE 2: Catalog of Triggered Event Reports following from the Great 18 April 1906 California Earthquake

\begin{tabular}{|c|c|c|c|c|c|c|}
\hline Date Felt & $\begin{array}{c}\text { Time Felt } \\
\text { (PST) }\end{array}$ & $\begin{array}{l}\text { Location Felt } \\
\text { (City) }\end{array}$ & $\begin{array}{c}\text { Location Felt } \\
\text { (County) }\end{array}$ & $\begin{array}{l}\text { Unreliable? } \\
\text { Not Felt? }^{+}\end{array}$ & Source & Relevant Citations and other Notes \\
\hline & & & & & & $\begin{array}{l}\text { week. The shock of Wednesday morning was distinctly noted in } \\
\text { Salome, though no damage was done. He was about forty miles } \\
\text { from there in the mountains, at the time, in company with another } \\
\text { man. The cabin in which they were stopping shook quite } \\
\text { noticeably, according to his friend. Mr. Pratt was some distance } \\
\text { away and though he did not see the shaking of the cabin he } \\
\text { plainly felt the quaking of the earth. However, he had no } \\
\text { knowledge of the San Francisco horror or that the earthquake } \\
\text { had done any damage until four days later when he returned to } \\
\text { Salome." } \\
\text { Note that the statement regarding "all western Arizona" was } \\
\text { merely speculation on the part of C. H. Pratt, and it was not } \\
\text { confirmed by the report. It is not clear whether this event was the } \\
\text { San Francisco mainshock or a separate triggered event, possibly the } \\
\text { same event felt in Phoenix that morning. }\end{array}$ \\
\hline 18-Apr-06 (?) & 12:31 & Los Angeles & Los Angeles & & $\begin{array}{l}\text { Lawson (1908), } \\
\text { vol. I, p. } 413\end{array}$ & $\begin{array}{l}\text { Lawson (1908) estimates Rossi-Forel intensity III } \\
\text { This is probably a misdated report of the earthquake in the } \\
\text { Los Angeles area at } 12: 31 \text { on } 19 \text { Apr } 1906 \text {. There is no other report } \\
\text { of an earthquake in this area on the afternoon of } 18 \text { Apr } 1906 \text {. }\end{array}$ \\
\hline 18-Apr-06 & $15: 00$ & Imperial & Imperial & & $\begin{array}{l}\text { Imperial Valley Press, } \\
21 \text { Apr 1906; p. } 5 \text {, c. } 3\end{array}$ & $\begin{array}{l}\text { "Imperial was visited by two distinct earthquakes Wednesday } \\
\text { afternoon, the first at } 3 \mathrm{p} \text {. m. the second at } 4: 20 \mathrm{p} \text {. m. No very } \\
\text { serious accidents; Mr. Varney's olive oil bottles, pickles and cans } \\
\text { got mixed up on the floor." } \\
\text { It is not clear which of the two events mentioned was responsible } \\
\text { for the items falling to the floor. From other reports, it is inferred } \\
\text { that the second event was responsible. }\end{array}$ \\
\hline 18-Apr-06 & $\sim 16: 15$ & San Jacinto & Riverside & & $\begin{array}{c}\text { Press and Horticulturist } \\
\text { (Riverside), } \\
20 \text { Apr 1906; p. } 5 \text {, c. } 3\end{array}$ & $\begin{array}{l}\text { "San Jacinto, April 18.-.... There were some who noticed a slight } \\
\text { shock here this morning at 5:20, which must have been a part of } \\
\text { the great earthquake which did so much damage in San Francisco. } \\
\text { Another prolonged, but not hard shock was felt at about 4:15 this } \\
\text { afternoon. It lasted several seconds." } \\
\text { See Table } 6 \text {. }\end{array}$ \\
\hline 18-Apr-06 & $16: 20$ & San Jacinto & Riverside & & $\begin{array}{l}\text { San Jacinto Register, } \\
26 \text { Apr 1906; p. 4, c. } 1\end{array}$ & $\begin{array}{l}\text { "... At } 4: 20 \mathrm{p} . \mathrm{m} \text {. that terrible day a long seismic wave caused a } \\
\text { feeling of trepidation for the balance of the night, but not the } \\
\text { slightest damage resulted." } \\
\text { Earlier in the article the writer referred to the mainshock in San } \\
\text { Francisco as "the great earth wave that swept the State of } \\
\text { California." The reference to the } 16: 20 \text { event as " "long seismic } \\
\text { wave," therefore, is not construed to imply anything about the type } \\
\text { of motion, only that it was long in duration. } \\
\text { See Table } 6 .\end{array}$ \\
\hline
\end{tabular}


TABLE 2: Catalog of Triggered Event Reports following from the Great 18 April 1906 California Earthquake

\begin{tabular}{|c|c|c|c|c|c|c|}
\hline Date Felt & $\begin{array}{l}\text { Time Felt } \\
\text { (PST) }\end{array}$ & $\begin{array}{l}\text { Location Felt } \\
\text { (City) }\end{array}$ & $\begin{array}{l}\text { Location Felt } \\
\text { (County) }\end{array}$ & $\begin{array}{l}\text { Unreliable? } \\
\text { Not Felt? }^{+}\end{array}$ & Source & Relevant Citations and other Notes \\
\hline 18-Apr-06 & $16: 20$ & Imperial & Imperial & & $\begin{array}{l}\text { Imperial Valley Press, } \\
21 \text { Apr 1906; p. } 5, \text { c. } 3\end{array}$ & $\begin{array}{l}\text { "Imperial was visited by two distinct earthquakes Wednesday } \\
\text { afternoon, the first at } 3 \mathrm{p} \text {. } \mathrm{m} \text {. the second at } 4: 20 \mathrm{p} \text {. } \mathrm{m} \text {. No very } \\
\text { serious accidents; Mr. Varney's olive oil bottles, pickles and cans } \\
\text { got mixed up on the floor." } \\
\text { It is not clear which of the two events mentioned was responsible } \\
\text { for the items falling to the floor. From other reports, it is inferred } \\
\text { that the second event was responsible. } \\
\text { See Table } 6 .\end{array}$ \\
\hline 18-Apr-06 & $\sim 16: 20$ & Tijuana & $\begin{array}{l}\text { Baja California } \\
\text { Norte, Mexico }\end{array}$ & & $\begin{array}{c}\text { San Diego Union, } \\
19 \text { Apr 1906; p. 5, c. } 1\end{array}$ & $\begin{array}{l}\text { “... Tia Juana [sic] reported the shock at close to } 4: 20 \ldots . . " \\
\text { See Table } 6 .\end{array}$ \\
\hline 18-Apr-06 & $\sim 16: 25$ & $\begin{array}{l}\text { Brawley } \\
\text { Imperial } \\
\text { Holtville } \\
\text { Calexico } \\
\text { El Centro }\end{array}$ & $\begin{array}{l}\text { Imperial } \\
\text { Imperial } \\
\text { Imperial } \\
\text { Imperial } \\
\text { Imperial }\end{array}$ & & $\begin{array}{l}\text { Imperial Valley Press, } \\
21 \text { Apr 1906; p. 5, c. } 4\end{array}$ & $\begin{array}{l}\text { "Quite a severe shock of earthquake was felt in the Valley on last } \\
\text { Wednesday afternoon about 4:25. Quite a lot of damage was } \\
\text { done to the adobe buildings in Brawley. The Imperial Valley } \\
\text { Bank and Bungalow Hotel were seriously shattered, and Varney } \\
\text { Bros.' store was wrecked. A residence belonging to D. D. Pellet } \\
\text { was also wrecked and several other buildings badly cracked. At } \\
\text { Imperial only slight damage was inflicted, such as knocking off } \\
\text { plaster and cracking the walls in the brick buildings. The Hotel } \\
\text { Alamo at Holtville, was quite severely shaken and cracked. The } \\
\text { other buildings were not seriously injured. No damage is } \\
\text { reported from Calexico. Here in El Centro we all were able to } \\
\text { notice it without great effort, and while the shock was on we felt } \\
\text { sure things were going to happen, yet there is no damage whatever } \\
\text { to report. Not a wall was cracked, nor was there any plaster } \\
\text { loosened. Two bottles of ketchup were shaken off the shelves of } \\
\text { the Valley Mercantile company, and some Breakfast Food boxes } \\
\text { fell in Rumsey's store. No damage resulted, as even the ketchup } \\
\text { bottles didn't break. But it was quite a lively shake just the } \\
\text { same...." } \\
\text { See Table 6. }\end{array}$ \\
\hline 18-Apr-06 & $16: 28$ & San Diego & $\begin{array}{l}\text { San Diego } \\
\text { San Diego }\end{array}$ & & $\begin{array}{l}\text { Los Angeles Examiner, } \\
19 \text { Apr 1906; p. 6, c. } 3\end{array}$ & $\begin{array}{l}\text { "SAN DIEGO, April 18.-San Diego experienced its first } \\
\text { earthquake of the day at 4:28 o'clock this afternoon. The shock } \\
\text { was a short one, but was quite pronounced while it lasted. All of } \\
\text { the business buildings in the city shook, chandeliers and pictures } \\
\text { swayed. The people in the business blocks were greatly } \\
\text { frightened and within a few seconds the streets were crowded } \\
\text { with agitated men and women. } \\
\text { "At the court house the employees were greatly frightened and in } \\
\text { less than half a minute the entire building was emptied. This } \\
\text { record was equalled by those employed in the city offices at the } \\
\text { city hall. } \\
\text { "The shock was also quite severe at Coronado and guests on the }\end{array}$ \\
\hline
\end{tabular}


TABLE 2: Catalog of Triggered Event Reports following from the Great 18 April 1906 California Earthquake

\begin{tabular}{|c|c|c|c|c|c|c|}
\hline Date Felt & $\begin{array}{l}\text { Time Felt } \\
\text { (PST) }\end{array}$ & $\begin{array}{l}\text { Location Felt } \\
\text { (City) }\end{array}$ & $\begin{array}{c}\text { Location Felt } \\
\text { (County) }\end{array}$ & $\begin{array}{c}\text { Unreliable? } \\
\text { Not Felt? }^{+}\end{array}$ & Source & Relevant Citations and other Notes \\
\hline & & $\begin{array}{l}\text { "the entire } \\
\text { western slope } \\
\text { of San Diego } \\
\text { County" }\end{array}$ & San Diego & & & $\begin{array}{l}\text { top floors of the hotel report their tables, chairs and desks shook } \\
\text { considerably. } \\
\text { "... The shock was apparently felt along the entire western slope } \\
\text { of San Diego county. Following the shock many employees of } \\
\text { different companies quit work, being unwilling to take chances by } \\
\text { remaining at their work in brick buildings. The local weather } \\
\text { office reports the course of the quake as being from southwest to } \\
\text { northeast." } \\
\text { See Table } 6 .\end{array}$ \\
\hline 18-Apr-06 & $16: 28$ & Ballast Point & San Diego & & $\begin{array}{l}\text { Lawson (1908), } \\
\text { vol. I, p. } 413\end{array}$ & $\begin{array}{l}\text { "Clock stopt at } 4^{\mathrm{h}} 28^{\mathrm{m}} 15^{\mathrm{s}} \text { pend. } 18^{\prime} \text {, facing E." Duration } 15 \\
\text { seconds. } \\
\text { See Table } 6 .\end{array}$ \\
\hline 18-Apr-06 & $16: 28$ & Temecula & Riverside & & $\begin{array}{l}\text { Lawson (1908), } \\
\text { vol. I, p. } 413\end{array}$ & $\begin{array}{l}\text { felt } \\
\text { See Table } 6 .\end{array}$ \\
\hline 18-Apr-06 & $16: 29$ & San Bernardino & San Bernardino & & $\begin{array}{l}\text { San Bernardino Daily Sun, } \\
19 \text { Apr 1906; p. 2, c. 6-7 }\end{array}$ & $\begin{array}{l}\text { "In San Bernardino yesterday two distinct shocks were felt. The } \\
\text { first occurred at 5:15 in the morning, exactly the same moment that } \\
\text { it occurred in San Francisco... The second shock occurred in the } \\
\text { afternoon at } 4: 29 \text {, which was quite perceptible to people, } \\
\text { especially in the upper floors of two or three story buildings. The } \\
\text { clocks in the Santa Fe station were stopped by this shock. Both } \\
\text { shocks were very light, however, as compared with disturbances } \\
\text { of this sort felt here in the past. Many clocks in residences } \\
\text { stopped." } \\
\text { See Table } 6 \text {. }\end{array}$ \\
\hline 18-Apr-06 & $16: 29$ & Tijuana & $\begin{array}{l}\text { Baja California } \\
\text { Norte, Mexico }\end{array}$ & & $\begin{array}{l}\text { Los Angeles Examiner, } \\
19 \text { Apr 1906; p. 6, c. } 3\end{array}$ & $\begin{array}{l}\text { "SAN DIEGO, April 18.-.... Tia Juana [sic] reported that the } \\
\text { quake reached there at 4:29 o'clock...." } \\
\text { See Table } 6 .\end{array}$ \\
\hline 18-Apr-06 & $16: 29: 45$ & San Diego & San Diego & & $\begin{array}{l}\text { San Diego Union, } \\
19 \text { Apr 1906; p. 5, c. } 1\end{array}$ & $\begin{array}{l}\text { "As people in this city yesterday afternoon were gathered in } \\
\text { groups discussing the terrible catastrophe at San Francisco or } \\
\text { were sitting in their offices at their business they were suddenly } \\
\text { subjected to an earthquake themselves. To be sure, it was not of } \\
\text { any great degree of intensity, and no damage was done to } \\
\text { property nor were any persons injured, but it gave San Diegans } \\
\text { and tourists, who may be stopping here a taste of the experience } \\
\text { with seismic phenomena. The taste was enough for most people, } \\
\text { and they will tell of their participation in the great earthquake of } \\
1906 \text { - even though they were on the outskirts, so to speak. } \\
\text { "An evening paper stated in one of its editions that the shock was } \\
\text { the most severe in the history of the city. This, however, is not } \\
\text { borne out by the statements of those who experienced former }\end{array}$ \\
\hline
\end{tabular}


TABLE 2: Catalog of Triggered Event Reports following from the Great 18 April 1906 California Earthquake

\begin{tabular}{|c|c|c|c|c|c|c|}
\hline Date Felt & $\begin{array}{c}\text { Time Felt } \\
\text { (PST) }\end{array}$ & $\begin{array}{c}\text { Location Felt } \\
\text { (City) }\end{array}$ & $\begin{array}{l}\text { Location Felt } \\
\text { (County) }\end{array}$ & $\begin{array}{l}\text { Unreliable? } \\
\text { Not Felt? }^{+}\end{array}$ & Source & Relevant Citations and other Notes \\
\hline & & $\begin{array}{c}\text { Alpine } \\
\text { Cuyamaca }\end{array}$ & $\begin{array}{l}\text { San Diego } \\
\text { San Diego }\end{array}$ & & & $\begin{array}{l}\text { Shocks for it was even lighter than some of quite recent years. } \\
\text { Chandeliers and hanging lamps were set swaying but not the least } \\
\text { damage was done.... } \\
\text { "At the office of Weather Observer Ford A. Carpenter, it was } \\
\text { reported that the shock came at 4:29:45, and its course was from } \\
\text { southwest to northeast. As there is no seismometer here it is } \\
\text { difficult to determine the degree of its intensity. Mr. Carpenter } \\
\text { would place it as in class No. } 4 \text { of the Rossi-Forel scale.... } \\
\text { "At Alpine the shock was felt with about the same degree of } \\
\text { intensity as here. } \\
\text { "A telephone message from Cuyamaca stated that the very } \\
\text { mountain seemed to rock and that the shock lasted for several } \\
\text { seconds.... } \\
\text { "When the shock was felt here there was a scurrying from office } \\
\text { buildings, including the city hall and the court houses. There was } \\
\text { no waiting on ceremony, but everybody made for the open with } \\
\text { all possible speed, many without hats or coats." } \\
\text { The "evening paper" mentioned above is assumed to be the Sun. } \\
\text { Compare this report with the articles in the San Diegan-Sun, } \\
18 \text { Apr } 1906, p .1, c .1-2, \text { and } 19 \text { Apr } 1906, \text { p. } 2, \text { c. } 4 . \\
\text { In light of comments in the later report (19 Apr) in the Sun, which } \\
\text { downplay comments in the Sun's first report, the Sun's reports are } \\
\text { not considered fully reliable, and the San Diego Union is believed to } \\
\text { have the most reliable account of the earthquake in San Diego. } \\
\text { See Table } 6 .\end{array}$ \\
\hline 18-Apr-06 & $16: 29: 45$ & San Diego & San Diego & & $\begin{array}{l}\text { San Diegan-Sun, } \\
19 \text { Apr 1906; p. 2, c. } 4\end{array}$ & $\begin{array}{l}\text { "The following is the official memorandum made by Weather } \\
\text { Observer Carpenter of the earthquake felt in San Diego } \\
\text { Wednesday atternoon: } \\
\text { "'The shock experienced at 4:29:45, S.W. N.E., } 20 \text { seconds and } \\
\text { was the worst shock experienced in San Diego for the past } 15 \\
\text { years.... } \\
\text { '“My conclusion as to the severity of the shock Wednesday was } \\
\text { based largely upon the visible vibration of two mercurial } \\
\text { barometers, each three feet in length, freely suspended in our } \\
\text { barometer case. These barometers vibrated to the limit of their } \\
\text { fastenings. The sway of the chandeliers and the disturbance of } \\
\text { the clock's pendulum were also taken into account in arriving at } \\
\text { the conclusion.' } \\
\text { "The important fact is not to be forgotten that while Wednesday's } \\
\text { shock was the most severe experienced in many years, it was not }\end{array}$ \\
\hline
\end{tabular}


TABLE 2: Catalog of Triggered Event Reports following from the Great 18 April 1906 California Earthquake

\begin{tabular}{|c|c|c|c|c|c|c|}
\hline Date Felt & $\begin{array}{l}\text { Time Felt } \\
\text { (PST) }\end{array}$ & $\begin{array}{l}\text { Location Felt } \\
\text { (City) }\end{array}$ & $\begin{array}{l}\text { Location Felt } \\
\text { (County) }\end{array}$ & $\begin{array}{l}\text { Unreliable? } \\
\text { Not Felt? }^{+}\end{array}$ & Source & Relevant Citations and other Notes \\
\hline & & & & & & $\begin{array}{l}\text { severe enough to stop a clock." } \\
\text { Compare this with the article in the San Diegan-Sun, } 18 \text { Apr 1906, } \\
\text { p. 1, c. 1-2, and with the article in the San Diego Union, } 19 \text { Apr } \\
1906, p .5, c .1 \text {. } \\
\text { In light of comments in the later report (above) in the Sun, which } \\
\text { downplay comments in the Sun's first report (18 Apr), the Sun's } \\
\text { reports are not considered fully reliable, and the San Diego Union } \\
\text { is believed to have the most reliable account of the earthquake in San } \\
\text { Diego. } \\
\text { See Table } 6 .\end{array}$ \\
\hline 18-Apr-06 & $16: 29: 45$ & San Diego & San Diego & & $\begin{array}{l}\text { Lawson (1908), } \\
\text { vol. I, p. 413 }\end{array}$ & $\begin{array}{l}\text { "Northwest and southeast. Strongest apparently at beginning. } \\
\text { Clock not stopt, but disturbed, losing about } 1 \text { m.; pend. about } 26 " . \\
\text { No sound phenomena." Duration } 20 \text { seconds. Lawson (1908) } \\
\text { estimates Rossi-Forel intensity IV-V. } \\
\text { See Table 6. }\end{array}$ \\
\hline 18-Apr-06 & $\begin{array}{c}\text { shortly } \\
\text { before } \\
16: 30\end{array}$ & Los Angeles & Los Angeles & & $\begin{array}{l}\text { Los Angeles Times, } \\
19 \text { Apr 1906; Part II, p. 3, c. } 3\end{array}$ & $\begin{array}{l}\text { "From several parts of the city reports have been received of a } \\
\text { slight temblor shortly before } 4: 30 \text { o'clock yesterday afternoon. } \\
\text { The officials in the Federal courts at the top of the Tajo Building } \\
\text { seemed to notice the shock most plainly, but in several other } \\
\text { downtown buildings persons felt it slightly. In a few cases the } \\
\text { swaying of a chandelier was the only sign noticed. No alarm was } \\
\text { occasioned, except the apprehension that it was the tail end of } \\
\text { another shock at San Francisco." } \\
\text { See Table 6. }\end{array}$ \\
\hline 18-Apr-06 & $\begin{array}{l}\text { 16:30, and } \\
\text { earlier times, } \\
\text { and later } \\
\text { times } \\
\text { (many events) }\end{array}$ & Brawley & Imperial & & $\begin{array}{l}\text { Brawley News, } \\
20 \text { Apr 1906; p. } 1\end{array}$ & $\begin{array}{l}\text { "Accustomed to earthquake shocks of more or less severity, the } \\
\text { residents of Brawley gave but little heed to the shakes manifested } \\
\text { Wednesday afternoon until at half past four, almost without } \\
\text { warning an extremely heavy shake threw the buildings hither and } \\
\text { thither, twisting the wooden structures until it seemed as if they } \\
\text { must topple over and causing the walls of the brick and adobe } \\
\text { buildings to bend outward and in many cases to crack open and } \\
\text { fall apart. Clocks stopped, dishes fell clattering to the floor, } \\
\text { windoow glass crashed, chimneys fell, and doors were forced off } \\
\text { their hinges while the clouds of dust arising from the fallen } \\
\text { buildings and the distant river banks attested the impotence of } \\
\text { man in the face of the mighty displeasure of Nature. } \\
\text { "With the many walls, bricks and timbers that were thrown to } \\
\text { the ground, it is a matter of wonder and congratulation that no } \\
\text { one was killed, but fortunately no one was hurt with the } \\
\text { exception of a small boy, the son of J. M. Price, of No. 8, on whom } \\
\text { a portion of an adobe wall fell, bruising him severely and } \\
\text { breaking his collarbone. }\end{array}$ \\
\hline
\end{tabular}


TABLE 2: Catalog of Triggered Event Reports following from the Great 18 April 1906 California Earthquake

\begin{tabular}{|c|c|c|c|c|c|c|}
\hline Date Felt & $\begin{array}{c}\text { Time Felt } \\
\text { (PST) }\end{array}$ & $\begin{array}{l}\text { Location Felt } \\
\text { (City) }\end{array}$ & $\begin{array}{l}\text { Location Felt } \\
\text { (County) }\end{array}$ & $\begin{array}{l}\text { Unreliable? } \\
\text { Not Felt? }^{+}\end{array}$ & Source & Relevant Citations and other Notes \\
\hline & & & & & & 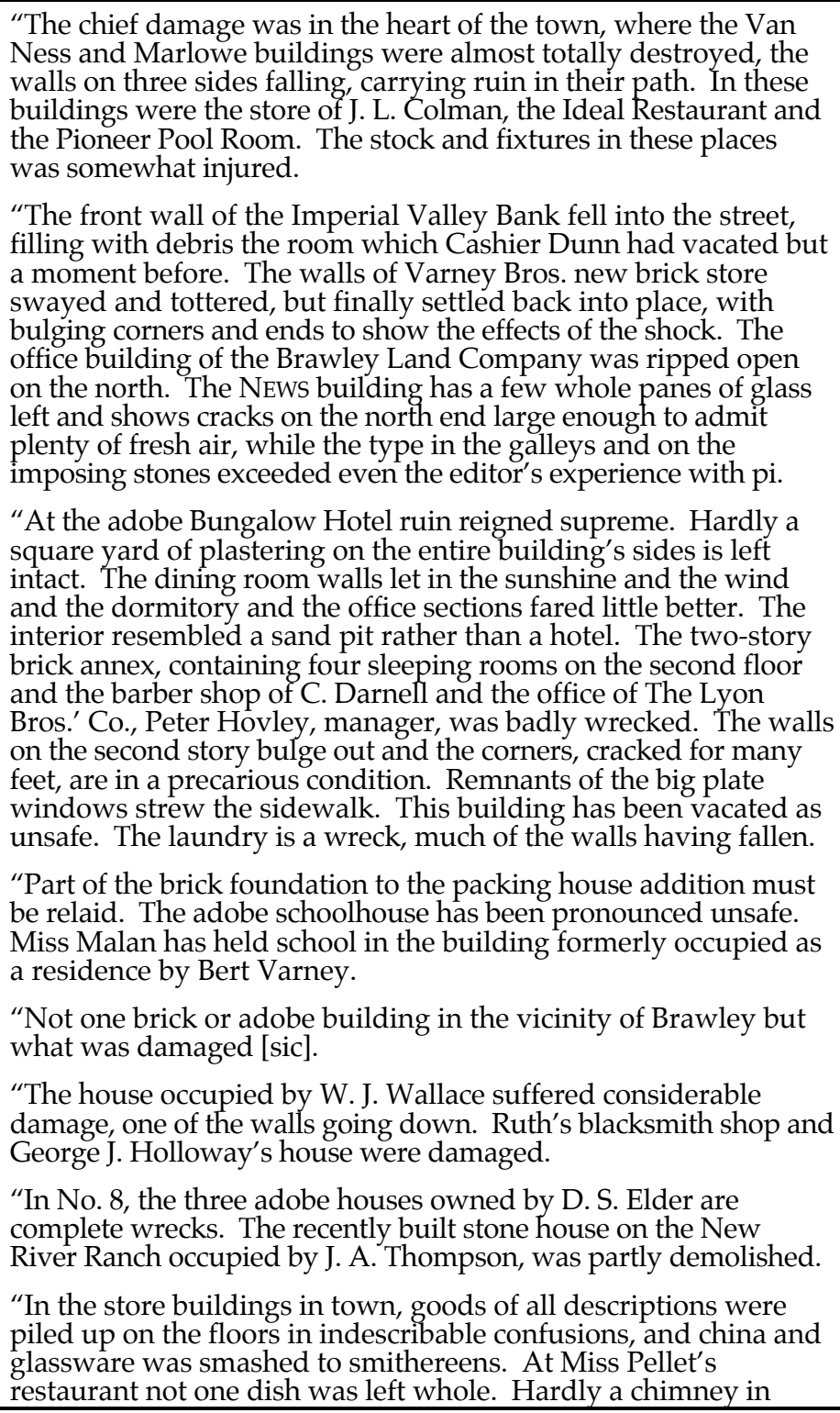 \\
\hline
\end{tabular}


TABLE 2: Catalog of Triggered Event Reports following from the Great 18 April 1906 California Earthquake

\begin{tabular}{|c|c|c|c|c|c|c|}
\hline Date Felt & $\begin{array}{l}\text { Time Felt } \\
\text { (PST) }\end{array}$ & $\begin{array}{l}\text { Location Felt } \\
\text { (City) }\end{array}$ & $\begin{array}{l}\text { Location Felt } \\
\text { (County) }\end{array}$ & $\begin{array}{l}\text { Unreliable? } \\
\text { Not Felt? }^{+}\end{array}$ & Source & Relevant Citations and other Notes \\
\hline & & $\begin{array}{l}\text { Holtville } \\
\text { Imperial } \\
\text { El Centro } \\
\text { Calexico }\end{array}$ & $\begin{array}{l}\text { Imperial } \\
\text { Imperial } \\
\text { Imperial } \\
\text { Imperial }\end{array}$ & & & $\begin{array}{l}\text { town is standing. } \\
\text { "As soon as the dust of the fallen debris had cleared away, ropes } \\
\text { were stretched before the buildings in the most dangerous } \\
\text { condition for the earthquake shocks continued at irregular } \\
\text { intervals and have kept up until this publication although no } \\
\text { further damage has resulted. The scene immediately following the } \\
\text { heavy shock was one long to be remembered. From the clouds of } \\
\text { dust emerged men, women and children, who with the tidings of } \\
\text { the terrible calamity at San Francisco yet ringing in their ears, } \\
\text { found themselves suddenly confronted with a similar disaster on } \\
\text { a smaller scale. Down the street toward the crowd rushed a } \\
\text { runaway horse, frightened by the shake, but was stopped midway } \\
\text { in its career by E. E. Pellet. With women screaming and children } \\
\text { crying, the first thought was for those injured, but a hurried } \\
\text { search revealed the fact that everyone was safe. At night few } \\
\text { lamps were lighted, through fear of a shock tipping them over. } \\
\text { "Wednesday night the residents of most of the buildings joined the } \\
\text { outdoor brigade and slept under the open sky. Bright and early } \\
\text { Thursday morning work began on repairing the damage. The } \\
\text { streets were cleared of rubbish so that by the time curious } \\
\text { visitors from nearby towns had arrived, much of the town had } \\
\text { again assumed a respectable appearance.... } \\
\text { "The loss in Brawley can be repaired, temporarily, for a few } \\
\text { thousand dollars, but many of the buildings must be rebuilt. The } \\
\text { total damage cannot be less than } \$ 15,000, \text { besides that in the } \\
\text { adjoining territory. A severe shock was felt in all parts of the } \\
\text { Imperial Valley, but Brawley was the worst sufferer, with } \\
\text { Holtville next, for the new buildings were severely damaged. } \\
\text { Imperial, El Centro and Calexico sustained little injury beyond a } \\
\text { few cracked walls." } \\
\text { See Table } 6 \text {. }\end{array}$ \\
\hline 18-Apr-06 & $\begin{array}{c}\text { 16:30, } \\
\text { other times } \\
\text { between } \\
13: 30 \text { and } \\
18: 20 \\
\text { (many events }\end{array}$ & $\begin{array}{c}\text { Brawley } \\
\text { Imperial Junction } \\
\text { (now Niland) }\end{array}$ & $\begin{array}{l}\text { Imperial } \\
\text { Imperial }\end{array}$ & & $\begin{array}{l}\text { San Bernardino Daily Sun, } \\
20 \text { Apr 1906; p. 2, c. } 4\end{array}$ & $\begin{array}{l}\text { “LOS ANGELES, April 19.-Assistant Superintendent } \\
\text { McCaffrey of the Southern Pacific received at } 8 \text { o'clock the } \\
\text { following telegram from Superintendent H. V. Platt, who, with } \\
\text { R. H. Ingram and other railroad officials, went to Imperial valley } \\
\text { a few days ago on an inspection trip: } \\
\text { '“IMPERIAL JUNCTION, April 19.- It is reported from Brawley } \\
\text {... that a serious earthquake occurred there at 4:30 p. m., } \\
\text { yesterday, and that all adobe and brick buildings were wrecked. } \\
\text { No damage to railroad property. There was continuous rumbling } \\
\text { and shaking from 1:30 to 6:20 p. m., and the shocks were felt at } \\
\text { Imperial Junction. } \\
\text { '“'At 5:22 p. m., it was reported from Brawley that the Brawley } \\
\text { bank building, the Paulin building and Varney Brothers' }\end{array}$ \\
\hline
\end{tabular}


TABLE 2: Catalog of Triggered Event Reports following from the Great 18 April 1906 California Earthquake

\begin{tabular}{|c|c|c|c|c|c|c|}
\hline Date Felt & $\begin{array}{c}\text { Time Felt } \\
\text { (PST) }\end{array}$ & $\begin{array}{l}\text { Location Felt } \\
\text { (City) }\end{array}$ & $\begin{array}{c}\text { Location Felt } \\
\text { (County) }\end{array}$ & $\begin{array}{c}\text { Unreliable? } \\
\text { Not Felt? }^{+}\end{array}$ & Source & Relevant Citations and other Notes \\
\hline & & $\mid \begin{array}{c}2 \text { mi. east of Pope } \\
\text { [Pope is } \sim 1 \mathrm{mi} \\
\text { north of Bombay } \\
\text { Beach, on the San } \\
\text { Andreas fault] }\end{array}$ & Imperial & & & $\begin{array}{l}\text { building, all brick blocks, were ruined. No other damage reported } \\
\text { last night. A very low ledge is reported two miles east of Pope, } \\
\text { and appears dangerous. It is believed to have been caused by the } \\
\text { earthquake, and trains have been given orders for six miles an } \\
\text { hour in that section, and section men have been sent out to } \\
\text { investigate...." } \\
\text { This is quite a curious report. The "very low ledge ... believed to } \\
\text { have been caused by the earthquake" could be any of a number of } \\
\text { possibilities, and it is not inconceivable that it describes a fault } \\
\text { scarp. The location is described as "two miles east of Pope." Pope } \\
\text { is a locality along the Southern Pacific railroad and lies precisely } \\
\text { on the San Andreas fault hence, the location of this reported ledge } \\
\text { would be within two miles of the San Andreas fault. It is also well } \\
\text { within the likely epicentral region determined by Meltzner and } \\
\text { Wald (2003). } \\
\text { But there may be a more likely explanation. Between } 1 \text { and } 2 \text { miles } \\
\text { ENE of Pope, the Southern Pacific railroad crosses over several } \\
\text { stream channels, one of them being of a fairly significant size. It is } \\
\text { possible that the intense shaking during the earthquake at the site } \\
\text { caused slumping along one of the banks of the channel. A resulting } \\
\text { erosional scarp could be the "ledge" that is described in the article. } \\
\text { See Table } 6 \text {. }\end{array}$ \\
\hline 18-Apr-06 & $16: 30$ & $\begin{array}{l}\text { Brawley } \\
\text { San Diego }\end{array}$ & $\begin{array}{c}\text { Imperial } \\
\text { San Diego }\end{array}$ & & $\begin{array}{c}\text { San Diego Union, } \\
22 \text { Apr 1906; p. 8, c. } 6\end{array}$ & $\begin{array}{l}\text { "A special dispatch to the Union last evening from the Imperial } \\
\text { Standard implied that the damage done at Brawley was not as } \\
\text { great as was first reported. By fixing the time, the dispatch shows } \\
\text { that the Brawley quake was the one we felt slightly here. The } \\
\text { dispatch was: } \\
\text { "Imperial, Calif., April 21.-An earthquake shock on } \\
\text { Wednesday at 4:30 p. m. damaged adobes at Brawley. There were } \\
\text { no casualties...." } \\
\text { See Table 6. }\end{array}$ \\
\hline 18-Apr-06 & $16: 30$ & Brawley & Imperial & & $\begin{array}{c}\text { San Diego Union, } \\
\text { 24 Apr 1906; p. 8, c. } 3\end{array}$ & $\begin{array}{l}\text { "Calexico, April 21-At 4:30 p. m. on the 18th inst the Imperial } \\
\text { valley was visited by an earthquake which lasted for a period of } \\
\text { two minutes. The little town of Brawley in the north end of the } \\
\text { valley was the worst sufferer. After the people had recovered } \\
\text { from the first fright and started to investigate the amount of } \\
\text { damage done, the discovery was made that not a single brick or } \\
\text { adobe building had escaped injury and some were totally } \\
\text { wrecked. } \\
\text { "These are the Bungalow hotel, public school, Paris restaurant, } \\
\text { and three adobe houses across the river in No. 8. Those damaged } \\
\text { include the First National bank, land office, Varney Bros., C. } \\
\text { Haack, D. D. Pellett, News office, Hutchings \& Co. and Brawley }\end{array}$ \\
\hline
\end{tabular}


TABLE 2: Catalog of Triggered Event Reports following from the Great 18 April 1906 California Earthquake

\begin{tabular}{|c|c|c|c|c|c|c|}
\hline Date Felt & $\begin{array}{l}\text { Time Felt } \\
\text { (PST) }\end{array}$ & $\begin{array}{l}\text { Location Felt } \\
\text { (City) }\end{array}$ & $\begin{array}{l}\text { Location Felt } \\
\text { (County) }\end{array}$ & $\begin{array}{l}\text { Unreliable? } \\
\text { Not Felt? }^{+}\end{array}$ & Source & Relevant Citations and other Notes \\
\hline & & $\begin{array}{l}\text { Imperial } \\
\text { El Centro } \\
\text { Silsbee } \\
\text { Holtville } \\
\text { Calexico }\end{array}$ & $\begin{array}{l}\text { Imperial } \\
\text { Imperial } \\
\text { Imperial } \\
\text { Imperial } \\
\text { Imperial }\end{array}$ & & & $\begin{array}{l}\text { Mercantile Co. } \\
\text { "The greater portion of the people living in frame houses suffered } \\
\text { more or less from the shaking down of dishes, lamps, bric-a-brac, } \\
\text { etc. That no lives were lost is little short of miraculous. The only } \\
\text { accidents reported were a woman and child injured slightly by } \\
\text { the collapse of a dwelling across the river. } \\
\text { "The towns of Imperial, El Centro, and Silsbee escaped without } \\
\text { injury. Holtville and Calexico were shaken some but no damage } \\
\text { was done beyond the cracking of several buildings of the former } \\
\text { place and the post office building at the latter." } \\
\text { See Table } 6 .\end{array}$ \\
\hline 18-Apr-06 & $16: 30$ & Brawley & Imperial & & $\begin{array}{l}\text { Lawson (1908), } \\
\text { vol. I, p. 414 }\end{array}$ & $\begin{array}{l}\text { "Northwest-southeast chimneys fell to west. Movable objects in } \\
\text { bldgs., thrown west-east. Oscillation followed by tremors. Clock } \\
\text { stopped at } 4^{\mathrm{h}} 30^{\mathrm{m}} \text {, facing south." Lawson (1908) estimates Rossi- } \\
\text { Forel intensity IX." } \\
\text { * Based on comparison with other reports of the damage in } \\
\text { Brawley, this estimate is clearly too high. Townley and Allen } \\
\text { (1939) estimate Rossi-Forel intensity VIII, although even that } \\
\text { seems to be on the high side. } \\
\text { See Table } 6 .\end{array}$ \\
\hline 18-Apr-06 & $16: 30$ & Coachella & Riverside & & $\begin{array}{c}\text { Los Angeles Times, } \\
19 \text { Apr 1906; Part II, p. 14, c. } 6\end{array}$ & $\begin{array}{l}\text { "COACHELLA, April 18.- Two distinct shocks of earthquake } \\
\text { were felt here at } 4: 30 \text { o'clock this afternoon. There was no } \\
\text { damage reported." } \\
\text { See Table } 6 \text {. }\end{array}$ \\
\hline 18-Apr-06 & 16:30 & Yuma & $\begin{array}{l}\text { Yuma Co. } \\
\text { (Arizona) }\end{array}$ & & $\begin{array}{l}\text { Arizona Sentinel (Yuma), } \\
18 \text { Apr 1906; p. 3, c. } 5\end{array}$ & $\begin{array}{l}\text { "A slight but distinct earthquake was felt here this afternoon at } \\
4: 30 \text {, lasting perhaps ten seconds. No damage was done, but on } \\
\text { account of the reports of the awful destruction at San Francisco } \\
\text { the quake caused considerable uneasiness. The direction of the } \\
\text { temblor was from northwest to southeast...." } \\
\text { See Table } 6 \text {. }\end{array}$ \\
\hline 18-Apr-06 & $16: 30$ & Yuma & $\begin{array}{l}\text { Yuma Co. } \\
\text { (Arizona) }\end{array}$ & & $\begin{array}{l}\text { Riverside Daily Press, } \\
19 \text { Apr 1906; p. 1, c. } 2\end{array}$ & $\begin{array}{l}\text { "YUMA, Ariz., April 19.-Yuma experienced nine or ten distinct } \\
\text { earthquake shocks at 4:30 p.m. and following the reports of } \\
\text { earthquakes elsewhere, caused quite a stir. Tenants of two-story } \\
\text { buildings felt it most and rushed out on the streets in haste. No } \\
\text { damage resulted." } \\
\text { Also in the Press and Horticulturist (Riverside) of } 20 \text { Apr 1906, } \\
\text { p. 1, c. 1. } \\
\text { See Table 6. }\end{array}$ \\
\hline
\end{tabular}


TABLE 2: Catalog of Triggered Event Reports following from the Great 18 April 1906 California Earthquake

\begin{tabular}{|c|c|c|c|c|c|c|}
\hline Date Felt & $\begin{array}{l}\text { Time Felt } \\
\text { (PST) }\end{array}$ & $\begin{array}{l}\text { Location Felt } \\
\text { (City) }\end{array}$ & $\begin{array}{l}\text { Location Felt } \\
\text { (County) }\end{array}$ & $\begin{array}{c}\text { Unreliable? } \\
\text { Not Felt? }^{+}\end{array}$ & Source & Relevant Citations and other Notes \\
\hline 18-Apr-06 & $16: 30$ & Yuma & $\begin{array}{l}\text { Yuma Co. } \\
\text { (Arizona) }\end{array}$ & & $\begin{array}{l}\text { Lawson (1908), } \\
\text { vol. I, p. } 414\end{array}$ & $\begin{array}{l}\text { "9 or } 10 \text { distinct shocks, slight rolling from east to west." } \\
\text { See Table } 6 \text {. }\end{array}$ \\
\hline 18-Apr-06 & $16: 30$ & Yuma & $\begin{array}{l}\text { Yuma Co. } \\
\text { (Arizona) }\end{array}$ & & $\begin{array}{l}\text { Townley and Allen (1939), } \\
\text { p. } 294\end{array}$ & $\begin{array}{l}\text { "Slight rolling vibration from east to west." } \\
\text { This report is attributed to S. Hackett of the U.S. Weather Bureau. } \\
\text { See Table } 6 .\end{array}$ \\
\hline 18-Apr-06 & $16: 30$ & San Diego & San Diego & & $\begin{array}{c}\text { San Diego Union, } \\
21 \text { Apr 1906; p. 4, c. 1-2 }\end{array}$ & $\begin{array}{l}\text { "All rumors that there has been a tidal wave or other disaster } \\
\text { here are pure invention. At 4:30 p. m. last Wednesday there was a } \\
\text { slight shock of earthquake. It did no damage whatever, and was } \\
\text { so light that many people did not feel it." } \\
\text { See Table } 6 \text {. }\end{array}$ \\
\hline 18-Apr-06 & $16: 30$ & $\begin{array}{c}\text { San Diego } \\
\text { National City }\end{array}$ & $\begin{array}{l}\text { San Diego } \\
\text { San Diego }\end{array}$ & unreliable & $\begin{array}{c}\text { San Diegan-Sun, } \\
18 \text { Apr 1906; p. 1, c. 1-2 }\end{array}$ & $\begin{array}{l}\text { "At 4:30 the strongest shock of earthquake known in San Diego } \\
\text { in } 15 \text { years was experienced. } \\
\text { "The direction was from northeast to southwest. } \\
\text { "It shook chandeliers, but did no damage, as far as can be } \\
\text { reported. Weather Observer Carpenter says: 'The shock, coming } \\
\text { from northeast to southwest, is the usual direction, as the records } \\
\text { for } 15 \text { or } 16 \text { quakes show that } 75 \text { per cent have come from that } \\
\text { direction. No record of anything stronger.' } \\
\text { "The weather bureau is in one of the tallest buildings of the city, } \\
\text { and the clock there was not stopped. But Mr. Carpenter said that } \\
\text { had the direction of the quake been different it would have } \\
\text { stopped the clock.... } \\
\text { "Three shocks occurred at National City. The first was a heavy } \\
\text { one and this was followed by two lighter quakes. Buildings } \\
\text { shook, but no damage is reported.... } \\
\text { "When the shock came at } 4: 30 \text { one of the roomers at the Keating } \\
\text { block rushed down stairs with all the clothes she could hurriedly } \\
\text { gather and fainted after reaching the street. } \\
\text { "Telephone communications from different parts of the city say } \\
\text { chandeliers swung and tall book cases swayed. This shows that } \\
\text { the shock was general all over the city." } \\
\text { Compare this with the article in the San Diegan-Sun, } 19 \text { Apr } 1906 \text {, } \\
\text { p. } 2, \text { c. } 4 \text {, and with the article in the San Diego Union, } 19 \text { Apr 1906, } \\
\text { p. 5, c. } 1 . \\
\text { In light of comments in the later report (19 Apr) in the Sun, which } \\
\text { downplay comments in the Sun's first report (above), the Sun's } \\
\text { reports are not considered fully reliable, and the San Diego Union } \\
\text { is believed to have the most reliable account of the earthquake in San }\end{array}$ \\
\hline
\end{tabular}


TABLE 2: Catalog of Triggered Event Reports following from the Great 18 April 1906 California Earthquake

\begin{tabular}{|c|c|c|c|c|c|c|}
\hline Date Felt & $\begin{array}{c}\text { Time Felt } \\
\text { (PST) }\end{array}$ & $\begin{array}{l}\text { Location Felt } \\
\text { (City) }\end{array}$ & $\begin{array}{c}\text { Location Felt } \\
\text { (County) }\end{array}$ & $\begin{array}{l}\text { Unreliable? } \\
\text { Not Felt? }^{+}\end{array}$ & Source & Relevant Citations and other Notes \\
\hline & & & & & & $\begin{array}{l}\text { Diego. } \\
\text { See Table 6. }\end{array}$ \\
\hline 18-Apr-06 & 16:30 & $\begin{array}{l}\text { San Diego } \\
\text { National City }\end{array}$ & $\begin{array}{l}\text { San Diego } \\
\text { San Diego }\end{array}$ & unreliable & $\begin{array}{l}\text { Riverside Daily Press, } \\
19 \text { Apr 1906; p. 1, c. 1-2 }\end{array}$ & $\begin{array}{l}\text { "SAN DIEGO, April 19-The shock here Wednesday afternoon } \\
\text { at } 4: 30 \text { o' clock was the heaviest in fifteen years. The direction } \\
\text { was from the northeast to the southwest. No damage was done.... } \\
\text { "The Weather Bureau station is in the tallest building in the city. } \\
\text { The clock was not stopped, but the pendulum was made to } \\
\text { wobble. } \\
\text { "National City, four miles south of here, reports three shocks, the } \\
\text { first a heavy one followed by two lighter ones." } \\
\text { This report is similar to a report in the San Diegan-Sun which was } \\
\text { deemed unreliable for San Diego. This report also appeared in the } \\
\text { Press and Horticulturist (Riverside) of } 20 \text { Apr 1906, p. } 1, c .1 \text {. } \\
\text { See Table } 6 .\end{array}$ \\
\hline 18-Apr-06 & $16: 30$ & \begin{tabular}{|c|} 
San Diego \\
National City \\
all sections of \\
San Diego County
\end{tabular} & $\begin{array}{l}\text { San Diego } \\
\text { San Diego } \\
\text { San Diego }\end{array}$ & unreliable & \begin{tabular}{c|} 
Los Angeles Times, \\
19 Apr 1906; Part I, p. 4, c. 5-6
\end{tabular} & $\begin{array}{l}\text { "SAN DIEGO, April 18.- (Exclusive Dispatch.) The shock here } \\
\text { this afternoon at 4:30 o'clock was the heaviest in fifteen years. } \\
\text { The direction was from the northeast to the southwest. No } \\
\text { damage was done.... } \\
\text { "The weather bureau station is in the tallest building in the city. } \\
\text { The clock was not stopped but the pendulum was made to wobble. } \\
\text { "National City, four miles south of here, reports three shocks, the } \\
\text { first a heavy one followed by three lighter ones. } \\
\text { "The shock penetrated to all sections of the county." } \\
\text { This report is similar to a report in the San Diegan-Sun which was } \\
\text { deemed unreliable for San Diego. } \\
\text { See Table 6. }\end{array}$ \\
\hline 18-Apr-06 & $16: 30$ & San Diego & San Diego & & \begin{tabular}{c|} 
Los Angeles Herald, \\
19 Apr 1906; Part I, p. 4, c. 6-7
\end{tabular} & $\begin{array}{l}\text { "SAN DIEGO, April 18.-While the people were gathered in } \\
\text { groups discussing the havoc that has been wrought at San } \\
\text { Francisco by earthquakes, at } 4: 30 \text { o'clock this afternoon a shock } \\
\text { was felt here, which threw the town into a state of panic. } \\
\text { "Everybody was worked up to a state of nervousness by news } \\
\text { from the north and when the shock came people thought that the } \\
\text { town was being destroyed. } \\
\text { "In a short time the shaking subsided and the town became quiet. } \\
\text { No damage was done...." } \\
\text { See Table } 6 .\end{array}$ \\
\hline
\end{tabular}


TABLE 2: Catalog of Triggered Event Reports following from the Great 18 April 1906 California Earthquake

\begin{tabular}{|c|c|c|c|c|c|c|}
\hline Date Felt & $\begin{array}{l}\text { Time Felt } \\
\text { (PST) }\end{array}$ & $\begin{array}{l}\text { Location Felt } \\
\text { (City) }\end{array}$ & $\begin{array}{l}\text { Location Felt } \\
\text { (County) }\end{array}$ & $\begin{array}{l}\text { Unreliable? } \\
\text { Not Felt? }^{+}\end{array}$ & Source & Relevant Citations and other Notes \\
\hline 18-Apr-06 & $16: 30$ & San Diego & San Diego & & $\begin{array}{c}\text { Los Angeles Times, } \\
19 \text { Apr 1906; Part II, p. 14, c. } 7\end{array}$ & $\begin{array}{l}\text { "SAN DIEGO, April 18.-[Exclusive Dispatch.] A slight shock } \\
\text { was felt here at 4:30 o' clock this afternoon. Many people } \\
\text { experienced the feeling of sea sickness. A number of women in } \\
\text { buildings fainted, or were rendered unconscious from fright, and } \\
\text { were hustled into the open. People rushed out of the larger } \\
\text { buildings into the streets. Numerous clocks were stopped and } \\
\text { dishes were rattled." } \\
\text { See Table } 6 \text {. }\end{array}$ \\
\hline 18-Apr-06 & $16: 30$ & San Diego & San Diego & & $\begin{array}{c}\text { Los Angeles Times, } \\
20 \text { Apr 1906; Part I, p. 8, c. } 5\end{array}$ & $\begin{array}{l}\text { "SAN DIEGO, April 19.- - Telegrams are being received in this } \\
\text { city showing that the report has been sent out from Los Angeles } \\
\text { that San Diego had suffered damage from earthquake. There has } \\
\text { been absolutely no damage done in this section, the only shock felt } \\
\text { being a very slight one at 4:30 p.m. yesterday...." } \\
\text { See Table } 6 .\end{array}$ \\
\hline 18-Apr-06 & $16: 30$ & San Diego & San Diego & & $\begin{array}{l}\text { Lawson (1908), } \\
\text { vol. I, p. } 413\end{array}$ & $\begin{array}{l}\text { "Heaviest in } 15 \text { years, northeast-southwest." } \\
\text { See Table } 6 .\end{array}$ \\
\hline 18-Apr-06 & $16: 30$ & Ballast Point & San Diego & & $\begin{array}{l}\text { Lawson (1908), } \\
\text { vol. I, p. } 414\end{array}$ & $\begin{array}{l}\text { "North-south. Horizontal. Clock stopt } 4^{\mathrm{h}} 30^{\mathrm{m}} \text {, facing NW., pend. } \\
\text { 17"." Duration: a few seconds. } \\
\text { See Table } 6 .\end{array}$ \\
\hline 18-Apr-06 & $16: 30$ & National City & San Diego & & $\begin{array}{l}\text { National City News, } \\
21 \text { Apr 1906; p. 1, c. } 2\end{array}$ & $\begin{array}{l}\text { "Wednesday afternoon at 4:30 o'clock this city experienced two } \\
\text { distinct earthquake shocks, followed by a slight tremor. The } \\
\text { shocks were strong enough so that everybody felt them. At the } \\
\text { home of the editor a large clock on a shelf stopped at half past } \\
\text { four to the dot. So far as we have been able to learn no damage } \\
\text { was done." } \\
\text { See Table } 6 \text {. }\end{array}$ \\
\hline 18-Apr-06 & $16: 30$ & National City & San Diego & & $\begin{array}{l}\text { Diary of Frank A. Kimball } \\
\text { (National City, CA), } \\
18 \text { Apr } 1906\end{array}$ & $\begin{array}{l}\text { An excerpt from the page dated WED. APRIL 18, 1906: } \\
\text { "A slight earthquake shock at } 4^{30} \text { P.M. did no damage." } \\
\text { A separate letter written by Frank A. Kimball on } 18 \text { April 1906, } \\
\text { dated "National City Calif. } 4 / 18,06, \text { " places Kimball in National } \\
\text { City on the day of the earthquake. } \\
\text { See Table } 6 .\end{array}$ \\
\hline
\end{tabular}


TABLE 2: Catalog of Triggered Event Reports following from the Great 18 April 1906 California Earthquake

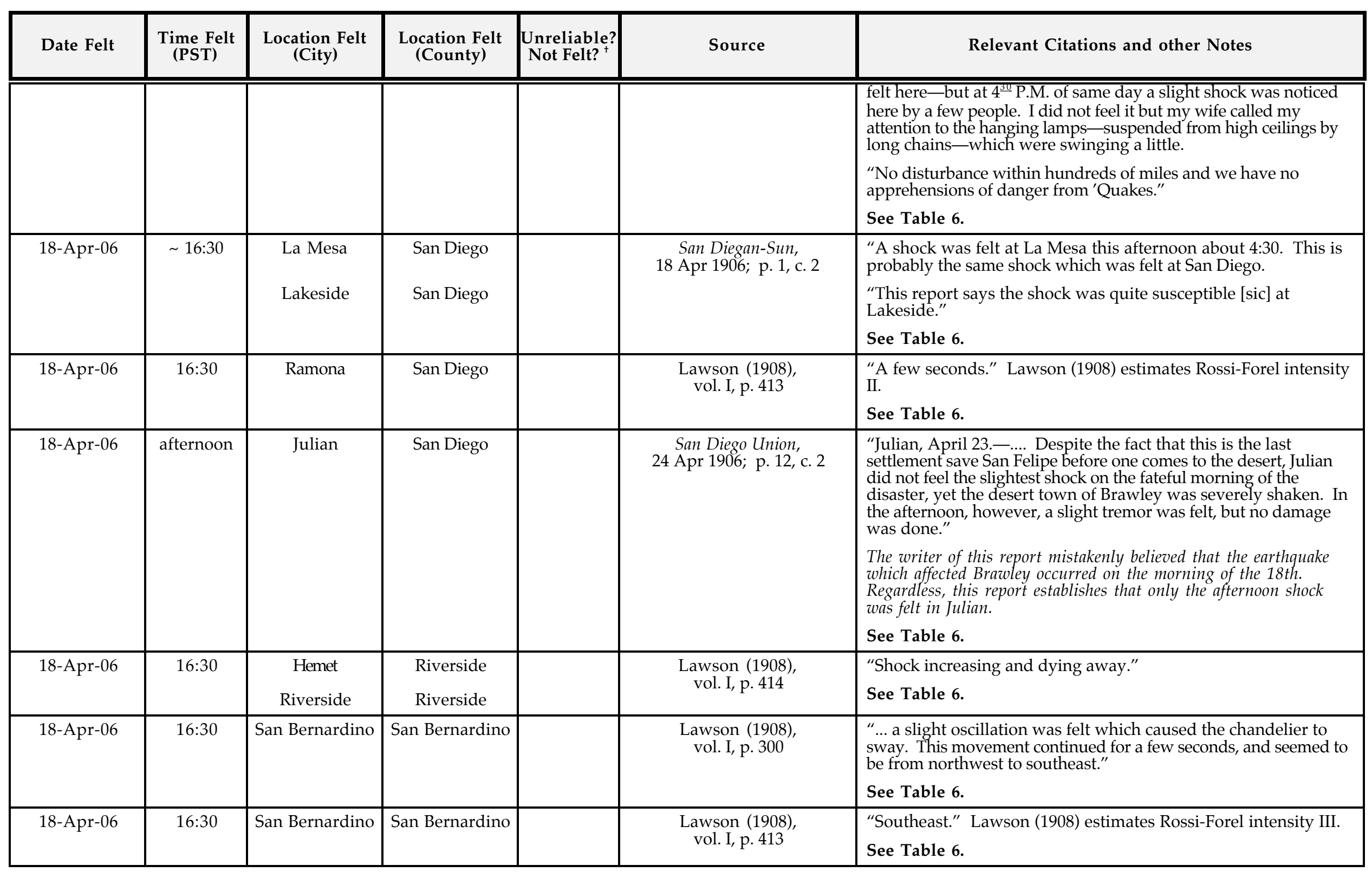


TABLE 2: Catalog of Triggered Event Reports following from the Great 18 April 1906 California Earthquake

\begin{tabular}{|c|c|c|c|c|c|c|}
\hline Date Felt & $\begin{array}{l}\text { Time Felt } \\
\text { (PST) }\end{array}$ & $\begin{array}{l}\text { Location Felt } \\
\text { (City) }\end{array}$ & $\begin{array}{l}\text { Location Felt } \\
\text { (County) }\end{array}$ & $\begin{array}{l}\text { Unreliable? } \\
\text { Not Felt? }^{+}\end{array}$ & Source & Relevant Citations and other Notes \\
\hline 18-Apr-06 & $16: 30$ & $\begin{array}{l}\text { San Juan } \\
\text { Capistrano }\end{array}$ & Orange & & $\begin{array}{l}\text { Lawson (1908), } \\
\text { vol. I, p. 414 }\end{array}$ & $\begin{array}{l}\text { "Slight." } \\
\text { See Table } 6 .\end{array}$ \\
\hline 18-Apr-06 & $\sim$ 16:30 & Santa Ana & Orange & & $\begin{array}{l}\text { Evening Blade (Santa Ana), } \\
19 \text { Apr 1906; p. 3, c. } 1\end{array}$ & $\begin{array}{l}\text { "Besides the faint shock of the earthquake felt here shortly after } 5 \\
\text { o'clock yesterday morning and noticed by a considerable number } \\
\text { of people through out the city, another shake occurred late } \\
\text { yesterday afternoon about 4:30, the effect of which was noticed } \\
\text { particularly in the western portion of the city where houses were } \\
\text { rocked perceptibly and pictures and other articles depending from } \\
\text { the walls were swung to and fro. The disturbance lasted only a } \\
\text { few seconds, but the jarring was so pronounced that it was } \\
\text { readily recognized as the result of an earthquake. F. . Thorp, a } \\
\text { resident of West Second street was lying ill in bed at the time and } \\
\text { he plainly noticed the swaying of the house and the vibration of } \\
\text { pendant electric light bulbs in the room he occupied, while other } \\
\text { residents of the locality were also apprised of the fact that a } \\
\text { seismic disturbance was in progress by the distinct rumbling and } \\
\text { jarring of their residences." } \\
\text { See Table } 6 \text {. }\end{array}$ \\
\hline 18-Apr-06 & afternoon & $\begin{array}{l}\text { Brawley } \\
\text { Cocopah }\end{array}$ & $\begin{array}{c}\text { Imperial } \\
\text { Baja California } \\
\text { Norte, Mexico }\end{array}$ & & Richter (1958), p. 485 & $\begin{array}{l}\text { "... on the afternoon of ... April 18, 1906, there was a strong shock } \\
\text { in Imperial Valley, which was then rather thinly settled; } \\
\text { nevertheless, there was damage at Brawley, and a water tank } \\
\text { was thrown down at the railroad station of Cocopah (Mexico)." } \\
\text { According to the National Imagery and Mapping Agency (NIMA) } \\
\text { GEOnet Names Server (GNS, available online at } \\
\text { http://wwww.nima.mil/gns/html/), the railroad station of Cocopah } \\
\text { also goes by the name Estacion Cocopar (or Cocopar) and is located } \\
\text { at lat } 32^{\circ} 33^{\prime} \text { ' N, lon } 115^{\circ} 14^{\prime} \text { W. } \\
\text { See Table 6. }\end{array}$ \\
\hline 18-Apr-06 & & Brawley & Imperial & & $\begin{array}{c}\text { San Diego Union, } \\
20 \text { Apr 1906; p. 2, c. } 4\end{array}$ & $\begin{array}{l}\text { "Los Angeles, April 19.--Reports this morning from Brawley ... } \\
\text { state that the town was practically wiped out by the earthquake } \\
\text { of yesterday. This is the only town in Southern California } \\
\text { known to have suffered from the shock. Southern Pacific officials } \\
\text { report today that the following buildings there, all brick } \\
\text { structures, were completely destroyed: } \\
\text { "Brawley bank, Paulin building and the principal merchandise } \\
\text { building of the town. In addition dozens of adobe houses were } \\
\text { razed to the ground. So far as known, there were no fatalities. } \\
\text { "Reports received tonight show the town of Brawley to have } \\
\text { suffered less by yesterday's earthquake shock than originally } \\
\text { stated. About one hundred buildings in Brawley and the } \\
\text { surrounding valley were damaged, but none of them was wholly } \\
\text { destroyed." }\end{array}$ \\
\hline
\end{tabular}


TABLE 2: Catalog of Triggered Event Reports following from the Great 18 April 1906 California Earthquake

\begin{tabular}{|c|c|c|c|c|c|c|}
\hline Date Felt & $\begin{array}{c}\text { Time Felt } \\
\text { (PST) }\end{array}$ & $\begin{array}{l}\text { Location Felt } \\
\text { (City) }\end{array}$ & $\begin{array}{l}\text { Location Felt } \\
\text { (County) }\end{array}$ & $\begin{array}{l}\text { Unreliable? } \\
\text { Not Felt? }^{+}\end{array}$ & Source & Relevant Citations and other Notes \\
\hline & & & & & & $\begin{array}{l}\text { The writer of this report apparently did not realize that the event } \\
\text { which affected Brawley was different from the mainshock in } \\
\text { northern California. From other reports, the damage in Brawley is } \\
\text { inferred to be a result of the Imperial Valley mainshock on the } \\
\text { afternoon of } 18 \text { April. } \\
\text { See Table } 6 .\end{array}$ \\
\hline 18-Apr-06 & & Brawley & Imperial & unreliable & $\begin{array}{c}\text { San Diego News, } \\
19 \text { Apr 1906; p. 1, c. } 5\end{array}$ & $\begin{array}{l}\text { "Los Angeles, April 19.-Reports this morning from Brawley ... } \\
\text { state that the town was practically wiped out by the earthquake } \\
\text { of yesterday. } \\
\text { "[Too much confidence must not be placed in this report, as it had } \\
\text { its birth in Los Angeles.]"* } \\
\text { The writer of this report apparently did not realize that the event } \\
\text { which affected Brawley was different from the mainshock in } \\
\text { northern California. From other reports, the damage in Brawley is } \\
\text { inferred to be a result of the Imperial Valley mainshock on the } \\
\text { afternoon of } 188 \text { April. In comparison to reports published in local } \\
\text { newspapers, this account is obviously exaggerated. } \\
\text { * This statement appeared as is (in brackets) at the end of the } \\
\text { newspaper report. It is inferred to be a note added by the editors } \\
\text { of the San Diego News. } \\
\text { See Table } 6 .\end{array}$ \\
\hline 18-Apr-06 & & Brawley & Imperial & unreliable & $\begin{array}{l}\text { Evening Blade (Santa Ana), } \\
19 \text { Apr 1906; p. 8, c. } 5\end{array}$ & $\begin{array}{l}\text { "LOS ANGELES, April 19.--Reports this morning from Brawley } \\
\text {... state that the town was practically wiped out by the } \\
\text { earthquake yesterday. This is the only town in Southern } \\
\text { California known to have suffered from the shock. It is not } \\
\text { known that there were any fatalities." } \\
\text { The writer of this report apparently did not realize that the event } \\
\text { which affected Brawley was different from the mainshock in } \\
\text { northern California. From other reports, the damage in Brawley is } \\
\text { inferred to be a result of the Imperial Valley mainshock on the } \\
\text { afternoon of } 18 \text { April. In comparison to reports published in local } \\
\text { newspapers, this account is obviously exaggerated. } \\
\text { See Table } 6 .\end{array}$ \\
\hline 18-Apr-06 (?) & & Brawley & Imperial & & $\begin{array}{l}\text { San Diegan-Sun, } \\
20 \text { Apr 1906; p. 2, c. } 1\end{array}$ & $\begin{array}{l}\text { "LOS ANGELES, April 20.-Brawley is the only town in } \\
\text { Southern California that suffered from the earthquake. These } \\
\text { structures were destroyed: The Brawley bank, Paulin building } \\
\text { and the principal merchandise building, including a number of } \\
\text { houses. The adobe houses fell." } \\
\text { The actual time and date of the earthquake at issue are not stated. } \\
\text { The writer of this report apparently did not realize that the event } \\
\text { which affected Brawley was different from the mainshock in }\end{array}$ \\
\hline
\end{tabular}


TABLE 2: Catalog of Triggered Event Reports following from the Great 18 April 1906 California Earthquake

\begin{tabular}{|c|c|c|c|c|c|c|}
\hline Date Felt & $\begin{array}{l}\text { Time Felt } \\
\text { (PST) }\end{array}$ & $\begin{array}{l}\text { Location Felt } \\
\text { (City) }\end{array}$ & $\begin{array}{l}\text { Location Felt } \\
\text { (County) }\end{array}$ & $\begin{array}{c}\text { Unreliable? } \\
\text { Not Felt? }^{+}\end{array}$ & Source & Relevant Citations and other Notes \\
\hline & & & & & & $\begin{array}{l}\text { northern California. From other reports, the damage in Brawley is } \\
\text { inferred to be a result of the Imperial Valley mainshock on the } \\
\text { afternoon of } 18 \text { April. } \\
\text { See Table } 6 .\end{array}$ \\
\hline 18-Apr-06 (?) & & $\begin{array}{c}\text { Brawley } \\
\text { Imperial } \\
\text { Calexico } \\
\text { Holtville } \\
\text { Heber }\end{array}$ & $\begin{array}{l}\text { Imperial } \\
\text { Imperial } \\
\text { Imperial } \\
\text { Imperial } \\
\text { Imperial }\end{array}$ & & $\begin{array}{l}\text { San Diegan-Sun, } \\
21 \text { Apr 1906; p. 4, c. } 1\end{array}$ & $\begin{array}{l}\text { "Secretary James Jasper of the chamber of commerce, has received } \\
\text { this wire information as to the quake damage in Brawley: 'Seven } \\
\text { buildings in Brawley were badly damaged. Some of them are a } \\
\text { total wreck. The New river track house was destroyed. It is the } \\
\text { total damage in the valley. } \\
\text { "'Imperial, Calexico, Holtville and Heber are all right...."' } \\
\text { The actual time and date of the earthquake at issue are not stated, } \\
\text { although it is inferred to be the Imperial Valley mainshock on the } \\
\text { afternoon of } 18 \text { April. } \\
\text { See Table } 6 .\end{array}$ \\
\hline 18-Apr-06 & & Brawley & Imperial & & \begin{tabular}{|l} 
Los Angeles Times, \\
20 Apr 1906; Part II, p. 9, c. 2
\end{tabular} & $\begin{array}{l}\text { "BRAWLEY, April 19.-[Exclusive Dispatch.] The earthquake } \\
\text { here yesterday did only slight damage and there was nothing } \\
\text { about it to warrant the sensational reports that have been sent } \\
\text { out magnifying it greatly. Five or six small buildings were } \\
\text { slightly injured, but none of them was razed or even collapsed by } \\
\text { the tremor. It caused only ordinary alarm." } \\
\text { See Table } 6 \text {. }\end{array}$ \\
\hline 18-Apr-06 (?) & & Brawley & Imperial & & $\begin{array}{c}\text { Brawley News, } \\
27 \text { Apr 1906; p. 4, c. } 1\end{array}$ & $\begin{array}{l}\text { "A look over the results of the earthquake shows that the damage } \\
\text { was more apparent than real. Most of the buildings damaged } \\
\text { were of temporary construction. Not one frame building was } \\
\text { injured and the two brick buildings that suffered loss can be } \\
\text { repaired with little difficulty. The dust had hardly cleared away } \\
\text { from the streets when the work of repairing and rebuilding } \\
\text { commenced. In two or three weeks the only visible reminder of the } \\
\text { earthquake will be a few cracked walls." } \\
\text { The actual time and date of the earthquake at issue are not stated, } \\
\text { although it is inferred to be the Imperial Valley mainshock on the } \\
\text { afternoon of } 18 \text { April. } \\
\text { See Table } 6 \text {. }\end{array}$ \\
\hline 18-Apr-06 & $\begin{array}{c}\text { a few minutes } \\
\text { after } 16: 30\end{array}$ & San Diego & San Diego & & $\begin{array}{c}\text { Los Angeles Herald, } \\
19 \text { Apr 1906; Part I, p. 4, c. 6-7 }\end{array}$ & $\begin{array}{l}\text { "SAN DIEGO, April 18.-While the people were gathered in } \\
\text { groups discussing the havoc that has been wrought at San } \\
\text { Francisco by earthquakes, at 4:30 o'clock this afternoon a shock }\end{array}$ \\
\hline
\end{tabular}


TABLE 2: Catalog of Triggered Event Reports following from the Great 18 April 1906 California Earthquake

\begin{tabular}{|c|c|c|c|c|c|c|}
\hline Date Felt & $\begin{array}{l}\text { Time Felt } \\
\text { (PST) }\end{array}$ & $\begin{array}{l}\text { Location Felt } \\
\text { (City) }\end{array}$ & $\begin{array}{l}\text { Location Felt } \\
\text { (County) }\end{array}$ & $\begin{array}{l}\text { Unreliable? }^{\text {Not Felt? }}{ }^{+}\end{array}$ & Source & Relevant Citations and other Notes \\
\hline & & & & & & $\begin{array}{l}\text { was felt here, which threw the town into a state of panic.... } \\
\text { "A second shock came a few minutes later and the people were } \\
\text { again panic stricken. Chandeliers and pictures swayed, but } \\
\text { further than this no trouble occurred." }\end{array}$ \\
\hline 18-Apr-06 & $20: 45$ & Glendora & Los Angeles & & $\begin{array}{l}\text { Diary of Minnie Warren } \\
\text { (Glendora, CA), } \\
\text { 18 Apr 1906 }\end{array}$ & $\begin{array}{l}\text { Entry for } 18 \text { Apr 1906: } \\
\text { "Terrible earth quake \& fire in San Francisco. Warm day. } \\
\text { Light shocks of earth quakes at night at 8:45 - 9:10 - 10:30." }\end{array}$ \\
\hline 18-Apr-06 & 21:00 & Chino & San Bernardino & & $\begin{array}{l}\text { Chino Valley Champion, } \\
20 \text { Apr 1906; p. 1, c. } 2\end{array}$ & "A slight shock was felt here...." \\
\hline 18-Apr-06 & 21:05 & $\begin{array}{c}\text { Lordsburg } \\
\text { (now La Verne) }\end{array}$ & Los Angeles & & $\begin{array}{l}\text { Los Angeles Times, } \\
19 \text { Apr 1906; Part II, p. 14, c. } 4\end{array}$ & $\begin{array}{l}\text { "LORDSBURG, April 18.- This community experienced an } \\
\text { earthquake at 9:05 o' clock tonight. The shock was so severe that } \\
\text { many of the women about here will have a sleepless night." }\end{array}$ \\
\hline 18-Apr-06 & $21: 10$ & Glendora & Los Angeles & & $\begin{array}{l}\text { Diary of Minnie Warren } \\
\text { (Glendora, CA), } \\
\text { 18 Apr 1906 }\end{array}$ & $\begin{array}{l}\text { Entry for } 18 \text { Apr 1906: } \\
\text { “Terrible earth quake \& fire in San Francisco. Warm day. } \\
\text { Light shocks of earth quakes at night at 8:45 - 9:10 - 10:30." }\end{array}$ \\
\hline 18-Apr-06 & 22:30 & Glendora & Los Angeles & & $\begin{array}{l}\text { Diary of Minnie Warren } \\
\text { (Glendora, CA), } \\
\text { 18 Apr 1906 }\end{array}$ & $\begin{array}{l}\text { Entry for } 18 \text { Apr 1906: } \\
\text { "Terrible earth quake \& fire in San Francisco. Warm day. } \\
\text { Light shocks of earth quakes at night at 8:45 - 9:10 - 10:30." }\end{array}$ \\
\hline 18-Apr-06 & $\begin{array}{c}\text { night } \\
\text { (many events }\end{array}$ & $\begin{array}{c}\text { Brawley and /or } \\
\text { Imperial }\end{array}$ & Imperial & & $\begin{array}{l}\text { San Diego Union, } \\
22 \text { Apr 1906; p. 8, c. } 6\end{array}$ & $\begin{array}{l}\text { [quoting a dispatch from the Imperial Standard:] “'Imperial, Calif., } \\
\text { April } 21 \text {. - An earthquake shock on Wednesday at } 4: 30 \mathrm{p} \text {. m. } \\
\text { damaged adobes at Brawley. There were no casualties. Slight } \\
\text { shocks were felt on Wednesday night and on Thursday, but there } \\
\text { was no further damage.'” }\end{array}$ \\
\hline $\begin{array}{l}\text { 18-Apr-06, } \\
\text { others }\end{array}$ & (many events) & Paisley & $\begin{array}{l}\text { Lake Co. } \\
\text { (Oregon) }\end{array}$ & & $\begin{array}{l}\text { Lake County Examiner, } \\
26 \text { Apr } 1906 ; \text { p. } 1 \text {, c. } 1-2\end{array}$ & $\begin{array}{l}\text { "Shocks were felt distinctly at Paisley on the day of the big } \\
\text { earthquake and many others." }\end{array}$ \\
\hline 19-Apr-06 & $\begin{array}{c}\sim 01: 30, \\
\text { other times } \\
\text { between } \\
\sim 01: 30 \text { and } \\
\sim 03: 00 \\
\text { (four events } \\
\text { total) }\end{array}$ & Paisley & $\begin{array}{l}\text { Lake Co. } \\
\text { (Oregon) }\end{array}$ & & $\begin{array}{l}\text { Lawson (1908), } \\
\text { vol. I, p. } 163\end{array}$ & $\begin{array}{l}\text { "At Paisley no shock was noticed on April 18, but on Thursday, } \\
\text { April 19, about } 1^{\mathrm{h}} 30^{\mathrm{m}} \text { A.M., a tremor was felt, strong enough to } \\
\text { generally awaken people, and during the next hour and a half } \\
\text { three more shocks were felt. Considerable excitement was caused, } \\
\text { some people going out-of-doors and one rather delicate woman } \\
\text { being made sick...." }\end{array}$ \\
\hline 19-Apr-06 & (many events) & $\begin{array}{c}\text { Brawley and / or } \\
\text { Imperial }\end{array}$ & Imperial & & $\begin{array}{l}\text { San Diego Union, } \\
22 \text { Apr 1906; p. 8, c. } 6\end{array}$ & $\begin{array}{l}\text { [quoting a dispatch from the Imperial Standard:] “'Imperial, Calif., } \\
\text { April } 21 \text {. - An earthquake shock on Wednesday at } 4: 30 \mathrm{p} \text {. m. } \\
\text { damaged adobes at Brawley. There were no casualties. Slight } \\
\text { shocks were felt on Wednesday night and on Thursday, but there } \\
\text { was no further damage.'” }\end{array}$ \\
\hline
\end{tabular}


TABLE 2: Catalog of Triggered Event Reports following from the Great 18 April 1906 California Earthquake

\begin{tabular}{|c|c|c|c|c|c|c|}
\hline Date Felt & $\begin{array}{l}\text { Time Felt } \\
\text { (PST) }\end{array}$ & $\begin{array}{l}\text { Location Felt } \\
\text { (City) }\end{array}$ & $\begin{array}{l}\text { Location Felt } \\
\text { (County) }\end{array}$ & $\begin{array}{l}\text { Unreliable? } \\
\text { Not Felt? }^{+}\end{array}$ & Source & Relevant Citations and other Notes \\
\hline 19-Apr-06 & noon & Avalon & Los Angeles & & $\begin{array}{l}\text { Oregon Daily Journal } \\
\text { (Portland), } \\
20 \text { Apr 1906; p. } 10, \text { c. } 3\end{array}$ & $\begin{array}{l}\text { "Los Angeles, April 20.-Three slight shocks following in rapid } \\
\text { succession shook southern California and startled the visitors at } \\
\text { Avalon at noon yesterday. No damage was done and there have } \\
\text { been no repetitions of tremors since.... The story that any one was } \\
\text { killed at Avalon is absolutely untrue." } \\
\text { See Table } 7 .\end{array}$ \\
\hline 19-Apr-06 & noon & Los Angeles & Los Angeles & & $\begin{array}{l}\text { Diary of Selena Gray Ingram } \\
\text { (Los Angeles, CA), } \\
19 \text { Apr } 1906\end{array}$ & $\begin{array}{l}\text { Written in the top margin of the page for the } 19 \text { Apr } 1906 \text { entry: } \\
\text { "We had a shock in Los Angeles today at noon-but no damage } \\
\text { was done." } \\
\text { See Table 7. }\end{array}$ \\
\hline 19-Apr-06 & $\begin{array}{c}\text { shortly } \\
\text { after noon }\end{array}$ & Hollywood & Los Angeles & & $\begin{array}{l}\text { Los Angeles Examiner, } \\
20 \text { Apr 1906; p. 7, c. } 7\end{array}$ & $\begin{array}{l}\text { "... Hollywood also felt the tremor shortly after noon yesterday. } \\
\text { A slight crack in a wall of a building was the full extent of the } \\
\text { damage...." } \\
\text { See Table } 7 .\end{array}$ \\
\hline 19-Apr-06 & $12: 25$ & San Pedro & Los Angeles & & $\begin{array}{l}\text { Lawson (1908), } \\
\text { vol. I, p. } 415\end{array}$ & $\begin{array}{l}\text { "Horizontal tremors } 10 \mathrm{~s} \text {. before, increased intensity, strongest at } \\
\text { end. No sound." Duration } 15 \text { seconds. } \\
\text { See Table } 7 \text {. }\end{array}$ \\
\hline 19-Apr-06 & $12: 28$ & Long Beach & Los Angeles & & \begin{tabular}{|c|} 
Los Angeles Times, \\
20 Apr 1906; Part II, p. 14, c. 1
\end{tabular} & $\begin{array}{l}\text { "LONG BEACH, April 19.-This city was visited by an } \\
\text { earthquake shock at 12:28 o' clock this afternoon. The shock was } \\
\text { of three or four seconds' duration, and was from north to south } \\
\text { and seemed to be stronger north of town. Windows and doors } \\
\text { rattled, but no damage is reported beyond the tension on the } \\
\text { nerves of people already on a hair-trigger strain. All the city } \\
\text { schools were dismissed at noon today because the children were } \\
\text { too restless and unstrung to do any studying." } \\
\text { See Table } 7 \text {. }\end{array}$ \\
\hline 19-Apr-06 & $12: 28$ & Long Beach & Los Angeles & & $\begin{array}{l}\text { Long Beach Evening Tribune, } \\
19 \text { Apr 1906; p. 4, c. 5-6 }\end{array}$ & $\begin{array}{l}\text { "A slight tremor was noticed in Long Beach at } 12: 28 \text { today, and } \\
\text { timid ones, ready to jump at the dropping of a pin, avowed it was } \\
\text { a quake and then looked over to the east to see if 'Old Baldy' was } \\
\text { smoking. The shock, if it was such, was noticed only within }\end{array}$ \\
\hline
\end{tabular}


TABLE 2: Catalog of Triggered Event Reports following from the Great 18 April 1906 California Earthquake

\begin{tabular}{|c|c|c|c|c|c|c|}
\hline Date Felt & $\begin{array}{l}\text { Time Felt } \\
\text { (PST) }\end{array}$ & $\begin{array}{l}\text { Location Felt } \\
\text { (City) }\end{array}$ & $\begin{array}{l}\text { Location Felt } \\
\text { (County) }\end{array}$ & $\begin{array}{l}\text { Unreliable? } \\
\text { Not Felt? }^{+}\end{array}$ & Source & Relevant Citations and other Notes \\
\hline & & & & & & $\begin{array}{l}\text { doors. Outside it was not felt." } \\
\text { See Table } 7 .\end{array}$ \\
\hline 19-Apr-06 & $12: 29$ & $\begin{array}{l}\text { Santa Monica } \\
\text { Venice }\end{array}$ & $\begin{array}{l}\text { Los Angeles } \\
\text { Los Angeles }\end{array}$ & & \begin{tabular}{|} 
Daily Outlook (Santa Monica) \\
19 Apr 1906; p. 1, c. 4
\end{tabular} & $\begin{array}{l}\text { "At 12:29 today the Santa Monica bay section heard the awful } \\
\text { rumble and roar and felt the vibrations and undulations of an } \\
\text { earthquake shock. The tremblor moved from north to south, } \\
\text { apparently quite closely following the coast line. The } \\
\text { disturbance had a duration of thirty-two seconds and during that } \\
\text { time there was a perceptible swaying of buildings and creaking } \\
\text { and crackling of timbers. } \\
\text { "A slight crack under the window of the Joseph Kuhrts building } \\
\text { at the door of the Kuhrts building [sic] at the corner of Utah and } \\
\text { Second was observed. At Venice several of the tall brick } \\
\text { buildings were cracked just a little." } \\
\text { See Table } 7 \text {. }\end{array}$ \\
\hline 19-Apr-06 & $12: 30$ & Sawtelle & Los Angeles & & \begin{tabular}{|c|} 
Los Angeles Times, \\
20 Apr 1906; Part II, p. 14, c. 2
\end{tabular} & $\begin{array}{l}\text { "SAWTELLE, April 19.-This community received a severe } \\
\text { shaking up at } 12: 30 \text { o' clock today. To all appearances the } \\
\text { movement of the temblor was from north to south. So decided } \\
\text { were the vibrations that canned goods on the shelves in grocery } \\
\text { stores were shaken to the floor with a crash. Mirrors in barber } \\
\text { shops were broken. People ran out of their houses in alarm, their } \\
\text { faces depicting terror, but there was no damage to any of the } \\
\text { buildings in the city." } \\
\text { See Table 7. }\end{array}$ \\
\hline 19-Apr-06 & $12: 30$ & $\begin{array}{l}\text { Soldiers Home } \\
\text { (now Veterans } \\
\text { Administration } \\
\text { land, east of } \\
\text { Brentwood, west } \\
\text { of Westwood) }\end{array}$ & Los Angeles & & \begin{tabular}{|c|} 
Los Angeles Times, \\
20 Apr 1906; Part II, p. 14, c. 2
\end{tabular} & $\begin{array}{l}\text { "SOLDIERS' HOME, April 19.--The earthquake here half an } \\
\text { hour after noon today was severe in the barracks. Many of the } \\
\text { veterans rushed out of the buildings. Local Manager H. H. } \\
\text { Markham, who is visiting here, said he was startled by the } \\
\text { shock...." } \\
\text { See Table 7. }\end{array}$ \\
\hline 19-Apr-06 & $12: 30$ & San Pedro & Los Angeles & & \begin{tabular}{|c|} 
Los Angeles Times, \\
20 Apr 1906; Part II, p. 14, c. 2
\end{tabular} & $\begin{array}{l}\text { "SAN PEDRO, April 19._.... At exactly 12:30 o'clock today } \\
\text { there was an earthquake shock felt here that was sufficient to } \\
\text { cause a jarring and shaking up of the buildings, creating } \\
\text { considerable excitement in the downtown district, but doing no } \\
\text { damage. } \\
\text { "People in all the business houses rushed into the streets and for } \\
\text { a time there was some alarm. It was all over in a moment, } \\
\text { however, and all uneasiness soon passed away. } \\
\text { "Several slight cracks in buildings were reported; glass bottles } \\
\text { were thrown from the shelves in the drug stores and dishes in the } \\
\text { restaurants rattled greatly. No damage at all was reported. } \\
\text { People living in the resident district felt it slightly, but not so }\end{array}$ \\
\hline
\end{tabular}


TABLE 2: Catalog of Triggered Event Reports following from the Great 18 April 1906 California Earthquake

\begin{tabular}{|c|c|c|c|c|c|c|}
\hline Date Felt & $\begin{array}{l}\text { Time Felt } \\
\text { (PST) }\end{array}$ & $\begin{array}{l}\text { Location Felt } \\
\text { (City) }\end{array}$ & $\begin{array}{l}\text { Location Felt } \\
\text { (County) }\end{array}$ & $\begin{array}{l}\text { Unreliable? } \\
\text { Not Felt? }^{+}\end{array}$ & Source & Relevant Citations and other Notes \\
\hline & & & & & & $\begin{array}{l}\text { great as downtown. } \\
\text { "It was sufficient to knock the plaster off the tower of the town } \\
\text { clock and loosen considerable earth on Knob Hill." } \\
\text { See Table } 7 .\end{array}$ \\
\hline 19-Apr-06 & $12: 30$ & Avalon & Los Angeles & & \begin{tabular}{|c|} 
Los Angeles Times, \\
20 Apr 1906; Part II, p. 10, c. 4
\end{tabular} & $\begin{array}{l}\text { "AVALON, April 19.-A slight shock of earthquake was felt } \\
\text { here at 12:30 today, but was so slight as to be unnoticed by the } \\
\text { majority of people...." } \\
\text { Note that, with respect to Avalon and Catalina Island, this report } \\
\text { contradicts information given in the Los Angeles Examiner of } 20 \\
\text { Apr 1906 ( } p .7, \text { c. 7), which states that the earthquake was not felt } \\
\text { on Catalina Island. } \\
\text { See Table } 7 \text {. }\end{array}$ \\
\hline 19-Apr-06 (?) & & Avalon & Los Angeles & & \begin{tabular}{c|} 
Los Angeles Times, \\
21 Apr 1906; Part II, p. 14, c. 3
\end{tabular} & $\begin{array}{l}\text { "AVALON, April 20.-The uncalled-for rumor of an earthquake } \\
\text { here ... caused a great deal of anxiety, as was evidenced by } \\
\text { numerous telegrams received from anxious friends and relatives } \\
\text { on the mainland. } \\
\text { "The canard had the further effect of greatly influencing the } \\
\text { travel here, the passenger list today being the lightest of the year, } \\
\text { to date. The one little tremor experienced was really too light to } \\
\text { be called an earthquake, not more than a dozen people feeling it." } \\
\text { Note that, with respect to Avalon and Catalina Island, this report } \\
\text { contradicts information given in the Los Angeles Examiner of } 20 \\
\text { Apr } 1906 \text { (p. 7, c. 7), which states that the earthquake was not felt } \\
\text { on Catalina Island. } \\
\text { See Table } 7 \text {. }\end{array}$ \\
\hline 19-Apr-06 & $12: 30$ & Santa Ana & Orange & & $\begin{array}{l}\text { Evening Blade (Santa Ana), } \\
19 \text { Apr 1906; p. 8, c. } 3\end{array}$ & $\begin{array}{l}\text { "Another slight shock of earthquake was felt today at Santa Ana } \\
\text { at 12:30, the tremor being sufficient to sway the chandeliers in the } \\
\text { various rooms of the county court house and jar the whole } \\
\text { building from foundation to cupola. The vibrations were from } \\
\text { northeast to southwest and lasted for several seconds." } \\
\text { See Table } 7 \text {. }\end{array}$ \\
\hline 19-Apr-06 & $12: 30$ & Santa Ana & Orange & & $\begin{array}{l}\text { Los Angeles Examiner, } \\
20 \text { Apr 1906; p. } 7, \text { c. } 7\end{array}$ & $\begin{array}{l}\text { "... A slight shock at } 12: 30 \text { o'clock yesterday is reported from } \\
\text { Santa Ana. No damage was done...." } \\
\text { See Table } 7 .\end{array}$ \\
\hline 19-Apr-06 & $12: 30$ & Riverside & Riverside & & $\begin{array}{l}\text { Riverside Daily Press, } \\
19 \text { Apr 1906; p. 8, c. } 3\end{array}$ & $\begin{array}{l}\text { "Riverside also experienced a tiny shiver at 12:30, not large } \\
\text { enough to be felt by the majority, but still perceptible in tall } \\
\text { buildings." } \\
\text { See Table } 7 \text {. }\end{array}$ \\
\hline
\end{tabular}


TABLE 2: Catalog of Triggered Event Reports following from the Great 18 April 1906 California Earthquake

\begin{tabular}{|c|c|c|c|c|c|c|}
\hline Date Felt & $\begin{array}{l}\text { Time Felt } \\
\text { (PST) }\end{array}$ & $\begin{array}{c}\text { Location Felt } \\
\text { (City) }\end{array}$ & $\begin{array}{l}\text { Location Felt } \\
\text { (County) }\end{array}$ & $\begin{array}{c}\text { Unreliable? } \\
\text { Not Felt? }^{+}\end{array}$ & Source & Relevant Citations and other Notes \\
\hline 19-Apr-06 & $12: 30$ & Riverside & Riverside & & \begin{tabular}{|c|} 
Los Angeles Times, \\
20 Apr 1906; Part II, p. 14, c. 3
\end{tabular} & $\begin{array}{l}\text { "RIVERSIDE, April 19.-.... At } 12: 30 \text { o'clock today there was a } \\
\text { slight shake here of the same character as the tremor of } \\
\text { yesterday." } \\
\text { See Table } 7 \text {. }\end{array}$ \\
\hline 19-Apr-06 & $12: 31$ & Los Angeles & Los Angeles & & $\begin{array}{l}\text { Riverside Daily Press, } \\
19 \text { Apr 1906; p. } 8, \text { c. } 3\end{array}$ & $\begin{array}{l}\text { "LOS ANGELES, April 19.-(Special to Press.)-Los Angeles } \\
\text { was thrown into a tremor of fright at 12:31 today by two sharp } \\
\text { and distinct earthquake shocks. These lasted but a few seconds } \\
\text { and did no appreciable damage, but the feelings of the people were } \\
\text { at such a high pitch that they became panicky and rushed out of } \\
\text { doors at the first tremor. Although the shocks were light, the } \\
\text { feeling was so intense that a large number refused to return to } \\
\text { brick buildings again and sought the parks to spend the remainder } \\
\text { of the afternoon." } \\
\text { See Table 7. }\end{array}$ \\
\hline 19-Apr-06 & $12: 31$ & Los Angeles & Los Angeles & & $\begin{array}{l}\text { Oregon Daily Journal } \\
\text { (Portland), } \\
20 \text { Apr 1906; p. } 10, \text { c. } 3\end{array}$ & $\begin{array}{l}\text { "... it was so slight that that many people did not notice it, and no } \\
\text { damage was done in any way." } \\
\text { See Table } 7 .\end{array}$ \\
\hline 19-Apr-06 & $12: 31: 00$ & Los Angeles & Los Angeles & & $\begin{array}{l}\text { Lawson (1908), } \\
\text { vol. I, p. } 414\end{array}$ & $\begin{array}{l}\text { "Increased intensity, } 1 \text { max., strongest at middle. No sound." } \\
\text { Duration } 20-30 \text { seconds. } \\
\text { See Table } 7 .\end{array}$ \\
\hline 19-Apr-06 & $12: 31: 15$ & Los Angeles & Los Angeles & & $\begin{array}{l}\text { Los Angeles Express, } \\
19 \text { Apr 1906; p. 3, c. 3-4 }\end{array}$ & $\begin{array}{l}\text { "Attempts not only to make the East believe that Los Angeles is } \\
\text { seriously affected by the earthquake shocks, but to create fear } \\
\text { here, have come to light through investigation of an absurd } \\
\text { message sent to the war department by some irresponsible person } \\
\text { in San Francisco.... } \\
\text { "The fake came to light in a message to Los Angeles as follows: } \\
\text { "WASHINGTON, April 19.- The war department has received } \\
\text { the following telegram from San Francisco: 'Los Angeles says } \\
\text { building rocking like a boat. Just lost connection with Los } \\
\text { Angeles immediately after this report. Men probably left } \\
\text { building." } \\
\text { "While there was a tremor of the earth's surface in Los Angeles, } \\
\text { it was so slight as to be barely noticeable, except in the tallest } \\
\text { buildings, and at the United States weather observatory it was } \\
\text { classed as nothing unusual. } \\
\text { "A few persons asserted that they had felt the shock, but until the } \\
\text { news from the North came many thought that any temblor which } \\
\text { they might have believed themselves to have experienced was } \\
\text { more the effect of an overwrought imagination and nervousness } \\
\text { caused by the disaster in San Francisco. }\end{array}$ \\
\hline
\end{tabular}


TABLE 2: Catalog of Triggered Event Reports following from the Great 18 April 1906 California Earthquake

\begin{tabular}{|c|c|c|c|c|c|c|}
\hline Date Felt & $\begin{array}{c}\text { Time Felt } \\
\text { (PST) }\end{array}$ & $\begin{array}{l}\text { Location Felt } \\
\text { (City) }\end{array}$ & $\begin{array}{l}\text { Location Felt } \\
\text { (County) }\end{array}$ & $\begin{array}{l}\text { Unreliable? } \\
\text { Not Felt? }^{+}\end{array}$ & Source & Relevant Citations and other Notes \\
\hline & & & & & & $\begin{array}{l}\text { "G. E. Franklin, at the head of the United States weather bureau, } \\
\text { in his report of the quake ten minutes after it had occurred, said: } \\
\text { "There was nothing at all unusual in the shock. I timed it } \\
\text { as happening at } 12: 31^{1} /{ }_{4} \mathrm{o}^{\prime} \text { clock. It was of hardly sufficient } \\
\text { strength to move the pendulum of the large clock in my office, and } \\
\text { of a single undulation, seemed to be moving from north to } \\
\text { south...." } \\
\text { See Table } 7 .\end{array}$ \\
\hline 19-Apr-06 & 12:31:40 & $\begin{array}{l}\text { Los Angeles } \\
\text {. }\end{array}$ & $\begin{array}{l}\text { Los Angeles } \\
\text { - }\end{array}$ & & $\begin{array}{l}\text { Los Angeles Examiner, } \\
20 \text { Apr 1906; p. } 7, \text { c. } 7\end{array}$ & $\begin{array}{l}\text { "Los Angeles and surrounding towns experienced a slight } \\
\text { earthquake shock at } 12: 31 \text { o'clock yesterday afternoon, but no } \\
\text { damage whatever was caused by the disturbance. } \\
\text { "The temblor came at a time when the downstairs cafes, hotels } \\
\text { and office buildings were filled with people, but beyond causing } \\
\text { momentary fright to nervously inclined persons, the shock had no } \\
\text { effect whatever. } \\
\text { "The exact time of the quake was 12:31:40 p. m., as recorded by } \\
\text { Observer Franklin of the United States Weather Bureau. It lasted } \\
\text { only about three seconds, though many excited individuals } \\
\text { thought it lasted much longer... } \\
\text { “'It amounted to absolutely nothing,' said Mr. Franklin. 'My } \\
\text { office boy, who was keenly alert, noticed it, but thought someone } \\
\text { had simply slammed a door.' } \\
\text { "Rumors were current that many of the big buildings had settled } \\
\text { and that cracks had appeared in the Conservative Life, city jail } \\
\text { and other buildings, but these were proved by investigation to be } \\
\text { absolutely untrue. } \\
\text { "A crack in one of the stones in the jail building was noticed by } \\
\text { some for the first time, although it had been there for nearly ten } \\
\text { years. Neither the Conservative Life nor any of the other } \\
\text { buildings in the city was affected in the least. } \\
\text { “When the temblor was felt, the timid rushed from the big } \\
\text { buildings and in several of the cafes where noonday lunchers } \\
\text { were dining, several made the earthquake scare an excuse to get } \\
\text { out in a hurry. } \\
\text { "At the various beach resorts the shock was felt and the incoming } \\
\text { cars were soon crowded by people who were frightened by } \\
\text { predictions of a tidal wave. The ocean was perfectly serene and } \\
\text { no cause whatever for the excitement could be found. }\end{array}$ \\
\hline & & Ocean Park & Los Angeles & & & $\begin{array}{l}\text { "At Ocean Park guests of the Hotel Decatur fled from the } \\
\text { buildings and the streets were soon thronged with residents, } \\
\text { many of them carrying personal effects. Their fears were soon }\end{array}$ \\
\hline
\end{tabular}


TABLE 2: Catalog of Triggered Event Reports following from the Great 18 April 1906 California Earthquake

\begin{tabular}{|c|c|c|c|c|c|c|}
\hline Date Felt & $\begin{array}{c}\text { Time Felt } \\
\text { (PST) }\end{array}$ & $\begin{array}{l}\text { Location Felt } \\
\text { (City) }\end{array}$ & $\begin{array}{l}\text { Location Felt } \\
\text { (County) }\end{array}$ & $\begin{array}{l}\text { Unreliable? } \\
\text { Not Felt? }^{+}\end{array}$ & Source & Relevant Citations and other Notes \\
\hline & & $\begin{array}{l}\text { Sawtelle } \\
\text { Venice } \\
\text { Long Beach } \\
\text { San Pedro } \\
\text { Pasadena } \\
\text { Monrovia } \\
\text { Whittier } \\
\text { Hollywood } \\
\text { Catalina Island } \\
\text { Ontario }\end{array}$ & $\begin{array}{l}\text { Los Angeles } \\
\text { Los Angeles } \\
\text { Los Angeles } \\
\text { Los Angeles } \\
\text { Los Angeles } \\
\text { Los Angeles } \\
\text { Los Angeles } \\
\text { Los Angeles } \\
\text { Los Angeles } \\
\text { San Bernardino }\end{array}$ & Not Felt & & $\begin{array}{l}\text { allayed and the majority of them returned to their homes. } \\
\text { "At Sawtelle it was reported that canned goods and other } \\
\text { articles were shaken from the shelves of stores, but this rumor } \\
\text { was found to be greatly exaggerated. People rushed into the } \\
\text { streets and an old soldier was knocked from his crutches, but was } \\
\text { not injured. } \\
\text { "At Venice bits of plastering fell from the walls of several } \\
\text { buildings and a high chimney was slightly cracked, but no damage } \\
\text { of any consequence occurred. } \\
\text { "Long Beach, San Pedro, Pasadena, Monrovia, Whittier, } \\
\text { Hollywood and other outlying towns felt the shock slightly but } \\
\text { no serious damage was caused. } \\
\text { "Sensation mongers started a foolish report to the effect that } \\
\text { Catalina Island had suffered fearfully from the effects of the } \\
\text { seismic wave, but reports from the resort stated that the shock } \\
\text { had not even been felt there. } \\
\text { "At Ontario the shocks of the earthquake were so slight as to } \\
\text { pass unnoticed by most of the residents...." } \\
\text { Note that, with respect to Avalon and Catalina Island, this report } \\
\text { contradicts information given in the Los Angeles Times of } 20 \text { Apr } \\
1906 \text { (Part II, p. 10, c. 4) and } 21 \text { Apr 1906 (Part II, p. 14, c. 3), } \\
\text { which states that the earthquake was felt lightly in Avalon. } \\
\text { See Table 7. }\end{array}$ \\
\hline 19-Apr-06 & 12:31:41 & Los Angeles & Los Angeles & & $\begin{array}{l}\text { Lawson (1908), } \\
\text { vol. I, p. } 414\end{array}$ & $\begin{array}{l}\text { felt } \\
\text { See Table } 7 .\end{array}$ \\
\hline 19-Apr-06 & $\begin{array}{c}\sim \text { 12:33, } \\
\text { other times } \\
\text { between } \\
\sim 12: 33 \text { and } \\
\sim 13: 33 \\
\text { (many events) }\end{array}$ & Los Angeles & Los Angeles & & $\begin{array}{l}\text { Lawson (1908), } \\
\text { vol. I, p. } 415\end{array}$ & $\begin{array}{l}\text { "Two shocks about } 6 \mathrm{~m} \text {. apart followed by slight tremors for } \\
\text { about } 1 \text { h." } \\
\text { See Table } 7 .\end{array}$ \\
\hline 19-Apr-06 & 12:35 & Ventura & Ventura & & $\begin{array}{l}\text { Daily Free Press (Ventura), } \\
19 \text { Apr 1906; p. 2, c. } 1\end{array}$ & $\begin{array}{l}\text { "Another slight tremor was felt here at 12:35 today. The shake } \\
\text { was slight but it was very noticeable and set all hanging articles } \\
\text { in motion. The shake had a tendency to cause much alarm in the } \\
\text { city, fearing that it might be worse in other places than it was } \\
\text { here. No damage has been reported as a result of today's shake." } \\
\text { See Table 7. }\end{array}$ \\
\hline
\end{tabular}


TABLE 2: Catalog of Triggered Event Reports following from the Great 18 April 1906 California Earthquake

\begin{tabular}{|c|c|c|c|c|c|c|}
\hline Date Felt & $\begin{array}{l}\text { Time Felt } \\
\text { (PST) }\end{array}$ & $\begin{array}{l}\text { Location Felt } \\
\text { (City) }\end{array}$ & $\begin{array}{l}\text { Location Felt } \\
\text { (County) }\end{array}$ & $\begin{array}{l}\text { Unreliable? }^{\text {Not Felt? }}{ }^{+}\end{array}$ & Source & Relevant Citations and other Notes \\
\hline 19-Apr-06 & $12: 50$ & Los Angeles & Los Angeles & unreliable & $\begin{array}{c}\text { The Independent } \\
\text { (Santa Barbara), } \\
19 \text { Apr 1906; p. 1, c. 1-3 }\end{array}$ & $\begin{array}{l}\text { "LOS ANGELES, April 19.-... a distinct earthquake shock was } \\
\text { felt throughout this city. The seismic disturbance was sufficient } \\
\text { to make the large buildings in the down town districts tremble } \\
\text { perceptibly, in several parts of the city chimneys were thrown } \\
\text { down and other minor damage done. This coming at a time when } \\
\text { the public mind is so wrought up over the fearful results of the } \\
\text { earthquake in San Francisco immediately created the utmost } \\
\text { consternation, almost amounting to a panic. Men turned pale and } \\
\text { women became hysterical. Many of the occupants of the large } \\
\text { public buildings sought the streets, but the commotion quickly } \\
\text { subsided, though the feeling of nervousness remained. Out in the } \\
\text { residence portion of the city, however, women and children fled } \\
\text { from their homes into the streets and many of them have refused to } \\
\text { return. The shock has been sufficient to create a general panicky } \\
\text { feeling." } \\
\text { In comparison to reports published in local newspapers, this } \\
\text { account is obviously exaggerated. } \\
\text { See Table } 7 \text {. }\end{array}$ \\
\hline 19-Apr-06 & $\begin{array}{c}\text { 12:50, } \\
\text { and later } \\
\text { (two events) }\end{array}$ & Los Angeles & Los Angeles & unreliable & $\begin{array}{l}\text { San Diegan-Sun, } \\
19 \text { Apr 1906; p. 1, c. 6-7 }\end{array}$ & $\begin{array}{l}\text { "Shortly after noon Thursday the report was confirmed at the } \\
\text { Western Union telegraph office that Los Angeles had experienced } \\
\text { an earthquake shock at 12:50 p. m. today. } \\
\text { "No damage was done, but the shock was sharp. } \\
\text { "Employees of the Western Union Telegraph company in Los } \\
\text { Angeles, it is stated, deserted their work, but later returned. } \\
\text { "For a time all communication with Los Angeles was cut off. } \\
\text { "Bensel Smythe, the Sun's special representative at Los Angeles, } \\
\text { 'phoned the Sun at 1:25 p. m. that the earthquake was felt only in } \\
\text { the business part of the city. } \\
\text { "An elevator in the Bryson building was left suspended between } \\
\text { the second and third floors and was still there full of people at } \\
\text { the hour of receipt of the message. } \\
\text { "The Bryson building is located at Second and Spring streets.... } \\
\text { "The report reached San Diego that Los Angeles has had a second } \\
\text { shock today." } \\
\text { In comparison to reports published in local newspapers, this } \\
\text { account is obviously exaggerated. } \\
\text { See Table 7. }\end{array}$ \\
\hline 19-Apr-06 & $13: 15$ & San Bernardino & San Bernardino & & $\begin{array}{c}\text { Los Angeles Times, } \\
20 \text { Apr 1906; Part II, p. 14, c. } 3\end{array}$ & $\begin{array}{l}\text { "SAN BERNARDINO, April 19.-.... A slight shock was } \\
\text { perceptible here at } 1: 15 \text { o' clock this afternoon." }\end{array}$ \\
\hline
\end{tabular}


TABLE 2: Catalog of Triggered Event Reports following from the Great 18 April 1906 California Earthquake

\begin{tabular}{|c|c|c|c|c|c|c|}
\hline Date Felt & $\begin{array}{l}\text { Time Felt } \\
\text { (PST) }\end{array}$ & $\begin{array}{l}\text { Location Felt } \\
\text { (City) }\end{array}$ & $\begin{array}{l}\text { Location Felt } \\
\text { (County) }\end{array}$ & $\begin{array}{l}\text { Unreliable? } \\
\text { Not Felt? }^{+}\end{array}$ & Source & Relevant Citations and other Notes \\
\hline & & & & & & See Table 7. \\
\hline 19-Apr-06 & afternoon & Los Angeles & Los Angeles & & $\begin{array}{l}\text { Los Angeles Examiner, } \\
20 \text { Apr 1906; p. 6, c. } 2\end{array}$ & $\begin{array}{l}\text { "Los Angelenos have determined not to be discomfited by any } \\
\text { little temblor that comes along. } \\
\text { "Yesterday afternoon at the Jonathan Club there were a hundred } \\
\text { or more men about town playing dominoes and loafing about } \\
\text { waiting for the general lunch hour. } \\
\text { "It was at this time that the little temblor came along and gave the } \\
\text { Huntington building a shake that set the chandeliers to swinging. } \\
\text { "The men playing dominoes simply looked up for a minute and } \\
\text { continued their game. } \\
\text { "Walter Parker and Phil Stanton were playing a game.... } \\
\text { "Just as the tremblor swung the building, Stanton became } \\
\text { impatient, and said: 'It's your play, Walter; get a move on.' } \\
\text { '“It seems to me,' replied Parker, looking up at the dancing } \\
\text { chandeliers and gripping the arms of his chair, 'that I am } \\
\text { moving."” } \\
\text { See Table 7. }\end{array}$ \\
\hline 19-Apr-06 & 14:02 & Reno & $\begin{array}{l}\text { Washoe Co. } \\
\text { (Nevada) }\end{array}$ & & $\begin{array}{l}\text { Reno Evening Gazette, } \\
19 \text { Apr 1906; p. } 4, \text { c. } 5\end{array}$ & $\begin{array}{l}\text { "At 2:02 o' clock this afternoon a distinct earthquake shock was } \\
\text { felt in Reno. It was most perceptible on University hill, where it } \\
\text { attracted the attention of many students while at their classes. } \\
\text { There was a perceptible earth movement, followed by another. } \\
\text { They were so slight, however, that no alarm was felt, although a } \\
\text { number of the young men and women became nervous. Down } \\
\text { town a number of people felt the shock." }\end{array}$ \\
\hline 19-Apr-06 & $\sim$ 14:05 & $\begin{array}{c}\text { Reno } \\
\text { Olinghouse } \\
\text { Hazen }\end{array}$ & $\begin{array}{l}\text { Washoe Co. } \\
\text { (Nevada) } \\
\text { Washoe Co. } \\
\text { (Nevada) } \\
\text { Churchill Co. } \\
\text { (Nevada) }\end{array}$ & & $\begin{array}{l}\text { Lawson (1908), } \\
\text { vol. I, p. 324 }\end{array}$ & $\begin{array}{l}\text { "The Earthquake of April 19, } 1906 \text {, about } 2^{h} 5^{m} P . M .: \\
\text { "This shock was mentioned by so few persons that I was at first } \\
\text { inclined to consider it imaginary. It was reported, however, by } \\
\text { reliable persons not known to each other in three different towns. } \\
\text { The most definite accounts are as follows: } \\
\text { "Reno (Miss Lewers).- - Observer on the third floor of the } \\
\text { Agricultural Building at the University, in the photographic } \\
\text { laboratory; felt a very distinct shock, but did not remember the } \\
\text { direction of movement. } \\
\text { "Olinghouse (Miss Norris).- The person reporting and her sister } \\
\text { were sitting in the house and felt a distinct shock. Fearing it was } \\
\text { the forerunner of a larger earthquake, they ran outside. } \\
\text { "Hazen.-A shock not generally felt was noted distinctly by Mrs. } \\
\text { MacGregor, at the Reclamation Service headquarters." }\end{array}$ \\
\hline
\end{tabular}


TABLE 2: Catalog of Triggered Event Reports following from the Great 18 April 1906 California Earthquake

\begin{tabular}{|c|c|c|c|c|c|c|}
\hline Date Felt & $\begin{array}{l}\text { Time Felt } \\
\text { (PST) }\end{array}$ & $\begin{array}{l}\text { Location Felt } \\
\text { (City) }\end{array}$ & $\begin{array}{l}\text { Location Felt } \\
\text { (County) }\end{array}$ & $\begin{array}{l}\text { Unreliable? } \\
\text { Not Felt? }^{+}\end{array}$ & Source & Relevant Citations and other Notes \\
\hline 19-Apr-06 & $16: 30$ & $\begin{array}{l}\text { Santa Barbara } \\
\text { and vicinity }\end{array}$ & Santa Barbara & & $\begin{array}{l}\text { Los Angeles Examiner, } \\
20 \text { Apr 1906; p. 7, c. } 7\end{array}$ & $\begin{array}{l}\text { "... Santa Barbara and vicinity was disturbed by a mild tremor.... } \\
\text { The shock, which ordinarily would have been considered as } \\
\text { insignificant, caused a momentary panic among the people, who } \\
\text { are wrought up over the northern disaster...." }\end{array}$ \\
\hline 19-Apr-06 & $\begin{array}{c}\sim 20: 15, \\
\text { other times } \\
\text { between } \\
\sim 20: 15 \text { and } \\
\sim 22: 15 \\
\text { (four events } \\
\text { total) }\end{array}$ & \begin{tabular}{|c|} 
Hazen \\
Olinghouse \\
Wadsworth \\
Fernley \\
Carson Dam \\
Browns Station* \\
Reno \\
Fallon \\
Lovelock
\end{tabular} & $\begin{array}{c}\text { Churchill Co. } \\
\text { (Nevada) } \\
\text { Washoe Co. } \\
\text { (Nevada) } \\
\text { Washoe Co. } \\
\text { (Nevada) } \\
\text { Lyon Co. } \\
\text { (Nevada) } \\
\text { Churchill Co. } \\
\text { (Nevada) } \\
\text { Pershing Co.* } \\
\text { (Nevada) } \\
\text { Washoe Co. } \\
\text { (Nevada) } \\
\text { Churchill Co. } \\
\text { (Nevada) } \\
\text { Pershing Co. } \\
\text { (Nevada) }\end{array}$ & $\begin{array}{l}\text { Not Felt } \\
\text { Not Felt } \\
\text { Not Felt }\end{array}$ & $\begin{array}{l}\text { Townley and Allen (1939), } \\
\text { p. } 280\end{array}$ & $\begin{array}{l}\text { "Points in Western Nevada. This list reported by Professor } \\
\text { George D. Louderback, University of Nevada, Reno: } \\
\text { Hazen. Windows rattled; gas jets swung north to south. } \\
\text { Olinghouse. Windows rattled; crowd in hotel bar-room scared } \\
\text { and ran outside. } \\
\text { Wadsworth. Sharp, quick shock like a blast; windows rattled. } \\
\text { Finley. }{ }^{* *} \text { Quite strong in tent.-Mr. Post at Reclamation } \\
\text { Service Camp. } \\
\text { Carson Dam. Twelve miles west of Fallon; shock plainly felt. } \\
\text { Brown's Station." Men preparing for bed scared and ran out of } \\
\text { house. } \\
\text { Not felt at Reno, Fallon, Lovelock, and east. } \\
\text { The time was variously given as about 8, about 9, somewhat after } \\
\text { 8, and between 8:30 and 9 p.m. Mr. L. H. Taylor, engineer in } \\
\text { charge at Survey Camp, gives 8:15 as the time, and the more } \\
\text { reliable reports confirm this. Three aftershocks during the next } \\
\text { two hours." } \\
\text { * See note about Browns Station following the citation for this event } \\
\text { from Lawson (1908) below. } \\
\text { ** This is most likely a misspelling of the town of Fernley. } \\
\text { Comparison to the report in Lawson (1908) makes this obvious. } \\
\text { See Table 8. }\end{array}$ \\
\hline 19-Apr-06 & $\begin{array}{l}\text { between } \\
20: 15 \text { and } \\
20: 30\end{array}$ & 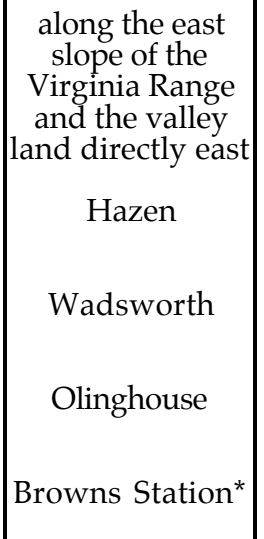 & $\begin{array}{l}\text { Lyon and } \\
\text { Churchill Cos. } \\
\text { (Nevada) } \\
\text { Churchill Co. } \\
\text { (Nevada) } \\
\text { Washoe Co. } \\
\text { (Nevada) } \\
\text { Washoe Co. } \\
\text { (Nevada) } \\
\text { Pershing Co.* } \\
\text { (Nevada) }\end{array}$ & & $\begin{array}{l}\text { Lawson (1908), } \\
\text { vol. I, p. 324-325 }\end{array}$ & $\begin{array}{l}\text { "The Earthquake of April 19, 1906, } 8^{h} 15^{m} \text { to } 8^{h} 30^{m} P . M \text {. } \\
\text { (Intensity, IV-V.) This earthquake was distinctly felt along the } \\
\text { east slope of the Virginia range and the valley land directly east } \\
\text { and not far north or south of Lat. } 39^{\circ} 31 \text { '. Wherever reported it } \\
\text { was much stronger than the shake produced by the California } \\
\text { earthquake of the previous day. It was generally felt at Hazen, } \\
\text { Wadsworth, Olinghouse, and neighboring places where it is hard } \\
\text { to find any one that noticed any effects of the great quake. In } \\
\text { Hazen it rattled windows, made gas jets and lamps swing, and } \\
\text { doors swing on hinges. The railroad station clock is said to have } \\
\text { stopt. At Wadsworth, it made the windows rattle and caused } \\
\text { some fear, owing to reports of the San Francisco disaster. One } \\
\text { person describes it as a quick sharp shock like a blast. At } \\
\text { Olinghouse also it was felt as a sharp shock-one called it a } \\
\text { quiver-and caused windows to rattle. It was felt as far east as } \\
\text { Brown's Station. It was apparently not felt at Fallon, tho it was } \\
\text { distinctly felt } 12 \text { miles west at Carson Dam. In the Reclamation }\end{array}$ \\
\hline
\end{tabular}


TABLE 2: Catalog of Triggered Event Reports following from the Great 18 April 1906 California Earthquake

\begin{tabular}{|c|c|c|c|c|c|c|}
\hline Date Felt & $\begin{array}{c}\text { Time Felt } \\
\text { (PST) }\end{array}$ & $\begin{array}{l}\text { Location Felt } \\
\text { (City) }\end{array}$ & $\begin{array}{c}\text { Location Felt } \\
\text { (County) }\end{array}$ & $\begin{array}{l}\text { Unreliable? } \\
\text { Not Felt? }^{+}\end{array}$ & Source & Relevant Citations and other Notes \\
\hline & & $\begin{array}{c}\text { Fallon } \\
\text { Carson Dam } \\
\text { Fernley }\end{array}$ & $\begin{array}{c}\text { Churchill Co. } \\
\text { (Nevada) } \\
\text { Churchill Co. } \\
\text { (Nevada) } \\
\text { Lyon Co. } \\
\text { (Nevada) }\end{array}$ & Not Felt & & 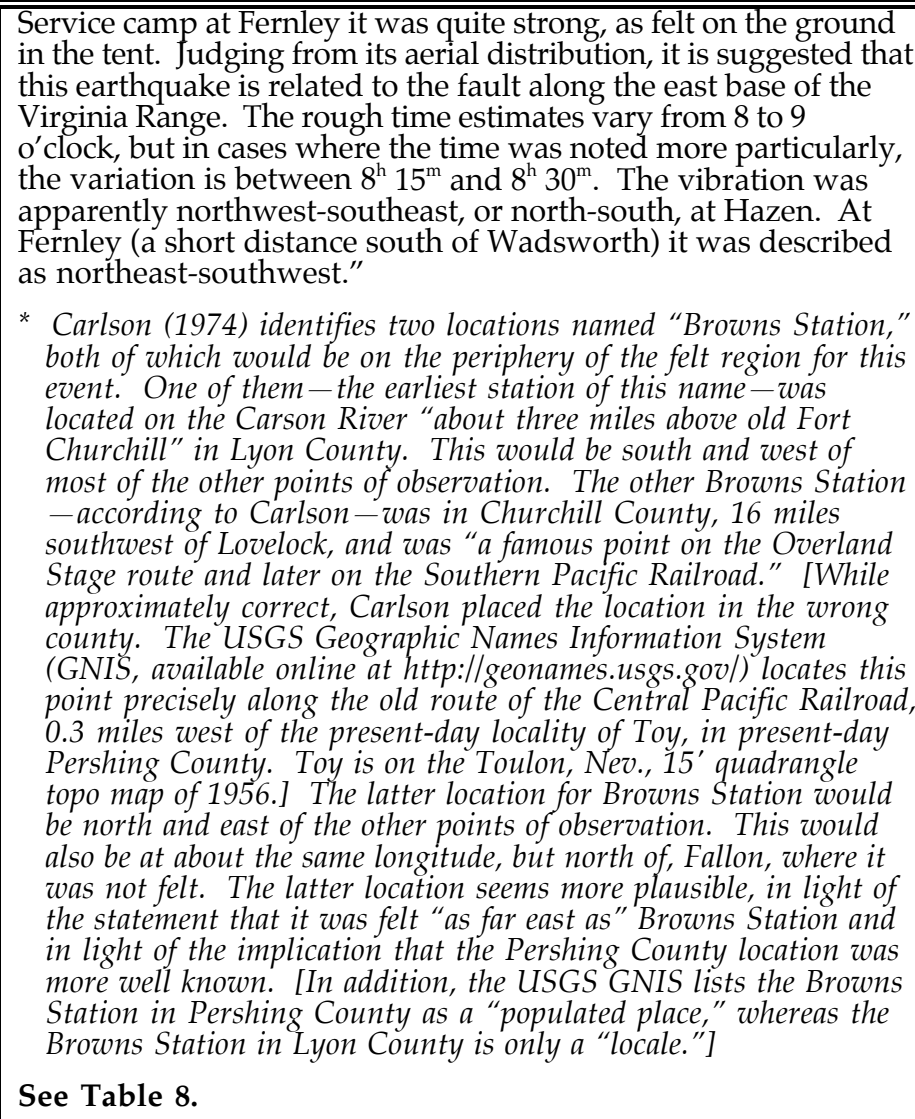 \\
\hline 19-Apr-06 & $\begin{array}{c}\text { between } \\
20: 15 \text { and } \\
20: 30 \text {, and } \\
\text { during the } \\
\text { following } \\
1.5 \text { hours } \\
\text { (four events } \\
\text { total) }\end{array}$ & $\begin{array}{c}\text { "Hazen, } \\
\text { Wadsworth, } \\
\text { etc." } \\
\text { (see list in } \\
\text { previous entry) }\end{array}$ & $\begin{array}{c}\text { see list in } \\
\text { previous entry }\end{array}$ & & $\begin{array}{l}\text { Lawson (1908), } \\
\text { vol. I, p. 415 }\end{array}$ & $\begin{array}{l}\text { "On east slope of Virginia Range, Sierra Nevadas; northwest- } \\
\text { southeast. During next } 1.5 \mathrm{~h} \text {. } 3 \text { more." Lawson (1908) estimates } \\
\text { Rossi-Forel intensity IV-V for the shock at 20:15-20:30. } \\
\text { This report is attributed to "G. D. L." There is a key to people's } \\
\text { initials following the list of aftershocks in Lawson (1908), but } \\
\text { "G. D. L." is not included in the key. The report in Townley and } \\
\text { Allen (1939) for the same earthquake credits George D. Louderback } \\
\text { of the University of Nevada, Reno, and indeed, G. D. Louderback } \\
\text { was a co-author of Lawson (1908), making the reference obvious. } \\
\text { See Table 8. }\end{array}$ \\
\hline
\end{tabular}


TABLE 2: Catalog of Triggered Event Reports following from the Great 18 April 1906 California Earthquake

\begin{tabular}{|c|c|c|c|c|c|c|}
\hline Date Felt & $\begin{array}{c}\text { Time Felt } \\
\text { (PST) }\end{array}$ & $\begin{array}{l}\text { Location Felt } \\
\text { (City) }\end{array}$ & $\begin{array}{l}\text { Location Felt } \\
\text { (County) }\end{array}$ & $\begin{array}{l}\text { Unreliable? } \\
\text { Not Felt? }^{+}\end{array}$ & Source & Relevant Citations and other Notes \\
\hline $\begin{array}{l}\text { 19-Apr-06 or } \\
\text { 20-Apr-06 }\end{array}$ & night & $\begin{array}{l}\text { Steamboat } \\
\text { Springs }\end{array}$ & $\begin{array}{l}\text { Washoe Co. } \\
\text { (Nevada) }\end{array}$ & & $\begin{array}{l}\text { Lawson (1908), } \\
\text { vol. I, p. } 325\end{array}$ & $\begin{array}{l}\text { "... A second shock, seemingly as hard as the first, was felt the } \\
\text { second or third night after [the California mainshock]." } \\
\text { See Table } 8 .\end{array}$ \\
\hline 19-Apr-06 (?) & $20: 50$ & \begin{tabular}{c|} 
vicinity of \\
Roberts Canyon
\end{tabular} & Los Angeles & & $\begin{array}{l}\text { Diary of Robert B. Waterman } \\
\text { (La Cañada, CA), } \\
19 \text { Apr 1906 }\end{array}$ & $\begin{array}{l}\text { Excerpt from the entry of } 19 \text { Apr 1906: } \\
\text { "Earthquake at } 8.50 \text { p.m" } \\
\text { Based on numerous reports of earthquakes in the region at a similar } \\
\text { time of night on } 18 \text { Apr } 1906 \text {, it seems possible that Waterman's } \\
\text { report is a misdated account of one of the } 18 \text { Apr events. } \\
\text { * Mr. Waterman was spending several days camping and opening } \\
\text { up a hiking trail in and near a place called Roberts Canyon. } \\
\text { Durham (1998) identifies two locations named "Roberts Canyon" } \\
\text { in southern California, both of which are in Los Angeles County. } \\
\text { One is drained by a stream that flows } 1.5 \text { miles to the San Gabriel } \\
\text { River } 8 \text { miles northeast of Glendora city hall; the other is drained } \\
\text { by a stream that flows } 5.5 \text { miles to lowlands } 2 \text { miles north of } \\
\text { Azusa city hall. The former location (NE of Glendora) was named } \\
\text { Roberts Canyon on the Pomona (1904) } 15 \text { ' quadrangle but was } \\
\text { called Williams Canyon on the Glendora (1953) } 7.5 \text { ' quadrangle. } \\
\text { (t is still known as Williams Canyon today.) The latter location } \\
\text { (N of Azusa) was named Rogers Canyon on the Los Angeles } \\
\text { County (1935) map but was called Roberts Canyon on the Azusa } \\
\text { (1953) 7.5' quadrangle. (It is known as Roberts Canyon today.) } \\
\text { Based on this information alone, it might seem most likely that in } \\
1906 \text { "Roberts Canyon" referred to the canyon NE of Glendora. } \\
\text { However, Mr. Waterman also noted in his diary that on } 19 \text { Apr } \\
1906, \text { he was at a place called "Brown's Gulch," below the } \\
\text { Roberts Canyon saddle; there is only one Browns Gulch, and it is } \\
\text { drained by a stream that flows } 2.5 \text { miles to San Gabriel Canyon } \\
4.5 \text { miles north of Glendora city hall. Browns Gulch is separated } \\
\text { from Roberts Canyon (N of Azusa) by a ridge (with a series of } \\
\text { saddles), but it is not near Williams Canyon. In this context, it } \\
\text { seems most likely that Waterman was in the canyon N of Azusa. }\end{array}$ \\
\hline 20-Apr-06 & 00:30 & \begin{tabular}{|c|} 
vicinity of \\
Roberts Canyon
\end{tabular} & Los Angeles & & $\begin{array}{l}\text { Diary of Robert B. Waterman } \\
\text { (La Cañada, CA), } \\
20 \text { Apr 1906 }\end{array}$ & $\begin{array}{l}\text { Excerpt from the entry of } 20 \text { Apr 1906: } \\
\text { "Earthquake at } 12.30 \text { midnight" } \\
\text { * Mr. Waterman was spending several days camping and opening } \\
\text { up a hiking trail in and near a place called Roberts Canyon. } \\
\text { See note about Roberts Canyon following the citation for the event } \\
\text { at 20:50 on } 19 \text { Apr } 1906 \text {. }\end{array}$ \\
\hline
\end{tabular}


TABLE 2: Catalog of Triggered Event Reports following from the Great 18 April 1906 California Earthquake

\begin{tabular}{|c|c|c|c|c|c|c|}
\hline Date Felt & $\begin{array}{l}\text { Time Felt } \\
\text { (PST) }\end{array}$ & $\begin{array}{l}\text { Location Felt } \\
\text { (City) }\end{array}$ & $\begin{array}{l}\text { Location Felt } \\
\text { (County) }\end{array}$ & $\begin{array}{l}\text { Unreliable? } \\
\text { Not Felt? }^{+}\end{array}$ & Source & Relevant Citations and other Notes \\
\hline $\begin{array}{l}\text { 18-Apr-06 to } \\
\text { 20-Apr-06 }\end{array}$ & \begin{tabular}{|c|}
18 Apr to \\
12:00 20 Apr \\
(many events
\end{tabular} & $\begin{array}{l}\text { Imperial } \\
\text { Brawley }\end{array}$ & $\begin{array}{l}\text { Imperial } \\
\text { Imperial }\end{array}$ & & $\begin{array}{c}\text { San Diego Union, } \\
21 \text { Apr 1906; p. 4, c. } 3\end{array}$ & $\begin{array}{l}\text { "In confirmation of the dispatch of Thursday regarding the } \\
\text { damage done at Brawley the following special was received last } \\
\text { evening. } \\
\text { "Imperial, Cal., April 20-There were several severe shocks up to } \\
\text { noon today. The full brunt of the ten previous shocks was felt in } \\
\text { the vicinity of Brawley, doing property damage amounting to } \\
\text { fifteen thousand dollars. Every adobe and brick in the town is } \\
\text { either ruined or badly shattered, taking practically all the } \\
\text { business section. The Bungalow Hotel is cracked and the walls } \\
\text { are askew. Heavy shelf hardware was thrown on the floor in } \\
\text { business buildings. } \\
\text { "The bank building's front lays on the sidewalk, while Varney } \\
\text { Bros. new brick store is almost a total wreck and the goods are } \\
\text { being moved. Five adobe business blocks east of the bank are } \\
\text { practically ruined and will have to be rebuilt. The brick block } \\
\text { owned by _.-. Paulin of Los Angeles is in bad shape. The walls } \\
\text { are bulged out and the fire wall is in the street. Constant } \\
\text { recurring of shocks yesterday and last night caused the people to } \\
\text { sleep in the open. } \\
\text { "The damage at Imperial is confined to a slight fall of plastering. } \\
\text { There is no damage elsewhere except at a few adobe ranch houses } \\
\text { in the vicinity of Brawley." } \\
\text { A very similar article appeared in the Press and Horticulturist of } \\
\text { Corona of } 27 \text { Apr } 1906, p .2, c .5 \text {. } \\
\text { * The initials are illegible. The Press and Horticulturist of Corona } \\
\text { gives this name as F.C. Pauline. }\end{array}$ \\
\hline 20-Apr-06 (?) & $12: 33$ & Santa Monica & Los Angeles & & $\begin{array}{l}\text { Lawson (1908), } \\
\text { vol. I, p. 415 }\end{array}$ & $\begin{array}{l}\text { "North-south. Time not accurate." Lawson (1908) estimates } \\
\text { Rossi-Forel intensity III } \\
\text { This is probably a misdated report of the earthquake in the } \\
\text { Los Angeles area at 12:31 on } 19 \text { Apr } 1906 \text {. There is no other report } \\
\text { of an earthquake in this area on the afternoon of } 20 \text { Apr } 1906 \text {. }\end{array}$ \\
\hline $\begin{array}{l}\text { week ending } \\
24-A p r-06\end{array}$ & \begin{tabular}{|c|}
$\sim 03: 00$ on \\
24 Apr, \\
other times \\
(many events)
\end{tabular} & San Jacinto & Riverside & & $\begin{array}{c}\text { Press and Horticulturist of } \\
\text { Corona (Corona), } \\
27 \text { Apr 1906; p. 5, c. } 5\end{array}$ & $\begin{array}{l}\text { "San Jacinto, April 24.-.... A slight earthquake shock was felt } \\
\text { here about } 3 \text { o' clock this morning. A number of slight shocks have } \\
\text { occurred here during the past week, but most of them have been so } \\
\text { slight that but few have noticed them." }\end{array}$ \\
\hline 24-Apr-06 & 03:00 & San Jacinto & Riverside & & $\begin{array}{l}\text { San Jacinto Register, } \\
26 \text { Apr 1906; p. 5, c. } 2\end{array}$ & "slight but noticeable" \\
\hline 24-Apr-06 & 06:00 & San Jacinto & Riverside & & $\begin{array}{l}\text { San Jacinto Register, } \\
26 \text { Apr 1906; p. } 5 \text {, c. } 2\end{array}$ & "slight but noticeable" \\
\hline
\end{tabular}


TABLE 2: Catalog of Triggered Event Reports following from the Great 18 April 1906 California Earthquake

\begin{tabular}{|c|c|c|c|c|c|c|}
\hline Date Felt & $\begin{array}{c}\text { Time Felt } \\
\text { (PST) }\end{array}$ & $\begin{array}{c}\text { Location Felt } \\
\text { (City) }\end{array}$ & $\begin{array}{c}\text { Location Felt } \\
\text { (County) }\end{array}$ & $\begin{array}{c}\text { Unreliable? } \\
\text { Not Felt? }\end{array}$ & Source & Relevant Citations and other Notes \\
\hline \hline $\begin{array}{c}\text { 18-Apr-06 to } \\
\text { 27-Apr-06 (?) }\end{array}$ & (many events & Holtville & Imperial & & $\begin{array}{c}\text { Imperial Valley Press, } \\
\text { 28 Apr 1906; p. 8, c. 3 }\end{array}$ & $\begin{array}{l}\text { “The earthquake shocks of the past few days, although quite } \\
\text { plainly felt, have not resulted in any damage to property in or } \\
\text { about Holtville." }\end{array}$ \\
\hline 29-Apr-06 & $\sim 09: 00$ & Paisley & $\begin{array}{c}\text { Lake Co. } \\
\text { (Oregon) }\end{array}$ & & $\begin{array}{c}\text { Lawson (1908), } \\
\text { vol. I, p. 418 }\end{array}$ & “Milk spilt northwest-southeast." \\
\hline
\end{tabular}

\section{Selected Aftershocks of the 18 Apr 1906 Imperial Valley Earthquake}

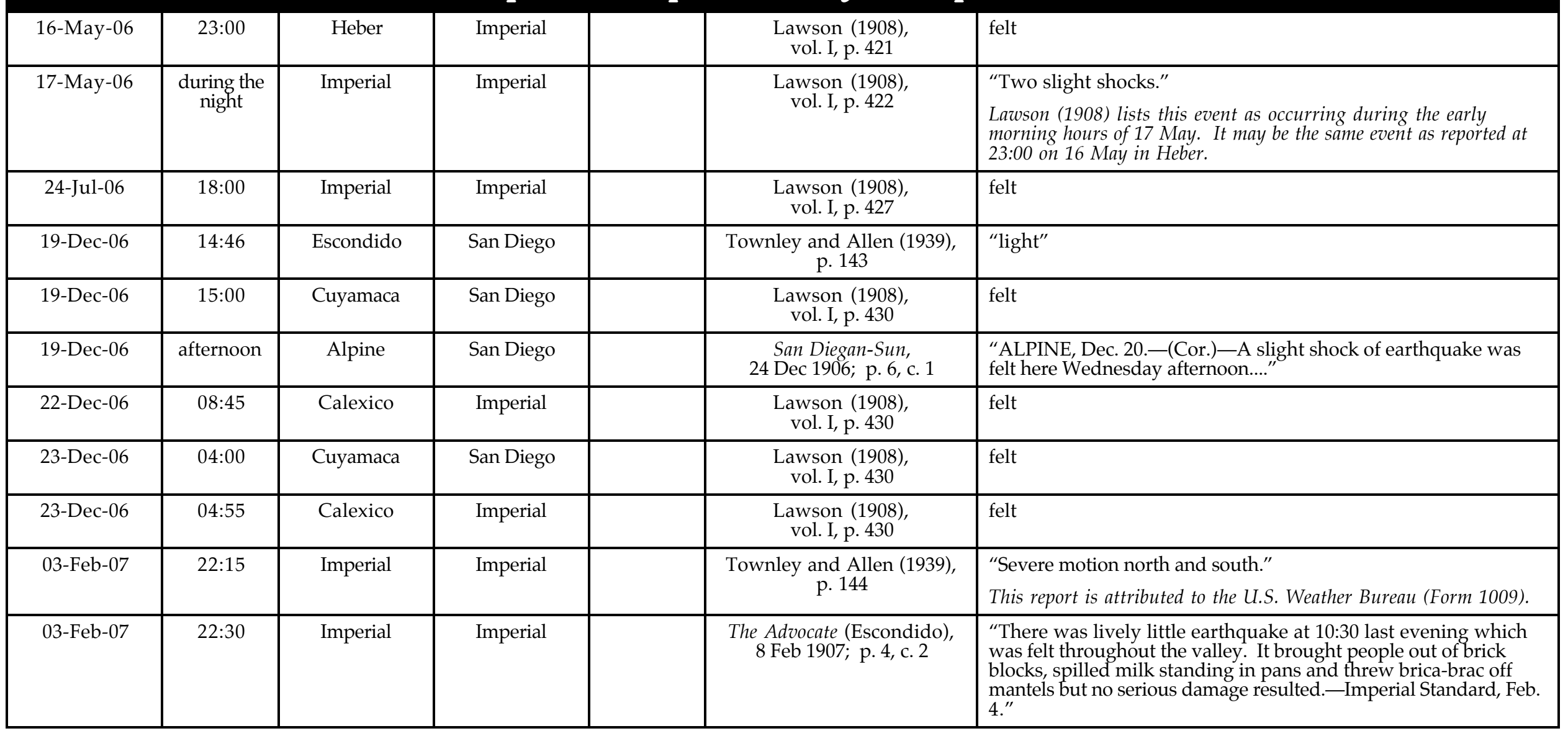


TABLE 2: Catalog of Triggered Event Reports following from the Great 18 April 1906 California Earthquake

\begin{tabular}{|c|c|c|c|c|c|c|}
\hline Date Felt & $\begin{array}{l}\text { Time Felt } \\
\text { (PST) }\end{array}$ & $\begin{array}{l}\text { Location Felt } \\
\text { (City) }\end{array}$ & $\begin{array}{l}\text { Location Felt } \\
\text { (County) }\end{array}$ & $\begin{array}{l}\text { Unreliable? } \\
\text { Not Felt? }^{+}\end{array}$ & Source & Relevant Citations and other Notes \\
\hline 03-Feb-07 & $\sim 22: 30$ & $\begin{array}{l}\text { Calexico, } \\
\text { elsewhere in the } \\
\text { Imperial Valley }\end{array}$ & Imperial & & $\begin{array}{l}\text { Calexico Chronicle, } \\
7 \text { Feb 1907; p. } 5, \text { c. } 1\end{array}$ & $\begin{array}{l}\text { "The earthquake ... was quite a severe one, and succeeded in } \\
\text { bringing the occupants of brick houses out into the street, scantily } \\
\text { attired, in quick order. The shock was general throughout the } \\
\text { Valley, but no damage has been reported." }\end{array}$ \\
\hline 27-Jul-07 & 05:20 & Heber & Imperial & & $\begin{array}{l}\text { Townley and Allen (1939), } \\
\text { p. } 145\end{array}$ & $\begin{array}{l}\text { felt } \\
\text { This report is attributed to the U.S. Weather Bureau (Form 1009). }\end{array}$ \\
\hline 28-Jul-07 & $06: 28$ & Calexico & Imperial & & $\begin{array}{l}\text { Townley and Allen (1939), } \\
\text { p. } 145\end{array}$ & $\begin{array}{l}\text { "Light" } \\
\text { This report is attributed to the U.S. Weather Bureau (Form 1009). }\end{array}$ \\
\hline 28-Jul-07 & 07:49 & Calexico & Imperial & & $\begin{array}{l}\text { Townley and Allen (1939), } \\
\text { p. } 145\end{array}$ & $\begin{array}{l}\text { "Light" } \\
\text { This report is attributed to the U.S. Weather Bureau (Form 1009). }\end{array}$ \\
\hline 28-Jul-07 & $15: 14$ & Calexico & Imperial & & $\begin{array}{l}\text { Townley and Allen (1939), } \\
\text { p. } 145\end{array}$ & $\begin{array}{l}\text { "Light" } \\
\text { This report is attributed to the U.S. Weather Bureau (Form 1009). }\end{array}$ \\
\hline
\end{tabular}




\section{TABLE 2: Catalog of Triggered Event Reports following from the Great 18 April 1906 California Earthquake}

\section{General Comments:}

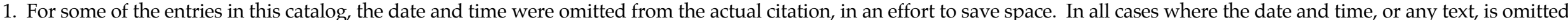
from the citation, it is replaced by editorial ellipses. The date and time are always given (when known) under the appropriate columns in the table.

2. Obvious typographical errors in newspaper sources were corrected without comment.

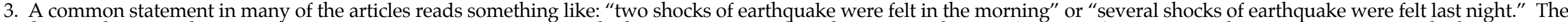

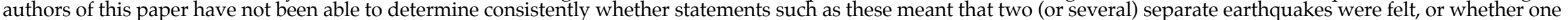

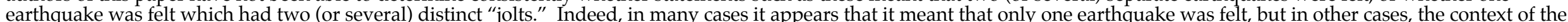

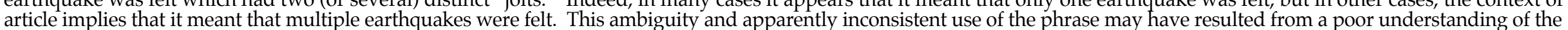
earthquake process, i.e., some people at the time may have thought that earthquakes which occurred minutes apart were all part of the same event.

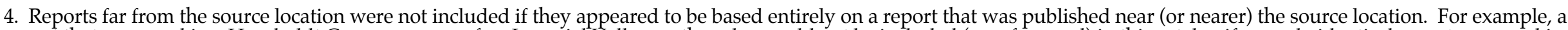

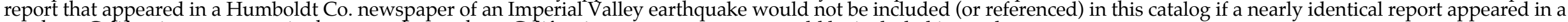
southern California newspaper; in that case, the southern California newspaper report would be included instead.

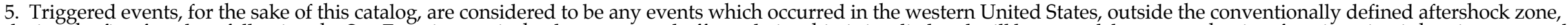

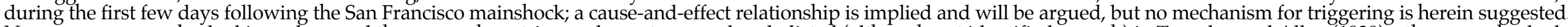

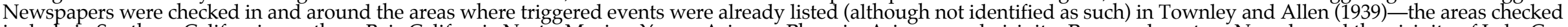

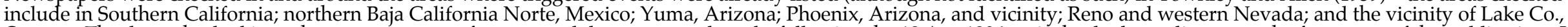

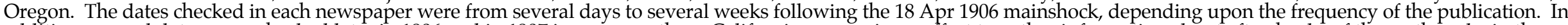

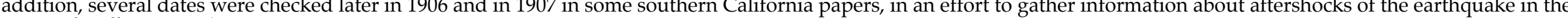
Imperial Valley on 18 Apr 1906.

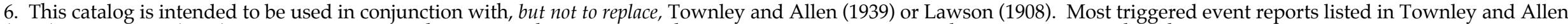

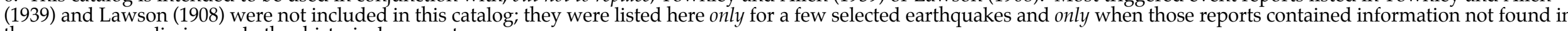
the newspapers, diaries, and other historic documents.

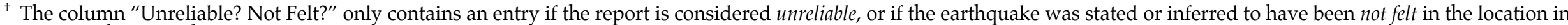
question; otherwise, this column is left blank. 
TABLE 3: NEWSPAPERS AND MANUSCRIPTS CHECKED

\begin{tabular}{|c|c|}
\hline TITLE & DATES CHECKED \\
\hline \multicolumn{2}{|l|}{ Alameda County } \\
\hline Alameda Daily Argus (Alameda) & $\begin{array}{l}\text { 1906: Apr 25-26, May 5, May 9, May 11, May 18, Jun 5, } \\
\text { Jun 16, Jul 20; 1907: Jan 8-9, Jan 31, Jun 5, Sept 26, } \\
\text { Oct 3, Oct 29-30 }\end{array}$ \\
\hline Daily Encinal (Alameda) & $\begin{array}{l}\text { 1906: Apr 25-26, May 5, May 9, May 11, May 18, Jun 5, } \\
\text { Jun 16, Jul } 20\end{array}$ \\
\hline Berkeley Advance (Berkeley) & 1906: May 17-24 \\
\hline Berkeley Daily Gazette (Berkeley) & $\begin{array}{l}\text { 1906: Apr 22-May 9, May 12, May 15-18, Jun 5, Jun 11, } \\
\text { Jun 16, Jun 22-23, Jul 17, Jul 20; 1907: Jan 9, Jan 31, } \\
\text { Mar 2, Mar 25, Mar 30, May 13, Jun 5, Jun 10, Jun 13, } \\
\text { Jun 22, Sept 26, Oct 3, Oct 29, [Oct 30 skimmed*] } \\
\text { * For the issue denoted as skimmed, only certain } \\
\text { sections of the newspaper were checked; there is a } \\
\text { small possibility that some earthquake articles were } \\
\text { overlooked. }\end{array}$ \\
\hline Fruitvale Progress (Fruitvale) & 1906: May 25 \\
\hline Livermore Echo (Livermore) & $\begin{array}{l}\text { 1906: Apr 19-May 24, Jun 7, Jun 21, Jul 19-26; } 1907 \text { : } \\
\text { Jan 10, Jan 31-Feb 7, Mar 7, Apr 4, Jun 6-27, Sept 26- } \\
\text { Oct 10, Oct } 31\end{array}$ \\
\hline Livermore Herald (Livermore) & $\begin{array}{l}\text { 1906: Apr 21-May 19, Jun 9-30, Jul 21; 1907: Jan 12, } \\
\text { Feb 2, Mar 9, Mar 30-Apr 6, May 18, Jun 8-29 }\end{array}$ \\
\hline Oakland Enquirer (Oakland) & $\begin{array}{l}\text { 1906: Apr 19-27, May 5, May 9, May 11-12, May 14-15, } \\
\text { May 17-18, Jun 5, Jun 11, Jun 16, Jun 22-23, Jul 17-18, } \\
\text { Jul 20; 1907: Jan 8-9, Jan 31, Mar 2, Mar 25, Mar 30- } \\
\text { Apr 1, May 13, Jun 5, Jun 10, Jun 13, Jun 22, Sept 26, } \\
\text { Oct 3, Oct 29-30 }\end{array}$ \\
\hline Oakland Herald (Oakland) & $\begin{array}{l}\text { 1906: Apr 18-27, May 5, May 11-12, May 14-15, May } \\
\text { 17-18, Jun 5, Jun 11, Jun 16, Jun 22-23, Jul 17-18, Jul 20; } \\
\text { 1907: Jan 8-9, Jan 31, Mar 2, Mar 25, Mar 30-Apr 1, } \\
\text { May 13, Jun 5, Jun 10, Jun 13, Jun 22, Sept 26, Oct 3, Oct } \\
\text { 29-30 }\end{array}$ \\
\hline Oakland Times (Oakland) & $\begin{array}{l}\text { 1906: Apr 19-28, May 7, May 9-10, May 12, May 15, May } \\
\text { 17-18, Jun 5-6, Jun 11-12, Jun 16, Jun 23-25 }\end{array}$ \\
\hline Oakland Tribune (Oakland) & $\begin{array}{l}\text { 1906: Apr 18-27, May 5, May 9, May 11-12, May 14-15, } \\
\text { May 17-18, Jun 5, Jun 10-11, Jun 16, Jun 22-23, Jul } \\
\text { 17-18, Jul 20; 1907: Jan 8-9, Jan 31, Mar 2, Mar 25, Mar } \\
\text { 30-31, May 13, Jun 5, Jun 10, Jun 13, Jun 22, Sept 26, } \\
\text { Oct 3, Oct 29 }\end{array}$ \\
\hline Sun And Letter (West Berkeley) & 1906: May 19 \\
\hline \multicolumn{2}{|l|}{ Amador County } \\
\hline Amador Dispatch (Jackson) & 1906: Apr 20, May 18, Jun 8; 1907: Jun 7, Oct 4, Nov 1 \\
\hline Amador Ledger (Jackson) & $\begin{array}{l}\text { 1906: Apr 20-27, May 18-25, Jun 8; 1907: Jun 7, Oct 4, } \\
\text { Nov } 1\end{array}$ \\
\hline Amador Record (Sutter Creek) & 1906: Apr 19-26, May 24, Jun 7; 1907: Oct 3-10, Oct 31 \\
\hline
\end{tabular}




\section{TABLE 3: NEWSPAPERS AND MANUSCRIPTS CHECKED}

\begin{tabular}{|c|c|}
\hline \multicolumn{2}{|l|}{ Butte County } \\
\hline Chico Record (Chico) & 1907: Jan 17-20, Aug 11-14 \\
\hline Chico Semi-Weekly Record (Chico) & 1906: Apr 20-May 11 \\
\hline Gridley Herald (Gridley) & 1906: Apr 20-May 25, Sept 14; 1907: Jun 7, Aug 16 \\
\hline Oroville Daily Register (Oroville) & $\begin{array}{l}\text { 1906: Apr 19-May 9, May 15-19, Sept 11; 1907: Jun 5-7 } \\
\text { [several pages of Jun } 5 \text { \& } 6 \text { issues missing], Aug } 12-13\end{array}$ \\
\hline \multicolumn{2}{|l|}{ Calaveras County } \\
\hline Calaveras Chronicle (Mokelumne Hill) & 1906: Apr 21-28, May 19, Jun 9; 1907: Jun 8, Oct 5 \\
\hline Calaveras Prospect (San Andreas) & $\begin{array}{l}\text { 1906: Apr 21-28, May 19-26, Jun 9; 1907: Jun 8, Oct 5, } \\
\text { Nov } 2\end{array}$ \\
\hline \multicolumn{2}{|l|}{ Colusa County } \\
\hline Daily Colusa Sun (Colusa) & $\begin{array}{l}\text { 1906: Apr 20-May 10, May 14-19, May 31-Jun 6, } \\
\text { Jun 15-18, Jul 24-26, Nov 30-Dec 3; 1907: Jan 31-Feb 2, } \\
\text { Mar 25-26, Mar 30-Apr 1, May 13-14, Jun 5-7, Jun 10-12, } \\
\text { Jun 22-24, Aug 12-14, Oct 3-5, Oct 29-31 }\end{array}$ \\
\hline Williams Farmer (Williams) & $\begin{array}{l}\text { 1906: Apr 21-Jun 23; } \\
\text { MISSING: 1906: May } 5\end{array}$ \\
\hline \multicolumn{2}{|l|}{ Contra Costa County } \\
\hline Antioch Ledger (Antioch) & $\begin{array}{l}\text { 1906: Apr 21-Aug 18, Dec 15-22; 1907: Jan 12-19, } \\
\text { Feb 2-9, Mar 9, Mar 30-Apr 6, May 18, Jun 8-29, } \\
\text { Sept 28-Oct 5, Nov } 2\end{array}$ \\
\hline Byron Times (Byron) & 1907: Sept 27, Oct 4-11, Nov 1 \\
\hline Contra Costa Gazette (Martinez) & $\begin{array}{l}\text { 1906: Apr 21-Aug 18, Dec 15-22; 1907: Jan 12-19, } \\
\text { Feb 2-9, Mar 9-16, Mar 30-Apr 6, May 18, Jun 8-29, } \\
\text { Sept 28-Oct 5, Nov } 2\end{array}$ \\
\hline Daily Gazette (Martinez) & $\begin{array}{l}\text { 1906: Apr 26, May 6-8, May 15-16, May 18-19, Jun 1, } \\
\text { Jun 12, Jun 16-17, Jun 23-24; 1907: Jan 8-9, Jan 31- } \\
\text { Feb 1, Mar 3, Mar 26, Mar 31, Jun 14, Oct 30-31 }\end{array}$ \\
\hline Richmond Terminal (Richmond) & $\begin{array}{l}\text { 1906: May 5-Aug 18, Dec 15; 1907: Jan 12-19, Feb 2-9, } \\
\text { Mar 2-9, Mar 30-Apr 6, May 18, Jun 8-29, Sept 28- } \\
\text { Oct 12, Nov 2-9; } \\
\text { MISSING: 1906: Apr 21-28, Jun 9, Dec } 22\end{array}$ \\
\hline
\end{tabular}




\section{TABLE 3: NEWSPAPERS AND MANUSCRIPTS CHECKED}

\begin{tabular}{|c|c|}
\hline \multicolumn{2}{|l|}{ Del Norte County } \\
\hline Crescent City News (Crescent City) & $\begin{array}{l}1906 \text { Jul } 26 \text { - } 1907 \text { Mar } 7 \text {; scattered issues checked } \\
\text { thereafter, through } 1907 \text { Nov 28; } \\
\text { MISSING: many? }\end{array}$ \\
\hline Del Norte Record (Crescent City) & $\begin{array}{l}1906 \text { Apr } 21 \text { - } 1907 \text { Mar 9; scattered issues checked } \\
\text { thereafter, through } 1907 \text { Dec } 7\end{array}$ \\
\hline \multicolumn{2}{|l|}{ El Dorado County } \\
\hline Georgetown Gazette (Georgetown) & 1906: Apr 20-May 25; 1907: Aug 16-23, Nov 1-8 \\
\hline El Dorado Republican (Placerville) & $\begin{array}{l}\text { 1906: Apr 19-May 3, May 17-24; 1907: Aug 15-22, } \\
\text { Oct 31-Nov } 7\end{array}$ \\
\hline Placerville Nugget (Placerville) & $\begin{array}{l}\text { 1906: Apr 18-20, Apr 23-24, May 15-18; 1907: Aug 12-13, } \\
\text { Oct 29-30 }\end{array}$ \\
\hline \multicolumn{2}{|l|}{ Fresno County } \\
\hline Fowler Ensign (Fowler) & $\begin{array}{l}\text { 1907: Apr 6, Apr 20, Jun 8, Jun 22-Jul 6, Jul 27, Sept 21- } \\
\text { Oct 5, Nov } 2\end{array}$ \\
\hline Fresno Evening Democrat (Fresno) & 1906: Oct 11, Nov 12, Dec 7-8; 1907: Jul 2, Jul 22 \\
\hline Fresno Morning Republican (Fresno) & $\begin{array}{l}\text { 1906: Apr 19-30, May 3-6, May 8-10, May 12, May 18, } \\
\text { Jun 5-6, Jun 16, Jul 5, Jul 7-8, Jul 21-22, Aug 1-2, Aug } \\
\text { 15, Aug 19-20, Oct 12, Nov 13, Dec 7-8; 1907: Jan 6-9, } \\
\text { Jan 31-Feb 1, Mar 31, Apr 18, Jun 5, Jun 19-20, Jun 27- } \\
\text { 28, Jul 2, Jul 21-22, Sept 16-17, Sept 23-24, Sept 26-27, } \\
\text { Oct 4, Oct } 30\end{array}$ \\
\hline Fresno Tribune (Fresno) & $\begin{array}{l}\text { 1907: Jul 2, Jul 22, Sept 16, Sept 23-24, Sept 26, Oct 3-4, } \\
\text { Oct } 29\end{array}$ \\
\hline Fresno County Enterprise (Selma) & $\begin{array}{l}\text { 1906: Apr 19-26, May 24, Jul 12, Dec 13; 1907: Jan 10, } \\
\text { Sept 26, Oct } 31\end{array}$ \\
\hline Selma Irrigator (Selma) & $\begin{array}{l}\text { 1906: Apr 21-28, May 19, Jul 7-14, Dec 8; 1907: Jan 12, } \\
\text { Jun 8, Jun 22, Sept 28, Nov } 2\end{array}$ \\
\hline \multicolumn{2}{|l|}{ Glenn County } \\
\hline Glenn Transcript (Willows) & $\begin{array}{l}\text { 1906: Apr 18-Jun 23, Jul 25-28, Aug 1-4, Aug 22, } \\
\text { Sept 19-29, Dec 1, Dec 26-29; 1907: Jan 12-26, May 18, } \\
\text { Jun 5-8, Aug 10-17, Oct 5-19, Nov 23-27; } \\
\text { MISSING: 1906: May 2-9; 1907: Jan } 16\end{array}$ \\
\hline Willows Review (Willows) & $\begin{array}{l}1906 \text { Apr } 20 \text { - 1908 Jan 10; } \\
\text { MISSING: 1906: May 11, Jun 22, Jul 20, Oct 26; } 1907 \text { : } \\
\text { Oct } 4\end{array}$ \\
\hline
\end{tabular}




\section{TABLE 3: NEWSPAPERS AND MANUSCRIPTS CHECKED}

\begin{tabular}{|c|c|}
\hline \multicolumn{2}{|l|}{ Humboldt County } \\
\hline Arcata Union (Arcata) & $\begin{array}{l}1906 \text { Apr 21-Sept 29; scattered issues checked } \\
\text { thereafter, through } 1907 \text { Nov } 30\end{array}$ \\
\hline Blue Lake Advocate (Blue Lake) & $\begin{array}{l}1906 \text { Apr 21-Oct } 6 \text {; scattered issues checked thereafter, } \\
\text { through } 1907 \text { Dec } 7\end{array}$ \\
\hline Cape Mendocino Lighthouse Logs (Cape Mendocino) & 1906 Apr - 1907 Dec \\
\hline Daily Humboldt Times (Eureka) & $\begin{array}{l}\text { 1906 Apr } 19 \text { - } 1907 \text { Jan 6, } 1907 \text { Aug 8-31; } \\
\text { MISSING: } 1906 \text { Dec } 26\end{array}$ \\
\hline Humboldt Daily Standard (Eureka) & $\begin{array}{l}\text { 1906 Apr } 18 \text { - } 1907 \text { Dec } 31 \text {; } \\
\text { MISSING: 1906: July 7, 23, Aug 10-26, Sept 4, 17, Oct 4, } \\
\text { Nov 1; 1907: Jan 8, 18, Feb 13, 22, May 22, June 3, Dec } 17\end{array}$ \\
\hline \multicolumn{2}{|l|}{ Imperial County } \\
\hline Brawley News (Brawley) & $\begin{array}{l}\text { 1906: Apr 20-Jul 27, Dec 28*; 1907: Feb 8, Aug 2-16 } \\
* \text { Most of the issue dated } 1906 \text { Dec } 28 \text { is missing. }\end{array}$ \\
\hline Calexico Chronicle (Calexico) & $\begin{array}{l}\text { 1906: Apr 26-May 24, Jul 26, Dec } 27 * ; 1907 \text { : Feb 7, Aug } \\
1-15 \\
* \text { Part of the issue dated } 1906 \text { Dec } 27 \text { is missing. The } \\
\text { issue of } 1906 \text { Apr } 19 \text { is also missing. }\end{array}$ \\
\hline Imperial Valley Press (El Centro) & $\begin{array}{l}\text { 1906: Apr 21-May 26, Jul 28, Dec 29; 1907: Feb 9, Jul } 30 \\
\text { "Extra", Aug 3-17 }\end{array}$ \\
\hline \multicolumn{2}{|l|}{ Kern County } \\
\hline Daily Californian (Bakersfield) & $\begin{array}{l}\text { 1906: May 18, Jul 7, Dec 7-8; 1907: Jul 2, Jul 22, Sept } \\
\text { 19-20, Sept 23-24 }\end{array}$ \\
\hline Morning Echo (Bakersfield) & $\begin{array}{l}\text { 1906: Apr 18-20, Apr 26, May 18, Jul 7-8, Dec 7-9; } 1907 \text { : } \\
\text { Jan 8-9, Jun 5, Jun 19-20, Sept 20, Sept } 24\end{array}$ \\
\hline \multicolumn{2}{|l|}{ Kings County } \\
\hline Hanford Daily Journal (Hanford) & $\begin{array}{l}\text { 1906: Apr 18-May 10, May 18, Jun 5, Jul 7, Jul 21-23, } \\
\text { Aug 1-2, Dec 7-8; 1907: Mar 30-Apr 1, Apr 17-18, Jun 5, } \\
\text { Jun 19, Jun 24, Jun 27, Jul 2, Jul 22, Sept 23-24 }\end{array}$ \\
\hline Hanford Semi-Weekly Journal (Hanford) & 1907: Sept 24-27 \\
\hline Hanford Daily Sentinel (Hanford) & 1907: Sept 23-24, Sept 26 \\
\hline Hanford Weekly Sentinel (Hanford) & $\begin{array}{l}\text { 1906: Apr 19-May 24, Jun 7, Jul 12, Jul 26-Aug 9, } \\
\text { Dec 13; 1907: Apr 4, Apr 18, Jun 6, Jun 20-Jul 4, Jul 25, } \\
\text { Sept 26 }\end{array}$ \\
\hline
\end{tabular}




\section{TABLE 3: NEWSPAPERS AND MANUSCRIPTS CHECKED}

\begin{tabular}{|c|c|}
\hline \multicolumn{2}{|l|}{ Lake County } \\
\hline Lake County Bee (Lakeport) & 1906 Apr 18 - 1907 Dec 25 \\
\hline \multicolumn{2}{|l|}{ Lassen County } \\
\hline Big Valley Gazette (Bieber) & $\begin{array}{l}\text { 1906: Apr 19-May 3, Jul 12-19; 1907: Jan 3, Jan 24, } \\
\text { Mar 28-Apr 11, Aug 15 }\end{array}$ \\
\hline Lassen Advocate (Susanville) & $\begin{array}{l}\text { 1906: Apr 19-May 3, Jul 12-19; 1907: Jan 24, Apr 11, } \\
\text { Aug 16, Nov } 29\end{array}$ \\
\hline \multicolumn{2}{|l|}{ Los Angeles County } \\
\hline Diary of Minnie (Horn) Warren (Glendora) & $\begin{array}{l}\text { 1906: Apr 18-23 } \\
\text { Held at the Huntington Library in San Marino, CA }\end{array}$ \\
\hline Diary of Robert Benjamin Waterman (La Cañada) & $\begin{array}{l}\text { 1906: Apr 18-20 } \\
\text { Held at the California State Library in Sacramento }\end{array}$ \\
\hline Long Beach Daily Telegram (Long Beach) & 1906: Apr 18-20 \\
\hline Long Beach Evening Tribune (Long Beach) & 1906: Apr 18-19 \\
\hline Los Angeles Examiner (Los Angeles) & 1906: Apr 19-20 \\
\hline Los Angeles Express (Los Angeles) & 1906: Apr 18-19 \\
\hline Los Angeles Herald (Los Angeles) & $\begin{array}{l}\text { 1906: Apr } 19 *-20 \\
* \text { Page } 1 \text { of the issue dated Apr } 19 \text { was not filmed. }\end{array}$ \\
\hline Los Angeles Times (Los Angeles) & $\begin{array}{l}\text { 1906: Apr 19-20, [Apr } 21 \text { skimmed*] } \\
\text { * For the issue denoted as skimmed, only columns } \\
\text { written by correspondents from nearby towns were } \\
\text { read; there is a small possibility that some news of } \\
\text { earthquakes was overlooked. }\end{array}$ \\
\hline Diary of Selena Gray (Galt) Ingram (Los Angeles) & $\begin{array}{l}\text { 1906: Apr } 18-19 \\
\text { Held at the Huntington Library in San Marino, CA }\end{array}$ \\
\hline Pasadena Daily News (Pasadena) & 1906: Apr 18-19 \\
\hline Daily Outlook (Santa Monica) & 1906: Apr 18-19 \\
\hline \multicolumn{2}{|l|}{ Madera County } \\
\hline Madera Mercury (Madera) & $\begin{array}{l}\text { 1906: Apr 21-May 19, Jun 9-23, Jul 7-14, Jul 28-Aug 4, } \\
\text { Aug 18-25, Oct 13, Nov 17, Dec 8-15; 1907: Jan 12, Feb 2, } \\
\text { Apr 6, Apr 20, Jun 8, Jun 22-Jul 6, Jul 27, Sept 21-Oct 5, } \\
\text { Nov } 2\end{array}$ \\
\hline
\end{tabular}




\section{TABLE 3: NEWSPAPERS AND MANUSCRIPTS CHECKED}

\begin{tabular}{|c|c|}
\hline \multicolumn{2}{|l|}{ Marin County } \\
\hline Point Reyes Lighthouse Logs (Point Reyes) & 1906 Apr - 1907 Dec \\
\hline Marin County Tocsin (San Rafael) & $\begin{array}{l}\text { 1906: Apr 21-Aug 18, Dec 15-22; 1907: Jan 12-19, } \\
\text { Feb 2-9, Mar 9, Mar 30-Apr 13, May 18-25, Jun 8-Jul 6, } \\
\text { Sept 28-Oct 12, Nov 2-9 }\end{array}$ \\
\hline Marin Journal (San Rafael) & $\begin{array}{l}\text { 1906: Apr 19-Aug 16, Dec 13-20; 1907: Jan 10-17, } \\
\text { Jan 31-Feb 7, Mar 7-14, Mar 28-Apr 11, May 16-23, } \\
\text { Jun 6-Jul 4, Sept 26-Oct 10, Oct 31-Nov } 7\end{array}$ \\
\hline Sausalito News (Sausalito) & $\begin{array}{l}\text { 1906: Apr 21-Aug 18, Dec 15-22; 1907: Jan 12-19, Feb } \\
\text { 2-9, Mar 9-16, Mar 30-Apr 13, May 18-25, Jun 8-Jul 6, } \\
\text { Sept 28-Oct 12, Nov 2-9 }\end{array}$ \\
\hline \multicolumn{2}{|l|}{ Mariposa County } \\
\hline Mariposa Gazette (Mariposa) & $\begin{array}{l}\text { 1906: Apr 21-May 19, Jun 9, Jul 7-14; 1907: Jun 8, } \\
\text { Jun 22, Sept 28, Nov } 2\end{array}$ \\
\hline \multicolumn{2}{|l|}{ Mendocino County } \\
\hline Mendocino Beacon (Mendocino) & $\begin{array}{l}1906 \text { Apr } 21 \text { - } 1908 \text { Jan 4; } \\
\text { MISSING: an "Extra" Edition published some time } \\
\text { between Apr } 21 \text { and Apr } 281906\end{array}$ \\
\hline Point Arena Lighthouse Logs (Point Arena) & 1906 Apr - 1907 Dec \\
\hline Dispatch Democrat (Ukiah) & 1906: May 18 \\
\hline Ukiah Republican Press (Ukiah) & $\begin{array}{l}1906 \text { Apr } 20 \text { - } 1907 \mathrm{Dec} 27 \text {; } \\
\text { MISSING: several issues, incl. all of Oct } 1906\end{array}$ \\
\hline \multicolumn{2}{|l|}{ Merced County } \\
\hline Dos Palos Star (Dos Palos) & $\begin{array}{l}\text { 1906: Jun 9, Jul 7, Aug 4; 1907: Feb 2, Jun 8, Jun 22- } \\
\text { Jul 6, Jul 27, Sept 21-Oct 5, Nov } 2\end{array}$ \\
\hline Merced Express (Merced) & $\begin{array}{l}\text { 1906: Apr 21-May 19, Jun 9-23, Jul 7-Aug 4, Aug 18-25, } \\
\text { Oct 13, Nov 17, Dec 8-15; 1907: Jan 12, Feb 2, Apr 6, } \\
\text { Apr 20, Jun 8, Jun 22-Jul 6, Jul 27, Sept 21-Oct 5, Nov } 2\end{array}$ \\
\hline \multicolumn{2}{|l|}{ Modoc County } \\
\hline New Era (Alturas) & $\begin{array}{l}\text { 1906: Apr 25-May 2, Jul 18; 1907: Jan 23, Mar 20, } \\
\text { Apr 10 }\end{array}$ \\
\hline
\end{tabular}




\section{TABLE 3: NEWSPAPERS AND MANUSCRIPTS CHECKED}

\begin{tabular}{|c|c|}
\hline \multicolumn{2}{|l|}{ Mono County } \\
\hline Bridgeport Chronicle-Union (Bridgeport) & 1906: Apr 18 “Extra”, Apr 21, May 19; 1907: Jun 8 \\
\hline \multicolumn{2}{|l|}{ Monterey County } \\
\hline King City Rustler / Salinas Valley Rustler (King City) & $\begin{array}{l}\text { 1906: Apr 20-May 25, Jun 8, Jun 22, Jul 6-13, Jul 27- } \\
\text { Aug 3, Aug 17-24, Oct 12, Nov 16, Dec 7-14; 1907: Jan 11, } \\
\text { Feb 1, Apr 5, Apr 19, Jun 7, Jun 21, Jul 5, Jul 26, } \\
\text { Sept 20-Oct 11, Nov } 1\end{array}$ \\
\hline Monterey Daily Cypress (Monterey) & $\begin{array}{l}\text { 1907: Jan 31-Feb 1, Apr 18, Jun 19, Jul 21, Sept 17, } \\
\text { Sept 24, Sept 26-27, Oct 4, Oct } 30\end{array}$ \\
\hline Daily Review (Pacific Grove) & $\begin{array}{l}\text { 1906: Apr 18-May 12, May 18, Jun 5, Jun 16, Jul 5, Jul 7, } \\
\text { Jul 21-23, Aug 1-2, Aug 14, Aug 20, Oct 11, Nov 12, Dec } \\
\text { 7-10; 1907: Mar 30-Apr 1, Apr 17-18, Jun 5, Jun 19, } \\
\text { Jun 27, Sept 23-24 }\end{array}$ \\
\hline Pacific Grove Review (Pacific Grove) & 1906: May 18-25, Jul 13 \\
\hline Salinas Daily Index (Salinas) & 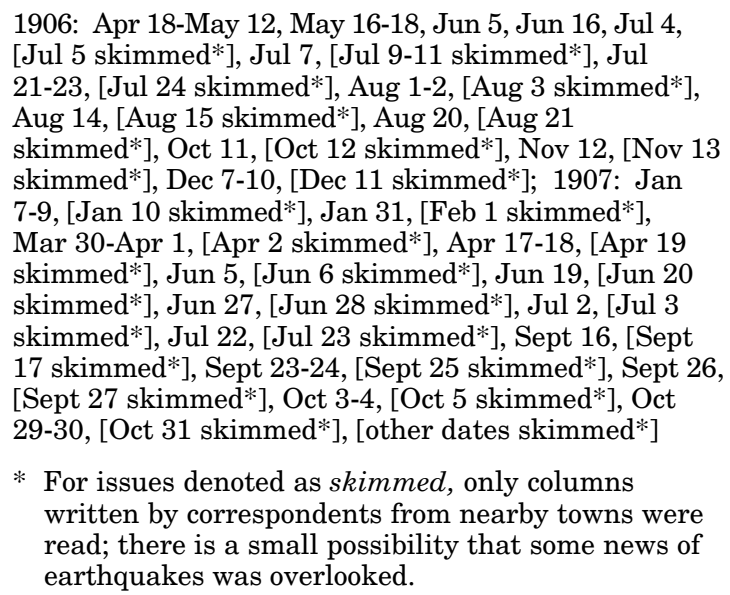 \\
\hline Salinas Weekly Journal (Salinas) & $\begin{array}{l}\text { 1906: Apr 21-May 19, Jun 9-23, Jul 7-14, Jul 28-Aug 4, } \\
\text { Aug 18-25, Oct 13, Nov 17, Dec 8; 1907: Jan 12, Feb 2, } \\
\text { Apr 6, Apr 20, Jun 8, Jun 22-Jul 6, Jul 27, Sept 21-Oct 5, } \\
\text { Nov } 2\end{array}$ \\
\hline
\end{tabular}




\section{TABLE 3: NEWSPAPERS AND MANUSCRIPTS CHECKED}

\begin{tabular}{|c|c|}
\hline \multicolumn{2}{|l|}{ Napa County } \\
\hline Napa Daily Journal (Napa) & $\begin{array}{l}\text { 1906: Apr 18-May 27, Jun 1-19, Jun 23-29, Jul 21-24, } \\
\text { Aug 3-8; 1907: Jan 3-4, Jan 15-17, Jan 22-26, Jan 31- } \\
\text { Feb 3, Mar 26-27, Mar 31-Apr 2, May 14-15, Jun 5-8, } \\
\text { Jun 11-13, Jun 22-25, Aug 11-13, Oct 4-6 }\end{array}$ \\
\hline Napa Daily Register (Napa) & $\begin{array}{l}\text { 1906: May 25-28, May 31-Jun 18, Jun 22-Jul 2, Jul 20-26, } \\
\text { Aug 1-8, Aug 13-15, Aug 22-25, Aug 30-Sept 3, Sept } \\
\text { 20-22, Sept 25-28, Oct 8-10, Oct 17-20, Nov 5-6, Nov } \\
\text { 15-17, Dec 24-26; 1907: Jan 2-4, Jan 14-16, Jan 21-25, } \\
\text { Jan 31-Feb 2, Mar 25-26, May 13-14, Jun 5-12, Jun 22-24, } \\
\text { Aug 12-13, Oct 3-5 }\end{array}$ \\
\hline Napa Register (Napa) & 1906: Apr 20-Aug 10 \\
\hline St. Helena Star (St. Helena) & $\begin{array}{l}\text { 1906: Apr 20-Aug 17; 1907: Jan 4-Feb 8, Mar 29-Apr 5, } \\
\text { May 17-24, Jun 7-Jul 5, Aug 16-23, Oct 4-11 }\end{array}$ \\
\hline \multicolumn{2}{|l|}{ Nevada County } \\
\hline Daily Morning Union (Grass Valley and Nevada City) & $\begin{array}{l}\text { 1906: Apr 19-21, Apr 24-25, May 15-20; 1907: Aug 13-14, } \\
\text { Oct 30-Nov } 1\end{array}$ \\
\hline Truckee Semi-Weekly Republican (Truckee) & 1906: Apr 18-28, May 16-19 \\
\hline \multicolumn{2}{|l|}{ Orange County } \\
\hline Anaheim Gazette (Anaheim) & 1906: Apr 19-26 \\
\hline Fullerton Tribune (Fullerton) & 1906: Apr 26 \\
\hline Evening Blade (Santa Ana) & 1906: Apr 18-19 \\
\hline \multicolumn{2}{|l|}{ Placer County } \\
\hline Placer County Republican (Auburn) & $\begin{array}{l}\text { 1906: Apr 19-May 3, May 17-24; 1907: Aug 15-22, } \\
\text { Oct 31-Nov } 7\end{array}$ \\
\hline Placer Herald (Auburn) & $\begin{array}{l}\text { 1906: Apr 21-May 5, May 19-26; 1907: Aug 17-24, } \\
\text { Nov 2-9 }\end{array}$ \\
\hline Colfax Sentinel (Colfax) & 1906: Apr 20-May 4, May 18-25; 1907: Aug 23 \\
\hline Newcastle News (Newcastle) & $\begin{array}{l}\text { 1906: Apr 18-May 2, May 16-23; 1907: Aug 14-21, } \\
\text { Oct 30-Nov } 6\end{array}$ \\
\hline \multicolumn{2}{|l|}{ Plumas County } \\
\hline Plumas National-Bulletin (Quincy) & $\begin{array}{l}\text { 1906: Apr 19-May 10, Jul 9-16; 1907: Jan 17-21, } \\
\text { Aug 12-15 }\end{array}$ \\
\hline
\end{tabular}




\section{TABLE 3: NEWSPAPERS AND MANUSCRIPTS CHECKED}

\begin{tabular}{|c|c|}
\hline \multicolumn{2}{|l|}{ Riverside County } \\
\hline Corona Independent (Corona) & 1906: Dec 28; 1907: Feb 8 \\
\hline Press and Horticulturist of Corona (Corona) & 1906: Apr 27-May 4 \\
\hline Hemet News (Hemet) & 1906: Apr 20, Dec 28; 1907: Feb 8 \\
\hline Press and Horticulturist (Riverside) & 1906: Apr 20 \\
\hline Riverside Daily Press (Riverside) & 1906: Apr 18-20, Dec 22-24; 1907: Feb 4 \\
\hline San Jacinto Register (San Jacinto) & 1906: Apr 26, Dec 27 \\
\hline \multicolumn{2}{|l|}{ Sacramento County } \\
\hline Folsom Weekly Telegraph (Folsom) & 1906: Apr 21-Jun 23; 1907: Jun 8-15, Aug 17, Nov 2-9 \\
\hline Weekly Galt Gazette (Galt) & 1906: Apr 21-Jun 23; 1907: Jun 8-15, Aug 17, Nov 2-9 \\
\hline Oak Park Ledger (Oak Park) & 1906: Apr 20-Jun 22; 1907: Jun 7-14, Aug 16, Nov 1-8 \\
\hline Sacramento Bee (Sacramento) & $\begin{array}{l}\text { 1906: Apr 18-26, May 14-18, Jun 5, Jun 16; } 1907 \text { : } \\
\text { Jun 5-6, Aug 12, Oct 29-30; } \\
\text { MISSING: 1906: Apr 19 }\end{array}$ \\
\hline Sacramento Star (Sacramento) & $\begin{array}{l}\text { 1906: Apr 18-26, May 14-18, Jun 5, Jun 16; } 1907 \text { : } \\
\text { Jun 5-6, Aug 12-13, Oct 29-30 }\end{array}$ \\
\hline Sacramento Union (Sacramento) & $\begin{array}{l}\text { 1906: Apr 19-26, May 15-19, Jun 5-6, Jun 16-17; } 1907 \text { : } \\
\text { Jun 5-6, Aug 11-13, Oct 30-31 }\end{array}$ \\
\hline \multicolumn{2}{|l|}{ San Benito County } \\
\hline Free Lance (Hollister) & $\begin{array}{l}\text { 1906: Apr 20-May 25, Jun 8, Jun 22, Jul 6-13, Jul 27- } \\
\text { Aug 3, Aug 17-24, Oct 12, Nov 16, Dec 7-14; 1907: Jan 11, } \\
\text { Feb 1, Apr 5, Apr 19, Jun 7, Jun 21-Jul 5, Jul 26, } \\
\text { Sept 20-Oct 11, Nov } 1\end{array}$ \\
\hline San Benito Advance (Hollister) & $\begin{array}{l}\text { 1906: Apr 20-May 25, Jun 8, Jun 22, Jul 6-13, Jul 27- } \\
\text { Aug 3, Aug 17-24, Oct 12, Nov 16, Dec 7-14; 1907: Jan 11, } \\
\text { Feb 1, Apr 5, Apr 19, Jun 21-Jul 5, Jul 26, Sept 18-Oct 9, } \\
\text { Oct 30-Nov } 6\end{array}$ \\
\hline \multicolumn{2}{|l|}{ San Bernardino County } \\
\hline Chino Valley Champion (Chino) & 1906: Apr 20-27 \\
\hline Needles Eye (Needles) & 1906: Apr 21-28 \\
\hline The Citrograph (Redlands) & 1906: Apr 21 \\
\hline Daily Times - Index (San Bernardino) & 1906: Apr 18-19 \\
\hline San Bernardino Daily Sun (San Bernardino) & 1906: Apr 19-20 \\
\hline
\end{tabular}


TABLE 3: NEWSPAPERS AND MANUSCRIPTS CHECKED

\begin{tabular}{|c|c|}
\hline San Diego County & \\
\hline The Advocate (Escondido) & 1906: Dec 28; 1907: Feb 8 \\
\hline Escondido Times (Escondido) & 1906: Apr 20, Dec 28; 1907: Feb 8 \\
\hline La Jolla Breakers (La Jolla) & 1906: Apr 19-26 \\
\hline National City News (National City) & 1906: Apr 21, Dec 22-29; 1907: Feb 9 \\
\hline Diary of Augustus B. Kimball (National City) & $\begin{array}{l}\text { 1906: Apr 18-23, Dec 22-25; 1907: Feb 3-5 } \\
\text { Held at the National City Public Library }\end{array}$ \\
\hline Diary of Frank A. Kimball (National City) & $\begin{array}{l}\text { 1906: Apr 18-23, Dec 22-25; 1907: Feb 3-5 } \\
\text { Held at the National City Public Library }\end{array}$ \\
\hline Letters of Frank A. Kimball (National City) & $\begin{array}{l}\text { various } \\
\text { Held at the National City Public Library }\end{array}$ \\
\hline Oceanside Blade (Oceanside) & 1906: Apr 21, Dec 22-29; 1907: Feb 9 \\
\hline Evening Tribune (San Diego) & $\begin{array}{l}\text { 1906: Apr 18-19, [Apr 20-30 skimmed*], Dec 22-24; } \\
\text { 1907: Feb 4; } \\
\text { MISSING: 1906: Apr } 24 \\
\text { * For issues denoted as skimmed, only headlines were } \\
\text { read; there is a small possibility that some news of } \\
\text { earthquakes was overlooked. }\end{array}$ \\
\hline San Diegan - Sun (San Diego) & $\begin{array}{l}\text { 1906: Apr 18-19, [Apr 20-30 skimmed*], Dec 22-24, [Dec } \\
\text { 25-27 skimmed*]; 1907: Feb 4, [Feb 5-7 skimmed*] } \\
\text { * For issues denoted as skimmed, only headlines were } \\
\text { read; there is a small possibility that some news of } \\
\text { earthquakes was overlooked. }\end{array}$ \\
\hline San Diego News (San Diego) & 1906: Apr 19-May 3, Dec 27; 1907: Feb 7 \\
\hline San Diego Union (San Diego) & $\begin{array}{l}\text { 1906: Apr 19-20, [Apr 21-30 skimmed*], Dec 23-24; } \\
\text { 1907: Feb } 4 \\
\text { * For issues denoted as skimmed, only headlines were } \\
\text { read; there is a small possibility that some news of } \\
\text { earthquakes was overlooked. }\end{array}$ \\
\hline
\end{tabular}




\section{TABLE 3: NEWSPAPERS AND MANUSCRIPTS CHECKED}

\begin{tabular}{|c|c|}
\hline \multicolumn{2}{|l|}{ San Francisco County } \\
\hline The Bulletin (San Francisco) & $\begin{array}{l}\text { 1906: Apr 20-May 2, May 5, May 7, May 9, May 11, May } \\
\text { 14-15, May 17-18, May 31, Jun 5, Jun 10-11, Jun 16, Jun } \\
\text { 22-23, Jul 17-18, Jul 20; 1907: Jan 8-9, Jan 31, Mar 2, } \\
\text { Mar 25, Mar 30-Apr 1, May 13, Jun 5, Jun 10, Jun 13, } \\
\text { Jun 22, Sept 26, Oct 3, Oct 29 }\end{array}$ \\
\hline Evening Post (San Francisco) & 1906: May 18, Jun 5 \\
\hline San Francisco Call (San Francisco) & $\begin{array}{l}\text { 1906: Apr 19*, Apr 21-May 2, May 6-7, May 9-10, May } \\
\text { 12, May 15, May 17-19, May 31-Jun 1, Jun 5-6, Jun 10-11, } \\
\text { Jun 16-17, Jun 23-24, Jul 18, Jul 20-21; 1907: Jan 8-9, } \\
\text { Jan 31, Mar 3, Mar 25, Mar 31, May 13, Jun 5, Jun 11, } \\
\text { Jun 14, Jun 22-23, Sept 27, Oct 4, Oct 30 } \\
\text { MISSING: 1906: Apr 30 } \\
\text { * The issue dated } 1906 \text { Apr } 19 \text { was issued jointly with } \\
\text { the San Francisco Chronicle and San Francisco } \\
\text { Examiner under the name "Call-Chronicle- } \\
\text { Examiner." No paper was issued Apr 20. }\end{array}$ \\
\hline San Francisco Chronicle (San Francisco) & $\begin{array}{l}\text { 1906: Apr 19*-May 7, May 9-10, May 12, May 15, May } \\
\text { 17-18, May 31-Jun 1, Jun 5-6, Jun 10-11, Jun 16-17, Jun } \\
\text { 23-24, Jul 5, Jul 18, Jul 20-21, Aug 5-6, Dec 9-10; 1907: } \\
\text { Jan 8-9, Jan 31-Feb 1, Mar 3, Mar 25-26, Mar 31-Apr 1, } \\
\text { May 13, Jun 5-6, Jun 11, Jun 14, Jun 22-23, Sept 26-27, } \\
\text { Oct 4, Oct 30 } \\
\text { * The issue dated } 1906 \text { Apr } 19 \text { was issued jointly with } \\
\text { the San Francisco Call and San Francisco Examiner } \\
\text { under the name "Call-Chronicle-Examiner." }\end{array}$ \\
\hline San Francisco Examiner (San Francisco) & $\begin{array}{l}\text { 1906: Apr 19*-May 2, May 6-7, May 9-10, May 12, May } \\
\text { 15, May 17-18, May 31-Jun 1, Jun 5-6, Jun 10-11, Jun } \\
\text { 16-17, Jun 23-24, Jul 18, Jul 20-21 } \\
\text { * The issue dated } 1906 \text { Apr } 19 \text { was issued jointly with } \\
\text { the San Francisco Call and San Francisco Chronicle } \\
\text { under the name "Call-Chronicle-Examiner." }\end{array}$ \\
\hline Diary of Charles Prinegar (San Francisco) & $\begin{array}{l}\text { 1906: Apr 19-May } 6 \\
\text { Held at the Huntington Library in San Marino, CA }\end{array}$ \\
\hline \multicolumn{2}{|l|}{ San Joaquin County } \\
\hline Lodi Sentinel (Lodi) & $\begin{array}{l}\text { 1906: Apr 19, Apr 26, May 8, May 19, Jun 5-7, Jun 16-19; } \\
\text { 1907: Jan 31-Feb 2, Jun 6, Oct } 5\end{array}$ \\
\hline Evening Mail (Stockton) & $\begin{array}{l}\text { 1906: Apr 18-19, Apr 23-26, May 5, May 18, Jun 5, } \\
\text { Jun 16; 1907: Jan 31, Jun 5, Oct 3-4, Oct } 29\end{array}$ \\
\hline Stockton Daily Evening Record (Stockton) & $\begin{array}{l}\text { 1906: Apr 18-19, Apr 23, Apr 25-26, May 5, May 18, } \\
\text { Jun 5, Jun 16; 1907: Jan 31, Jun 5, Oct 3-4, Oct } 29\end{array}$ \\
\hline Stockton Daily Independent (Stockton) & 1907: Jan 31-Feb 1, Jun 5, Oct 4, Oct 30 \\
\hline Tracy Weekly Press (Tracy) & 1906: Apr 21 \\
\hline
\end{tabular}




\section{TABLE 3: NEWSPAPERS AND MANUSCRIPTS CHECKED}

\begin{tabular}{|c|c|}
\hline \multicolumn{2}{|l|}{ San Luis Obispo County } \\
\hline Paso Robles Leader (Paso Robles) & 1907: Oct 2 \\
\hline Diary of A. F. Sinsheimer (San Luis Obispo) & various dates checked by T. Toppozada (CDMG) \\
\hline San Luis Obispo Breeze (San Luis Obispo) & 1907: Sept 16 , Sept $23-24$, Sept 26 , Oct 3-4, Oct $29-30$ \\
\hline Semi-Weekly Breeze (San Luis Obispo) & $\begin{array}{l}\text { 1906: Apr 20-May 22, [May } 25 \text { skimmed*], Jun 5-8, } \\
\text { [Jun } 12 \text { skimmed*], Jun 19, [Jun } 22 \text { skimmed*], Jul } \\
\text { 6-10, [Jul } 13 \text { skimmed*], Jul } 24 \text {, [Jul } 27 \text { skimmed*], } \\
\text { Aug } 2^{* *-7, ~[A u g ~} 10 \text { skimmed*], Aug } 14-21 \text {, [Aug } 24 \\
\text { skimmed*], Oct } 12 \text {, [Oct } 16 \text { skimmed*], Nov 13, [Nov } 16 \\
\text { skimmed*], Dec 7-14, [Dec } 18 \text { skimmed*]; 1907: Apr } 2 \text {, } \\
\text { [Apr } 5 \text { skimmed*], Apr 19, [Apr } 23 \text { skimmed*], Jun 7, } \\
\text { [Jun } 11 \text { skimmed*], Jun } 21 \text {, [Jun } 25 \text { skimmed*], Jun 28- } \\
\text { Jul 5, [Jul } 9 \text { skimmed*], Jul 23, [Jul } 26 \text { skimmed*], } \\
\text { Sept } 24 \text {, [Sept } 27 \text { skimmed*] } \\
\text { * For issues denoted as skimmed, only columns } \\
\text { written by correspondents from nearby towns were } \\
\text { read; there is a small possibility that some news of } \\
\text { earthquakes was overlooked. } \\
\text { ** Published Thursday, Aug } 2 \text {, not Friday, Aug } 3 \text {. }\end{array}$ \\
\hline San Luis Obispo Tribune (San Luis Obispo) & $\begin{array}{l}\text { 1906: Apr 20-May 22, Jun 5-8, Jul 10, Jul 24, Aug 3, Dec } \\
\text { 7-11; 1907: Apr 2, Apr 19, Jun 7, Jun 21, Jun 28, Jul 2-5, } \\
\text { Jul 23, Sept 24-27 }\end{array}$ \\
\hline Templeton Advance (Templeton) & $\begin{array}{l}\text { 1906: Jun 6, Jun 20, Jul 4; 1907: Feb 6, Apr 3, Apr 24, } \\
\text { Jun 5-Jul 3, Jul 24, Oct 30-Nov } 6\end{array}$ \\
\hline \multicolumn{2}{|l|}{ San Mateo County } \\
\hline Redwood City Democrat (Redwood City) & $\begin{array}{l}\text { 1906: May 3-24, Jun 7-28, Jul 19-26; 1907: Jan 10, } \\
\text { Jan 31-Feb 7, Mar 7, Mar 28-Apr 4, May 16, Jun 6-27, } \\
\text { Sept 26-Oct 10, Oct } 31\end{array}$ \\
\hline Times-Gazette (Redwood City) & $\begin{array}{l}\text { 1906: Apr 21-May 19, Jun 9-30, Jul 21; 1907: Jan 12, } \\
\text { Feb 2, Mar 2-9, Mar 30-Apr 6, May 18, Jun 8-29, Sept 28- } \\
\text { Oct 5, Nov } 2\end{array}$ \\
\hline San Mateo Leader (San Mateo) & $\begin{array}{l}\text { 1906: Apr 25-May 23, Jun 6-27, Jul 18-25; 1907: Jan 9, } \\
\text { Feb 6, Mar 6, Mar 27-Apr 3, May 15, Jun 5-26, Oct 2-9, } \\
\text { Oct } 30\end{array}$ \\
\hline San Mateo Times (San Mateo) & $\begin{array}{l}\text { 1906: Apr 21-May 12, Jun 9-30, Jul 21; 1907: Jan 12, } \\
\text { Feb 2, Mar 2-9, Mar 30-Apr 6, May 18, Jun 8-29, Sept 28- } \\
\text { Oct 5, Nov } 2\end{array}$ \\
\hline $\begin{array}{l}\text { South San Francisco Enterprise (South San } \\
\text { Francisco) }\end{array}$ & $\begin{array}{l}\text { 1907: Jan 12, Feb 2, Mar 2-9, Mar 30-Apr 6, May 18, Jun } \\
\text { 8-29, Sept 28-Oct 5, Nov } 2\end{array}$ \\
\hline \multicolumn{2}{|l|}{ Santa Barbara County } \\
\hline The Independent (Santa Barbara) & 1906: Apr 18-19, May 18, Jul 7 \\
\hline Morning Press (Santa Barbara) & $\begin{array}{l}\text { 1906: Apr 19-20, May 18, Jul 7-8, Dec 7-9; 1907: Jul 2-3, } \\
\text { Jul 21-23, Sept } 24\end{array}$ \\
\hline Weekly Press (Santa Barbara) & 1907: Jun 6 \\
\hline
\end{tabular}




\section{TABLE 3: NEWSPAPERS AND MANUSCRIPTS CHECKED}

\begin{tabular}{|c|c|}
\hline Santa Barbara Herald (Santa Barbara) & $\begin{array}{l}\text { 1906: Jul 6-13, Dec 7-14; 1907: May 25, Jun 8, Sept } \\
\text { 21-28 }\end{array}$ \\
\hline Santa Maria Times (Santa Maria) & $\begin{array}{l}\text { 1906: Apr 21, May 19, Jul 7-14, Dec 8-15; 1907: Jul 6, } \\
\text { Jul 27, Sept } 28\end{array}$ \\
\hline \multicolumn{2}{|l|}{ Santa Clara County } \\
\hline Diary of Henry Lloyd Tevis (Alma) & various dates checked by T. Toppozada (CDMG) \\
\hline Gilroy Advocate (Gilroy) & $\begin{array}{l}\text { 1906: Apr 21-May 19, Jun 9-23, Jul 7-21; 1907: Jan 12, } \\
\text { Feb 2, Mar 2-9, Mar 30-Apr 6, May 18, Jun 8-29, Sept 28- } \\
\text { Oct 5, Nov } 2\end{array}$ \\
\hline Gilroy Gazette (Gilroy) & 1907: Jun 28, Oct 4 \\
\hline Los Gatos Mail (Los Gatos) & $\begin{array}{l}\text { 1906: Apr 26-May 24, Jun 7, Jun 21, Jul 12-26; 1907: } \\
\text { Jan 10, Jan 31, Mar 7, Mar 28-Apr 4, May 16, Jun 6-27, } \\
\text { Sept 26-Oct 10, Oct } 31\end{array}$ \\
\hline Los Gatos News (Los Gatos) & $\begin{array}{l}\text { 1906: Apr 20-May 25, Jun 8-29, Jul 13-27; 1907: Jan 11, } \\
\text { Feb 1, Mar 8, Mar 29-Apr 5, May 17, Jun 7-14, Jun 28, } \\
\text { Sept 27-Oct 4, Nov } 1\end{array}$ \\
\hline Diary of Samuel Haines (Mountain View) & various dates checked by T. Toppozada (CDMG) \\
\hline Mountain View Register (Mountain View) & $\begin{array}{l}\text { 1907: Jan 11, Feb 1, Mar 8, Mar 29-Apr 5, May 17, Jun } \\
\text { 7-14, Jun 28, Sept 27-Oct 4, Nov } 1\end{array}$ \\
\hline Daily Palo Alto (Palo Alto; Stanford University) & $\begin{array}{l}\text { 1907: Jan 8-9, Jan 31, Mar 4, Mar 25, Mar 30, Sept 26, } \\
\text { Oct 4, Oct 29-30 }\end{array}$ \\
\hline Daily Palo Alto Times (Palo Alto) & 1907: Jan 8-9, Jan 31, Jun 5, Sept 26, Oct 3, Oct 29-30 \\
\hline Palo Altan (Palo Alto) & $\begin{array}{l}\text { 1906: May 3-24, Jun 8-29, Jul 13-27; 1907: Jan 11, Feb 1, } \\
\text { Mar 8, Mar 29-Apr 5, May 17, Jun 7-14, Jun 28, Sept 27- } \\
\text { Oct 4, Nov 1; } \\
\text { MISSING: 1906: Apr 13-27, Jun 1, Jun 22, Jul 27; 1907: } \\
\text { Nov } 1\end{array}$ \\
\hline San Jose Herald (San Jose) & $\begin{array}{l}\text { 1906: Apr 19*, Apr 22, May 2-4, May 6, May 18-19, Jun } \\
\text { 5, Jun 10, Jun 16-17, Jun 24, Jul 8; 1907: Jan 8-9, Jan 31, } \\
\text { Mar 2-3, Mar 30-31, Jun 5, Jun 10, Jun 13, Jun 22, } \\
\text { Sept 26, Oct 3-4, Oct 29-30 } \\
\text { On Sundays, the San Jose Mercury and San Jose } \\
\text { Herald were combined and published as the } \\
\text { "Sunday Mercury and Herald". } \\
\text { * The issue dated } 1906 \text { Apr } 19 \text { was issued jointly with } \\
\text { the San Jose Mercury under the name "Mercury and } \\
\text { Herald." }\end{array}$ \\
\hline San Jose Mercury (San Jose) & $\begin{array}{l}\text { 1906: Apr 19*-28, May 3-6, May 9-10, May 12, May 15, } \\
\text { May 17-19, Jun 5-6, Jun 10-11, Jun 16-17, Jun 23-24, Jul } \\
\text { 7-8, Jul 18, Jul 20-21; 1907: Jan 8-9, Jan 31-Feb 1, Mar 3, } \\
\text { Mar 31, Jun 5-6, Jun 11, Jun 14, Jun 22-23, Sept 27, } \\
\text { Oct 4, Oct } 30 \\
\text { On Sundays, the San Jose Mercury and San Jose } \\
\text { Herald were combined and published as the } \\
\text { "Sunday Mercury and Herald". } \\
\text { * The issue dated } 1906 \text { Apr } 19 \text { was issued jointly with } \\
\text { the San Jose Herald under the name "Mercury and } \\
\text { Herald." }\end{array}$ \\
\hline Santa Clara News (Santa Clara) & $\begin{array}{l}\text { 1906: Apr 24-May 22, Jun 5-26, Jul 10, Jul 24; 1907: Jan } \\
\text { 8-15, Feb 5, Mar 5, Mar 26-Apr 2, May 14, Jun 11-25, Oct } \\
\text { 1-8, Nov 5 }\end{array}$ \\
\hline
\end{tabular}




\section{TABLE 3: NEWSPAPERS AND MANUSCRIPTS CHECKED}

\begin{tabular}{|c|c|}
\hline \multicolumn{2}{|l|}{ Santa Cruz County } \\
\hline Mountain Echo (Boulder Creek) & $\begin{array}{l}\text { 1906: Apr 21-May 19, [May 26-Jun } 2 \text { skimmed*], Jun } \\
\text { 9-23, [Jun 30 skimmed*], Jul 7-21; 1907: Jan 12, Feb 2, } \\
\text { Mar 9, Apr 6, Jun 8-29, Sept 28-Oct 5, Nov } 2 \\
\text { MISSING: 1906: Jul 14 } \\
\text { * For issues denoted as skimmed, only certain } \\
\text { sections of the newspaper -- wherein descriptions } \\
\text { of earthquakes appeared most commonly -- were } \\
\text { checked; there is a small possibility that some } \\
\text { earthquake articles were overlooked. }\end{array}$ \\
\hline Santa Cruz Morning Sentinel (Santa Cruz) & $\begin{array}{l}\text { 1906: Apr 19-27, May 3-6, May 9, May 12, May 18, Jun } \\
\text { 5-6, Jun 16, Jul 7, Jul 18, Jul 20-21; 1907: Jan 31-Feb 1, } \\
\text { Mar 3, Mar 31, Jun 5-6, Jun 11, Jun 14, Jun 22-23, Sept } \\
\text { 27, Oct 4, Oct } 30\end{array}$ \\
\hline Santa Cruz Surf (Santa Cruz) & $\begin{array}{l}\text { 1906: Apr 20-27, May 2-5, May 11, May 18, Jun 5, Jun 16, } \\
\text { Jul 7, Jul 17, Jul 20; 1907: Jan 8-9, Jan 31, Mar 2, } \\
\text { Mar 30-Apr 1, Jun 5, Jun 10, Jun 13, Jun 22, Sept 26, } \\
\text { Oct 3-4, Oct 29-30 }\end{array}$ \\
\hline Evening Pajaronian (Watsonville) & $\begin{array}{l}\text { 1906: Apr 18-27, May 2-5, May 7, May 9, May 11, May 18, } \\
\text { Jun 5, Jun 16, Jul 7, Jul 17-18, Jul 20; 1907: Jan 8-9, Jan } \\
\text { 31, Mar 2, Mar 30-Apr 1, Jun 5, Jun 10, Jun 13, Jun 22, } \\
\text { Sept 24, Sept 26, Oct 3-4, Oct 29-30 }\end{array}$ \\
\hline \multicolumn{2}{|l|}{ Shasta County } \\
\hline Courier Free-Press (Redding) & $\begin{array}{l}\text { 1906: Apr 18-Jun 20, [Jun 21-Jul } 11 \text { skimmed*], } \\
\text { Jul 12-14, [Jul 16-Dec 31 skimmed*]; } 1907: \text { Jan 2-4, } \\
\text { [Jan 5-12 skimmed*], Jan 14-16, [Jan 17 skimmed*], } \\
\text { Jan 18, [Jan 19-Feb 9 skimmed*], Feb 11-13, [Feb 14-18 } \\
\text { skimmed*], Feb 19-20, [Feb 21-May 15 skimmed*], } \\
\text { May 16, [May 17-Aug } 7 \text { skimmed*], Aug 8-24, Oct 7-8, } \\
\text { [Oct 9-12 skimmed*], Oct 14-16, [Oct 17-24 skimmed*], } \\
\text { Nov 22-23, [Nov 25-27 skimmed*]; } \\
\text { MISSING: 1906: Apr 30-May 1, Sept 5, Sept 27, Oct 1, } \\
\text { Nov 6, Nov 8, Dec 1, Dec 8, Dec 20, Dec } 24-25 ; 1907: \text { Mar } \\
\text { 2, Apr 6, Apr 18, Apr 23, Jul 2, Aug 6, Aug } 23 \text {, Nov } 20 \\
\text { * For issues denoted as skimmed, only certain } \\
\text { sections of the newspaper -- wherein descriptions } \\
\text { of earthquakes appeared most commonly -- were } \\
\text { checked; there is a small possibility that some } \\
\text { earthquake articles were overlooked. }\end{array}$ \\
\hline Searchlight (Redding) & $\begin{array}{l}\text { 1906: Apr 19-30, May 8, Jul 7-8, Jul 13-14; 1907: Jan 3, } \\
\text { Jan 17-20, Aug 9-15 }\end{array}$ \\
\hline \multicolumn{2}{|l|}{ Sierra County } \\
\hline Mountain Messenger (Downieville) & $\begin{array}{l}\text { 1906: Apr 21-28, May 19-26, Sept 15; 1907: Aug 17, } \\
\text { Nov 2-9 }\end{array}$ \\
\hline
\end{tabular}




\section{TABLE 3: NEWSPAPERS AND MANUSCRIPTS CHECKED}

\begin{tabular}{|c|c|}
\hline \multicolumn{2}{|l|}{ Siskiyou County } \\
\hline Dunsmuir News (Dunsmuir) & 1907: Jan 4-25, Aug 9-16 \\
\hline Scott Valley Advance (Etna) & 1906: Apr 19-May 3; 1907: Jan 3-10, Aug 8-22 \\
\hline Farmer And Miner (Fort Jones) & 1906: Apr 25-May 2; 1907: Jan 9, Aug 14-21 \\
\hline Sisson Headlight (Sisson / Mount Shasta) & 1906: Apr 26-May 3, Jul 5-19; 1907: Jan 3-10, Aug 8-22 \\
\hline Siskiyou News (Yreka) & $\begin{array}{l}\text { 1906: Apr 19-Jun 21, Jul 12-19, Aug 2-9, Sept 20-27, } \\
\text { Nov 8-15, Dec 27; 1907: Jan 3-24, Feb 14-28, May 23, } \\
\text { Aug 8-29, Oct 10-24, Nov } 28\end{array}$ \\
\hline Yreka Journal (Yreka) & 1906: Apr 25; 1907: Jan 2-9, Jan 23, Aug 14 \\
\hline \multicolumn{2}{|l|}{ Solano County } \\
\hline Dixon Tribune (Dixon) & $\begin{array}{l}\text { 1906: Apr 21-Jun 23; 1907: Feb 8, Mar 29-Apr 5, } \\
\text { May 17-24, Jun 7-Jul 5, Oct 4-11, Nov 1-8 }\end{array}$ \\
\hline Solano Republican (Fairfield) & $\begin{array}{l}\text { 1906: Apr 20-Jun 29; 1907: Feb 1, Mar 29-Apr 12, } \\
\text { May 17-24, Jun 7-Jul 5, Oct 4-11, Nov 1-8 }\end{array}$ \\
\hline Vacaville Reporter (Vacaville) & $\begin{array}{l}\text { 1906: Apr 21-Jun 23; 1907: Feb 2-9, Mar 30-Apr 6, } \\
\text { May 18-25, Jun 8-29, Oct 5-12, Nov 2-9 }\end{array}$ \\
\hline \multicolumn{2}{|l|}{ Sonoma County } \\
\hline Cloverdale Reveille (Cloverdale) & $\begin{array}{l}\text { 1906: Apr 21-May 19, Jun 2-9, Jun 23-Nov 3, Nov 17- } \\
\text { Dec 29; 1907: Jan 5-Feb 16, Apr 27, Jul 20, Aug 3, Sep 7- } \\
\text { Dec 28; 1908: Jan 4-11 }\end{array}$ \\
\hline Santa Rosa Press-Democrat (Santa Rosa) & $\begin{array}{l}\text { 1906: Apr 19, Apr 21*, Apr 23-28*, Apr 30-May 2*, } \\
\text { May 19, May 26, May 31, Jun 5-8, Jun 10, Jun 12-17, } \\
\text { June 19-24, June 26-30, Jul 1-4, Jul 12-14, Jul 20-22, } \\
\text { Jul 25-Aug 8, Aug 22-25, Aug 29-Sep 5, Sep 21-29, } \\
\text { Oct 9-11, Oct 17-20, Nov 6-7, Nov 15-18, Dec 1-2, Dec } \\
\text { 9-11, Dec 23-27; 1907: Jan 3-4, Jan 15-16, Jan 22-25, } \\
\text { Jan 31-Feb 1, Mar 26, Mar 31-Apr 2, May 14, Jun 5-7, } \\
\text { Jun 11, Jun 22-23, Aug 11-13, Oct 4-6 } \\
\text { * Issues dated 1906 Apr 21-May } 2 \text { were issued jointly } \\
\text { with the Santa Rosa Republican under the name } \\
\text { "Democrat-Republican." }\end{array}$ \\
\hline Santa Rosa Republican (Santa Rosa) & $\begin{array}{l}\text { 1906: Apr 18, Apr 21*, Apr 23-28*, Apr 30-May 2*, } \\
\text { May 18, May 21-Jun 11, Jun 14-Jul 17, Jul 19-26, } \\
\text { Jul 30-Sep 5, Sep 20-22, Sep 25-28, Oct 8-10, Oct 17-19, } \\
\text { Nov 5-7, Nov 15-17, Nov 30-Dec 3, Dec 8-11, Dec 24-26; } \\
\text { 1907: Jan 2-5, Jan 14-18, Jan 21-28, Jan 31-Feb 4, } \\
\text { Mar 25-28, Mar 30, May 13-16, Jun 6-14, Jun 22-26, } \\
\text { Aug 12-15, Sep 26-28, Oct 3-9, Oct 14-18, Oct 26-31, } \\
\text { Nov 22-25, Dec 31; 1908: Jan 2 } \\
\text { * Issues dated 1906 Apr 21-May } 2 \text { were issued jointly } \\
\text { with the Santa Rosa Press-Democrat under the } \\
\text { name "Democrat-Republican." }\end{array}$ \\
\hline Sonoma Index-Tribune (Sonoma) & $\begin{array}{l}1906 \text { Apr } 21 \text { - } 1908 \text { Jan } 4 \text {; } \\
\text { MISSING: a few scattered issues, incl. } 1906 \text { Sep } 8\end{array}$ \\
\hline Windsor Herald (Windsor) & 1906: Apr 28, May 12-19 \\
\hline
\end{tabular}




\section{TABLE 3: NEWSPAPERS AND MANUSCRIPTS CHECKED}

\begin{tabular}{|c|c|}
\hline \multicolumn{2}{|l|}{ Stanislaus County } \\
\hline Modesto Daily Evening News (Modesto) & $\begin{array}{l}\text { 1906: Apr 18-19, Apr 25-26, May 5, May 18; 1907: Oct 3, } \\
\text { Oct 29-30 }\end{array}$ \\
\hline Stanislaus County Weekly News (Modesto) & $\begin{array}{l}\text { 1906: Apr 20-27, May 11, May 25, Jun 8, Jun 22; } 1907 \text { : } \\
\text { Feb 1, Jun } 7\end{array}$ \\
\hline \multicolumn{2}{|l|}{ Sutter County } \\
\hline Sutter County Farmer (Yuba City) & $\begin{array}{l}\text { 1906: Apr 20-27, May 18-25; 1907: Jun 7-14, Aug 16, } \\
\text { Nov 1-8 }\end{array}$ \\
\hline Sutter Independent (Yuba City) & $\begin{array}{l}\text { 1906: Apr 19-26, May 17-24; 1907: Jun 6-13, Aug 15, } \\
\text { Oct 31-Nov } 7\end{array}$ \\
\hline \multicolumn{2}{|l|}{ Tehama County } \\
\hline Corning Observer (Corning) & $\begin{array}{l}\text { 1906: Apr 19-Jun 21, Jul 26, Dec 6; 1907: Jan 17-24, } \\
\text { Aug 8-15, Oct 10-17, Nov } 28\end{array}$ \\
\hline Daily People's Cause (Red Bluff) & 1906: Apr 18-25 \\
\hline Weekly People's Cause (Red Bluff) & 1907: Aug 10-24 \\
\hline Red Bluff Daily News (Red Bluff) & $\begin{array}{l}1906 \text { Apr } 19 \text { - } 1907 \text { Dec } 31 \\
\text { MISSING: a few scattered issues }\end{array}$ \\
\hline \multicolumn{2}{|l|}{ Trinity County } \\
\hline Weekly Trinity Journal (Weaverville) & $\begin{array}{l}1906 \text { Apr } 21 \text { - } 1907 \text { Mar 9; scattered issues checked } \\
\text { thereafter, through } 1907 \text { Dec } 7\end{array}$ \\
\hline \multicolumn{2}{|l|}{ Tulare County } \\
\hline Alta Advocate (Dinuba) & 1907: Jun 7, Sept 24-27 \\
\hline Exeter Sun (Exeter) & $\begin{array}{l}\text { 1906: Apr 19-May 24, Jun 7, Jun 21, Jul 5, Jul 26-Aug 9, } \\
\text { Aug 23, Oct 18, Nov } 16\end{array}$ \\
\hline Lindsay Gazette (Lindsay) & $\begin{array}{l}\text { 1906: Apr 20-27, May 18-25, Jul 13, Dec 7-14; } 1907 \text { : } \\
\text { Jun 7, Sept } 27\end{array}$ \\
\hline Daily Visalia Delta (Visalia) & $\begin{array}{l}\text { 1906: Apr 19-20, May 18, Jul 7-8, Dec 7-8; 1907: Jun 5-6, } \\
\text { Sept } 24\end{array}$ \\
\hline Tulare County Times (Visalia) & $\begin{array}{l}\text { 1906: Apr 19-26, May 24, Jul 12, Dec 13; 1907: Jun 6, } \\
\text { Sept } 26\end{array}$ \\
\hline Visalia Daily Times (Visalia) & 1906: Apr 18, Apr 21, Apr 23-24 \\
\hline Visalia Morning Courier (Visalia) & 1906: Apr 19-20, May 18 \\
\hline
\end{tabular}




\section{TABLE 3: NEWSPAPERS AND MANUSCRIPTS CHECKED}

\begin{tabular}{|c|c|}
\hline \multicolumn{2}{|l|}{ Tuolumne County } \\
\hline Tuolumne Prospector (Groveland) & 1906: Apr 28, May 19, Jun 9; 1907: Jun 8, Nov 2 \\
\hline Mother Lode Magnet (Jamestown) & $\begin{array}{l}\text { 1906: Apr 18-May 2, May 23, Jun 6; 1907: Jun 5, Oct 9, } \\
\text { Oct 30-Nov } 6\end{array}$ \\
\hline Mother Lode Banner / The Banner (Sonora) & 1906: Apr 20-27, May 18, Jun 8; 1907: Jun 7, Nov 1 \\
\hline Tuolumne Independent (Sonora) & $\begin{array}{l}\text { 1906: Apr 21-28, May 19, Jun 9; 1907: Jun 8, Oct 5, } \\
\text { Nov } 2\end{array}$ \\
\hline Union Democrat (Sonora) & $\begin{array}{l}\text { 1906: Apr 21-28, May 19, Jun 9; 1907: Jun 8, Oct 5, } \\
\text { Nov } 2\end{array}$ \\
\hline \multicolumn{2}{|l|}{ Ventura County } \\
\hline The Ojai (Nordhoff) & $\begin{array}{l}\text { 1906: Apr 21, May 19, Jul 7-14, Dec 8; 1907: May 25, } \\
\text { Jun 8, Sept 21-28 }\end{array}$ \\
\hline Oxnard Courier (Oxnard) & 1907: Jun 7, Sept 20-27 \\
\hline Santa Paula Chronicle (Santa Paula) & $\begin{array}{l}\text { 1906: May 24, Jul 13, Dec 7-14; 1907: May 24, Jun 7, } \\
\text { Sept } 27\end{array}$ \\
\hline Daily Free Press (Ventura) & 1906: Apr 18-19, Jul 7 \\
\hline Ventura Free Press (Ventura) & $\begin{array}{l}\text { 1906: Apr 20, May 18-25, Jul 6-13, Dec 7-14; 1907: } \\
\text { May 24, Jun 7, Sept 20-27 }\end{array}$ \\
\hline Ventura Daily Democrat (Ventura) & $\begin{array}{l}\text { 1906: Apr 19-20, May 18-19, Jul 7-8, Dec 7-9; 1907: May } \\
\text { 22-23, Sept 20, Sept } 24\end{array}$ \\
\hline \multicolumn{2}{|l|}{ Yolo County } \\
\hline Winters Express (Winters) & $\begin{array}{l}\text { 1906: Apr 20-Jun 22; 1907: Feb 1-8, Mar 29-Apr 12, } \\
\text { May 17-24, Jun 7-Jul 5, Aug 16-23, Oct 4-11, Nov 1-8 }\end{array}$ \\
\hline Home Alliance (Woodland) & $\begin{array}{l}\text { 1906: Apr 20-Jun 28; 1907: Jan 31-Feb 7, Mar 28- } \\
\text { Apr 11, May 16-23, Jun 6-Jul 4, Aug 15-22, Oct 3-10, } \\
\text { Oct 31-Nov } 7\end{array}$ \\
\hline Woodland Daily Democrat (Woodland) & $\begin{array}{l}\text { 1906: Apr 18-27, May 5-9, May 14-19, May 31-Jun 2, } \\
\text { Jun 4-6, Jun 15-18; 1907: Jan 31-Feb 2, Mar 25-26, } \\
\text { Mar 30-Apr 1, May 13-14, Jun 5-7, Jun 10-12, Jun 22-24, } \\
\text { Aug 12-13, Oct 3-5, Oct 29-31 }\end{array}$ \\
\hline \multicolumn{2}{|l|}{ Yuba County } \\
\hline Marysville Daily Appeal (Marysville) & $\begin{array}{l}\text { 1906: Apr 19-26, May 15-20; 1907: Jun 5-8, Aug 11-14, } \\
\text { Oct 30-Nov } 1\end{array}$ \\
\hline
\end{tabular}




\section{TABLE 3: NEWSPAPERS AND MANUSCRIPTS CHECKED}

Coconino County, AZ

Coconino Sun (Flagstaff)

1906: Apr 21

\section{Gila County, AZ}

Arizona Silver Belt (Globe)

1906: Apr 19-26

\section{Maricopa County, AZ}

Arizona Gazette (Phoenix)

Arizona Republican (Phoenix)
1906: Apr 18-20

1906: Apr 18-21, [Apr 22-26 skimmed*]

* For issues denoted as skimmed, only headlines were read; there is a small possibility that some news of earthquakes was overlooked.

Pima County, AZ

Arizona Daily Star (Tucson)

1906: Apr 18-21

Tucson Citizen (Tucson)

1906: Apr 18-19

\section{Pinal County, AZ}

Arizona Blade and the Florence Tribune (Florence)

1906: Apr 21-28

Yavapai County, AZ

Arizona Journal-Miner (Prescott)

Prescott Morning Courier (Prescott)
1906: Apr 19-20

1906: Apr 19, Apr 21

\section{Yuma County, AZ}




\section{TABLE 3: NEWSPAPERS AND MANUSCRIPTS CHECKED}

Carson City, NV

Carson City News (Carson City)

1906: Apr 18-23

Carson Weekly (Carson City)

1906: Apr 23

Morning Appeal (Carson City)

1906: Apr 19-22

\section{Churchill County, NV}

Churchill Standard (Fallon)

1906: Apr 21-28

\section{Douglas County, NV}

Record-Courier (Gardnerville)

\section{Lyon County, NV}

Lyon County Times (Yerington)

1906: Apr 21-28

\section{Pershing County, NV}

Lovelock Tribune (Lovelock)

1906: Apr 20-27

\section{Storey County, NV}

Daily Territorial Enterprise (Virginia City)

1906: Apr 19-22

Virginia Evening Chronicle (Virginia City)

1906: Apr 18-23

\section{Washoe County, NV}

Daily Nevada State Journal (Reno)

Reno Evening Gazette (Reno)

Nevada Forum (Sparks)
1906: Apr 18 "Extra", Apr 19-22

1906: Apr 18-23

1906: Apr 18-23 


\section{TABLE 3: NEWSPAPERS AND MANUSCRIPTS CHECKED}

\begin{tabular}{|c|c|}
\hline \multicolumn{2}{|l|}{ Coos County, OR } \\
\hline Bandon Recorder (Bandon) & 1906: Apr 19-May 3 \\
\hline Coquille Herald (Coquille) & 1906: Apr 18-May 2 \\
\hline Weekly Coast Mail (Marshfield) & 1906: Apr 21-May 5 \\
\hline \multicolumn{2}{|l|}{ Curry County, OR } \\
\hline Port Orford Tribune (Port Orford) & $\begin{array}{l}\text { 1906: Apr 18- Jun 20, Aug 1-8, Nov 7-14, Dec 26; 1907: } \\
\text { Jan 2, Jan 16-23, Feb 13-20, May 22, Aug 14-28, Oct 9-30, } \\
\text { Nov 27, Dec 4; 1908: Jan 1-8 }\end{array}$ \\
\hline \multicolumn{2}{|l|}{ Douglas County, OR } \\
\hline Roseburg Twice A Week Review (Roseburg) & 1906: Apr 19-30 \\
\hline Umpqua Valley News (Roseburg) & 1906: Apr 19-30 \\
\hline \multicolumn{2}{|l|}{ Jackson County, OR } \\
\hline Ashland Tidings (Ashland) & $\begin{array}{l}\text { 1906: Apr 19-Jun 14; 1907: Jan 14-21, Feb 14-18; } \\
\text { Aug 8-29; Oct 10-21; Nov 25-28 }\end{array}$ \\
\hline Valley Record (Ashland) & $\begin{array}{l}\text { 1906: Apr 19-Jun 14; 1907: Jan 2-23, Feb 13-20; } \\
\text { Aug 7-28; Oct 9-23; Nov } 27\end{array}$ \\
\hline Medford Mail (Medford) & $\begin{array}{l}\text { 1906: Apr 20-Jun 8, Aug 3; 1907: Jan 4-18, Feb 15, } \\
\text { Aug 9-23, Oct 11-18, Nov } 29\end{array}$ \\
\hline \multicolumn{2}{|l|}{ Josephine County, OR } \\
\hline Oregon Observer (Grants Pass) & 1907: Aug 7-28, Oct 9-30, Nov 27 \\
\hline Rogue River Courier (Grants Pass) & 1906: Apr 27-May 4; 1907: Aug 16 \\
\hline \multicolumn{2}{|l|}{ Klamath County, OR } \\
\hline Klamath Falls Express (Klamath Falls) & 1907: Jan 3-24, Feb 14-21, Apr 11, Aug 15-29 \\
\hline
\end{tabular}




\section{TABLE 3: NEWSPAPERS AND MANUSCRIPTS CHECKED}

\begin{tabular}{|c|c|}
\hline \multicolumn{2}{|l|}{ Lake County, OR } \\
\hline Lake County Examiner (Lakeview) & 1906: Apr 19-26 \\
\hline \multicolumn{2}{|l|}{ Lane County, OR } \\
\hline Eugene Daily Guard (Eugene) & 1906: Apr 18, Apr 23-26 \\
\hline Morning Register (Eugene) & 1906: Apr 19, Apr 24-26 \\
\hline \multicolumn{2}{|l|}{ Multnomah County, OR } \\
\hline Morning Oregonian (Portland) & $\begin{array}{l}\text { 1906: [Apr 18-22 skimmed*], Apr 23, [Apr 24-26 } \\
\text { skimmed*] } \\
\text { * For issues denoted as skimmed, only headlines were } \\
\text { read; there is a small possibility that some news of } \\
\text { earthquakes was overlooked. }\end{array}$ \\
\hline Oregon Daily Journal (Portland) & $\begin{array}{l}\text { 1906: [Apr 18-22 skimmed*], Apr 23-25, [Apr } 26 \\
\text { skimmed*] } \\
\text { * For issues denoted as skimmed, only headlines were } \\
\text { read; there is a small possibility that some news of } \\
\text { earthquakes was overlooked. }\end{array}$ \\
\hline \multicolumn{2}{|l|}{ Baja California Norte, MEXICO } \\
\hline Periódico Oficial (Ensenada) & 1906: Apr 25-May 5 \\
\hline
\end{tabular}


TABLE 4: COORDINATES FOR LOCATIONS IN TABLES 1-2 AND 5-15

\begin{tabular}{|c|c|c|c|c|c|}
\hline Location & County & State & Latitude (N) & Longitude (W) & Source \\
\hline Alameda & Alameda & California & $37^{\circ} 45^{\prime} 55^{\prime \prime}$ & $122^{\circ} 14^{\prime} 26^{\prime \prime}$ & USGS GNIS \\
\hline $\begin{array}{c}\text { Alameda } \\
\text { (Alameda Pier) }\end{array}$ & Alameda & California & $37^{\circ} 47^{\prime} 28^{\prime \prime}$ & $122^{\circ} 16^{\prime} 32^{\prime \prime}$ & USGS GNIS \\
\hline Berkeley & Alameda & California & $37^{\circ} 52^{\prime} 18^{\prime \prime}$ & $122^{\circ} 16^{\prime} 18^{\prime \prime}$ & USGS GNIS \\
\hline Dimond & Alameda & California & $37^{\circ} 47^{\prime} 58^{\prime \prime}$ & $122^{\circ} 13^{\prime} 00^{\prime \prime}$ & $\begin{array}{c}\text { USGS GNIS; } \\
\text { Durham (1998) }\end{array}$ \\
\hline Emeryville & Alameda & California & $37^{\circ} 49^{\prime} 53^{\prime \prime}$ & $122^{\circ} 17^{\prime} 03^{\prime \prime}$ & USGS GNIS \\
\hline Livermore & Alameda & California & $37^{\circ} 40^{\prime} 55^{\prime \prime}$ & $121^{\circ} 46^{\prime} 01^{\prime \prime}$ & USGS GNIS \\
\hline Mills College & Alameda & California & $37^{\circ} 46^{\prime} 47^{\prime \prime}$ & $122^{\circ} 10^{\prime} 51^{\prime \prime}$ & USGS GNIS \\
\hline $\begin{array}{c}\text { Niles } \\
\text { (now Niles } \\
\text { District) }\end{array}$ & Alameda & California & $37^{\circ} 34^{\prime} 44^{\prime \prime}$ & $121^{\circ} 58^{\prime} 36^{\prime \prime}$ & $\begin{array}{c}\text { USGS GNIS; } \\
\text { Durham (1998) }\end{array}$ \\
\hline Oakland & Alameda & California & $37^{\circ} 48^{\prime} 16^{\prime \prime}$ & $122^{\circ} 16^{\prime} 11^{\prime \prime}$ & USGS GNIS \\
\hline Pleasanton & Alameda & California & $37^{\circ} 39^{\prime} 45^{\prime \prime}$ & $121^{\circ} 52^{\prime} 25^{\prime \prime}$ & USGS GNIS \\
\hline Chico & Butte & California & $39^{\circ} 43^{\prime} 43^{\prime \prime}$ & $121^{\circ} 50^{\prime} 11^{\prime \prime}$ & USGS GNIS \\
\hline Oroville & Butte & California & $39^{\circ} 30^{\prime} 50^{\prime \prime}$ & $121^{\circ} 33^{\prime} 19^{\prime \prime}$ & USGS GNIS \\
\hline Colusa & Colusa & California & $39^{\circ} 12^{\prime} 52^{\prime \prime}$ & $122^{\circ} 00^{\prime} 30^{\prime \prime}$ & USGS GNIS \\
\hline Antioch & Contra Costa & California & $38^{\circ} 00^{\prime} 18^{\prime \prime}$ & $121^{\circ} 48^{\prime} 17^{\prime \prime}$ & USGS GNIS \\
\hline Byron & Contra Costa & California & $37^{\circ} 52^{\prime} 02^{\prime \prime}$ & $121^{\circ} 38^{\prime} 13^{\prime \prime}$ & USGS GNIS \\
\hline Crockett & Contra Costa & California & $38^{\circ} 03^{\prime} 09^{\prime \prime}$ & $122^{\circ} 12^{\prime} 43^{\prime \prime}$ & USGS GNIS \\
\hline Martinez & Contra Costa & California & $38^{\circ} 01^{\prime} 10^{\prime \prime}$ & $122^{\circ} 07^{\prime} 59^{\prime \prime}$ & USGS GNIS \\
\hline Oakley & Contra Costa & California & $37^{\circ} 59^{\prime} 51^{\prime \prime}$ & $121^{\circ} 42^{\prime} 41^{\prime \prime}$ & USGS GNIS \\
\hline Richmond & Contra Costa & California & $37^{\circ} 56^{\prime} 09^{\prime \prime}$ & $122^{\circ} 20^{\prime} 48^{\prime \prime}$ & USGS GNIS \\
\hline Crescent City & Del Norte & California & $41^{\circ} 45^{\prime} 22^{\prime \prime}$ & $124^{\circ} 12^{\prime} 02^{\prime \prime}$ & USGS GNIS \\
\hline Georgetown & El Dorado & California & $38^{\circ} 54^{\prime} 25^{\prime \prime}$ & $120^{\circ} 50^{\prime} 15^{\prime \prime}$ & USGS GNIS \\
\hline Coalinga & Fresno & California & $36^{\circ} 08^{\prime} 23^{\prime \prime}$ & $120^{\circ} 21^{\prime} 33^{\prime \prime}$ & USGS GNIS \\
\hline Fresno & Fresno & California & $36^{\circ} 44^{\prime} 52^{\prime \prime}$ & $119^{\circ} 46^{\prime} 17^{\prime \prime}$ & USGS GNIS \\
\hline Willows & Glenn & California & $39^{\circ} 31^{\prime} 28^{\prime \prime}$ & $122^{\circ} 11^{\prime} 33^{\prime \prime}$ & USGS GNIS \\
\hline $\begin{array}{l}\text { Scotia road, } \\
\text { between Alton } \\
\text { and Fortuna }\end{array}$ & Humboldt & California & $40^{\circ} 33^{\prime} 10^{\prime \prime}$ & $124^{\circ} 08^{\prime} 40^{\prime \prime}$ & $\begin{array}{l}\text { Fortuna (1972) } \\
\text { 7.5' Topo Quad }\end{array}$ \\
\hline \multicolumn{6}{|c|}{ See the note about this location in Table 1, following the citation for the event at 01:10 on 23 Apr 1906.} \\
\hline Arcata & Humboldt & California & $40^{\circ} 52^{\prime} 00^{\prime \prime}$ & $124^{\circ} 04^{\prime} 54^{\prime \prime}$ & USGS GNIS \\
\hline Blocksburg & Humboldt & California & $40^{\circ} 16^{\prime} 34^{\prime \prime}$ & $123^{\circ} 38^{\prime} 07^{\prime \prime}$ & USGS GNIS \\
\hline Blue Lake & Humboldt & California & $40^{\circ} 52^{\prime} 59^{\prime \prime}$ & $123^{\circ} 58^{\prime} 58^{\prime \prime}$ & USGS GNIS \\
\hline Briceland & Humboldt & California & $40^{\circ} 06^{\prime} 29^{\prime \prime}$ & $123^{\circ} 53^{\prime} 56^{\prime \prime}$ & USGS GNIS \\
\hline $\begin{array}{c}\text { Cape Mendocino } \\
\text { (Lighthouse) }\end{array}$ & Humboldt & California & $40^{\circ} 26^{\prime} 25^{\prime \prime}$ & $124^{\circ} 24^{\prime} 21^{\prime \prime}$ & USGS GNIS \\
\hline Eureka & Humboldt & California & $40^{\circ} 48^{\prime} 08^{\prime \prime}$ & $124^{\circ} 09^{\prime} 45^{\prime \prime}$ & USGS GNIS \\
\hline Falk & Humboldt & California & $40^{\circ} 41^{\prime} 05^{\prime \prime}$ & $124^{\circ} 07^{\prime} 26^{\prime \prime}$ & USGS GNIS \\
\hline Ferndale & Humboldt & California & $40^{\circ} 34^{\prime} 35^{\prime \prime}$ & $124^{\circ} 15^{\prime} 46^{\prime \prime}$ & USGS GNIS \\
\hline Fieldbrook & Humboldt & California & $40^{\circ} 57^{\prime} 57^{\prime \prime}$ & $124^{\circ} 02^{\prime} 04^{\prime \prime}$ & USGS GNIS \\
\hline
\end{tabular}


TABLE 4: COORDINATES FOR LOCATIONS IN TABLES 1-2 AND 5-15

\begin{tabular}{|c|c|c|c|c|c|}
\hline Location & County & State & Latitude (N) & Longitude (W) & Source \\
\hline Fields Landing & Humboldt & California & $40^{\circ} 43^{\prime} 29^{\prime \prime}$ & $124^{\circ} 12^{\prime} 50^{\prime \prime}$ & USGS GNIS \\
\hline Fortuna & Humboldt & California & $40^{\circ} 35^{\prime} 54^{\prime \prime}$ & $124^{\circ} 09^{\prime} 22^{\prime \prime}$ & USGS GNIS \\
\hline Garberville & Humboldt & California & $40^{\circ} 06^{\prime} 01^{\prime \prime}$ & $123^{\circ} 47^{\prime} 38^{\prime \prime}$ & USGS GNIS \\
\hline Glendale & Humboldt & California & $40^{\circ} 54^{\prime} 00^{\prime \prime}$ & $124^{\circ} 00^{\prime} 57^{\prime \prime}$ & USGS GNIS \\
\hline Grizzly Bluff & Humboldt & California & $40^{\circ} 33^{\prime} 45^{\prime \prime}$ & $124^{\circ} 10^{\prime} 15^{\prime \prime}$ & Durham (1998) \\
\hline Hoopa & Humboldt & California & $41^{\circ} 03^{\prime} 02^{\prime \prime}$ & $123^{\circ} 40^{\prime} 23^{\prime \prime}$ & USGS GNIS \\
\hline Hydesville & Humboldt & California & $40^{\circ} 32^{\prime} 52^{\prime \prime}$ & $124^{\circ} 05^{\prime} 46^{\prime \prime}$ & USGS GNIS \\
\hline Orick & Humboldt & California & $41^{\circ} 17^{\prime} 13^{\prime \prime}$ & $124^{\circ} 03^{\prime} 31^{\prime \prime}$ & USGS GNIS \\
\hline Pepperwood & Humboldt & California & $40^{\circ} 26^{\prime} 46^{\prime \prime}$ & $123^{\circ} 59^{\prime} 30^{\prime \prime}$ & USGS GNIS \\
\hline Petrolia & Humboldt & California & $40^{\circ} 19^{\prime} 32^{\prime \prime}$ & $124^{\circ} 17^{\prime} 09^{\prime \prime}$ & USGS GNIS \\
\hline Reed Mountain & Humboldt & California & $40^{\circ} 01^{\prime} 34^{\prime \prime}$ & $123^{\circ} 44^{\prime} 38^{\prime \prime}$ & USGS GNIS \\
\hline Rocky Glen & Humboldt & California & $40^{\circ} 11^{\prime} 14^{\prime \prime}$ & $123^{\circ} 46^{\prime} 13^{\prime \prime}$ & USGS GNIS \\
\hline Ryan Slough & Humboldt & California & $40^{\circ} 47^{\prime} 18^{\prime \prime}$ & $124^{\circ} 06^{\prime} 50^{\prime \prime}$ & USGS GNIS \\
\hline Stone Lagoon & Humboldt & California & $41^{\circ} 14^{\prime} 38^{\prime \prime}$ & $124^{\circ} 05^{\prime} 36^{\prime \prime}$ & USGS GNIS \\
\hline $\begin{array}{c}\text { Trinidad Head } \\
\text { (Lighthouse) }\end{array}$ & Humboldt & California & $41^{\circ} 03^{\prime} 07^{\prime \prime}$ & $124^{\circ} 09^{\prime} 01^{\prime \prime}$ & USGS GNIS \\
\hline Upper Mattole & Humboldt & California & $40^{\circ} 15^{\prime} 30^{\prime \prime}$ & $124^{\circ} 11^{\prime} 30^{\prime \prime}$ & Durham (1998) \\
\hline Waddington & Humboldt & California & $40^{\circ} 34^{\prime} 02^{\prime \prime}$ & $124^{\circ} 12^{\prime} 02^{\prime \prime}$ & USGS GNIS \\
\hline Brawley & Imperial & California & $32^{\circ} 58^{\prime} 43^{\prime \prime}$ & $115^{\circ} 31^{\prime} 46^{\prime \prime}$ & USGS GNIS \\
\hline Calexico & Imperial & California & $32^{\circ} 40^{\prime} 44^{\prime \prime}$ & $115^{\circ} 29^{\prime} 53^{\prime \prime}$ & USGS GNIS \\
\hline El Centro & Imperial & California & $32^{\circ} 47^{\prime} 31^{\prime \prime}$ & $115^{\circ} 33^{\prime} 44^{\prime \prime}$ & USGS GNIS \\
\hline Heber & Imperial & California & $32^{\circ} 43^{\prime} 51^{\prime \prime}$ & $115^{\circ} 31^{\prime} 44^{\prime \prime}$ & USGS GNIS \\
\hline Holtville & Imperial & California & $32^{\circ} 48^{\prime} 40^{\prime \prime}$ & $115^{\circ} 22^{\prime} 46^{\prime \prime}$ & USGS GNIS \\
\hline Imperial & Imperial & California & $32^{\circ} 50^{\prime} 51^{\prime \prime}$ & $115^{\circ} 34^{\prime} 07^{\prime \prime}$ & USGS GNIS \\
\hline $\begin{array}{l}\text { Imperial Junction } \\
\text { (now Niland) }\end{array}$ & Imperial & California & $33^{\circ} 14^{\prime} 24^{\prime \prime}$ & $115^{\circ} 31^{\prime} 05^{\prime \prime}$ & $\begin{array}{c}\text { USGS GNIS; } \\
\text { Durham (1998) }\end{array}$ \\
\hline Pope & Imperial & California & $33^{\circ} 21^{\prime} 57^{\prime \prime}$ & $115^{\circ} 43^{\prime} 19^{\prime \prime}$ & USGS GNIS \\
\hline $\begin{array}{l}2 \text { mi. east of Pope } \\
\text { (along railroad) }\end{array}$ & Imperial & California & $33^{\circ} 22^{\prime} 32^{\prime \prime}$ & $115^{\circ} 41^{\prime} 18^{\prime \prime}$ & $\begin{array}{l}\text { Frink (1992) \& } \\
\text { Frink NW (1992) } \\
\text { 7.5' Topo Quads }\end{array}$ \\
\hline Silsbee & Imperial & California & $32^{\circ} 45^{\prime} 33^{\prime \prime}$ & $115^{\circ} 38^{\prime} 14^{\prime \prime}$ & $\begin{array}{l}\text { USGS GNIS; } \\
\text { Durham (1998); } \\
\text { USGS (1908); } \\
\text { CSMB (1909); } \\
\text { Brawley (1945) } \\
\text { 15' Topo Quad; } \\
\text { Seeley (1976) } \\
\text { 7.5' Topo Quad }\end{array}$ \\
\hline \multicolumn{6}{|c|}{$\begin{array}{l}\text { United States Geological Survey's (1908) map and California State Mining Bureau's (1909) map show a place } \\
\text { called Silsbee located about 5-6 miles WSW of El Centro, although neither map is precise in its location. Brawley } \\
\text { (1945) 15' Topo Quad [War Department, Corps of Engineers, U. S. Army] and Seeley (1976) 7.5' Topo Quad } \\
\text { do not show Silsbee, but they do show the (now abandoned) Silsbee school, situated } 5 \text { miles WSW of El Centro; } \\
\text { Brawley (1945) 15' Topo Quad shows Silsbee school amidst a small cluster of buildings. Durham (1998) notes } \\
\text { that Silsbee post office was destroyed by overflow from the Colorado River, although he does not specify when } \\
\text { this occurred. Because we could not obtain a precise location for Silsbee, its location will be approximated by } \\
\text { that of Silsbee school. }\end{array}$} \\
\hline Bakersfield & Kern & California & $35^{\circ} 22^{\prime} 24^{\prime \prime}$ & $119^{\circ} 01^{\prime} 04^{\prime \prime}$ & USGS GNIS \\
\hline
\end{tabular}


TABLE 4: COORDINATES FOR LOCATIONS IN TABLES 1-2 AND 5-15

\begin{tabular}{|c|c|c|c|c|c|}
\hline Location & County & State & Latitude (N) & Longitude (W) & Source \\
\hline Hanford & Kings & California & $36^{\circ} 19^{\prime} 39^{\prime \prime}$ & $119^{\circ} 38^{\prime} 41^{\prime \prime}$ & USGS GNIS \\
\hline Lemoore & Kings & California & $36^{\circ} 18^{\prime} 03^{\prime \prime}$ & $119^{\circ} 46^{\prime} 55^{\prime \prime}$ & USGS GNIS \\
\hline Bartlett Springs & Lake & California & $39^{\circ} 11^{\prime} 02^{\prime \prime}$ & $122^{\circ} 42^{\prime} 12^{\prime \prime}$ & USGS GNIS \\
\hline $\begin{array}{c}\text { Cache Creek, } \\
\text { about } 4 \text { miles east } \\
\text { of the junction of } \\
\text { North Fork with } \\
\text { Cache Creek }\end{array}$ & Lake & California & $38^{\circ} 57^{\prime} 18^{\prime \prime}$ & $122^{\circ} 27^{\prime} 03^{\prime \prime}$ & $\begin{array}{l}\text { Wilson Valley } \\
\text { (1958) \& Lower } \\
\text { Lake (1993) } \\
\text { 7.5' Topo Quads }\end{array}$ \\
\hline Kelseyville & Lake & California & $38^{\circ} 58^{\prime} 41^{\prime \prime}$ & $122^{\circ} 50^{\prime} 18^{\prime \prime}$ & USGS GNIS \\
\hline Lakeport & Lake & California & $39^{\circ} 02^{\prime} 35^{\prime \prime}$ & $122^{\circ} 54^{\prime} 53^{\prime \prime}$ & USGS GNIS \\
\hline Middletown & Lake & California & $38^{\circ} 45^{\prime} 09^{\prime \prime}$ & $122^{\circ} 36^{\prime} 50^{\prime \prime}$ & USGS GNIS \\
\hline Quicksilver & Lake & California & $38^{\circ} 42^{\prime} 50^{\prime \prime}$ & $122^{\circ} 38^{\prime} 27^{\prime \prime}$ & $\begin{array}{l}\text { Durham (1998); } \\
\text { CSMB (1909); } \\
\text { Calistoga (1943) } \\
\text { 15' Topo Quad }\end{array}$ \\
\hline
\end{tabular}

California State Mining Bureau's (1909) map shows a place called Quicksilver located just south of Middletown near the Lake-Sonoma County line, although the location is not precise. Calistoga (1943) 15' Topo Quad does not show Quicksliver, but it does show a "Great Western mine" in the same general area (within a mile or two). The location of Quicksilver will be approximated by that of the Great Western mine.

\begin{tabular}{|c|c|c|c|c|c|}
\hline Upper Lake & Lake & California & $39^{\circ} 09^{\prime} 53^{\prime \prime}$ & $122^{\circ} 54^{\prime} 34^{\prime \prime}$ & USGS GNIS \\
\hline $\begin{array}{c}\text { Avalon } \\
\text { Catalina Island })\end{array}$ & Los Angeles & California & $33^{\circ} 20^{\prime} 34^{\prime \prime}$ & $118^{\circ} 19^{\prime} 37^{\prime \prime}$ & USGS GNIS \\
\hline Glendora & Los Angeles & California & $34^{\circ} 08^{\prime} 10^{\prime \prime}$ & $117^{\circ} 51^{\prime} 52^{\prime \prime}$ & USGS GNIS \\
\hline Hollywood & Los Angeles & California & $34^{\circ} 05^{\prime} 54^{\prime \prime}$ & $118^{\circ} 19^{\prime} 33^{\prime \prime}$ & USGS GNIS \\
\hline Long Beach & Los Angeles & California & $33^{\circ} 46^{\prime} 01^{\prime \prime}$ & $118^{\circ} 11^{\prime} 18^{\prime \prime}$ & USGS GNIS \\
\hline $\begin{array}{c}\text { Lordsburg } \\
\text { now La Verne) }\end{array}$ & Los Angeles & California & $34^{\circ} 06^{\prime} 03^{\prime \prime}$ & $117^{\circ} 46^{\prime} 01^{\prime \prime}$ & $\begin{array}{c}\text { USGS GNIS; } \\
\text { Durham (1998) }\end{array}$ \\
\hline Los Angeles & Los Angeles & California & $34^{\circ} 03^{\prime} 08^{\prime \prime}$ & $118^{\circ} 14^{\prime} 34^{\prime \prime}$ & USGS GNIS \\
\hline Monrovia & Los Angeles & California & $34^{\circ} 08^{\prime} 53^{\prime \prime}$ & $117^{\circ} 59^{\prime} 53^{\prime \prime}$ & USGS GNIS \\
\hline Ocean Park & Los Angeles & California & $34^{\circ} 00^{\prime} 08^{\prime \prime}$ & $118^{\circ} 28^{\prime} 58^{\prime \prime}$ & USGS GNIS \\
\hline Pasadena & Los Angeles & California & $34^{\circ} 08^{\prime} 52^{\prime \prime}$ & $118^{\circ} 08^{\prime} 37^{\prime \prime}$ & USGS GNIS \\
\hline Roberts Canyon & Los Angeles & California & $34^{\circ} 09^{\prime} 46^{\prime \prime}$ & $117^{\circ} 54^{\prime} 16^{\prime \prime}$ & $\begin{array}{c}\text { USGS GNIS; } \\
\text { Durham (1998); } \\
\text { Azusa (1953) \& } \\
\text { Glendora (1953) } \\
7.5^{\prime} \text { Topo Quads }\end{array}$ \\
\hline
\end{tabular}

See the note about Roberts Canyon in Table 2, following the citation for the event at 20:50 on 19 Apr 1906.

\begin{tabular}{|c|c|c|c|c|c|}
\hline San Pedro & Los Angeles & California & $33^{\circ} 44^{\prime} 09^{\prime \prime}$ & $118^{\circ} 17^{\prime} 29^{\prime \prime}$ & USGS GNIS \\
\hline Santa Monica & Los Angeles & California & $34^{\circ} 01^{\prime} 10^{\prime \prime}$ & $118^{\circ} 29^{\prime} 25^{\prime \prime}$ & USGS GNIS \\
\hline Sawtelle & Los Angeles & California & $34^{\circ} 01^{\prime} 50^{\prime \prime}$ & $118^{\circ} 27^{\prime} 45^{\prime \prime}$ & USGS GNIS \\
\hline $\begin{array}{c}\text { Soldiers Home } \\
\text { (now Veterans } \\
\text { Administration } \\
\text { land, west of } \\
\text { Westwood) }\end{array}$ & Los Angeles & California & $34^{\circ} 03^{\prime} 40^{\prime \prime}$ & $118^{\circ} 27^{\prime} 50^{\prime \prime}$ & $\begin{array}{c}\text { Beverly Hills } \\
(1995) 7.5^{\prime} \text { Topo } \\
\text { Quad }\end{array}$ \\
\hline Venice & Los Angeles & California & $33^{\circ} 59^{\prime} 27^{\prime \prime}$ & $118^{\circ} 27^{\prime} 33^{\prime \prime}$ & USGS GNIS \\
\hline Whittier & Los Angeles & California & $33^{\circ} 58^{\prime} 45^{\prime \prime}$ & $118^{\circ} 01^{\prime} 55^{\prime \prime}$ & USGS GNIS \\
\hline Bolinas & Marin & California & $37^{\circ} 54^{\prime} 34^{\prime \prime}$ & $122^{\circ} 41^{\prime} 07^{\prime \prime}$ & USGS GNIS \\
\hline
\end{tabular}


TABLE 4: COORDINATES FOR LOCATIONS IN TABLES 1-2 AND 5-15

\begin{tabular}{|c|c|c|c|c|c|}
\hline Location & County & State & Latitude (N) & Longitude (W) & Source \\
\hline Corte Madera & Marin & California & $37^{\circ} 55^{\prime} 32^{\prime \prime}$ & $122^{\circ} 31^{\prime} 35^{\prime \prime}$ & USGS GNIS \\
\hline Kentfield & Marin & California & $37^{\circ} 57^{\prime} 08^{\prime \prime}$ & $122^{\circ} 33^{\prime} 22^{\prime \prime}$ & USGS GNIS \\
\hline Larkspur & Marin & California & $37^{\circ} 56^{\prime} 03^{\prime \prime}$ & $122^{\circ} 32^{\prime} 03^{\prime \prime}$ & USGS GNIS \\
\hline Mill Valley & Marin & California & $37^{\circ} 54^{\prime} 22^{\prime \prime}$ & $122^{\circ} 32^{\prime} 38^{\prime \prime}$ & USGS GNIS \\
\hline $\begin{array}{l}\text { Point Bonita } \\
\text { (Lighthouse) }\end{array}$ & Marin & California & $37^{\circ} 48^{\prime} 56^{\prime \prime}$ & $122^{\circ} 31^{\prime} 43^{\prime \prime}$ & USGS GNIS \\
\hline $\begin{array}{l}\text { Point Reyes } \\
\text { Lighthouse }\end{array}$ & Marin & California & $37^{\circ} 59^{\prime} 45^{\prime \prime}$ & $123^{\circ} 01^{\prime} 20^{\prime \prime}$ & USGS GNIS \\
\hline San Rafael & Marin & California & $37^{\circ} 58^{\prime} 25^{\prime \prime}$ & $122^{\circ} 31^{\prime} 48^{\prime \prime}$ & USGS GNIS \\
\hline Sausalito & Marin & California & $37^{\circ} 51^{\prime} 33^{\prime \prime}$ & $122^{\circ} 29^{\prime} 03^{\prime \prime}$ & USGS GNIS \\
\hline Tomales & Marin & California & $38^{\circ} 14^{\prime} 47^{\prime \prime}$ & $122^{\circ} 54^{\prime} 16^{\prime \prime}$ & USGS GNIS \\
\hline Branscomb & Mendocino & California & $39^{\circ} 39^{\prime} 13^{\prime \prime}$ & $123^{\circ} 37^{\prime} 28^{\prime \prime}$ & USGS GNIS \\
\hline Covelo & Mendocino & California & $39^{\circ} 47^{\prime} 35^{\prime \prime}$ & $123^{\circ} 14^{\prime} 49^{\prime \prime}$ & USGS GNIS \\
\hline Fort Bragg & Mendocino & California & $39^{\circ} 26^{\prime} 45^{\prime \prime}$ & $123^{\circ} 48^{\prime} 15^{\prime \prime}$ & USGS GNIS \\
\hline Laytonville & Mendocino & California & $39^{\circ} 41^{\prime} 18^{\prime \prime}$ & $123^{\circ} 28^{\prime} 54^{\prime \prime}$ & USGS GNIS \\
\hline Mendocino & Mendocino & California & $39^{\circ} 18^{\prime} 28^{\prime \prime}$ & $123^{\circ} 47^{\prime} 54^{\prime \prime}$ & USGS GNIS \\
\hline Point Arena & Mendocino & California & $38^{\circ} 54^{\prime} 32^{\prime \prime}$ & $123^{\circ} 41^{\prime} 31^{\prime \prime}$ & USGS GNIS \\
\hline $\begin{array}{l}\text { Point Arena } \\
\text { Lighthouse }\end{array}$ & Mendocino & California & $38^{\circ} 57^{\prime} 17^{\prime \prime}$ & $123^{\circ} 44^{\prime} 22^{\prime \prime}$ & USGS GNIS \\
\hline Potter Valley & Mendocino & California & $39^{\circ} 19^{\prime} 20^{\prime \prime}$ & $123^{\circ} 06^{\prime} 43^{\prime \prime}$ & USGS GNIS \\
\hline Ukiah & Mendocino & California & $39^{\circ} 09^{\prime} 01^{\prime \prime}$ & $123^{\circ} 12^{\prime} 24^{\prime \prime}$ & USGS GNIS \\
\hline Willits & Mendocino & California & $39^{\circ} 24^{\prime} 35^{\prime \prime}$ & $123^{\circ} 21^{\prime} 16^{\prime \prime}$ & USGS GNIS \\
\hline Los Banos & Merced & California & $37^{\circ} 03^{\prime} 30^{\prime \prime}$ & $120^{\circ} 50^{\prime} 56^{\prime \prime}$ & USGS GNIS \\
\hline Volta & Merced & California & $37^{\circ} 05^{\prime} 51^{\prime \prime}$ & $120^{\circ} 55^{\prime} 30^{\prime \prime}$ & USGS GNIS \\
\hline Canby & Modoc & California & $41^{\circ} 26^{\prime} 38^{\prime \prime}$ & $120^{\circ} 52^{\prime} 09^{\prime \prime}$ & USGS GNIS \\
\hline Corral de Tierra & Monterey & California & $36^{\circ} 34^{\prime} 12^{\prime \prime}$ & $121^{\circ} 43^{\prime} 53^{\prime \prime}$ & USGS GNIS \\
\hline Gonzales & Monterey & California & $36^{\circ} 30^{\prime} 24^{\prime \prime}$ & $121^{\circ} 26^{\prime} 36^{\prime \prime}$ & USGS GNIS \\
\hline Jamesburg & Monterey & California & $36^{\circ} 22^{\prime} 11^{\prime \prime}$ & $121^{\circ} 35^{\prime} 21^{\prime \prime}$ & USGS GNIS \\
\hline King City & Monterey & California & $36^{\circ} 12^{\prime} 46^{\prime \prime}$ & $121^{\circ} 07^{\prime} 30^{\prime \prime}$ & USGS GNIS \\
\hline Monterey & Monterey & California & $36^{\circ} 36^{\prime} 01^{\prime \prime}$ & $121^{\circ} 53^{\prime} 37^{\prime \prime}$ & USGS GNIS \\
\hline $\begin{array}{l}\text { Point Piños } \\
\text { (Lighthouse) }\end{array}$ & Monterey & California & $36^{\circ} 38^{\prime} 01^{\prime \prime}$ & $121^{\circ} 55^{\prime} 57^{\prime \prime}$ & USGS GNIS \\
\hline Salinas & Monterey & California & $36^{\circ} 40^{\prime} 40^{\prime \prime}$ & $121^{\circ} 39^{\prime} 16^{\prime \prime}$ & USGS GNIS \\
\hline San Lucas & Monterey & California & $36^{\circ} 07^{\prime} 44^{\prime \prime}$ & $121^{\circ} 01^{\prime} 10^{\prime \prime}$ & USGS GNIS \\
\hline $\begin{array}{l}\text { San Miguel } \\
\text { Canyon }\end{array}$ & Monterey & California & $36^{\circ} 45^{\prime} 59^{\prime \prime}$ & $121^{\circ} 40^{\prime} 12^{\prime \prime}$ & USGS GNIS \\
\hline Napa & Napa & California & $38^{\circ} 17^{\prime} 50^{\prime \prime}$ & $122^{\circ} 17^{\prime} 04^{\prime \prime}$ & USGS GNIS \\
\hline Napa Redwoods & Napa & California & $\begin{array}{c}38^{\circ} 21^{\prime} 50^{\prime \prime} \\
(?)\end{array}$ & $\begin{array}{c}122^{\circ} 24^{\prime} 53^{\prime \prime} \\
(?)\end{array}$ & $\begin{array}{l}\text { Durham (1998); } \\
\text { Sonoma (1978) } \\
\text { 7.5' Topo Quad }\end{array}$ \\
\hline
\end{tabular}

The coordinates are for a site called Redwood; it is not clear if this is the same location.

St. Helena

Napa

California

$38^{\circ} 30^{\prime} 19^{\prime \prime}$

$122^{\circ} 28^{\prime} 09^{\prime \prime}$

USGS GNIS 
TABLE 4: COORDINATES FOR LOCATIONS IN TABLES 1-2 AND 5-15

\begin{tabular}{|c|c|c|c|c|c|}
\hline Location & County & State & Latitude (N) & Longitude (W) & Source \\
\hline Yountville & Napa & California & $38^{\circ} 24^{\prime} 06^{\prime \prime}$ & $122^{\circ} 21^{\prime} 35^{\prime \prime}$ & USGS GNIS \\
\hline French Corral & Nevada & California & $39^{\circ} 18^{\prime} 22^{\prime \prime}$ & $121^{\circ} 09^{\prime} 37^{\prime \prime}$ & USGS GNIS \\
\hline Grass Valley & Nevada & California & $39^{\circ} 13^{\prime} 09^{\prime \prime}$ & $121^{\circ} 03^{\prime} 36^{\prime \prime}$ & USGS GNIS \\
\hline Nevada City & Nevada & California & $39^{\circ} 15^{\prime} 42^{\prime \prime}$ & $121^{\circ} 00^{\prime} 54^{\prime \prime}$ & USGS GNIS \\
\hline North San Juan & Nevada & California & $39^{\circ} 22^{\prime} 10^{\prime \prime}$ & $121^{\circ} 06^{\prime} 10^{\prime \prime}$ & USGS GNIS \\
\hline $\begin{array}{l}\text { Shady Creek } \\
\text { gravel mine }\end{array}$ & Nevada & California & $39^{\circ} 21^{\prime} 23^{\prime \prime}$ & $121^{\circ} 02^{\prime} 58^{\prime \prime}$ & $\begin{array}{c}\text { Nevada City } \\
\text { (1995) 7.5' Topo } \\
\text { Quad }\end{array}$ \\
\hline \multicolumn{6}{|c|}{$\begin{array}{l}\text { There are several gravel mines along Shady Creek between } 39^{\circ} 20^{\prime} 28^{\prime \prime}, 121^{\circ} 04^{\prime} 37^{\prime \prime} \text {, and } 39^{\circ} 21^{\prime} 53^{\prime \prime} \text {, } \\
121^{\circ} 01^{\prime} 16^{\prime \prime} ; \text { the coordinates listed above are those of one gravel mine approximately in the middle. }\end{array}$} \\
\hline $\begin{array}{l}\text { San Juan } \\
\text { Capistrano }\end{array}$ & Orange & California & $33^{\circ} 30^{\prime} 06^{\prime \prime}$ & $117^{\circ} 39^{\prime} 42^{\prime \prime}$ & USGS GNIS \\
\hline Santa Ana & Orange & California & $33^{\circ} 44^{\prime} 44^{\prime \prime}$ & $117^{\circ} 52^{\prime} 01^{\prime \prime}$ & USGS GNIS \\
\hline La Porte & Plumas & California & $39^{\circ} 40^{\prime} 56^{\prime \prime}$ & $120^{\circ} 58^{\prime} 59^{\prime \prime}$ & USGS GNIS \\
\hline Quincy & Plumas & California & $39^{\circ} 56^{\prime} 13^{\prime \prime}$ & $120^{\circ} 56^{\prime} 46^{\prime \prime}$ & USGS GNIS \\
\hline Coachella & Riverside & California & $33^{\circ} 40^{\prime} 49^{\prime \prime}$ & $116^{\circ} 10^{\prime} 23^{\prime \prime}$ & USGS GNIS \\
\hline Hemet & Riverside & California & $33^{\circ} 44^{\prime} 51^{\prime \prime}$ & $116^{\circ} 58^{\prime} 16^{\prime \prime}$ & USGS GNIS \\
\hline Riverside & Riverside & California & $33^{\circ} 57^{\prime} 12^{\prime \prime}$ & $117^{\circ} 23^{\prime} 43^{\prime \prime}$ & USGS GNIS \\
\hline San Jacinto & Riverside & California & $33^{\circ} 47^{\prime} 02^{\prime \prime}$ & $116^{\circ} 57^{\prime} 28^{\prime \prime}$ & USGS GNIS \\
\hline Temecula & Riverside & California & $33^{\circ} 29^{\prime} 37^{\prime \prime}$ & $117^{\circ} 08^{\prime} 51^{\prime \prime}$ & USGS GNIS \\
\hline Fair Oaks & Sacramento & California & $38^{\circ} 38^{\prime} 41^{\prime \prime}$ & $121^{\circ} 16^{\prime} 16^{\prime \prime}$ & USGS GNIS \\
\hline Sacramento & Sacramento & California & $38^{\circ} 34^{\prime} 54^{\prime \prime}$ & $121^{\circ} 29^{\prime} 36^{\prime \prime}$ & USGS GNIS \\
\hline Hollister & San Benito & California & $36^{\circ} 51^{\prime} 09^{\prime \prime}$ & $121^{\circ} 24^{\prime} 02^{\prime \prime}$ & USGS GNIS \\
\hline Panoche & San Benito & California & $36^{\circ} 35^{\prime} 49^{\prime \prime}$ & $120^{\circ} 49^{\prime} 57^{\prime \prime}$ & USGS GNIS \\
\hline Chino & San Bernardino & California & $34^{\circ} 00^{\prime} 44^{\prime \prime}$ & $117^{\circ} 41^{\prime} 17^{\prime \prime}$ & USGS GNIS \\
\hline Ontario & San Bernardino & California & $34^{\circ} 03^{\prime} 48^{\prime \prime}$ & $117^{\circ} 39^{\prime} 00^{\prime \prime}$ & USGS GNIS \\
\hline San Bernardino & San Bernardino & California & $34^{\circ} 06^{\prime} 30^{\prime \prime}$ & $117^{\circ} 17^{\prime} 20^{\prime \prime}$ & USGS GNIS \\
\hline Alpine & San Diego & California & $32^{\circ} 50^{\prime} 06^{\prime \prime}$ & $116^{\circ} 45^{\prime} 56^{\prime \prime}$ & USGS GNIS \\
\hline Ballast Point & San Diego & California & $32^{\circ} 41^{\prime} 11^{\prime \prime}$ & $117^{\circ} 14^{\prime} 22^{\prime \prime}$ & USGS GNIS \\
\hline Coronado & San Diego & California & $32^{\circ} 41^{\prime} 09^{\prime \prime}$ & $117^{\circ} 10^{\prime} 56^{\prime \prime}$ & USGS GNIS \\
\hline Cuyamaca & San Diego & California & $32^{\circ} 59^{\prime} 05^{\prime \prime}$ & $116^{\circ} 34^{\prime} 12^{\prime \prime}$ & USGS GNIS \\
\hline Escondido & San Diego & California & $33^{\circ} 07^{\prime} 09^{\prime \prime}$ & $117^{\circ} 05^{\prime} 08^{\prime \prime}$ & USGS GNIS \\
\hline Julian & San Diego & California & $33^{\circ} 04^{\prime} 43^{\prime \prime}$ & $116^{\circ} 36^{\prime} 04^{\prime \prime}$ & USGS GNIS \\
\hline La Mesa & San Diego & California & $32^{\circ} 46^{\prime} 04^{\prime \prime}$ & $117^{\circ} 01^{\prime} 20^{\prime \prime}$ & USGS GNIS \\
\hline Lakeside & San Diego & California & $32^{\circ} 51^{\prime} 26^{\prime \prime}$ & $116^{\circ} 55^{\prime} 17^{\prime \prime}$ & USGS GNIS \\
\hline National City & San Diego & California & $32^{\circ} 40^{\prime} 41^{\prime \prime}$ & $117^{\circ} 05^{\prime} 54^{\prime \prime}$ & USGS GNIS \\
\hline Ramona & San Diego & California & $33^{\circ} 02^{\prime} 30^{\prime \prime}$ & $116^{\circ} 52^{\prime} 02^{\prime \prime}$ & USGS GNIS \\
\hline San Diego & San Diego & California & $32^{\circ} 42^{\prime} 55^{\prime \prime}$ & $117^{\circ} 09^{\prime} 23^{\prime \prime}$ & USGS GNIS \\
\hline $\begin{array}{l}\text { Mile Rocks } \\
\text { (Mile Rock } \\
\text { Lighthouse) }\end{array}$ & San Francisco & California & $37^{\circ} 47^{\prime} 33^{\prime \prime}$ & $122^{\circ} 30^{\prime} 34^{\prime \prime}$ & $\begin{array}{c}\text { USGS GNIS; } \\
\text { Durham (1998); } \\
\text { Lawson (1908) }\end{array}$ \\
\hline
\end{tabular}


TABLE 4: COORDINATES FOR LOCATIONS IN TABLES 1-2 AND 5-15

\begin{tabular}{|c|c|c|c|c|c|}
\hline Location & County & State & Latitude (N) & Longitude (W) & Source \\
\hline San Francisco & San Francisco & California & $37^{\circ} 46^{\prime} 30^{\prime \prime}$ & $122^{\circ} 25^{\prime} 06^{\prime \prime}$ & USGS GNIS \\
\hline $\begin{array}{l}\text { Southampton } \\
\text { Shoal }\end{array}$ & San Francisco & California & $37^{\circ} 53^{\prime} 27^{\prime \prime}$ & $122^{\circ} 24^{\prime} 21^{\prime \prime}$ & USGS GNIS \\
\hline $\begin{array}{l}\text { Yerba Buena } \\
\text { (Lighthouse?) }\end{array}$ & $\begin{array}{c}\text { San Francisco } \\
(?)\end{array}$ & California & $\begin{array}{c}37^{\circ} 48^{\prime} 27^{\prime \prime} \\
(?)\end{array}$ & $122^{\circ} \underset{(?)}{21^{\prime}} 40^{\prime \prime}$ & $\begin{array}{l}\text { USGS GNIS; } \\
\text { Durham (1998) }\end{array}$ \\
\hline \multicolumn{6}{|c|}{ See the note about Yerba Buena in Table 1, following the citation for the event at 20:22 on 17 May 1906.} \\
\hline Stockton & San Joaquin & California & $37^{\circ} 57^{\prime} 28^{\prime \prime}$ & $121^{\circ} 17^{\prime} 23^{\prime \prime}$ & USGS GNIS \\
\hline $\begin{array}{c}\text { Avila } \\
\text { (now Avila Beach) }\end{array}$ & San Luis Obispo & California & $35^{\circ} 10^{\prime} 48^{\prime \prime}$ & $120^{\circ} 43^{\prime} 51^{\prime \prime}$ & $\begin{array}{l}\text { USGS GNIS; } \\
\text { Durham (1998) }\end{array}$ \\
\hline Cambria & San Luis Obispo & California & $35^{\circ} 33^{\prime} 51^{\prime \prime}$ & $121^{\circ} 04^{\prime} 47^{\prime \prime}$ & USGS GNIS \\
\hline Cayucos & San Luis Obispo & California & $35^{\circ} 26^{\prime} 34^{\prime \prime}$ & $120^{\circ} 53^{\prime} 28^{\prime \prime}$ & USGS GNIS \\
\hline San Luis Obispo & San Luis Obispo & California & $35^{\circ} 16^{\prime} 58^{\prime \prime}$ & $120^{\circ} 39^{\prime} 31^{\prime \prime}$ & USGS GNIS \\
\hline San Simeon & San Luis Obispo & California & $35^{\circ} 38^{\prime} 38^{\prime \prime}$ & $121^{\circ} 11^{\prime} 23^{\prime \prime}$ & USGS GNIS \\
\hline Templeton & San Luis Obispo & California & $35^{\circ} 32^{\prime} 59^{\prime \prime}$ & $120^{\circ} 42^{\prime} 18^{\prime \prime}$ & USGS GNIS \\
\hline Half Moon Bay & San Mateo & California & $37^{\circ} 27^{\prime} 49^{\prime \prime}$ & $122^{\circ} 25^{\prime} 39^{\prime \prime}$ & USGS GNIS \\
\hline Menlo Park & San Mateo & California & $37^{\circ} 27^{\prime} 14^{\prime \prime}$ & $122^{\circ} 10^{\prime} 52^{\prime \prime}$ & USGS GNIS \\
\hline Redwood City & San Mateo & California & $37^{\circ} 29^{\prime} 07^{\prime \prime}$ & $122^{\circ} 14^{\prime} 07^{\prime \prime}$ & USGS GNIS \\
\hline San Gregorio & San Mateo & California & $37^{\circ} 19^{\prime} 38^{\prime \prime}$ & $122^{\circ} 23^{\prime} 08^{\prime \prime}$ & USGS GNIS \\
\hline San Mateo & San Mateo & California & $37^{\circ} 33^{\prime} 47^{\prime \prime}$ & $122^{\circ} 19^{\prime} 28^{\prime \prime}$ & USGS GNIS \\
\hline Guadalupe & Santa Barbara & California & $34^{\circ} 58^{\prime} 18^{\prime \prime}$ & $120^{\circ} 34^{\prime} 15^{\prime \prime}$ & USGS GNIS \\
\hline Santa Barbara & Santa Barbara & California & $34^{\circ} 25^{\prime} 15^{\prime \prime}$ & $119^{\circ} 41^{\prime} 50^{\prime \prime}$ & USGS GNIS \\
\hline Santa Maria & Santa Barbara & California & $34^{\circ} 57^{\prime} 11^{\prime \prime}$ & $120^{\circ} 26^{\prime} 05^{\prime \prime}$ & USGS GNIS \\
\hline Surf & Santa Barbara & California & $34^{\circ} 41^{\prime} 04^{\prime \prime}$ & $120^{\circ} 36^{\prime} 09^{\prime \prime}$ & USGS GNIS \\
\hline Agnew & Santa Clara & California & $37^{\circ} 23^{\prime} 41^{\prime \prime}$ & $121^{\circ} 57^{\prime} 29^{\prime \prime}$ & USGS GNIS \\
\hline Alma & Santa Clara & California & $37^{\circ} 11^{\prime} 00^{\prime \prime}$ & $121^{\circ} 59^{\prime} 05^{\prime \prime}$ & Durham (1998) \\
\hline Campbell & Santa Clara & California & $37^{\circ} 17^{\prime} 14^{\prime \prime}$ & $121^{\circ} 56^{\prime} 56^{\prime \prime}$ & USGS GNIS \\
\hline Cupertino & Santa Clara & California & $37^{\circ} 19^{\prime} 23^{\prime \prime}$ & $122^{\circ} 01^{\prime} 52^{\prime \prime}$ & USGS GNIS \\
\hline Edenvale & Santa Clara & California & $37^{\circ} 15^{\prime} 54^{\prime \prime}$ & $121^{\circ} 49^{\prime} 01^{\prime \prime}$ & USGS GNIS \\
\hline Gilroy & Santa Clara & California & $37^{\circ} 00^{\prime} 21^{\prime \prime}$ & $121^{\circ} 34^{\prime} 02^{\prime \prime}$ & USGS GNIS \\
\hline Los Gatos & Santa Clara & California & $37^{\circ} 13^{\prime} 36^{\prime \prime}$ & $121^{\circ} 58^{\prime} 25^{\prime \prime}$ & USGS GNIS \\
\hline Mount Hamilton & Santa Clara & California & $37^{\circ} 20^{\prime} 31^{\prime \prime}$ & $121^{\circ} 38^{\prime} 31^{\prime \prime}$ & USGS GNIS \\
\hline Mountain View & Santa Clara & California & $37^{\circ} 23^{\prime} 10^{\prime \prime}$ & $122^{\circ} 04^{\prime} 58^{\prime \prime}$ & USGS GNIS \\
\hline Palo Alto & Santa Clara & California & $37^{\circ} 26^{\prime} 31^{\prime \prime}$ & $122^{\circ} 08^{\prime} 31^{\prime \prime}$ & USGS GNIS \\
\hline San Jose & Santa Clara & California & $37^{\circ} 20^{\prime} 22^{\prime \prime}$ & $121^{\circ} 53^{\prime} 38^{\prime \prime}$ & USGS GNIS \\
\hline Santa Clara & Santa Clara & California & $37^{\circ} 21^{\prime} 15^{\prime \prime}$ & $121^{\circ} 57^{\prime} 15^{\prime \prime}$ & USGS GNIS \\
\hline Sunnyvale & Santa Clara & California & $37^{\circ} 22^{\prime} 08^{\prime \prime}$ & $122^{\circ} 02^{\prime} 07^{\prime \prime}$ & USGS GNIS \\
\hline $\begin{array}{c}\text { Wright's Station } \\
\text { (now Wrights) }\end{array}$ & Santa Clara & California & $37^{\circ} 08^{\prime} 21^{\prime \prime}$ & $121^{\circ} 56^{\prime} 45^{\prime \prime}$ & $\begin{array}{c}\text { USGS GNIS; } \\
\text { Durham (1998) }\end{array}$ \\
\hline Boulder Creek & Santa Cruz & California & $37^{\circ} 07^{\prime} 34^{\prime \prime}$ & $122^{\circ} 07^{\prime} 16^{\prime \prime}$ & USGS GNIS \\
\hline Santa Cruz & Santa Cruz & California & $36^{\circ} 58^{\prime} 27^{\prime \prime}$ & $122^{\circ} 01^{\prime} 47^{\prime \prime}$ & USGS GNIS \\
\hline Scotts Valley & Santa Cruz & California & $37^{\circ} 03^{\prime} 04^{\prime \prime}$ & $122^{\circ} 00^{\prime} 49^{\prime \prime}$ & USGS GNIS \\
\hline
\end{tabular}


TABLE 4: COORDINATES FOR LOCATIONS IN TABLES 1-2 AND 5-15

\begin{tabular}{|c|c|c|c|c|c|}
\hline Location & County & State & Latitude $(\mathrm{N})$ & Longitude (W) & Source \\
\hline Watsonville & Santa Cruz & California & $36^{\circ} 54^{\prime} 37^{\prime \prime}$ & $121^{\circ} 45^{\prime} 21^{\prime \prime}$ & USGS GNIS \\
\hline $\begin{array}{l}4 \text { miles south of } \\
\text { Wright's Station } \\
\text { (now } \\
4 \text { miles south } \\
\text { of Wrights) }\end{array}$ & Santa Cruz & California & $37^{\circ} 04^{\prime} 53^{\prime \prime}$ & $121^{\circ} 56^{\prime} 45^{\prime \prime}$ & $\begin{array}{l}\text { Durham (1998); } \\
\text { Laurel (1987) \& } \\
\text { Los Gatos (1978) } \\
\text { 7.5' Topo Quads }\end{array}$ \\
\hline Anderson & Shasta & California & $40^{\circ} 26^{\prime} 54^{\prime \prime}$ & $122^{\circ} 17^{\prime} 48^{\prime \prime}$ & USGS GNIS \\
\hline Baird & Shasta & California & $40^{\circ} 47^{\prime} 33^{\prime \prime}$ & $122^{\circ} 17^{\prime} 43^{\prime \prime}$ & USGS GNIS \\
\hline Kennett & Shasta & California & $40^{\circ} 44^{\prime} 30^{\prime \prime}$ & $122^{\circ} 24^{\prime} 23^{\prime \prime}$ & USGS GNIS \\
\hline McCloud fishery & Shasta & California & \multicolumn{2}{|c|}{$\begin{array}{c}\text { on McCloud River, } \\
\text { near Baird (?) }\end{array}$} & $\begin{array}{c}\text { description in } \\
\text { original } \\
\text { newspaper source }\end{array}$ \\
\hline Redding & Shasta & California & $40^{\circ} 35^{\prime} 12^{\prime \prime}$ & $122^{\circ} 23^{\prime} 26^{\prime \prime}$ & USGS GNIS \\
\hline Shasta & Shasta & California & $40^{\circ} 35^{\prime} 58^{\prime \prime}$ & $122^{\circ} 29^{\prime} 27^{\prime \prime}$ & USGS GNIS \\
\hline Viola & Shasta & California & $40^{\circ} 31^{\prime} 05^{\prime \prime}$ & $121^{\circ} 40^{\prime} 36^{\prime \prime}$ & USGS GNIS \\
\hline Dunsmuir & Siskiyou & California & $41^{\circ} 12^{\prime} 30^{\prime \prime}$ & $122^{\circ} 16^{\prime} 15^{\prime \prime}$ & USGS GNIS \\
\hline Etna & Siskiyou & California & $41^{\circ} 27^{\prime} 25^{\prime \prime}$ & $122^{\circ} 53^{\prime} 37^{\prime \prime}$ & USGS GNIS \\
\hline Fort Jones & Siskiyou & California & $41^{\circ} 36^{\prime} 28^{\prime \prime}$ & $122^{\circ} 50^{\prime} 21^{\prime \prime}$ & USGS GNIS \\
\hline Greenview & Siskiyou & California & $41^{\circ} 33^{\prime} 03^{\prime \prime}$ & $122^{\circ} 54^{\prime} 16^{\prime \prime}$ & USGS GNIS \\
\hline Hornbrook & Siskiyou & California & $41^{\circ} 54^{\prime} 37^{\prime \prime}$ & $122^{\circ} 33^{\prime} 17^{\prime \prime}$ & USGS GNIS \\
\hline $\begin{array}{l}\text { Mt. Shasta } \\
\text { (the summit) }\end{array}$ & Siskiyou & California & $41^{\circ} 24^{\prime} 34^{\prime \prime}$ & $122^{\circ} 11^{\prime} 38^{\prime \prime}$ & USGS GNIS \\
\hline $\begin{array}{c}\text { Sisson } \\
\text { (now the town of } \\
\text { Mt. Shasta) }\end{array}$ & Siskiyou & California & $41^{\circ} 18^{\prime} 36^{\prime \prime}$ & $122^{\circ} 18^{\prime} 34^{\prime \prime}$ & $\begin{array}{c}\text { USGS GNIS; } \\
\text { Durham (1998) }\end{array}$ \\
\hline Yreka & Siskiyou & California & $41^{\circ} 44^{\prime} 08^{\prime \prime}$ & $122^{\circ} 38^{\prime} 00^{\prime \prime}$ & USGS GNIS \\
\hline Mare Island & Solano & California & $38^{\circ} 05^{\prime} 44^{\prime \prime}$ & $122^{\circ} 16^{\prime} 17^{\prime \prime}$ & USGS GNIS \\
\hline Vallejo & Solano & California & $38^{\circ} 06^{\prime} 15^{\prime \prime}$ & $122^{\circ} 15^{\prime} 20^{\prime \prime}$ & USGS GNIS \\
\hline Bennett Valley & Sonoma & California & $38^{\circ} 26^{\prime} 26^{\prime \prime}$ & $122^{\circ} 40^{\prime} 32^{\prime \prime}$ & USGS GNIS \\
\hline Peachland & Sonoma & California & $\begin{array}{c}38^{\circ} 26^{\prime} 40^{\prime \prime} \\
(?)\end{array}$ & $\begin{array}{c}122^{\circ} 53^{\prime} 45^{\prime \prime} \\
(?)\end{array}$ & $\begin{array}{l}\text { USGS GNIS; } \\
\text { Durham (1998); } \\
\text { Camp Meeker } \\
\quad(1995) \& \\
\text { pebastopol (1973) } \\
\text { 7.5' Topo Quads }\end{array}$ \\
\hline \multicolumn{6}{|c|}{$\begin{array}{c}\text { No current or historical map could be located which identified a town by the name of Peachland, although } \\
\text { Durham (1998) mentions a Peachland post office located amidst peach orchards } 5 \text { miles NW of Sebastopol. } \\
\text { USGS GNIS does not have latitude-longitude coordinates for Peachland post office but notes that it was located } \\
\text { along Green Valley Road. The coordinates listed above are those of a point along Green Valley Road, in an } \\
\text { orchard, approximately } 5 \text { miles NW of Sebastopol. }\end{array}$} \\
\hline Petaluma & Sonoma & California & $38^{\circ} 13^{\prime} 57^{\prime \prime}$ & $122^{\circ} 38^{\prime} 08^{\prime \prime}$ & USGS GNIS \\
\hline Santa Rosa & Sonoma & California & $38^{\circ} 26^{\prime} 26^{\prime \prime}$ & $122^{\circ} 42^{\prime} 48^{\prime \prime}$ & USGS GNIS \\
\hline Sonoma & Sonoma & California & $38^{\circ} 17^{\prime} 31^{\prime \prime}$ & $122^{\circ} 27^{\prime} 25^{\prime \prime}$ & USGS GNIS \\
\hline Modesto & Stanislaus & California & $37^{\circ} 38^{\prime} 21^{\prime \prime}$ & $120^{\circ} 59^{\prime} 45^{\prime \prime}$ & USGS GNIS \\
\hline Oakdale & Stanislaus & California & $37^{\circ} 46^{\prime} 00^{\prime \prime}$ & $120^{\circ} 50^{\prime} 46^{\prime \prime}$ & USGS GNIS \\
\hline Corning & Tehama & California & $39^{\circ} 55^{\prime} 40^{\prime \prime}$ & $122^{\circ} 10^{\prime} 41^{\prime \prime}$ & USGS GNIS \\
\hline Red Bluff & Tehama & California & $40^{\circ} 10^{\prime} 43^{\prime \prime}$ & $122^{\circ} 14^{\prime} 05^{\prime \prime}$ & USGS GNIS \\
\hline
\end{tabular}


TABLE 4: COORDINATES FOR LOCATIONS IN TABLES 1-2 AND 5-15

\begin{tabular}{|c|c|c|c|c|c|}
\hline Location & County & State & Latitude (N) & Longitude (W) & Source \\
\hline \hline Burnt Ranch & Trinity & California & $40^{\circ} 48^{\prime} 33^{\prime \prime}$ & $123^{\circ} 28^{\prime} 23^{\prime \prime}$ & USGS GNIS \\
\hline Hayfork & Trinity & California & $40^{\circ} 33^{\prime} 16^{\prime \prime}$ & $123^{\circ} 10^{\prime} 55^{\prime \prime}$ & USGS GNIS \\
\hline Island Mountain & Trinity & California & $40^{\circ} 01^{\prime} 35^{\prime \prime}$ & $123^{\circ} 29^{\prime} 21^{\prime \prime}$ & USGS GNIS \\
\hline $\begin{array}{c}\text { New River } \\
\text { (mining district?) }\end{array}$ & Trinity & California & $\begin{array}{c}40^{\circ} 57^{\prime} 05^{\prime \prime} \\
(?)\end{array}$ & $\begin{array}{c}123^{\circ} 23^{\prime} \text { 05" } \\
(?)\end{array}$ & $\begin{array}{c}\text { Official Map } \\
(1915) ; \\
\text { Ironside Mtn. } \\
(1951) \text { 15' Topo } \\
\text { Quad }\end{array}$ \\
\hline
\end{tabular}

No current or historical map or gazetteer could be located which identified a town by the name of New River. Some historical newspaper reports referred to a New River mining district, although that place could not be located either. A map of Trinity County (Official Map, 1915) shows several mines along the New River in Trinity County, near the town of Quinby, which is less than $1 \mathrm{~km}$ upstream from the present-day town of Denny. These mines may comprise what was the New River mining district, and that may be the location to which "New River" refers. The coordinates listed above are those of one mine approximately in the center of the group.

\begin{tabular}{|c|c|c|c|c|c|}
\hline Ruth & Trinity & California & $40^{\circ} 16^{\prime} 11^{\prime \prime}$ & $123^{\circ} 19^{\prime} 13^{\prime \prime}$ & USGS GNIS \\
\hline Weaverville & Trinity & California & $40^{\circ} 43^{\prime} 52^{\prime \prime}$ & $122^{\circ} 56^{\prime} 27^{\prime \prime}$ & USGS GNIS \\
\hline Visalia & Tulare & California & $36^{\circ} 19^{\prime} 49^{\prime \prime}$ & $119^{\circ} 17^{\prime} 28^{\prime \prime}$ & USGS GNIS \\
\hline $\begin{array}{c}\text { throughout } \\
\text { Tuolumne County }\end{array}$ & Tuolumne & California & $37^{\circ} 57^{\prime} 12^{\prime \prime}$ & $120^{\circ} 25^{\prime} 18^{\prime \prime}$ & USGS GNIS
\end{tabular}
The coordinates are for Jamestown, where the report was published.

\begin{tabular}{|c|c|c|c|c|c|}
\hline Ventura & Ventura & California & $34^{\circ} 16^{\prime} 42^{\prime \prime}$ & $119^{\circ} 17^{\prime} 32^{\prime \prime}$ & USGS GNIS \\
\hline Capay & Yolo & California & $38^{\circ} 42^{\prime} 28^{\prime \prime}$ & $122^{\circ} 02^{\prime} 49^{\prime \prime}$ & USGS GNIS \\
\hline Capay Valley & Yolo & California & $38^{\circ} 42^{\prime} 39^{\prime \prime}$ & $122^{\circ} 02^{\prime} 46^{\prime \prime}$ & USGS GNIS \\
\hline Rumsey & Yolo & California & $38^{\circ} 53^{\prime} 18^{\prime \prime}$ & $122^{\circ} 14^{\prime} 11^{\prime \prime}$ & USGS GNIS \\
\hline Woodland & Yolo & California & $38^{\circ} 40^{\prime} 43^{\prime \prime}$ & $121^{\circ} 46^{\prime} 20^{\prime \prime}$ & USGS GNIS \\
\hline Challenge & Yuba & California & $39^{\circ} 29^{\prime} 15^{\prime \prime}$ & $121^{\circ} 13^{\prime} 21^{\prime \prime}$ & USGS GNIS \\
\hline Marysville & Yuba & California & $39^{\circ} 08^{\prime} 45^{\prime \prime}$ & $121^{\circ} 35^{\prime} 25^{\prime \prime}$ & USGS GNIS \\
\hline Salome & La Paz & Arizona & $33^{\circ} 46^{\prime} 52^{\prime \prime}$ & $113^{\circ} 36^{\prime} 50^{\prime \prime}$ & USGS GNIS \\
\hline Phoenix & Maricopa & Arizona & $33^{\circ} 26^{\prime} 54^{\prime \prime}$ & $112^{\circ} 04^{\prime} 24^{\prime \prime}$ & USGS GNIS \\
\hline Yuma & Yuma & Arizona & $32^{\circ} 43^{\prime} 31^{\prime \prime}$ & $114^{\circ} 37^{\prime} 25^{\prime \prime}$ & USGS GNIS \\
\hline Carson Dam & Churchill & Nevada & $39^{\circ} 29^{\prime} 30^{\prime \prime}$ & $118^{\circ} 59^{\prime} 30^{\prime \prime}$ & $\begin{array}{c}\text { USGS GNIS; } \\
\text { Sheckler } \\
\text { Reservoir (1985) } \\
\text { \& Fallon (1985) } \\
\text { 7.5' Topo Quads }\end{array}$ \\
\hline Fallon & Churchill & Nevada & $39^{\circ} 28^{\prime} 25^{\prime \prime}$ & $118^{\circ} 46^{\prime} 35^{\prime \prime}$ & USGS GNIS \\
\hline Hazen & Churchill & Nevada & $39^{\circ} 33^{\prime} 55^{\prime \prime}$ & $119^{\circ} 02^{\prime} 43^{\prime \prime}$ & USGS GNIS \\
\hline Fernley & Lyon & Nevada & $39^{\circ} 36^{\prime} 29^{\prime \prime}$ & $119^{\circ} 15^{\prime} 03^{\prime \prime}$ & USGS GNIS \\
\hline Browns Station & Pershing & Nevada & $40^{\circ} 01^{\prime} 02^{\prime \prime}$ & $118^{\circ} 40^{\prime} 39^{\prime \prime}$ & $\begin{array}{c}\text { USGS GNIS; } \\
\text { Carlson (1974); } \\
\text { Toulon Peak } \\
\text { (1987) } \\
\text { 7.5' Topo Quad }\end{array}$ \\
\hline
\end{tabular}

See the note about Browns Station in Table 2, following the citation for the event "between 20:15 and 20:30" on 19 Apr 1906.

\begin{tabular}{|c|c|c|c|c|c|}
\hline Lovelock & Pershing & Nevada & $40^{\circ} 10^{\prime} 46^{\prime \prime}$ & $118^{\circ} 28^{\prime} 21^{\prime \prime}$ & USGS GNIS \\
\hline Olinghouse & Washoe & Nevada & $39^{\circ} 39^{\prime} 30^{\prime \prime}$ & $119^{\circ} 25^{\prime} 41^{\prime \prime}$ & USGS GNIS \\
\hline Reno & Washoe & Nevada & $39^{\circ} 31^{\prime} 47^{\prime \prime}$ & $119^{\circ} 48^{\prime} 46^{\prime \prime}$ & USGS GNIS \\
\hline
\end{tabular}


TABLE 4: COORDINATES FOR LOCATIONS IN TABLES 1-2 AND 5-15

\begin{tabular}{|c|c|c|c|c|c|}
\hline Location & County & State & Latitude (N) & Longitude (W) & Source \\
\hline $\begin{array}{l}\text { Steamboat } \\
\text { Springs }\end{array}$ & Washoe & Nevada & $39^{\circ} 23^{\prime} 19^{\prime \prime}$ & $119^{\circ} 44^{\prime} 33^{\prime \prime}$ & USGS GNIS \\
\hline Wadsworth & Washoe & Nevada & $39^{\circ} 38^{\prime} 02^{\prime \prime}$ & $119^{\circ} 17^{\prime} 04^{\prime \prime}$ & USGS GNIS \\
\hline Glendale & Douglas & Oregon & $42^{\circ} 44^{\prime} 11^{\prime \prime}$ & $123^{\circ} 25^{\prime} 20^{\prime \prime}$ & USGS GNIS \\
\hline Roseburg & Douglas & Oregon & $43^{\circ} 13^{\prime} 00^{\prime \prime}$ & $123^{\circ} 20^{\prime} 26^{\prime \prime}$ & USGS GNIS \\
\hline Ashland & Jackson & Oregon & $42^{\circ} 11^{\prime} 41^{\prime \prime}$ & $122^{\circ} 42^{\prime} 30^{\prime \prime}$ & USGS GNIS \\
\hline Medford & Jackson & Oregon & $42^{\circ} 19^{\prime} 36^{\prime \prime}$ & $122^{\circ} 52^{\prime} 28^{\prime \prime}$ & USGS GNIS \\
\hline Grants Pass & Josephine & Oregon & $42^{\circ} 26^{\prime} 21^{\prime \prime}$ & $123^{\circ} 19^{\prime} 38^{\prime \prime}$ & USGS GNIS \\
\hline Merlin & Josephine & Oregon & $42^{\circ} 31^{\prime} 03^{\prime \prime}$ & $123^{\circ} 25^{\prime} 07^{\prime \prime}$ & USGS GNIS \\
\hline Paisley & Lake & Oregon & $42^{\circ} 41^{\prime} 38^{\prime \prime}$ & $120^{\circ} 32^{\prime} 42^{\prime \prime}$ & USGS GNIS \\
\hline Eugene & Lane & Oregon & $44^{\circ} 03^{\prime} 08^{\prime \prime}$ & $123^{\circ} 05^{\prime} 08^{\prime \prime}$ & USGS GNIS \\
\hline Portland & Multnomah & Oregon & $45^{\circ} 31^{\prime} 25^{\prime \prime}$ & $122^{\circ} 40^{\prime} 30^{\prime \prime}$ & USGS GNIS \\
\hline Seattle & King & Washington & $47^{\circ} 36^{\prime} 23^{\prime \prime}$ & $122^{\circ} 19^{\prime} 51^{\prime \prime}$ & USGS GNIS \\
\hline \begin{tabular}{|c|} 
Cocopah \\
(a.k.a. \\
Estación Cocopar)
\end{tabular} & & $\begin{array}{l}\text { Baja California } \\
\text { Norte, Mexico }\end{array}$ & $32^{\circ} 33^{\prime} 00^{\prime \prime}$ & $115^{\circ} 14^{\prime} 00^{\prime \prime}$ & NIMA GNS \\
\hline Tijuana & & $\begin{array}{l}\text { Baja California } \\
\text { Norte, Mexico }\end{array}$ & $32^{\circ} 32^{\prime} 00^{\prime \prime}$ & $117^{\circ} 01^{\prime} 00^{\prime \prime}$ & NIMA GNS \\
\hline
\end{tabular}

\section{$\underline{\text { Source Codes: }}$}

USGS GNIS: U.S. Geological Survey (USGS) Geographic Names Information System (GNIS) -- Available online at http://geonames.usgs.gov/

NIMA GNS: National Imagery and Mapping Agency (NIMA) GEOnet Names Server (GNS) -- Available online at http:// www.nima.mil/gns/html/

Topo Quads are U.S. Geological Survey 7.5-minute topographic quadrangle maps, unless otherwise noted.

Other sources are listed in the references section of this report. 
TABLE 5: PRIMARY REPORTS FOR THE 18 APR 1906, 14:28 AFTERSHOCK

\section{SEE CORRESPONDING FIGURE 2}

This aftershock occurred only hours after the mainshock, at a time when aftershocks were occurring at a high frequency. That there was a relatively large aftershock at about 14:28 on the afternoon of 18 Apr 1906 is inferred from a number of widelyspaced reports of an unusually large earthquake at around that time; nevertheless, there are reports of two or more closely-timed events from some of those locations, and in some cases it is not clear which reports describe which event. Although the preferred interpretation is that there was a single large event at around 14:28, with several smaller events a few minutes before and after, the data support an alternative interpretation: there may have been two large aftershocks, one near San Francisco at 14:25, and one near Santa Cruz at 14:28. In the table below, we use the assumption that there was only one large event in assigning the intensities at each location; if there were two large events, however, the intensities assigned below would be smaller at some locations for the earlier event, and smaller at other locations for the later event.

\section{Location Described: $\quad$ Alameda, Alameda Co.}

Report 1: $\quad$ Lawson (1908), vol. I, p. 413

felt at Alameda Pier

MMI for this location: Uncertain

Location Described: $\quad$ Berkeley, Alameda Co.

Report 1: $\quad$ Lawson (1908), vol. I, p. 413

Ewing seismograph recording at 14:24:37. Another event at 14:28:50.

MMI for this location: Uncertain

Location Described: Antioch, Contra Costa Co.

Report 1: $\quad$ Lawson (1908), vol. I, p. 413

felt at Antioch

MMI for this location: Uncertain

\section{Location Described: $\quad$ Salinas, Monterey Co.}

Report 1: $\quad$ Salinas Weekly Journal, 21 Apr 1906; p. 3, c. 2-3

(Under the heading "From Thursday's Daily Journal":) “... During the day and until midnight slight shocks, to the number of twenty or more, kept our people in a state of nervous suspense. A frisky one at 2:28 sent people running pell mell into the streets."

Report 2: $\quad$ San Luis Obispo Tribune, 20 Apr 1906; p. 1, c. 4

"Salinas April 18:-.... There were three distinct shocks here this morning followed by 3 more at 2:25 o' clock this afternoon...."

Report 3: $\quad$ Lawson (1908), vol. I, p. 413

felt at Salinas

MMI for this location: $\quad$ IV 
TABLE 5: PRIMARY REPORTS FOR THE 18 APR 1906, 14:28 AFTERSHOCK

Location Described: $\quad$ Sacramento, Sacramento Co.

Report 1: $\quad$ Lawson (1908), vol. I, p. 413

"Very light."

MMI for this location: Uncertain

Location Described: $\quad$ San Francisco, San Francisco Co.

Report 1: $\quad$ Lawson (1908), vol. I, p. 413

Event at 14:24: "Very light."

Event at 14:25: Duration 4 seconds. Lawson (1908) estimates Rossi-Forel intensity III.

Event at 14:28: "Very light."

MMI for this location: Uncertain

\section{Location Described: $\quad$ Southampton Shoal, San Francisco Co.}

Report 1: $\quad$ Lawson (1908), vol. I, p. 413

“Vertical throw north-south tremor 20s. before; no noise." Duration 5 seconds.

MMI for this location: $\quad$ Uncertain

\section{Location Described: $\quad$ Stockton, San Joaquin Co.}

Report 1: $\quad$ Lawson (1908), vol. I, p. 413

"Very light."

MMI for this location: Uncertain

Location Described: $\quad$ San Simeon, San Luis Obispo Co.

Report 1: $\quad$ Lawson (1908), vol. I, p. 299

“... at San Simeon ... the shock of the afternoon (of April 18) was also noticed, which was not the case farther south...."

MMI for this location: Uncertain

\section{Location Described: $\quad$ Agnew, Santa Clara Co.}

Report 1: $\quad$ San Jose Mercury and Herald (combined issue), 19 Apr 1906; p. 4, c. 4-5

"The State Hospital for the Insane at Agnews lies in a mass of ruins.... The second shock that occurred about 2 o'clock terrified the rescuing parties and part of the walls of the Administration Building that remained standing fell to the ground with a crash."

MMI for this location: IV ?

Location Described: $\quad$ Los Gatos, Santa Clara Co.

Report 1: $\quad$ Lawson (1908), vol. I, p. 413

felt at Los Gatos

MMI for this location: Uncertain 
TABLE 5: PRIMARY REPORTS FOR THE 18 APR 1906, 14:28 AFTERSHOCK

\section{Location Described: $\quad$ Mount Hamilton, Santa Clara Co.}

Report 1: $\quad$ Lawson (1908), vol. I, p. 413

Event at 14:23:10: Lawson (1908) estimates Rossi-Forel intensity II.

Event at 14:28:36: Lawson (1908) estimates Rossi-Forel intensity III.

MMI for this location: Uncertain

\section{Location Described: $\quad$ Santa Clara, Santa Clara Co.}

Report 1: $\quad$ San Jose Mercury and Herald (combined issue), 19 Apr 1906; p. 4, c. 7

"minor shock"

MMI for this location: Uncertain

Location Described: $\quad$ Boulder Creek, Santa Cruz Co.

Report 1: $\quad$ Mountain Echo (Boulder Creek), 21 Apr 1906; p. 3, c. 1

"There have been numerous light shocks of earthquake every day since Wednesday and on

Wednesday afternoon there were two quite heavy shocks just before half past two o'clock."

MMI for this location: IV ?

Location Described: $\quad$ Scotts Valley, Santa Cruz Co.

Report 1: $\quad$ Lawson (1908), vol. I, p. 413

"Extra hard, stopt clock hanging on wall facing south, 20" pend. Stopt clock facing NW. by WNW., pend. about 5"." Lawson (1908) estimates Rossi-Forel intensity IV.

MMI for this location: V ?

Location Described: “4 miles south of Wrights*”, Santa Cruz Co.

Report 1: $\quad$ Lawson (1908), vol. I, p. 413

"Slight."

* The locality given in Lawson (1908) is "4 miles south of Wright's Station." According to Durham (1998), Wright's Station is an old name for Wrights, a village in Santa Clara County, near the Santa Cruz County line. Four miles south of this point would be in Santa Cruz County.

MMI for this location: $\quad$ Uncertain

Location Described: $\quad$ Mare Island, Solano Co.

Report 1: $\quad$ Lawson (1908), vol. I, p. 413

Event at 14:22: "Slight." Duration 1-2 seconds.

Event at 14:27: "Slight." Duration 1-2 seconds.

MMI for this location: $\quad$ Uncertain 
TABLE 5: PRIMARY REPORTS FOR THE 18 APR 1906, 14:28 AFTERSHOCK

\section{Location Described: $\quad$ Modesto, Stanislaus Co.}

Report 1: $\quad$ Modesto Daily Evening News, 18 Apr 1906; p. 1, c. 4

".... another distinct shock of earthquake was felt in Modesto, being especially noticeable in the downtown business blocks...."

MMI for this location: III 


\section{TABLE 6: PRIMARY REPORTS FOR THE 18 APR 1906 TRIGGERED EVENT at 16:30 in the IMPERIAL VALLEY, CALIFORNIA}

\section{SEE CORRESPONDING FIGURE 3}

\section{Location Described: $\quad$ Brawley, Imperial Co.}

Many newspapers outside Brawley reported the earthquake in Brawley. Some of these reports appear to be based upon reports that are listed below, and they contain no new information. Only reports with unique information are listed below.

\section{Report 1: $\quad$ Brawley News, 20 Apr 1906; p. 1}

"Accustomed to earthquake shocks of more or less severity, the residents of Brawley gave but little heed to the shakes manifested Wednesday afternoon until at half past four, almost without warning an extremely heavy shake threw the buildings hither and thither, twisting the wooden structures until it seemed as if they must topple over and causing the walls of the brick and adobe buildings to bend outward and in many cases to crack open and fall apart. Clocks stopped, dishes fell clattering to the floor, window glass crashed, chimneys fell, and doors were forced off their hinges while the clouds of dust arising from the fallen buildings and the distant river banks attested the impotence of man in the face of the mighty displeasure of Nature.

"With the many walls, bricks and timbers that were thrown to the ground, it is a matter of wonder and congratulation that no one was killed, but fortunately no one was hurt with the exception of a small boy, the son of J. M. Price, of No. 8, on whom a portion of an adobe wall fell, bruising him severely and breaking his collarbone.

"The chief damage was in the heart of the town, where the Van Ness and Marlowe buildings were almost totally destroyed, the walls on three sides falling, carrying ruin in their path. In these buildings were the store of J. L. Colman, the Ideal Restaurant and the Pioneer Pool Room. The stock and fixtures in these places was somewhat injured.

"The front wall of the Imperial Valley Bank fell into the street, filling with debris the room which Cashier Dunn had vacated but a moment before. The walls of Varney Bros. new brick store swayed and tottered, but finally settled back into place, with bulging corners and ends to show the effects of the shock. The office building of the Brawley Land Company was ripped open on the north. The NEws building has a few whole panes of glass left and shows cracks on the north end large enough to admit plenty of fresh air, while the type in the galleys and on the imposing stones exceeded even the editor's experience with pi.

"At the adobe Bungalow Hotel ruin reigned supreme. Hardly a square yard of plastering on the entire building's sides is left intact. The dining room walls let in the sunshine and the wind and the dormitory and the office sections fared little better. The interior resembled a sand pit rather than a hotel. The two-story brick annex, containing four sleeping rooms on the second floor and the barber shop of C. Darnell and the office of The Lyon Bros.' Co., Peter Hovley, manager, was badly wrecked. The walls on the second story bulge out and the corners, cracked for many feet, are in a precarious condition. Remnants of the big plate windows strew the sidewalk. This building has been vacated as unsafe. The laundry is a wreck, much of the walls having fallen.

"Part of the brick foundation to the packing house addition must be relaid. The adobe schoolhouse has been pronounced unsafe. Miss Malan has held school in the building formerly occupied as a residence by Bert Varney.

"Not one brick or adobe building in the vicinity of Brawley but what was damaged [sic].

"The house occupied by W. J. Wallace suffered considerable damage, one of the walls going down. Ruth's blacksmith shop and George J. Holloway's house were damaged.

"In No. 8, the three adobe houses owned by D. S. Elder are complete wrecks. The recently built stone house on the New River Ranch occupied by J. A. Thompson, was partly demolished.

"In the store buildings in town, goods of all descriptions were piled up on the floors in indescribable confusions, and china and glassware was smashed to smithereens. At Miss Pellet's restaurant not one dish was left whole. Hardly a chimney in town is standing.

"As soon as the dust of the fallen debris had cleared away, ropes were stretched before the buildings in the most dangerous condition for the earthquake shocks continued at irregular intervals and have kept up until this publication although no further damage has resulted. The scene immediately following the heavy shock was one long to be remembered. From the clouds of dust emerged men, women and children, who with the tidings of the terrible calamity at San Francisco yet ringing in their ears, found themselves suddenly confronted with a similar disaster on a smaller scale. Down the street toward the crowd rushed a runaway horse, frightened by the shake, but was stopped 


\section{TABLE 6: PRIMARY REPORTS FOR THE 18 APR 1906 TRIGGERED EVENT at 16:30 in the IMPERIAL VALLEY, CALIFORNIA}

midway in its career by E. E. Pellet. With women screaming and children crying, the first thought was for those injured, but a hurried search revealed the fact that everyone was safe. At night few lamps were lighted, through fear of a shock tipping them over.

"Wednesday night the residents of most of the buildings joined the outdoor brigade and slept under the open sky. Bright and early Thursday morning work began on repairing the damage. The streets were cleared of rubbish so that by the time curious visitors from nearby towns had arrived, much of the town had again assumed a respectable appearance....

"The loss in Brawley can be repaired, temporarily, for a few thousand dollars, but many of the buildings must be rebuilt. The total damage cannot be less than $\$ 15,000$, besides that in the adjoining territory. A severe shock was felt in all parts of the Imperial Valley, but Brawley was the worst sufferer, with Holtville next, for the new buildings were severely damaged. Imperial, El Centro and Calexico sustained little injury beyond a few cracked walls."

Report 2: $\quad$ Brawley News, 27 Apr 1906; p. 4, c. 1

"A look over the results of the earthquake shows that the damage was more apparent than real. Most of the buildings damaged were of temporary construction. Not one frame building was injured and the two brick buildings that suffered loss can be repaired with little difficulty. The dust had hardly cleared away from the streets when the work of repairing and rebuilding commenced. In two or three weeks the only visible reminder of the earthquake will be a few cracked walls."

The actual time and date of the earthquake at issue are not stated, although it is inferred to be the Imperial Valley mainshock on the afternoon of 18 April.

Report 3: $\quad$ Imperial Valley Press, 21 Apr 1906; p. 5, c. 4

“Quite a severe shock of earthquake was felt in the Valley on last Wednesday afternoon about 4:25. Quite a lot of damage was done to the adobe buildings in Brawley. The Imperial Valley Bank and Bungalow Hotel were seriously shattered, and Varney Bros.' store was wrecked. A residence belonging to D. D. Pellet was also wrecked and several other buildings badly cracked...."

Report 4: $\quad$ San Diego Union, 20 Apr 1906; p. 2, c. 4

"Los Angeles, April 19.--Reports this morning from Brawley ... state that the town was practically wiped out by the earthquake of yesterday. This is the only town in Southern California known to have suffered from the shock. Southern Pacific officials report today that the following buildings there, all brick structures, were completely destroyed:

"Brawley bank, Paulin building and the principal merchandise building of the town. In addition dozens of adobe houses were razed to the ground. So far as known, there were no fatalities.

"Reports received tonight show the town of Brawley to have suffered less by yesterday's earthquake shock than originally stated. About one hundred buildings in Brawley and the surrounding valley were damaged, but none of them was wholly destroyed."

The writer of this report apparently did not realize that the event which affected Brawley was different from the mainshock in northern California. From other reports, the damage in Brawley is inferred to be a result of the Imperial Valley mainshock on the afternoon of 18 April.

Report 5: $\quad$ San Diego Union, 22 Apr 1906; p. 8, c. 6

"A special dispatch to the Union last evening from the Imperial Standard implied that the damage done at Brawley was not as great as was first reported. By fixing the time, the dispatch shows that the Brawley quake was the one we felt slightly here. The dispatch was:

“'Imperial, Calif., April 21.-An earthquake shock on Wednesday at 4:30 p. m. damaged adobes at Brawley. There were no casualties....'"

Report 6: $\quad$ San Diego Union, 24 Apr 1906; p. 8, c. 3

"Calexico, April 21-At 4:30 p. m. on the 18th inst the Imperial valley was visited by an earthquake which lasted for a period of two minutes. The little town of Brawley in the north end of the valley was the worst sufferer. After the people had recovered from the first fright and started to investigate the amount of damage done, the discovery was made that not a single brick or adobe building had escaped injury and some were totally wrecked.

"These are the Bungalow hotel, public school, Paris restaurant, and three adobe houses across the river in No. 8. Those damaged include the First National bank, land office, Varney Bros., C. Haack, D. D. Pellett, News office, Hutchings \& Co. and Brawley Mercantile Co.

"The greater portion of the people living in frame houses suffered more or less from the shaking down of dishes, lamps, bric-a-brac, etc. That no lives were lost is little short of miraculous. The 
TABLE 6: PRIMARY REPORTS FOR THE 18 APR 1906 TRIGGERED EVENT at 16:30 in the IMPERIAL VALLEY, CALIFORNIA

only accidents reported were a woman and child injured slightly by the collapse of a dwelling across the river...."

Report 7: $\quad$ San Diegan-Sun, 21 Apr 1906; p. 4, c. 1

"Secretary James Jasper of the chamber of commerce, has received this wire information as to the quake damage in Brawley: 'Seven buildings in Brawley were badly damaged. Some of them are a total wreck. The New river track house was destroyed. It is the total damage in the valley....'”

The actual time and date of the earthquake at issue are not stated, although it is inferred to be the Imperial Valley mainshock on the afternoon of 18 April.

Report 8: $\quad$ San Bernardino Daily Sun, 20 Apr 1906; p. 2, c. 4

[quoting a telegram from Southern Pacific Railroad Superintendent H. V. Platt, who was in the Imperial Valley at the time:] "IMPERIAL JUNCTION, April 19.- It is reported from Brawley ... that a serious earthquake occurred there at 4:30 p. m., yesterday, and that all adobe and brick buildings were wrecked. No damage to railroad property....

"'At 5:22 p. m., it was reported from Brawley that the Brawley bank building, the Paulin building and Varney Brothers' building, all brick blocks, were ruined. No other damage reported last night...."

Report 9: $\quad$ Los Angeles Times, 20 Apr 1906; Part II, p. 9, c. 2

“BRAWLEY, April 19.-[Exclusive Dispatch.] The earthquake here yesterday did only slight damage and there was nothing about it to warrant the sensational reports that have been sent out magnifying it greatly. Five or six small buildings were slightly injured, but none of them was razed or even collapsed by the tremor. It caused only ordinary alarm."

Report 10: $\quad$ Lawson (1908), vol. I, p. 414

"Northwest-southeast chimneys fell to west. Movable objects in bldgs., thrown west-east. Oscillation followed by tremors. Clock stopped at $4^{\mathrm{h}} 30^{\mathrm{m}}$, facing south." Lawson (1908) estimates Rossi-Forel intensity IX.*

* Based on comparison with other reports of the damage in Brawley, this estimate is clearly too high. Townley and Allen (1939) estimate Rossi-Forel intensity VIII, although even that seems to be on the high side.

MMI for this location: VII-VIII (preferred: VIII)

\section{Location Described: $\quad$ Calexico, Imperial Co.}

Report 1: $\quad$ San Diego Union, 24 Apr 1906; p. 8, c. 3

"Calexico, April 21-... Holtville and Calexico were shaken some but no damage was done beyond the cracking of several buildings of the former place and the post office building at the latter."

Report 2: $\quad$ Brawley News, 20 Apr 1906; p. 1

“... A severe shock was felt in all parts of the Imperial Valley, but Brawley was the worst sufferer, with Holtville next, for the new buildings were severely damaged. Imperial, El Centro and Calexico sustained little injury beyond a few cracked walls."

Report 3: $\quad$ Imperial Valley Press, 21 Apr 1906; p. 5, c. 4

"... No damage is reported from Calexico...."

Report 4: $\quad$ San Diegan-Sun, 21 Apr 1906; p. 4, c. 1

"Secretary James Jasper of the chamber of commerce, has received this wire information....

"'Imperial, Calexico, Holtville and Heber are all right....'”

\section{MMI for this location: $\quad$ V}


TABLE 6: PRIMARY REPORTS FOR THE 18 APR 1906 TRIGGERED EVENT at 16:30 in the IMPERIAL VALLEY, CALIFORNIA

\section{Location Described: $\quad$ El Centro, Imperial Co.}

Report 1: $\quad$ Imperial Valley Press, 21 Apr 1906; p. 5, c. 4

“... Here in El Centro we all were able to notice it without great effort, and while the shock was on we felt sure things were going to happen, yet there is no damage whatever to report. Not a wall was cracked, nor was there any plaster loosened. Two bottles of ketchup were shaken off the shelves of the Valley Mercantile company, and some Breakfast Food boxes fell in Rumsey's store. No damage resulted, as even the ketchup bottles didn't break. But it was quite a lively shake just the same...."

Report 2: $\quad$ Brawley News, 20 Apr 1906; p. 1

“... A severe shock was felt in all parts of the Imperial Valley, but Brawley was the worst sufferer, with Holtville next, for the new buildings were severely damaged. Imperial, El Centro and Calexico sustained little injury beyond a few cracked walls."

Report 3: $\quad$ San Diego Union, 24 Apr 1906; p. 8, c. 3

"... The towns of Imperial, El Centro, and Silsbee escaped without injury...."

MMI for this location: V

\section{Location Described: Heber, Imperial Co.}

Report 1: $\quad$ San Diegan-Sun, 21 Apr 1906; p. 4, c. 1

"Secretary James Jasper of the chamber of commerce, has received this wire information....

"Imperial, Calexico, Holtville and Heber are all right....'”

\section{MMI for this location: Uncertain}

\section{Location Described: Holtville, Imperial Co.}

Report 1: $\quad$ Imperial Valley Press, 21 Apr 1906; p. 5, c. 4

“... The Hotel Alamo at Holtville, was quite severely shaken and cracked. The other buildings were not seriously injured...."

Report 2: $\quad$ Brawley News, 20 Apr 1906; p. 1

"... A severe shock was felt in all parts of the Imperial Valley, but Brawley was the worst sufferer, with Holtville next, for the new buildings were severely damaged. Imperial, El Centro and Calexico sustained little injury beyond a few cracked walls."

Report 3: $\quad$ San Diego Union, 24 Apr 1906; p. 8, c. 3

“... Holtville and Calexico were shaken some but no damage was done beyond the cracking of several buildings of the former place and the post office building at the latter."

Report 4: $\quad$ San Diegan-Sun, 21 Apr 1906; p. 4, c. 1

"Secretary James Jasper of the chamber of commerce, has received this wire information....

"Imperial, Calexico, Holtville and Heber are all right....'”

MMI for this location: VI

\section{Location Described: $\quad$ Imperial, Imperial Co.}

Report 1: $\quad$ Imperial Valley Press, 21 Apr 1906; p. 5, c. 3

"Imperial was visited by two distinct earthquakes Wednesday afternoon, the first at $3 \mathrm{p}$. m. the second at 4:20 p. m. No very serious accidents; Mr. Varney's olive oil bottles, pickles and cans got mixed up on the floor."

It is not clear which of the two events mentioned was responsible for the items falling to the floor. From other reports, it is inferred that the second event was responsible. 
TABLE 6: PRIMARY REPORTS FOR THE 18 APR 1906 TRIGGERED EVENT at 16:30 in the IMPERIAL VALLEY, CALIFORNIA

Report 2: $\quad$ Imperial Valley Press, 21 Apr 1906; p. 5, c. 4

"... At Imperial only slight damage was inflicted, such as knocking off plaster and cracking the walls in the brick buildings...."

Report 3: $\quad$ Brawley News, 20 Apr 1906; p. 1

“... A severe shock was felt in all parts of the Imperial Valley, but Brawley was the worst sufferer, with Holtville next, for the new buildings were severely damaged. Imperial, El Centro and Calexico sustained little injury beyond a few cracked walls."

Report 4: $\quad$ San Diego Union, 24 Apr 1906; p. 8, c. 3

“... The towns of Imperial, El Centro, and Silsbee escaped without injury...."

Report 5: $\quad$ San Diegan-Sun, 21 Apr 1906; p. 4, c. 1

"Secretary James Jasper of the chamber of commerce, has received this wire information....

"'Imperial, Calexico, Holtville and Heber are all right....'"

MMI for this location: VI

\section{Location Described: $\quad$ Imperial Junction, Imperial Co. (now Niland, CA)}

Report 1: $\quad$ San Bernardino Daily Sun, 20 Apr 1906; p. 2, c. 4

[quoting a telegram from Southern Pacific Railroad Superintendent H. V. Platt, who was in the Imperial Valley at the time:] "IMPERIAL JUNCTION, A pril 19.--It is reported from Brawley ... that a serious earthquake occurred there at 4:30 p. m, yesterday, and that all adobe and brick buildings were wrecked. No damage to railroad property. There was continuous rumbling and shaking from 1:30 to 6:20 p. m., and the shocks were felt at Imperial Junction....'"

\section{MMI for this location: Uncertain}

\section{Location Described: $\quad 2$ miles east of Pope, Imperial Co.}

Report 1: $\quad$ San Bernardino Daily Sun, 20 Apr 1906; p. 2, c. 4

[quoting a telegram from Southern Pacific Railroad Superintendent H. V. Platt, who was in the Imperial Valley at the time:] “'IMPERIAL JUNCTION, April 19.- It is reported from Brawley ... that a serious earthquake occurred there at 4:30 p. m., yesterday....

"'A very low ledge is reported two miles east of Pope, and appears dangerous. It is believed to have been caused by the earthquake, and trains have been given orders for six miles an hour in that section, and section men have been sent out to investigate...."'

This is quite a curious report. The "very low ledge ... believed to have been caused by the earthquake" could be any of a number of possibilities, and it is not inconceivable that it describes a fault scarp. The location is described as "two miles east of Pope." Pope is a locality along the Southern Pacific railroad and lies precisely on the San Andreas fault; hence, the location of this reported ledge would be within two miles of the San Andreas fault. It is also well within the likely epicentral region determined by Meltzner and Wald (2003).

But there may be a more likely explanation. Between 1 and 2 miles ENE of Pope, the Southern Pacific railroad crosses over several stream channels, one of them being of a fairly significant size. It is possible that the intense shaking during the earthquake at the site caused slumping along one of the banks of the channel. A resulting erosional scarp could be the "ledge" that is described in the article.

\section{MMI for this location: $\quad$ Uncertain}

\section{Location Described: $\quad$ Silsbee, Imperial Co.}

Report 1: $\quad$ San Diego Union, 24 Apr 1906; p. 8, c. 3

“... The towns of Imperial, El Centro, and Silsbee escaped without injury...."

\section{MMI for this location: Uncertain}


TABLE 6: PRIMARY REPORTS FOR THE 18 APR 1906 TRIGGERED EVENT at 16:30 in the IMPERIAL VALLEY, CALIFORNIA

Location Described: $\quad$ Los Angeles, Los Angeles Co.

Report 1: $\quad$ Los Angeles Times, 19 Apr 1906; Part II, p. 3, c. 3

"From several parts of the city reports have been received of a slight temblor shortly before 4:30 o'clock yesterday afternoon. The officials in the Federal courts at the top of the Tajo Building seemed to notice the shock most plainly, but in several other downtown buildings persons felt it slightly. In a few cases the swaying of a chandelier was the only sign noticed. No alarm was occasioned, except the apprehension that it was the tail end of another shock at San Francisco."

MMI for this location: III

Location Described: $\quad$ San Juan Capistrano, Orange Co.

Report 1: $\quad$ Lawson (1908), vol. I, p. 414

"Slight."

MMI for this location: Uncertain

Location Described: $\quad$ Santa Ana, Orange Co.

Report 1: $\quad$ Evening Blade (Santa Ana), 19 Apr 1906; p. 3, c. 1

"Besides the faint shock of the earthquake felt here shortly after 5 o'clock yesterday morning and noticed by a considerable number of people through out the city, another shake occurred late yesterday afternoon about 4:30, the effect of which was noticed particularly in the western portion of the city where houses were rocked perceptibly and pictures and other articles depending from the walls were swung to and fro. The disturbance lasted only a few seconds, but the jarring was so pronounced that it was readily recognized as the result of an earthquake. F. F. Thorp, a resident of West Second street was lying ill in bed at the time and he plainly noticed the swaying of the house and the vibration of pendant electric light bulbs in the room he occupied, while other residents of the locality were also apprised of the fact that a seismic disturbance was in progress by the distinct rumbling and jarring of their residences."

MMI for this location: IV-V (preferred: IV)

\section{Location Described: Coachella, Riverside Co.}

Report 1: $\quad$ Los Angeles Times, 19 Apr 1906; Part II, p. 14, c. 6

"COACHELLA, April 18.-Two distinct shocks of earthquake were felt here at 4:30 o'clock this afternoon. There was no damage reported."

MMI for this location: IV ?

Location Described: Hemet, Riverside Co.

Report 1: $\quad$ Lawson (1908), vol. I, p. 414

"Shock increasing and dying away."

MMI for this location: Uncertain

Location Described: $\quad$ Riverside, Riverside Co.

Report 1: $\quad$ Lawson (1908), vol. I, p. 414

"Shock increasing and dying away."

MMI for this location: Uncertain 


\section{TABLE 6: PRIMARY REPORTS FOR THE 18 APR 1906 TRIGGERED EVENT}

at 16:30 in the IMPERIAL VALLEY, CALIFORNIA

\section{Location Described: $\quad$ San Jacinto, Riverside Co.}

Report 1: $\quad$ San Jacinto Register, 26 Apr 1906; p. 4, c. 1

“... At 4:20 p. m. that terrible day a long seismic wave caused a feeling of trepidation for the balance of the night, but not the slightest damage resulted."

Earlier in the article the writer referred to the mainshock in San Francisco as "the great earth wave that swept the State of California." The reference to the 16:20 event as "a long seismic wave," therefore, is not construed to imply anything about the type of motion, only that it was long in duration.

Report 2: $\quad$ Press and Horticulturist (Riverside), 20 Apr 1906; p. 5, c. 3

"San Jacinto, April 18._.... There were some who noticed a slight shock here this morning at 5:20, which must have been a part of the great earthquake which did so much damage in San Francisco. Another prolonged, but not hard shock was felt at about 4:15 this afternoon. It lasted several seconds."

MMI for this location: IV?

\section{Location Described: $\quad$ Temecula, Riverside Co.}

Report 1: $\quad$ Lawson (1908), vol. I, p. 413

felt at Temecula

MMI for this location: $\quad$ Uncertain

\section{Location Described: $\quad$ San Bernardino, San Bernardino Co.}

Report 1: $\quad$ San Bernardino Daily Sun, 19 Apr 1906; p. 2, c. 6-7

"In San Bernardino yesterday two distinct shocks were felt. The first occurred at 5:15 in the morning, exactly the same moment that it occurred in San Francisco.... The second shock occurred in the afternoon at 4:29, which was quite perceptible to people, especially in the upper floors of two or three story buildings. The clocks in the Santa Fe station were stopped by this shock. Both shocks were very light, however, as compared with disturbances of this sort felt here in the past. Many clocks in residences stopped."

Report 2: $\quad$ Lawson (1908), vol. I, p. 300

"... a slight oscillation was felt which caused the chandelier to sway. This movement continued for a few seconds, and seemed to be from northwest to southeast."

Report 3: $\quad$ Lawson (1908), vol. I, p. 413

"Southeast." Lawson (1908) estimates Rossi-Forel intensity III.

MMI for this location: $\quad$ IV

\section{Location Described: $\quad$ Alpine, San Diego Co.}

Report 1: $\quad$ San Diego Union, 19 Apr 1906; p. 5, c. 1

"... At Alpine the shock was felt with about the same degree of intensity as here [in San Diego]...."

MMI for this location: Uncertain 
TABLE 6: PRIMARY REPORTS FOR THE 18 APR 1906 TRIGGERED EVENT at 16:30 in the IMPERIAL VALLEY, CALIFORNIA

Location Described: $\quad$ Ballast Point, San Diego Co.

Report 1: $\quad$ Lawson (1908), vol. I, p. 413

“Clock stopt at $4^{\mathrm{h}} 28^{\mathrm{m}} 15^{\mathrm{s}}$ pend. 18 ", facing E." Duration 15 seconds.

Report 2: $\quad$ Lawson (1908), vol. I, p. 414

“North-south. Horizontal. Clock stopt $4^{\mathrm{h}} 30^{\mathrm{m}}$, facing NW., pend. 17"." Duration: a few seconds.

MMI for this location: Uncertain

Location Described: $\quad$ Coronado, San Diego Co.

Report 1: $\quad$ Los Angeles Examiner, 19 Apr 1906; p. 6, c. 3

"... The shock was also quite severe at Coronado and guests on the top floors of the hotel report their tables, chairs and desks shook considerably...."

MMI for this location: $\quad$ IV

Location Described: $\quad$ Cuyamaca, San Diego Co.

Report 1: $\quad$ San Diego Union, 19 Apr 1906; p. 5, c. 1

“... A telephone message from Cuyamaca stated that the very mountain seemed to rock and that the shock lasted for several seconds...."

MMI for this location: Uncertain

Location Described: Julian, San Diego Co.

Report 1: $\quad$ San Diego Union, 24 Apr 1906; p. 12, c. 2

"Julian, April 23.-.... Despite the fact that this is the last settlement save San Felipe before one comes to the desert, Julian did not feel the slightest shock on the fateful morning of the disaster, yet the desert town of Brawley was severely shaken. In the afternoon, however, a slight tremor was felt, but no damage was done."

The writer of this report mistakenly believed that the earthquake which affected Brawley occurred on the morning of the 18th. Regardless, this report establishes that only the afternoon shock was felt in Julian.

MMI for this location: IV ?

Location Described: $\quad$ Lakeside, San Diego Co.

Report 1: $\quad$ San Diegan-Sun, 18 Apr 1906; p. 1, c. 2

“... This report says the shock was quite susceptible [sic] at Lakeside."

MMI for this location: Uncertain

Location Described: $\quad$ La Mesa, San Diego Co.

Report 1: $\quad$ San Diegan-Sun, 18 Apr 1906; p. 1, c. 2

"A shock was felt at La Mesa this afternoon about 4:30. This is probably the same shock which was felt at San Diego...."

MMI for this location: Uncertain 


\section{TABLE 6: PRIMARY REPORTS FOR THE 18 APR 1906 TRIGGERED EVENT at 16:30 in the IMPERIAL VALLEY, CALIFORNIA}

\section{Location Described: $\quad$ National City, San Diego Co.}

Several newspapers outside National City reported the earthquake in National City. Some of these reports appear to be based upon one of the reports listed below, and they contain no new information. Only reports with unique information are listed below.

Report 1: $\quad$ National City News, 21 Apr 1906; p. 1, c. 2

"Wednesday afternoon at 4:30 o'clock this city experienced two distinct earthquake shocks, followed by a slight tremor. The shocks were strong enough so that everybody felt them. At the home of the editor a large clock on a shelf stopped at half past four to the dot. So far as we have been able to learn no damage was done."

Report 2: $\quad$ Diary of Frank A. Kimball (National City, CA), 18 Apr 1906

An excerpt from the page dated WED. APRIL 18, 1906:

"A slight earthquake shock at $4^{30}$ P.M. did no damage."

A separate letter written by Frank A. Kimball on 18 April 1906, dated "National City Calif. 4/18, 06," places Kimball in National City on the day of the earthquake.

Report 3: $\quad$ Letter of Frank A. Kimball (National City, CA), dated 28 Apr 1906

An excerpt from a letter dated "April 28 [190]6" to A. Snyder Esq., signed by Frank A. Kimball:

"The dreadful calamity that befel [sic] San Francisco and adjacent towns was not felt in Southern California-the 'Quake' struck San Francisco at $5^{\frac{15}{3}}$ A.M. Wednesday 4/18- but was not felt here- but at $4^{30}$ P.M. of same day a slight shock was noticed here by a few people. I did not feel it but my wife called my attention to the hanging lamps-suspended from high ceilings by long chains - which were swinging a little.

"No disturbance within hundreds of miles and we have no apprehensions of danger from 'Quakes."

Report 4: $\quad$ San Diegan-Sun, 18 Apr 1906; p. 1, c. 1-2

“... Three shocks occurred at National City. The first was a heavy one and this was followed by two lighter quakes. Buildings shook, but no damage is reported...."

MMI for this location: IV

\section{Location Described: $\quad$ Ramona, San Diego Co.}

Report 1: $\quad$ Lawson (1908), vol. I, p. 413

"A few seconds." Lawson (1908) estimates Rossi-Forel intensity II.

\section{MMI for this location: Uncertain}

\section{Location Described: $\quad$ San Diego, San Diego Co.}

Many newspapers outside San Diego reported the earthquake in San Diego. Some of these reports appear to be based upon reports that are listed below, and they contain no new information. Only reports with unique information are listed below.

Report 1: $\quad$ San Diego Union, 19 Apr 1906; p. 5, c. 1

"As people in this city yesterday afternoon were gathered in groups discussing the terrible catastrophe at San Francisco or were sitting in their offices at their business they were suddenly subjected to an earthquake themselves. To be sure, it was not of any great degree of intensity, and no damage was done to property nor were any persons injured, but it gave San Diegans and tourists, who may be stopping here a taste of the experience with seismic phenomena. The taste was enough for most people, and they will tell of their participation in the great earthquake of 1906-even though they were on the outskirts, so to speak.

"An evening paper stated in one of its editions that the shock was the most severe in the history of the city. This, however, is not borne out by the statements of those who experienced former shocks 


\section{TABLE 6: PRIMARY REPORTS FOR THE 18 APR 1906 TRIGGERED EVENT at 16:30 in the IMPERIAL VALLEY, CALIFORNIA}

for it was even lighter than some of quite recent years. Chandeliers and hanging lamps were set swaying but not the least damage was done....

"At the office of Weather Observer Ford A. Carpenter, it was reported that the shock came at 4:29:45, and its course was from southwest to northeast. As there is no seismometer here it is difficult to determine the degree of its intensity. Mr. Carpenter would place it as in class No. 4 of the Rossi-Forel scale...

"When the shock was felt here there was a scurrying from office buildings, including the city hall and the court houses. There was no waiting on ceremony, but everybody made for the open with all possible speed, many without hats or coats."

The "evening paper" mentioned above is assumed to be the Sun. Compare this report with the articles in the San Diegan-Sun, 18 Apr 1906, p. 1, c. 1-2, and 19 Apr 1906, p. 2, c. 4.

In light of comments in the later report (19 Apr) in the Sun, which downplay comments in the Sun's first report, the Sun's reports are not considered fully reliable, and the San Diego Union is believed to have the most reliable account of the earthquake in San Diego.

Report 2: $\quad$ San Diegan-Sun, 18 Apr 1906; p. 1, c. 1-2

[UNRELIABLE]

"At 4:30 the strongest shock of earthquake known in San Diego in 15 years was experienced.

"The direction was from northeast to southwest.

"It shook chandeliers, but did no damage, as far as can be reported. Weather Observer Carpenter says: 'The shock, coming from northeast to southwest, is the usual direction, as the records for 15 or 16 quakes show that 75 per cent have come from that direction. No record of anything stronger.'

"The weather bureau is in one of the tallest buildings of the city, and the clock there was not stopped. But Mr. Carpenter said that had the direction of the quake been different it would have stopped the clock....

"When the shock came at 4:30 one of the roomers at the Keating block rushed down stairs with all the clothes she could hurriedly gather and fainted after reaching the street.

"Telephone communications from different parts of the city say chandeliers swung and tall book cases swayed. This shows that the shock was general all over the city."

Compare this with the article in the San Diegan-Sun, 19 Apr 1906, p. 2, c. 4, and with the article in the San Diego Union, 19 Apr 1906, p. 5, c. 1.

In light of comments in the later report (19 Apr) in the Sun, which downplay comments in the Sun's first report (above), the Sun's reports are not considered fully reliable, and the San Diego Union is believed to have the most reliable account of the earthquake in San Diego.

Report 3: $\quad$ San Diegan-Sun, 19 Apr 1906; p. 2, c. 4

"The following is the official memorandum made by Weather Observer Carpenter of the earthquake felt in San Diego Wednesday afternoon:

"'The shock experienced at 4:29:45, S.W. N.E., 20 seconds and was the worst shock experienced in San Diego for the past 15 years....

"'My conclusion as to the severity of the shock Wednesday was based largely upon the visible vibration of two mercurial barometers, each three feet in length, freely suspended in our barometer case. These barometers vibrated to the limit of their fastenings. The sway of the chandeliers and the disturbance of the clock's pendulum were also taken into account in arriving at the conclusion.'

"The important fact is not to be forgotten that while Wednesday's shock was the most severe experienced in many years, it was not severe enough to stop a clock."

Compare this with the article in the San Diegan-Sun, 18 Apr 1906, p. 1, c. 1-2, and with the article in the San Diego Union, 19 Apr 1906, p. 5, c. 1.

In light of comments in the later report (above) in the Sun, which downplay comments in the Sun's first report (18 Apr), the Sun's reports are not considered fully reliable, and the San Diego Union is believed to have the most reliable account of the earthquake in San Diego.

Report 4: $\quad$ San Diego Union, 21 Apr 1906; p. 4, c. 1-2

"All rumors that there has been a tidal wave or other disaster here are pure invention. At 4:30 p. m last Wednesday there was a slight shock of earthquake. It did no damage whatever, and was so light that many people did not feel it." 
TABLE 6: PRIMARY REPORTS FOR THE 18 APR 1906 TRIGGERED EVENT at 16:30 in the IMPERIAL VALLEY, CALIFORNIA

Report 5: $\quad$ San Diego Union, 22 Apr 1906; p. 8, c. 6

"A special dispatch to the Union last evening from the Imperial Standard implied that the damage done at Brawley was not as great as was first reported. By fixing the time, the dispatch shows that the Brawley quake was the one we felt slightly here. The dispatch was:

"'Imperial, Calif., April 21.-An earthquake shock on Wednesday at 4:30 p. m. damaged adobes at Brawley. There were no casualties....'"

Report 6: $\quad$ Los Angeles Examiner, 19 Apr 1906; p. 6, c. 3

"SAN DIEGO, April 18.-San Diego experienced its first earthquake of the day at 4:28 o'clock this afternoon. The shock was a short one, but was quite pronounced while it lasted. All of the business buildings in the city shook, chandeliers and pictures swayed. The people in the business blocks were greatly frightened and within a few seconds the streets were crowded with agitated men and women.

"At the court house the employees were greatly frightened and in less than half a minute the entire building was emptied. This record was equalled by those employed in the city offices at the city hall.

“... The shock was apparently felt along the entire western slope of San Diego county. Following the shock many employees of different companies quit work, being unwilling to take chances by remaining at their work in brick buildings. The local weather office reports the course of the quake as being from southwest to northeast."

Report 7: $\quad$ Los Angeles Herald, 19 Apr 1906; Part I, p. 4, c. 6-7

"SAN DIEGO, April 18.-While the people were gathered in groups discussing the havoc that has been wrought at San Francisco by earthquakes, at 4:30 o'clock this afternoon a shock was felt here, which threw the town into a state of panic.

"Everybody was worked up to a state of nervousness by news from the north and when the shock came people thought that the town was being destroyed.

"In a short time the shaking subsided and the town became quiet. No damage was done...."

Report 8: $\quad$ Los Angeles Times, 19 Apr 1906; Part II, p. 14, c. 7

"SAN DIEGO, April 18.-[Exclusive Dispatch.] A slight shock was felt here at 4:30 o'clock this afternoon. Many people experienced the feeling of sea sickness. A number of women in buildings fainted, or were rendered unconscious from fright, and were hustled into the open. People rushed out of the larger buildings into the streets. Numerous clocks were stopped and dishes were rattled."

Report 9: $\quad$ Los Angeles Times, 20 Apr 1906; Part I, p. 8, c. 5

"SAN DIEGO, April 19.-Telegrams are being received in this city showing that the report has been sent out from Los Angeles that San Diego had suffered damage from earthquake. There has been absolutely no damage done in this section, the only shock felt being a very slight one at 4:30 pm. yesterday...."

Report 10: $\quad$ Lawson (1908), vol. I, p. 413

"Northwest and southeast. Strongest apparently at beginning. Clock not stopt, but disturbed, losing about $1 \mathrm{~m}$.; pend. about 26". No sound phenomena." Duration 20 seconds. Lawson (1908) estimates Rossi-Forel intensity IV-V.

Report 11: $\quad$ Lawson (1908), vol. I, p. 413

"Heaviest in 15 years, northeast-southwest."

\section{MMI for this location: IV-V (preferred: IV)}

\section{Location Described: $\quad$ Yuma, Yuma Co., Arizona}

Report 1: $\quad$ Arizona Sentinel (Yuma), 18 Apr 1906; p. 3, c. 5

"A slight but distinct earthquake was felt here this afternoon at 4:30, lasting perhaps ten seconds. No damage was done, but on account of the reports of the awful destruction at San Francisco the quake caused considerable uneasiness. The direction of the temblor was from northwest to southeast...." 
TABLE 6: PRIMARY REPORTS FOR THE 18 APR 1906 TRIGGERED EVENT at 16:30 in the IMPERIAL VALLEY, CALIFORNIA

Report 2: $\quad$ Riverside Daily Press, 19 Apr 1906; p. 1, c. 2 Press and Horticulturist (Riverside), 20 Apr 1906; p. 1, c. 1

"YUMA, Ariz., April 19.-Yuma experienced nine or ten distinct earthquake shocks at 4:30 p.m. and following the reports of earthquakes elsewhere, caused quite a stir. Tenants of two-story buildings felt it most and rushed out on the streets in haste. No damage resulted."

Report 3: $\quad$ Lawson (1908), vol. I, p. 414

"9 or 10 distinct shocks, slight rolling from east to west."

Report 4: $\quad$ Townley and Allen (1939), p. 294

"Slight rolling vibration from east to west."

This report is attributed to S. Hackett of the U.S. Weather Bureau.

MMI for this location: IV-V (preferred: IV)

\section{Location Described: Cocopah, Baja California, Mexico}

Report 1: $\quad$ Richter (1958), p. 485

"... on the afternoon of ... April 18, 1906, there was a strong shock in Imperial Valley, which was then rather thinly settled; nevertheless, there was damage at Brawley, and a water tank was thrown down at the railroad station of Cocopah (Mexico)."

According to the National Imagery and Mapping Agency (NIMA) GEOnet Names Server (GNS, available online at http://www.nima.mil/gns/html/), the railroad station of Cocopah also goes by the name Estación Cocopar (or Cocopar) and is located at lat $32^{\circ} 33^{\prime} \mathrm{N}$, lon $115^{\circ} 14^{\prime} \mathrm{W}$.

MMI for this location: Uncertain

Location Described: Tijuana, Baja California, Mexico

Report 1: $\quad$ San Diego Union, 19 Apr 1906; p. 5, c. 1

“... Tia Juana [sic] reported the shock at close to 4:20...."

Report 2: $\quad$ Los Angeles Examiner, 19 Apr 1906; p. 6, c. 3

"SAN DIEGO, April 18._... Tia Juana [sic] reported that the quake reached there at 4:29 o'clock...."

MMI for this location: Uncertain 


\section{TABLE 7: PRIMARY REPORTS FOR THE 19 APR 1906 TRIGGERED EVENT at 12:31 near SANTA MONICA BAY, CALIFORNIA}

\section{SEE CORRESPONDING FIGURE 4}

\section{Location Described: $\quad$ Avalon, Los Angeles Co.}

Report 1: $\quad$ Los Angeles Times, 20 Apr 1906; Part II, p. 10, c. 4

“AVALON, April 19.-A slight shock of earthquake was felt here at 12:30 today, but was so slight as to be unnoticed by the majority of people...."

Note that, with respect to Avalon and Catalina Island, this report contradicts information given in the Los Angeles Examiner of 20 Apr 1906 (p. 7, c. 7), which states that the earthquake was not felt on Catalina Island.

Report 2: $\quad$ Los Angeles Times, 21 Apr 1906; Part II, p. 14, c. 3

"AVALON, April 20.-The uncalled-for rumor of an earthquake here ... caused a great deal of anxiety, as was evidenced by numerous telegrams received from anxious friends and relatives on the mainland.

"The canard had the further effect of greatly influencing the travel here, the passenger list today being the lightest of the year, to date. The one little tremor experienced was really too light to be called an earthquake, not more than a dozen people feeling it."

Note that, with respect to Avalon and Catalina Island, this report contradicts information given in the Los Angeles Examiner of $20 \mathrm{Apr} 1906(p .7, c .7)$, which states that the earthquake was not felt on Catalina Island.

Report 3: $\quad$ Los Angeles Examiner, 20 Apr 1906; p. 7, c. 7

"... Sensation mongers started a foolish report to the effect that Catalina Island had suffered fearfully from the effects of the seismic wave, but reports from the resort stated that the shock had not even been felt there...."

Note that, with respect to Avalon and Catalina Island, this report contradicts information given in the Los Angeles Times of 20 Apr 1906 (Part II, p. 10, c. 4) and 21 Apr 1906 (Part II, p. 14, c. 3), which states that the earthquake was felt lightly in Avalon.

Report 4: Oregon Daily Journal (Portland), 20 Apr 1906; p. 10, c. 3

"Los Angeles, April 20.-Three slight shocks following in rapid succession shook southern California and startled the visitors at Avalon at noon yesterday. No damage was done and there have been no repetitions of tremors since.... The story that any one was killed at Avalon is absolutely untrue."

MMI for this location: III

\section{Location Described: $\quad$ Hollywood, Los Angeles Co.}

Report 1: $\quad$ Los Angeles Examiner, 20 Apr 1906; p. 7, c. 7

"... Hollywood ... felt the shock slightly but no serious damage was caused...."

Report 2: $\quad$ Los Angeles Examiner, 20 Apr 1906; p. 7, c. 7

“... Hollywood also felt the tremor shortly after noon yesterday. A slight crack in a wall of a building was the full extent of the damage...."

\section{MMI for this location: IV-V (preferred: IV)}




\title{
TABLE 7: PRIMARY REPORTS FOR THE 19 APR 1906 TRIGGERED EVENT at 12:31 near SANTA MONICA BAY, CALIFORNIA
}

\section{Location Described: $\quad$ Long Beach, Los Angeles Co.}

\author{
Report 1: $\quad$ Long Beach Evening Tribune, 19 Apr 1906; p. 4, c. 5-6
}

"A slight tremor was noticed in Long Beach at 12:28 today, and timid ones, ready to jump at the dropping of a pin, avowed it was a quake and then looked over to the east to see if 'Old Baldy' was smoking. The shock, if it was such, was noticed only within doors. Outside it was not felt."

Report 2: $\quad$ Los Angeles Times, 20 Apr 1906; Part II, p. 14, c. 1

"LONG BEACH, April 19.- This city was visited by an earthquake shock at 12:28 o'clock this afternoon. The shock was of three or four seconds' duration, and was from north to south and seemed to be stronger north of town. Windows and doors rattled, but no damage is reported beyond the tension on the nerves of people already on a hair-trigger strain. All the city schools were dismissed at noon today because the children were too restless and unstrung to do any studying."

Report 3: $\quad$ Los Angeles Examiner, 20 Apr 1906; p. 7, c. 7

"... Long Beach ... felt the shock slightly but no serious damage was caused...."

\section{MMI for this location: IV}

\section{Location Described: $\quad$ Los Angeles, Los Angeles Co.}

Report 1: $\quad$ Los Angeles Examiner, 20 Apr 1906; p. 7, c. 7

“Los Angeles and surrounding towns experienced a slight earthquake shock at 12:31 o'clock yesterday afternoon, but no damage whatever was caused by the disturbance.

"The temblor came at a time when the downstairs cafes, hotels and office buildings were filled with people, but beyond causing momentary fright to nervously inclined persons, the shock had no effect whatever.

"The exact time of the quake was 12:31:40 p. m., as recorded by Observer Franklin of the United States Weather Bureau. It lasted only about three seconds, though many excited individuals thought it lasted much longer....

"'It amounted to absolutely nothing,' said Mr. Franklin. 'My office boy, who was keenly alert, noticed it, but thought someone had simply slammed a door.'

"Rumors were current that many of the big buildings had settled and that cracks had appeared in the Conservative Life, city jail and other buildings, but these were proved by investigation to be absolutely untrue.

"A crack in one of the stones in the jail building was noticed by some for the first time, although it had been there for nearly ten years. Neither the Conservative Life nor any of the other buildings in the city was affected in the least.

"When the temblor was felt, the timid rushed from the big buildings and in several of the cafes where noonday lunchers were dining, several made the earthquake scare an excuse to get out in a hurry.

"At the various beach resorts the shock was felt and the incoming cars were soon crowded by people who were frightened by predictions of a tidal wave. The ocean was perfectly serene and no cause whatever for the excitement could be found...."

Report 2: $\quad$ Los Angeles Examiner, 20 Apr 1906; p. 6, c. 2

"Los Angelenos have determined not to be discomfited by any little temblor that comes along.

"Yesterday afternoon at the Jonathan Club there were a hundred or more men about town playing dominoes and loafing about waiting for the general lunch hour.

"It was at this time that the little temblor came along and gave the Huntington building a shake that set the chandeliers to swinging.

"The men playing dominoes simply looked up for a minute and continued their game. 


\section{TABLE 7: PRIMARY REPORTS FOR THE 19 APR 1906 TRIGGERED EVENT}

at 12:31 near SANTA MONICA BAY, CALIFORNIA

“Walter Parker and Phil Stanton were playing a game....

"Just as the tremblor swung the building, Stanton became impatient, and said: 'It's your play, Walter; get a move on.'

"'It seems to me,' replied Parker, looking up at the dancing chandeliers and gripping the arms of his chair, 'that I am moving.'"

Report 3: $\quad$ Los Angeles Express, 19 Apr 1906; p. 3, c. 3-4

"Attempts not only to make the East believe that Los Angeles is seriously affected by the earthquake shocks, but to create fear here, have come to light through investigation of an absurd message sent to the war department by some irresponsible person in San Francisco....

"The fake came to light in a message to Los Angeles as follows:

“'WASHINGTON, April 19.- The war department has received the following telegram from San Francisco: 'Los Angeles says building rocking like a boat. Just lost connection with Los Angeles immediately after this report. Men probably left building."

"While there was a tremor of the earth's surface in Los Angeles, it was so slight as to be barely noticeable, except in the tallest buildings, and at the United States weather observatory it was classed as nothing unusual.

"A few persons asserted that they had felt the shock, but until the news from the North came many thought that any temblor which they might have believed themselves to have experienced was more the effect of an overwrought imagination and nervousness caused by the disaster in San Francisco.

"G. E. Franklin, at the head of the United States weather bureau, in his report of the quake ten minutes after it had occurred, said:

“'There was nothing at all unusual in the shock. I timed it as happening at $12: 31{ }^{1} /{ }_{4} \mathrm{o}^{\prime}$ clock. It was of hardly sufficient strength to move the pendulum of the large clock in my office, and of a single undulation, seemed to be moving from north to south....'"

Report 4: $\quad$ Diary of Selena Gray Ingram (Los Angeles, CA), 19 Apr 1906

Written in the top margin of the page for the 19 Apr 1906 entry:

"We had a shock in Los Angeles today at noon-but no damage was done."

Report 5: $\quad$ Lawson (1908), vol. I, p. 414

"Increased intensity, 1 max., strongest at middle. No sound." Duration 20-30 seconds.

Time listed for this event is 12:31:00.

Report 6: $\quad$ Lawson (1908), vol. I, p. 414

Felt at Los Angeles. Time listed for this event is 12:31:41.

Report 7: $\quad$ Lawson (1908), vol. I, p. 415

"Two shocks about $6 \mathrm{~m}$. apart followed by slight tremors for about $1 \mathrm{~h} . "$

Time listed for this event is 12:33.

Report 8: $\quad$ Riverside Daily Press, 19 Apr 1906; p. 8, c. 3

"LOS ANGELES, April 19.--(Special to Press.) - Los Angeles was thrown into a tremor of fright at 12:31 today by two sharp and distinct earthquake shocks. These lasted but a few seconds and did no appreciable damage, but the feelings of the people were at such a high pitch that they became panicky and rushed out of doors at the first tremor. Although the shocks were light, the feeling was so intense that a large number refused to return to brick buildings again and sought the parks to spend the remainder of the afternoon."

Report 9: $\quad$ Oregon Daily Journal (Portland), 20 Apr 1906; p. 10, c. 3

"... it was so slight that that many people did not notice it, and no damage was done in any way." 


\section{TABLE 7: PRIMARY REPORTS FOR THE 19 APR 1906 TRIGGERED EVENT}

at 12:31 near SANTA MONICA BAY, CALIFORNIA

Report 10: $\quad$ The Independent (Santa Barbara), 19 Apr 1906; p. 1, c. 1-3

[UNRELIABLE]

“LOS ANGELES, April 19._... a distinct earthquake shock was felt throughout this city. The seismic disturbance was sufficient to make the large buildings in the down town districts tremble perceptibly, in several parts of the city chimneys were thrown down and other minor damage done. This coming at a time when the public mind is so wrought up over the fearful results of the earthquake in San Francisco immediately created the utmost consternation, almost amounting to a panic. Men turned pale and women became hysterical. Many of the occupants of the large public buildings sought the streets, but the commotion quickly subsided, though the feeling of nervousness remained. Out in the residence portion of the city, however, women and children fled from their homes into the streets and many of them have refused to return. The shock has been sufficient to create a general panicky feeling."

In comparison to reports published in local newspapers, this account is obviously exaggerated.

Report 11: $\quad$ San Diegan-Sun, 19 Apr 1906; p. 1, c. 6-7

[UNRELIABLE]

"Shortly after noon Thursday the report was confirmed at the Western Union telegraph office that Los Angeles had experienced an earthquake shock at 12:50 p. m. today.

"No damage was done, but the shock was sharp.

"Employees of the Western Union Telegraph company in Los Angeles, it is stated, deserted their work, but later returned.

“For a time all communication with Los Angeles was cut off.

“Bensel Smythe, the Sun's special representative at Los Angeles, 'phoned the Sun at 1:25 p. m. that the earthquake was felt only in the business part of the city.

"An elevator in the Bryson building was left suspended between the second and third floors and was still there full of people at the hour of receipt of the message.

"The Bryson building is located at Second and Spring streets....

"The report reached San Diego that Los Angeles has had a second shock today."

In comparison to reports published in local newspapers, this account is obviously exaggerated.

MMI for this location: $\quad$ IV

Location Described: $\quad$ Monrovia, Los Angeles Co.

Report 1: $\quad$ Los Angeles Examiner, 20 Apr 1906; p. 7, c. 7

“... Monrovia ... felt the shock slightly but no serious damage was caused...."

MMI for this location: Uncertain

\section{Location Described: $\quad$ Ocean Park, Los Angeles Co.}

Report 1: $\quad$ Los Angeles Examiner, 20 Apr 1906; p. 7, c. 7

“... At Ocean Park guests of the Hotel Decatur fled from the buildings and the streets were soon thronged with residents, many of them carrying personal effects. Their fears were soon allayed and the majority of them returned to their homes...."

MMI for this location: V ?

\section{Location Described: $\quad$ Pasadena, Los Angeles Co.}

Report 1: $\quad$ Los Angeles Examiner, 20 Apr 1906; p. 7, c. 7

“... Pasadena ... felt the shock slightly but no serious damage was caused...."

MMI for this location: Uncertain 


\section{TABLE 7: PRIMARY REPORTS FOR THE 19 APR 1906 TRIGGERED EVENT at 12:31 near SANTA MONICA BAY, CALIFORNIA}

\section{Location Described: $\quad$ San Pedro, Los Angeles Co.}

Report 1: $\quad$ Los Angeles Times, 20 Apr 1906; Part II, p. 14, c. 2

"SAN PEDRO, April 19._.... At exactly 12:30 o'clock today there was an earthquake shock felt here that was sufficient to cause a jarring and shaking up of the buildings, creating considerable excitement in the downtown district, but doing no damage.

"People in all the business houses rushed into the streets and for a time there was some alarm. It was all over in a moment, however, and all uneasiness soon passed away.

"Several slight cracks in buildings were reported; glass bottles were thrown from the shelves in the drug stores and dishes in the restaurants rattled greatly. No damage at all was reported. People living in the resident district felt it slightly, but not so great as downtown.

"It was sufficient to knock the plaster off the tower of the town clock and loosen considerable earth on Knob Hill."

Report 2: $\quad$ Los Angeles Examiner, 20 Apr 1906; p. 7, c. 7

"... San Pedro ... felt the shock slightly but no serious damage was caused...."

Report 3: $\quad$ Lawson (1908), vol. I, p. 415

"Horizontal tremors 10 s. before, increased intensity, strongest at end. No sound." Duration 15 seconds.

MMI for this location: $\quad$ V

\section{Location Described: $\quad$ Santa Monica, Los Angeles Co.}

Report 1: $\quad$ Daily Outlook (Santa Monica), 19 Apr 1906; p. 1, c. 4

"At 12:29 today the Santa Monica bay section heard the awful rumble and roar and felt the vibrations and undulations of an earthquake shock. The tremblor moved from north to south, apparently quite closely following the coast line. The disturbance had a duration of thirty-two seconds and during that time there was a perceptible swaying of buildings and creaking and crackling of timbers.

"A slight crack under the window of the Joseph Kuhrts building at the door of the Kuhrts building [sic] at the corner of Utah and Second was observed...."

Report 2: $\quad$ Los Angeles Times, 20 Apr 1906; Part II, p. 14, c. 2

"SANTA MONICA, April 19.-At 12:20 today Santa Monica felt, with distinctness that carried alarm with it, the undulations of an earthquake shock. There were apparently three separate shakes, all moving from north to south and lasting thirty-two seconds...."

\section{MMI for this location: IV-V (preferred: V)}

\section{Location Described: Sawtelle, Los Angeles Co.}

Report 1: $\quad$ Los Angeles Times, 20 Apr 1906; Part II, p. 14, c. 2

“SAWTELLE, April 19.-This community received a severe shaking up at 12:30 o'clock today. To all appearances the movement of the temblor was from north to south. So decided were the vibrations that canned goods on the shelves in grocery stores were shaken to the floor with a crash. Mirrors in barber shops were broken. People ran out of their houses in alarm, their faces depicting terror, but there was no damage to any of the buildings in the city."

Report 2: $\quad$ Los Angeles Examiner, 20 Apr 1906; p. 7, c. 7

"... At Sawtelle it was reported that canned goods and other articles were shaken from the shelves of stores, but this rumor was found to be greatly exaggerated. People rushed into the streets and an old soldier was knocked from his crutches, but was not injured...."

\section{MMI for this location: $\quad$ V}




\section{TABLE 7: PRIMARY REPORTS FOR THE 19 APR 1906 TRIGGERED EVENT}

at 12:31 near SANTA MONICA BAY, CALIFORNIA

Location Described: $\quad$ Soldiers Home, Los Angeles Co. (now Veterans Administration land, west of Westwood)

Report 1: $\quad$ Los Angeles Times, 20 Apr 1906; Part II, p. 14, c. 2

“SOLDIERS' HOME, April 19.-The earthquake here half an hour after noon today was severe in the barracks. Many of the veterans rushed out of the buildings. Local Manager H. H. Markham, who is visiting here, said he was startled by the shock...."

MMI for this location: V ?

\section{Location Described: $\quad$ Venice, Los Angeles Co.}

Report 1: $\quad$ Los Angeles Examiner, 20 Apr 1906; p. 7, c. 7

"... At Venice bits of plastering fell from the walls of several buildings and a high chimney was slightly cracked, but no damage of any consequence occurred...."

Report 2: $\quad$ Los Angeles Times, 20 Apr 1906; Part II, p. 14, c. 2

"SANTA MONICA, April 19._.... Except for a few minor cracks in the taller of the brick buildings at Venice the quake left no scars.".

Report 3: $\quad$ Daily Outlook (Santa Monica), 19 Apr 1906; p. 1, c. 4

"... At Venice several of the tall brick buildings were cracked just a little."

MMI for this location: $\quad$ VI

Location Described: Whittier, Los Angeles Co.

Report 1: $\quad$ Los Angeles Examiner, 20 Apr 1906; p. 7, c. 7

"... Whittier ... felt the shock slightly but no serious damage was caused...."

MMI for this location: Uncertain

\section{Location Described: $\quad$ Santa Ana, Orange Co.}

Report 1: $\quad$ Evening Blade (Santa Ana), 19 Apr 1906; p. 8, c. 3

"Another slight shock of earthquake was felt today at Santa Ana at 12:30, the tremor being sufficient to sway the chandeliers in the various rooms of the county court house and jar the whole building from foundation to cupola. The vibrations were from northeast to southwest and lasted for several seconds."

Report 2: $\quad$ Los Angeles Examiner, 20 Apr 1906; p. 7, c. 7

“... A slight shock at 12:30 o' clock yesterday is reported from Santa Ana. No damage was done...."

MMI for this location: III-IV (preferred: IV)

\section{Location Described: $\quad$ Riverside, Riverside Co.}

Report 1: $\quad$ Riverside Daily Press, 19 Apr 1906; p. 8, c. 3

"Riverside also experienced a tiny shiver at 12:30, not large enough to be felt by the majority, but still perceptible in tall buildings."

Report 2: $\quad$ Los Angeles Times, 20 Apr 1906; Part II, p. 14, c. 3

"RIVERSIDE, April 19.-.... At 12:30 o'clock today there was a slight shake here of the same character as the tremor of yesterday."

MMI for this location: III 


\section{TABLE 7: PRIMARY REPORTS FOR THE 19 APR 1906 TRIGGERED EVENT}

at 12:31 near SANTA MONICA BAY, CALIFORNIA

\section{Location Described: $\quad$ Ontario, San Bernardino Co.}

Report 1: $\quad$ Los Angeles Examiner, 20 Apr 1906; p. 7, c. 7

"... At Ontario the shocks of the earthquake were so slight as to pass unnoticed by most of the residents...."

MMI for this location: III

\section{Location Described: $\quad$ San Bernardino, San Bernardino Co.}

Report 1: $\quad$ Los Angeles Times, 20 Apr 1906; Part II, p. 14, c. 3

"SAN BERNARDINO, April 19._... A slight shock was perceptible here at 1:15 o'clock this afternoon."

MMI for this location: III

\section{Location Described: Ventura, Ventura Co.}

Report 1: $\quad$ Daily Free Press (Ventura), 19 Apr 1906; p. 2, c. 1

"Another slight tremor was felt here at 12:35 today. The shake was slight but it was very noticeable and set all hanging articles in motion. The shake had a tendency to cause much alarm in the city, fearing that it might be worse in other places than it was here. No damage has been reported as a result of today's shake."

MMI for this location: IV 


\section{TABLE 8: PRIMARY REPORTS FOR THE 19 APR 1906 TRIGGERED EVENT}

at 20:15 near FERNLEY, LYON COUNTY, NEVADA

\section{SEE CORRESPONDING FIGURE 5}

\section{Location Described: $\quad$ Carson Dam, Churchill Co., Nevada}

Report 1: $\quad$ Lawson (1908), vol. I, p. 324-325

“... It was apparently not felt at Fallon, tho it was distinctly felt 12 miles west at Carson Dam...."

Report 2: $\quad$ Townley and Allen (1939), p. 280

"Carson Dam. Twelve miles west of Fallon; shock plainly felt."

MMI for this location: $\quad$ Uncertain

\section{Location Described: $\quad$ Fallon, Churchill Co., Nevada}

Report 1: $\quad$ Lawson (1908), vol. I, p. 324-325

“... It was apparently not felt at Fallon...."

Report 2: $\quad$ Townley and Allen (1939), p. 280

"Not felt at Reno, Fallon, Lovelock, and east."

MMI for this location: Not Felt

\section{Location Described: Hazen, Churchill Co., Nevada}

Report 1: $\quad$ Lawson (1908), vol. I, p. 324-325

“... It was generally felt at Hazen, Wadsworth, Olinghouse, and neighboring places where it is hard to find any one that noticed any effects of the great quake. In Hazen it rattled windows, made gas jets and lamps swing, and doors swing on hinges. The railroad station clock is said to have stopt.... The vibration was apparently northwest-southeast, or north-south, at Hazen...."

Report 2: $\quad$ Townley and Allen (1939), p. 280

"Windows rattled; gas jets swung north to south."

MMI for this location: IV-V

\section{Location Described: $\quad$ Fernley, Lyon Co., Nevada}

Report 1: $\quad$ Lawson (1908), vol. I, p. 324-325

“... In the Reclamation Service camp at Fernley it was quite strong, as felt on the ground in the tent.... At Fernley ... it was described as northeast-southwest."

Report 2: $\quad$ Townley and Allen (1939), p. 280

"Quite strong in tent.-Mr. Post at Reclamation Service Camp."

MMI for this location: $\quad \mathrm{V}$ 


\section{TABLE 8: PRIMARY REPORTS FOR THE 19 APR 1906 TRIGGERED EVENT}

at 20:15 near FERNLEY, LYON COUNTY, NEVADA

\section{Location Described: $\quad$ Browns Station, Pershing Co., Nevada}

Report 1: $\quad$ Lawson (1908), vol. I, p. 324-325

“... It was felt as far east as Brown's Station...."*

Report 2: $\quad$ Townley and Allen (1939), p. 280

"Men preparing for bed scared and ran out of house."

* Carlson (1974) identifies two locations named "Browns Station," both of which would be on the periphery of the felt region for this event. One of them-the earliest station of this name-was located on the Carson River "about three miles above old Fort Churchill" in Lyon County. This would be south and west of most of the other points of observation. The other Browns Station -according to Carlson-was in Churchill County, 16 miles southwest of Lovelock, and was "a famous point on the Overland Stage route and later on the Southern Pacific Railroad." [While approximately correct, Carlson placed the location in the wrong county. The USGS Geographic Names Information System (GNIS, available online at http://geonames.usgs.gov/) locates this point precisely along the old route of the Central Pacific Railroad, 0.3 miles west of the present-day locality of Toy, in present-day Pershing County. Toy is on the Toulon, Nev., 15' quadrangle topo map of 1956.] The latter location for Browns Station would be north and east of the other points of observation. This would also be at about the same longitude, but north of, Fallon, where it was not felt. The latter location seems more plausible, in light of the statement that it was felt "as far east as" Browns Station and in light of the implication that the Pershing County location was more well known. [In addition, the USGS GNIS lists the Browns Station in Pershing County as a "populated place," whereas the Browns Station in Lyon County is only a "locale."]

MMI for this location: IV ?

\section{Location Described: $\quad$ Lovelock, Pershing Co., Nevada}

Report 1: $\quad$ Townley and Allen (1939), p. 280

"Not felt at Reno, Fallon, Lovelock, and east."

MMI for this location: $\quad$ Not Felt

\section{Location Described: Olinghouse, Washoe Co., Nevada}

Report 1: $\quad$ Lawson (1908), vol. I, p. 324-325

“... It was generally felt at Hazen, Wadsworth, Olinghouse, and neighboring places where it is hard to find any one that noticed any effects of the great quake.... At Olinghouse also it was felt as a sharp shock—one called it a quiver—and caused windows to rattle...."

Report 2: $\quad$ Townley and Allen (1939), p. 280

"Windows rattled; crowd in hotel bar-room scared and ran outside."

MMI for this location: IV

\section{Location Described: $\quad$ Reno, Washoe Co., Nevada}

Report 1: $\quad$ Townley and Allen (1939), p. 280

“Not felt at Reno, Fallon, Lovelock, and east."

MMI for this location: $\quad$ Not Felt 


\section{TABLE 8: PRIMARY REPORTS FOR THE 19 APR 1906 TRIGGERED EVENT}

at 20:15 near FERNLEY, LYON COUNTY, NEVADA

\section{Location Described: $\quad$ Steamboat Springs, Washoe Co., Nevada}

Report 1: $\quad$ Lawson (1908), vol. I, p. 325

"... A second shock, seemingly as hard as the first, was felt the second or third night after [the California mainshock]."

The date and time of the event described cannot be resolved.

\section{MMI for this location: Uncertain [may have been a different event]}

\section{Location Described: $\quad$ Wadsworth, Washoe Co., Nevada}

Report 1: $\quad$ Lawson (1908), vol. I, p. 324-325

"... It was generally felt at Hazen, Wadsworth, Olinghouse, and neighboring places where it is hard to find any one that noticed any effects of the great quake.... At Wadsworth, it made the windows rattle and caused some fear, owing to reports of the San Francisco disaster. One person describes it as a quick sharp shock like a blast...."

Report 2: $\quad$ Townley and Allen (1939), p. 280

"Sharp, quick shock like a blast; windows rattled."

MMI for this location: IV

\section{Location Described: $\quad$ East slope of the Virginia Range, Nevada}

Report 1: $\quad$ Lawson (1908), vol. I, p. 324-325

"The Earthquake of April 19, 1906, $8^{h} 15^{m}$ to $8^{h} 30^{m}$ P. M. (Intensity, IV-V.)-This earthquake was distinctly felt along the east slope of the Virginia range and the valley land directly east and not far north or south of Lat. $39^{\circ} 31^{\prime}$. Wherever reported it was much stronger than the shake produced by the California earthquake of the previous day...."

Report 2: $\quad$ Lawson (1908), vol. I, p. 415

“On east slope of Virginia Range, Sierra Nevadas; northwest-southeast. During next 1.5 h. 3 more." Lawson (1908) estimates Rossi-Forel intensity IV-V for the shock at 20:15-20:30.

This report is attributed to "G. D. L." There is a key to people's initials following the list of aftershocks in Lawson (1908), but "G. D. L." is not included in the key. The report in Townley and Allen (1939) for the same earthquake credits George D. Louderback of the University of Nevada, Reno, and indeed, G. D. Louderback was a co-author of Lawson (1908), making the reference obvious.

\section{MMI for this location: Uncertain}


TABLE 9: PRIMARY REPORTS FOR THE 23 APR 1906, 01:10 AFTERSHOCK

\section{SEE CORRESPONDING FIGURE 6}

\section{Location Described: $\quad$ Oakland, Alameda Co.}

Report 1: $\quad$ Courier-Free Press (Redding), 23 Apr 1906; p. 1, c. 2

[UNRELIABLE]

"The shake was felt as far north as Portland and Seattle and south in Oakland and San Francisco, though no damage was reported from any section in the state."

These statements must be erroneous. The report is not corroborated in either the Oregon Daily Journal or the Morning Oregonian, both of which were published daily in Portland. Also, there are no reliable reports which suggest that this earthquake was felt in Oakland, San Francisco, or Seattle.

\section{MMI for this location: Unreliable}

\section{Location Described: $\quad$ Chico, Butte Co.}

Report 1: $\quad$ Chico Semi-Weekly Record, 24 Apr 1906; p. 1, c. 6

"The shock was felt by several in Chico, but was not of sufficient severity to awaken more than a few in the town."

\section{MMI for this location: III}

\section{Location Described: $\quad$ Crescent City, Del Norte Co.}

Report 1: $\quad$ Del Norte Record, 28 Apr 1906; p. 3, c. 2

"... another earthquake shock was felt here. Some who were awakened reported that the shock was more severe than that on the morning of the 18th inst. The western and eastern portions of town received the heaviest shock. No damage was done...."

Report 2: $\quad$ Humboldt Times, 24 Apr 1906; p. 8, c. 4

[UNRELIABLE]

"As nearly as can be learned the recent shake extended farther north than did the other, and it is reported that Arcata and the towns in the northern part of the county felt the thrill, and that Crescent City and Grants Pass got it stronger than ever before...."

Report 3: $\quad$ Oregon Daily Journal (Portland), 23 Apr 1906; p. 9, c. 6

[UNRELIABLE]

"Telephone reports from Crescent City, California, state that that place was severely shaken last night, as was Sisson and other northern California towns."

Report 4: $\quad$ Lawson (1908), vol. I, p. 416

“... Woke up everybody, no damage."

MMI for this location: IV ?

\section{Location Described: Georgetown, El Dorado Co.}

Report 1: $\quad$ Georgetown Gazette, 4 May 1906; p. 3, c. 1

"An earthquake shock was felt here shortly after one o'clock Monday morning. No damage done."

Although the article implies that the "Monday morning" to which it refers was the Monday of that week, i.e., $30 \mathrm{Apr}$, it is also possible that it was the previous Monday, $23 \mathrm{Apr}$. The lack of corroborating reports from nearby localities for $30 \mathrm{Apr}$, and the existence of a felt report from Grass Valley (to the north) for an event at about 01:15 on the morning of 23 Apr, suggest that this may be the 23 Apr event.

MMI for this location: Uncertain [may have been a different event] 
TABLE 9: PRIMARY REPORTS FOR THE 23 APR 1906, 01:10 AFTERSHOCK

\section{Location Described: $\quad$ Arcata, Humboldt Co.}

Report 1: $\quad$ Humboldt Times, 24 Apr 1906; p. 7, c. 6-7

“ARCATA, April 23.-.... Another earthquake shock was felt here this morning at about 3 o'clock. Although not as violent as the first one, it caused a little damage and aroused people in some instances from their houses."

Report 2: $\quad$ Humboldt Times, 24 Apr 1906; p. 8, c. 4

"As nearly as can be learned the recent shake extended farther north than did the other, and it is reported that Arcata and the towns in the northern part of the county felt the thrill, and that Crescent City and Grants Pass got it stronger than ever before...."

MMI for this location: $\quad$ V

Location Described: $\quad$ Blocksburg, Humboldt Co.

Report 1: $\quad$ Humboldt Standard, 26 Apr 1906; p. 6, c. 1

"a double sharp shake with distinct rumblings"

MMI for this location: $\quad$ Uncertain

\section{Location Described: $\quad$ Cape Mendocino, Humboldt Co.}

Report 1: $\quad$ Lighthouse Log for Cape Mendocino Lighthouse, 23 Apr 1906

"shock of earthquake 0:55 a.m. and started stopped clock in tower woke up everybode [sic] and rushing out of hous [sic] but no damage was done the shock traveled from South to North."

This report describes an earthquake at 00:55 on 23 Apr; another earthquake was felt at 01:17.

Report 2: $\quad$ Lawson (1908), vol. I, p. 416

"Vertical. Southwest-northeast. Direction NE. increasing intensity. Clock stopt. Pend. 22", facing SW. No sound." Duration 6 seconds.

This report describes an earthquake at 00:55 on 23 Apr; another earthquake was felt at 01:17. These reports are probably not independent of the Cape Mendocino lighthouse logs.

Report 3: $\quad$ Humboldt Times, 29 Apr 1906; p. 5, c. 2

[UNRELIABLE]

"Information was received over the telephone at this office last evening to the effect that the earthquake which occurred last Monday morning, demolished the keeper's house at the Cape Mendocino light-house. The stone tower which contains the light was not damaged and neither was any of the other buildings."

This report appears to be incorrect. The lighthouse log, kept by the lighthouse keeper at Cape Mendocino, states that no damage was done at Cape Mendocino by this earthquake. The lighthouse log is considered more reliable, since it is a first-hand account.

MMI for this location: $\quad$ V

\section{Location Described: $\quad$ Eureka, Humboldt Co.}

Report 1: $\quad$ Humboldt Standard, 23 Apr 1906; p. 5, c. 5-6

"Ever since the disastrous quake at 5:11 a. m. Wednesday [April 18], there have been innumerable shocks of more or less severity at intervals but none approaching the severity of the first. One o[f] the heaviest of these occurred at 1:10 o'clock this morning and caused considerable consternation among the people owing to the length of time that the vibrations continued. In fact the period was fully as long as that of the first shake of Wednesday. However, besides rattling things about considerably, spilling liquids from open dishes, and stopping clocks, as far as learned there was no serious damage done about the city. The only exciting incident appears to have been the breaking of a live electric wire in front of the Daly Bros. store at Fourth and F streets. This did no damage however." 
TABLE 9: PRIMARY REPORTS FOR THE 23 APR 1906, 01:10 AFTERSHOCK

Report 2: $\quad$ Humboldt Times, 24 Apr 1906; p. 8, c. 4

"As compared with the shock of last Wednesday morning, the quakes felt here yesterday morning did little or no damage. A window pane here and there which had been cracked from the big temblor fell out, a few bricks which had become loosened on a number of chimneys about town tumbled down, putting the fear of the Almighty in the hearts of many, and the houses generally were shaken up, sufficiently to awaken the populace. There were many who remained awake the remainder of the night and few of the more timid who sought the streets....

"Locally [in Eureka] there were two shocks. The first was at 1:10 a. m., with vibrations from south to north and lasting 14 seconds. The second was exactly at 6:07 a. m. ... lasting four seconds."

From the wording, it appears that the first paragraph is mostly about the 01:10 shock and not the 06:07 shock; from this account, and from others in Eureka and southern Humboldt County, it appears that the 06:07 shock was significantly less intense in that area than the 01:10 shock.

Report 3: $\quad$ Courier-Free Press (Redding), 23 Apr 1906; p. 1, c. 2

[UNRELIABLE]

"slight ... no damage was done"

Report 4: $\quad$ Lawson (1908), vol. I, p. 416

"South-north. Stopt clocks." Duration 14 seconds. Lawson (1908) estimates Rossi-Forel intensity V-VI.

MMI for this location: $\quad \mathrm{V}$

\section{Location Described: $\quad$ Ferndale, Humboldt Co.}

Report 1: Humboldt Standard, 23 Apr 1906; p. 5, c. 5-6

"Telephonic communication with Ferndale was partially restored late this forenoon, when it was learned that the shock this morning did little or no damage there. A few more bricks were knocked out of the walls of the Russ, Early \& Williams wrecked brick store, a few movable articles about town were disturbed, and that was about all."

Report 2: $\quad$ Humboldt Times, 24 Apr 1906; p. 8, c. 4

"The shock was felt at Ferndale, but comparatively no damage was done. In fact it was felt by all the valley towns about the same as in Eureka...."

Report 3: $\quad$ Lawson (1908), vol. I, p. 416

"Severe shock." Duration 10 seconds.

MMI for this location: $\quad$ V

Location Described: $\quad$ Fieldbrook, Humboldt Co.

Report 1: $\quad$ Arcata Union, 28 Apr 1906; p. 8, c. 3

"People were awakened from their sleep ... by another earthquake."

The time of the event is not given in this report, except that it occurred in the morning.

MMI for this location: Uncertain

\section{Location Described: Hydesville, Humboldt Co.}

Report 1: $\quad$ Humboldt Standard, 23 Apr 1906; p. 5, c. 5-6

"The telephone wire was working spasmodically as far as Hydesville, and from there it was learned that no damage was done by this morning's earthquake."

\section{MMI for this location: Uncertain}


TABLE 9: PRIMARY REPORTS FOR THE 23 APR 1906, 01:10 AFTERSHOCK

\section{Location Described: $\quad$ Orick, Humboldt Co.}

Report 1: $\quad$ Arcata Union, 28 Apr 1906; p. 8, c. 3

“Orick. / April 23, 1906. / This vicinity was visited by an earthquake Wednesday morning [18 Apr] at 5:20 a. m. This morning at 1 o'clock there was another fully as heavy as the first and at half past five another, fully as heavy as any preceding. All the damage done was to break a few panes of glass."

It is not clear which of the earthquakes mentioned were responsible for breaking the panes of glass.

MMI for this location: $\quad$ V

Location Described: $\quad$ Trinidad Head, Humboldt Co.

Report 1: $\quad$ Lawson (1908), vol. I, p. 416

"East-west tremor $5 \mathrm{~s}$. before, short and heavy; clock stopt $12^{\mathrm{h}} 48^{\mathrm{m}}$ a. m., facing east; sound like thunder, preceded and continued during shock; same throughout, no change." Duration 8 seconds.

MMI for this location: Uncertain

Location Described: $\quad$ between Alton and Fortuna (?), Humboldt Co.

Report 1: $\quad$ Humboldt Standard, 23 Apr 1906; p. 5, c. 5-6

"One effect of the earthquake shock of early this morning was to cause a slide to come in on the Scotia road, which prevented the train from coming in from there with the overland mail this morning and delayed the arrival of the train from Alton about one hour."

What was called the Scotia road probably ran from Fortuna to the south, through Scotia. Because the slide blocked the trains from both Scotia and Alton, the slide must have occurred north of Alton, which is between Scotia and Fortuna. Hence the slide most likely occurred between Alton and Fortuna. For several hundred meters north of Alton, the road and railroad tracks run along the base of an escarpment, and this seems to be the most likely location of the slide.

MMI for this location: Uncertain

\section{Location Described: $\quad$ San Rafael, Marin Co.}

Report 1: $\quad$ Marin Journal, 26 Apr 1906; p. 5, c. 3

“A slight earthquake shock was felt here at about 1 o'clock Monday night. It was of short duration and no damage."

It is not clear whether "about 1 o'clock Monday night" refers to the early morning of 23 or 24 Apr.

\section{MMI for this location: Uncertain [may have been a different event]}

\section{Location Described: $\quad$ Point Arena Lighthouse, Mendocino Co.}

Report 1: $\quad$ Lighthouse Log for Point Arena Lighthouse, 22 Apr 1906

“At $11^{30}$ p.m. slight jar in tower."

Although the timing is a little off, this is inferred to be the event of the early morning of 23 Apr. Even if it is not the same event as the earthquake felt across much of northern California on 23 Apr, this entry in the lighthouse log still provides some constraints: if the lighthouse keeper would bother to note a "slight" earthquake in his log, but he did not note a different earthquake about two hours later, the later earthquake (i.e., the event felt across much of northern California) must not have been strong enough to wake him. If that is the case, the later event probably did not have an intensity (MMI) greater than IV.

MMI for this location: III? 
TABLE 9: PRIMARY REPORTS FOR THE 23 APR 1906, 01:10 AFTERSHOCK

\section{Location Described: $\quad$ Grass Valley, Nevada Co.}

Report 1: $\quad$ Daily Morning Union (Grass Valley and Nevada City), 24 Apr 1906; p. 2, c. 5

"Some watches caught it at 1:15 and some at 1:16 yesterday morning. The shock was sufficient to set two-story dwellings a-quiver, but did not possess strength enough to rattle doors and windows and shake people up as did the shocks last Wednesday. The course of the quake seemed to be about the same as that of last week, from southeast to northwest. Only light sleepers were awakened, but the few who chanced to be up at that hour give a dependable account of the shock, which lasted fully fifteen seconds."

MMI for this location: III

\section{Location Described: $\quad$ La Porte, Plumas Co.}

Report 1: $\quad$ Plumas National-Bulletin, 23 Apr 1906; p. 1, c. 5

"Several of our citizens [in Quincy] emphatically declare that there was a pronounced earthquake shock last night at about $1 \mathrm{a}$. $\mathrm{m}$. Rumors to the same effect come over the telephone line from the La Porte way, but we are unable to secure telephone communication with lower country points to confirm or deny the rumor...."

MMI for this location: III

\section{Location Described: Quincy, Plumas Co.}

Report 1: $\quad$ Plumas National-Bulletin, 23 Apr 1906; p. 1, c. 5

"Several of our citizens [in Quincy] emphatically declare that there was a pronounced earthquake shock last night at about $1 \mathrm{a}$. $\mathrm{m}$. Rumors to the same effect come over the telephone line from the La Porte way, but we are unable to secure telephone communication with lower country points to confirm or deny the rumor...."

MMI for this location: III

\section{Location Described: $\quad$ Sacramento, Sacramento Co.}

Report 1: $\quad$ The Searchlight (Redding), 24 Apr 1906; p. 1, c. 1-2

[UNRELIABLE]

"a slight tremor of the earth"

This report is not corroborated in any of the Sacramento newspapers.

Report 2: $\quad$ Humboldt Standard, 23 Apr 1906; p. 1, c. 4-5

[UNRELIABLE]

"A very slight shock was felt in Sacramento."

The time of the event is not given in this report, except that it occurred in the morning. This report is not corroborated in any of the Sacramento newspapers.

\section{MMI for this location: Unreliable}

\section{Location Described: $\quad$ San Francisco, San Francisco Co.}

Report 1: $\quad$ Courier-Free Press (Redding), 23 Apr 1906; p. 1, c. 2

[UNRELIABLE]

"The shake was felt as far north as Portland and Seattle and south in Oakland and San Francisco, though no damage was reported from any section in the state."

These statements must be erroneous. The report is not corroborated in either the Oregon Daily Journal or the Morning Oregonian, both of which were published daily in Portland. Also, there are no reliable reports which suggest that this earthquake was felt in Oakland, San Francisco, or Seattle.

Report 2: $\quad$ Del Norte Record, 28 Apr 1906; p. 3, c. 2

[UNRELIABLE] 
TABLE 9: PRIMARY REPORTS FOR THE 23 APR 1906, 01:10 AFTERSHOCK

“... The shock was felt in Grants Pass, but not in San Francisco."

It is not clear where the report about the earthquake being unfelt in San Francisco originated from, and considering that no sources in San Francisco either confirmed or denied feeling this earthquake, the statement in the Del Norte Record should not be fully trusted. Note that it conflicts with the statement in the Courier-Free Press (Redding), above.

\section{MMI for this location: Unreliable}

\section{Location Described: $\quad$ Stockton, San Joaquin Co.}

Report 1: $\quad$ The Searchlight (Redding), 24 Apr 1906; p. 1, c. 1-2

[UNRELIABLE]

"For a period of perhaps six seconds the earth quivered slightly.... Only people of nervous, restless temperament were awakened by the tremor."

This report is not corroborated in any of the Stockton newspapers.

\section{MMI for this location: Unreliable}

\section{Location Described: $\quad$ Kennett, Shasta Co.}

Report 1: $\quad$ The Searchlight (Redding), 25 Apr 1906; p. 3, c. 3

“The earthquake at 1 o'clock Monday morning was felt by everybody working on night shift in the smelter."

\section{MMI for this location: Uncertain}

\section{Location Described: $\quad$ Redding, Shasta Co.}

Report 1: $\quad$ The Searchlight (Redding), 24 Apr 1906; p. 1, c. 1-2

“Two distinct shocks of earthquake shook up Redding at 1:10 o' clock Monday morning. The second shock, which was much the sharper, came about ten seconds after the first. The total duration of the seismic disturbance is variously estimated at from ten to twenty seconds.

"Guests in the Lorenz, Golden Eagle and Temple hotels were alarmed and a few came down into the office or out into the street, dressed only in their night clothing. The electric clock in the Temple Hotel stopped at 1:10 a. m. No other electric clocks in town were affected.

"The quake awakened people throughout Redding, but hundreds and hundreds of sleepers were not disturbed at all and first learned of the earthquake when they arose for the day.

"As compared with the shake-up of last Wednesday morning, the earthquake of yesterday morning is described by some as being sharper, while others insist that it was not so sharp. Perhaps the happy mean is about the correct estimate and Monday's quiver was only a duplicate of that of last Wednesday.

"H. Bemis, who sleeps in the Gem Lodging-house, says he was awakened by a jerking motion of his bed. The jerking ceased momentarily, but for a few seconds-perhaps eight or ten-the bed continued to tremble a little, and then came the last and final jerking, much sharper than the shake-up that had awakened him. With that the event was over. During the earthquake he could hear a tapping on the windows, perhaps caused by the rattling of the panes. An open door somewhere in the house swung on its hinges, grinding out a noise something like 'hee-haw, hee-haw!'”

Report 2: $\quad$ Courier-Free Press (Redding), 23 Apr 1906; p. 1, c. 2

“The people of Redding experienced another earthquake shock at 1:20 o'clock Monday morning. In some sections of town the twister was felt more plainly than in others. Many people slept through it all, not knowing of any disturbance until they awakened and were told of the affair by their neighbors, whose slumbers had been disturbed.

"The shock was accompanied by a rumbling noise similar to that made by a locomotive. Many who felt the shock did not consider it of sufficient import to get out of bed, while others made hasty exits from their lodgings. 
TABLE 9: PRIMARY REPORTS FOR THE 23 APR 1906, 01:10 AFTERSHOCK

"Several guests at the Lorenz and Golden Eagle hotels were awakened but none were badly frightened.

"A stone and concrete fence on the north Liberty street premises of A. J. Martin ... was cracked in several places.

Note that "twister" is used in this article as a reference to the earthquake.

Report 3: $\quad$ Chico Semi-Weekly Record, 24 Apr 1906; p. 1, c. 6

"REDDING, April 23.-At 1:10 this morning a very distinct shock of earthquake was felt here. It lasted about eight seconds and there were two strong pulsations.

"The shock caused considerable alarm, particularly among the guests in the various hotels. They were nervous, however, because of the San Francisco horror, and to this fact was due their fright, more than to the severity of the earthquake...."

Report 4: $\quad$ Humboldt Standard, 23 Apr 1906; p. 1, c. 4-5

[UNRELIABLE]

“... The earthquake this morning lasted eight seconds at Redding, Cal. Chimneys were thrown down and the guests at the Hotel Lorenz rushed into the streets clad only in their night robes."

The time of the event is not given in this report, except that it occurred in the morning.

Report 5: $\quad$ Humboldt Times, 24 Apr 1906; p. 8, c. 4

[UNRELIABLE]

“... At Redding it lasted eight seconds, and a few chimneys tumbled down, and there was a shirttail brigade."

Report 6: $\quad$ Ashland Tidings, 23 Apr 1906; p. 3, c. 3

"... Redding, on the south, felt a slight tremor, and there was more or less seismic disturbance through California which disarranged the telegraph lines for an hour."

Report 7: $\quad$ Umpqua Valley News, 23 Apr 1906; p. 7, c. 6

[UNRELIABLE]

"At half past one o'clock last night there was an earthquake felt at various points throughout Southern Oregon. The tremor was quite perceptible at Grants Pass, where for some twenty seconds the earth trembled and buildings swayed to-and-fro, but no damage resulted. Ashland also felt the same shock.

"Further down, in north California the tremor was much stronger. At Redding the chimneys tumbled down and caused considerable confusion, but aside from that there was no damage done."

\section{MMI for this location: $\quad$ IV}

\section{Location Described: $\quad$ Dunsmuir, Siskiyou Co.}

Report 1: $\quad$ Courier-Free Press (Redding), 23 Apr 1906; p. 1, c. 1

“DUNSMUIR, April 23.- This section was visited by a severe twister at 1:20 o'clock this morning and many people were frightened into the belief that the end of the world had arrived.

"The earthquake was most strongly felt on the hill and in the higher sections of town. Down town and along the level of the railroad track the shake resembled the rumbling of a locomotive, an accustomed sound here, and the people did not notice it.

"But up on the hill back of the main street there was a lively shaking up of windows, dishes and furniture.

"Frank Talmadge, who lives on the hill section, says his house was severely wrenched and shaken. The windows rattled, Talmadge's bed swayed perceptibly and he hastily telephoned down town to see how much damage was done. Clocks were stopped in various parts of town.

"The shock awakened all the residents of the hill section and was twice as severe as the one of Wednesday morning."

"Twister" is used in this article as a reference to the earthquake.

\section{MMI for this location: IV-V (preferred: IV)}


TABLE 9: PRIMARY REPORTS FOR THE 23 APR 1906, 01:10 AFTERSHOCK

\section{Location Described: $\quad$ Fort Jones, Siskiyou Co.}

Report 1: $\quad$ Farmer and Miner (Fort Jones), 25 Apr 1906; p. 3, c. 2

"Another slight earthquake was felt in Fort Jones.... It was feared that more damage might be done around the [San Francisco] bay but the fears were groundless."

\section{MMI for this location: Uncertain}

\section{Location Described: $\quad$ Hornbrook, Siskiyou Co.}

Report 1: $\quad$ Valley Record (Ashland), 26 Apr 1906; p. 7, c. 6

"A slight shock of Earthquake was felt by some people in Ashland at 1:10 Tuesday morning, also at Sisson, Hornbrook and other points in Siskiyou...."

Tuesday would be 24 Apr; later in the same article, however, the date is given as 23 Apr. [The remainder of this article is listed chronologically in this catalog under 23 Apr, under (nearly) identical entries published in the Morning Oregonian (Portland).] Because this source is internally inconsistent, and because the 01:10 time of the event matches the time of an event known to have occurred on 23 Apr (but not on 24 Apr), the obvious inference is that the date stated above ("Tuesday") is in error. It should state the date as being Monday morning, 23 Apr.

\section{MMI for this location: Uncertain}

\section{Location Described: $\quad$ Sisson, Siskiyou Co. (now the town of Mt. Shasta, CA)}

Report 1: $\quad$ The Searchlight (Redding), 24 Apr 1906; p. 1, c. 1-2, and p. 2, c. 2

"SISSON, April 23-5 a. m.-Two earthquake shocks occurred here this morning at 1:15, though the exact time is in dispute. There was an interval of about fifteen seconds between the shocks, and the last one was much more severe than the first.

"The earthquake was almost an exact duplicate of that of last Wednesday morning. Windows rattled, doors were slammed shut, and restless sleepers were awakened. There was a continued tremor between the two shocks, the last one closing the seismic exhibition with a bang."

Report 2: $\quad$ Courier-Free Press (Redding), 23 Apr 1906; p. 1, c. 3

"SISSON, April 23.-Sisson folks experienced a very slight shock of earthquake this morning at 1:20 o'clock. The shock was lighter than that of Wednesday and not a particle of damage was done. Windows rattled some."

Report 3: $\quad$ Valley Record (Ashland), 26 Apr 1906; p. 7, c. 6

"A slight shock of Earthquake was felt by some people in Ashland at 1:10 Tuesday morning, also at Sisson, Hornbrook and other points in Siskiyou...."

Tuesday would be 24 Apr; later in the same article, however, the date is given as 23 Apr. [The remainder of this article is listed chronologically in this catalog under 23 Apr, under (nearly) identical entries published in the Morning Oregonian (Portland).] Because this source is internally inconsistent, and because the 01:10 time of the event matches the time of an event known to have occurred on 23 Apr (but not on 24 Apr), the obvious inference is that the date stated above ("Tuesday") is in error. It should state the date as being Monday morning, 23 Apr.

Report 4: $\quad$ Oregon Daily Journal (Portland), 23 Apr 1906; p. 9, c. 6

[UNRELIABLE]

"Telephone reports from Crescent City, California, state that that place was severely shaken last night, as was Sisson and other northern California towns."

MMI for this location: IV 
TABLE 9: PRIMARY REPORTS FOR THE 23 APR 1906, 01:10 AFTERSHOCK

\title{
Location Described: $\quad$ Yreka, Siskiyou Co.
}

\author{
Report 1: $\quad$ Siskiyou News, 26 Apr 1906; p. 2, c. 5
}

“There was an earthquake Monday morning about 1 o'clock which was felt by many in Yreka, and telegraph reports state that it was felt from Portland to Sacramento. It was very light and did no damage anywhere, but in the highly wrought state of the people the wildest rumors of damage and destruction were started and for a time found credence. Sam Luttrel was driving from Fort Jones with a load of Yreka passengers. He met a man about three miles out of Yreka driving to Fort Jones who told him that the earthquake had been very severe in Yreka, cracking the Masonic building from top to bottom and doing other material damage. But the quake was hardly perceptible in Yreka and cracked nothing more substantial than some individual's excitable imagination."

Report 2: $\quad$ Yreka Journal, 25 Apr 1906; p. 3, c. 4

“... All that occurred in any part of Siskiyou last week, was a slight jar, which stopped a few clocks and made a slight vibration of insignificant force. Clocks stopped at the first shock in San Francisco on the 18th, and the other shock last Sunday night, the 22d, was lighter and did not even stop a clock anywhere...."

The event of Sunday night, 22 Apr, is inferred to be the event of the early morning of 23 Apr. The location is not given any more specifically than "Siskiyou," but the paper was published in Yreka.

Report 3: $\quad$ The Searchlight (Redding), 24 Apr 1906; p. 2, c. 3-4

"YREKA, April 23-8 a. m.-Two distinct shocks of earthquake were experienced here.... The second shock, coming five or six seconds after the first, was the most severe. Opinions differ as to whether the disturbance this morning was greater than that of last Wednesday morning. People are nervous on the subject of earthquakes and are disposed, naturally, to exaggerate impressions formed.

"Mrs. Charles Cady insists that she was almost thrown out of bed by the earthquake....

"No damage whatever has been reported from any quarter of Yreka."

Report 4: $\quad$ Courier-Free Press (Redding), 23 Apr 1906; p. 1, c. 3

“YREKA, April 23.-Quite a severe shock of earthquake occurred here at 1:15 o'clock this morning. The shock was felt more distinctly than the one of Wednesday, but no damage was done other than to put a keen edge to the fears of the people.

"Windows rattled and people were awakened from sound slumbers."

Report 5: $\quad$ Humboldt Standard, 23 Apr 1906; p. 1, c. 4-5

[UNRELIABLE]

"... At Yreka it was more severe than on Wednesday [18 Apr]."

The time of the event is not given in this report, except that it occurred in the morning.

Report 6: $\quad$ Humboldt Times, 24 Apr 1906; p. 8, c. 4

[UNRELIABLE]

"The shock was felt at Yreka more severely than the Wednesday quake at that place...."

MMI for this location: IV

\section{Location Described: $\quad$ Red Bluff, Tehama Co.}

Report 1: $\quad$ Red Bluff Daily News, 24 Apr 1906; p. 1, c. 2

"Light sleepers were awakened ... by a slight earth tremor which stopped the clocks in the United States Weather Bureau, H. H. Wiedenieck's and G. C. Wilkin's. The shock was felt as far north as Grants' Pass and as far South of here but no damage was done before Mother Earth stopped trembling...."

Report 2: $\quad$ Daily People's Cause (Red Bluff), 23 Apr 1906; p. 1, c. 2

"Another shock of earthquake was felt in Red Bluff at about ten minutes to one this Monday morning, although the shock was not so severe as the one of last Wednesday morning. Only a few people felt it as most people were sleeping soundly at that hour. Several clocks about town were stopped by the shock."

\section{MMI for this location: $\quad$ IV}


TABLE 9: PRIMARY REPORTS FOR THE 23 APR 1906, 01:10 AFTERSHOCK

Location Described: $\quad$ Burnt Ranch, Trinity Co.

Report 1: $\quad$ Blue Lake Advocate, 5 May 1906; p. 2, c. 2

“... we were treated to three more temblors about 1 o' clock a.m. No damage was done in this locality; in fact there has been no danger done in Trinity county, that your correspondent has heard of so far."

MMI for this location: Uncertain

Location Described: $\quad$ Hayfork, Trinity Co.

Report 1: $\quad$ The Searchlight (Redding), 26 Apr 1906; p. 3, c. 1

“The earthquake shock ... was not very heavy. No damage was done, but it was a reminder."

MMI for this location: Uncertain

Location Described: $\quad$ New River, Trinity Co.

Report 1: $\quad$ Humboldt Times, 28 Apr 1906; p. 6, c. 2

"another heavy shock"

MMI for this location: $\quad$ Uncertain

\section{Location Described: $\quad$ Weaverville, Trinity Co.}

Report 1: Weekly Trinity Journal, 27 Apr 1906; p. 2, c. 1

"...there was another earthquake shock but not so severe as the one of the 18th inst. It was strong enough, however to rouse apprehensions as to damage elsewhere. Fortunately these fears proved unfounded. While the shock was general no damage was suffered in the State beyond the toppling of a few chimneys."

Report 2: $\quad$ Courier-Free Press (Redding), 23 Apr 1906; p. 1, c. 2

“WEAVERVILLE, April 23.-Many Weaverville people were awakened from sound slumbers this morning at 1:15 o'clock by a slight earthquake shock and rumbling that lasted possibly two seconds.

"The shock here was not so severe as that on Wednesday but the people were of course frightened. All they have heard for five days is earthquake and they are ready to go into a panic at the slightest tremble of the earth. No damage resulted this morning."

Report 3: $\quad$ The Searchlight (Redding), 24 Apr 1906; p. 2, c. 2-3

“WEAVERVILLE, April 23.-8 a. m.-Slight shocks of earthquake were felt here at 1:08 this morning. The duration of the temblor was only a few seconds-perhaps six or eight. But few people were awakened by it. The earthquake was very much lighter than that of last Wednesday morning, according to the reports of those who observed both."

MMI for this location: $\quad$ IV

\section{Location Described: Challenge, Yuba Co.}

Report 1: $\quad$ Marysville Daily Appeal, 26 Apr 1906; p. 2, c. 1

"... there was a light shock again in the early morning of the 23d."

MMI for this location: Uncertain 
TABLE 9: PRIMARY REPORTS FOR THE 23 APR 1906, 01:10 AFTERSHOCK

\section{Location Described: $\quad$ Glendale, Douglas Co., Oregon}

Report 1: $\quad$ Ashland Tidings, 23 Apr 1906; p. 3, c. 3

"Wild rumors flew along the wires this morning from the south of a reported disastrous earthquake throughout Oregon last night. The TIDINGS was called up by phone from Redding to confirm a report that Ashland and Grants Pass had been damaged, but had to deny knowledge of any disturbance here, although some people reported a slight tremor at 1:10 o'clock this morning. Others, including the telegraph operators who were on duty all night here, knew nothing of it. The Grants Pass telephone office reported a slight tremor in that city and at Glendale and Merlin. Redding, on the south, felt a slight tremor, and there was more or less seismic disturbance through California which disarranged the telegraph lines for an hour."

Report 2: $\quad$ Medford Mail, 27 Apr 1906; p. 1, c. 1

"Light sleepers-and some of those whose slumbers are usually profound-were aroused about 1:20 Monday morning [in Medford] by a distinct, though comparatively, slight seismic movement. J. S. Howard was awakened by the shock and noted the time-1:20. Dr. Pickel had the same experience and on making a professional call at Central Point later in the morning was asked about the first thing whether the temblor had been felt in Medford or not. Distinct shocks were felt at Ashland, Grants Pass and Glendale."

Report 3: $\quad$ Morning Oregonian (Portland), 23 Apr 1906; p. 3, c. 1

[UNRELIABLE]

“GLENDALE, Or., April 23.-(Special.)-A distinct shock of earthquake was felt in this city at 11 minutes after 1 o'clock this morning. The shock was apparently heavier than the one of April 18, causing buildings to rock and rattle."

\section{MMI for this location: Uncertain}

\section{Location Described: $\quad$ Ashland, Jackson Co., Oregon}

Report 1: $\quad$ Ashland Tidings, 23 Apr 1906; p. 3, c. 3

"Wild rumors flew along the wires this morning from the south of a reported disastrous earthquake throughout Oregon last night. The TIDINGS was called up by phone from Redding to confirm a report that Ashland and Grants Pass had been damaged, but had to deny knowledge of any disturbance here, although some people reported a slight tremor at 1:10 o'clock this morning. Others, including the telegraph operators who were on duty all night here, knew nothing of it. The Grants Pass telephone office reported a slight tremor in that city and at Glendale and Merlin. Redding, on the south, felt a slight tremor, and there was more or less seismic disturbance through California which disarranged the telegraph lines for an hour."

Report 2: $\quad$ Medford Mail, 27 Apr 1906; p. 1, c. 1

"Light sleepers-and some of those whose slumbers are usually profound-were aroused about 1:20 Monday morning [in Medford] by a distinct, though comparatively, slight seismic movement. J. S. Howard was awakened by the shock and noted the time-1:20. Dr. Pickel had the same experience and on making a professional call at Central Point later in the morning was asked about the first thing whether the temblor had been felt in Medford or not. Distinct shocks were felt at Ashland, Grants Pass and Glendale."

Report 3: $\quad$ Valley Record (Ashland), 26 Apr 1906; p. 7, c. 6

"A slight shock of Earthquake was felt by some people in Ashland at 1:10 Tuesday morning, also at Sisson, Hornbrook and other points in Siskiyou...."

Tuesday would be 24 Apr; later in the same article, however, the date is given as 23 Apr. [The remainder of this article is listed chronologically in this catalog under 23 Apr, under (nearly) identical entries published in the Morning Oregonian (Portland).] Because this source is internally inconsistent, and because the 01:10 time of the event matches the time of an event known to have occurred on 23 Apr (but not on 24 Apr), the obvious inference is that the date stated above ("Tuesday") is in error. It should state the date as being Monday morning, 23 Apr.

Report 4: $\quad$ Umpqua Valley News, 23 Apr 1906; p. 7, c. 6

[UNRELIABLE]

"At half past one o'clock last night there was an earthquake felt at various points throughout Southern Oregon. The tremor was quite perceptible at Grants Pass, where for some twenty seconds the earth trembled and buildings swayed to-and-fro, but no damage resulted. Ashland also felt the same shock." 
TABLE 9: PRIMARY REPORTS FOR THE 23 APR 1906, 01:10 AFTERSHOCK

Report 5: $\quad$ Eugene Daily Guard, 23 Apr 1906; p. 1, c. 3

“a very slight earthquake shock."

The time of the event is not given in this report, except that it occurred in the morning.

Report 6: $\quad$ Humboldt Standard, 23 Apr 1906; p. 1, c. 4-5

[UNRELIABLE]

“... At Ashland, Oregon, and Grant's Pass it was severe...."

The time of the event is not given in this report, except that it occurred in the morning.

Report 7: $\quad$ Courier-Free Press (Redding), 23 Apr 1906; p. 1, c. 1

[UNRELIABLE]

“ASHLAND, Ore., April 23.-Southern Oregon had a lively shakeup this morning about 1:15 o'clock, but so far no damage has been reported from any point in this section.

"The temblor this morning was more severe than the one of Wednesday. Houses shook and windows rattled, dishes were knocked over and people were awakened in every part of the town.

"Since the earthquake of Wednesday there have been predictions that Portland and the north coast would be the next to receive a visit from earthquakes, and the people were in a nervous state that was not at all improved by this morning's shake. Many of them ran from their homes in scant attire expecting to see the business part of the town in ruins."

Report 8: $\quad$ The Searchlight (Redding), 24 Apr 1906; p. 1, c. 1-2

[UNRELIABLE]

"Reports reaching Redding early Monday morning said that the earthquake was heavy in Ashland and Grants Pass, heavier in the latter city, where chimneys were thrown down....

"No damage was done in Ashland and what was done in Grants Pass is hardly worth mentioning."

MMI for this location: III

\section{Location Described: $\quad$ Medford, Jackson Co., Oregon}

Report 1: $\quad$ Medford Mail, 27 Apr 1906; p. 1, c. 1

"Light sleepers-and some of those whose slumbers are usually profound-were aroused about 1:20 Monday morning by a distinct, though comparatively, slight seismic movement. J. S. Howard was awakened by the shock and noted the time-1:20. Dr. Pickel had the same experience and on making a professional call at Central Point later in the morning was asked about the first thing whether the temblor had been felt in Medford or not. Distinct shocks were felt at Ashland, Grants Pass and Glendale."

Report 2: $\quad$ Daily People's Cause (Red Bluff), 23 Apr 1906; p. 1, c. 2

[UNRELIABLE]

"A report was current here today that Medford, Oregon, and Seattle had suffered by the shock, but this report was not confirmed."

The statement about Medford "suffering" appears to be exaggerated in comparison with reports from papers near Medford, and there are no reliable reports which suggest that this earthquake was felt in Seattle.

MMI for this location: $\quad$ IV

\section{Location Described: $\quad$ Grants Pass, Josephine Co., Oregon}

Report 1: $\quad$ Ashland Tidings, 23 Apr 1906; p. 3, c. 3

"Wild rumors flew along the wires this morning from the south of a reported disastrous earthquake throughout Oregon last night. The TIDINGS was called up by phone from Redding to confirm a report that Ashland and Grants Pass had been damaged, but had to deny knowledge of any disturbance here, although some people reported a slight tremor at 1:10 o'clock this morning. Others, including the telegraph operators who were on duty all night here, knew nothing of it. The Grants Pass telephone office reported a slight tremor in that city and at Glendale and Merlin. Redding, on the south, felt a slight tremor, and there was more or less seismic disturbance through California which disarranged the telegraph lines for an hour."

Report 2: $\quad$ Medford Mail, 27 Apr 1906; p. 1, c. 1 
TABLE 9: PRIMARY REPORTS FOR THE 23 APR 1906, 01:10 AFTERSHOCK

"Light sleepers-and some of those whose slumbers are usually profound-were aroused about 1:20 Monday morning [in Medford] by a distinct, though comparatively, slight seismic movement. J. S. Howard was awakened by the shock and noted the time-1:20. Dr. Pickel had the same experience and on making a professional call at Central Point later in the morning was asked about the first thing whether the temblor had been felt in Medford or not. Distinct shocks were felt at Ashland, Grants Pass and Glendale."

Report 3: $\quad$ Roseburg Twice A Week Review, 23 Apr 1906; p. 3, c. 4

"GRANTS PASS, Or., April 23-A slight earthquake was felt here and in neighboring towns.... No damage."

Report 4: $\quad$ Umpqua Valley News, 23 Apr 1906; p. 7, c. 6

[UNRELIABLE]

"At half past one o'clock last night there was an earthquake felt at various points throughout Southern Oregon. The tremor was quite perceptible at Grants Pass, where for some twenty seconds the earth trembled and buildings swayed to-and-fro, but no damage resulted. Ashland also felt the same shock."

Report 5: $\quad$ Morning Oregonian (Portland), 23 Apr 1906; p. 3, c. 1

[UNRELIABLE]

“GRANTS PASS, Or., April 23.-_(Special.)_An earthquake shock which broke some windows and awoke sleeping citizens was felt here at 1:11 this morning. The shock lasted between 15 and 20 seconds and was accompanied by a distinct rumbling noise. The motion of the undulation was from east to west and the oscillation was sufficient to set hanging lamps and pictures to swaying.

"Mayor George Good states that the shock was felt all over his house, which is a structure 75 feet in length and two stories high. His children, who were asleep, were awakened and cried out in alarm, and a relative who was sleeping in an adjoining room, despite the fact that he is quite deaf, was aroused by the sway of electric light fixtures attached to the bed.

"Within a few minutes after the shock frightened citizens began calling up the local telephone exchange to ascertain the cause of the commotion. The telephone manager had been raised by the shock and was able to allay the fears of all, as practically no damage had been done beyond the breaking of window glass."

Report 6: $\quad$ Morning Oregonian (Portland), 24 Apr 1906; p. 7, c. 2

[UNRELIABLE]

“GRANTS PASS, Or., April 23.-(Special.)—The heaviest shock of earthquake ever experienced in Southern Oregon was felt in this city at 1:13 A. M. last night. It made doors and windows rattle and awakened many people. A shock not quite so heavy as this was felt here on the morning and to the very minute of the big earthquake that wrecked San Francisco and other California towns."

Report 7: $\quad$ Oregon Daily Journal (Portland), 23 Apr 1906; p. 9, c. 6

[UNRELIABLE]

“Grants Pass, Or., April 23.--Severe earthquake shocks occurred here at 1 o'clock this morning. The tremor continued for about 20 seconds, rattling windows and doors and stopping clocks. People were awakened, many going out into the streets. At the Hotel Josephine nearly all the guests awoke and came down into the lobby. It was feared for a while that serious damage would result."

Report 8: $\quad$ Del Norte Record, 28 Apr 1906; p. 3, c. 2

"... The shock was felt in Grants Pass...."

Report 9: $\quad$ Humboldt Standard, 23 Apr 1906; p. 1, c. 4-5

[UNRELIABLE]

"... At Ashland, Oregon, and Grant's Pass it was severe...."

The time of the event is not given in this report, except that it occurred in the morning.

Report 10: $\quad$ Humboldt Times, 24 Apr 1906; p. 8, c. 4

[UNRELIABLE]

"As nearly as can be learned the recent shake extended farther north than did the other, and it is reported that Arcata and the towns in the northern part of the county felt the thrill, and that Crescent City and Grants Pass got it stronger than ever before...."

Report 11: $\quad$ The Searchlight (Redding), 24 Apr 1906; p. 1, c. 1-2

[UNRELIABLE]

"Reports reaching Redding early Monday morning said that the earthquake was heavy in Ashland and Grants Pass, heavier in the latter city, where chimneys were thrown down....

"No damage was done in Ashland and what was done in Grants Pass is hardly worth mentioning."

\section{MMI for this location: Uncertain}


TABLE 9: PRIMARY REPORTS FOR THE 23 APR 1906, 01:10 AFTERSHOCK

\title{
Location Described: $\quad$ Merlin, Josephine Co., Oregon
}

\author{
Report 1: $\quad$ Ashland Tidings, 23 Apr 1906; p. 3, c. 3
}

"Wild rumors flew along the wires this morning from the south of a reported disastrous earthquake throughout Oregon last night. The TIDINGS was called up by phone from Redding to confirm a report that Ashland and Grants Pass had been damaged, but had to deny knowledge of any disturbance here, although some people reported a slight tremor at 1:10 o'clock this morning. Others, including the telegraph operators who were on duty all night here, knew nothing of it. The Grants Pass telephone office reported a slight tremor in that city and at Glendale and Merlin. Redding, on the south, felt a slight tremor, and there was more or less seismic disturbance through California which disarranged the telegraph lines for an hour."

\section{MMI for this location: Uncertain}

\section{Location Described: $\quad$ Eugene, Lane Co., Oregon}

Report 1: $\quad$ Eugene Daily Guard, 23 Apr 1906; p. 2, c. 1

"The earthquake seems to be moving northward- is getting a little too close for comfort. Grant's Pass, where they felt a tremble early this morning, is less than two hundred miles from Eugene."

This comment in the Eugene Daily Guard implies that the earthquake of the morning of 23 Apr was NOT felt in Eugene.

\section{MMI for this location: Uncertain, but probably Not Felt}

\section{Location Described: $\quad$ Portland, Multnomah Co., Oregon}

Report 1: $\quad$ Courier-Free Press (Redding), 23 Apr 1906; p. 1, c. 2

[UNRELIABLE]

"The shake was felt as far north as Portland and Seattle and south in Oakland and San Francisco, though no damage was reported from any section in the state."

These statements must be erroneous. The report is not corroborated in either the Oregon Daily Journal or the Morning Oregonian, both of which were published daily in Portland. Also, there are no reliable reports which suggest that this earthquake was felt in Oakland, San Francisco, or Seattle.

Report 2: $\quad$ The Searchlight (Redding), 24 Apr 1906; p. 1, c. 1-2

[UNRELIABLE]

"An alarming report from Portland, coming no one knew how, was that the city was in flames, the fire having followed the earthquake. This report was soon denied, emphatically, in a dispatch received about 9 o'clock from Ashland."

Report 3: $\quad$ Humboldt Standard, 23 Apr 1906; p. 1, c. 4-5

[UNRELIABLE]

"Portland, Oregon has received a heavy shock...."

The time of the event is not given in this report, except that it occurred in the morning. Again, this report is not corroborated by any Portland newspapers.

Report 4: $\quad$ Humboldt Times, 24 Apr 1906; p. 8, c. 4

[UNRELIABLE]

“... Even Portland is reported as getting shaken up, in the same manner as Eureka was Wednesday morning, perhaps not so seriously."

Once again, this report is not corroborated by any Portland newspapers.

Report 5: $\quad$ Oregon Daily Journal (Portland), 23 Apr 1906; p. 9, c. 6

This article, under the title "Southern Oregon Towns Shaken by Quakes," described the earthquake as occurring in southern Oregon and northern California, but it did not mention anything about an earthquake felt in Portland or northern Oregon. This absence strongly suggests that the earthquake was not felt in Portland. 
TABLE 9: PRIMARY REPORTS FOR THE 23 APR 1906, 01:10 AFTERSHOCK

Report 6: $\quad$ Morning Oregonian (Portland), 24 Apr 1906; p. 7, c. 2

"WASHINGTON, [D.C.,] April 23.-(Special.)—The Southern Oregon earthquake was recorded on the Government seismograph in this city this morning...."

The reference to "Southern Oregon," taken together with the absence of any report of felt earthquakes in Portland on this date, suggests that this aftershock was not felt in Portland or northern Oregon.

\section{MMI for this location: $\quad$ Uncertain, but probably Not Felt}

\section{Location Described: $\quad$ Seattle, King Co., Washington}

Report 1: $\quad$ Courier-Free Press (Redding), 23 Apr 1906; p. 1, c. 2

[UNRELIABLE]

"The shake was felt as far north as Portland and Seattle and south in Oakland and San Francisco, though no damage was reported from any section in the state."

These statements must be erroneous. The report is not corroborated in either the Oregon Daily Journal or the Morning Oregonian, both of which were published daily in Portland. Also, there are no reliable reports which suggest that this earthquake was felt in Oakland, San Francisco, or Seattle.

Report 2: $\quad$ Daily People's Cause (Red Bluff), 23 Apr 1906; p. 1, c. 2

[UNRELIABLE]

"A report was current here today that Medford, Oregon, and Seattle had suffered by the shock, but this report was not confirmed."

The statement about Medford "suffering" appears to be exaggerated in comparison with reports from papers near Medford, and there are no reliable reports which suggest that this earthquake was felt in Seattle.

MMI for this location: Unreliable

\section{Location Described: Northern California and Oregon (in general)}

Report 1: $\quad$ Daily Colusa Sun, 25 Apr 1906; p. 1, c. 2

[UNRELIABLE]

"The northern part of California and the southern portion of Oregon escaped the great earthquake of Wednesday, the 18th, but that portion of our coast has been experiencing shocks of greater or less degree during the past few days. Reports from Portland, Grants Pass, Ashland, Jacksonville and Eugene in Oregon and Redding, Sisson, Weaverville, Yreka, and several other Northern California towns is to the effect that much uneasiness is felt, though no damage has resulted from the shake."

Although the date of the event (or events) is not given specifically, it is probably referring to the 23 Apr event. The information in this article does not appear to be entirely accurate. The report of an earthquake felt in Portland is not corroborated in either the Oregon Daily Journal or the Morning Oregonian, both of which were published daily in Portland, nor is the report of an earthquake felt in Eugene corroborated in either the Eugene Daily Guard or the Morning Register, both of which were published daily in Eugene.

Report 2: $\quad$ Arcata Union, 25 Apr 1906; p. 1, c. 3-4

[UNRELIABLE]

"The earthquake which visited us again on Monday morning, seemed to have worked as far north as Portland, but no great amount of damage is reported from this tremblor."

This report appears to be incorrect. The report of an earthquake felt in Portland is not corroborated in either the Oregon Daily Journal or the Morning Oregonian, both of which were published daily in Portland.

\section{MMI for this location: Unreliable}


TABLE 9: PRIMARY REPORTS FOR THE 23 APR 1906, 01:10 AFTERSHOCK

\section{Other Information: Instrumental Data}

Report 1: $\quad$ Morning Oregonian (Portland), 24 Apr 1906; p. 7, c. 2

"WASHINGTON, [D.C.,] April 23.-(Special.)—The Southern Oregon earthquake was recorded on the Government seismograph in this city this morning, between 4:25 and 5 o'clock, Washington time, three hours later than Oregon time. The instrument showed the heaviest shock occurred from 4:29 to 4:33, just 17 minutes after it was felt in Oregon. This is exactly the time required for the San Francisco shock to traverse the continent."

MMI for this location: $\quad$ N/A 
TABLE 10: PRIMARY REPORTS FOR THE 25 APR 1906, 15:17 AFTERSHOCK

\section{SEE CORRESPONDING FIGURE 7}

\section{Location Described: $\quad$ Alameda, Alameda Co.}

Report 1: $\quad$ Lawson (1908), vol. I, p. 418

felt at Alameda Pier

MMI for this location: Uncertain

\section{Location Described: $\quad$ Berkeley, Alameda Co.}

Report 1: $\quad$ Berkeley Daily Gazette, 25 Apr 1906; p. 1, c. 1

“... a severe earthquake was felt in this city which caused a general exodus from the brick buildings in the business section. The temblor was the most severe that has been felt since the one of a week ago this morning, which caused the destruction of San Francisco's business section.

"So far as has been learned the earthquake caused no damage in this section, although it is feared a number of the partially wrecked buildings in Oakland and San Francisco may have suffered.

"Occupants of the First National Bank building were not alarmed, a majority of them remaining in their offices.

"The earthquake was of several seconds duration. Its direction appeared to be from south to north. The officials at the University were unable to give a report of the earthquake this afternoon, but will be prepared to give a seismographic record of today's disturbance and the numerous recent temblors."

Report 2: $\quad$ Lawson (1908), vol. I, p. 417

"Walking with Dr. King, not felt by either of us." [Statement of S. Albrecht.] Duration 7 seconds. Lawson (1908) estimates Rossi-Forel intensity IV-V. Time listed for this event is 15:15.

It is not clear what justification there is for Lawson's (1908) estimate of R-F intensity IV-V, especially in light of the fact that neither the observer nor his companion felt the shock.

Report 3: $\quad$ Lawson (1908), vol. I, p. 418

“2 tremors about 5 s. apart. Time is of last one." Time listed for this event is 15:18:20.

MMI for this location: IV-V (preferred: V)

Location Described: $\quad$ Niles, Alameda Co. (now the area of Niles District, CA)

Report 1: $\quad$ Lawson (1908), vol. I, p. 418

felt at Niles

MMI for this location: Uncertain

\section{Location Described: $\quad$ Oakland, Alameda Co.}

Report 1: $\quad$ San Francisco Call, 26 Apr 1906; p. 2, c. 4

“OAKLAND, April 25.--An earthquake jarred this city ... and occasioned another scare. The shock was short and stiff. People were frightened from buildings and many persons hurried for safety into the middle of the streets. In several instances the cracks in structures that were damaged by the great temblor of one week ago were widened and loose plaster and bricks thrown down." 
TABLE 10: PRIMARY REPORTS FOR THE 25 APR 1906, 15:17 AFTERSHOCK

Report 2: $\quad$ The Bulletin (San Francisco), 26 Apr 1906; p. 6, c. 2-3

Oakland Herald, 26 Apr 1906; p. 2, c. 3-4

"The shock of earthquake felt at 3:15 yesterday afternoon was No. 37 of the series in which is included the one responsible for starting the fire that caused the destruction of San Francisco. It was a little less than three seconds in duration and would be rated as a number three. Numbers one and two are not perceptible shocks, and can be observed only through the agency of seismic instruments. These registered the earthquake that did all the damage in the city as a number nine.

"At the Chabot Observatory, Oakland, it was said today that the shock felt yesterday was much lighter than the average layman thought.

“'The people are now all tuned up for shocks,' said Professor Burckhalter, 'and they unconsciously exaggerate the dimensions of the slightest quake. That of yesterday afternoon was of a significance hardly worth talking about. Instruments are fortunately without nerves and have enabled us to be assured that it was incapable of any material consequence.'”

It is not clear whether the statement in the first paragraph about it lasting three seconds and being "rated as a number three" describes the earthquake in San Francisco or Oakland. By comparison to reports in the Oakland Enquirer (27 Apr) and The Bulletin (28 Apr), it appears as though all of this information came from Professor Burckhalter at Chabot Observatory in Oakland; still, there are minor inconsistencies between all three reports that are puzzling.

Report 3: $\quad$ Oakland Enquirer, 27 Apr 1906; p. 2, c. 5

"Professor Burckhalter of the Chabot Observatory states that the earthquake which occurred yesterday afternoon at fifteen minutes after 3 o' clock, was only a small one, in spite of the miniature panic it caused. It lasted only two seconds, he says, and ordinarily would hardly be noticed.

"It was rumored that yesterday's shake was due to an extra large dynamite explosion in San Francisco. Professor Burckhalter says that such was not the case, and that the dynamiting over there has no effect on the earth's crust over here."

Although the earthquake is stated to have occurred "yesterday," the report almost certainly refers to the earthquake at around 15:15 on 25 Apr; compare this with the report in The Bulletin (San Francisco), 26 Apr 1906, p. 6, c. 2-3.

Report 4: $\quad$ The Bulletin (San Francisco), 28 Apr 1906; p. 7, c. 1

[quoting Professor Burckhalter of the Chabot Observatory in Oakland:] ““... The intensity of earthquakes I have graded into ten classes ... the disturbance that is barely perceptible to a human being I call the No. 1. The earthquake of Wednesday morning, April 18, was a No. 9....

"'There was a shock felt yesterday afternoon at 1 o'clock, but it was of but a very short duration and was classed as a No. 3. The shock which was felt Wednesday at 4:30 in the afternoon was of no longer duration but was of No. 4 intensity. The others which have been felt since Wednesday of last week have been of No. 2 and No. 3 and No. 1 intensity and of less degree which I have not recorded."'

"The shock ... at 4:30" almost certainly refers to the earthquake at around 15:15 on 25 Apr; compare this with the report in The Bulletin (San Francisco), 26 Apr 1906, p. 6, c. 2-3.

Report 5: $\quad$ Oakland Times, 26 Apr 1906; p. 1, c. 4

“... there was an earthquake shock which, while not serious in its consequences, nevertheless had the effect of badly frightening people. Many rushed from their homes bareheaded and into the streets, looking at each other with blanched faces, fearing a repetition of the shock of last week. Practically no damage was done, only a few loose bricks toppling from their shaky positions, not having been securely replaced since the earth quake of April 18. The shock yesterday consisted of one short, sharp 'jerk.' It is said by the scientists that it was one of the to be expected 'settling' shocks caused by the earth's crust in the affected region adjusting its self to the conditions caused by the great quake.

"The building inspecting authorities say that no damage whatever was caused by the shock...."

Report 6: $\quad$ Santa Cruz Morning Sentinel, 26 Apr 1906; p. 1, c. 3

“OAKLAND, Cal., April 25.-Oakland and the cities of San Francisco bay were visited by another earthquake shock.... The shock was not severe, but it lasted fully ten seconds. No buildings were reported damaged anew and no lives lost." 
TABLE 10: PRIMARY REPORTS FOR THE 25 APR 1906, 15:17 AFTERSHOCK

Report 7: $\quad$ Marysville Daily Appeal, 26 Apr 1906; p. 1, c. 5-6

“OAKLAND, April 25.-At 3:20 o'clock this afternoon another earthquake shock was felt in this city, which caused consternation in many quarters and especially among the sufferers who were made homeless by the shock of a week ago. As far as can be learned the tremblor did no material damage, although a number of rickety walls were shaken down. So far no loss of life has been reported.

"At Oakland mole the trains which were standing on the tracks ready to receive passengers, were moved several feet by the force of the shock.

"The tremblor was sufficient to cause a small wave on the bay, which, so far as learned, did no damage to shipping.

"Out at the different camps of refugees consternation reigned for a short time, but the soldiers on guard quickly quelled the disturbance and quieted the fears of the sufferers."

Some of the statements from Oakland are difficult to believe and may weaken the article's credibility.

Report 8: $\quad$ Fresno Morning Republican, 26 Apr 1906; p. 1, c. 1-2

“OAKLAND, April 25.-A sharp shock of earthquake was felt here at 3:20 o'clock. It lasted about seven or eight seconds."

From this article, it is not clear whether "3:20" refers to 3:20 am or 3:20 pm; however, by comparison to similar reports, the time is inferred to be in the afternoon.

Report 9: $\quad$ Lawson (1908), vol. I, p. 417

Duration 3 seconds. Lawson (1908) estimates Rossi-Forel intensity III. Time listed for this event is 15:15.

Report 10: $\quad$ Lawson (1908), vol. I, p. 417

“Noticed ... on clock marked U. S. Observatory." Time listed for this event is 15:17:15.

MMI for this location: IV-V (preferred: IV)

Location Described: $\quad$ Antioch, Contra Costa Co.

Report 1: $\quad$ Lawson (1908), vol. I, p. 418

felt at Antioch

MMI for this location: Uncertain

\section{Location Described: $\quad$ Martinez, Contra Costa Co.}

Report 1: $\quad$ Daily Gazette (Martinez), 26 Apr 1906; p. 1, c. 4

"Martinez experienced a very heavy shock of earthquake shortly after 3 o'clock Wednesday afternoon. The tremblor was the heaviest since the one of April 18th and shook buildings violently, rattled dishes and caused the entire population to make a rush for the streets, in fear of a repetition of the earthquake that wrecked half of California. As far as can be ascertained, no serious damage was done beyond giving everyone a good scare. A plate glass window in Bergamini's store was thrown down."

\section{MMI for this location: IV-V (preferred: V)}

\section{Location Described: $\quad$ Point Bonita, Marin Co.}

Report 1: $\quad$ Lawson (1908), vol. I, p. 417

"Direction NW., no tremor, just a jar, 1 max. strongest at beginning, no sound, may have been blasting." Duration 2 seconds. Lawson (1908) estimates Rossi-Forel intensity V.

\section{MMI for this location: Uncertain}


TABLE 10: PRIMARY REPORTS FOR THE 25 APR 1906, 15:17 AFTERSHOCK

\section{Location Described: $\quad$ Napa, Napa Co.}

Report 1: $\quad$ Lawson (1908), vol. I, p. 417

"Sharp."

Townley and Allen (1939) describe this as "slight," but as their source is presumed to be Lawson (1908), it is assumed that Townley and Allen incorrectly copied the information.

Report 2: $\quad$ Napa Daily Journal, 27 Apr 1906; p. 2, c. 1

"The shake at 3:15 Wednesday afternoon caused one death in San Francisco, the victim being Mrs. Annie Whitaker...."

The article gives the impression that the writer expected people to already be aware of the earthquake; this would probably be the case only if it was felt locally; hence, it is inferred that the earthquake was felt in Napa; however, the inference is not without uncertainty.

\section{MMI for this location: Uncertain}

\section{Location Described: $\quad$ Napa Redwoods, Napa Co.}

Report 1: $\quad$ Napa Daily Journal, 28 Apr 1906; p. 2, c. 2

“... yesterday at 3:25 p. m. one of the hardest, though but short, since [the mainshock]...."

This was part of a long article written by a regular correspondent, dated "Napa Redwoods, April 27, 1906." "Yesterday" would therefore suggest the earthquake occurred on 26 Apr. It is possible, however, that the first part of the article, containing the above passage, was written a day before the article was signed and dated, in which case "yesterday" may refer to the 25 Apr event instead.

\section{MMI for this location: Uncertain [may have been a different event]}

\section{Location Described: $\quad$ Yountville, Napa Co.}

Report 1: $\quad$ Lawson (1908), vol. I, p. 417

"Undulatory twist, quite severe."

MMI for this location: Uncertain

Location Described: Sacramento, Sacramento Co.

Report 1: $\quad$ Marysville Daily Appeal, 26 Apr 1906; p. 1, c. 5-6

"SACRAMENTO, April 25.-The earthquake which occurred at San Francisco was hardly noticeable here."

MMI for this location: $\quad$ II

\section{Location Described: Mile Rocks, San Francisco Co.}

Report 1: $\quad$ Lawson (1908), vol. I, p. 417

"Slight."

Durham (1998) identifies two locations named Mile Rocks, one in Sonoma County and the other in San Francisco County. Looking at the maps in the atlas portion of Lawson (1908), the San Francisco County "Mile Rocks" location is on Maps 4, 17, and 19, whereas the Sonoma County location of that name is not on any of the maps. From this, the inference is made that "Mile Rocks" in the list of aftershocks in Lawson (1908) refers to the San Francisco County location.

\section{MMI for this location: Uncertain}


TABLE 10: PRIMARY REPORTS FOR THE 25 APR 1906, 15:17 AFTERSHOCK

\section{Location Described: $\quad$ San Francisco, San Francisco Co.}

Report 1: $\quad$ Diary of Charles Prinegar (San Francisco, CA), 25 Apr 1906 (pp. 74-78)

"... At three o' clock another earth quake came that nearly tore the Post Office down. I was on third floor and thought my time had surely come when bricks and marble and such began to fall all around me...."

Report 2: $\quad$ Diary of Charles Prinegar (San Francisco, CA), 26 Apr 1906 (pp. 78-81)

"... There were a great many killed yesterday when the quake came by falling walls and it does not look good to me....

"I would like to see one of the eastern papers for the papers out here does [sic] not say a thing about the disaster or never mentions a soul that was injured or killed. All they tell about is the heroic work that people have done and where the homeless can get relief, etc...."

Report 3: $\quad$ Diary of Charles Prinegar (San Francisco, CA), 30 Apr 1906 (pp. 102-110)

"... If I had only known that there would not be any more earth-quakes I could just as well kept on at the Post Office and be making two dollars per day. I would have to walk four miles to work and the same at night, but I would have done it, if that quake had not come the first day I worked there. It scared me about as bad as the first one did, and I did not want to take any chances, every one that comes weakens the building that much more, and it looks now as if it would fall at any time...."

Although this event scared the writer "about as bad as the first one did," he also wrote in his diary, on 29 Apr 1906, that all the aftershocks put together "would hardly make as great a one as the first one was.

Report 4: $\quad$ San Francisco Examiner, 26 Apr 1906; p. 1, c. 3

“There was a distinct shock at 3:15 yesterday afternoon. It was felt all over the city, and caused general alarm. People in houses ran into the street. Those in the parks and streets did not notice it and were surprised when told there had been another seismic disturbance....

"Mrs. Whitaker was at work in the kitchen of her home on Shotwell street in the Mission district when the shock came. The chimney, which had been left in a tottering condition by the heavy quake last Wednesday, crashed through the roof upon the young woman....

"The shock did no serious damage to property. Not a building was harmed to any extent. Here and there bricks in unstable chimneys fell.

"It was one of several small shocks which have followed the big earthquake of April 18th...."

Report 5: $\quad$ San Francisco Chronicle, 26 Apr 1906; p. 2, c. 3

“... A slight earthquake shock which was felt in the city shortly after 3 o'clock [yesterday afternoon] caused a leaning chimney at 308 Shotwell street to topple over and crash through the roof of the house...."

Report 6: $\quad$ Oakland Enquirer, 26 Apr 1906; p. 8, c. 3

"An earthquake shook San Francisco at half-past 3 o'clock yesterday afternoon. It was a little more severe than any that have occurred since the day of the big temblor. In the section of the ruins a few bricks were thrown out of place, but no walls fell and there was only one fatality.

“Mrs. Tillie L. Whittaker of 308 Shotwell street lost her life. A chimney fell from a building adjoining her home, crashed through the roof and falling bricks and debris fractured Mrs. Whittaker's skull.... The chimney that fell was about two stories above the roof of her dwelling and timbers, plaster, and shingles went down with a roar...."

Report 7: $\quad$ Oakland Times, 26 Apr 1906; p. 1, c. 4

"... In San Francisco a number of tottering walls were thrown down."

Report 8: $\quad$ Lawson (1908), vol. I, p. 417

"Double waves recorded on seismograph." Time listed for this event is 15:17:10.

MMI for this location: V 
TABLE 10: PRIMARY REPORTS FOR THE 25 APR 1906, 15:17 AFTERSHOCK

\section{Location Described: $\quad$ San Francisco Peninsula}

Report 1: $\quad$ Lawson (1908), vol. I, p. 417

"Strongly felt on ground, causing landsliding along coast cliffs, lasting $10 \mathrm{~s}$. with a slight repetition after 10 s." Duration 15 seconds. Lawson (1908) estimates Rossi-Forel intensity V.

The duration listed in the "Duration" column (15 seconds) is inconsistent with the duration as described under "Remarks."

MMI for this location: Uncertain

\section{Location Described: $\quad$ Stockton, San Joaquin Co.}

Report 1: $\quad$ The Evening Mail (Stockton), 26 Apr 1906; p. 3, c. 5

"A slight shock of earthquake was felt.... In high buildings it was quite perceptible and in some residences it caused temporary alarm, although many persons did not feel it at all."

Report 2: $\quad$ Stockton Daily Evening Record, 26 Apr 1906; p. 8, c. 4

"Another slight earthquake was felt.... The vibration was very light and many did not notice it."

MMI for this location:

Location Described: $\quad$ Mount Hamilton, Santa Clara Co.

Report 1: $\quad$ Lawson (1908), vol. I, p. 418

Lawson (1908) estimates Rossi-Forel intensity II-III. Time listed for this event is 15:17:40.

MMI for this location: Uncertain

Location Described: $\quad$ San Jose, Santa Clara Co.

Report 1: $\quad$ San Jose Mercury, 26 Apr 1906; p. 7, c. 4

"An earthquake lasting about four seconds was perceptible.... It did no damage as far as could be ascertained, but the shock was sufficient to send people rushing from their homes in terror of a repetition of Wednesday's disaster. The disturbance was registered at Lick Observatory, but very faintly."

MMI for this location: $\quad$ IV

\section{Location Described: $\quad$ Vallejo, Solano Co.}

Report 1: $\quad$ Fresno Morning Republican, 26 Apr 1906; p. 1, c. 6-7

"VALLEJO, April 25.-A severe earthquake shock was felt.... The temblor lasted two seconds and the oscillation was from north to south. The people ran from residences and stores in a greatly alarmed condition and the schools were quickly dismissed. No danger [sic] is reported."

MMI for this location: IV 
TABLE 11: PRIMARY REPORTS FOR THE 17 MAY 1906, 20:21 AFTERSHOCK

\section{SEE CORRESPONDING FIGURE 8}

\section{Location Described: $\quad$ Alameda, Alameda Co.}

Report 1: $\quad$ Lawson (1908), vol. I, p. 422

felt at Alameda Pier

MMI for this location: Uncertain

\section{Location Described: $\quad$ Berkeley, Alameda Co.}

Report 1: $\quad$ Berkeley Daily Gazette, 18 May 1906; p. 1, c. 6

"An earthquake occurred last night at 8 o'clock 31 minutes and 29 seconds which lasted eight seconds, but did no damage whatever.

"The temblor was felt in all parts of the city and many nervous people scampered from their homes fearing that a repetition of the one of April 18 was at hand. The effect of the temblor on most buildings was described as having a grinding sensation, but no damage resulted...."

It is not entirely clear which locations are meant by "all parts of the city"; however, it was a common practice of the time to refer to San Francisco simply as "the city." It is inferred that this description applies, at least in part, to the city of Berkeley. It probably also applies to San Francisco, and perhaps to other Bay Area locations as well.

Report 2: $\quad$ Lawson (1908), vol. I, p. 422

"East-west." Duration 8 seconds. Felt in the Faculty Club at U.C. Berkeley.

MMI for this location: Uncertain

Location Described: $\quad$ Livermore, Alameda Co.

Report 1: $\quad$ Livermore Echo, 24 May 1906; p. 1, c. 3

"A sharp earthquake shock was felt here about 8:24 o'clock last Thursday evening, and caused lights, etc., suspended from the ceiling to sway quite perceptibly."

Report 2: $\quad$ Livermore Herald, 19 May 1906; p. 2, c. 1

“There was a lively earthquake shock Thursday evening about 8:25 which reminded nervous people that the ground is not yet stable."

MMI for this location: IV

\section{Location Described: Oakland, Alameda Co.}

Many newspapers outside the Bay Area reported the earthquake in Oakland. Many of these reports were very similar, appearing to come from the same original source, although in other cases some of the reports appeared to be exaggerated. In general, distal reports such as these are considered less reliable than proximal reports (such as those which are listed below), hence the distal reports are not listed.

Report 1: $\quad$ Oakland Enquirer, 18 May 1906; p. 10, c. 2

Oakland Times, 18 May 1906; p. 1, c. 1

"Last evening at 8:20 there was another earthquake shock of about two seconds' duration, which sent hearts jumping, for while it lasted it was rather energetic. So far as is known there was no damage."

Report 2: $\quad$ Oakland Times, 18 May 1906; p. 1, c. 3 
TABLE 11: PRIMARY REPORTS FOR THE 17 MAY 1906, 20:21 AFTERSHOCK

\begin{abstract}
"At twenty minutes past eight o'clock last night an earthquake of some force shook Oakland and had enough energy back of it to throw many people into a considerable scare. Some were so badly done out of their wits that they refused to go to bed for the remainder of the night and camped on their doorsteps. The City Council committees were in session at the time. Although thick in the business of ordinances and resolutions each separate city father dropped his work. Several men in the lobby rose and left the room. City Attorney McElroy confessed to being frightened, and the faces of others went white. But it is confidently expected that there will be no other quake of sufficient force to do any damage."
\end{abstract}

Report 3: $\quad$ Oakland Tribune, 18 May 1906; p. 4, c. 2

"While the members of the City Council were deep in the consideration of municipal business during the meeting of the Council committees last night ... an earthquake rocked the City Hall, and in an instant the business of the meeting was forgotten. Councilmen and lobby __ * seized their hats, and made ready to fly to the safety of the open air, should the shock become more violent.

"Several gentlemen ... took no chances but left the Council chamber with more haste than dignity and sought safety in the _* ${ }^{*}$ until assured that the __* was over. When satisfied that there was no danger of the immediate destruction of the City Hall by the convulsions of Mother Earth, those who had fled returned, the City Fathers resumed the business which had been interrupted and the earthquake was forgotten."

* This word is illegible.

Report 4: $\quad$ Berkeley Daily Gazette, 18 May 1906; p. 1, c. 6

“... In Oakland persons ran from the buildings into the streets, and while very perceptible in all parts of the city no damage was done...."

Report 5: $\quad$ San Francisco Chronicle, 18 May 1906; p. 1, c. 6

“OAKLAND, May 17.-A slight shock of earthquake, lasting several seconds, occurred on this side of the bay at 8:15 o' clock to-night. While sharp enough to be perceptible all over the city, it was not heavy enough to do any damage."

Report 6: $\quad$ Lawson (1908), vol. I, p. 422

"Chandelier swung with period of 1.25 s. Shock NW.-SE. at Vernon St." Duration 12 seconds. Lawson (1908) estimates Rossi-Forel intensity IV-V.

MMI for this location: IV

Location Described: $\quad$ Crockett, Contra Costa Co.

Report 1: $\quad$ Daily Gazette (Martinez), 19 May 1906; p. 4, c. 1

“CROCKETT ITEMS ... May 18, 1906.... A baby temblor caused hearts to come up in the mouths for a few seconds last night."

MMI for this location: $\quad$ III

Location Described: Bolinas, Marin Co.

Report 1: $\quad$ Lawson (1908), vol. I, p. 422

Duration 8 seconds. Lawson (1908) estimates Rossi-Forel intensity III.

MMI for this location: Uncertain

Location Described: $\quad$ Point Bonita, Marin Co.

Report 1: $\quad$ Lawson (1908), vol. I, p. 422

“Nearly vertical. Direction N., no tremor, just a jar, 1 max., strongest at beginning. No sound, may have been blasting." Duration 2 seconds.

MMI for this location: Uncertain 
TABLE 11: PRIMARY REPORTS FOR THE 17 MAY 1906, 20:21 AFTERSHOCK

\section{Location Described: $\quad$ Potter Valley, Mendocino Co.}

Report 1: $\quad$ Ukiah Republican Press, 25 May 1906; p. 4, c. 5

“POTTER, May 22.—.... Two shocks of earthquake were experienced here Thursday evening last...."

The time of the event is not given in this report, except that it occurred in the evening. A lack of felt reports anywhere between Napa and Potter Valley suggests that the event felt in Potter Valley was not the same as the event felt in the San Francisco Bay Area and to the south.

MMI for this location: Uncertain [may have been a different event]

\section{Location Described: $\quad$ Corral de Tierra, Monterey Co.}

Report 1: $\quad$ Salinas Daily Index, 18 May 1906; p. 1, c. 4

“... Reports from ... Corral de Tierra ... show that the shock was felt, but no damage was done."

MMI for this location: Uncertain

Location Described: $\quad$ Gonzales, Monterey Co.

Report 1: $\quad$ Lawson (1908), vol. I, p. 422

felt at Gonzales

MMI for this location: Uncertain

Location Described: $\quad$ King City, Monterey Co.

Report 1: $\quad$ King City Rustler, 18 May 1906; p. 1, c. 5

"Last night at about 8:45 windows began rattling, slightly at first, but presently in an ominously violent manner, causing people to look at each other in an inquiring sort of manner that seemed to say: 'Isn't about time to hike outside?'

"The trembling lasted about 18 seconds, then came a succession of thumps that only lasted a few seconds, but rocked some of the people out of their houses pretty lively. It was nearly as severe as No. 1 of the Big Series that came on the 18th of last month, but unlike that one, it was not followed up. No damage whatsoever was done here."

MMI for this location: $\quad$ IV

Location Described: $\quad$ Monterey, Monterey Co.

Report 1: $\quad$ Salinas Daily Index, 18 May 1906; p. 1, c. 4

“... Reports from ... Monterey ... show that the shock was felt, but no damage was done."

MMI for this location: Uncertain

Location Described: $\quad$ Point Piños, Monterey Co.

Report 1: $\quad$ Lawson (1908), vol. I, p. 422

"Horizontal. Two max. alike, sound like water in pipe with air in it." Duration 22 seconds.

MMI for this location: Uncertain 
TABLE 11: PRIMARY REPORTS FOR THE 17 MAY 1906, 20:21 AFTERSHOCK

\section{Location Described: $\quad$ Salinas, Monterey Co.}

Many newspapers outside the Salinas area reported the earthquake in Salinas. Many of these reports were very similar, appearing to come from the same original source, although in other cases some of the reports appeared to be exaggerated. In general, distal reports such as these are considered less reliable than proximal reports (such as those which are listed below), hence the distal reports are not listed.

Report 1: $\quad$ Salinas Daily Index, 18 May 1906; p. 1, c. 4

“There was another perceptible earthquake shake last night at 8:25. Residents on Main Street are making records for themselves in getting down stairs and out of public buildings...."

Report 2: $\quad$ Salinas Weekly Journal, 19 May 1906; p. 3, c. 3

(Under the heading "From Friday's Daily Journal":) "A sharp shock of earthquake here at 8:25 last evening caused many persons to rush into the street."

Report 3: $\quad$ San Jose Mercury, 18 May 1906; p. 1, c. 2

[UNRELIABLE]

(Under the heading "By the Associated Press":) "SALINAS, May 17.-An earthquake shock, the heaviest since April 18, was felt here about 8:15 this evening. The shock, which was accompanied by a heavy rumble, came from the northeast to southwest and lasted 21 seconds. No damage was done."

The wording of this article is remarkably similar to the description in the Times-Gazette of Redwood City (19 May 1906, p. 3, c. 7), describing the effects in Menlo Park. As the latter piece appears as part of a regular column, and not as part of an Associated Press report, the latter is deemed more reliable, and the report in the San Jose Mercury is ignored.

Report 4: $\quad$ Lawson (1908), vol. I, p. 422

felt in Salinas

MMI for this location: V ?

\section{Location Described: $\quad$ Napa, Napa Co.}

Report 1: $\quad$ Napa Register, 25 May 1906; p. 5, c. 4

"An earthquake shock that was barely perceptible in Napa occurred at 8:15 Thursday evening...."

It is not clear whether the date of this event was 17 or 24 May; however, based on the timing of the event and on other felt reports in the area on 17 May (and not on 24 May) it is presumed that this is the 17 May event.

Report 2: $\quad$ Lawson (1908), vol. I, p. 422

felt in Napa

MMI for this location: $\quad$ II

\section{Location Described: $\quad$ Sacramento, Sacramento Co.}

Report 1: $\quad$ The Home Alliance (Woodland), 18 May 1906; p. 2, c. 1

[UNRELIABLE]

"... It is reported as being quite severe in Sacramento."

This statement is almost certainly erroneous. No newspapers in or near Sacramento reported feeling the earthquake locally.

MMI for this location: Unreliable 
TABLE 11: PRIMARY REPORTS FOR THE 17 MAY 1906, 20:21 AFTERSHOCK

\section{Location Described: $\quad$ Panoche, San Benito Co.}

Report 1: $\quad$ The Free Lance (Hollister), 25 May 1906; p. 4, c. 2

(Under the heading "Panoche Items":) "There was quite a heavy shock here last Thursday night."

MMI for this location: Uncertain

Location Described: $\quad$ Mile Rocks, San Francisco Co.

Report 1: $\quad$ Lawson (1908), vol. I, p. 422

“Vertical. Strongest in middle." Duration 35 seconds.

Durham (1998) identifies two locations named Mile Rocks, one in Sonoma County and the other in San Francisco County. Looking at the maps in the atlas portion of Lawson (1908), the San Francisco County "Mile Rocks" location is on Maps 4, 17, and 19, whereas the Sonoma County location of that name is not on any of the maps. From this, the inference is made that "Mile Rocks" in the list of aftershocks in Lawson (1908) refers to the San Francisco County location.

\section{MMI for this location: Uncertain}

\section{Location Described: $\quad$ San Francisco, San Francisco Co.}

A number of newspapers outside the Bay Area reported the earthquake in San Francisco. Most of these reports were very similar, appearing to come from the same original source, although in other cases some of the reports appeared to be exaggerated. In general, distal reports such as these are considered less reliable than proximal reports (such as those which are listed below), hence the distal reports are not listed.

Report 1: $\quad$ Berkeley Daily Gazette, 18 May 1906; p. 1, c. 6

"... The temblor was felt in all parts of the city and many nervous people scampered from their homes fearing that a repetition of the one of April 18 was at hand. The effect of the temblor on most buildings was described as having a grinding sensation, but no damage resulted...."

It is not entirely clear which locations are meant by "all parts of the city"; however, it was a common practice of the time to refer to San Francisco simply as "the city." It is inferred that this description applies, at least in part, to the city of Berkeley. It probably also applies to San Francisco, and perhaps to other Bay Area locations as well.

Report 2: $\quad$ Santa Cruz Morning Sentinel, 18 May 1906; p. 1, c. 5

"... The shock was felt in San Francisco.... The Associated Press reports that no damage was done...."

Report 3: $\quad$ Lawson (1908), vol. I, p. 422

"Moderate rolling motion."

MMI for this location: IV ?

\section{Location Described: Southampton Shoal, San Francisco Co.}

Report 1: $\quad$ Lawson (1908), vol. I, p. 422

"Southeast-northwest. Rumbling before shake and continuing 2 s. after." Duration 2 seconds.

MMI for this location: Uncertain 
TABLE 11: PRIMARY REPORTS FOR THE 17 MAY 1906, 20:21 AFTERSHOCK

\section{Location Described: $\quad$ Yerba Buena, San Francisco Co.}

Report 1: $\quad$ Lawson (1908), vol. I, p. 422

“Light."

Yerba Buena probably refers to the lighthouse station on Yerba Buena Island in San Francisco Bay (Lawson collected a lot of aftershock data from lighthouse stations), although it may instead refer to the land grant of that name in Santa Clara County.

MMI for this location: $\quad$ Uncertain

\section{Location Described: $\quad$ San Francisco Peninsula}

Report 1: $\quad$ Lawson (1908), vol. I, p. 422

"About the heaviest since first shock, causing people to rush out-of-doors." Duration 20 seconds. Lawson (1908) estimates Rossi-Forel intensity VI.

MMI for this location: Uncertain

\section{Location Described: $\quad$ Stockton, San Joaquin Co.}

Report 1: $\quad$ The Evening Mail (Stockton), 18 May 1906; p. 3, c. 3

"There was a slight earthquake shock last evening at 8:30. It was not generally felt, and there was no damage."

Report 2: $\quad$ Stockton Daily Evening Record, 18 May 1906; p. 5, c. 2

"A slight shock of earthquake was felt in this city about 8:15 o'clock last evening. The shock was so slight that not more than one in three persons felt it."

MMI for this location: $\quad$ II

\section{Location Described: $\quad$ San Luis Obispo, San Luis Obispo Co.}

Report 1: $\quad$ San Luis Obispo Tribune, 22 May 1906; p. 7, c. 3

"Many in this city felt a slight earthquake shock about 8:40 o'clock last evening."

Although the reference to "last evening" would imply the event took place on 21 May 1906, this article was printed in a box otherwise comprised of reports of the event on 17 May. The 20:40 event time matches the time given in all the other reports in the "box" (which all describe the 17 May event). Most likely, this "box" was first published in the daily version of this paper, on 18 May 1906, then reprinted verbatim in the San Luis Obispo Tribune, a semi-weekly paper. When it was reprinted, "last evening" was not corrected as it should have been to reflect the passage of several days' time. The daily version of this paper could not be located.

Report 2: $\quad$ Santa Cruz Morning Sentinel, 18 May 1906; p. 1, c. 5

“... The shock was felt ... slightly at San Luis Obispo. The Associated Press reports that no damage was done...."

MMI for this location: $\quad$ III-IV (preferred: III)

\section{Location Described: $\quad$ Menlo Park, San Mateo Co.}

Report 1: $\quad$ Times-Gazette (Redwood City), 19 May 1906; p. 3, c. 7

(Under the heading "Menlo Park Occurrences":) "An earthquake shock, the heaviest since April 18, was felt here about 8:15 Thurs. evening. The shock, which was accompanied by a heavy rumble, came from the northeast to southwest and lasted 21 seconds. No damage was done."

MMI for this location: IV ? 
TABLE 11: PRIMARY REPORTS FOR THE 17 MAY 1906, 20:21 AFTERSHOCK

\section{Location Described: $\quad$ Campbell, Santa Clara Co.}

Report 1: $\quad$ Lawson (1908), vol. I, p. 422

"Violent."

MMI for this location: Uncertain

Location Described: $\quad$ Los Gatos, Santa Clara Co.

Report 1: $\quad$ Los Gatos Mail, 24 May 1906; p. 4, c. 1

"The temblor last Thursday evening at 8:20 was a pretty big chunk of the jar. Those who know, however, say it only felt like thirty cents compared with the dollar kind they had April 18th."

Report 2: $\quad$ San Jose Mercury, 19 May 1906; p. 12, c. 5

“LOS GATOS, May 18.-No serious damage was done by last night's temblor, which was the most severe shake since April 18th. It occurred about twenty minutes past 8 o'clock."

Report 3: $\quad$ San Francisco Chronicle, 18 May 1906; p. 1, c. 6

“... At Los Gatos and along the foothills, where the shock of April 18th was lightest and did the least damage, [this] shock was felt more distinctly than in [San Jose]. Some plaster was knocked down in various places."

Report 4: $\quad$ Berkeley Daily Gazette, 18 May 1906; p. 1, c. 6

"... At Los Gatos and along the foothills the temblor was felt more distinctly than in the cities and plastering was shaken from the walls in many homes."

Report 5: $\quad$ Lawson (1908), vol. I, p. 422

"Short, but with considerable vertical motion." Lawson (1908) estimates Rossi-Forel intensity V.

MMI for this location: $\quad$ VI

Location Described: $\quad$ Mount Hamilton, Santa Clara Co.

Report 1: $\quad$ Lawson (1908), vol. I, p. 422

“Vertical slightly, 2 max. 5 s. and 10 s. after beginning, mean of two observers." Duration 14 seconds. Lawson (1908) estimates Rossi-Forel intensity IV.

MMI for this location: Uncertain

\section{Location Described: $\quad$ San Jose, Santa Clara Co.}

Many newspapers outside the Bay Area reported the earthquake in San Jose. Many of these reports were very similar, appearing to come from the same original source, although in other cases some of the reports appeared to be exaggerated. In general, distal reports such as these are considered less reliable than proximal reports (such as those which are listed below), hence the distal reports are not listed.

Report 1: $\quad$ San Jose Mercury, 18 May 1906; p. 9, c. 1

"The most severe shock since the earthquake of April 18 was experienced yesterday evening at 8.21.16. The vibrations east and west, lasted approximately fifteen seconds, beginning easily and ending with considerable violence. No damage has been reported. In the Jose Theater an incipient panic was quelled by the presence of mind of those on the stage, who continued their lines and declined to be interrupted." 
TABLE 11: PRIMARY REPORTS FOR THE 17 MAY 1906, 20:21 AFTERSHOCK

Report 2: $\quad$ San Francisco Chronicle, 18 May 1906; p. 1, c. 6

"SAN JOSE, May 17.-A sharp earthquake was felt in this city this evening. At the Lick Observatory the shock continued for ten seconds, and was severest at 8:26 o' clock.

"No damage occurred in this city, nor, so far as could be ascertained, in the neighborhood.

"A mild panic, however, prevailed for some time all over the city and surroundings. People rushed from their homes and remained outside for hours. Many are bringing their tents again into use. Two automobiles felt the shock distinctly, although traveling at a rapid pace.

"At the San Jose Theater, where the Frank Bacon company was presenting 'The Hills of California,' the audience commenced to stampede, but was quieted. No one was injured...."

Report 3: $\quad$ San Francisco Examiner, 18 May 1906; p. 3, c. 4

"SAN JOSE, May 17.-Frightened by prophesies of the world's end, hundreds of women became panic stricken to-night when what seemed the heaviest shock since April 18th rocked the town. Despite the apparent force of the temblor, however, not even the shakiest walls were injured or disturbed.

"At the Jose Theatre a crowded house rose as the lights upon the stage went out, and rushed towards the doors. The coolness of the employees and several other men stopped the panic before any one had been injured. Although many left the theatre, the performance was continued. For days San Jose has been deeply agitated over the mysterious appearance upon the fences and dead walls of the city of placards and signs predicting the speedy end of the earth....

"When the shock came to-night the scenes throughout the residence section of the city were those of a wildly disturbed community. Women rushed from every house screaming and terrorstricken. Crying to one another that the end of the world had come, they dashed from their homes without a thought of consequences. The efforts to calm them by the men that remained collected were futile-their fear was not one that could be reasoned with. Blind, unreasoning terror, superstitious fright, was all powerful. There was scarcely a street upon which were not huddled frightened groups of women seeking refuge from the houses that rocked with the force of the quake. To persuade the nervous to return to the houses was a difficult task, and in a few instances impromptu tents formed the night's shelter."

MMI for this location: $\quad$ V

Location Described: $\quad$ Sunnyvale, Santa Clara Co.

Report 1: $\quad$ San Jose Mercury, 19 May 1906; p. 12, c. 4

"SUNNYVALE, May 18.-At 8:20 p.m. we experienced another jar, lasting about ten seconds. It occasioned some anxiety and uneasiness, but no damage was done."

MMI for this location: $\quad$ IV

\section{Location Described: $\quad$ Boulder Creek, Santa Cruz Co.}

Report 1: $\quad$ The Mountain Echo (Boulder Creek), 19 May 1906; p. 3, c. 2

"There was another quite heavy shock of earthquake at 8:24 Thursday evening, causing many people to hurriedly vacate their homes for the streets and sidewalks."

MMI for this location: $\quad$ V

\section{Location Described: $\quad$ Santa Cruz, Santa Cruz Co.}

Report 1: $\quad$ Santa Cruz Morning Sentinel, 18 May 1906; p. 1, c. 5

"A little more severe earthquake shock than usual was felt in this city at 8:30 on Thursday evening, lasting for about ten seconds.

"Although the vibrations in many buildings on Pacific Av. were quite noticeable, and in fact all over the city, there was very little alarm, no one was hurt and not a pane of glass nor a piece of plaster was broken, so far as known...." 
TABLE 11: PRIMARY REPORTS FOR THE 17 MAY 1906, 20:21 AFTERSHOCK

Report 2: $\quad$ Santa Cruz Surf, 18 May 1906; p. 8, c. 1

"The hardest shock of earthquake since the one on the 18th of April was felt last evening. There was practically no damage, but the shock was heavy enough to drive people into the street."

MMI for this location: IV-V (preferred: V)

\section{Location Described: $\quad$ Watsonville, Santa Cruz Co.}

Report 1: $\quad$ Santa Cruz Morning Sentinel, 18 May 1906; p. 1, c. 5

“... The shock was felt in ... Watsonville.... The Associated Press reports that no damage was done...."

Report 2: $\quad$ Salinas Daily Index, 18 May 1906; p. 1, c. 4

"... Reports from ... Watsonville ... show that the shock was felt, but no damage was done."

Report 3: $\quad$ San Luis Obispo Tribune, 22 May 1906; p. 7, c. 2-3

"... Reports from Watsonville and Salinas state that the shock was quite severe at both those places."

MMI for this location: Uncertain

\section{Location Described: $\quad$ Vallejo, Solano Co.}

Report 1: $\quad$ The Tuolumne Independent (Sonora), 19 May 1906; p. 3, c. 4

"... A shock was also felt at Vallejo...."

Report 2: $\quad$ Union Democrat (Sonora), 19 May 1906; p. 1, c. 4

"A telephone message received in Sonora Thursday night at nine o'clock announced another severe earthquake shock in San Francisco, Oakland, San Jose, and Vallejo. No damage was reported."

The date and time of the event are not stated in the article, but it is inferred to be the event of the night of 17 May.

MMI for this location: Uncertain

Location Described: $\quad$ Modesto, Stanislaus Co.

Report 1: $\quad$ Modesto Daily Evening News, 18 May 1906; p. 4, c. 3

"A slight earthquake was felt here at 8:23 o'clock last evening. It jarred the chandeliers a bit, but that was about all."

MMI for this location: III

Location Described: Oakdale, Stanislaus Co.

Report 1: $\quad$ Lawson (1908), vol. I, p. 422

"Very slight...."

MMI for this location: Uncertain 
TABLE 11: PRIMARY REPORTS FOR THE 17 MAY 1906, 20:21 AFTERSHOCK

\section{Location Described: $\quad$ Woodland, Yolo Co.}

Report 1: $\quad$ The Home Alliance (Woodland), 18 May 1906; p. 2, c. 1

"A slight earthquake shock was felt here last night...."

Report 2: $\quad$ Sacramento Bee, 18 May 1906; p. 7, c. 1

"... A slight shock of earthquake was felt by a number of people in Woodland last night."

MMI for this location: III

\section{Location Described: $\quad$ Marysville, Yuba Co.}

Report 1: $\quad$ Marysville Daily Appeal, 18 May 1906; p. 4, c. 2

"Word was received in this city last night that another quite severe earthquake was felt at San Francisco last evening about 8 o'clock. No damage was done."

From the nature of this report, it appears that the earthquake was not felt in Marysville. Contrary to the implication of this report, the earthquake does not appear to have been felt "severely" in San Francisco.

MMI for this location: $\quad$ Uncertain, but probably Not Felt 
TABLE 12: PRIMARY REPORTS FOR THE 6 JUL 1906, 22:55 AFTERSHOCK

\section{SEE CORRESPONDING FIGURE 9}

\section{Location Described: $\quad$ Coalinga, Fresno Co.}

Report 1: $\quad$ Hanford Weekly Sentinel, 12 Jul 1906; p. 2, c. 3

"A report came over the railroad wire Saturday saying that there was an earthquake shock in Coalinga at about 10 o'clock Friday night. The report stated that the Odd Fellows were holding a meeting, and the severity of the jar caused the company to hurry onto the streets. No damage is reported from the temblor, but the people were badly frightened...."

Report 2: $\quad$ Hanford Daily Journal, 7 Jul 1906; p.5, c. 3

"An earthquake shock, lasting several seconds, visited Coalinga shortly after 10 o'clock last night, causing no damage, but almost creating a panic at a meeting of the local lodge of Odd Fellows, which was in session at the time...."

Report 3: $\quad$ Fresno Morning Republican, 8 Jul 1906; p. 7, c. 4

"HANFORD, July 7.- A slight earthquake shock was felt in Coalinga, Lemoore and Hanford shortly after 10 o' clock last night. It was most severe in Coalinga, where it was of sufficient power to cause considerable fright. No damage has been reported."

Report 4: $\quad$ Tulare County Times (Visalia), 12 Jul 1906; p. 2, c. 2

(Under the heading "(From Saturday's Daily Times)":) "It was rumored around town today that a severe earthquake was felt last night at Coalinga, Volta, and Los Banos. At the two former places the shock was quite severe and many people rushed out of their houses. The shock occurred about 11 p. m."

MMI for this location: $\quad$ V

Location Described: $\quad$ Fresno, Fresno Co.

Report 1: $\quad$ Fresno Morning Republican, 8 Jul 1906; p. 7, c. 4

"HANFORD, July 7.-A slight earthquake shock was felt in Coalinga, Lemoore and Hanford shortly after 10 o'clock last night. It was most severe in Coalinga, where it was of sufficient power to cause considerable fright. No damage has been reported."

The lack of a report from Fresno in this or in other Fresno newspapers suggests that this earthquake was not felt in Fresno.

\section{MMI for this location: $\quad$ Uncertain, but probably Not Felt}

\section{Location Described: $\quad$ Hanford, Kings Co.}

Report 1: $\quad$ Hanford Weekly Sentinel, 12 Jul 1906; p. 2, c. 3

"A report came over the railroad wire Saturday saying that there was an earthquake shock in Coalinga at about 10 o'clock Friday night. The report stated that the Odd Fellows were holding a meeting, and the severity of the jar caused the company to hurry onto the streets. No damage is reported from the temblor, but the people were badly frightened.

"Railroad men coming from Lemoore Saturday morning, said that the shock was felt there at about the same time that Coalinga was shaken, but the jar was not so perceptible. The disturbance was felt here by a few, and was apparently very slight, but Hanford will not be envious of the two towns to the west on account of their being favored by a greater shock."

Report 2: $\quad$ Hanford Daily Journal, 7 Jul 1906; p.5, c. 3

"... several Hanfordites state that the trembling was slightly noticeable in this city." 
TABLE 12: PRIMARY REPORTS FOR THE 6 JUL 1906, 22:55 AFTERSHOCK

Report 3: $\quad$ Fresno Morning Republican, 8 Jul 1906; p. 7, c. 4

“HANFORD, July 7.-A slight earthquake shock was felt in Coalinga, Lemoore and Hanford shortly after 10 o'clock last night. It was most severe in Coalinga, where it was of sufficient power to cause considerable fright. No damage has been reported."

MMI for this location: II

\section{Location Described: $\quad$ Lemoore, Kings Co.}

Report 1: $\quad$ Hanford Weekly Sentinel, 12 Jul 1906; p. 2, c. 3

"A report came over the railroad wire Saturday saying that there was an earthquake shock in Coalinga at about 10 o'clock Friday night. The report stated that the Odd Fellows were holding a meeting, and the severity of the jar caused the company to hurry onto the streets. No damage is reported from the temblor, but the people were badly frightened.

"Railroad men coming from Lemoore Saturday morning, said that the shock was felt there at about the same time that Coalinga was shaken, but the jar was not so perceptible. The disturbance was felt here by a few, and was apparently very slight, but Hanford will not be envious of the two towns to the west on account of their being favored by a greater shock."

Report 2: $\quad$ Hanford Daily Journal, 7 Jul 1906; p.5, c. 3

“... Brakeman Roberts, of the Coalinga-Goshen S. P. passenger train, reports that the shock was plainly felt by him in Lemoore...."

Report 3: $\quad$ Fresno Morning Republican, 8 Jul 1906; p. 7, c. 4

"HANFORD, July 7.-A slight earthquake shock was felt in Coalinga, Lemoore and Hanford shortly after 10 o' clock last night. It was most severe in Coalinga, where it was of sufficient power to cause considerable fright. No damage has been reported."

MMI for this location: III?

\section{Location Described: $\quad$ Los Banos, Merced Co.}

Report 1: $\quad$ Tulare County Times (Visalia), 12 Jul 1906; p. 2, c. 2

(Under the heading "(From Saturday's Daily Times)":) "It was rumored around town today that a severe earthquake was felt last night at Coalinga, Volta, and Los Banos. At the two former places the shock was quite severe and many people rushed out of their houses. The shock occurred about 11 p. m."

Report 2: $\quad$ Lawson (1908), vol. I, p. 426

felt in Los Banos

MMI for this location: III?

\section{Location Described: $\quad$ Volta, Merced Co.}

Report 1: $\quad$ Tulare County Times (Visalia), 12 Jul 1906; p. 2, c. 2

[UNRELIABLE]

(Under the heading "(From Saturday's Daily Times)":) "It was rumored around town today that a severe earthquake was felt last night at Coalinga, Volta, and Los Banos. At the two former places the shock was quite severe and many people rushed out of their houses. The shock occurred about 11 p. m."

It seems unlikely that Volta would have a sufficiently higher intensity than Los Banos, given the proximity of the two locations, the similar underlying geology, and the fact that the epicenter is almost certainly closer to Los Banos than to Volta.

MMI for this location: Uncertain 
TABLE 12: PRIMARY REPORTS FOR THE 6 JUL 1906, 22:55 AFTERSHOCK

\section{Location Described: $\quad$ King City, Monterey Co.}

Report 1: $\quad$ Salinas Daily Index, 11 Jul 1906; p. 1, c. 4

"KING CITY, July 10.- This section was treated to quite a severe shock of earthquake last Friday night at 10:50 o'clock. No damage."

MMI for this location: IV ?

\section{Location Described: $\quad$ Salinas, Monterey Co.}

Report 1: $\quad$ Lawson (1908), vol. I, p. 426

felt in Salinas

MMI for this location: Uncertain

Location Described: $\quad$ San Lucas, Monterey Co.

Report 1: $\quad$ Salinas Daily Index, 10 Jul 1906; p. 1, c. 4

“SAN LUCAS, July 9th.-San Lucas was startled by an earthquake about 11 o'clock Friday night nearly as heavy as the one April the 18th. So far no damage has been reported."

MMI for this location: IV ?

\section{Location Described: $\quad$ San Luis Obispo, San Luis Obispo Co.}

Report 1: $\quad$ Semi-Weekly Breeze (San Luis Obispo), 10 Jul 1906; p. 5, c. 2

"Some did and others did not feel a slight temblor at seven minutes to 11 o'clock...."

MMI for this location: $\quad$ III

Location Described: $\quad$ Mount Hamilton, Santa Clara Co.

Report 1: $\quad$ Lawson (1908), vol. I, p. 426

"Light. East to west."

MMI for this location: Uncertain

\section{Location Described: $\quad$ Santa Cruz, Santa Cruz Co.}

Report 1: $\quad$ Semi-Weekly Breeze (San Luis Obispo), 10 Jul 1906; p. 5, c. 2

“... Reports from Santa Cruz and Watsonville state that several distinct shocks were felt, but no damage was done. However there is no cause for alarm as a slight shock is a daily occurrence in the northern cities."

MMI for this location: III

\section{Location Described: $\quad$ Watsonville, Santa Cruz Co.}

Report 1: $\quad$ Semi-Weekly Breeze (San Luis Obispo), 10 Jul 1906; p. 5, c. 2

“... Reports from Santa Cruz and Watsonville state that several distinct shocks were felt, but no damage was done. However there is no cause for alarm as a slight shock is a daily occurrence in the northern cities."

MMI for this location: III 
TABLE 12: PRIMARY REPORTS FOR THE 6 JUL 1906, 22:55 AFTERSHOCK

\section{Location Described: $\quad$ Visalia, Tulare Co.}

Report 1: $\quad$ Tulare County Times (Visalia), 12 Jul 1906; p. 2, c. 2

(Under the heading "(From Saturday's Daily Times)":) "It was rumored around town today that a severe earthquake was felt last night at Coalinga, Volta, and Los Banos. At the two former places the shock was quite severe and many people rushed out of their houses. The shock occurred about 11 p. m."

The nature of this report, and the lack of a report from Visalia in this or in other Visalia newspapers, suggest that this earthquake was not felt in Visalia.

\section{MMI for this location: $\quad$ Uncertain, but probably Not Felt}


TABLE 13: PRIMARY REPORTS FOR THE 5 JUN 1907, 00:27 AFTERSHOCK

\section{SEE CORRESPONDING FIGURE 10}

\section{Location Described: $\quad$ Alameda, Alameda Co.}

Report 1: $\quad$ Alameda Daily Argus, 5 Jun 1907; p. 1, c. 7

“There was a sharp earthquake shock at 12:30 o'clock this morning. The shock was one of the most severe since the big quake of April of last year, and rocked houses and agitated timid nerves. Some wall pieces and ornaments were hurled to the floor in several homes, but no chimneys were cracked or other damage sustained.

"Mr. Perrine of 2138 Alameda avenue, father of Professor Charles Perrine, the well known astronomer, possesses the only seismograph in Alameda.... The record shows three-quarters of an inch, almost directly east and west, with a slight variation to the southeast and northwest.

"According to Mr. Perrine the shock occurred at exactly 12:29."

MMI for this location: $\quad$ V

\section{Location Described: $\quad$ Berkeley, Alameda Co.}

Report 1: $\quad$ Berkeley Daily Gazette, 5 Jun 1907; p. 1, c. 3

“There was a baby earthquake in Berkeley about 12:30 o'clock this morning. It was not a very serious affair, but as it was slow in action nervous people feared that it might be preliminary to a more serious disturbance. Light sleepers in frail buildings were awakened, but it was such a minor shake that they turned over and went to sleep again.... No damage whatever is reported.

“The seismograph at the students' observatory caught the records distinctly and the belief is that the center of the vibrations was about fifty miles away. Here is the official reading of the seismograph:

“The earthquake of this morning started at 12:26:37 P. S. T. The preliminary tremor lasted for six seconds when the main shock began. This was in two parts, the first and more severe lasting for twenty-one seconds, the other lasting for twenty-eight seconds, giving a total duration of 49 seconds for the main shock. The Omori Seismograph from which these data have been taken showed smaller tremors for nearly three minutes. The direction of the vibrations was from southwest to northeast. A greater disturbance is shown in the east and west component than in the north and south. The center of the shock is about fifty miles distant. The maximum amplitude of the shock is one-onehundredth of an inch."'

Report 2: $\quad$ Townley and Allen (1939), p. 145

“[Rossi-Forel] Intensity IV to V at Berkeley....

"At Berkeley this shock wrote the largest seismogram obtained to that date on the instrument installed at the University of California in June of the previous year, with maximum amplitude of $251 \mu$ and 1.9 seconds period in the east-west component, and an interval $L-P$ of six seconds, corresponding to a distance of origin of about thirty miles."

Report 3: $\quad$ Oak Park Ledger, 7 Jun 1907; p. 1, c. 4

[UNRELIABLE]

“... Berkeley was almost shaken to pieces last Tuesday night....”

This is almost certainly the 5 Jun 1907 event. The tone of this article was that of an editorial, and the descriptions were without doubt exaggerated. No measure of credibility should be given to the description of shaking above.

MMI for this location: IV

\section{Location Described: Dimond, Alameda Co.}

Report 1: $\quad$ Townley and Allen (1939), p. 145

"Dimond, near Oakland, distinct"

MMI for this location: Uncertain 
TABLE 13: PRIMARY REPORTS FOR THE 5 JUN 1907, 00:27 AFTERSHOCK

\section{Location Described: $\quad$ Livermore, Alameda Co.}

Report 1: $\quad$ Livermore Echo, 6 Jun 1907; p. 1, c. 3

"A short sharp shock of earthquake was felt here at 12:25 Wednesday morning, followed by a lighter shake, and many light sleepers were awakened."

Report 2: $\quad$ Livermore Herald, 8 Jun 1907; p. 3, c. 1

"A sharp shock of earthquake was felt here Wednesday morning about 12:30. It was accompanied by a subterranean roar which was much more noticeable than that which preceded the big quake last year."

Report 3: $\quad$ Townley and Allen (1939), p. 145

"Reports with no description came from ... Livermore, Alameda Co. ..."

MMI for this location: IV

Location Described: Mills College, Alameda Co.

Report 1: $\quad$ Townley and Allen (1939), p. 145

"Reports with no description came from ... Mills College, ... Alameda Co. ..."

\section{MMI for this location: Uncertain}

\section{Location Described: Oakland, Alameda Co.}

Report 1: $\quad$ The Bulletin (San Francisco), 5 Jun 1907; p. 1, c. 5

Oakland Tribune, 5 Jun 1907; p. 10, c. 2

"... The seismograph at Chabot observatory in Oakland registered an observation quite different from that of Professor McAdie [in San Francisco]. According to the Chabot instrument the earthquake occurred at 12:27, two minutes later than in [San Francisco], lasted three seconds and had a general direction of from northwest to southeast. It was a number five shock, according to the Oakland observation."

It is probable that by "number five" the article is referring to the intensity on the Rossi-Forel scale. A Rossi-Forel V corresponds, very roughly, with a Modified Mercalli Intensity V.

Report 2: $\quad$ Mother Lode Magnet (Jamestown), 5 Jun 1907; p. 3, c. 5

“There was a lively shake up by el temblor about San Francisco bay at shortly past midnight last night. A phone message from Oakland this a. $\mathrm{m}$. states that no damage of note was done...."

Report 3: $\quad$ The Morning Echo (Bakersfield), 5 Jun 1907; p. 1, c. 2-6

“... By telephone to Oakland it was learned that a very severe earthquake was felt at 12:45 in San Francisco, Oakland and other cities as far south as Stockton....

"The telephone operator at Oakland said that no reports of serious damage had been received up to 2 o'clock.

"A later report by telephone from the telephone operator at Oakland said that the shock occurred at 12:38 and lasted 11 seconds. The shock caused great terror, but so far it appeared that little damage had been done."

Report 4: $\quad$ Townley and Allen (1939), p. 145

"Oakland, rather heavy, of five seconds duration"

MMI for this location: Uncertain 
TABLE 13: PRIMARY REPORTS FOR THE 5 JUN 1907, 00:27 AFTERSHOCK

\section{Location Described: $\quad$ Martinez, Contra Costa Co.}

Report 1: $\quad$ Contra Costa Gazette, 8 Jun 1907; p. 5, c. 1

(Under the heading "FROM THURSDAY'S DAILY":) "On Wednesday morning, somewhere about 12:30 a.m., there was a short but pretty sharp earthquake shock. It was noticed by a good many who were not asleep at the time and it woke up quite a number."

MMI for this location: $\quad$ IV

\section{Location Described: $\quad$ Fresno, Fresno Co.}

Report 1: $\quad$ The Morning Echo (Bakersfield), 5 Jun 1907; p. 1, c. 2-6

“... By telephone to Oakland it was learned that a very severe earthquake was felt at 12:45 in San Francisco, Oakland and other cities as far south as Stockton. No shock was felt at Fresno or in this city....

"A later report by telephone from the telephone operator at Oakland said that the shock occurred at 12:38 and lasted 11 seconds. The shock caused great terror, but so far it appeared that little damage had been done."

MMI for this location: $\quad$ Not Felt

\section{Location Described: $\quad$ Bakersfield, Kern Co.}

Report 1: $\quad$ The Morning Echo (Bakersfield), 5 Jun 1907; p. 1, c. 2-6

“... By telephone to Oakland it was learned that a very severe earthquake was felt at 12:45 in San Francisco, Oakland and other cities as far south as Stockton. No shock was felt at Fresno or in this city....

"A later report by telephone from the telephone operator at Oakland said that the shock occurred at 12:38 and lasted 11 seconds. The shock caused great terror, but so far it appeared that little damage had been done."

\section{MMI for this location: $\quad$ Not Felt}

\section{Location Described: $\quad$ Kentfield, Marin Co.}

Report 1: $\quad$ Townley and Allen (1939), p. 145

"Kentfield, Marin Co., sharp"

MMI for this location: Uncertain

\section{Location Described: Napa, Napa Co.}

Report 1: $\quad$ Napa Daily Journal, 6 Jun 1907; p. 3, c. 3

"A distinct shock of earthquake was felt in this city at 12:25 Wednesday morning."

Report 2: $\quad$ Townley and Allen (1939), p. 145

"Napa State Hospital, light"

MMI for this location: III?

\section{Location Described: $\quad$ Sacramento, Sacramento Co.}

Report 1: $\quad$ San Francisco Call, 5 Jun 1907; p. 3, c. 7

[UNRELIABLE]

“... The dispatcher at Oakland pier stated that no reports of the temblor's having been felt in the interior had been received except from Sacramento. No damage was reported." 
TABLE 13: PRIMARY REPORTS FOR THE 5 JUN 1907, 00:27 AFTERSHOCK

The nature of this report, and the lack of any corroborating reports, makes the Sacramento report seem rather questionable.

\section{MMI for this location: Unreliable}

\section{Location Described: $\quad$ San Francisco, San Francisco Co.}

Many newspapers outside San Francisco reported the earthquake in San Francisco. Some of these reports appear to be based upon reports that are listed below, and they contain no new information. Only reports with unique information are listed below.

Report 1: $\quad$ The Bulletin (San Francisco), 5 Jun 1907; p. 1, c. 5

"A heavy earthquake shock startled this city from its sleep this morning when the day was just twenty-five minutes old. It lasted for several seconds and was felt distinctly in all parts of town. No damage has been reported.

"According to Professor McAdie, of the Weather Bureau, the temblor ranks as number four in the seismic scale. The earthquake of April last year ranks as number nine...."

It is probable that by "number four" the article is referring to the intensity on the Rossi-Forel scale. A Rossi-Forel IV corresponds, very roughly, with a Modified Mercalli Intensity IV.

Report 2: $\quad$ San Francisco Call, 5 Jun 1907; p. 3, c. 7

"Two small but distinct earthquake shocks were felt in San Francisco and the bay cities at 12:26 this morning...."

Report 3: $\quad$ Sacramento Star, 5 Jun 1907; p. 1, c. 5

"SAN FRANCISCO, June 5.--An earthquake shock of easy, undulating movement and lasting several seconds occurred in San Francisco and vicinity at 12:40 this morning. The shock was the longest since the great quake of April, 1906, but it caused no damage. Hundreds of persons rushed into the streets in their night clothes but the excitement soon subsided when it was found that no damage was done."

Report 4: $\quad$ San Jose Mercury, 5 Jun 1907; p. 1, c. 4

"SAN FRANCISCO, June 4.-An earthquake shock lasting about ten seconds was felt here at 12:27 this morning. The oscillation was from north to south. No damage has been reported."

The date on this report clearly should be June 5, not June 4. Many other newspapers carried the same report, also with the incorrect dateline. A few papers, including the Stockton Daily Independent (5 June 1907; p. 1, c. 4) carried the report and corrected the date to read June 5.

Report 5: $\quad$ Evening Pajaronian (Watsonville), 5 Jun 1907; p. 1, c. 5

"San Francisco, June 5.-This city and neighboring cities bordering on the bay experienced a severe earthquake shock shortly after midnight.... No serious damage is reported."

Report 6: $\quad$ The Morning Echo (Bakersfield), 5 Jun 1907; p. 1, c. 2-6

[UNRELIABLE]

"Reports reached here early this morning by way of the railroad telegraph lines of an earthquake shock in San Francisco, occurring some time after midnight. The Southern Pacific operator in the Flood building said that the shock seemed as heavy as the one that caused the disaster of last spring. The furniture in the office danced about the room. So far as the railroad operator knew the damage in the city was not great. The wires were working well.

"By telephone to Oakland it was learned that a very severe earthquake was felt at 12:45 in San Francisco, Oakland and other cities as far south as Stockton....

“The telephone operator at Oakland said that no reports of serious damage had been received up to 2 o'clock.

"A later report by telephone from the telephone operator at Oakland said that the shock occurred at 12:38 and lasted 11 seconds. The shock caused great terror, but so far it appeared that little damage had been done."

In comparison to other reports from San Francisco, this account seems greatly exaggerated.

\section{MMI for this location: IV-V (preferred: IV)}


TABLE 13: PRIMARY REPORTS FOR THE 5 JUN 1907, 00:27 AFTERSHOCK

\section{Location Described: $\quad$ Stockton, San Joaquin Co.}

Several newspapers outside Stockton reported the earthquake in Stockton. These reports appear to be based upon one of the reports listed below, and they contain no new information. Only reports with unique information are listed below.

Report 1: $\quad$ Stockton Daily Independent, 5 Jun 1907; p. 5, c. 4

"At 12:40 o'clock this morning a tremblor lasting from one and a half to two seconds was distinctly felt in Stockton. Persons sleeping in second stories were at a loss to know just what caused the disturbance and one after another sought the telephone to verify their impressions. Operators along the Associated Press wires from San Francisco reported having felt the shock."

Report 2: $\quad$ Stockton Daily Evening Record, 5 Jun 1907; p. 5, c. 4

"Stockton was visited by a slight temblor at 12:40 this morning that lasted from one and a half to two seconds. Residents sleeping in upper stories were at a loss to know just what caused the disturbance and sought the telephones to verify their impressions. Telegraph operators along the wires between here and San Francisco reported having felt the shock."

MMI for this location: $\quad$ III

\section{Location Described: $\quad$ San Luis Obispo, San Luis Obispo Co.}

Report 1: $\quad$ Semi-Weekly Breeze (San Luis Obispo), 7 Jun 1907; p. 4, c. 5

"San Francisco, June 5.-San Francisco and the bay cities experienced a sharp earthquake at 12:30 this morning. There was no damage done, but the shocks were severe and the people were very much excited.

"Shocks were felt as far south as San Jose...."

The nature of this report, and the lack of a report from San Luis Obispo in this or in other San Luis Obispo newspapers, suggest that this earthquake was not felt in San Luis Obispo.

MMI for this location: $\quad$ Uncertain, but probably Not Felt

\section{Location Described: $\quad$ Half Moon Bay, San Mateo Co.}

Report 1: $\quad$ Los Gatos Mail, 20 Jun 1907; p. 5, c. 3

"The earthquake last week injured a concrete building in course of construction at Half Moon Bay, opening a gap an inch wide from top to bottom, says the advocate."

The original article (which may have been printed in the Coast Advocate, published in Half Moon Bay) could not be located, and the date it was originally published is uncertain; it may have been as much as a week old by the time it was re-printed in the Los Gatos Mail. The date of the event is even less certain.

MMI for this location: Uncertain [may have been a different event]

\section{Location Described: $\quad$ Menlo Park, San Mateo Co.}

Report 1: $\quad$ Townley and Allen (1939), p. 145

"Reports with no description came from ... Menlo Park, San Mateo Co. ..."

MMI for this location: Uncertain 
TABLE 13: PRIMARY REPORTS FOR THE 5 JUN 1907, 00:27 AFTERSHOCK

\section{Location Described: $\quad$ Redwood City, San Mateo Co.}

Report 1: $\quad$ Times-Gazette (Redwood City), 8 Jun 1907; p. 3, c. 6

(Under the heading "NEWS GATHERED IN REDWOOD CITY AND VICINITY":) "An earthquake visited this community Wednesday morning at 12:25 which made up in severity what it lacked in duration."

MMI for this location: Uncertain

\section{Location Described: $\quad$ San Gregorio, San Mateo Co.}

Report 1: $\quad$ Redwood City Democrat, 13 Jun 1907; p. 3, c. 3

"SAN GREGORIO, June 12-... Two heavy shocks of earthquake were felt during the week at San Gregorio."

The dates of the two events are not known, but most likely, they are the events of 5 Jun and 10 Jun.

\section{MMI for this location: Uncertain [may have been a different event]}

\section{Location Described: $\quad$ Alma, Santa Clara Co.}

Report 1: $\quad$ Diary of Henry Lloyd Tevis (Alma, CA), 5 Jun 1907

"Weather overcast all day. Quite a heavy earthquake shock occurred during the night. Examiner said it was 'No. 4.' E.L.D. returned on morning train and met H.L.T. at 4:20 San Jose in the Large Loco [sic]."

According to T. Toppozada (CDMG; written comm., 2001), two sets of diaries for each year exist-one for the ranch and one for the office. Tevis did not write the diaries, his valet did. No mention is given of the valet's name. Tevis lived in Alma, outside of Los Gatos on the road to Santa Cruz. He was an early California millionaire and had a ranch near Los Gatos and a house in San Francisco. The location where the aforementioned earthquake was felt is not stated but is inferred from the rest of the diary entry.

MMI for this location: Uncertain

\section{Location Described: $\quad$ Campbell, Santa Clara Co.}

Report 1: $\quad$ Townley and Allen (1939), p. 145

"Campbell, Santa Clara Co., light"

MMI for this location: Uncertain

\section{Location Described: $\quad$ Los Gatos, Santa Clara Co.}

Report 1: $\quad$ Los Gatos Mail, 6 Jun 1907; p. 1, c. 4

"At 12:27 o'clock yesterday morning occurred a quite determined jolt occasioned by some internal disturbance of Mother Earth. The shock lasted five or six seconds, perhaps, and caused many a person to 'sit up and take notice.' Some even got out of bed and out into the cold, cold world evidently from fear that something might drop. But nothing did drop or fall down, and so far as has been learned no damage was done...."

Report 2: $\quad$ Los Gatos News, 7 Jun 1907; p. 3, c. 1

"There was a shock of earthquake the other evening that would have been unnoticed if it had not been for the experience of last year. Everybody is looking for trouble and excitement. Every little counts."

Based on the time reported from nearby communities, this was probably the earthquake of the early morning of 5 Jun. 
TABLE 13: PRIMARY REPORTS FOR THE 5 JUN 1907, 00:27 AFTERSHOCK

Report 3: $\quad$ Townley and Allen (1939), p. 145

"Los Gatos, a few miles farther west [than Campbell], light"

MMI for this location: IV

\section{Location Described: $\quad$ Mountain View, Santa Clara Co.}

Report 1: $\quad$ Mountain View Register, 7 Jun 1907; p. 3, c. 3

"A little earthquake shock was felt by the citizens of Mountain View last Tuesday night at about 12:30. It was felt all along the peninsula but no damage is reported. In San Francisco it lasted about ten seconds while here it was only about six. It is hard to explain the thoughts of a person when old mother earth begins to rock even though she merely disturbs your midnight slumbers."

MMI for this location: Uncertain

Location Described: $\quad$ Mount Hamilton, Santa Clara Co.

Report 1: $\quad$ Townley and Allen (1939), p. 145

"[Rossi-Forel Intensity] II at Mount Hamilton"

MMI for this location: Uncertain

\section{Location Described: $\quad$ Palo Alto, Santa Clara Co.}

Report 1: $\quad$ Daily Palo Alto Times, 5 Jun 1907; p. 4, c. 2

"The earth trembled at 12:27 this morning. The shock was probably the most severe that has been experienced since the day of the historic shakeup. The shock this morning lasted six seconds and was felt all along the peninsula and the shake was accompanied by a rumbling noise. No damage was done."

MMI for this location: Uncertain

\section{Location Described: $\quad$ San Jose, Santa Clara Co.}

Many newspapers outside San Jose reported the earthquake in San Jose. Some of these reports appear to be based upon one of the reports listed below, and they contain no new information. Only reports with unique information are listed below.

Report 1: $\quad$ San Jose Mercury, 5 Jun 1907; p. 1, c. 4

"SAN FRANCISCO, June 4.-An earthquake shock ... was felt here at 12:27 this morning....

"The same shock was experienced in San Jose, lasting about six seconds and of sufficient violence to send many people in lodging houses down town hustling from their beds into the street, there to gather in groups and recall past unpleasantries. No damage has been reported."

The date on this report clearly should be June 5, not June 4. Many other newspapers carried a similar report with an incorrect dateline. A few papers, including the Evening Mail of Stockton (5 June 1907; p. 1, c. 7) carried the report and corrected the date to read June 5.

Report 2: $\quad$ Evening Pajaronian (Watsonville), 5 Jun 1907; p. 1, c. 5

"San Francisco, June 5.-This city and neighboring cities bordering on the bay experienced a severe earthquake shock shortly after midnight.... No serious damage is reported. San Jose also felt the shock severely." 
TABLE 13: PRIMARY REPORTS FOR THE 5 JUN 1907, 00:27 AFTERSHOCK

Report 3: $\quad$ Townley and Allen (1939), p. 145

"Reports with no description came from ... San Jose."

This report establishes the date and time of the event as 5 Jun 1907, 00:27.

MMI for this location: IV-V (preferred: V)

\section{Location Described: $\quad$ Santa Clara, Santa Clara Co.}

Report 1: $\quad$ Townley and Allen (1939), p. 145

"severe at Santa Clara, duration six to seven seconds"

MMI for this location: Uncertain

Location Described: $\quad$ Boulder Creek, Santa Cruz Co.

Report 1: $\quad$ Townley and Allen (1939), p. 145

"Reports with no description came from ... Boulder Creek, Santa Cruz Co. ..."

MMI for this location: Uncertain

\section{Location Described: $\quad$ Peachland, Sonoma Co.}

Report 1: $\quad$ Townley and Allen (1939), p. 145

"Reports with no description came from ... Sonoma and Peachland, Sonoma Co. ..."

MMI for this location: Uncertain

Location Described: $\quad$ Sonoma, Sonoma Co.

Report 1: $\quad$ Sonoma Index-Tribune, 8 Jun 1907; p. 3, c. 1

"There was quite a heavy shock on Wednesday morning, at 12:20...."

Report 2: $\quad$ Townley and Allen (1939), p. 145

"Reports with no description came from ... Sonoma and Peachland, Sonoma Co. ..."

MMI for this location: III?

\section{Location Described: Jamestown, Tuolumne Co.}

Report 1: $\quad$ Mother Lode Magnet (Jamestown), 5 Jun 1907; p. 3, c. 5

"There was a lively shake up by el temblor about San Francisco bay at shortly past midnight last night.... The shock was distinctly felt throughout Tuolumne county."

MMI for this location: III ? 


\section{TABLE 14: PRIMARY REPORTS FOR THE 8 AUG 1907 AFTERSHOCKS at $04: 44$ and 06:05}

\section{SEE CORRESPONDING FIGURE 11}

On the early morning of 8 Aug 1907, two moderate earthquakes (along with several smaller ones) occurred in the Humboldt County vicinity. Based on the majority of the descriptions, the two larger earthquakes seem to be similar, although three reports identify contrasts between the two: according to the Humboldt Standard, "the second was the heavier" in Eureka, and according to two reports in the Humboldt Times, the first one was longer in Eureka, and the hardest was at about 5:00 in Upper Mattole. In the table below (and in the accompanying map), we assume that the two events were similar in size and location, although the first event may have been somewhat closer to Upper Mattole, and the second event may have been somewhat closer to Eureka.

Location Described: $\quad$ Arcata, Humboldt Co.

Report 1: $\quad$ Humboldt Times, 13 Aug 1907; p. 2, c. 1-2

"... Thursday morning two light [earthquake shocks] were felt...."

MMI for this location: Uncertain

Location Described: $\quad$ Blocksburg, Humboldt Co.

Report 1: $\quad$ Humboldt Standard, 10 Aug 1907; p. 7, c. 7

“Blocksburg, August 8-... Today about 4:45 a. m. we were treated to a decided jolt, and at 6:15 a. m we had a sharp movement north and south...."

MMI for this location: Uncertain

Location Described: $\quad$ Blue Lake, Humboldt Co.

Report 1: $\quad$ Humboldt Times, 11 Aug 1907; p. 8, c. 1

"BLUE LAKE, August 10.-Quite a heavy earthquake was felt here early Thursday morning."

MMI for this location: Uncertain

Location Described: $\quad$ Eureka, Humboldt Co.

Report 1: $\quad$ Humboldt Standard, 8 Aug 1907; p. 1, c. 3

"Two light earthquake shocks were felt this morning, the first at 4:39 o'clock and the second about 6 o'clock. The vibrations were from north to south and each lasted about six seconds. The second was the heavier but neither did any damage."

Report 2: $\quad$ Humboldt Times, 9 Aug 1907; p. 3, c. 1

“Two very light earthquake shocks were felt yesterday morning, the first occurring at 4:44 o' clock and the second at 6:05 o'clock. The vibrations came from a southerly to northerly direction and lasted during the first shock six seconds. The second shock lasted about three seconds...."

Report 3: $\quad$ Townley and Allen (1939), p. 145

“1907 August 8. 4:44 a.m. and 6:05 a.m. At Eureka: 'very light, duration about six seconds, neither maximum nor minimum intensity, only steady shaking of the earth.'"

This compilation of reports is attributed to the U.S. Weather Bureau (Form 1009). It is not clear whether the descriptions refer to the 04:44 event, the 06:05 event, or both.

MMI for this location: IV ? 


\section{TABLE 14: PRIMARY REPORTS FOR THE 8 AUG 1907 AFTERSHOCKS}

at 04:44 and 06:05

\section{Location Described: $\quad$ Falk, Humboldt Co.}

Report 1: $\quad$ Humboldt Standard, 12 Aug 1907; p. 3, c. 1

"Falk, August 8-Two light earthquake shocks were felt here this morning, the first about 4:30 and the second at 6 o'clock. No damage was done."

\section{MMI for this location: Uncertain}

\section{Location Described: $\quad$ Ferndale, Humboldt Co.}

Report 1: $\quad$ Humboldt Times, 9 Aug 1907; p. 3, c. 1

“... At Ferndale three shocks were felt one at 4:45 o'clock another at 5:15 and the third at 6:10 o'clock. The shocks were of but short duration and did no damage to the valley town."

Report 2: $\quad$ Humboldt Standard, 9 Aug 1907; p. 7, c. 1-2

"Ferndale, August 8-... Our people were awakened in the early hours this morning by a couple of slight shocks of earthquake...."

MMI for this location: IV

\section{Location Described: Garberville, Humboldt Co.}

Report 1: $\quad$ Humboldt Standard, 13 Aug 1907; p. 7, c. 4

"Garberville, Aug. 9.-.... Did you feel the earthquake? was the first question asked yesterday morning, when a couple met on the street, and it was not only one but two good sized quakes we were treated to, the first occurring at 4:55 o' clock in the morning, and the second a few moments after 6 o'clock."

Report 2: $\quad$ Humboldt Times, 14 Aug 1907; p. 6, c. 2-3

“GARBERVILLE, Aug. 11-... Thursday morning we were shaken up twice before six o'clock....”

MMI for this location: IV ?

\section{Location Described: Grizzly Bluff, Humboldt Co.}

Report 1: $\quad$ Humboldt Times, 10 Aug 1907; p. 2, c. 3

"GRIZZLY BLUFF, Aug. 9.-.... [Thursday] morning ... we experienced two decided shocks within about an hour of each other."

MMI for this location: IV?

\section{Location Described: $\quad$ Pepperwood, Humboldt Co.}

Report 1: $\quad$ Humboldt Standard, 10 Aug 1907; p. 7, c. 7

"Pepperwood, Aug. 8-... Two heavy earthquakes were felt this morning but no damage was done, only a few things were knocked down in Young's store. One was at 5:15 and the other at 6:05 a. m."

\section{MMI for this location: $\quad$ V}




\section{TABLE 14: PRIMARY REPORTS FOR THE 8 AUG 1907 AFTERSHOCKS}

at 04:44 and 06:05

\section{Location Described: $\quad$ Upper Mattole, Humboldt Co.}

Report 1: $\quad$ Humboldt Standard, 12 Aug 1907; p. 3, c. 4

"Upper Mattole, August 8-There were two heavy shocks of earthquake at this place this morning. The first about 4:45 and the second about 6 a. $\mathrm{m}$. They were both lively shakes and caused some people to run for open ground. No damage was done."

Report 2: $\quad$ Humboldt Times, 13 Aug 1907; p. 2, c. 4

“UPPER MATTOLE, Aug. 9.-Several sharp shocks of earthquake were felt here yesterday morning, the hardest being about 5 o'clock."

Report 3: $\quad$ Townley and Allen (1939), p. 145

“1907 August 8. 4:44 a.m. and 6:05 a.m. Upper Mattole, Humboldt Co. 'Quite severe, followed by several lighter shocks during the month."

This compilation of reports is attributed to the U.S. Weather Bureau (Form 1009). It is not clear whether the descriptions refer to the 04:44 event, the 06:05 event, or both.

\section{MMI for this location: $\quad$ V}

\section{Location Described: $\quad$ Branscomb, Mendocino Co.}

Report 1: $\quad$ Townley and Allen (1939), p. 145

"1907 August 8. 4:44 a.m. and 6:05 a.m. ... felt at Branscomb, Mendocino Co."

This compilation of reports is attributed to the U.S. Weather Bureau (Form 1009).

\section{MMI for this location: Uncertain}

\section{Location Described: $\quad$ Ruth, Trinity Co.}

Report 1: $\quad$ Humboldt Standard, 27 Aug 1907; p. 7, c. 7

"Ruth, Trinity Co., August 23-... We know that Mother Earth is very uneasy for the temblors of the 9th, 11th, and 12th insts. were quite hard, but the one on the 18th at 3:20 p. m. was the most severe...."

The reported date of this event (9 Aug) is probably incorrect, as it is described here as quite hard, but no other locality reported an event on that date; it is probably the 8 Aug event.

\section{MMI for this location: Uncertain [may have been a different event]}


TABLE 15: PRIMARY REPORTS FOR THE 11 AUG 1907, 04:19 AFTERSHOCK

\section{SEE CORRESPONDING FIGURE 12}

\section{Location Described: $\quad$ Chico, Butte Co.}

Report 1: $\quad$ The Searchlight (Redding), 13 Aug 1907; p. 1, c. 3-4

"CHICO, August 12.--An earthquake was distinctly felt in Chico at 4:30 or a little later yesterday morning. Many people were awakened by the shock and their tales agree with those few late retirers who were still up as to the time and duration of the quake. It lasted something less than a quarter of a minute. No damage."

Report 2: $\quad$ Chico Record, 13 Aug 1907; p. 5, c. 1

"A slight earthquake shock was felt in this city.... The tremor seemed to extend between Redding and Sacramento. No damage was done."

MMI for this location: IV

Location Described: $\quad$ Oroville, Butte Co.

Report 1: $\quad$ Oroville Daily Register, 12 Aug 1907; p. 1, c. 5

"A slight earthquake shock is reported to have been felt...."

MMI for this location: III?

\section{Location Described: Colusa, Colusa Co.}

Report 1: $\quad$ Daily Colusa Sun, 13 Aug 1907; p. 4, c. 5

"It is sleepy time at 4 a. m. That is the reason the light shake last Sunday morning was not heard from in all quarters. No one waked up, no damage done."

MMI for this location: $\quad$ Not Felt

\section{Location Described: $\quad$ Crescent City, Del Norte Co.}

Report 1: $\quad$ Del Norte Record, 17 Aug 1907; p. 3, c. 1

"Quite a heavy earthquake was felt in Humboldt county last Sunday morning, at an early hour. Del Norter's [sic] felt no quake so far as heard from."

\section{MMI for this location: $\quad$ Not Felt}

\section{Location Described: $\quad$ Willows, Glenn Co.}

Report 1: $\quad$ Glenn Transcript, 14 Aug 1907; p. 3, c. 2

"We had an earthquake here ... but it was so light that but few people knew that we had such a visitor."

Report 2: $\quad$ Willows Review, 16 Aug 1907; p. 3, c. 2

"A slight earthquake shock was felt here.... It lasted for about two seconds but no damage was done."

Report 3: $\quad$ Townley and Allen (1939), p. 146

“This shock was ... reported from ... Willows, Glenn Co. ..."

This report is credited to U.S. Weather Bureau Form 1009.

MMI for this location: III 
TABLE 15: PRIMARY REPORTS FOR THE 11 AUG 1907, 04:19 AFTERSHOCK

\section{Location Described: $\quad$ Arcata, Humboldt Co.}

Report 1: $\quad$ Humboldt Times, 13 Aug 1907; p. 2, c. 1-2

"... two [earthquake shocks], a quite hard one and one light one, were felt early in the morning."

MMI for this location: Uncertain

Location Described: Blocksburg, Humboldt Co.

Report 1: $\quad$ Humboldt Times, 13 Aug 1907; p. 7, c. 6

"BLOCKSBURG, Aug. 11.-The people of our little burg were awakened from their slumbers by quite a severe shock of earthquake.... The shock was heavy enough to stop clocks, but otherwise no damage was done."

Report 2: $\quad$ Humboldt Standard, 13 Aug 1907; p. 7, c. 7

"Blocksburg, Aug. 11.-At 4:25 a. m. we had quite a shake up, at first gentle and then severe, stopping clocks, etc., etc., and accompanied by a roaring noise. Except for that of the 19th [sic] of April, 1906, it was the most pronounced in 32 years."

Report 3: $\quad$ Townley and Allen (1939), p. 146

"At Blocksburg and Covelo clocks stopped."

This report is credited to A. H. Bell's manuscript list of earthquakes at Eureka, Calif., 1887 to 1913.

MMI for this location: V ?

\section{Location Described: $\quad$ Briceland, Humboldt Co.}

Report 1: $\quad$ Humboldt Times, 15 Aug 1907; p. 8, c. 4-6

"BRICELAND, Aug. 11... A very heavy earthquake shook things up here at an early hour this morning. It lasted much longer than the two which occurred earlier in the week."

MMI for this location: Uncertain

\section{Location Described: $\quad$ Cape Mendocino, Humboldt Co.}

Report 1: $\quad$ Lighthouse Log for Cape Mendocino Lighthouse, 11 Aug 1907

"a light earthquake shock 4.15 a.m."

MMI for this location: Uncertain

\section{Location Described: $\quad$ Eureka, Humboldt Co.}

Report 1: $\quad$ Humboldt Standard, 12 Aug 1907; p. 4, c. 7

"Early morning shakes are getting to be a feature of the terrestrial phenomena in these parts of late. Yesterday morning [11 Aug] and again this morning [12 Aug] the people were treated to a rattling of windows and doors. The quake of yesterday morning was quite prolonged but as far as can be learned did no damage in this city...."

Report 2: $\quad$ Humboldt Times, 14 Aug 1907; p. 8, c. 4

"A light earthquake shock was felt Sunday morning at 4:19 o'clock in this city and for some distance down the coast. The report of Observer Bell of the local Weather Bureau shows that the shock lasted 15 seconds with the vibrations running from southeast to northwest...."

Report 3: $\quad$ Townley and Allen (1939), p. 146

"Quite heavy; southeast to northwest; duration about fifteen seconds; steady shaking." 
TABLE 15: PRIMARY REPORTS FOR THE 11 AUG 1907, 04:19 AFTERSHOCK

This report is credited to A. H. Bell's manuscript list of earthquakes at Eureka, Calif., 1887 to 1913.

MMI for this location: $\quad$ IV

Location Described: $\quad$ Falk, Humboldt Co.

Report 1: $\quad$ Humboldt Standard, 16 Aug 1907; p. 7, c. 5

“... Another earthquake shock was felt ... but no damage was done."

MMI for this location: Uncertain

Location Described: $\quad$ Ferndale, Humboldt Co.

Report 1: $\quad$ Humboldt Standard, 12 Aug 1907; p. 4, c. 7

"Early morning shakes are getting to be a feature of the terrestrial phenomena in these parts of late. Yesterday morning [11 Aug] and again this morning [12 Aug] the people [of Eureka] were treated to a rattling of windows and doors. The quake of yesterday morning was quite prolonged but as far as can be learned did no damage in this city. At Ferndale it was a little sharper and one of the results was the cracking of the plaster in the Ferndale Bank where the vault is built into a wall.

Report 2: $\quad$ Humboldt Standard, 13 Aug 1907; p. 7, c. 6

"Ferndale, August 12-... Quite a heavy shock of earthquake was felt yesterday morning and another this morning, followed each morning by two lighter ones. No damage reported. There was no sudden jerk such as is usually felt."

MMI for this location: $\quad$ V

\section{Location Described: $\quad$ Fortuna, Humboldt Co.}

Report 1: $\quad$ Townley and Allen (1939), p. 146

"This shock was felt at Fortuna, where plaster in bank building became loosened somewhat near safe."

This report is credited to A. H. Bell's manuscript list of earthquakes at Eureka, Calif., 1887 to 1913.

MMI for this location: $\quad$ V

\section{Location Described: Garberville, Humboldt Co.}

Report 1: $\quad$ Humboldt Times, 14 Aug 1907; p. 6, c. 2-3

"GARBERVILLE, Aug. 11-... a seismic disturbance nearly equal to the long-to-be-remembered one of April 18th last year disturbed the town, the shock lasting some seconds, the rocking motion being perceptible for some time after the first shock...."

MMI for this location: $\quad$ Uncertain

\section{Location Described: $\quad$ near Reed Mountain (?), Humboldt Co.}

Report 1: $\quad$ Humboldt Standard, 16 Aug 1907; p. 7, c. 5

“Garberville, August 13-... Mr. and Mrs. Joe Caton returned yesterday from their hunting trip above the Reed ranges. The morning of the earthquake they were camped on a high ridge and knew nothing of the disturbance at the time."

Too much significance should not be placed in the fact that this event was not felt by two particular people who were outdoors and possibly moving about at the time.

MMI for this location: Uncertain 
TABLE 15: PRIMARY REPORTS FOR THE 11 AUG 1907, 04:19 AFTERSHOCK

\section{Location Described: $\quad$ Rocky Glen (?), Humboldt Co.}

Report 1: $\quad$ Humboldt Standard, 16 Aug 1907; p. 7, c. 5

"Garberville, August 13-.... Mrs. J. E. Sinclair of Rocky Glenn [sic] and daughter Emma were in town today shopping, and inquiring how we fared during the earthquake. The shocks were about the same degree at Rocky Glenn [sic] as here."

MMI for this location: Uncertain

Location Described: $\quad$ Ryan Slough, Humboldt Co.

Report 1: $\quad$ Humboldt Standard, 14 Aug 1907; p. 3, c. 5

"One result of the earthquake shock of early Sunday morning, not hitherto reported, was the throwing down of the smokestack at the McKay \& Co.'s shingle mill on Ryan Slough...."

MMI for this location: Uncertain

Location Described: $\quad$ Branscomb, Mendocino Co.

Report 1: $\quad$ Townley and Allen (1939), p. 146

"This shock was ... reported from Branscomb, Mendocino Co. ..."

This report is credited to U.S. Weather Bureau Form 1009.

MMI for this location: Uncertain

\section{Location Described: Covelo, Mendocino Co.}

Report 1: $\quad$ Humboldt Times, 14 Aug 1907; p. 8, c. 4

"... At Covelo the shock was great enough to stop several of the clocks."

Report 2: $\quad$ Townley and Allen (1939), p. 146

"At Blocksburg and Covelo clocks stopped."

This report is credited to A. H. Bell's manuscript list of earthquakes at Eureka, Calif., 1887 to 1913.

MMI for this location: V ?

\section{Location Described: $\quad$ Fort Bragg, Mendocino Co.}

Report 1: $\quad$ Humboldt Times, 14 Aug 1907; p. 8, c. 4

"The shock was felt at ... Fort Bragg...."

Report 2: $\quad$ Townley and Allen (1939), p. 146

"... felt at Fort Bragg and Willits, Mendocino Co."

This report is credited to A. H. Bell's manuscript list of earthquakes at Eureka, Calif., 1887 to 1913.

MMI for this location: Uncertain

Location Described: $\quad$ Laytonville, Mendocino Co.

Report 1: $\quad$ Humboldt Times, 14 Aug 1907; p. 8, c. 4

"The shock was felt at Laytonville...." 
TABLE 15: PRIMARY REPORTS FOR THE 11 AUG 1907, 04:19 AFTERSHOCK

Report 2: $\quad$ Townley and Allen (1939), p. 146

"Laytonville, Mendocino Co., operator reported vibrations from east to west...."

This report is credited to A. H. Bell's manuscript list of earthquakes at Eureka, Calif., 1887 to 1913.

MMI for this location: Uncertain

\section{Location Described: $\quad$ Mendocino, Mendocino Co.}

Report 1: $\quad$ Mendocino Beacon, 17 Aug 1907; p. 1, c. 1-2

"A sharp shock of earthquake startled some of our people from their slumbers last Sunday morning about 3:40 o'clock. No damage was done, unless it was to some of the more sensitive nerves. In fact the majority of the people did not feel the temblor."

Report 2: $\quad$ Mendocino Beacon, 17 Aug 1907; p. 5, c. 2

"A slight seismic disturbance awakened the people of Mendocino from sound slumber last Sunday morning at 4:15. It was of short duration and was not repeated."

MMI for this location: $\quad$ IV

\section{Location Described: Willits, Mendocino Co.}

Report 1: $\quad$ Humboldt Times, 14 Aug 1907; p. 8, c. 4

"The shock was felt at ... Willits...."

Report 2: $\quad$ Townley and Allen (1939), p. 146

“... felt at Fort Bragg and Willits, Mendocino Co."

This report is credited to A. H. Bell's manuscript list of earthquakes at Eureka, Calif., 1887 to 1913.

MMI for this location: Uncertain

\section{Location Described: $\quad$ French Corral, Nevada Co.}

Report 1: $\quad$ Daily Morning Union (Grass Valley and Nevada City), 13 Aug 1907; p. 6, c. 3

“... Persons coming in from French Corral and North San Juan yesterday report that the Sunday morning early tremor was felt at those camps...."

MMI for this location: Uncertain

\section{Location Described: $\quad$ Grass Valley, Nevada Co.}

Report 1: $\quad$ Sacramento Union, 12 Aug 1907; p. 6, c. 3

"GRASS VALLEY, Aug. 11.-Three distinct shocks of earthquake were felt here this morning at about 3:50 o'clock. Each shock was of about two seconds' duration, and the vibration was from west to east. The disturbance was heavy enough to awaken and frighten a number of people, but no damage has been reported. Some persons report hearing a peculiar rumbling noise preceding and during the continuance of the quakes."

MMI for this location: IV

\section{Location Described: $\quad$ Nevada City, Nevada Co.}

Report 1: Daily Morning Union (Grass Valley and Nevada City), 13 Aug 1907; p. 6, c. 3

"A seismic tremor passed through this part of the country Sunday morning about 4 o'clock, sufficiently strong to arouse many persons from their slumbers...." 
TABLE 15: PRIMARY REPORTS FOR THE 11 AUG 1907, 04:19 AFTERSHOCK

Report 2: $\quad$ Townley and Allen (1939), p. 146

“This shock was ... reported from ... Nevada City, Nevada Co. ..."

This report is credited to U.S. Weather Bureau Form 1009.

MMI for this location: IV

\section{Location Described: $\quad$ North San Juan, Nevada Co.}

Report 1: $\quad$ Daily Morning Union (Grass Valley and Nevada City), 13 Aug 1907; p. 6, c. 3

“... Persons coming in from French Corral and North San Juan yesterday report that the Sunday morning early tremor was felt at those camps...."

MMI for this location: Uncertain

\section{Location Described: $\quad$ Shady Creek gravel mine, Nevada Co.}

Report 1: $\quad$ Daily Morning Union (Grass Valley and Nevada City), 13 Aug 1907; p. 6, c. 3

“... Superintendent Graham of the Shady Creek gravel mine was in Nevada City yesterday and said the trembling was experienced in his camp...."

MMI for this location: Uncertain

\section{Location Described: $\quad$ La Porte, Plumas Co.}

Report 1: $\quad$ Townley and Allen (1939), p. 146

"This shock was ... reported from ... La Porte, Plumas Co. ..."

This report is credited to U.S. Weather Bureau Form 1009.

\section{MMI for this location: Uncertain}

\section{Location Described: $\quad$ San Francisco, San Francisco Co.}

Report 1: $\quad$ Humboldt Standard, 12 Aug 1907; p. 4, c. 7

"... Report from San Francisco this morning was to the effect that it was scarcely noticeable there."

From the context, it is not completely clear whether the report from San Francisco refers to the event on 11 Aug or to another event (on 12 Aug) which was also mentioned in the article.

Report 2: $\quad$ Humboldt Times, 13 Aug 1907; p.3, c. 1

"No great earthquake shock was felt in San Francisco Sunday morning as was reported on the streets here yesterday. People incoming by the steamers from San Francisco yesterday stated that the shock was very light and nothing more than usual, for tremors are still a common occurrence in the metropolis."

MMI for this location: II

\section{Location Described: $\quad$ Baird, Shasta Co.}

Report 1: $\quad$ The Searchlight (Redding), 13 Aug 1907; p. 1, c. 3-4

“BAIRD, August 12.-A sharp earthquake shock was felt here at 4:30 yesterday morning. All persons in camp along the [McCloud] river felt it, but the severest shock was undoubtedly at the McCloud fishery. Captain Lambson, superintendent of the fishery, awakened by the earthquake, looked at his watch immediately. It was 4:30 according to his time. It was a distant and sharp shock at first, dying away in gentle quivers whose duration was from eight to ten seconds." 
TABLE 15: PRIMARY REPORTS FOR THE 11 AUG 1907, 04:19 AFTERSHOCK

Report 2: $\quad$ The Searchlight (Redding), 13 Aug 1907; p. 1, c. 3-4

"Sunday's earthquake was felt generally all over the Sacramento Valley, but seems to have been most pronounced at the McCloud fishery [on McCloud River, near Baird (?)]. Adolph Dobrowsky, who was camping out near the fishery, was awake when the shock occurred and noted the time and duration. It was 4:30 and lasted about ten seconds."

MMI for this location: $\quad$ V

Location Described: $\quad$ Redding, Shasta Co.

Report 1: $\quad$ The Searchlight (Redding), 13 Aug 1907; p. 1, c. 3-4

"In Redding many were awakened from their early morning's sleep. In private houses and in allnight restaurants the rattling of dishes and cooking utensils proclaimed the sharpness of the seismic disturbance. It was noticeable on the road by the drivers of a few vehicles.

"The shock was well defined, starting at about 4:30 and lasting not more than ten seconds. No reports have been received of the breaking of even the lightest articles on bureaus and mantels, however, and most healthy sleepers slept right through the shock."

MMI for this location: $\quad$ IV

Location Described: Sisson, Siskiyou Co. (now the town of Mt. Shasta, CA)

Report 1: $\quad$ The Searchlight (Redding), 13 Aug 1907; p. 1, c. 3-4

"SISSON, August 12.-This place was disturbed yesterday morning by a temblor which startled those who felt it and frightened a few, though the earthquake was slight and lasted but a few seconds. It came at 4:30 a. m."

MMI for this location: IV

\section{Location Described: Corning, Tehama Co.}

Report 1: Corning Observer, 15 Aug 1907; p. 1, c. 2

"About four o'clock Sunday morning those of us who were awake were startled by a short series of earthquake shocks. The vibrations seemed to be from east to west and the doors and windows rattled for about thirty seconds. Aside from curiosity and a slight alarm among a few the shock did not create much comment...."

\section{MMI for this location: IV}

\section{Location Described: $\quad$ Red Bluff, Tehama Co.}

Report 1: $\quad$ Weekly People's Cause (Red Bluff), 17 Aug 1907; p. 8, c. 3

"A portion of Red Bluff's population was furnished with some excitement early Sunday morning that all $\mathrm{did}^{*}$ share. The reason that all did not share in the excitement was that some of the people were sleeping too soundly.

"At about 4 o'clock Sunday morning Red Bluff was visited by an earthquake that made the doors and windows of many of the houses rattle....

"No harm resulted from the earthquake, the vibrations only being of a few seconds duration."

* Compare this article with similar articles that appeared in the Courier-Free Press and the Searchlight, both of Redding. The latter two articles were presumably copied from the Daily People's Cause (the daily version of this paper, which could not be located for 1907). In the two Redding papers, the word "not" appears at the place marked by an asterisk above; in this article, however, the word "not" does not appear at that location. Based on the inconsistency, and from the context, it appears that this was an accidental typographical omission. It is inferred that the line was intended to read "... excitement early Sunday morning that all did not share." 
TABLE 15: PRIMARY REPORTS FOR THE 11 AUG 1907, 04:19 AFTERSHOCK

Report 2: $\quad$ Courier-Free Press (Redding), 13 Aug 1907; p. 7, c. 1

"RED BLUFF, Aug. $18^{*}$-A portion of Red Bluff's population was furnished with some excitement early Sunday morning that all did not share. The reason that all did not share in the excitement was that some of the people were sleeping too soundly.

“At about 4 o'clock Sunday morning Red Bluff was visited by an earthquake that made the doors and windows of many of the houses rattle....

"No harm resulted from the earthquake, the vibrations only being of a few seconds duration."

* The dateline is clearly incorrect; it should be either Aug. 12 or 13.

Report 3: $\quad$ The Searchlight (Redding), 14 Aug 1907; p. 6, c. 2

"Red Bluff was furnished with some excitement early Sunday morning in which all did not share. The reason that all did not share in the excitement was that some of the people were sleeping too soundly, says the Cause.

"At about 4 o'clock Sunday morning Red Bluff was visited by an earthquake that made the doors and windows of many of the houses rattle....

"No harm resulted from the earthquake, the vibrations only being of a few seconds duration."

MMI for this location: IV

Location Described: $\quad$ Island Mountain, Trinity Co.

Report 1: $\quad$ Humboldt Standard, 17 Aug 1907; p. 5, c. 5

“Island Mountain, Aug. 12-... Saturday morning at 4 o'clock the people of the island were awakened by a heavy earthquake."

The reported date of this event, Saturday, 10 Aug 1907, is almost certainly incorrect, as it is described here as heavy, but no other locality reported an event on this date; it is probably the 11 Aug event.

MMI for this location: Uncertain

Location Described: $\quad$ Ruth, Trinity Co.

Report 1: $\quad$ Humboldt Standard, 27 Aug 1907; p. 7, c. 7

"Ruth, Trinity Co., August 23-... We know that Mother Earth is very uneasy for the temblors of the 9th, 11th, and 12th insts. were quite hard, but the one on the 18th at 3:20 p. m. was the most severe...."

\section{MMI for this location: Uncertain}

\section{Location Described: $\quad$ Weaverville, Trinity Co.}

Report 1: Weekly Trinity Journal, 17 Aug 1907; p. 3, c. 6

"An earthquake shock was felt by a number of our citizens on Sunday morning about 4:30. No damage done."

Report 2: $\quad$ Courier-Free Press (Redding), 14 Aug 1907; p. 7, c. 3

“WEAVERVILLE, Aug. 14._.... The earthquake Sunday morning at 4:30 was plainly felt by several of our citizens."

MMI for this location: IV ? 
TABLE 15: PRIMARY REPORTS FOR THE 11 AUG 1907, 04:19 AFTERSHOCK

\section{Other Information: Instrumental Data}

Report 1: $\quad$ Townley and Allen (1939), p. 146

"This shock ... made a decided record on the seismograph at Berkeley, and seems to have registered on a number of distant seismographs, the most distant being that at Tiflis [now Tbilisi, the capital of the Republic of Georgia]."

This report is credited to the Strassburg [Strasbourg?] catalog of teleseisms recorded during 1907.

MMI for this location: $\quad$ N/A 


\section{FIGURE CAPTIONS}

\section{Figure 1}

Map of northern California showing faults (lines), the extent of the 1906 rupture of the San Andreas fault (thick line), and the 1906 epicenter (star) of Bolt (1968). Inset map shows the location of the larger map.

\section{Figure 2}

Map showing the intensity distribution for the 18 Apr 1906, 14:28 aftershock. Triangles designate locations for which there is intensity information; adjacent to each triangle is either a Roman numeral (indicating the Modified Mercalli intensity), or " $F$ " or "NF" (indicating felt or not felt, respectively, at that location). Thin lines are faults, and the thick line is the location of the 1906 rupture. Inset map shows the location of the larger map. A complete list of intensities for this event is given in Table 5.

\section{Figure 3}

Map showing the intensity distribution for the 18 Apr 1906 triggered event in the Imperial Valley. Triangles designate locations for which there is intensity information; adjacent to each triangle is either a Roman numeral (indicating the Modified Mercalli intensity), or " $F$ " or "NF" (indicating felt or not felt, respectively, at that location). Three "F" observations have been omitted from the figure for the sake of map legibility, because those points are near other observations: Heber, Silsbee, and Ballast Point. Thin lines are faults. Inset map shows the location of the larger map. A complete list of intensities for this event is given in Table 6.

\section{Figure 4}

Map showing the intensity distribution for the 19 Apr 1906 triggered event near Santa Monica Bay. Triangles designate locations for which there is intensity information; adjacent to each triangle is either a Roman numeral (indicating the Modified Mercalli intensity), or "F" or "NF" (indicating felt or not felt, respectively, at that location). Thin lines are faults. Inset map shows the location of the larger map. A complete list of intensities for this event is given in Table 7.

\section{$\underline{\text { Figure } 5}$}

Map showing the intensity distribution for the 19 Apr 1906 triggered event near Fernley, Nevada. Triangles designate locations for which there is intensity information; adjacent to each triangle is either a Roman numeral (indicating the Modified Mercalli intensity), or " $F$ " or "NF" (indicating felt or not felt, respectively, at that location). Thin lines are faults. Inset map shows the location of the larger map. A complete list of intensities for this event is given in Table 8.

\section{Figure 6}

Map showing the intensity distribution for the 23 Apr 1906 aftershock. Triangles designate locations for which there is intensity information; adjacent to each triangle is either a Roman numeral (indicating the Modified Mercalli intensity), or "F" or "NF" (indicating felt or not felt, respectively, at that location). Thin lines are faults, and the thick line is the location of the 1906 rupture. Inset map shows the location of the larger map. A complete list of intensities for this event is given in Table 9. 


\section{FIGURE CAPTIONS}

\section{Figure 7}

Map showing the intensity distribution for the 25 Apr 1906 aftershock. Triangles designate locations for which there is intensity information; adjacent to each triangle is either a Roman numeral (indicating the Modified Mercalli intensity), or "F" or "NF" (indicating felt or not felt, respectively, at that location). Two "F" observations have been omitted from the figure for the sake of map legibility, because those points are near other observations: Alameda pier and Mile Rocks. Thin lines are faults, and the thick line is the location of the 1906 rupture. Inset map shows the location of the larger map. A complete list of intensities for this event is given in Table 10.

\section{Figure 8}

Map showing the intensity distribution for the 17 May 1906 aftershock. Triangles designate locations for which there is intensity information; adjacent to each triangle is either a Roman numeral (indicating the Modified Mercalli intensity), or " $\mathrm{F}$ " or "NF" (indicating felt or not felt, respectively, at that location). Six "F" observations have been omitted from the figure for the sake of map legibility, because those points are near other observations: Alameda pier, Point Bonita, Point Piños, Mile Rocks, Yerba Buena, and Campbell. Thin lines are faults, and the thick line is the location of the 1906 rupture. Inset map shows the location of the larger map. A complete list of intensities for this event is given in Table 11.

\section{Figure 9}

Map showing the intensity distribution for the 6 Jul 1906 aftershock. Triangles designate locations for which there is intensity information; adjacent to each triangle is either a Roman numeral (indicating the Modified Mercalli intensity), or " $\mathrm{F}$ " or "NF" (indicating felt or not felt, respectively, at that location). Thin lines are faults, and the thick line is the location of the 1906 rupture. Inset map shows the location of the larger map. A complete list of intensities for this event is given in Table 12.

\section{Figure 10}

Map showing the intensity distribution for the 5 Jun 1907 aftershock. Triangles designate locations for which there is intensity information; adjacent to each triangle is either a Roman numeral (indicating the Modified Mercalli intensity), or " $\mathrm{F}$ " or "NF" (indicating felt or not felt, respectively, at that location). Nine " $F$ " observations have been omitted from the figure for the sake of map legibility, because those points are near other observations: Dimond, Mills College, Oakland, Half Moon Bay, Menlo Park, San Gregorio, Alma, Campbell, and Santa Clara. Thin lines are faults, and the thick line is the location of the 1906 rupture. Inset map shows the location of the larger map. A complete list of intensities for this event is given in Table 13.

\section{Figure 11}

Map showing the intensity distribution for the 8 Aug 1907 aftershocks, which are assumed to be similar. Triangles designate locations for which there is intensity information; adjacent to each triangle is either a Roman numeral (indicating the Modified Mercalli intensity), or "F" or "NF" (indicating felt or not felt, respectively, at that location). Thin lines are faults, and the thick line is the location of the 1906 rupture. Inset map shows the location of the larger map. A complete list of intensities for this event is given in Table 14 . 


\section{FIGURE CAPTIONS}

\section{Figure 12}

Map showing the intensity distribution for the 11 Aug 1907 aftershock. Triangles designate locations for which there is intensity information; adjacent to each triangle is either a Roman numeral (indicating the Modified Mercalli intensity), or "F" or "NF" (indicating felt or not felt, respectively, at that location). Two "F" observations have been omitted from the figure for the sake of map legibility, because those points are near other observations: Ryan Slough and Shady Creek gravel mine. Thin lines are faults, and the thick line is the location of the 1906 rupture. Inset map shows the location of the larger map. A complete list of intensities for this event is given in Table 15. 


\section{San Francisco Earthquake (Mainshock) Rupture}

Figure 1

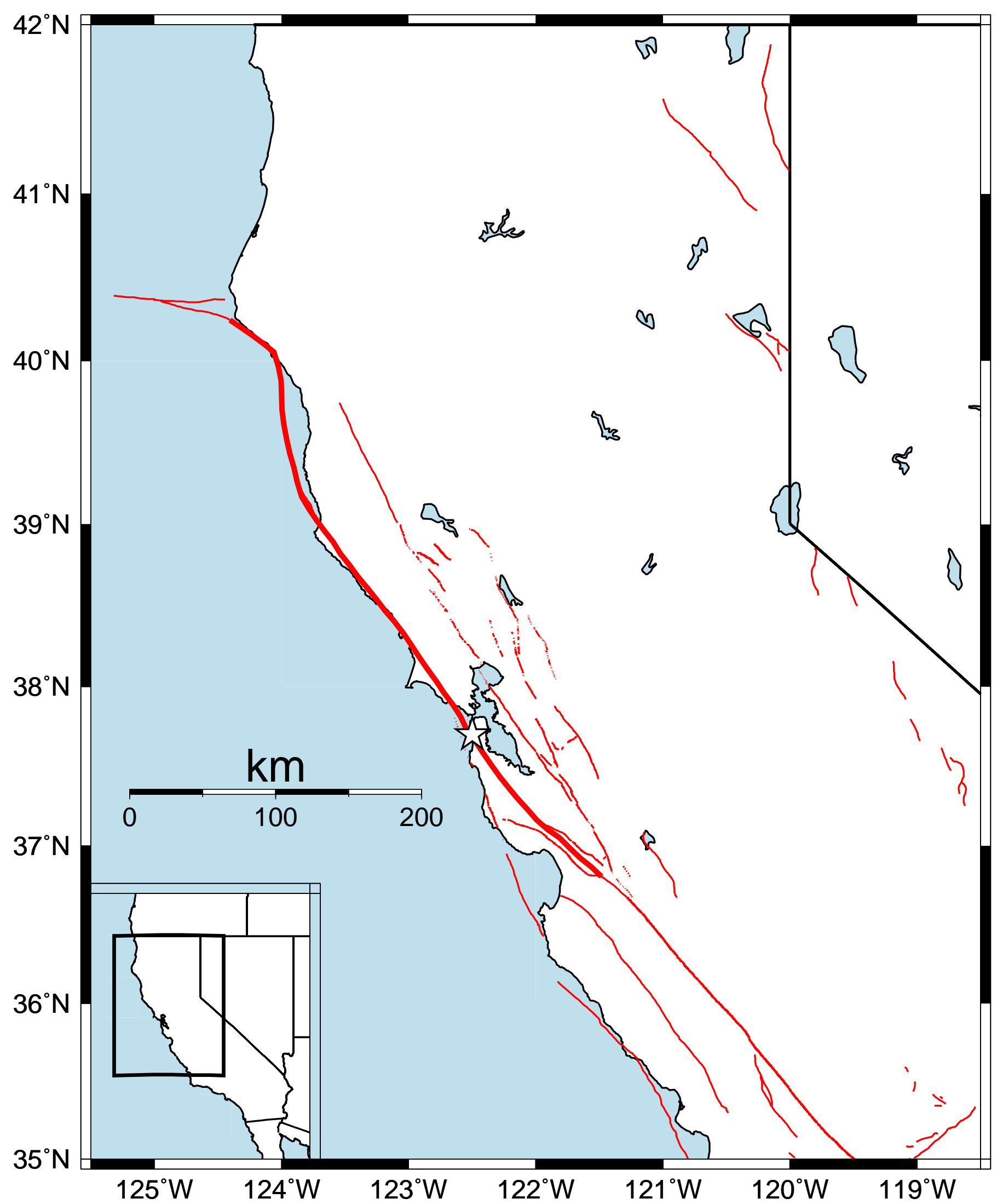




\section{Apr 1906, 14:28 Aftershock}

Figure 2

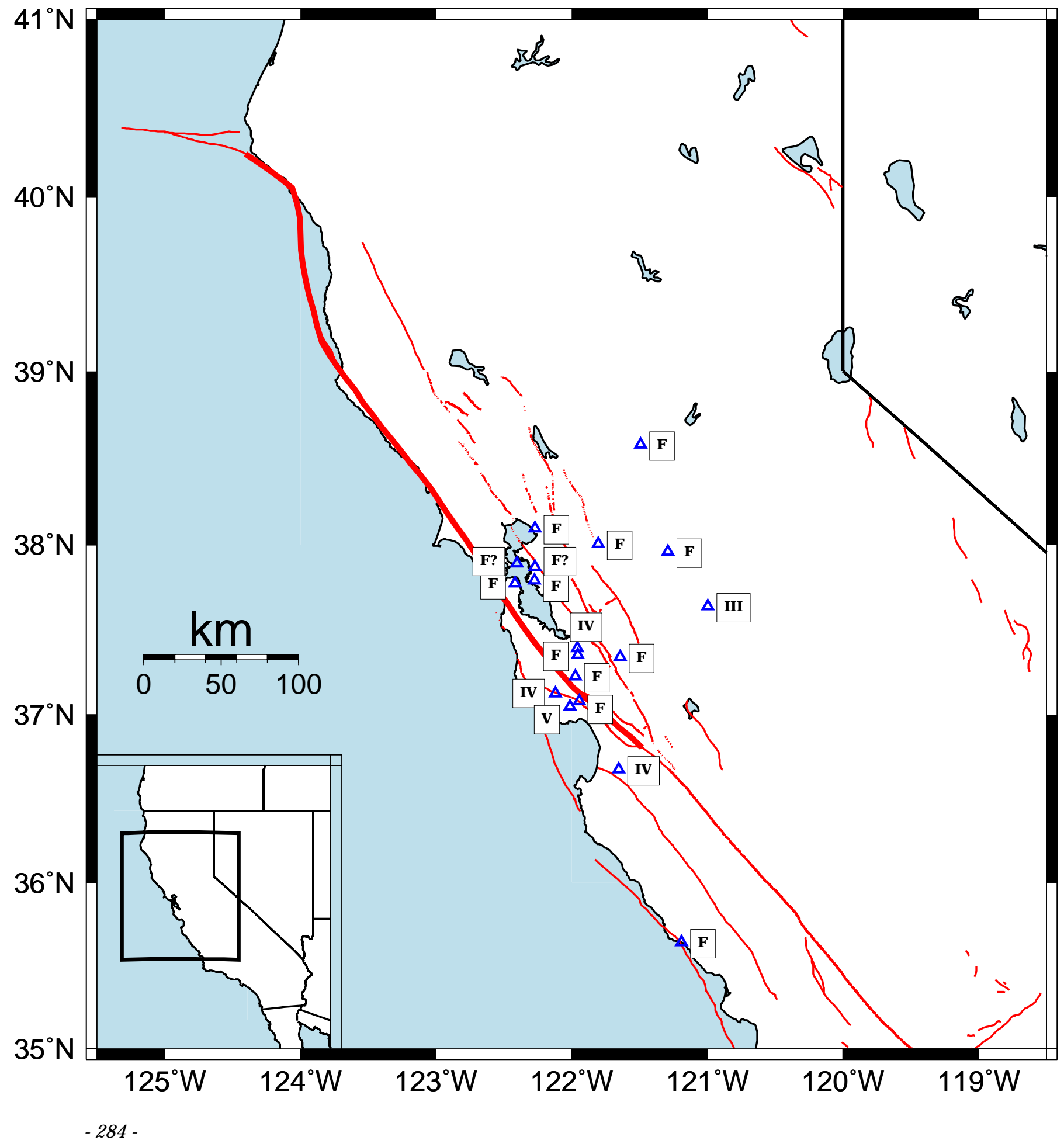




\section{Apr 1906, 16:30 I mperial Valley Triggered Event}

Figure 3

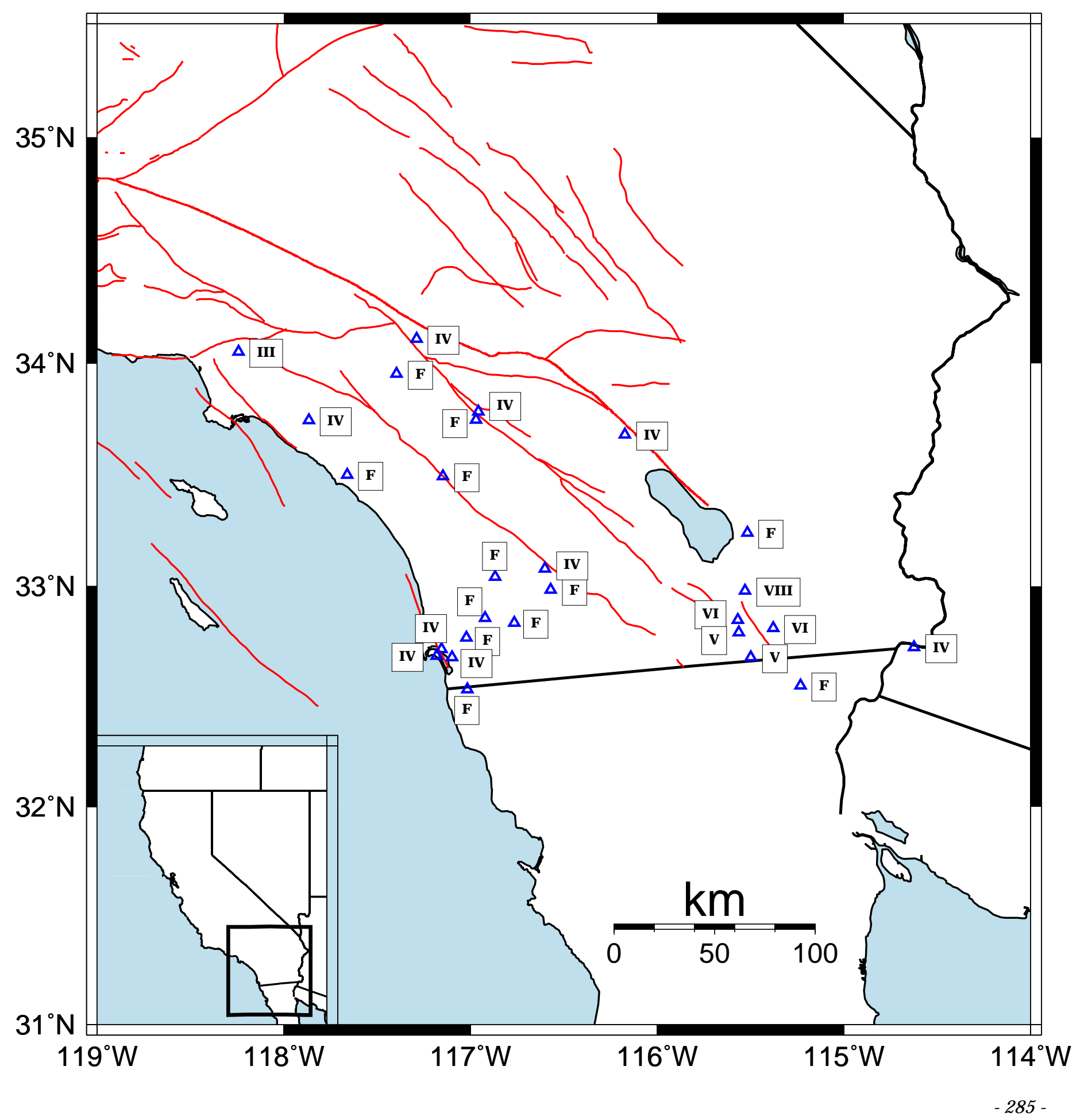


19 Apr 1906, 12:31 Santa Monica Bay Triggered Event

Figure 4

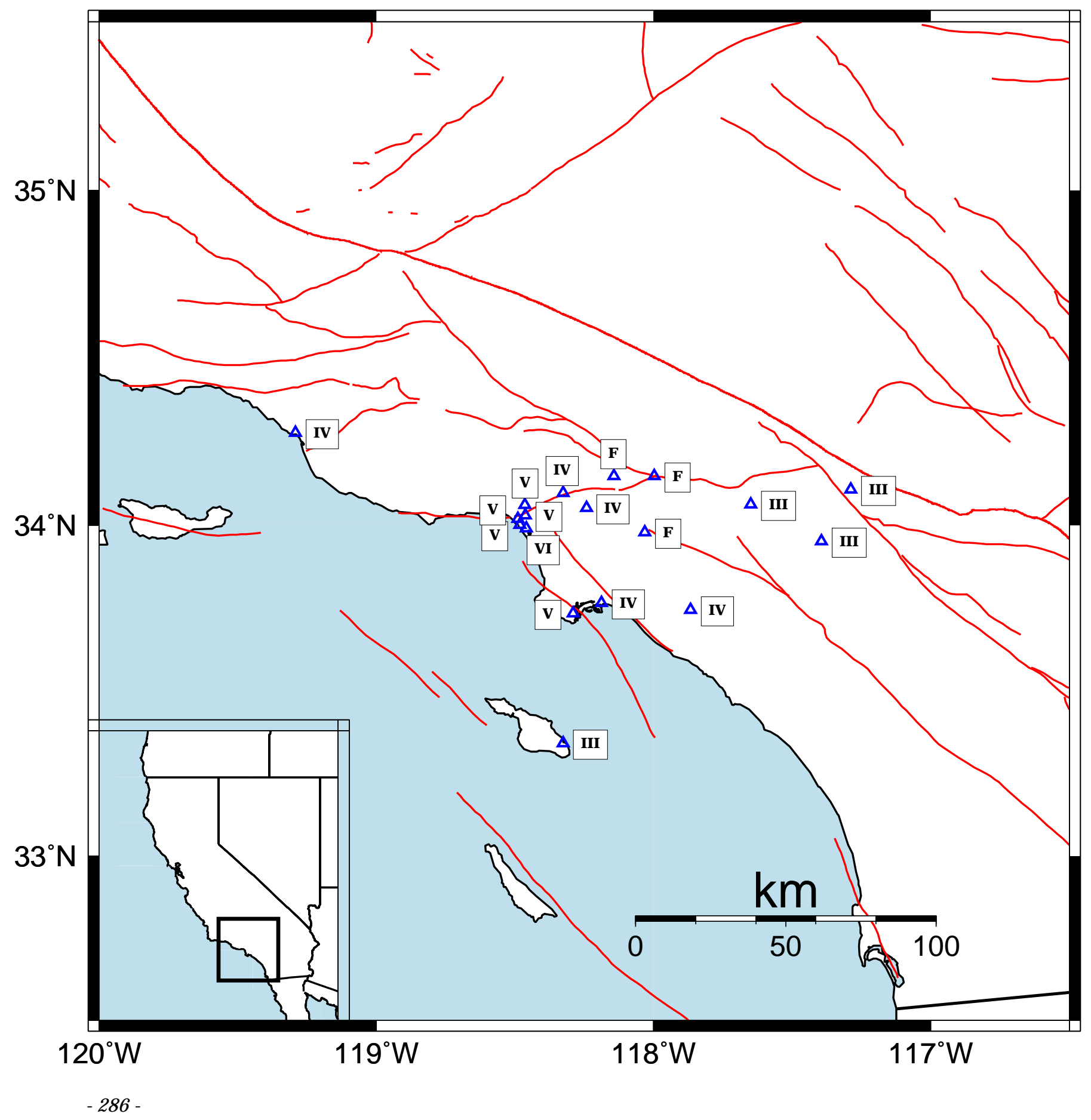




\section{Apr 1906, 20:15 Fernley, Lyon Co., NV Triggered Event}

Figure 5

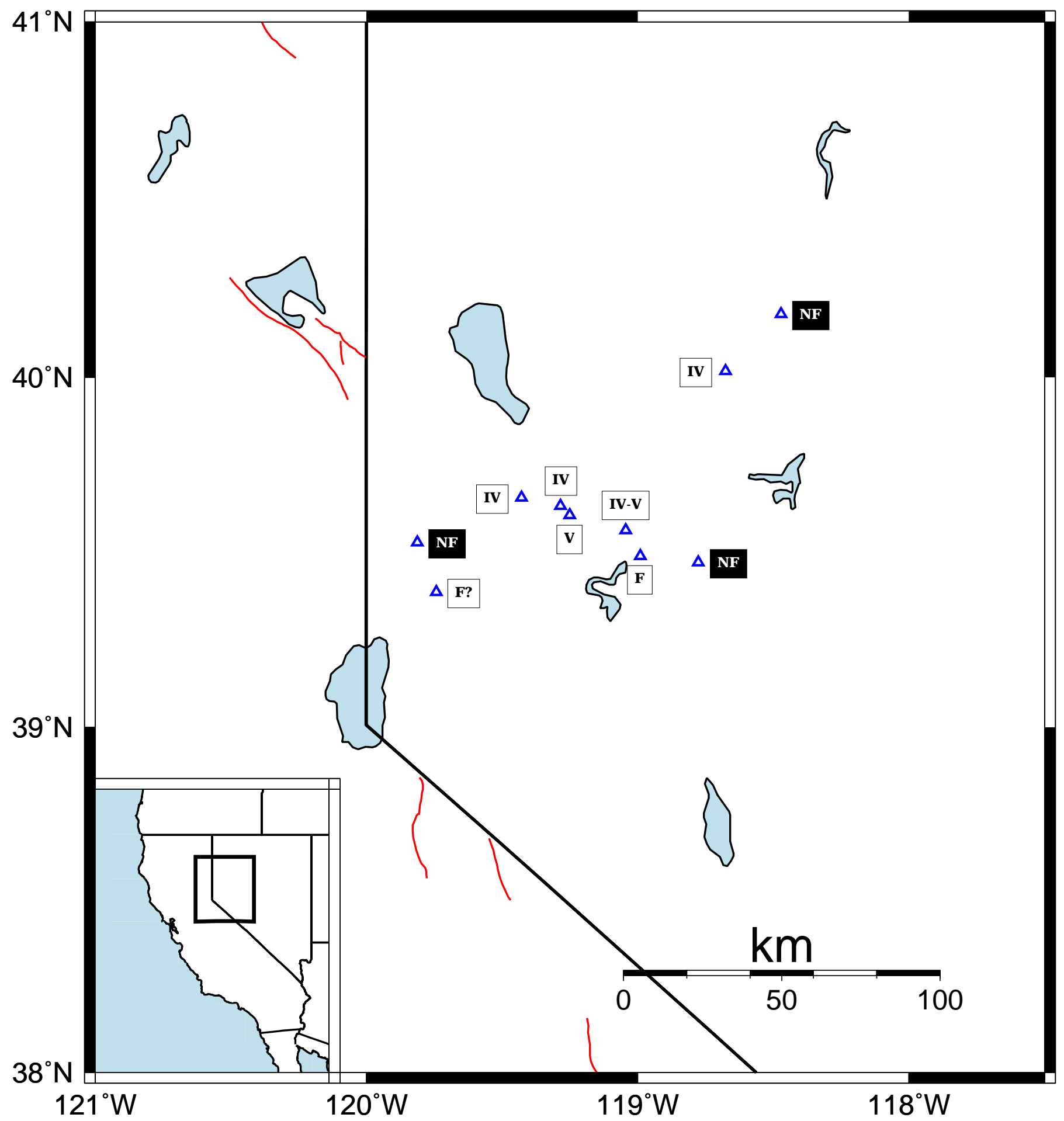




\section{Apr 1906, 01:10 Aftershock}

Figure 6

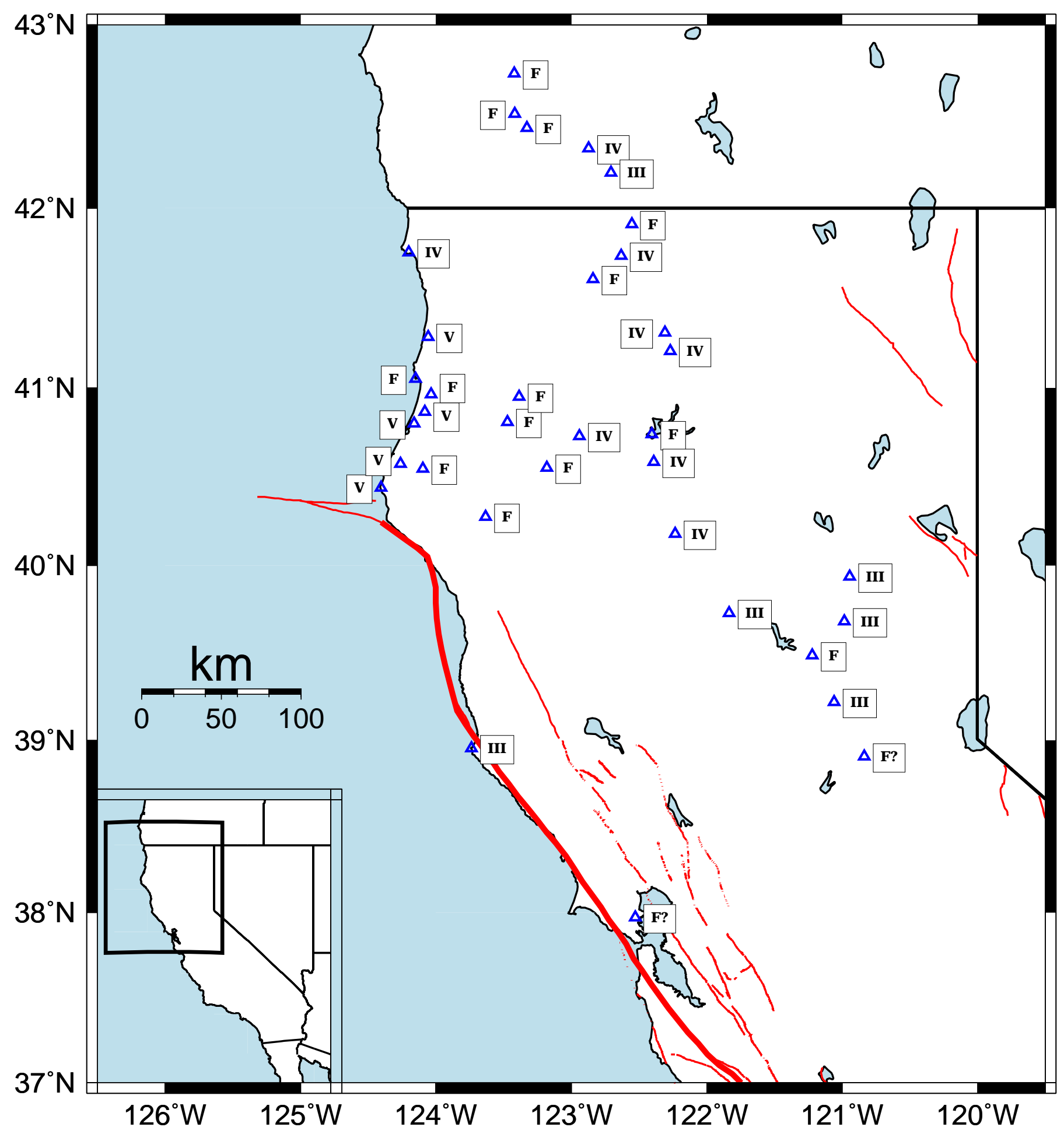


25 Apr 1906, 15:17 Aftershock

Figure 7

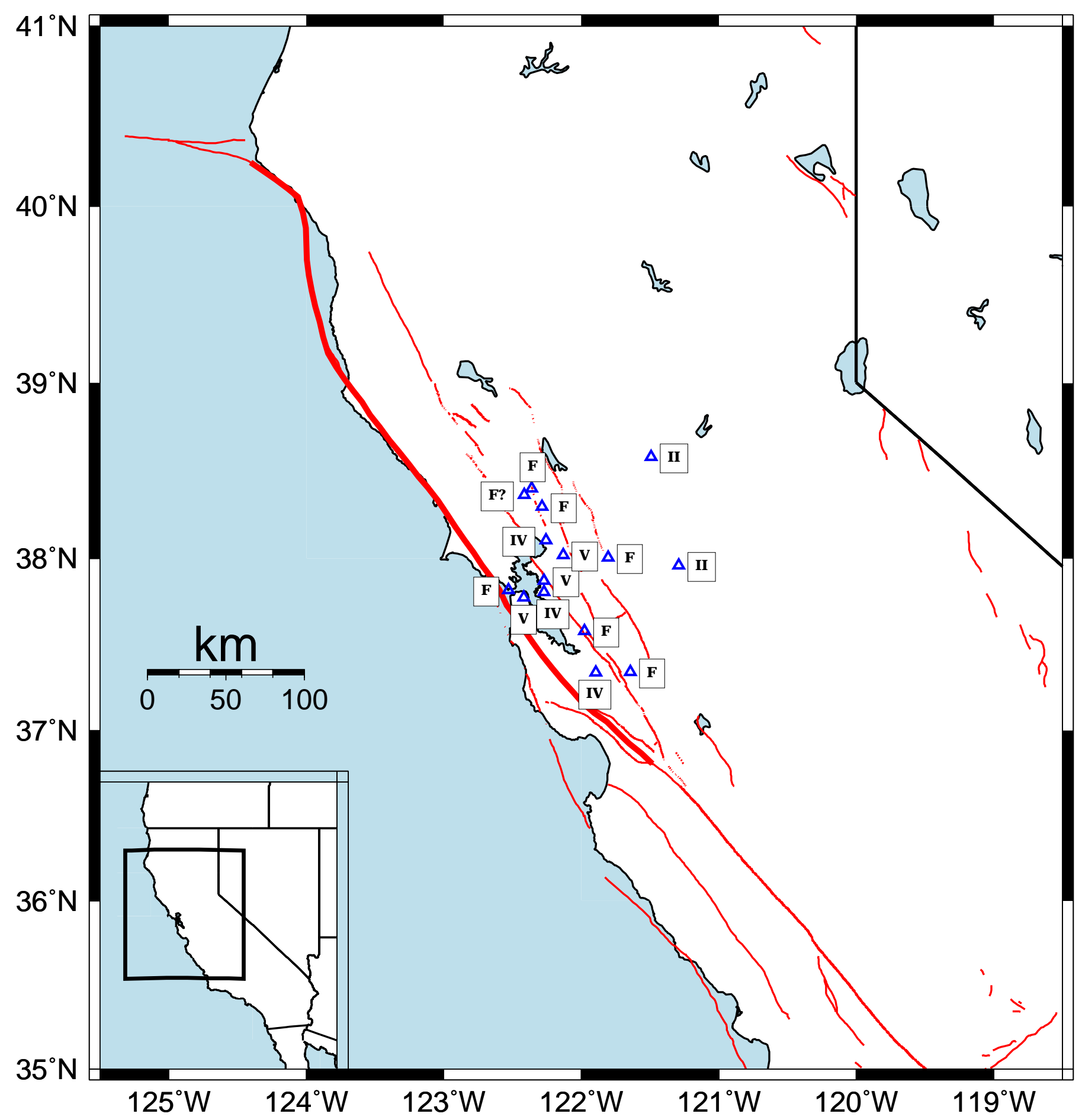


17 May 1906, 20:21 Aftershock

Figure 8

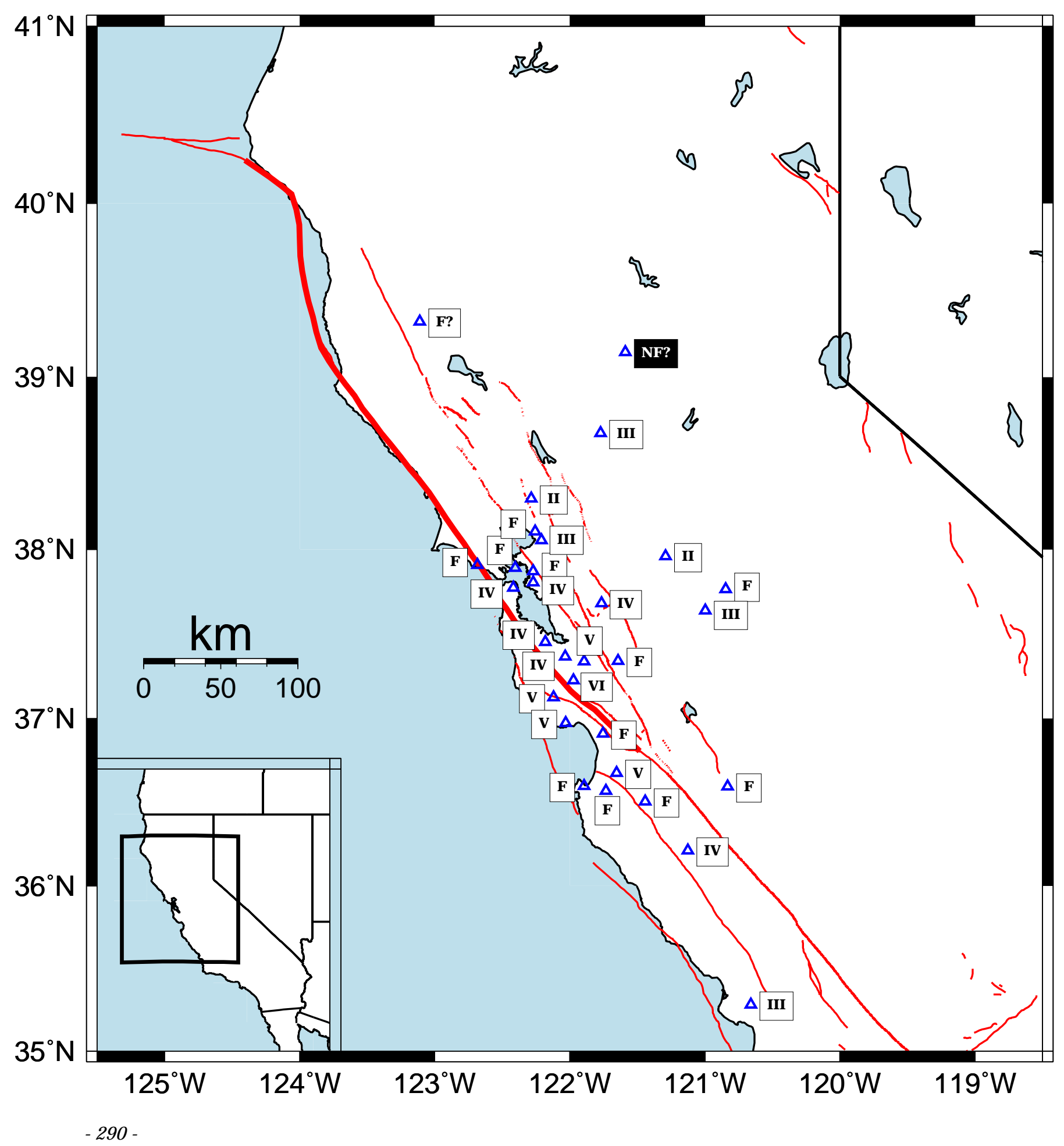




\section{J ul 1906, 22:55 Aftershock}

Figure 9

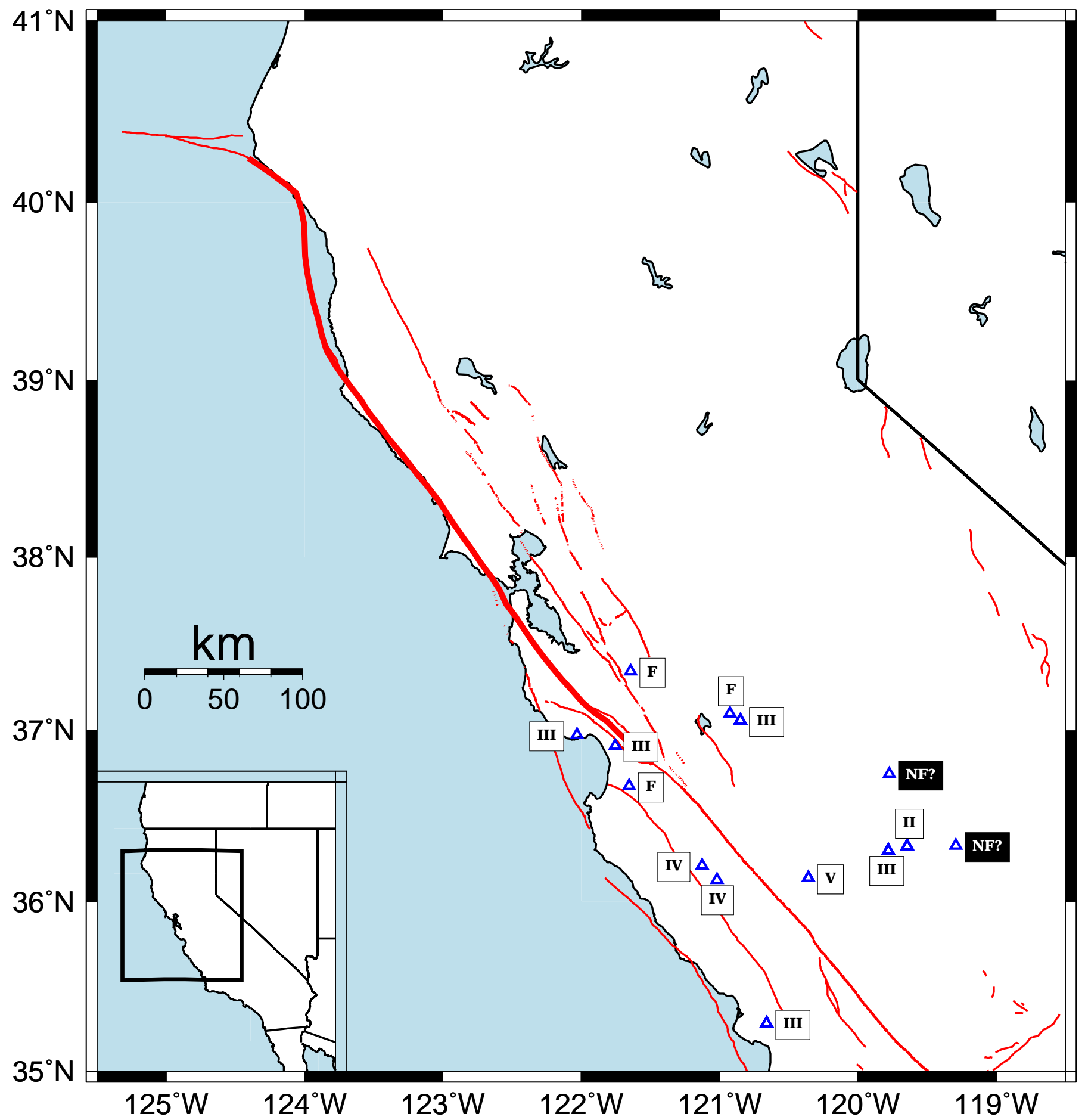




\section{J un 1907, 00:27 Aftershock}

Figure 10

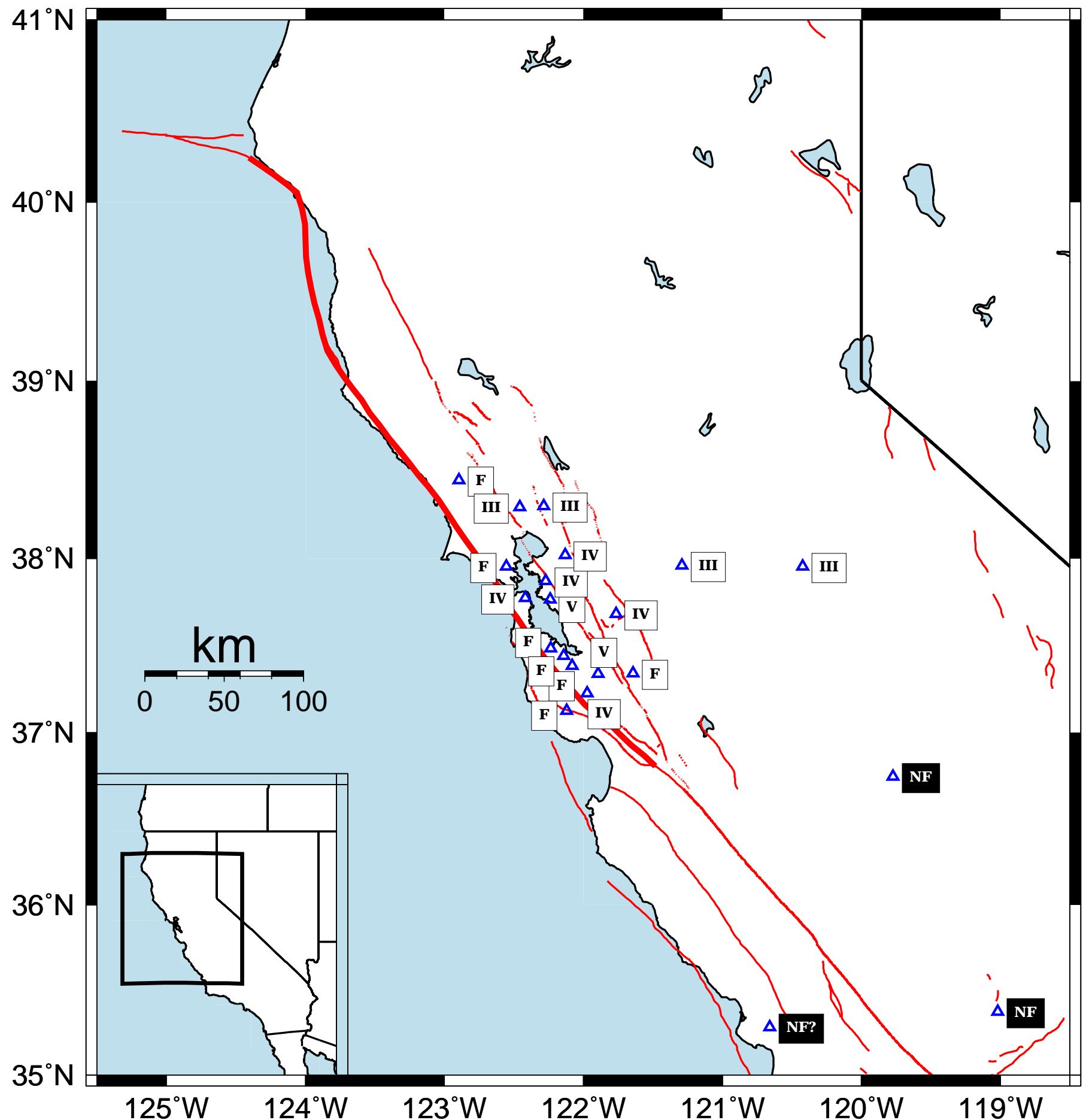


8 Aug 1907 Aftershocks at 04:44 and 06:05

Figure 11

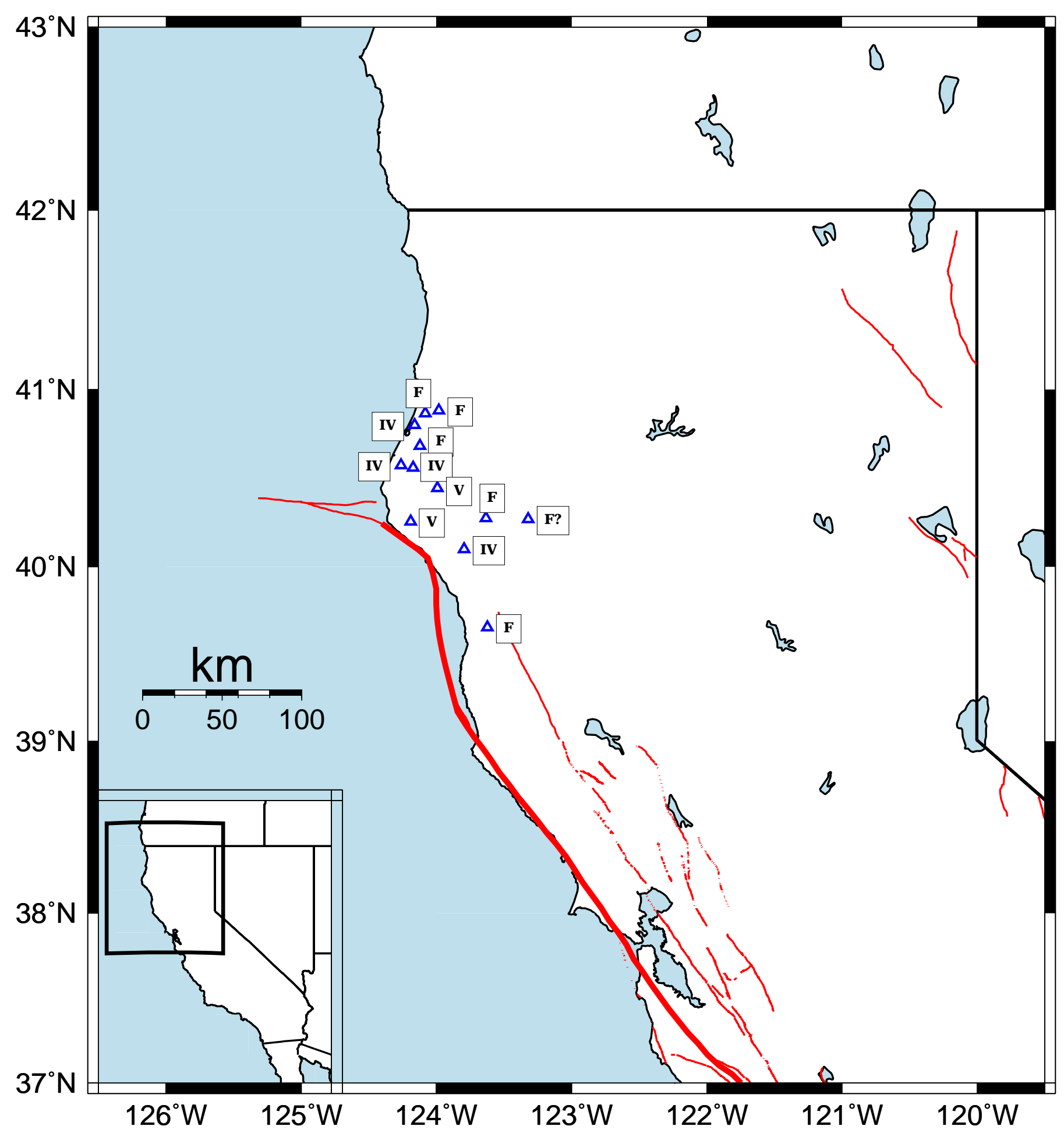




\section{Aug 1907, 04:19 Aftershock}

Figure 12

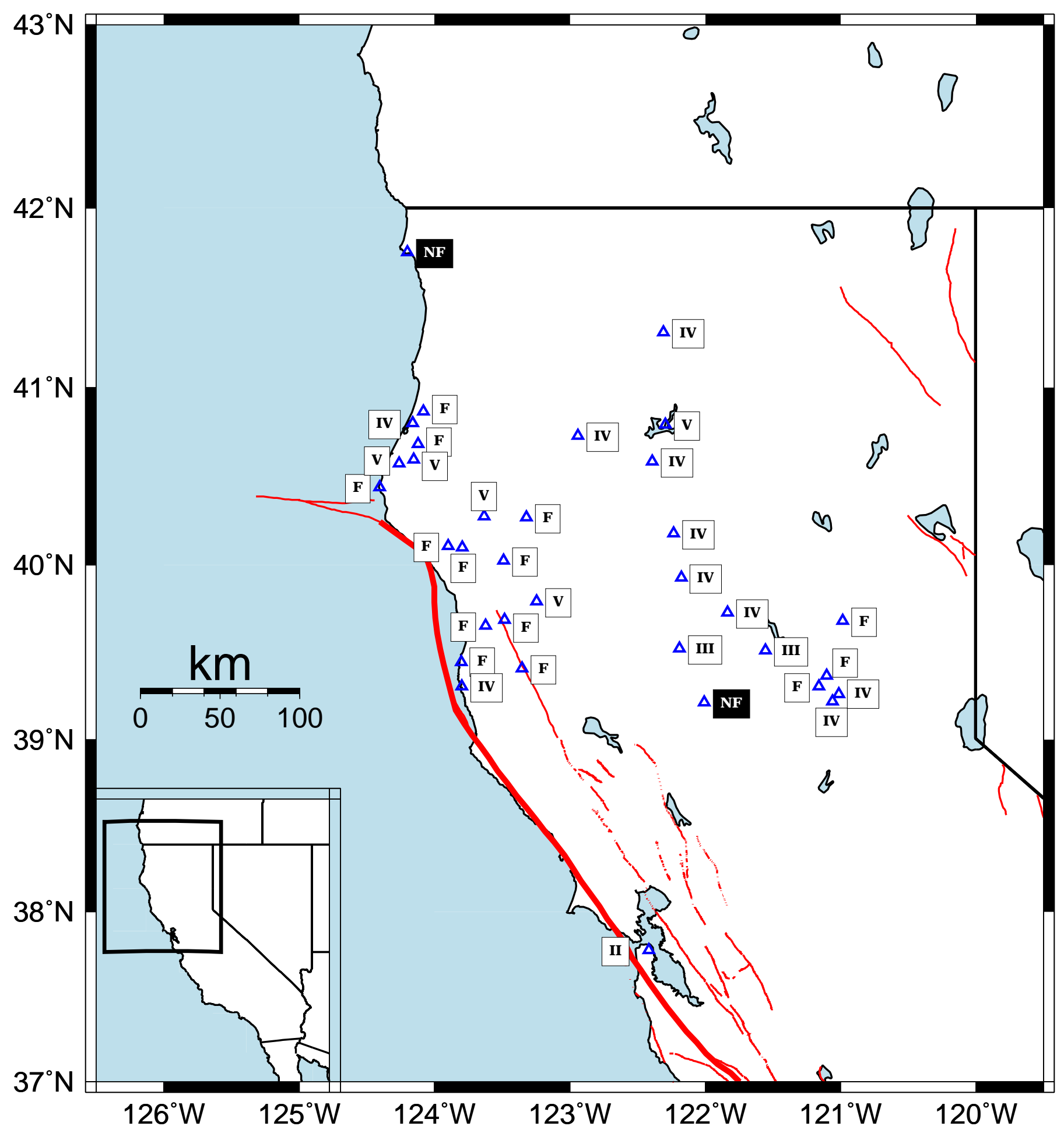




\section{Appendix 1: Modified Mercalli Intensity Scale (Wood and Neumann, 1931; Toppozada and Parke, 1982)}

Items added by Toppozada and Parke (1982) are enclosed in brackets. Items not applied by Toppozada and Parke (1982) or the present authors in strikethrough type. Items applied by Toppozada and Parke (1982) but not by the present authors in italics and strikethrough type. see discussion following this table.

I Not felt -- or, except rarely under especially favorable circumstances. Under certain conditions, at and outside the boundary of the area in which a great shock is felt:

sometimes birds, animals, reported uneasy or disturbed; sometimes dizziness or nausea experienced;

sometimes trees, structures, liquids, bodies of water, may sway -doors may swing, very slowly.

II Felt indoors by few, especially on upper floors, or by sensitive or nervous persons.

Also, as in grade $I$, but often more noticeably: sometimes hanging objects may swing, especially when delicately suspended;

sometimes trees, structures, liquids, bodies of water, may sway, doors may swing, very slowly;

sometimes birds, animals, reported uneasy or disturbed; sometimes dizziness or nausea experienced.

III Felt indoors by several [a number, some], motion usually rapid vibration. Sometimes not recognized to be an earthquake at first.

Duration estimated in some cases.

Vibration like that due to passing of light, or lightly loaded trucks, or heavy trucks some distance away.

Hanging objects may swing slightly.

Movements may be appreciable on upper levels of tall structures.

Rocked standing motor cars slightly.

IV Felt indoors by many, outdoors by few.

Awakened few, especially light sleepers.

Frightened no one, unless apprehensive from previous experience.

Vibration like that due to passing of heavy, or heavily loaded trucks.

Sensation like heavy body striking building, or falling of heavy objects inside.

Rattling of dishes, windows, doors; glassware and crockery clink and clash.

Creaking of walls, frame, especially in the upper range of this grade. Hanging objects swung, in numerous instances.

Disturbed liquids in open vessels slightly.

Rocked standing motor cars noticeably.

[Frightened a few or several.] 


\section{Appendix 1: Modified Mercalli Intensity Scale (Wood and Neumann, 1931; Toppozada and Parke, 1982)}

Felt indoors by practically all, outdoors by many or most: outdoors direction estimated.

Awakened many, or most.

Frightened few [many] -- slight excitement, a few ran outdoors.

Buildings trembled throughout.

Broke dishes, glassware, to some extent.

Cracked windows -- in some cases, but not generally.

Overturned vases, small or unstable objects, in many instances, with occasional fall.

Hanging objects, doors, swing generally or considerably.

Knocked pictures against walls, or swung them out of place.

Opened, or closed, doors, shutters, abruptly.

Pendulum clocks stopped, started, or ran fast, or slow.

Moved small objects, furnishings, the latter to slight extent.

Spilled liquids in small amounts from well-filled open containers.

Trees, bushes, shaken slightly.

[Minor cracking of plaster.]

[Felt by most at an hour when most would be asleep.]

[Rang very small bells, i.e. door bells.]

$\underline{\mathrm{VI}}$

Felt by all, indoors and outdoors.

Frightened [most or all], excitement general, some alarm, many [or all] ran outdoors.

Awakened all.

Persons made to move unsteadily.

Trees, bushes, shaken slightly to moderately.

Liquid set in strong motion.

Small bells rang -- church, chapel, school, etc.

Damage slight in poorly built buildings.

Fall of plaster in small amount.

Cracked plaster somewhat, especially fine eracks, chimneys in some instances.

Broke dishes, glassware, in considerable quantity, also some windows.

Fall of knick-knacks, books, pictures.

Overturned furniture in many instances.

Moved furnishings of moderately heavy kind.

[Some brick walls cracked slightly.]

[A few loose bricks knocked from walls.]

[Many plaster walls cracked.]

[Some, or many, found it difficult to stand.]

VII Frightened all-- general alarm, all ran outdoors.

some, or many, found it difficult to stand.

Noticed by persons driving motor cars [or horse drawn carriages].

Frees and bushes shaken moderately to strongly.

Waves on ponds, lakes, and running water.

Water turbid from mud stirred up.

Ineaving to some extent of sand or gravel stream banks.

Rang large church bells, etc.

Suspended objects made to quiver. 


\section{Appendix 1: Modified Mercalli Intensity Scale (Wood and Neumann, 1931; Toppozada and Parke, 1982)}

Damage negligible in buildings of good design and construction, slight to moderate in well-built ordinary buildings, considerable in poorly built or badly designed buildings, adobe houses, old walls

(especially where laid up without mortar), spires, etc.

Cracked chimneys to considerable extent, walls to some extent.

Fall of plaster in considerable to large amount, also some stucco.

Broke numerous windows, furniture to some extent.

Shook down loosened brickwork and tiles.

Broke weak chimneys at the roof-line (sometimes damaging roofs).

Fall of cornices from towers and high buildings.

Dislodged bricks and stones.

Overturned heavy furniture, with damage from breaking.

Damage considerable to conerete irrigation ditehes.

[Fall of a few fire walls.]

Disturbed persons driving motor cars.

Trees shaken strongly branches, trunks, broken off, especially palm trees.

Ejected sand and mud in small amounts.

Changes: temporary, permanent; in flow of springs and wells; dry wells renewed flow; in temperature of spring and well waters.

Damage slight in structures (brick) built especially to withstand earthquakes. Considerable in ordinary substantial buildings, partial collapse, racked, tumbled down, wooden houses in some cases [those on stilts]; threw out panel walls in frame structures, broke off decayed piling.

Fall of walls.

Cracked, broke, solid stone walls seriously.

Wet ground to some extent, also ground on steep slopes.

Twisting, fall, of [most or all] chimneys, columns, monuments, also factory stacks, towers.

Moved conspicuously, overturned, very heavy furniture.

[Moved frame structures on their foundations.]

[Weak adobe buildings may collapse.]

IX Panic general.

Eracked ground conspicuously.

Damage considerable in (masonry) structures built especially to withstand earthquakes:

threw out of plumb some wood-frame houses built especially to withstand earthquakes;

great in substantial (masonry) buildings, some collapse in large part [partial collapse of a number of buildings or a few buildings largely collapsed or both]; or wholly shifted frame buildings off foundations; racked frames; serious to reservoirs; underground pipes sometimes broken. 


\section{Appendix 1: Modified Mercalli Intensity Scale (Wood and Neumann, 1931; Toppozada and Parke, 1982)}

Eracked ground, especially when loose and wet, up to widths of several inches: fissures up to a yard in width ran parallel to canal and stream banks.

tandslides considerable from river banks and steep coasts. Shifted sand and mud horizontally on beaches and flat land. Changed level of water in wells. Threw water on banks of canals, lakes, rivers, etc. Damage serious to dams, dikes, embankments. Severe to well-built wooden structures and bridges, some destroyed. Developed dangerous cracks in excellent brick walls.

Destroyed most masonry and frame structures [of good construction], also their foundations.

Bent railroad rails slightly.

Tore apart, or exushed endwise, pipe lines buried in earth.

Open eracks and broad wavy folds in cement pavements and asphalt road surfaces.

Disturbances in ground many and widespread, varying with ground material. Broad fissures, earth slumps, and land slips in soft, wet ground. Fjected water in large amount charged with sand and mud. Caused sea-waves ("tidal" waves) of significant magnitude. Damage severe to wood-frame structures, especially near shock centers. Great to dams, dikes, embankments, often for long distances.

Few, if any, [well constructed] (masonry) structures remained standing.

Destroyed large well-built bridges by the wrecking of supporting piers or pillars.

Affected yielding wooden bridges less.

Bent railroad rails greatly, and thrust them endwise.

Put pipe lines buried in earth completely out of service.

Damage total -- practically all works of construction damaged greatly or destroyed.

Disturbances in ground great and varied, numerous shearing cracks.

tandslides, falls of roek of significant character, slumping of river banks, ete., numerous and extensive.

Wrenched loose, tore off, large rock masses.

Fault slips in firm rock, with notable horizontal and vertical offset displacements.

Water channels, surface and underground, disturbed and modified greatly.

Dammed lakes, produced waterfalls, deflected rivers, ete.

Waves seen on ground surfaces (actually seen, probably, in some eases).

Distorted lines of sight and level.

Threw objects upward into the air. 


\section{Appendix 1: Modified Mercalli Intensity Scale (Wood and Neumann, 1931; Toppozada and Parke, 1982)}

\section{Discussion of our application of the Modified Mercalli Intensity scale:}

Although we have generally followed the Modified Mercalli scale as presented in this table, we have treated some of the historic accounts with skepticism. As Toppozada and Parke (1982) noted, newspaper writers had a tendency to exaggerate or romanticize the response of the populace: some reports may have stated that an earthquake frightened people, when perhaps it only excited them. In addition, during the days and weeks following the 1906 mainshock, people tended to have lingering fears and were easily excitable; they may have also been more apt to rush outdoors. A number of newspaper reports describing 1906 aftershocks made statements to the effect that people were frightened by a particular aftershock, but the reports went on to say that, had it not been for the mainshock days or weeks earlier, few people would have made a fuss about that aftershock. For these reasons, physical effects of shaking - such as dishes or windows rattling, hanging objects swaying, or the awakening of people-were given more weight than were human responses.

One other rule we were careful to follow in our application of the Modified Mercalli scale was to avoid bias by damage to one or two buildings. For example, if one or two walls in a town collapsed during an earthquake, but no other walls in the town suffered serious damage, it is assumed that the walls that collapsed had structural flaws, and intensity VIII was not assigned simply because there was "fall of walls"; for intensity VIII to be assigned in that case, more evidence of intensity VIII effects would be needed. In a few cases, a range of intensities is assigned (for example, an assignment of intensity IV-V, meaning that the intensity could either be IV or V), but our preferred intensity is noted.

Finally, it should be noted that we have chosen to disregard one item of the scale in addition to the items already disregarded by Toppozada and Parke (1982). Wood and Neumann (1931) listed "Pendulum clocks stopped, started, or ran fast, or slow" as characteristic of MMI V. Yet in a number of accounts in the present report, this effect appears to have occurred at lower intensities, i.e., pendulum clocks were reported to have stopped when all other observations would indicate an intensity of IV or less. Therefore, the present authors felt that the stopping of pendulum clocks alone was not sufficient evidence to assign MMI V, and effects on clocks generally were not used in determining intensities. 

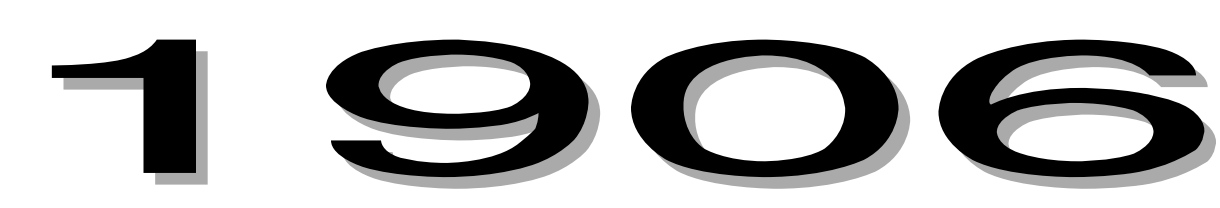

\begin{tabular}{|rrrrrrr|}
\hline \multicolumn{1}{|c|}{ January } \\
\hline $\mathrm{S}$ & $\mathrm{M}$ & $\mathrm{T}$ & $\mathrm{W}$ & $\mathrm{T}$ & $\mathrm{F}$ & $\mathrm{S}$ \\
& 1 & 2 & 3 & 4 & 5 & 6 \\
7 & 8 & 9 & 10 & 11 & 12 & 13 \\
14 & 15 & 16 & 17 & 18 & 19 & 20 \\
21 & 22 & 23 & 24 & 25 & 26 & 27 \\
28 & 29 & 30 & 31 & & & \\
& & & & & & \\
\hline
\end{tabular}

\begin{tabular}{|rrrrrrr|}
\hline \multicolumn{1}{|c|}{ February } \\
\hline $\mathrm{S}$ & $\mathrm{M}$ & $\mathrm{T}$ & $\mathrm{W}$ & $\mathrm{T}$ & $\mathrm{F}$ & $\mathrm{S}$ \\
& & & & 1 & 2 & 3 \\
4 & 5 & 6 & 7 & 8 & 9 & 10 \\
11 & 12 & 13 & 14 & 15 & 16 & 17 \\
18 & 19 & 20 & 21 & 22 & 23 & 24 \\
25 & 26 & 27 & 28 & & & \\
& & & & & & \\
\hline
\end{tabular}

\begin{tabular}{|rrrrrrr|}
\hline \multicolumn{1}{|c|}{ March } \\
\hline $\mathrm{S}$ & $\mathrm{M}$ & $\mathrm{T}$ & $\mathrm{W}$ & $\mathrm{T}$ & $\mathrm{F}$ & $\mathrm{S}$ \\
& & & & 1 & 2 & 3 \\
4 & 5 & 6 & 7 & 8 & 9 & 10 \\
11 & 12 & 13 & 14 & 15 & 16 & 17 \\
18 & 19 & 20 & 21 & 22 & 23 & 24 \\
25 & 26 & 27 & 28 & 29 & 30 & 31 \\
& & & & & & \\
\hline
\end{tabular}

\begin{tabular}{|rrrrrrr|}
\hline \multicolumn{1}{|c|}{ April } \\
\hline $\mathrm{S}$ & $\mathrm{M}$ & $\mathrm{T}$ & $\mathrm{W}$ & $\mathrm{T}$ & $\mathrm{F}$ & $\mathrm{S}$ \\
1 & 2 & 3 & 4 & 5 & 6 & 7 \\
8 & 9 & 10 & 11 & 12 & 13 & 14 \\
15 & 16 & 17 & 18 & 19 & 20 & 21 \\
22 & 23 & 24 & 25 & 26 & 27 & 28 \\
29 & 30 & & & & & \\
& & & & & & \\
\hline
\end{tabular}

\begin{tabular}{|rrrrrrr|}
\hline \multicolumn{1}{|c|}{ May } \\
\hline $\mathrm{S}$ & $\mathrm{M}$ & $\mathrm{T}$ & $\mathrm{W}$ & $\mathrm{T}$ & $\mathrm{F}$ & $\mathrm{S}$ \\
& & 1 & 2 & 3 & 4 & 5 \\
6 & 7 & 8 & 9 & 10 & 11 & 12 \\
13 & 14 & 15 & 16 & 17 & 18 & 19 \\
20 & 21 & 22 & 23 & 24 & 25 & 26 \\
27 & 28 & 29 & 30 & 31 & & \\
& & & & & & \\
\hline
\end{tabular}

\begin{tabular}{|rrrrrrr|}
\hline \multicolumn{1}{|c|}{ June } \\
\hline $\mathrm{S}$ & $\mathrm{M}$ & $\mathrm{T}$ & $\mathrm{W}$ & $\mathrm{T}$ & $\mathrm{F}$ & $\mathrm{S}$ \\
& & & & & 1 & 2 \\
3 & 4 & 5 & 6 & 7 & 8 & 9 \\
10 & 11 & 12 & 13 & 14 & 15 & 16 \\
17 & 18 & 19 & 20 & 21 & 22 & 23 \\
24 & 25 & 26 & 27 & 28 & 29 & 30 \\
& & & & & & \\
\hline
\end{tabular}

\begin{tabular}{|rrrrrrr|}
\hline \multicolumn{1}{|c|}{ July } \\
\hline $\mathrm{S}$ & $\mathrm{M}$ & $\mathrm{T}$ & $\mathrm{W}$ & $\mathrm{T}$ & $\mathrm{F}$ & $\mathrm{S}$ \\
1 & 2 & 3 & 4 & 5 & 6 & 7 \\
8 & 9 & 10 & 11 & 12 & 13 & 14 \\
15 & 16 & 17 & 18 & 19 & 20 & 21 \\
22 & 23 & 24 & 25 & 26 & 27 & 28 \\
29 & 30 & 31 & & & & \\
& & & & & & \\
\hline
\end{tabular}

\begin{tabular}{|rrrrrrr|}
\hline \multicolumn{1}{|c|}{ August } \\
\hline $\mathrm{S}$ & $\mathrm{M}$ & $\mathrm{T}$ & $\mathrm{W}$ & $\mathrm{T}$ & $\mathrm{F}$ & $\mathrm{S}$ \\
& & & 1 & 2 & 3 & 4 \\
5 & 6 & 7 & 8 & 9 & 10 & 11 \\
12 & 13 & 14 & 15 & 16 & 17 & 18 \\
19 & 20 & 21 & 22 & 23 & 24 & 25 \\
26 & 27 & 28 & 29 & 30 & 31 & \\
& & & & & & \\
\hline
\end{tabular}

\begin{tabular}{|rrrrrrrr|}
\hline \multicolumn{8}{|c|}{ September } \\
\hline $\mathrm{S}$ & $\mathrm{M}$ & $\mathrm{T}$ & $\mathrm{W}$ & $\mathrm{T}$ & $\mathrm{F}$ & $\mathrm{S}$ \\
& & & & & & 1 \\
2 & 3 & 4 & 5 & 6 & 7 & 8 \\
9 & 10 & 11 & 12 & 13 & 14 & 15 \\
16 & 17 & 18 & 19 & 20 & 21 & 22 \\
23 & 24 & 25 & 26 & 27 & 28 & 29 \\
30 & & & & & & \\
\hline
\end{tabular}

\begin{tabular}{|rrrrrrr|}
\hline \multicolumn{7}{|c|}{ October } \\
\hline $\mathrm{S}$ & $\mathrm{M}$ & $\mathrm{T}$ & $\mathrm{W}$ & $\mathrm{T}$ & $\mathrm{F}$ & $\mathrm{S}$ \\
& 1 & 2 & 3 & 4 & 5 & 6 \\
7 & 8 & 9 & 10 & 11 & 12 & 13 \\
14 & 15 & 16 & 17 & 18 & 19 & 20 \\
21 & 22 & 23 & 24 & 25 & 26 & 27 \\
28 & 29 & 30 & 31 & & & \\
& & & & & & \\
\hline
\end{tabular}

\begin{tabular}{|rrrrrrr|}
\hline \multicolumn{8}{|c|}{ November } \\
\hline $\mathrm{S}$ & $\mathrm{M}$ & $\mathrm{T}$ & $\mathrm{W}$ & $\mathrm{T}$ & $\mathrm{F}$ & $\mathrm{S}$ \\
& & & & 1 & 2 & 3 \\
4 & 5 & 6 & 7 & 8 & 9 & 10 \\
11 & 12 & 13 & 14 & 15 & 16 & 17 \\
18 & 19 & 20 & 21 & 22 & 23 & 24 \\
25 & 26 & 27 & 28 & 29 & 30 & \\
& & & & & & \\
\hline
\end{tabular}

\begin{tabular}{|rrrrrrrr|}
\hline \multicolumn{1}{|c|}{ December } \\
\hline $\mathrm{S}$ & $\mathrm{M}$ & $\mathrm{T}$ & $\mathrm{W}$ & $\mathrm{T}$ & $\mathrm{F}$ & $\mathrm{S}$ \\
& & & & & & 1 \\
2 & 3 & 4 & 5 & 6 & 7 & 8 \\
9 & 10 & 11 & 12 & 13 & 14 & 15 \\
16 & 17 & 18 & 19 & 20 & 21 & 22 \\
23 & 24 & 25 & 26 & 27 & 28 & 29 \\
30 & 31 & & & & & \\
\hline
\end{tabular}




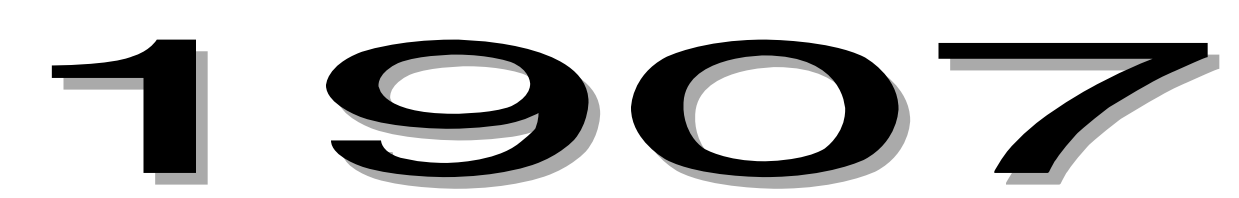

\begin{tabular}{|rrrrrrr|}
\hline \multicolumn{1}{|c|}{ January } \\
\hline $\mathrm{S}$ & $\mathrm{M}$ & $\mathrm{T}$ & $\mathrm{W}$ & $\mathrm{T}$ & $\mathrm{F}$ & $\mathrm{S}$ \\
& & 1 & 2 & 3 & 4 & 5 \\
6 & 7 & 8 & 9 & 10 & 11 & 12 \\
13 & 14 & 15 & 16 & 17 & 18 & 19 \\
20 & 21 & 22 & 23 & 24 & 25 & 26 \\
27 & 28 & 29 & 30 & 31 & & \\
& & & & & & \\
\hline
\end{tabular}

\begin{tabular}{|rrrrrrr|}
\hline \multicolumn{1}{|c|}{ April } \\
\hline $\mathrm{S}$ & $\mathrm{M}$ & $\mathrm{T}$ & $\mathrm{W}$ & $\mathrm{T}$ & $\mathrm{F}$ & $\mathrm{S}$ \\
& 1 & 2 & 3 & 4 & 5 & 6 \\
7 & 8 & 9 & 10 & 11 & 12 & 13 \\
14 & 15 & 16 & 17 & 18 & 19 & 20 \\
21 & 22 & 23 & 24 & 25 & 26 & 27 \\
28 & 29 & 30 & & & & \\
& & & & & & \\
\hline
\end{tabular}

\begin{tabular}{|rrrrrrr|}
\hline \multicolumn{1}{|c|}{ July } \\
\hline $\mathrm{S}$ & $\mathrm{M}$ & $\mathrm{T}$ & $\mathrm{W}$ & $\mathrm{T}$ & $\mathrm{F}$ & $\mathrm{S}$ \\
& 1 & 2 & 3 & 4 & 5 & 6 \\
7 & 8 & 9 & 10 & 11 & 12 & 13 \\
14 & 15 & 16 & 17 & 18 & 19 & 20 \\
21 & 22 & 23 & 24 & 25 & 26 & 27 \\
28 & 29 & 30 & 31 & & & \\
& & & & & & \\
\hline
\end{tabular}

\begin{tabular}{|rrrrrrr|}
\hline \multicolumn{1}{|c|}{ October } \\
\hline $\mathrm{S}$ & $\mathrm{M}$ & $\mathrm{T}$ & $\mathrm{W}$ & $\mathrm{T}$ & $\mathrm{F}$ & $\mathrm{S}$ \\
& & 1 & 2 & 3 & 4 & 5 \\
6 & 7 & 8 & 9 & 10 & 11 & 12 \\
13 & 14 & 15 & 16 & 17 & 18 & 19 \\
20 & 21 & 22 & 23 & 24 & 25 & 26 \\
27 & 28 & 29 & 30 & 31 & & \\
& & & & & & \\
\hline
\end{tabular}

\begin{tabular}{|rrrrrrrr|}
\hline \multicolumn{1}{|c|}{ February } \\
\hline $\mathrm{S}$ & $\mathrm{M}$ & $\mathrm{T}$ & $\mathrm{W}$ & $\mathrm{T}$ & $\mathrm{F}$ & $\mathrm{S}$ \\
& & & & & 1 & 2 \\
3 & 4 & 5 & 6 & 7 & 8 & 9 \\
10 & 11 & 12 & 13 & 14 & 15 & 16 \\
17 & 18 & 19 & 20 & 21 & 22 & 23 \\
24 & 25 & 26 & 27 & 28 & & \\
& & & & & & \\
\hline
\end{tabular}

\begin{tabular}{|rrrrrrr|}
\hline \multicolumn{10}{|c|}{ May } \\
\hline $\mathrm{S}$ & $\mathrm{M}$ & $\mathrm{T}$ & $\mathrm{W}$ & $\mathrm{T}$ & $\mathrm{F}$ & $\mathrm{S}$ \\
& & & 1 & 2 & 3 & 4 \\
5 & 6 & 7 & 8 & 9 & 10 & 11 \\
12 & 13 & 14 & 15 & 16 & 17 & 18 \\
19 & 20 & 21 & 22 & 23 & 24 & 25 \\
26 & 27 & 28 & 29 & 30 & 31 & \\
& & & & & & \\
\hline
\end{tabular}

\begin{tabular}{|rrrrrrrr|}
\hline \multicolumn{1}{|c|}{ March } \\
\hline $\mathrm{S}$ & $\mathrm{M}$ & $\mathrm{T}$ & $\mathrm{W}$ & $\mathrm{T}$ & $\mathrm{F}$ & $\mathrm{S}$ \\
& & & & & 1 & 2 \\
3 & 4 & 5 & 6 & 7 & 8 & 9 \\
10 & 11 & 12 & 13 & 14 & 15 & 16 \\
17 & 18 & 19 & 20 & 21 & 22 & 23 \\
24 & 25 & 26 & 27 & 28 & 29 & 30 \\
31 & & & & & & \\
\hline
\end{tabular}

\begin{tabular}{|rrrrrrrr|}
\hline \multicolumn{1}{|c|}{ June } \\
\hline $\mathrm{S}$ & $\mathrm{M}$ & $\mathrm{T}$ & $\mathrm{W}$ & $\mathrm{T}$ & $\mathrm{F}$ & $\mathrm{S}$ \\
& & & & & & 1 \\
2 & 3 & 4 & 5 & 6 & 7 & 8 \\
9 & 10 & 11 & 12 & 13 & 14 & 15 \\
16 & 17 & 18 & 19 & 20 & 21 & 22 \\
23 & 24 & 25 & 26 & 27 & 28 & 29 \\
30 & & & & & & \\
\hline
\end{tabular}

\begin{tabular}{|rrrrrrr|}
\hline \multicolumn{1}{|c|}{ August } \\
\hline $\mathrm{S}$ & $\mathrm{M}$ & $\mathrm{T}$ & $\mathrm{W}$ & $\mathrm{T}$ & $\mathrm{F}$ & $\mathrm{S}$ \\
& & & & 1 & 2 & 3 \\
4 & 5 & 6 & 7 & 8 & 9 & 10 \\
11 & 12 & 13 & 14 & 15 & 16 & 17 \\
18 & 19 & 20 & 21 & 22 & 23 & 24 \\
25 & 26 & 27 & 28 & 29 & 30 & 31 \\
& & & & & & \\
\hline
\end{tabular}

\begin{tabular}{|rrrrrrr|}
\hline \multicolumn{1}{|c|}{ September } \\
\hline $\mathrm{S}$ & $\mathrm{M}$ & $\mathrm{T}$ & $\mathrm{W}$ & $\mathrm{T}$ & $\mathrm{F}$ & $\mathrm{S}$ \\
1 & 2 & 3 & 4 & 5 & 6 & 7 \\
8 & 9 & 10 & 11 & 12 & 13 & 14 \\
15 & 16 & 17 & 18 & 19 & 20 & 21 \\
22 & 23 & 24 & 25 & 26 & 27 & 28 \\
29 & 30 & & & & & \\
& & & & & & \\
\hline
\end{tabular}

\begin{tabular}{|rrrrrrr|}
\hline \multicolumn{1}{|c|}{ November } \\
\hline $\mathrm{S}$ & $\mathrm{M}$ & $\mathrm{T}$ & $\mathrm{W}$ & $\mathrm{T}$ & $\mathrm{F}$ & $\mathrm{S}$ \\
& & & & & 1 & 2 \\
3 & 4 & 5 & 6 & 7 & 8 & 9 \\
10 & 11 & 12 & 13 & 14 & 15 & 16 \\
17 & 18 & 19 & 20 & 21 & 22 & 23 \\
24 & 25 & 26 & 27 & 28 & 29 & 30 \\
& & & & & & \\
\hline
\end{tabular}

